UNIVERSIDADE DE SÃO PAULO

FACULDADE DE FILOSOFIA, LETRAS E CIÊNCIAS HUMANAS

DEPARTAMENTO DE GEOGRAFIA

\title{
A DISPUTA PELA HEGEMONIA DO ESPAÇO NA BAÍA DOS CASTELHANOS
}

PAULO DA SILVA NOFFS

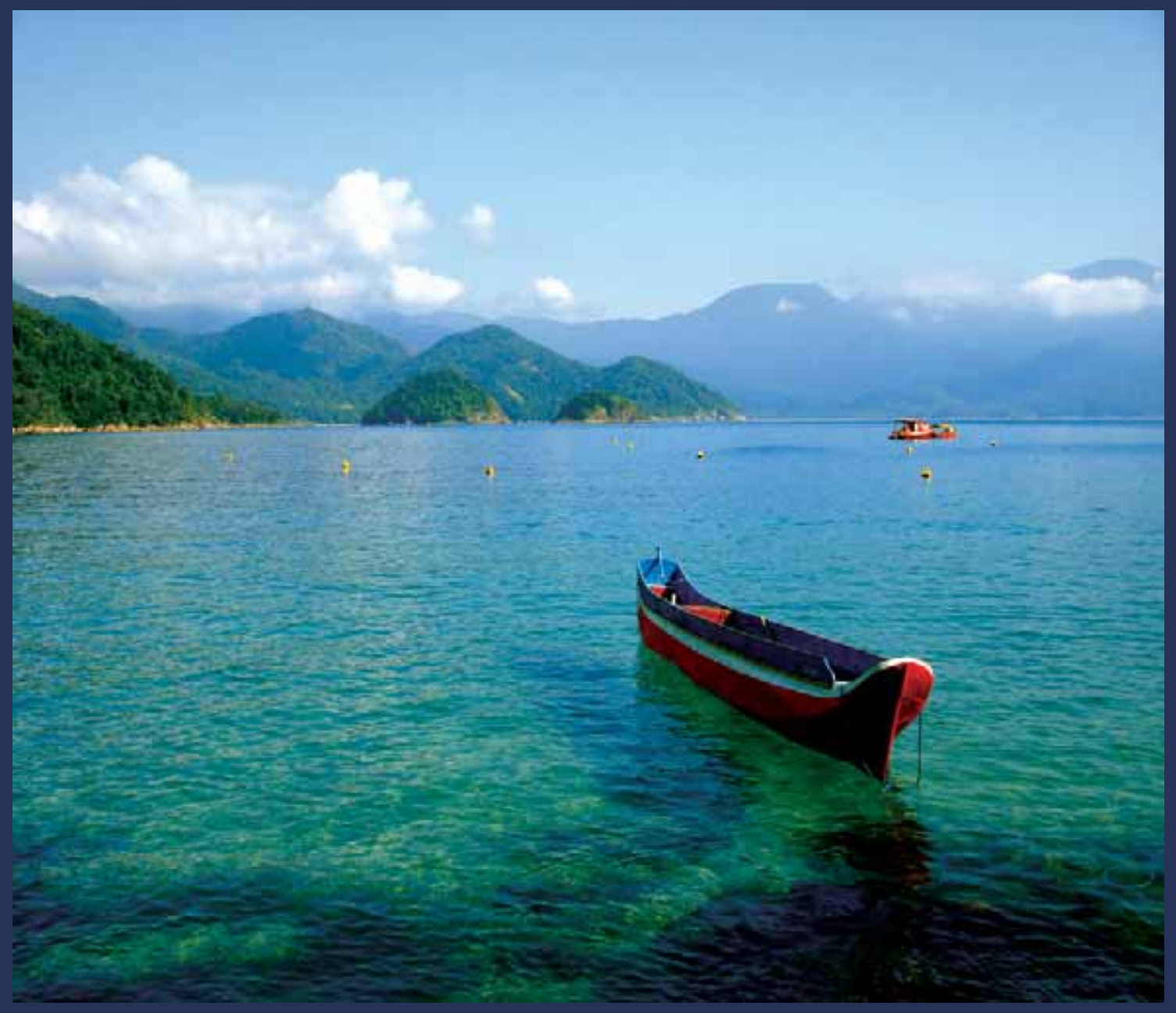

$$
\begin{aligned}
& \text { São Paulo } \\
& 2007
\end{aligned}
$$




\author{
UNIVERSIDADE DE SÃO PAULO \\ FACULDADE DE FILOSOFIA, LETRAS E CIÊNCIAS HUMANAS \\ DEPARTAMENTO DE GEOGRAFIA \\ PROGRAMA DE PÓS-GRADUAÇÃO EM GEOGRAFIA HUMANA
}

\title{
A DISPUTA PELA HEGEMONIA DO ESPAÇO NA BAÍA DOS CASTELHANOS
}

\author{
PAULO DA SILVA NOFFS
}

Tese apresentada ao programa de pósgraduação em Geografia Humana, do Departamento de Geografia da Faculdade de Filosofia, Letras e Ciências Humanas da Universidade de São Paulo, para obtenção do título de Doutor em Geografia Humana.

ORIENTADOR: PROF DR HEINZ DIETER HEIDEMANN

São Paulo

2007 
Ao meu pai, que tanta falta me faz. 


\section{AGRADECIMENTOS}

Em primeiro lugar, meu agradecimento especial a Celia, que ouviu, leu sugeriu, criticou e apontou direções quando foi preciso, como faz uma verdadeira companheira.

Depois a Raquel, que fez tantas coisas que nem sei quais nomear. Então deixo um agradecimento bem grande, que possa cobrir tudo, em especial, a sua presença.

A Mariana e o Alain que me forneceram informações e materiais preciosos.

Ao pessoal da Baía dos Castelhanos, principalmente a Da. Leopoldina, Sr. Anízio, Angélica, Almir, André, Sr. Pedro Madalena, Arlindo, Álvaro, Sr. Francelízio e tantos outros que me contaram sobre a história do lugar.

A Alice, minha irmã, que ajudou com pesquisas bibliográficas. Ao Diego que digitalizou os mapas.

E finalmente, ao Dieter, pela amizade e pela forma como conduziu as discussões, não me deixando afastar do "valor". 


\section{RESUMO}

Este trabalho trata do processo de transformação do espaço rural da produção mercantil simples de alimentos em espaço urbano relacionado ao turismo na Baía dos Castelhanos, Ilhabela.

A produção mercantil simples até meados da década de 1960 articulavase com o mercado de Santos por intermédio dos barcos a motor. A implantação da infra-estrutura rodoviária no Litoral Norte, simultaneamente pôs fim a este tipo de comércio e favoreceu o desenvolvimento do turismo na região.

Atualmente, o turismo local responde a lógica da reprodução capitalista e está subordinado principalmente ao crescimento da metrópole de São Paulo.

A disputa pela hegemonia do espaço na Baía dos Castelhanos está associada, por sua vez, à relação que se estabelece entre a população caiçara remanescente, os diversos segmentos de turismo e turistas e o Estado que regulamenta o uso do território. A relação é conflituosa em decorrência da forma como esses atores desejam se apropriar da renda gerada pela valorização do espaço.

Palavras-Chave: Baía dos Castelhanos, Ilhabela, Geografia, Espaço, Turismo. 


\begin{abstract}
This work discusses the transformation process of a rural area based on simple mercantile family farming production into a tourism related urban area at Baía dos Castelhanos, Ilhabela.

The mercantile family farming production in the 1960's was articulated with the trading market of Santos by intermediary motorboats. The implementation of a road infrastructure in the Litoral Norte of São Paulo, simultaneously helped putting an end to this commerce and favored the tourism development in the region.

Nowadays, the local tourism responds to the logics of capitalist reproduction and is subordinated mainly to the growth of the metropolis of São Paulo.

The dispute for hegemony in the Baía dos Castelhanos area is associated, on the other hand, with the relationship established between the reminiscent native population, the numerous touristic segments and visitors, and the State that regularizes the usage of the territory. This conflictuous relationship is due to the way these social agents are willing to appropriate the land rent generated by the valorization of the space.
\end{abstract}

Keywords: Baía dos Castelhanos, Ilhabela, Geography, Space, Tourism. 


\section{LISTA DAS ILUSTRAÇÕES}

MAPAS

Mapa 1 - Baía dos Castelhanos, Ilhabela, Parque Estadual de Ilhabela e o Litoral Norte 5

$\begin{array}{ll}\text { Mapa } 2 \text { - Estrutura Geológica da llha de São Sebastião } & 7\end{array}$

Mapa 3 - Vegetação da llha de São Sebastião 9

Mapa 4 - A floresta e a exploração do solo na llha de São Sebastião 58

Mapa 5 - Loteamentos sem Acessos na Costa Oceânica de Ilhabela 89

Mapa 6 - Loteamentos Vila Reale e Castelhanos $\quad 93$

Mapa 7 - Distribuição das propriedades na Praia dos Castelhanos 111

Mapa 8 - Localização dos Aparelhos de Cerco na Baía dos Castelhanos $\quad 119$

Mapa 9 - Uso e Ocupação do Solo, Praia dos Castelhanos, Canto do Ribeirão 137

Mapa 10 - Uso e Ocupação do Solo, Praia dos Castelhanos, Canto da Lagoa 138

Mapa 11 - Uso e Ocupação do Solo, Praias Mansa e Vermelha 139

Mapa 12 - Uso e Ocupação do Solo, Praia da Figueira $\quad 140$

Mapa 13 - Uso e Ocupação do Solo, Saco do Sombrio 141

FIGURAS

Figura 1 - Saco do Sombrio em 1951

$\begin{array}{ll}\text { Figura } 2 \text { - Favela em Maresias } & 78\end{array}$

Figura 3 - Canto do Ribeirão em 1962

Figura 4 - Loteamento Bonete 90

\section{QUADROS}

Quadro 1 - Evolução da População em Ilhabela entre 1854 e 1950

Quadro 2 - Ocupação da População por Setores de Atividades Rurais e Composição das Populações Urbana e Rural em $1950 \quad 67$

Quadro 3 - Principal Fonte de Renda dos Moradores da Costa Oceânica de Ilhabela $\quad 113$

Quadro 4 - Relação dos Aparelhos de Cerco na Baía dos Castelhanos 118

Quadro 5 - Frota de Embarcações na Baía dos Castelhanos 122

Quadro 6 - Empregados da Prefeitura e Pensionistas do INSS 125

Quadro 7 - Edificações Existentes na Baía dos Castelhanos por Tipo de Uso 128

Quadro 8 - Evolução da População na Baía dos Castelhanos 135

Quadro 9 - População da Baía dos Castelhanos por Segmento em 2007

FOTOS

Foto 1 - O canal de São Sebastião e o relevo de Ilhabela 6

Foto 2 - Relevo de Morros nas praias Mansa e Vermelha $\quad 8$

Foto 3 - O morro do Costão e a Praia Vermelha 11 
Foto 4 - Relevo de Morros na Praia da Figueira 12

Foto 5 - Floresta Ombrófila Densa Submontana na Península do Boi 12

Foto 6 - Vale do ribeirão do Engenho 13

Foto 7 - Regeneração da Vegetação na foz do ribeirão do Engenho 14

$\begin{array}{ll}\text { Foto } 8 \text { - Fazenda Engenho D'água } & 18\end{array}$

Foto 9 - Plantação de Banana Prata $\quad 22$

Foto 10 - Obras na rodovia SP-125 23

Foto 11 - Estrada de terra Perequê - Castelhanos $\quad 24$

Foto 12 e 13 - Queimada em morro da praia do Toque Toque Pequeno 30

Foto 14 e 15 - Práticas agrícolas não conservacionistas e solos degradados 31

Foto 16 e 17 - O turismo e a produção mercantil simples na Praia Vermelha 43

Foto 18 - Manutenção d rede de cerco no Saco do Sombrio 48

Foto 19 - Campos e capoeiras no Codó $\quad 52$

Foto 20 - Ruínas do engenho do Sr. Leonardo Reale 56

Foto 21 - Bananal do Sr. Manoel Rafael $\quad 59$

Foto 22 - Casa de farinha na Praia Vermelha 62

Foto 23 - Roça de mandioca da Da. Celeste no Canto do Ribeirão 63

Foto 24 - Canto do Ribeirão em 1962

Foto 25 - Lixo de família caiçara $\quad 98$

Foto 26 e 27 - Edificações irregulares no PElb 99

Foto 28, 29 e 30 - Edificações irregulares no Canto da Lagoa 100

Foto 31 e 32 - Casas novas e antigas na Praia Vermelha 103

Foto 33 - Casa de turista disfarçada de casa de caiçara no Saco do Sombrio 107

Foto 34 e 35 - Casas de turistas e de caiçaras na Praia da Figueira ' 108

Foto 36, 37 e 38 - Produção de mandioca para o fabrico de farinha 116

Foto 39, 40, 41 e 42 - Pesca de cerco 121

Foto 43 - Canoas saindo para a pesca da lula 122

Foto 44 e 45 - Casas de pau-a-pique e de alvenaria no Canto da Lagoa 127

Foto 46 - Lanchas no Saco do Eustáquio 131

Foto 47 e 48 - Bar e camping de praia no Canto da Lagoa 132

Foto 49 e 50 - Turistas na Praia dos Castelhanos 133

Foto 51 -Casa antiga no Saco do Sombrio 136 
SUMÁRIO

APRESENTAÇÃO

CAPÍTULO 1 - INFORMAÇÕES SOBRE A FORMAÇÃO DO TERRITÓRIO 4

1. A BAÍA DOS CASTELHANOS E O RELEVO DE ILHABELA 4

2. FORMAÇÃO TERRITORIAL 15

a) As Plantações de Café $\quad 15$

b) A Aguardente e as Canoas de Voga 18

c) Os Cercos Flutuantes do Saco do Sombrio 20

d) Os Bananais e o Cotidiano Caiçara na Década de 1950

e) As Estradas e o Turismo 22

CAPÍTULO 2 - FUNDAMENTOS METODOLÓGICOS E CONCEITUAIS 25

1- COMUNIDADES TRADICIONAIS 25

2 - A VALORIZAÇÃO DO ESPAÇO 32

CAPÍTULO 3 - A VALORIZAÇÃO DO ESPAÇO 44

1. O ESPAÇO DA PEQUENA PRODUÇÃO MERCANTIL -

CARACTERÍSTICAS E CONTRADIÇÕES 44

a) A Pesca de Cerco e os Barcos a Motor no Saco do Sombrio 45

b) O Engenho de Pinga e os Bananais 53

c) O Cotidiano na Baía dos Castelhanos até o Final dos Anos 50

d) O Isolamento 68

2. DA SITUAÇÃO DE ISOLAMENTO PARA A DE

RARIDADE - AS TRANSFORMAÇÕES DA SOCIEDADE

BRASILEIRA E A URBANIZAÇÃO DO LITORAL NORTE

CAPÍTULO 4 - CAIÇARAS, TURISTAS E O ESTADO

NA BAÍA DOS CASTELHANOS 81

1. TRANSFORMAÇÕES RECENTES NA BAÍA DOS CASTELHANOS 81

2. O ESTADO E O PODER PÚBLICO LOCAL 94

a) O Parque Estadual de Ilhabela e a Legislação Ambiental 94 
b) O Poder Público Municipal e o Plano Diretor de Desenvolvimento Socioambiental do Município de Ilhabela

97

3 - CAIÇARAS NA BAÍA DOS CASTELHANOS

112

4. TURISTAS NA BAÍA DOS CASTELHANOS

128

CAPÍTULO 5 - A DISPUTA PELA HEGEMONIA DO ESPAÇO

142

BIBLIOGRAFIA

154

ANEXO - CADASTRO DAS FAMÍLIAS CAIÇARAS, DAS CASAS DE TURISTAS E DAS ATIVIDADES COMERCIAIS NA BAÍA DOS CASTELHANOS

158 


\section{APRESENTAÇÃO}

O mar me fascina. Lembro-me, ainda jovem, de ouvir o barulho do motor daquelas pequenas canoas que retornavam à praia de Caraguatatuba cheias de peixe nas primeiras horas do dia. Não traziam redes, o que me intrigava. Eu não sabia, mas eles pescavam em águas piscosas da costa oceânica de llhabela com grandes redes de tresmalho que visitavam todos os dias bem cedo pela manhã.

Anos depois, pude conhecer a praia de Toque Toque Pequeno na costa sul de São Sebastião, onde a pesca e as plantações de banana eram muito importantes para a sobrevivência das famílias do lugar. O contato com o ritmo simples dos trabalhos na pesca e na roça fascina quem vive na cidade grande. Não havia como não se envolver pelo belo cenário das canoas no mar e as casas de barro emolduradas pela montanha e a Mata Atlântica. São armadilhas postas à frente dos pesquisadores para que fiquem arrebatados pela harmonia aparente e não vejam a história e as relações sociais que verdadeiramente determinam a vida dessas populações.

Os meus primeiros contatos com a Baía dos Castelhanos não foram diferentes. Ficava deslumbrado com aquela gente que morava em casas bem mais rústicas do que as que conheci em Toque Toque Pequeno. Também não havia casas de turistas e tampouco estabelecimentos comerciais, o que aprofundava a impressão de uma vida que dependia exclusivamente da pesca e da produção de alimentos.

Outra vez me vi diante de uma aparência que insistia em se apresentar como essência. Diante do cenário maravilhoso da Baía dos Castelhanos, insistia em enxergar a produção mercantil simples de alimentos onde o espaço urbano do turismo já se configurava hegemonicamente.

O problema residia na natureza "não-visível" das transformações que estavam ocorrendo no espaço da Baía dos Castelhanos, como por exemplo:

- Transformações que já ocorreram, mas não se materializaram, não criaram volumes no espaço, como foi o caso das transferências da posse da terra dos caiçaras para os especuladores e turistas; 
- Transformações que estavam ocorrendo em outros lugares e que modificavam a "situação" da Baía dos Castelhanos. A metropolização de São Paulo e a formação de outras metrópoles no sudeste brasileiro, a ampliação da infra-estrutura viária de acesso, a urbanização e destruição dos ambientes naturais do Litoral Norte deixavam o espaço da Baía dos Castelhanos mais "necessário" ao consumo e mais "próximo" dos centros consumidores capitalistas.

A Baía dos Castelhanos se inseria no mercado mais amplo, brasileiro e global, mas seu espaço ainda não era depositário de trabalho morto correspondente a essa nova forma do valor. Simultaneamente, os fluxos mercantis se ampliavam e percebia-se que os caiçaras se envolviam cada vez mais com atividades relacionadas ao turismo, afastando-se do trabalho nas roças de produção de alimentos.

Como geógrafo, deparei-me diante do próprio processo de valorização do espaço, das discussões sobre valor do espaço, valor no espaço ou produção do espaço. Percebi que se não penetrasse no significado da propriedade privada da terra e das rendas de monopólio e diferencial, o espaço a ser apreendido seria apenas o dos fenômenos visíveis e que se manifestam por meio das formas que ainda espelham o passado recente da produção mercantil simples.

O espaço da Baía dos Castelhanos reflete a ação dos caiçaras, dos turistas e do Estado. O turismo se manifesta de várias formas, com atores diferentes e interesses por vezes conflitantes, mas que tem em comum o desejo de explorar, de consumir a nova mercadoria natureza que a valorização do espaço proporciona. O Estado, principalmente por conta da presença do Parque Estadual de Ilhabela, que abrange parte considerável do território do município e da própria baía, e do Plano Diretor Socioambiental do município de Ilhabela, estabelece restrições e diretrizes direcionadas ao ordenamento do território. Teoricamente, sua ação se volta a conciliar turismo, crescimento urbano e conservação do meio ambiente. Em relação aos 
caiçaras, as políticas territoriais do Estado não manifestam claramente se são considerados como parte integrante da natureza ou da sociedade.

Estado, sociedade, espaço, valor, turismo, produção mercantil simples, mercantilização da terra e da natureza. São essas as palavras-chave deste trabalho. Bem empregadas, utilizadas com cuidado, apoiadas em conceitos, talvez dêem conta de explicar a disputa pela hegemonia do espaço na Baía dos Castelhanos.

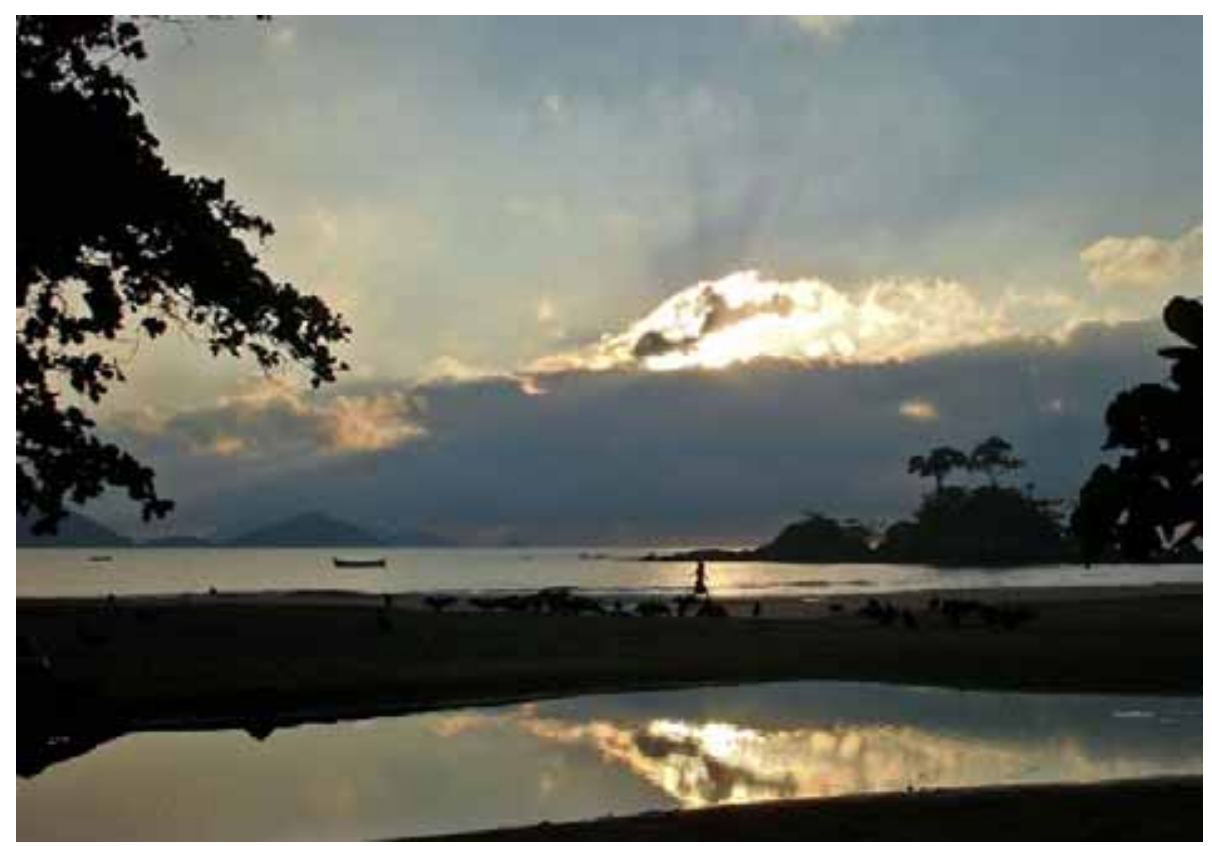

Amanhecer no Canto da Lagoa (Fotografia do autor de 2007) 


\section{CAPÍTULO 1 \\ INFORMAÇÕES SOBRE A FORMAÇÃO DO TERRITÓRIO}

\section{A BAÍA dos CASTELHANOS E O RELEVO DE ILHABELA}

O município de Ilhabela, São Paulo, ocupa uma superfície de 33.600 ha e é formado por um arquipélago de 15 ilhas, sendo as de São Sebastião, dos Búzios e da Vitória as principais. A área das duas últimas não ultrapassa 5\% do território do município e nelas residem apenas algumas famílias caiçaras. $A$ cidade de Ilhabela, os bairros, a vida social, econômica e cultural, a infraestrutura e o movimento turístico ficam na ilha de São Sebastião. O PElb Parque Estadual de Ilhabela ocupa 27.025 ha, representando 80,40\% da superfície do município. O mapa 1 mostra a localização do PEIB, da Baía dos castelhanos e da ilha de São Sebastião no Litoral Norte de São Paulo.

Quase toda a superfície de Ilhabela é constituída pela serra de São Sebastião, um grande maciço montanhoso disposto paralelamente ao canal que a separa do continente. Vista da cidade de São Sebastião, a serra mostra por inteiro sua vertente ocidental, que domina toda a paisagem do canal. $\mathrm{Na}$ vertente oposta da serra, situam-se a Baía dos Castelhanos e a enseada das Enchovas. Nesta face, o litoral é mais recortado e voltado para o mar aberto.

A montanha de Ilhabela tem origem e constituição distintas das outras estruturas que compõem a serra do Mar e que fazem dela um corpo diferenciado no litoral paulista.

As rochas que lhe dão forma e sustentação são as eruptivas alcalinas e as granito-gnáissicas. Estas últimas são do pré-cambriano, era geológica mais antiga da Terra, e constituem a base da serra do Mar e do Planalto Atlântico. As rochas alcalinas são posteriores, com idade entre 65 a 90 milhões de anos e não fazem parte da gênese da serra do Mar. Elas estão associadas às erupções vulcânicas da Bacia do Paraná que ocorreram no final da era mesozóica. Essas erupções atingiram o Litoral Norte em episódios isolados que ocasionaram a 
penetração de magma alcalino nas estruturas granito-gnáissicas existentes, dando origem às ilhas de São Sebastião, Búzios, Vitória e Monte de Trigo.

Mapa 1 - Baía dos Castelhanos, Ilhabela, Parque Estadual de Ilhabela e o Litoral Norte

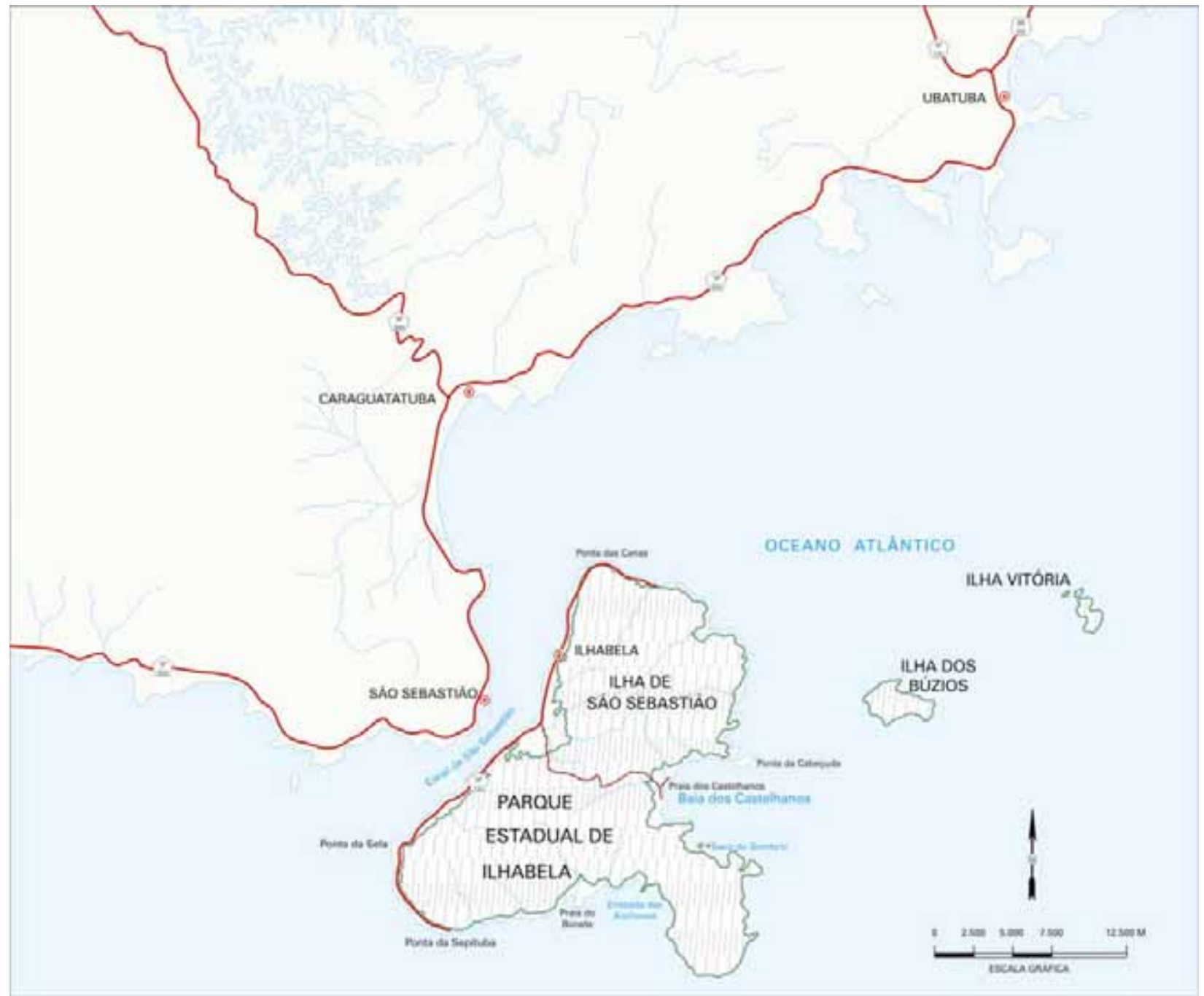

Fonte: Atlas das Unidades de Conservação Ambiental do Estado de São Paulo, Parte 1, Litoral, 1996 


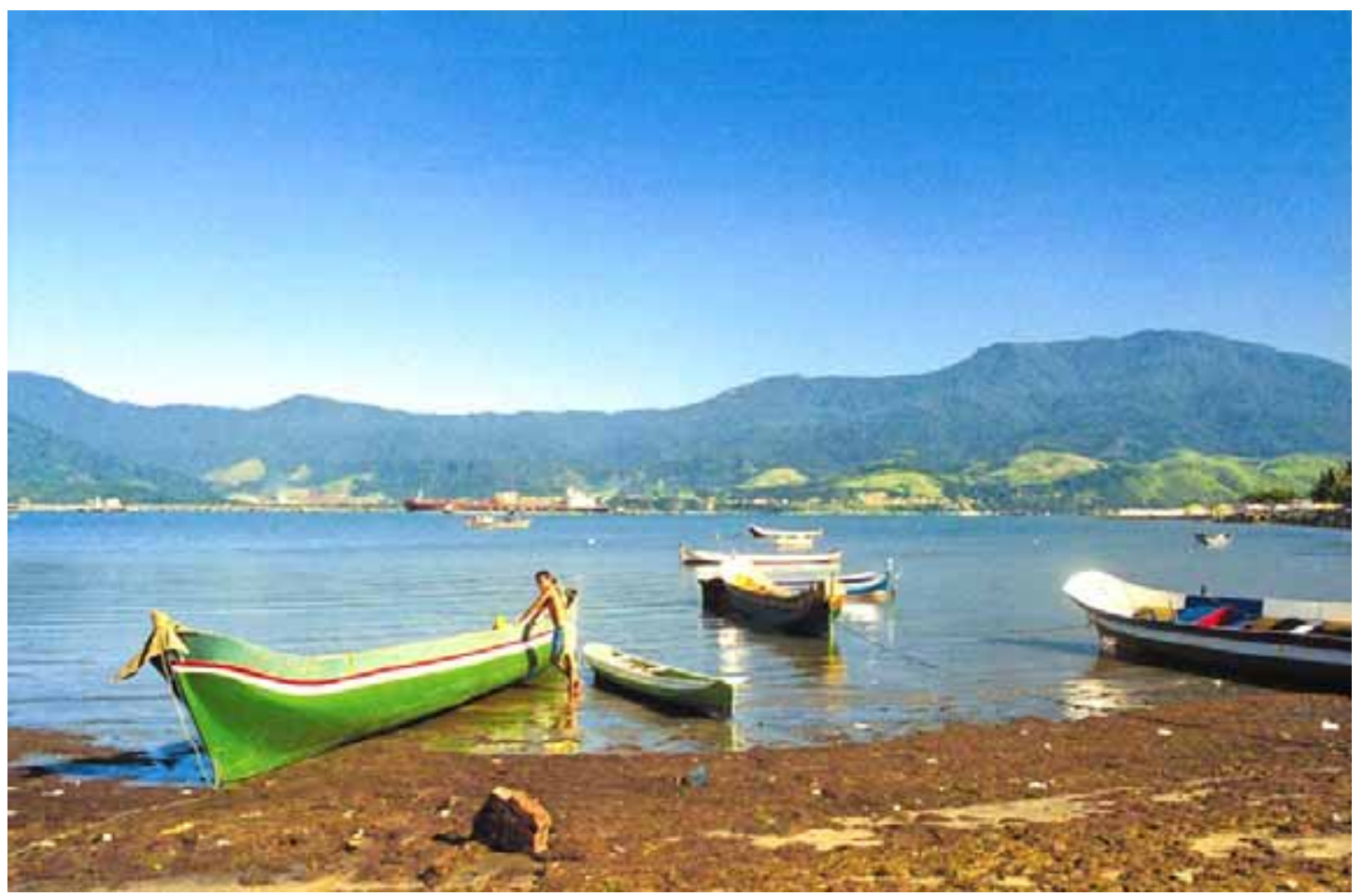

Foto 1, P. Noffs, 1997. O canal de São Sebastião e o relevo de llhabela. À direita, o maciço de São Sebastião sustentado por rochas eruptivas alcalinas. Do centro para a esquerda, com altitudes mais modestas, relevos que se originaram a partir de rochas granito-gnáissicas na região do bairro do Perequê. Podem ser observados, também, os morros cobertos por sapé e capoeiras, indicando que atividades agrícolas foram desenvolvida nessas áreas no passado.

Em Ilhabela, as volumosas intrusões de material eruptivo ocorreram em três grandes "stocks" de rochas. Elas dão suporte aos dois principais blocos montanhosos da llha, denominados Maciço de São Sebastião, ao sul, e Maciço da Serraria, ao norte, além da acidentada península do Boi, a sudeste, definindo, assim, as linhas principais do desenho de seu litoral. No maciço de São Sebastião estão o Pico de São Sebastião, a 1.375 metros sobre o nível do mar e o Morro do Papagaio, na cota 1.302 msnm. O Morro da Ponta Alta, no maciço da Serraria, está a 1.259 metros acima do nível do mar. (Mapa - 2 Estrutura geológica da llha de São Sebastião)

Os relevo associados às rochas alcalinas apresentam vertentes íngremes, localmente escarpadas, com declividades predominantemente superiores a $30 \%$. 


\section{Mapa 2 - Estrutura Geológica da llha de São Sebastião}

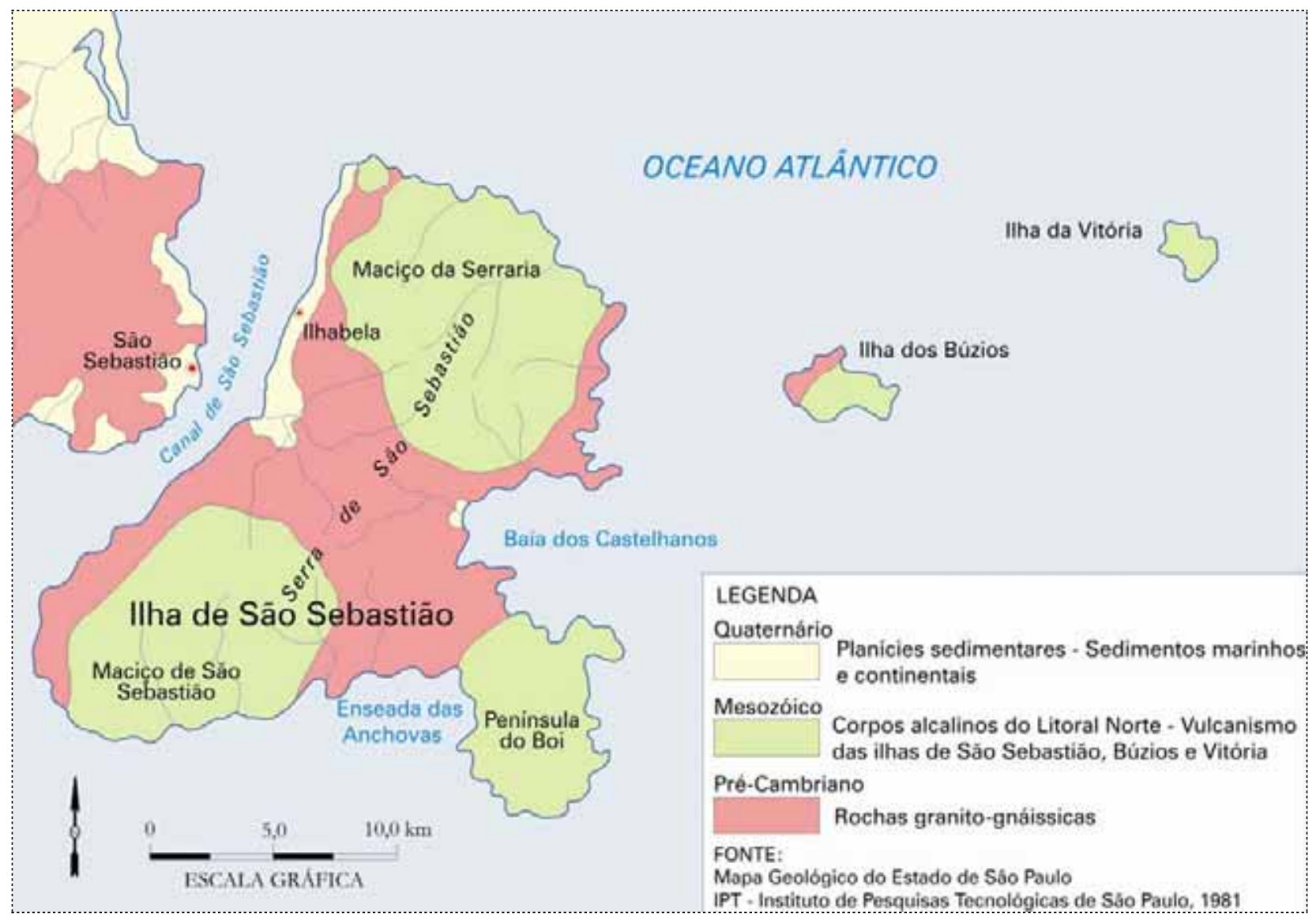

Entre esses blocos e contornando-os na zona do canal que separa a llha do continente, situam-se as formações pré-cambrianas. As rochas granitognáissicas, apesar de muito resistentes, são mais susceptíveis à erosão do que as alcalinas. $O$ relevo a elas associado também é montanhoso, mas apresentase mais rebaixado e dissecado, não ultrapassando a altitude de 940 metros alcançada pelo Morro dos Castelhanos, divisor de águas entre as bacias do ribeirão das Enchovas e do ribeirão do Engenho, este na Baía dos Castelhanos. Os topos dos seus morros estão nivelados entre 700 e $800 \mathrm{~m}$ (nas estruturas alcalinas, os topos estão nivelados a 1.200 metros acima do nível do mar).

Assim, o relevo da ilha de São Sebastião é formado por grandes blocos de morros escalonados, com pequenas praias e planícies encravadas nos contornos mais proeminentes, que quase sempre ocorrem sobre rochas granito-gnáisssicas. Devido às declividades alta e muito alta, as vertentes são 
muito instáveis, apresentando alta suscetibilidade à erosão e a escorregamentos, refletindo as condições climáticas locais, típicas de todo o litoral sudeste do Brasil, com chuvas distribuídas por todos os meses do ano e concentração nos meses de verão. "Ilhabela sofreu várias alterações em sua paisagem no transcorrer dos séculos, resultando em desmatamentos e perda de horizontes superficiais de solo. Estas alterações podem ser notadas em toda a orla da ilha, não só na porção voltada para o canal de São Sebastião onde estes processos são mais intensos, mas também nos trechos voltados para o mar aberto onde cortes rasos da vegetação, associada a práticas de queimadas, efetuados ao longo de décadas, descaracterizaram o meio." (SMA - Secretaria do Meio Ambiente de São Paulo, 1998: 17).

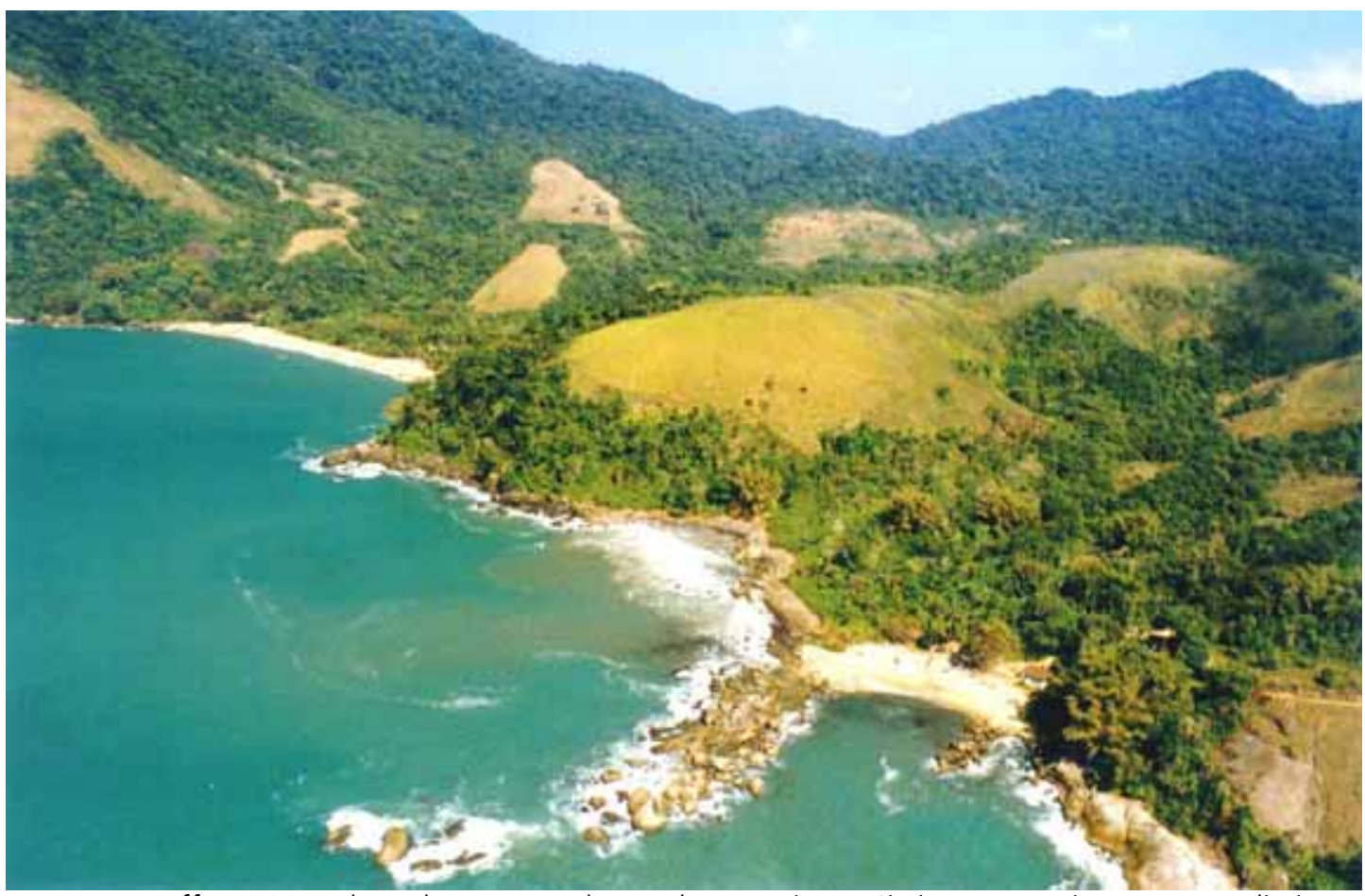

Foto 2, P. Noffs, 1988. Relevo de morros sobre rochas granito-gnáissicas nas praias Mansa, a direita, e Vermelha, a esquerda. Os campos de sapé desenvolveram-se sobre solos degradados por antigos canaviais do século XIX. As formações secundárias em estágios inicial e médio de recuperação da Floresta Ombrófila Submontana Densa que aparecem praticamente em toda a foto, indicam a extensão que os cultivos da banana, mandioca e de outras roças atingiram na região da Baía dos Castelhanos no transcurso do século XX. 


\section{Mapa 3 - Vegetação da llha de São Sebastião}

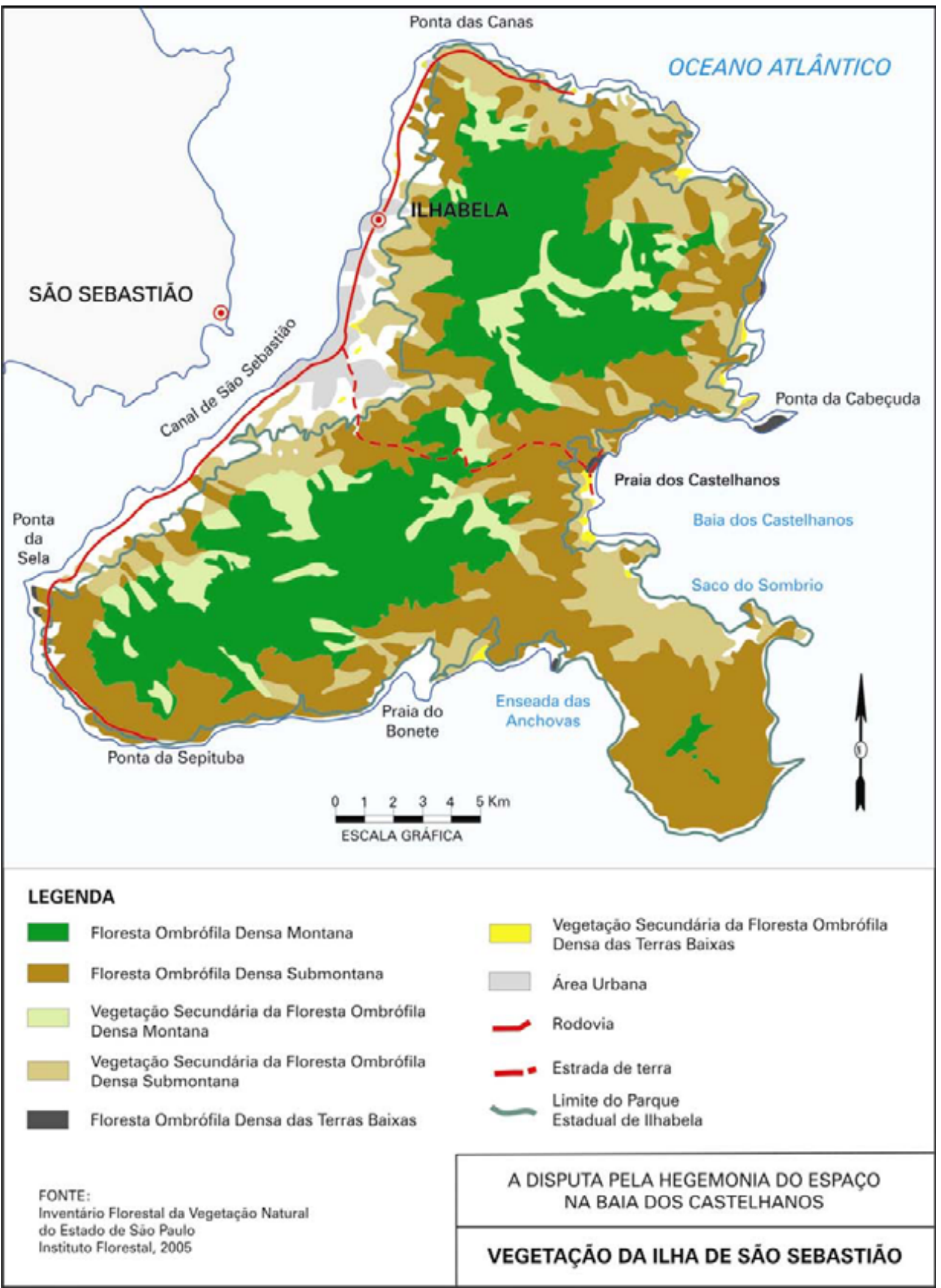


Efetivamente, no mapa 3 - Distribuição da Vegetação Natural na llha de São Sebastião, verifica-se a presença de formações florestais secundárias e de áreas sem cobertura de vegetação natural, indicando que no passado, porções consideráveis do município de llhabela foram desmatadas para o desenvolvimento de atividades agrícolas. A degradação da Mata Atlântica ocorreu de forma mais acentuada nos relevos próximos ao litoral e ao longo do canal de São Sebastião, afetando principalmente a Floresta Ombrófila Densa Submontana, a Floresta Ombrófila Densa das Terras Baixas e a Floresta Ombrófila Densa Montana. Chama a atenção a presença expressiva de vegetação secundária no interior da Floresta Ombrófila Densa Montana, sobre relevos escarpados a mais de 500 metros acima do nível do mar. (França em seu estudo sobre a Ilha se São Sebastião em 1951 já havia constatado que as plantações de café no século XIX atingiram terrenos até a cota $650 \mathrm{msnm}$ ). Segundo o Inventário Florestal da Vegetação Natural do Estado de São Paulo (SMA, 2005: 112, 113), o município de Ilhabela apresenta 29.704 ha $(88,4 \%$ de seu território) de vegetação natural, distribuída pelas formações Floresta Ombrófila Densa Montana, Floresta Ombrófila Densa Submontana, Floresta Ombrófila Densa das Terras Baixas e pelas Florestas Secundárias correspondentes a essas formações.

A Baía dos Castelhanos, na costa leste da llha, é resultado do processo de escavação das rochas granito-gnáissicas, que tende a removê-las do entorno das intrusões alcalinas. $\mathrm{O}$ trabalho combinado das erosões marinha e fluvial permite que o mar adentre a terra, já que uma promove o recuo das vertentes das montanhas e a outra escava a costa.

No fundo da baía está a praia dos Castelhanos, com sua planície formada por depósitos recentes, da era quaternária, de origem fluvial e marinha. Esta planície, juntamente com a do Perequê na costa voltada para o Canal de São Sebastião, são as duas únicas com alguma expressão em Ilhabela. O relevo de morros, que raramente alcança altitudes superiores a 300 ou 400 metros, contorna a planície e a baía. Nesta paisagem, separando as praias Vermelha e da Figueira, destaca-se o Morro do Costão. Trata-se de um grande bloco de granito aflorado, a cavaleiro da praia Vermelha. Do seu 


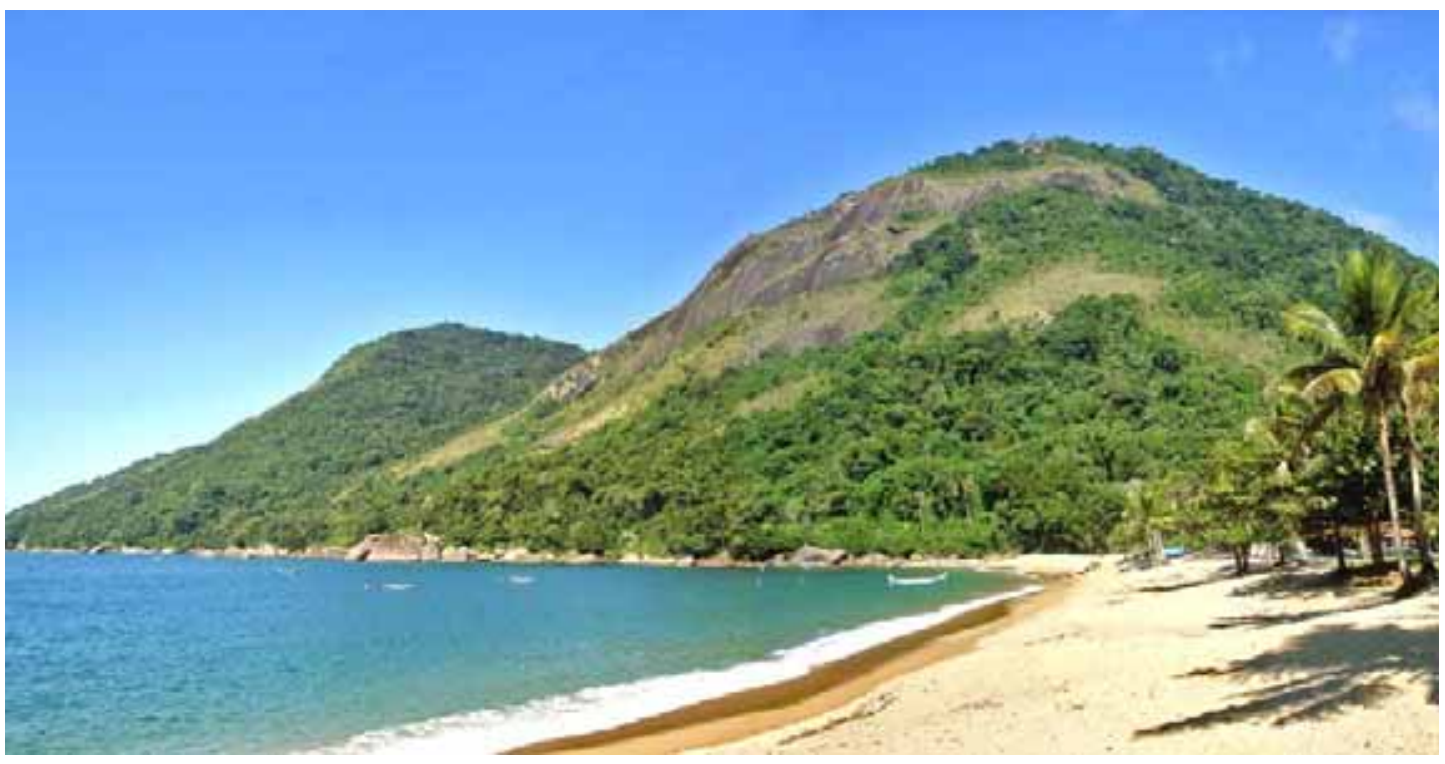

Foto 3, P. Noffs, 2007. Morro do Costão, um grande bloco de granito aflorado que separa as praias Vermelha e da Figueira.

cume, a 350m de altitude, avista-se toda a Baía dos Castelhanos, revelando uma deslumbrante paisagem. Em direção ao sul, ainda no interior da Baía, há o contato entre as rochas pré-cambrianas e as eruptivas da península do Boi. O Saco do Sombrio já se situa nesta última formação.

As feições mais notáveis do relevo da Baía dos Castelhanos são os vales do ribeirão do Engenho e de seu afluente, o córrego do Quilombo, dispostos na direção oeste-leste. Escavados profundamente nas rochas granitognáissicas pelo trabalho incessante da erosão de promover o recuo de suas vertentes em direção às cabeceiras, esses vales são os maiores responsáveis pela configuração do enorme anfiteatro que tão bem caracteriza a baía. 0 ribeirão do Engenho tem suas cabeceiras no Morro do Ramalho, aproximadamente a 900 metros acima do nível do mar. Seus afluentes da margem direita drenam a vertente norte do Morro dos Castelhanos. 0 córrego do Quilombo tem suas cabeceiras no Maciço da Serraria em altitudes também próximas dos $900 \mathrm{~m}$ e seus afluentes da margem esquerda escavam a vertente sul desse maciço. 


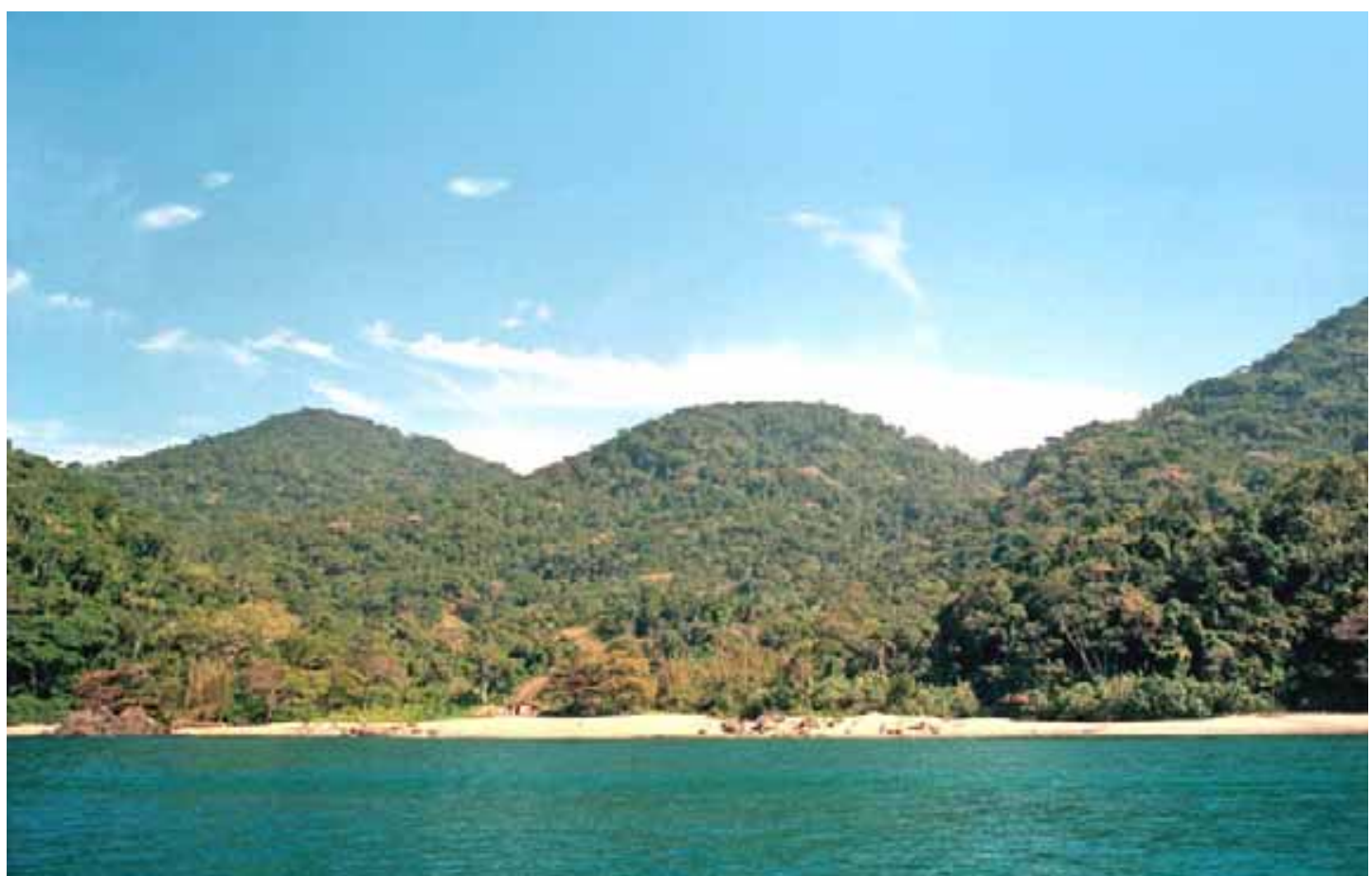

Foto 4, P. Noffs, 1997. Relevo de morros sustentado por rochas granito-gnáissicas contornando a Praia da Figueira. A Formação Secundária da Floresta Ombrófila Submontana Densa vêm se desenvolvendo sobre antigas áreas de roças e bananais.

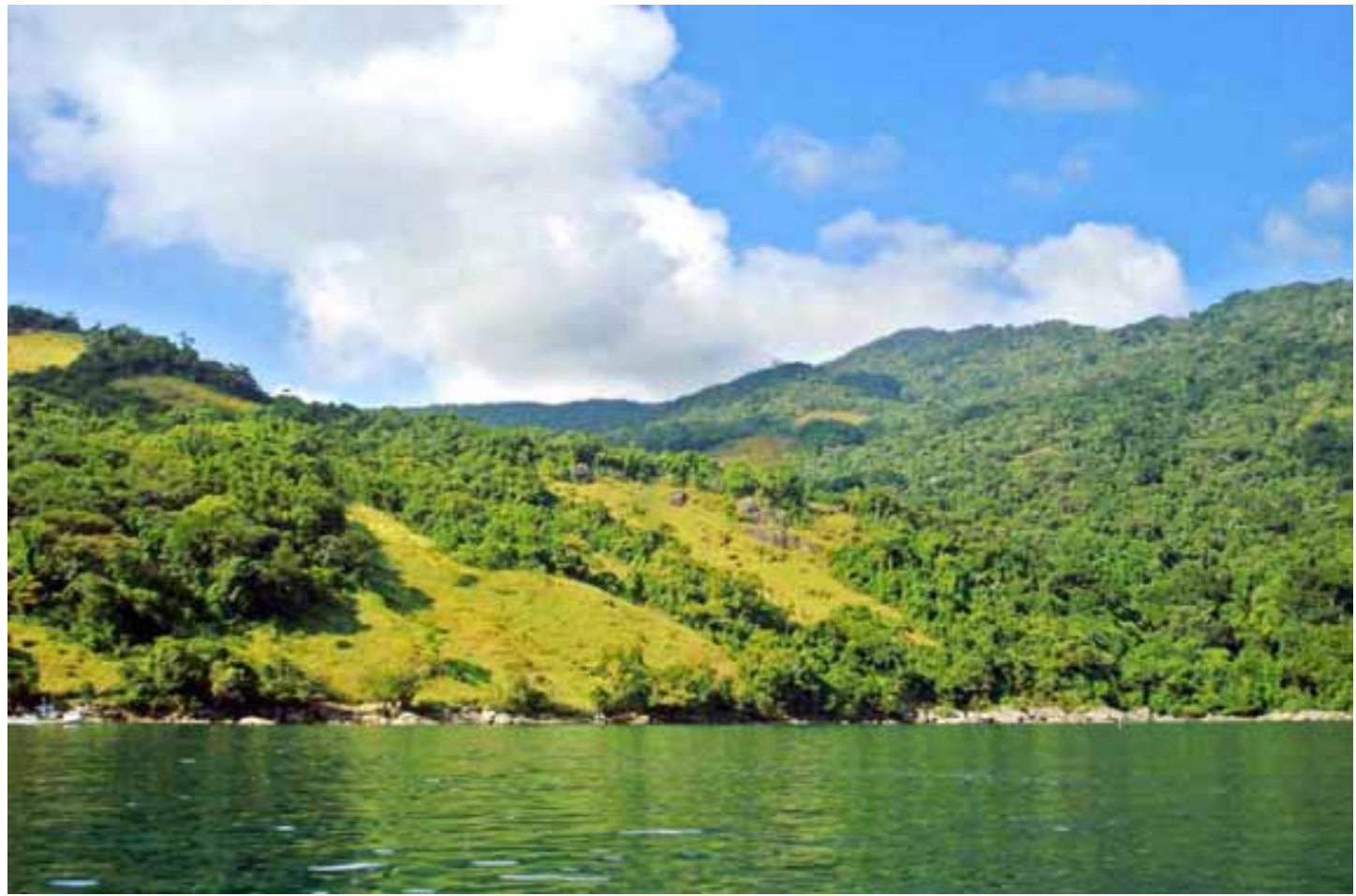

Foto 5, P. Noffs, 2007. Entrada oeste do Saco do Sombrio - Maciço da Península do Boi. Regeneração da Floresta Ombrófila Densa Submontana estendendo-se sobre relevos originados de rochas alcalinas em direção a Enseada das Enchovas. Os cultivos de cana-de-açúcar, mandioca e outros produtos da roça que foram cultivados desde antes do século XX na região do Saco do Sombrio, deixaram suas marcas no solo, dificultando a recuperação da vegetação natural. 
Dividindo as bacias dos dois cursos d'água, desce um esporão de serra, que desde o espigão central da ilha de São Sebastião vem perdendo altitude abruptamente, até se desfazer na planície dos Castelhanos, já bem próximo da linha da costa. Sobre ele foi construída a estrada de terra que liga a Baía dos Castelhanos ao bairro do Perequê e à cidade de Ilhabela. Dois outros córregos são importantes na configuração do referido anfiteatro: ao norte, o córrego da Praia do Gato, que tem seu vale principal aprofundado sobre terrenos ao sul do Maciço da Serraria, chegando suas nascentes a drenarem áreas acima da cota $1000 \mathrm{~m}$; ao sul, o córrego da Praia Mansa, que tem seu vale encaixado na vertente sul do morro dos Castelhanos. Podem ainda ser mencionados, os córregos da Cabeçuda, ao norte, e o da Praia Vermelha, ao sul. Os demais têm suas importâncias restritas ao fornecimento de água às populações residentes em suas bacias.

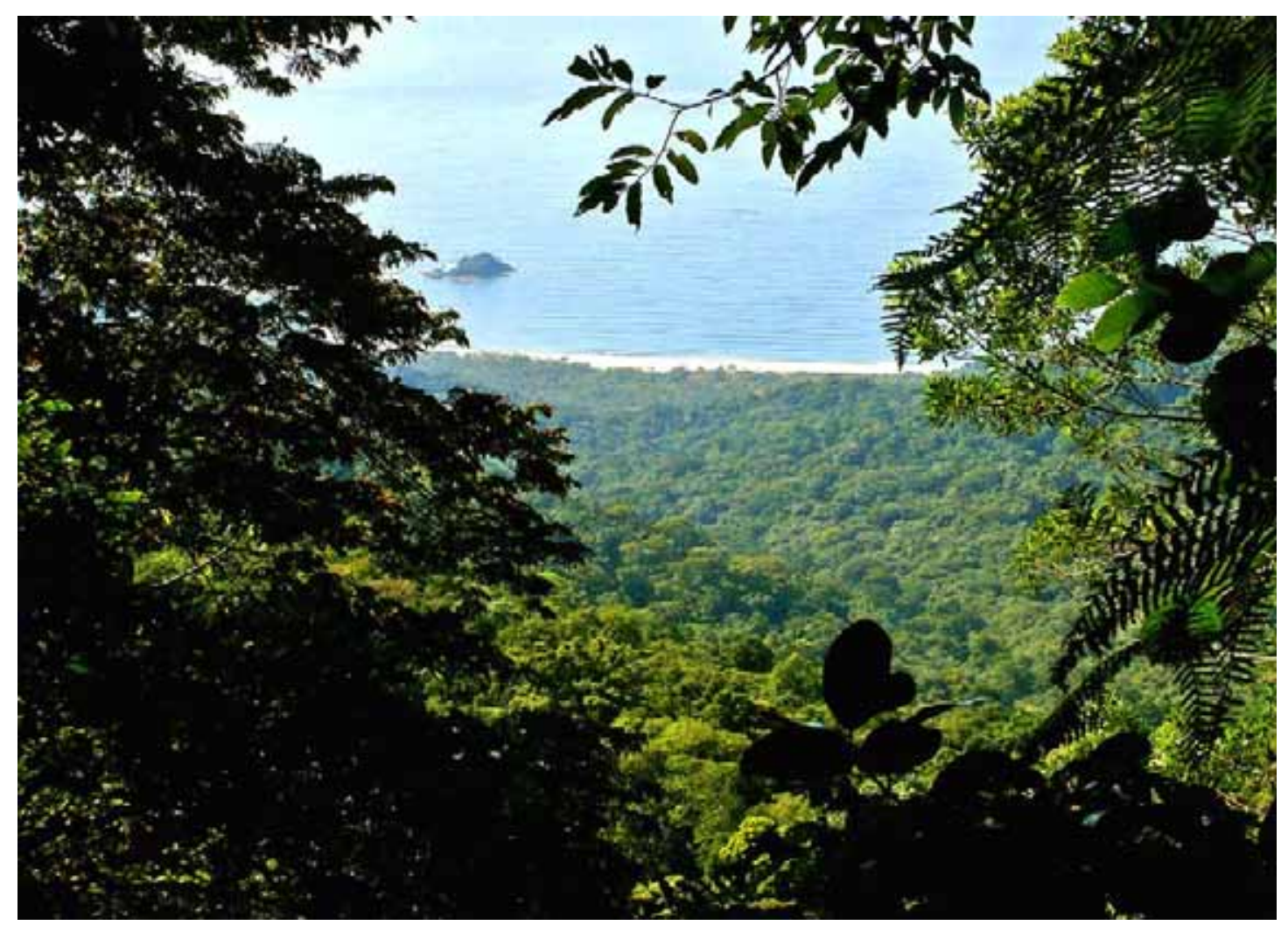

Foto 6, P. Noffs, 2007. Florestas Ombrólila Montana Densa e Ombrólila Submontana Densa desenvolvidas sobre o vale do ribeirão do Engenho na Baía dos Castelhanos. 
Preferencialmente sobre os morros, mas também nas planícies, desenvolveu-se toda a atividade agrícola da Baía dos Castelhanos. Atualmente, em decorrência da ocupação humana pretérita, surgem, sobre eles, as florestas secundárias e os campos de sapé, os quais sofreram sucessivas queimadas que impediram a regeneração florestal. Dominando a baía, mas ocorrendo nos relevos mais escarpados e distantes do litoral, está a floresta primária com as formações Floresta Ombrólila Montana Densa e Floresta Ombrólila Submontana Densa. As "fruteiras" nos quintais das casas e uma ou outra roça de mandioca nos morros, de tamanho quase sempre inferior a um hectare, não deixam esquecer o passado, quando essa região teve uma presença significativa na história de llhabela.

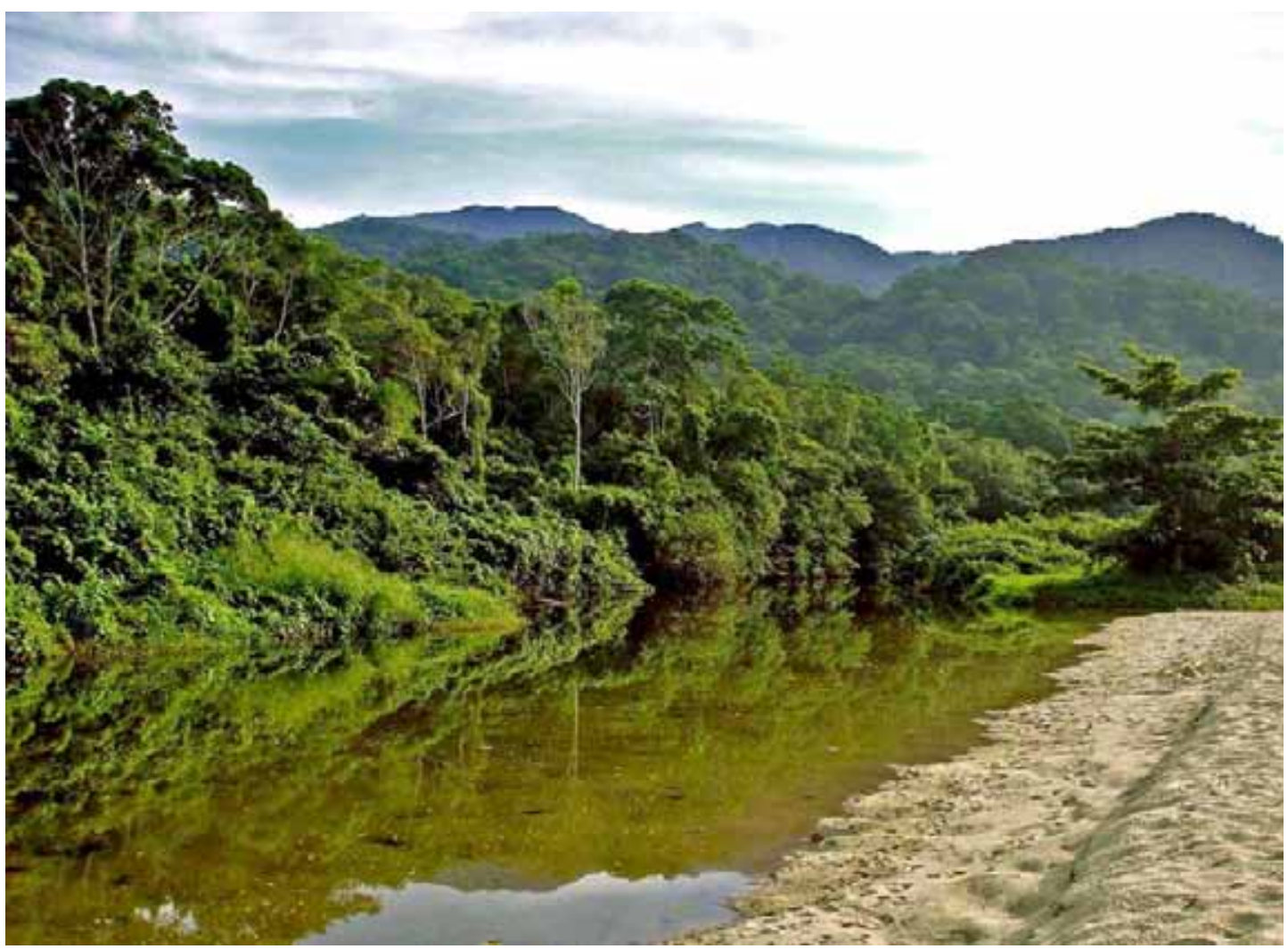

Foto 7, P. Noffs, 2007. Regeneração da Floresta Ombrófila Densa das Terras Baixas sobre a Planície dos Castelhanos na foz do ribeirão do Engenho. No mapa acima. esta área foi apresentada como Floresta Ombrófila Densa das Terras Baixas, mas até o meados da década de 1960, estava cultivada com canade-açúcar para a produção de pinga. Observa-se, ainda ao fundo, a Formação Secundária da Floresta Ombrófila Densa Submontana e o contorno de um trecho do Maciço da Serraria. 


\section{FORMAÇÃO TERRITORIAL}

A ocupação de llhabela teve início ainda no século XVI, com o plantio da cana para produção de açúcar, que constituiu o principal produto de exportação local até as primeiras décadas do século XIX. Como os demais municípios do Litoral Norte, sofreu influência, durante o século XVIII, da exportação do minério de ouro, oriundo das Minas Gerais e com destino aos portos de São Sebastião e Ubatuba, porém, as bases efetivas para a ocupação de seu território foram propiciadas pela cafeicultura.

\section{a) As Plantações de Café}

O café foi introduzido no Litoral Norte, inicialmente, em Ubatuba, por volta de 1770, expandindo-se em seguida para São Sebastião e Ilhabela, alcançando, ainda na primeira metade do século passado, um grande surto de desenvolvimento. Muitos foram os fatores que contribuíram para isso, destacando-se dois:

1- a presença de portos nas cidades de Ubatuba e São Sebastião, permitindo o embarque com destino ao Rio de Janeiro, de onde era exportado;

2- a facilidade dos fazendeiros locais de comprar, a preço reduzido, a mão-de-obra escrava. "...pode-se verificar como era fácil, em face da existência de portos negreiros, como os da Baía dos Castelhanos, adquirir mão-de-obra africana. Por preços insignificantes compravam-se negros doentes, julgados incapazes de vencer a subida da serra, pelas precárias condições em que chegavam ao porto de desembarque, depois de penosa viagem oceânica." (França, A., 1954:143)

Em 1836, quando o café já era o principal produto da então província de São Paulo, o Litoral Norte respondia por $14,2 \%$ de sua produção; era a região mais populosa e seus distritos rivalizavam com os mais prósperos do interior. 
A produção cafeeira atingiu o auge em llhabela no ano de 1854. Existiam, então, 225 fazendas, com 1.725 escravos, produzindo 1.647,50 toneladas de café (França, A., 1954: 145). No mesmo ano, São Sebastião produzia 1290 toneladas em 106 fazendas com 2185 escravos. (Almeida, P.,1959: 153).

A cidade de São Sebastião conheceu, neste período, uma fase de grande prosperidade - abertura de ruas, construção de novos edifícios assobradados e formação de numerosas fazendas. Verificou-se uma intensa cabotagem e as tropas de burros superlotavam o espaço que Ihes era destinado no porto. Entretanto, este fausto estava mais ligado ao escoamento dos produtos do Vale do Paraíba que à produção própria do município (Papy. L.,1957: 146).

A febre do café alastrou-se por llhabela. Novas fazendas foram abertas e antigos engenhos de açúcar fecharam, trocando suas plantações pela cafeicultura. Os cafezais subiram os morros até cotas superiores a $500 \mathrm{~m}$, estabelecendo limites territoriais que não foram ultrapassados por nenhuma outra forma de cultivo, anterior ou posterior a sua passagem.

Mas as terras e o clima do Litoral Norte não eram apropriados à cafeicultura que, restrita às exíguas baixadas litorâneas e às encostas próximas, não teve como se expandir. Os solos pobres, de baixa fertilidade, logo se exauriram, consumidos pela erosão e suas práticas agrícolas rudimentares. A região perdeu, ainda, com a abertura da Estrada de Ferro Central do Brasil, sua condição natural de exportadora da produção do Vale do Paraíba. As antigas rotas dos tropeiros, abertas ainda no período da mineração, que do Vale alcançavam Ubatuba (via Taubaté e São Luiz do Paraitinga) e São Sebastião (via São José dos Campos e Paraibuna ou Salesópolis), foram progressivamente abandonadas, pois as mercadorias passaram a ser transportadas por ferrovias para as cidades do Rio de Janeiro e de Santos.

Em contrapartida, pelo interior, o café avançava sobre matas virgens, conquistando novos espaços e introduzindo novas relações de trabalho para o desenvolvimento do capitalismo no Brasil. O regime de colonato, instalado nas novas áreas produtoras de café no interior paulista explica essa nova 
etapa e representa a adequação entre o capital e a introdução de relações de trabalho não tipicamente capitalistas.

A proibição do tráfego de escravos em 1850, agravou a crise de mão-deobra nas fazendas de café, subordinando os fazendeiros aos interesses de traficantes e banqueiros, aos quais hipotecava os escravos para obtenção de créditos. A abolição tornou-se uma bandeira para os fazendeiros, interessados no trabalho livre e em sua possibilidade de transferir à terra o capital imobilizado na pessoa do escravo. (Martins, 1979: 33)

A substituição do trabalho escravo no interior paulista foi possível com a vinda de imigrantes, principalmente da Itália, como parte de um amplo programa governamental. Foram introduzidos nas fazendas de café como colonos em substituição aos trabalhadores cativos. O colono devia realizar tarefas na propriedade do fazendeiro durante alguns anos antes de adquirir o direito de obter a sua própria propriedade.

Passava a existir concretamente a possibilidade de se investir na formação de novas fazendas. Frentes pioneiras desdobraram-se sobre terras virgens a procura dos melhores solos e distâncias foram encurtadas com a expansão da rede ferroviária a partir de 1866.

Enquanto no interior de São Paulo a utilização da mão-de-obra escrava era superada pelo trabalho livre, no Litoral Norte a abolição desferia o golpe final em uma economia que, sustentada pelo contrabando de escravos em Ilhabela, não encontrava mais fôlego em produzir para exportação. Logo após a abolição,um grande contingente de população, constituído basicamente por negros, migrou, principalmente para Santos, à procura de melhores condições de trabalho (Almeida, 1959: 203).

Assim, no final do século XIX, os portos do Litoral Norte se esvaziaram e embarcações de porte já não atracavam mais (Almeida, P., 1959: 156). O significativo intercâmbio que as cidades da região mantinham com as principais cidades do Brasil e até mesmo com algumas do exterior, entrou em declínio e rapidamente desapareceu. 


\section{b) A Aguardente e as Canoas de Voga}

Concomitante ao declínio do café, ocorreu uma tímida retomada do cultivo da cana. Ao contrário do período colonial, quando o objetivo era produzir açúcar, agora as plantações estavam voltadas à produção da aguardente. Em poucas décadas, as áreas anteriormente ocupadas com café, quando não foram retomadas pela floresta, viram-se substituídas, principalmente pelos cultivos da cana, e ainda pela pequena produção familiar de alimentos, cujo excedente também era destinado ao comércio.

As almanjarras (engenhos de açúcar movidos à tração animal) do período colonial foram substituídas pelos engenhos de "roda d'água", mais adequados à produção de pinga. Estes proliferaram por todo o Litoral norte $\mathrm{e}$ em Ilhabela, chegando ao número de trinta e seis na segunda década do século XX. As famílias que possuíam pequenas glebas cultivadas "davam sua cana para ser 'moída a terça' no engenho, sendo-lhes devolvidos dois terços do produto resultante, dos quais, aliás o próprio dono do engenho era o comprador." (Mussolini, G., 1980:224)

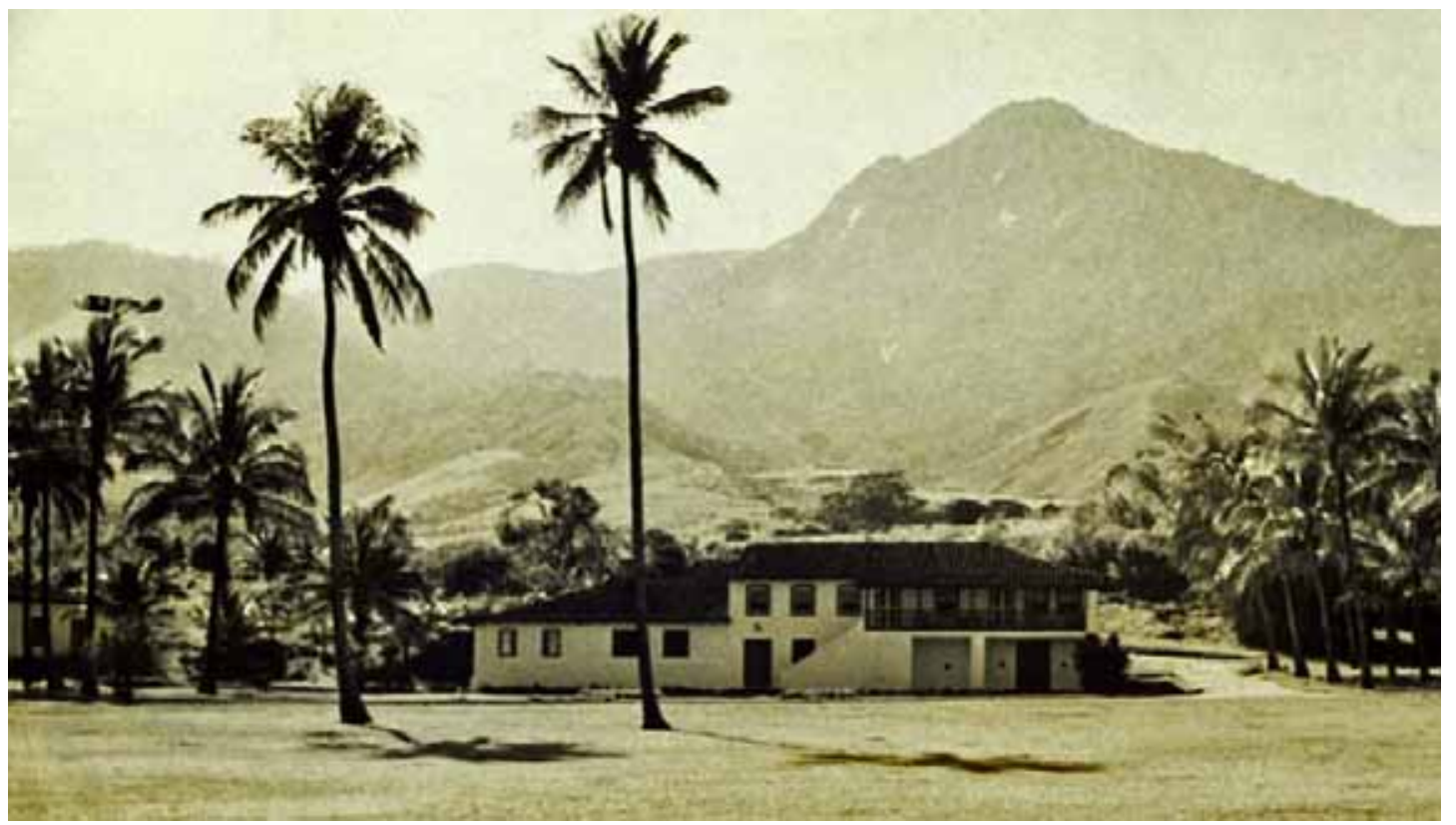

Foto 8, jornal Folha de São Paulo, 1966. A fazenda Engenho D’água no município de llhabela foi uma das mais importantes produtoras de aguardente do Litoral Norte. Destaca-se a intensa degradação a que foram submetidos os relevos de morros e de montanha e a vegetação natural pelos sucessivos cultivos de cana e café na região.(fotografia de 1966 do quando o engenho ainda estava em produção) 
À medida que as grandes embarcações abandonavam os portos de Ubatuba e São Sebastião, um sistema de transporte bastante peculiar era organizado, principalmente pelos donos de engenho, basicamente para levar a aguardente das áreas produtoras do litoral (essencialmente localizadas na Ilhabela) para a cidade de Santos: as canoas de voga. "Associadas à produção da aguardente, chegaram até os nossos dias as canoas de voga, tão célebres do Rio de Janeiro para o sul, quanto as jangadas ou as barcaças no Nordeste, também associadas à produção dos engenhos. Canoas que chegaram a atingir tão grandes proporções, principalmente nas costas de Santa Catarina e São Paulo, que neste último Estado podiam transportar até 14 pipas... Feitas de um só tronco escavado pacientemente a machado, enxó e mesmo a fogo herança indígena que é, e a forma mais generalizada de embarcação no Brasil - são também conhecidas por 'canoas bordadas', diferindo das comuns por serem dotadas, de popa a proa, de um bordo sobressalente que lhes aumenta a capacidade, pela forma de seus remos e pelo fato de estes se encaixarem em cavidades especiais, existentes nos bordos para este fim. ". (Mussolini, G., 1980: 225).

Contemporânea dos transportes ferroviário e rodoviário, uma canoa de voga levava aproximadamente 20 dias para realizar uma viagem, ida e volta, entre a ilha de São Sebastião e Santos e transportava, em média, $5.000 \mathrm{~kg}$ entre passageiros e mercadorias.

As canoas de voga não atendiam apenas aos engenhos. Abasteciam de mercadorias diversas (querosene, sal, roupas, ferramentas, etc.) os povoados dispersos pelas praias e costeiras do litoral Norte e recolhiam os excedentes da lavoura e da pesca para serem vendidos em Santos. As canoas de voga de Ilhabela ficaram famosas por buscarem carregamento de aguardente em outros municípios, chegando até Parati, no Rio de Janeiro, de onde seguiam para Santos. Os marinheiros ganhavam $15 \$ 000$ para remarem e transportavam por conta "a quitanda" -ovos, peixe seco, laranja, etc. (Mussolini, G., 1980: 225).

A llhabela foi o principal centro de construção dessas embarcações e as exportava para as demais localidades do Litoral Norte. Chegou a possuir uma frota de 38 canoas. Estima-se que a frota transportava anualmente, de Ilhabela para Santos, de 500 a 800 toneladas de mercadorias. 
Este sistema de transporte durou até o final da década de 20, quando embarcações a motor passaram a procurar as águas do Litoral Norte em busca de pescado para o mercado de Santos. Em 1929 não havia mais nenhuma canoa de voga na rota Ilhabela - Santos.

Organizado pelos produtores de cada praia, o transporte pelas canoas de voga, produto do trabalho artesanal local, representou uma forma de resistência contra o isolamento econômico imposto pelo desenvolvimento do capitalismo, que privilegiara outras áreas do Brasil para sua realização. Estimase entre 500 a 800 toneladas o montante de mercadorias que era transportado anualmente de Ilhabela para Santos pelas canoas de voga (França, A., 1954: 147).

\section{c) Os Cercos Flutuantes do Saco do Sombrio}

Por volta de 1920 os japoneses introduziram no Saco do Sombrio, pequeno porto pesqueiro situado na Baía dos Castelhanos, os primeiros cercos flutuantes do Brasil. Os cercos não passam de armadilhas engenhosas instaladas próximas aos costões, constituídas por redes fixas dispostas em forma de uma grande elipse e que são mantidas flutuando por gomos de taquaruçu. Os peixes são capturados vivos nas "visitas" que os pescadores realizam para a despesca, com o auxílio de duas canoas, três a quatro vezes por dia.

Rapidamente estas redes de pesca expandiram-se por llhabela e posteriormente por toda a costa norte do litoral paulista.

Praticada com técnicas e formas variadas ao longo da história, nenhum tipo de pesca nunca foi tão importante para o Litoral Norte como a dos cercos flutuantes. A partir do Saco do Sombrio, os japoneses introduziram uma nova dinâmica no Litoral Norte. Enquanto os pequenos produtores caiçaras praticavam a pesca com técnicas rudimentares e comercializavam apenas os eventuais excedentes, os japoneses a praticavam em bases capitalistas. A chegada contínua de novos imigrantes, ampliando as comunidades nipônicas estabelecidas no planalto, garantia um mercado estável para a produção de pescado. 
Os japoneses tornaram-se empresários da pesca. Foram proprietários das traineiras (muitas equipadas com câmaras frigoríficas) e dos cercos, construídos por eles próprios. Empregavam os caiçaras na produção e no transporte do pescado e as mulheres nas fábricas de conservas instaladas em São Sebastião. Introduziram vários melhoramentos na agricultura, como as hortas e o sistema de adubação do solo aproveitando restos de pescado.

Após alguns anos de pesca ruim ou, mais provavelmente, pela eclosão da segunda Grande Guerra, os japoneses retiraram-se do Sombrio e do Litoral Norte. As hortas desapareceram, mas os cercos ainda hoje são encontrados em todo o Litoral Norte de São Paulo e sul fluminense.

\section{d) Os Bananais e o Cotidiano Caiçara na Década de 1950}

Das outras atividades agrícolas desenvolvidas no Litoral Norte, merece destaque a exploração da banana prata. Da costa sul de São Sebastião ao extremo norte de Ubatuba, esta variedade era cultivada em pequena escala, muitas vezes na sombra da mata. Transformou-se, em pouco tempo, após a decadência dos engenhos de aguardente (assunto que será tratado mais adiante), na principal agricultura caiçara. A pequena produção familiar da banana, junto com o peixe e a farinha de mandioca, além do seu aspecto essencial na alimentação da população, constituiu a atividade comercial. A exemplo das roças de produção de alimentos, era cultivada em condições totalmente rudimentares, sem nenhuma técnica de conservação, correção ou melhoramento dos solos. Explorada em pequenas glebas abertas no meio da mata, quase sempre nos morros, em terrenos acidentados e úmidos, esta variedade de banana apresentava qualidade e produtividade incertas e era destinada basicamente ao mercado de Santos.

A banana produzida no Litoral Norte era recolhida, praia por praia, por pequenas embarcações motorizadas que, de resto, abasteciam, principalmente de bebidas e latarias, as diversas "vendas" espalhadas por suas praias e costeiras. 
Após a abertura da rodovia Bertioga - São Sebastião em 1962, o transporte da banana passou a ser feito basicamente por caminhões e os bananais da costa oceânica de Ilhabela foram abandonados.

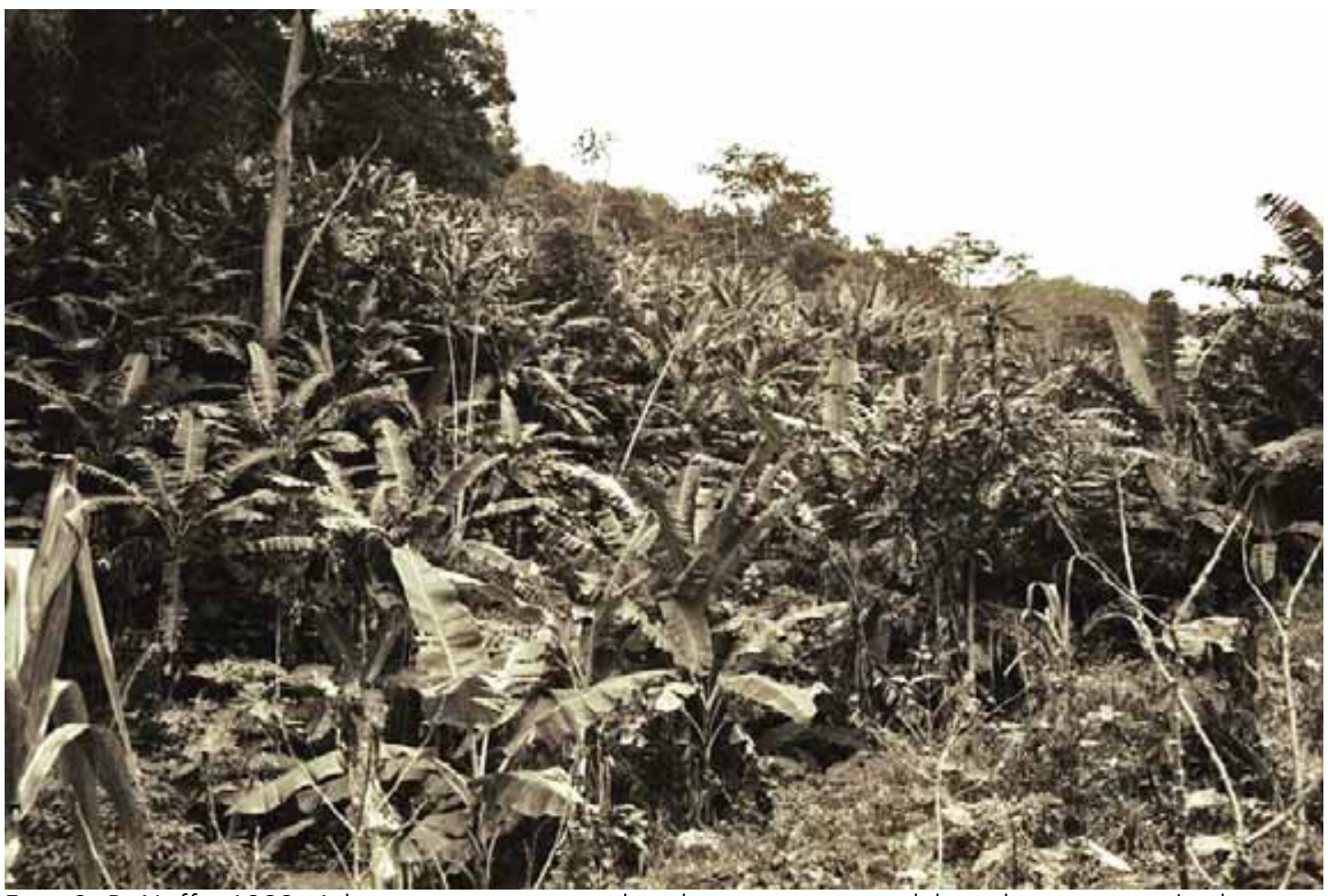

Foto 9, P. Noffs, 1988. A banana prata era explorada em pequenas glebas abertas no meio da mata, quase sempre nos morros, em terrenos acidentados e úmidos, como este na praia do Toque Toque Pequeno, na costa sul de São Sebastião.

\section{e) As Estradas e o Turismo}

Em 1939 foi inaugurada a rodovia dos Tamoios (SP-99), interligando Caraguatatuba e São José dos Campos e, nos anos 60, a SP-125 interligando Ubatuba e Taubaté. Em 1955 foi entregue ao tráfego o trecho completo entre São Sebastião, Caraguatatuba e Ubatuba (SP-55). Enquanto esses lugares podiam ser atingidos por automóveis, caminhões e ônibus, as localidades ao norte de Ubatuba, ao sul de São Sebastião e toda a Ilhabela dependiam de embarcações para realizar o transporte de pessoas e mercadorias.

$\mathrm{Na}$ década de 50 teve início o processo de urbanização das praias do Litoral Norte com as primeiras casas para turistas. O capeamento da rodovia 
dos Tamoios e da ligação São Sebastião, Caraguatatuba e Ubatuba no início da década de 60, aumentou o movimento de turistas à procura das praias nesse trecho do litoral, intensificando a dinâmica da transformação do solo rural em urbano. Na mesma época foi precariamente aberta a rodovia de terra de São Sebastião a Bertioga, permitindo a ligação de Santos com as cidades do Litoral Norte. Complementando a infra-estrutura viária, em 1964 as praias de Ilhabela, situadas ao longo do canal que a separa do continente, passaram a ser acessíveis aos automóveis com a inauguração do serviço de balsas que realiza a travessia da Barra Velha, nesse município, até o porto de São Sebastião.

As praias entre as cidades de São Sebastião e Ubatuba, principalmente as de Caraguatatuba, foram as mais favorecidas, intensificando, no início da década de 60, a transformação do solo rural em urbano promovida pelo desenvolvimento das atividades de turismo, o que imprimiu uma vigorosa mudança na economia local.

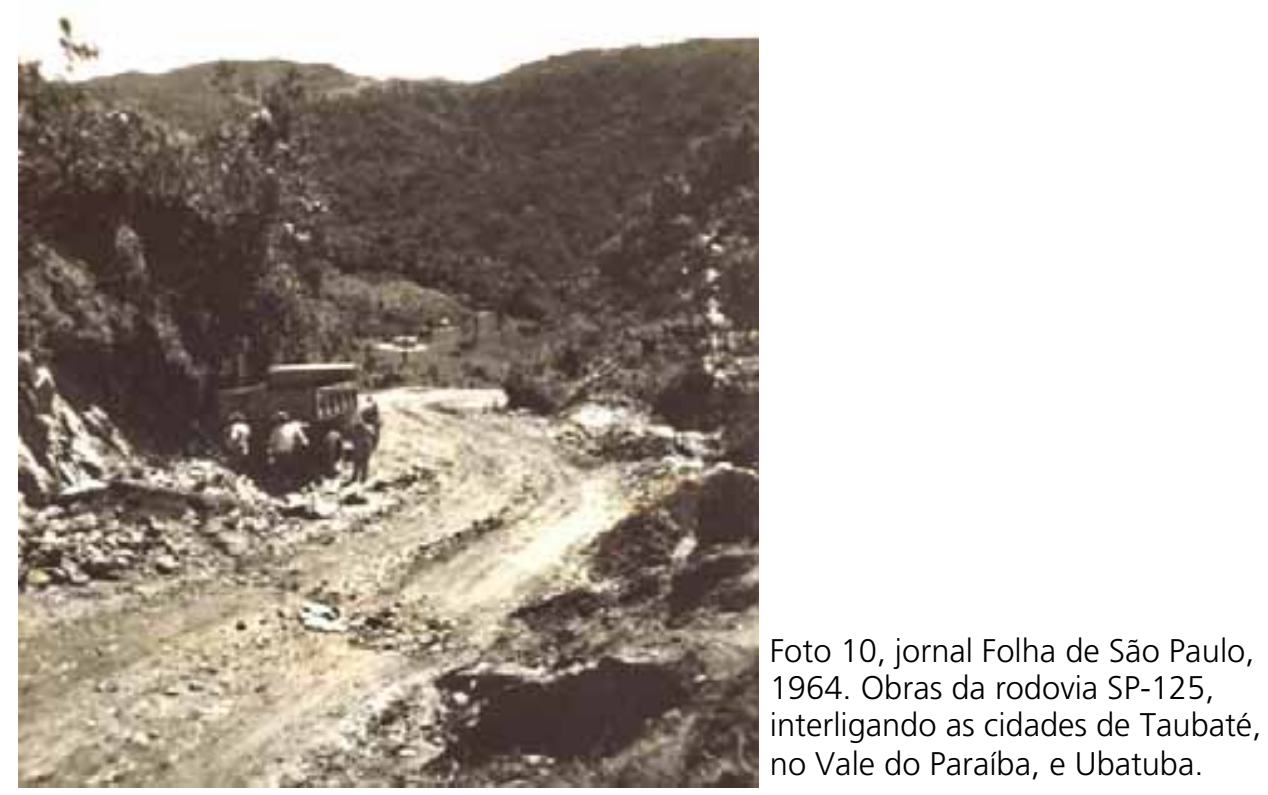

Em 1977 foi aberta a estrada para a praia dos Castelhanos, a partir do bairro do Perequê, na costa interna de Ilhabela (ou costa do canal). As demais localidades da baía continuaram sem acesso rodoviário. Mantida sempre em 
condições precárias, esta rodovia somente permite a passagem de jipes ou de veículos com tração nas 4 rodas.

Na primeira metade da década de 1980, o trecho da rodovia SP - 55 entre Bertioga e São Sebastião foi complementado e asfaltado, permitindo a interligação do Litoral Norte com a Baixada Santista e com o sistema viário Anchieta - Imigrantes, fato que impulsionou ainda mais o turismo e a urbanização na região de Ilhabela e São Sebastião, dando os contornos que esse litoral tem atualmente.

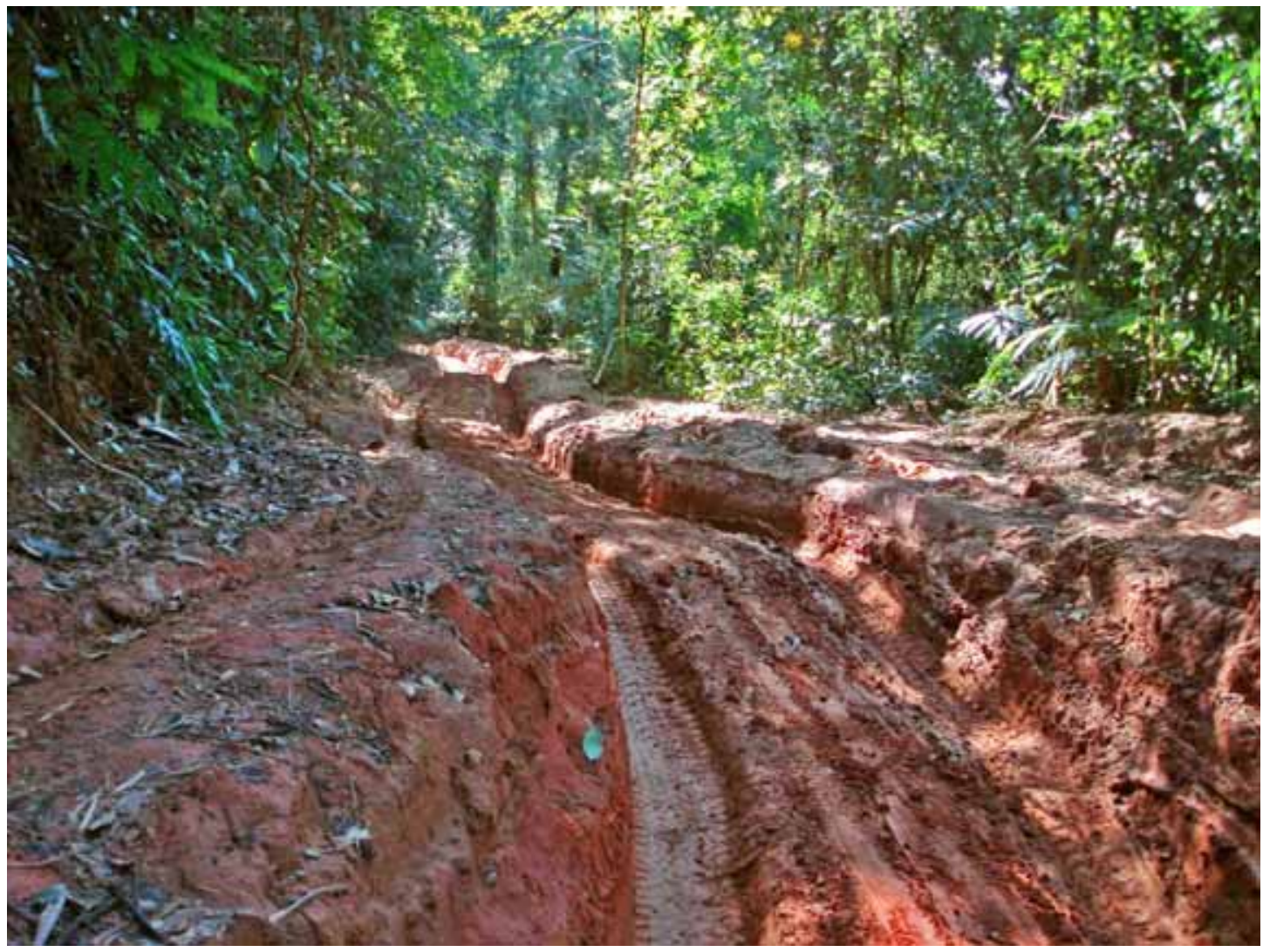

Foto 11, P. Noffs, 2007. Estrada de terra Perequê - Castelhanos em péssimo estado de conservação. Mesmo veículos com tração nas 4 rodas encontram muitas dificuldades para trafegar, principalmente na vertente da serra voltada para esta praia. Para a atual condição de tráfego, pode-se considerar que a Baía dos Castelhanos não tem acesso rodoviário. 


\section{CAPÍTULO 2 - FUNDAMENTOS CONCEITUAIS}

Várias abordagens são possíveis para investigar a transformação do espaço da pequena produção mercantil em espaço urbano do turismo na Baía dos Castelhanos. Duas delas podem ser destacadas:

\section{1- COMUNIDADES TRADICIONAIS}

Pesquisadores, ligados tanto à sociedade quanto à natureza, consideram os caiçaras inseridos no universo das Populações (ou Comunidades) Tradicionais. Apesar da qualidade inegável de alguns trabalhos produzidos por essa corrente, o conceito em que se baseiam apresenta muitos problemas. De acordo com Esterci "populações tradicionais é como têm sido chamados aqueles povos ou grupos que, vivendo em áreas periféricas à nossa sociedade, em situação de relativo isolamento face ao mundo ocidental, capitalista, construíram formas de se relacionar entre si e com os seres e coisas da natureza muito diferentes das formas vigentes na nossa sociedade... esses povos ou grupos, que podem ser muito diferentes entre si, já eram conhecidos através de uma multiplicidade de outros termos que, ora indicavam sua atividade econômica mais visível, ora indicavam sua origem étnica, ora se referiam aos espaços que habitavam ou a aspectos de sua cultura e seu modo de vida. Eram pescadores, seringueiros, babaçueiros, quebradeiras de coco, índios, quilombolas, varjeiros, ribeirinhos, caiçaras...". Ainda segundo esta autora "cada um dos povos referidos como tradicionais tem uma identidade, uma história partilhada, uma memória e um território. Enquanto as áreas que ocupavam não atraíam a cobiça de segmentos sociais mais poderosos, eles construíram suas próprias leis de acesso à terra e aos recursos da natureza (grifo meu), assumindo o controle de extensões mais inclusivas - os territórios - dentro dos quais se situavam tanto áreas de uso e domínio particular quanto áreas de uso e domínio comuns. $O$ acesso a esses territórios é fortemente condicionado à pertinência ao grupo, definindo-se através de 
laços de parentesco, compadrio ou vizinhança, de uma vivência histórica e uma memória, partilhadas - bases da construção da identidade e da distinção com relação aos de fora (grifo meu). (Esterci, 2005: 179)

Enunciado dessa forma, o conceito mostra-se frágil, com a autora querendo nos fazer acreditar em uma força invisível, que dá a mesma substância e organicidade a populações que têm origens diferentes, tanto espacial quanto historicamente, no território brasileiro. Também quer que acreditemos na existência de dois Brasis. Um, ocidental, capitalista, constituído de cidades, indústrias, lavouras comerciais, trabalhadores urbanos e rurais, empresários etc., de onde os segmentos sociais mais poderosos ambicionam os "territórios" do outro Brasil, ocupados pelas "populações tradicionais". Esse Brasil das comunidades tradicionais parece não ter história e nem economia, ao menos, economia moderna, produtora e consumidora de mercadorias. Ou usando suas próprias palavras, cada comunidade tem seu território e sua história, mas esta, muito associada ao mundo natural, limita-se a um passado imediato que alcança apenas algumas gerações: seus integrantes sempre viveram assim, em harmonia com a natureza, produzindo seus meios de subsistência segundo leis específicas de se relacionarem entre si e com a terra. Ressalta-se: as populações identificadas pela autora como tradicionais, cada uma vive em seu próprio território, sobre o qual exercem domínio e poder. Dessa forma, por não se subordinarem a uma formação econômica e social de caráter mais geral que lhes dêem materialidade, na perspectiva de Esterci, as comunidades vivem num tempo indefinido e o que produzem e como produzem é apartado da história e da formação do Estado brasileiro. A autora trata de pessoas e lugares concretos, mas o espaço e o tempo das comunidades parecem acontecer em outra dimensão, descolada daquela onde habitam "os de fora", os que estão em consonância com o desenvolvimento do capitalismo no Brasil. É como se as populações tradicionais fizessem parte da natureza e não da sociedade. Assim, Esterci idealiza uma sociedade onde não há relações sociais de produção e nem de mercado. As comunidades se relacionam verticalmente diretamente com a terra e com a natureza e, em sua visão, dependem apenas disso para existirem. 
Diegues talvez seja o autor mais referenciado nas discussões sobre as comunidades tradicionais, principalmente por conta de seus trabalhos relativos à pesca e aos caiçaras de um modo geral. Para ele, o modo de vida caiçara é "entendido como a forma pela qual as comunidades praianas ou praieiras do sudeste organizam a produção material, as relações sociais e simbólicas dentro de um determinado contexto espacial e cultural. A produção material e não material da vida não são espaços separados, mas combinam-se para produzir seu modo de vida." (Diegues: 2004, 22) Tal como Esterci, sua consideração é indefinida por não explicar e nem dar concretude ao que sejam produção material e relações sociais e simbólicas. Assim, descreve apenas um modelo vazio que serve para qualquer sociedade ou segmento populacional, em qualquer lugar do mundo e em qualquer tempo.

Quanto ao território caiçara, Diegues define que é "o espaço litorâneo entre o sul do Rio de Janeiro e o Paraná onde se desenvolveu um modo de vida baseado na pequena produção de mercadorias que associa a pequena agricultura e a pesca, além de elementos culturais comuns, como o linguajar característico, festas e uma forma particular de ver o mundo." (2004: 24).

Aprofundando um pouco mais sua compreensão sobre as comunidades tradicionais, encontra-se: "As culturas tradicionais não são estáticas, estão em constante mudança seja por fatores endógenos ou exógenos, sem que por isso deixem de estar inseridas em um modo de produção que denominamos de pequena produção mercantil. A assimilação de determinados padrões de consumo da sociedade capitalista nos países capitalistas periféricos não significa necessariamente mudança radical de padrões culturais básicos, uma vez que toda cultura tem capacidade de assimilar elementos culturais externos." (Diegues, 2004: 41).

Dessa forma, para o autor, as populações tradicionais constituem formas próprias de organização social, cuja subsistência é garantida pela pequena produção mercantil. Para Diegues e Nogara, o "Modo de Produção da Pequena Produção Mercantil" tem uma história mais longa que a do Capitalismo e Feudalismo e afirmam que a ordem escravocrata e a feudal desapareceram, mas a pequena produção mercantil continua existindo." (Diegues e Nogara, 1999: 85). Esses autores também apresentam uma visão dualista da realidade brasileira, atribuindo ao "país" das comunidades 
tradicionais, aquele que se desenvolveu "perifericamente à sociedade capitalista", um modo de produção próprio, independente do modo de produção capitalista dominante. Ao fazerem isso, cometem um duplo equívoco. Primeiro, por não considerarem que a produção familiar de alimentos - ou produção camponesa, como é conhecida pela maioria dos autores, não é um modelo importado, algo que tenha se estabelecido no Brasil à margem do desenvolvimento capitalista. Ao contrário, como está analisada nas páginas seguintes, nasceu articulada ao mercado, complementarmente ao modelo agrícola da monocultura exportadora, principalmente pela necessidade de abastecer as populações urbanas de gêneros alimentícios. Segundo, por banalizarem o conceito de modo de produção, esvaziando-o de seu significado principal, que é a forma contraditória de como a sociedade se organiza para produzir valor (ou mercadorias, em se tratando da sociedade capitalista). No modo de produção das comunidades tradicionais não há relações sociais de produção. A organização social das forças produtivas, ou seja, o antagonismo entre classes ou categorias sociais e as relações contraditórias entre o trabalho a as formas de apropriação das riquezas (valores) produzidas, as estruturas de produção, circulação e consumo de valores de uso e de troca, o Estado e o aparato jurídico que regulamenta o funcionamento da sociedade, as formas de propriedade, inclusive a da propriedade privada da terra, e as condições de acesso aos recursos naturais, enfim, tudo isso deixa de figurar no "Brasil" das comunidades tradicionais. Seguindo a risca o que dizem os autores que trabalham com esse conceito, o caiçara Pedro Euzébio enquanto trabalhava no bananal do Sr. Barbosa na Praia dos Castelhanos, cuja produção era destinada ao mercado, vivia no Brasil do modo de produção capitalista. E quando trabalhava em sua própria roça, em terras cedidas pelo Sr. Barbosa, produzindo alimentos basicamente para o consumo da família, vivia em outro "Brasil", subordinado ao modo de produção da pequena produção mercantil.

Esterci afirma ainda que sendo "sua atividade produtiva muito dependente dos ciclos da natureza, eles (os pequenos produtores familiares) não criam grandes concentrações, e as áreas que habitam, tendo uma baixa densidade populacional, são as mais preservadas entre as áreas habitadas do 
planeta." (Esterci, 2005: 179). Para Diegues "o fato de não utilizarem a escrita, de serem sociedades em que o conhecimento é gerado e transmitido pela oralidade através de um linguajar particular; conhecerem os ciclos naturais e dependerem deles para sua sobrevivência; de viverem em pequenos aglomerados com atividades organizadas no interior de unidades familiares, em que as técnicas tem baixo impacto sobre a natureza (grifo meu), fazem que as comunidades caiçaras possam ser definidas como tradicionais." (2004: 22). Assim, ambos os autores acrescentam a preservação da natureza como uma das condições para uma população ser considerada tradicional, ignorando a erosão dos solos e a devastação florestal que sua agricultura (a dos caiçaras), que desconhecia o emprego de técnicas conservacionistas, promoveu sobre vastas porções do litoral do sudeste brasileiro.

Em relação ao meio ambiente, esquecem que as técnicas agrícolas utilizadas pelos caiçaras, principalmente nos cultivos de mandioca, cana e banana, não diferem daquelas praticadas tradicionalmente no restante do país (roça itinerante, cultivo morro abaixo, desmatamento e a queimada como técnicas de limpeza do terreno). França expõe com clareza o emprego dessas técnicas em llhabela: "...as culturas características são as das roças itinerantes, localizadas tanto nas planícies secas como nos morros. ... Consiste em derrubar um trecho da mata (capoeira ou capoeirão, geralmente), incendiar e em seguida explorá-la por alguns anos (dois a três nos morros, três a mais anos nas planícies, dependendo das culturas e da fertilidade do solo), e abandonálo por vários anos (nunca menos de quinze nas encostas e um nas planícies). $A$ vegetação selvagem retoma, então, a posse do solo, a menos que novos incêndios, praticados todos os anos (grifo meu) na estação seca, o impeçam. Nas vizinhanças das cidades e de povoados, é comum essa última prática, às vezes destinada a proporcionar pastos para algumas vacas leiteiras; mas geralmente sem finalidade alguma, pelo simples hábito de queimar." (França, 1954: 55)

Vastas extensões da Mata Atlântica em Ilhabela deram lugar ao cultivo da mandioca, cana e banana prata, e plantações dessa última são encontradas no litoral ainda hoje. Ao longo de todo litoral norte paulista e sul fluminense, os morros pelados, cobertos apenas pelo capim sapé, testemunham a grande 
atividade agrícola praticada pelos caiçaras, com emprego do fogo como técnica de limpeza do terreno, num passado não muito distante.

$\mathrm{Na}$ perspectiva dos autores, para os quais os caiçaras da Baía dos Castelhanos integram as Populações Tradicionais, as transformações sociais são entendidas como interferências externas do mundo ocidental, capitalista (interesses econômicos, cobiça dos poderosos, especulação imobiliária, turismo predatório etc.), - são os de fora, nos dizeres de Esterci - que tendem a desagregar a sua cultura e suas relações harmoniosas com a natureza. Para esses pesquisadores, os caiçaras querem continuar desenvolvendo suas atividades tradicionais, mas seu território está sendo invadido por interesses econômicos poderosos e é necessário organizar, de fora para dentro, a resistência à destruição de sua cultura. A gradativa transferência da posse da terra para os de "fora" faz parte de um amplo processo de expulsão dos caiçaras de seu território. "...já se processava o implacável movimento de destruição da economia caiçara e da expulsão dos posseiros tradicionais, numa ação concertada pelo grande capital paulista de especuladores e das transnacionais do turismo (...) a partir de então, a estrutura e posse da terra deixam de ser aquelas típicas de uma economia camponesa, do sistema de queimada e da roça de alimentos, desmanteladas cruelmente pelo capitalismo selvagem." (Marcílio, 2006: 61). Com essas palavras, se expressa com exatidão o pensamento sobre as comunidades tradicionais. Já não se trata apenas da existência de dois Brasis. Foi necessário acrescentar ao pensamento dualista, que um representa o país do bem e o outro, o do mal.
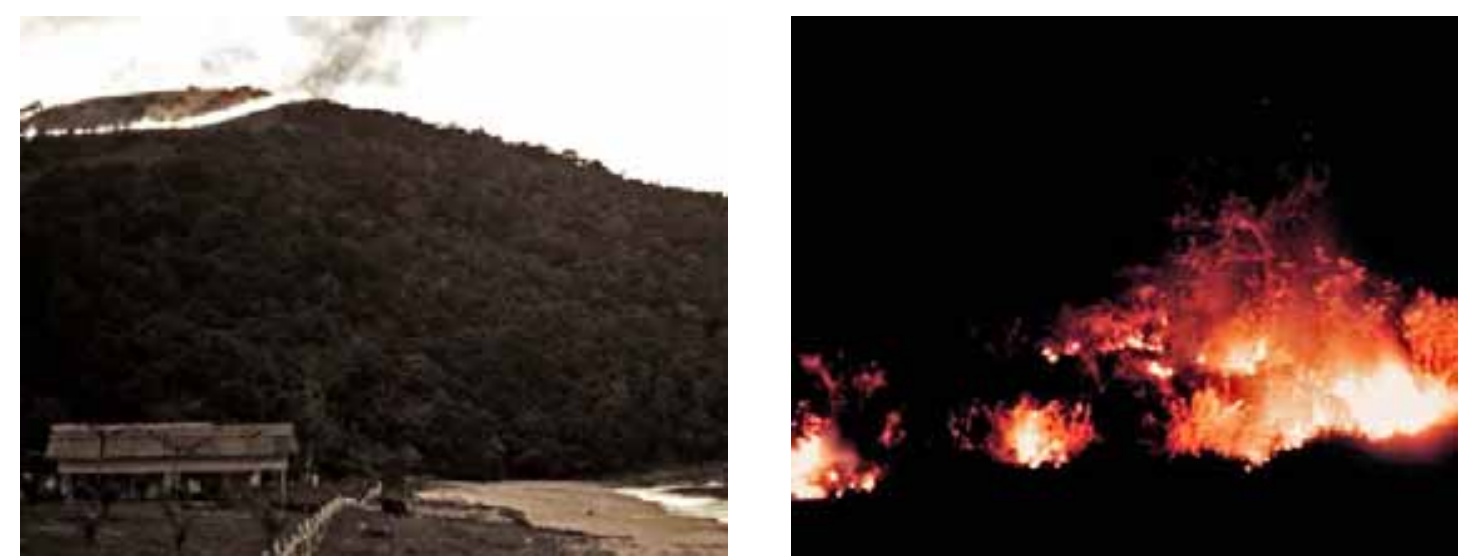

Fotos 12 e 13, P. Noffs, 1976. Qeimada em morro da praia do Toque Toque Pequeno, costa sul de São Sebastião. Às vezes era praticada sem finalidade alguma, pelo simples hábito de queimar. 


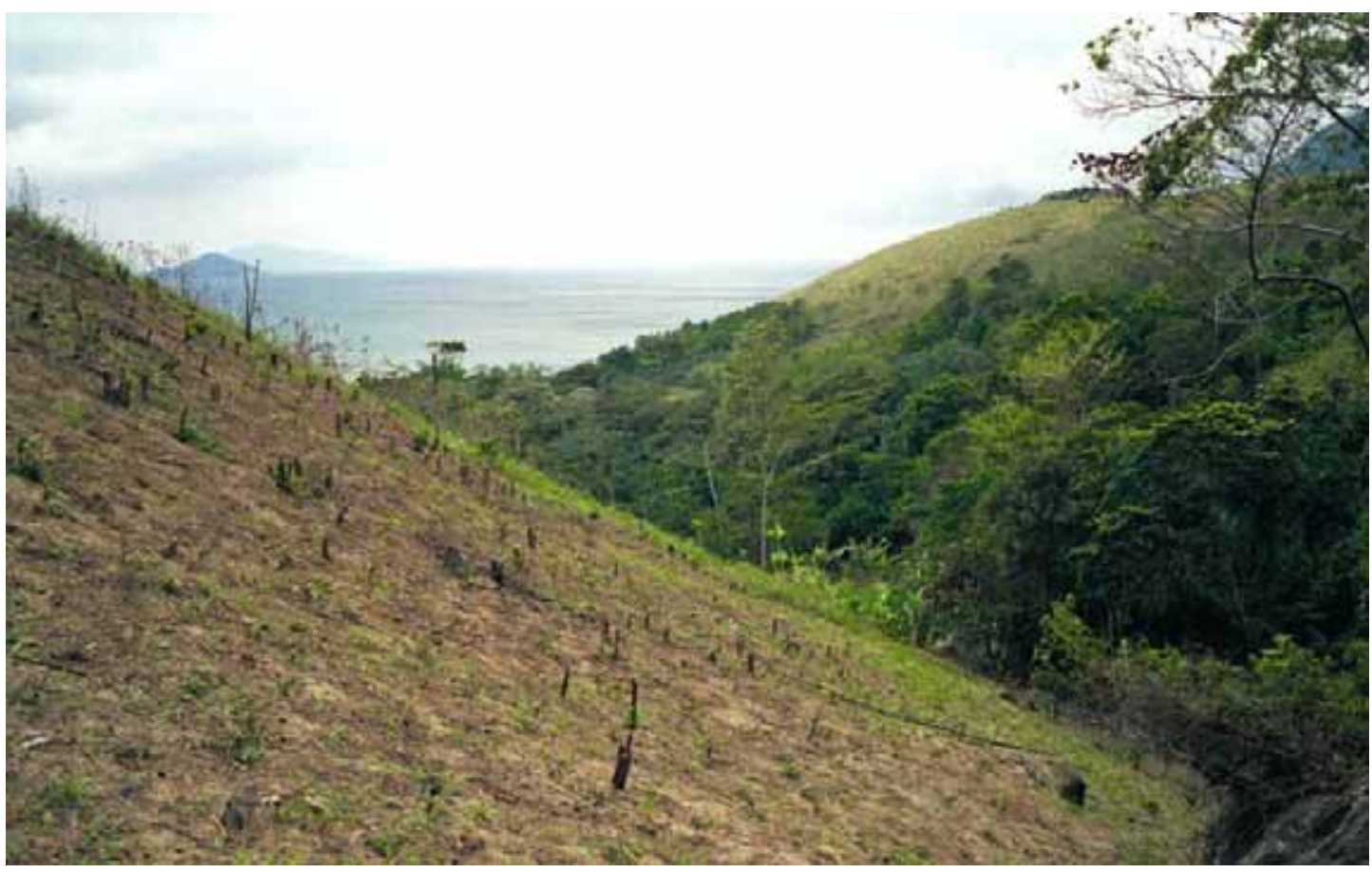

Foto 14, P. Noffs, 1996. Preparo da terra para o plantio de mandioca no sertão da Praia Mansa. A declividade acentuada do relevo, a queimada da vegetação como técnica de limpeza do solo e o plantio "morro abaixo" são práticas agrícolas que se opõem à noção de "baixo impacto sobre a natureza".

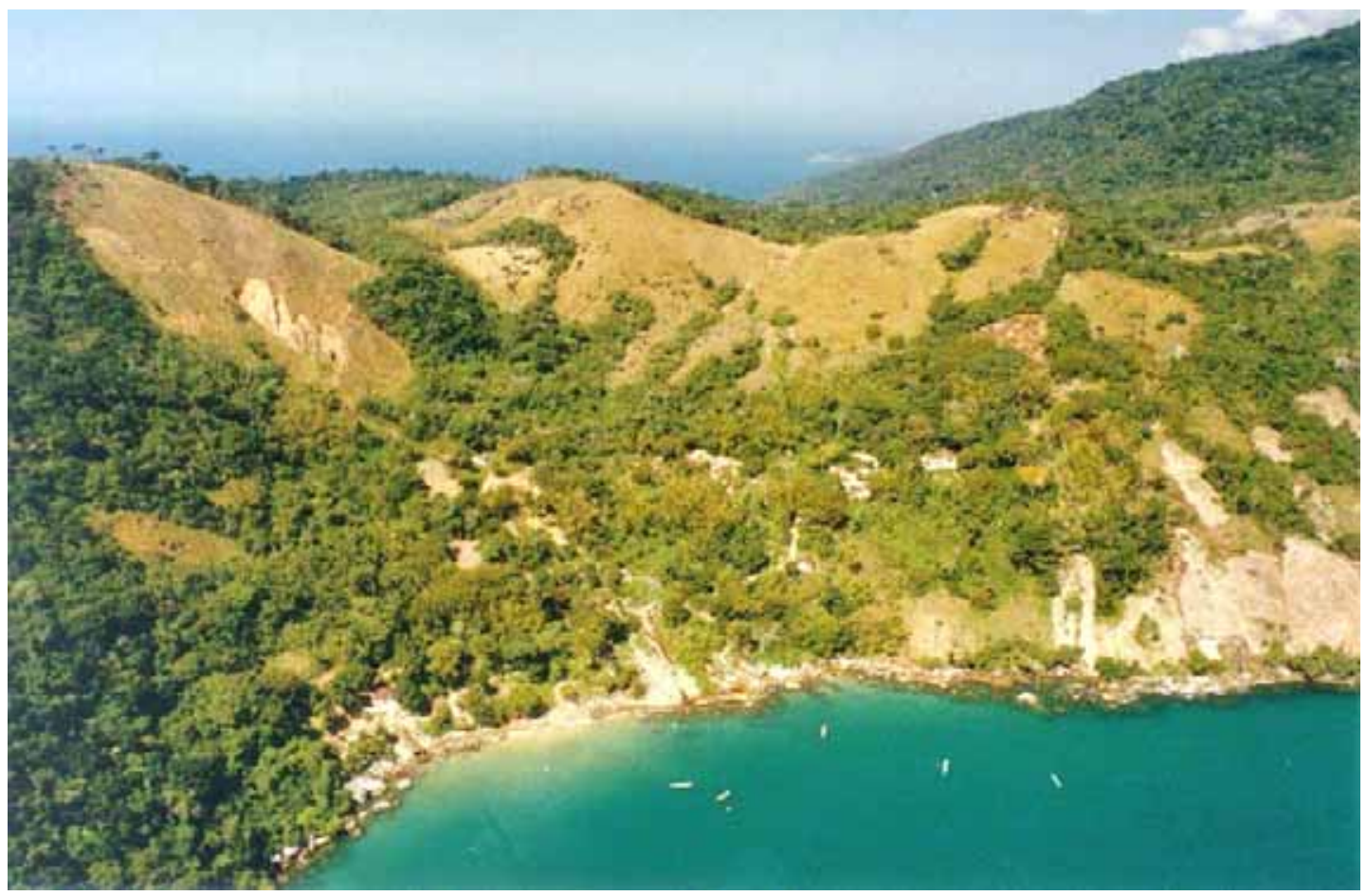

Foto 15, P. Noffs, 1988. Solos explorados até sua exaustão por cultivos de cana-de-açúcar e mandioca no Saco do Sombrio. Certamente estas áreas não estão entre as mais preservadas do Planeta. 


\section{2 - A VALORIZAÇÃO DO ESPAÇO}

O processo de valorização do espaço é outra abordagem possível (e adotada neste trabalho) para investigar as transformações que estão ocorrendo na Baía dos Castelhanos.

Inicialmente, é importante situar o caiçara no universo da produção mercantil simples, ou como preferem outros autores, do campesinato brasileiro. Segundo José Graziano da Silva são quatro os elementos fundamentais que definem a produção mercantil simples:

"a) utilização do trabalho familiar, ou seja, a família se configura como unidade de produção;

b) a posse dos instrumentos de trabalho ou de parte deles;

c) produção direta dos meios necessários à subsistência, seja produzindo alimentos para o auto consumo, seja produzindo (alimentos ou outras mercadorias) para a venda. Deve ficar claro que, embora a produção se destine em grande parte para o auto consumo, não se trata unicamente da produção de alimentos, por outro lado, não se trata de vender o que sobra do consumo, mas sim de realizar uma produção voltada para o mercado com a terra, a mão-de- obra e os meios de trabalho subtraídos da produção para a subsistência. Sob esse aspecto, a produção camponesa pode ser vista como uma produção mercantil simples;

d) não é fundamental a propriedade, mas sim a posse da terra, que mediatiza a produção como mercadoria. Sendo assim, não só o proprietário, como também o parceiro, o arrendatário, o posseiro, podem se afigurar como formas de produção camponesas." (Silva, 1980: 3)

A origem do campesinato brasileiro está associada à necessidade de abastecer de gêneros de primeira necessidade os núcleos urbanos e as grandes fazendas no período colonial, fazendo com que, paralela e complementarmente à economia exportadora, se organizasse a produção de gêneros de primeira necessidade. Inicialmente, destacou-se a figura do agregado, a quem o grande proprietário cedia terras gratuitamente ou em troca de pequenos serviços. Era um trabalhador autônomo, às vezes auxiliado por um escravo liberto ou um índio, constituindo pequenas lavouras, geralmente nas proximidades de algum núcleo urbano, a que abastecia. 
Ocupava as piores terras, restos inaproveitados da grande lavoura. Esta, aliás, produzia unicamente para exportação e, neste sentido, o solo e a mão-deobra escrava, principalmente nos períodos de alta de preço no mercado externo, eram utilizados totalmente para esta finalidade (Prado Jr., C., 1963: 153 e 154).

"Desta forma, a economia camponesa local respondia às exigências da economia colonial produzindo um pouco de produtos coloniais, e sempre um excedente de alimentos que também era colocado no mercado ou porto local, para servir ao abastecimento de outros portos, do Rio de Janeiro primeiramente, de Santos e São Sebastião, mas também de Salvador da Bahia e mesmo Pernambuco" (Marcílio, 2006: 48)

Além dos agregados, duas outras categorias sociais constituíam o campesinato: os posseiros e os sitiantes. "Ambos às vezes se confundiam porque a condição de posseiro dizia respeito à relação jurídica com a terra, quando o camponês tinha a posse, mas não tinha o domínio. O sitiante é o pequeno agricultor independente, dono de um sítio, um lugar na terra, e não de uma sesmaria. Agregados e moradores eram também, no entanto, tidos como sitiantes, já que sua área de roça no interior da fazenda também era definida como sítio, ou roçado" (Martins, J.S., 1981: 39 e 40).

A pequena lavoura camponesa, ainda que tivesse no mercado urbano seus centros consumidores, em geral, não podia localizar-se próxima às cidades, pois estas áreas eram preferencialmente ocupadas pela grande lavoura. Mesmo assim, a pequena produção procurava sempre as localidades de mais fácil acesso, geralmente próximas ao litoral. "Assim, os pontos da costa que não são suficientemente favorecidos para que neles se instalasse a grande lavoura, mas aceitáveis para uma atividade de segunda ordem, se tornarão área de concentração da agricultura de subsistência. Está no caso o litoral que se estende do Recôncavo Baiano até o Rio de Janeiro, e deste para o sul. Outras áreas particulares em que a agricultura de subsistência encontra condições propícias é ao longo das grandes vias de comunicação, freqüentadas pelas numerosas tropas de bêstas, que fazem todo o transporte por terra na colônia, e pelas boiadas que das fazendas do interior demandam os mercados do litoral" (Prado Jr., C., 1963: 155 e 157). 
Durante o período colonial a posse da terra era franqueada apenas a uma pequena camada da população, ou seja, aos fazendeiros. Entretanto, àqueles que não eram nem senhores e nem escravos, eram permitidas algumas condições de acesso à terra. O branco deserdado pelo morgadio podia formar uma posse e solicitar doação de sesmaria. Para mestiços e índios, a legalização da posse era quase impossível. Durante o período colonial, as sesmarias prevaleciam legalmente sobre o direito de posse. Os fazendeiros podiam ou não aceitar, como agregados, possíveis posseiros instalados em terras a si doadas: "A posse do fazendeiro conduzia a legitimação através do título de sesmaria: o mesmo não se dava com a posse do camponês, do mestiço, cujos direitos se efetivavam em nome do fazendeiro. Basicamente, tais situações configuravam a desigualdade dos direitos entre o fazendeiro e o camponês - desigualdade essa que definia os que tinham e os que não tinham direito, os incluídos e os excluídos" (Martins, 1981: 35).

A lei de terras de 1850 rompeu com a ordem colonial no campo e instaurou um novo regime fundiário (o regime de sesmarias fora abolido em 1822), transformando as terras devolutas em monopólio do Estado. Com essa lei, os camponeses que tinham posses formadas puderam regularizá-las, tornando-se proprietários. Os que não puderam regularizar ou vieram a formar posses após a promulgação da lei de terras, a regularização era permitida somente pela compra, obrigando-os a trabalhar nas grandes fazendas, desenvolvendo tarefas diversas e produzindo alimentos nas áreas não ocupadas pelo cultivo principal do fazendeiro para acumular algum capital. As terras acessíveis apenas mediante a compra propiciaram a formação de um campesinato moderno, diferente daquele formado por posseiros e agregados, pois o objetivo era produzir para o mercado e a terra já se constituía mercadoria (Martins, 1981: 41 a 44).

Espacialmente, esse novo campesinato vai se adaptar melhor às novas áreas produtoras de café do interior paulista. Nas velhas áreas do Vale do Paraíba e do Litoral Norte, a formação da produção mercantil simples foi um pouco diferente. Analisando questões fundiárias na economia camponesa no município de Ubatuba, Marcílio esclarece que "conseguia-se acesso à terra, antes de 1850, pela entrada simples de sua posse para a exploração, por um 
grupo doméstico. A partir daí, algumas famílias mais esclarecidas procuravam obter um título legal, público e registrado, que legitimasse sua posse. Mas foram poucos foram os que procuraram essa via. O comum era o usufruto da terra, sem preocupação com sua legalização. A posse, assim iniciada, acabava pertencendo de fato à família que a explorava, podendo mesmo transmiti-la aos seus descendentes ou vendê-la normalmente. Bastava, nestes casos, provar perante a autoridade local (o tabelião), e com testemunhas juramentadas, que a família era efetivamente posseira, que a posse era 'mansa', ou seja, não havia sido feita em terras já de outros e por eles contestadas." (Marcílio, 2006: 75). Mais adiante em sua análise, a autora acrescenta que "Com a Lei de 1850, interpõem-se barreiras para a formação de novas posses, com a exclusão de pequeno lavrador pobre. Apesar da lei, os caiçaras mantiveram seus usos tradicionais. Só que deixaram de ter o respaldo legal ou a segurança de poderem se transformar, de posseiros, em legítimos donos das terras que trabalhavam." (Marcílio, 2006: 77).

Essa autora conclui que a Lei de Terras de 1850, apesar de favorecer os proprietários e posseiros mais ricos, pouco interferiu na realidade local. Como os procedimentos impostos para regularizar a posse eram complexos e onerosos, considerando que a posse era a forma dominante de acesso à propriedade da terra no Litoral Norte (mais de $60 \%$ em Ubatuba contra cerca de $30 \%$ de terras tituladas, de acordo com estudos da própria autora) e que parte considerável dos posseiros era pobre, "o Aviso de 10 de abril de 1858 estabelecia que a posse de pessoa pobre fosse legitimada por conta do governo [...] A legislação sempre se refere aos direitos do posseiro, desde que ele pudesse provar que a terra estava ocupada por cultura e que nela morasse" (Petrone. M. T., citado por Marcílio, 2006: 81).

As fazendas de café no Litoral Norte, seguindo a tradição da agricultura nacional, organizaram-se sobre bases predatórias, extraindo da terra, no menor prazo possível, o máximo da sua capacidade, esgotando rapidamente os solos: "Atrás da lavoura que o esgotamento prematuro da terra impele incessantemente para diante, para novas regiões ainda inexploradas, vai se estendendo o deserto... estas terras, desprezadas pela fazenda, se tornam acessíveis às pequenas propriedades" (Prado Jr., 1935: 62 e 63). 
As sucessivas crises a que a economia cafeeira se via submetida, implicava, muitas vezes, na decomposição das fazendas, que podia ocorrer de duas formas distintas em finais do século XIX: retalhada e vendida em pequenos lotes como forma do proprietário reaver parte das perdas promovida pelo esgotamento dos solos; ou pelo gradual abandono das terras, instalando-se nelas, ocasionalmente, um ou outro sítio, o que ocorreu principalmente no Vale do Paraíba e em Ubatuba e São Sebastião (Prado Jr., 1935: 62 e seguintes).

O período, compreendido entre a última década do século XIX e as três primeiras do século $\mathrm{XX}$, é particularmente importante para o processo de valorização do espaço no Litoral Norte, considerando que nessas quatro décadas ocorreram significativas transformações na estrutura da produção, circulação e consumo de mercadorias e na redefinição dos papéis do campo e da cidade. Dois aspectos se destacam nesse processo:

1- Ubatuba e São Sebastião, cidades onde estavam localizados os dois portos mais importantes da região, concentravam as atividades comerciais do Litoral Norte e mantinham um bom intercâmbio com as cidades do Vale do Paraíba e de outras regiões do Estado e do País. A agricultura encontrou nessas cidades as condições para sua realização econômica, quer pela exportação de alguns produtos, quer pelo consumo da população urbana local (ou aquela em trânsito, inclusive a de animais), consumindo gêneros de primeira necessidade. As cidades desempenhavam funções administrativas e eram responsáveis pela organização da produção rural. Neste sentido, havia uma clara divisão do trabalho entre campo e cidade. Com a decadência da cafeicultura, o subseqüente êxodo populacional e a diminuição brutal do movimento portuário, perderam o caráter de organizadoras da produção agrícola. Era o empobrecimento progressivo das relações mercantis entre o campo e a cidade e, portanto, do Litoral Norte com os demais centros urbanos de São Paulo e do Brasil.

2- A economia do Litoral Norte com a decadência da cafeicultura passou a ser sustentada basicamente pela produção mercantil simples articulada ao mercado de Santos, primeiro com as canoas de voga e depois por meio dos barcos a motor. Lembrando que, mesmo no auge do período 
cafeeiro, a produção de alimentos ocupou sempre posição de destaque no total das áreas plantadas. (Noffs, 1988: 13-15)

Assim, após a decadência das fazendas de café no final do séc. XIX, a produção do espaço em Ilhabela e no Litoral Norte esteve associada aos canaviais e a produção de pinga, à pesca de cerco ou às plantações de banana. O depoimento do Sr. Pedro Eusébio, morador antigo da Praia dos Castelhanos, revela como funcionava a pequena produção mercantil no local em meados do século passado:

"Trabalhava um pouco com Barbosa um pouco com Leonardo, um pouco com Barbosa um pouco com Leonardo, e assim foi. Quando trabalhava com Barbosa era no bananal - "tinha bananal ali em cima na pancada d'água, carregava de lá nas costas até aqui na cachoeira, dali então carregava no carro de boi até a praia, embarcava na canoa para daqui então fazer a baldeação de navio, e o barco levava a banana, ia até Santos..." Eram esses mesmos barcos que traziam mantimentos para o Sr. Barbosa e para o Sr. Leonardo. Pirati, Ubatuba eram os nomes dos barcos. Quando era tempo de colheita, mandava o recado para o barco, então juntava o pessoal do Barbosa e do Leonardo e faziam a colheita de banana, laranja, limão, abóbora, melancia; colhiam e encaixotavam tudo. Leonardo tinha plantação de cana e levavam rapadura e açúcar em quantidade, e 2 a 3 tonéis de pinga.

Leonardo ia junto no navio, quando ele não podia, Barbosa é quem ia.

Quando trabalhava para o Leonardo era para carregar bagaço de cana: colocava no sol, depois que tava seco então tirava do sol, botava no paiol para depois então ir para o forno, para torrar e fazer a rapadura o açúcar. Na roça de cana, cortava cana, amarrava cana, carregava cana.

Trabalhava até sexta, quando era sábado eram dispensados então cuidavam da roça da família. A roça da família do Sr. Pedro era ali no caminho do mirante, lá tinha abóbora, cana, melancia, batata doce, milho. Feijão e arroz eles plantavam mas não dava nada. Plantavam para comer, para a família, quando a colheita era demais mandavam para o barco." (Trecho do depoimento do Sr. Pedro Euzébio, morador do Canto do Ribeirão - praia dos Castelhanos, in Pirró, 2004: 63)

Esse depoimento demonstra a existência de contradições no interior da organização da produção mercantil simples, ao deixar claro a dependência da 
produção familiar - o trabalho na roça - aos interesses da fazenda e do engenho. Ainda que todas as famílias tivessem a posse dos meios de trabalho e da terra onde moravam e exerciam suas atividades, dependiam para sua subsistência, em algum grau, da prestação de serviço, direto ou indireto, à fazenda e ao engenho.

Tais características não eram exclusivas da Baía dos Castelhanos. Nas áreas rurais do Litoral Norte, ao longo desse período, havia famílias que eram proprietárias de engenhos de pinga, de bananais ou de embarcações e aparelhos de pesca, enquanto que outras nada possuíam, além da força de trabalho para cultivar pequenas glebas com feijão, mandioca ou cana. Entretanto, as diferenças sociais e econômicas entre famílias de um mesmo povoado, ainda que fossem importantes, não eram significativas a ponto de caracterizar uma relação social de subordinação. Apesar da existência de fazendas e engenhos e de algumas propriedades produzirem mais que outras, os povoados estavam organizados em função da produção mercantil simples. (Noffs, 1988: 39- 40)

O espaço na Baía dos Castelhanos, até o final da década de 1950, foi determinado pela produção mercantil simples. Nesse período, a posse da terra e o trabalho familiar, realizado com técnicas simples e poucas ferramentas, garantiam a seus moradores a produção direta dos meios de subsistência. Os barcos a motor cumpriam papel relevante nesse processo, pois faziam o transporte da produção local ao mercado de Santos, onde era vendida, possibilitando a compra de outros gêneros não produzidos em suas praias, tais como, ferramentas, vestuário, equipamentos de pesca, sal, remédios etc. Assim, a terra era para os caiçaras objeto e meio de trabalho e a produção mercantil simples dependia do mercado de Santos para se realizar.

Nas décadas seguintes, praticamente em todo o Litoral Norte, inclusive em Ilhabela, o espaço urbano promovido pelo turismo se impôs hegemonicamente, destruindo, modificando ou subordinando a pequena produção mercantil. Entretanto, esse foi um processo que ocorreu espacial e temporalmente de forma diferenciada, fazendo com que, de um lado, algumas regiões com melhor acesso rodoviário, fossem amplamente urbanizadas ainda em seu início (década de 1960 e início de 70), e de outro, 
nas mais isoladas, aspectos da produção rural perdurassem no espaço por mais tempo, chegando em alguns poucos locais, a sobreviverem até os dias atuais, como acontece na costa oceânica de Ilhabela.

Entretanto, as trocas que se realizam no mercado urbano não apresentem mais as mesmas características de alguns anos atrás. A começar pelo mercado de peixe fresco que existia apenas precariamente em Ilhabela e São Sebastião. A Baía dos Castelhanos enviava para essas cidades somente uma modesta produção de peixe seco. Atualmente, o pescado é transportado fresco pelas canoas a motor dos próprios caiçaras diretamente para São Sebastião e Ilhabela. Os preços alcançados de algumas espécies mais nobres são altamente compensadores, decorrência da consolidação do turismo nessas cidades.

Por outro lado, os artigos consumidos pelos caiçaras (alimentos, roupas, artigos de higiene e limpeza, ferramentas, redes de pesca, combustíveis e, mais recentemente, geradores de eletricidade a óleo, aparelhos eletroeletrônicos, etc.) são produzidos numa economia de mercado globalizado, que se caracteriza pelo uso de tecnologia avançada, alta produtividade do trabalho, emprego de mão-de-obra barata, frutos do fim das economias nacionais e da integração dos mercados, dos meios de comunicação e dos transportes.

É por meio do pescado, principal artigo da produção mercantil simples, que o caiçara se defronta com essa rede de relações econômicas globalizadas. Com a venda de seus produtos no mercado de Ilhabela (peixaria, bares e restaurantes etc.) os caiçaras da Baía dos Castelhanos compram o gelo, as ferramentas, redes de pesca, gerador de energia, baterias, aparelhos televisivos e de som, fogão a gás e os botijões de gás, CDs e DVDs de artistas conhecidos e outros utensílios de consumo doméstico. Aparentemente nada mudou em relação ao sistema de trocas efetuado há décadas, entretanto, a produtividade de seu trabalho cada vez mais vem se tornando inferior ao trabalho socialmente necessário à produção das mesmas mercadorias em outros centros de pesca. Os equipamentos de captura, armazenamento e distribuição do pescado modernizaram-se muito no Brasil e no mundo, acompanhando a evolução tecnológica dos outros setores da economia. Em 
qualquer restaurante de Ilhabela, podem ser encontrados no cardápio salmão do Chile, atum do Peru, pescada branca de Santa Catarina, lagosta do Ceará, além de camarões produzidos em viveiros no Rio Grande Norte e trutas nas pisciculturas da serra da Mantiqueira.

O caiçara da Baía dos Castelhanos precisa aumentar as horas de seu trabalho para adquirir as mercadorias que consome e que são produzidas agora em uma economia estruturada sobre bases globalizadas (mais tecnologia, menos mão-de-obra e custos inferiores). A produção mercantil simples de subsistência na Baía dos Castelhanos não encontra mais condições estruturais de continuar existindo e a população caiçara paulatinamente vai se subordinando aos interesses dos negócios de turismo, seja pela prestação de serviços remunerados ou pelo comércio do pescado que cada vez mais se especializa para atender às exigência dos bares e restaurantes, principais consumidores da produção local.

Com a urbanização e inserção da Baía dos Castelhanos na rede das atividades e negócios do turismo, o espaço ganhou uma nova dimensão. A propriedade privada da terra, que até então estava voltada à produção de alimentos, passou a permitir aos seus proprietários a obtenção da renda da terra. Algumas famílias caiçaras que não venderam suas posses, viram-se diante de uma nova situação em que "sem sequer o explorar, sem the tocar com as mãos e até mesmo estando ausente, extrair do solo a renda absoluta e grande parte das rendas ditas diferenciais" (Lefebvre, 1972: 158)

Os campings de quintais são o melhor exemplo de como parte da população passou também a se beneficiar da renda de monopólio que a condição de proprietário da terra lhe confere. A extração da renda da terra permitiu a esses proprietários converter o dinheiro recebido dos campistas em capital, que pôde ser investido na construção e ampliação de edificações para o camping, na aquisição de equipamentos de pesca e de meios de transporte, transformando-os em pequenos empreendedores capitalistas e empregadores da mão-de-obra local.

Outra modificação importante a ser considerada é a transformação do trabalho familiar em mão-de-obra assalariada. Já é relativamente comum em toda a Baía dos Castelhanos encontrar caiçaras trabalhando como jardineiros, 
caseiros, serventes de pedreiro etc., em obras e residências de turistas e, até mesmo, de outros caiçaras.

O turismo hoje é uma realidade na Baía dos Castelhanos. Um dos pressupostos para sua realização é a existência de determinadas características, culturais e naturais, que fazem do espaço local um lugar especial, dotado de singularidades (ou de marcos especiais de distinção segundo Harvey, 2005: 232 e seguintes), tornando-o raro no conjunto do litoral brasileiro.

A arquitetura das casas, a disposição dos povoados nas praias e costeiras, as canoas, os cercos flutuantes e os equipamentos de pesca, os utensílios domésticos etc., são manifestações no espaço da obra artesanal caiçara. Constituem, ao lado de outras singularidades da natureza, marcos especiais de distinção a atrair interesses do turismo para os Castelhanos.

Entretanto, a produção artesanal era um dos aspectos que fundamentava a existência do campesinato no litoral paulista (produção direta dos meios de subsistência, economia monetária incipiente etc). Com o desenvolvimento urbano e de relações tipicamente capitalistas de produção, essas condições tendem a desaparecer ou a se subordinar aos novos interesses mercantis. As novas casas dos caiçaras são construídas em alvenaria, os materiais são comprados com dinheiro na cidade e os trabalhadores empregados nas obras são assalariados. Os utensílios domésticos são igualmente adquiridos com dinheiro nos mercados de Ilhabela ou de São Sebastião. Dinheiro que os caiçaras obtém vendendo peixe para os bares e restaurantes e artesanato para turistas, prestando serviços nas casas de veraneio, cobrando dos campistas para armarem barracas em seus quintais próximos à praia etc.

Das muitas correntes geográficas, a escolhida para realizar este trabalho tem a difícil tarefa de explicar porque os dois lados da montanha de Ilhabela parecem tão diferentes, se são manifestações do mesmo fenômeno social. Deve responder por qual razão o espaço da produção mercantil simples no outro lado da montanha, na costa oceânica de Ilhabela, apresenta-se para grande parte dos pesquisadores como um fenômeno mágico, diferenciado, parecendo ser o oposto das relações sociais e econômicas que o engendrou. 
É preciso muita investigação para explicar porque o valor que se realiza nesse espaço atualmente por meio do turismo, aniquila ou subordina aos seus interesses, a história e o trabalho acumulado ao longo de décadas pelos produtores locais. E ainda é necessário compreender que, se as praias e lugares da Baía dos Castelhanos fossem vazios, naturais, sem a obra material caiçara, sem as suas técnicas e sua cultura, o espaço igualmente se valorizaria porque responde a lógica de outros processos que se desenvolvem nas grandes cidades, onde são gerados os capitais, os fluxos de turismo e os seus consumidores. $O$ que está na mira do capital urbano que se realiza por meio do turismo, é a apropriação da natureza e a possibilidade de transformar suas singularidades em mercadorias acessíveis aos turistas-consumidores dessas mesmas cidades. São as relações sociais de produção, em seu sentido mais amplo de produzir e consumir mercadorias e que têm seu centro nevrálgico muito distante dos dois lados dessa montanha, que se encarregam de valorizar o espaço das praias da Baía dos Castelhanos. Nesse sentido, o trabalho morto acumulado no espaço, herança do passado camponês, teoricamente pode ser um empecilho à realização do valor.

E a produção do novo espaço urbano vinculado ao turismo não precisa necessariamente prescindir do espaço caiçara, rural. Nada impede que a arquitetura de suas casas, a pesca de cerco, as canoas, as redes etc. sejam igualmente mercantilizadas como a natureza. Essa é mais uma tarefa da Geografia escolhida: revelar os processos em curso na transformação do espaço rural da produção mercantil simples em espaço urbano do turismo; identificar seus agentes, compreender a ação do Estado e vislumbrar entre os agentes atuantes no espaço (caiçaras, turistas, comerciantes, especuladores, agentes imobiliários e de turismo), como se relacionam com a produção e o consumo do valor. De um ponto de vista conceitual, pode-se observar que o trabalho morto acumulado no espaço pela produção mercantil simples contribui pouco na composição geral do valor do novo espaço urbano do turismo. Afinal de contas, o que restou do espaço agrário-camponês em Maresias, São Sebastião? Interessa a alguém saber quem foi o Moreira que empresta seu nome ao canto mais charmoso daquela praia? 
Se os conceitos empregados derem conta de explicar porque nesse novo espaço da Baía dos Castelhanos alguns caiçaras se transformam em pequenos empresários capitalistas e outros em trabalhadores remunerados, terá sido grande a tarefa realizada.

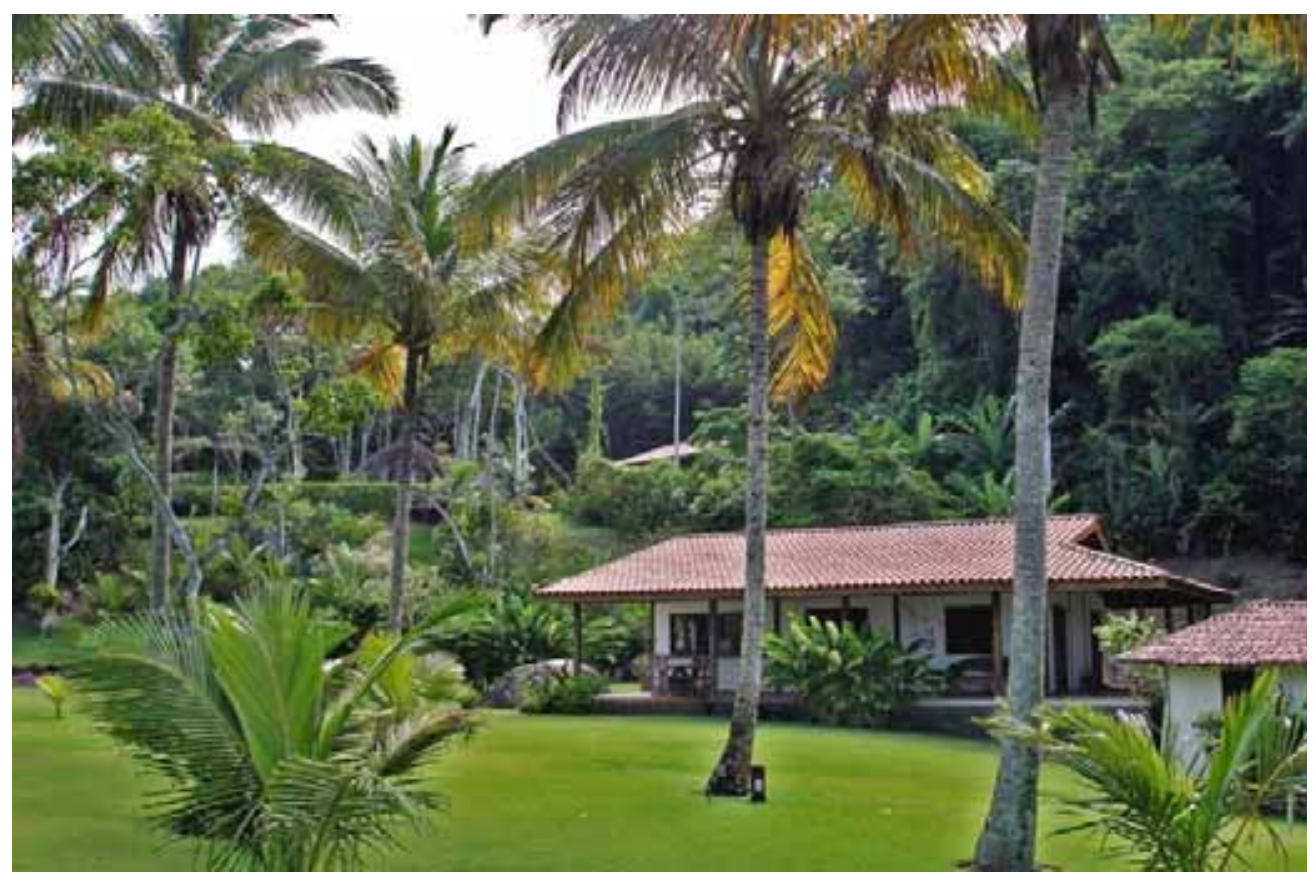

fotos 16 e 17, P. Noffs, 2007 e 1996. O novo espaço do turismo, das casas de veraneio, para se realizar prescindiu...

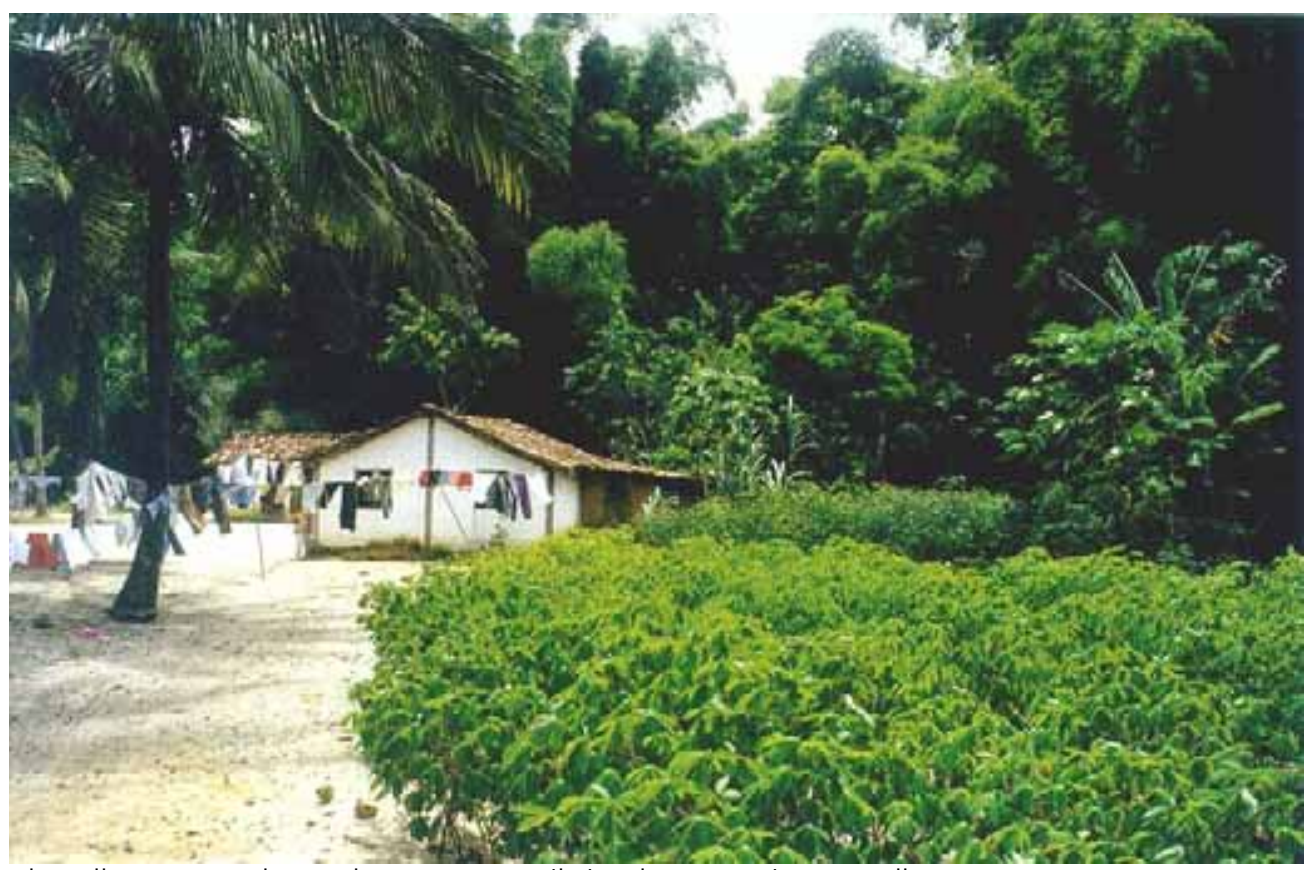

do velho espaço da produção mercantil simples na Praia Vermelha. 


\section{CAPÍTULO 3 \\ A VALORIZAÇÃO DO ESPAÇO}

\section{O ESPAÇO DA PRODUÇÃO MERCANTIL SIMPLES - CARACTERÍSTICAS E CONTRADIÇÕES}

Quando finalmente as obras da estrada de terra, iniciadas alguns anos antes no bairro do Perequê, chegaram à Praia dos Castelhanos em 1977, encontraram uma paisagem muito diferente daquelas existentes por todo o Litoral Norte de São Paulo, inclusive na própria Ilhabela.

Vista do alto da serra, a paisagem era dominada pela floresta primária, recobrindo vales profundos e esporões de morros que avançavam sobre o mar. Chegando a praia, a presença humana mostrava-se aos poucos: bananeiras entre árvores; capoeiras nos morros contornando campos de sapé; ruínas de antigos engenhos de pinga; algumas casas de pau-a-pique concentradas nos cantos da praia. Quase não havia moradores. Não existiam ruas, redes de distribuição de energia elétrica e telefone, casas de turistas. Uma ou outra roça de mandioca constituía a atividade agrícola. Vivia-se da pesca como mostravam as canoas e redes na praia e quintais das casas. Tampouco havia um bar ou uma pequena mercearia, tão comum em qualquer parte do litoral norte paulista, para abastecer as famílias caiçaras de gêneros de primeira necessidade. Tinha-se a impressão de um tempo parado, de um tipo de vida remanescente do período colonial na região sudeste brasileira.

Essa vida simples e apartada da turbulência que o crescimento urbano e do turismo promovia em todo o Litoral Norte paulista, encobria as condições peculiares em que se dava a produção capitalista do espaço na Baía dos Castelhanos. Em verdade, a simplicidade das famílias caiçaras, que tinham na produção de alimentos e na comercialização de poucos excedentes da roça e da pesca a base de suas sobrevivência - e confundida por muitos pesquisadores, como típica das "Comunidades Tradicionais do Brasil" representava a etapa final da hegemonia da produção do espaço pela 
produção mercantil simples articulada ao mercado de Santos pelos barcos a motor, que já durava pelo menos quatro décadas.

Desde 1920 até o início da década de 1960, três atividades agrícolas de caráter comercial eram praticadas na Baía dos Castelhanos, organizadas para atender ao mercado de Santos:

- a pesca de cerco no Saco do Sombrio;

- a produção da banana prata em toda a baía, mas principalmente na Praia dos Castelhanos;

- o cultivo da cana-de-açúcar para produção de pinga no engenho do Sr. Leonardo Reale.

\section{a) A Pesca de Cerco e os Barcos a Motor no Saco do Sombrio}

A pesca de cerco foi introduzida no Brasil inicialmente no Saco do Sombrio, Baía dos Castelhanos, por volta de 1920, pelo Sr. Kuzi Hamab, de procedência japonesa. $O$ primeiro aparelho de cerco foi construído para atender uma encomenda do Sr. Sumkit Kamati, também japonês, que havia se estabelecido em llhabela para praticar a pesca. Depois de algumas tentativas frustradas, esse engenho para a captura de peixes mostrou-se eficiente e a pesca de cerco rapidamente se alastrou pela Baía dos Castelhanos e daí se difundiu por todo o Litoral Norte de São Paulo e de outras regiões do Brasil. (ver Mussolini, 1980 e França, 1954)

O sucesso deve-se muito aos barcos de pesca a motor introduzidos no Litoral Norte, também por japoneses, simultaneamente aos cercos. Essas embarcações trouxeram uma nova dinâmica ao sistema de transporte vigente na época, que dependia, até então, das canoas de voga para o transporte de mercadorias e pessoas para a cidade de Santos.

No começo do século $X X$, llhabela tinha nos canaviais e na produção da pinga a base de sua economia. Nessa época, não havia ligação rodoviária nem ferroviária entre o Litoral Norte e o Vale do Paraíba e a cidade de São Paulo. As tropas de burro já há muito tempo não eram mais utilizadas para o transporte de mercadorias entre o litoral e o planalto. Assim, llhabela e o Litoral Norte dependiam da navegação de cabotagem para o escoamento e 
aquisição de produtos, que ocorriam preferencialmente por intermédio da cidade de Santos.

Com o declínio da economia cafeeira no Litoral Norte, particularmente em Ilhabela, onde chegou a ser expressiva até meados do século XIX, os barcos a vapor deixaram de freqüentar o porto de São Sebastião. No final daquele século e início do século $\mathrm{XX}$, a região contava apenas com as canoas de voga para fazer o transporte de pinga para o mercado de Santos e de lá trazer outros gêneros necessários à sobrevivência da sociedade local.

Em Ilhabela, a pesca, a criação doméstica de animais e as roças de mandioca, milho, feijão, batata doce, arroz etc. ocorriam na esfera da pequena produção familiar de alimentos e eram desenvolvidas complementarmente às lavouras de cana-de-açúcar e à produção de pinga nos engenhos. Geravam poucos excedentes que, via de regra, eram absorvidos localmente e em São Sebastião. A circulação de dinheiro e mercadorias era tão inexpressiva que, para alguns autores como França (1951: 149), essa situação podia ser considerada como de "regime de economia fechada."

Também esse era o quadro na Baía dos Castelhanos, agravado pela situação de isolamento de seus moradores, que precisavam percorrer a pé uma distância superior a $20 \mathrm{~km}$ através da serra para vender ou comprar alguma mercadoria, visitar parentes ou resolver algum problema na cidade.

Na praia dos Castelhanos havia dois engenhos movidos a roda d'água que também utilizavam as canoas de voga para escoar a produção de pinga diretamente para o mercado de Santos. A roça e a pesca eram atividades desenvolvidas preferencialmente para a alimentação das famílias. Quando ocorriam excedentes, destinavam-se mais para a troca em produtos entre famílias e vizinhos do que para o comércio. (França, 1954: 149).

Assim, não é difícil entender porque a pesca de cerco e os barcos a motor fizeram tanto sucesso em Ilhabela, substituindo rapidamente as canoas de voga. Para os padrões da época, representaram um grande avanço tecnológico na produção e circulação de mercadorias, integrando a insipiente economia do município ao mercado de Santos. Ressalta-se que esse novo sistema de pesca e transporte foi implementado em Ilhabela subordinado aos interesses de empresários da pesca de Santos (Mussolini, 1980: 243) que viam 
o comércio de peixes aumentar em função das novas demandas criadas com o crescimento urbano de São Paulo e das comunidades nipônicas estabelecidas no planalto. No Litoral Norte, como em outras regiões do litoral paulista, na primeira metade do século passado, a presença japonesa se fez sentir em toda a cadeia da produção pesqueira, desde os sistemas de captura, passando pelas industrias de salga e conserva, até a organização do transporte e comércio do pescado.

Ágeis, os barcos a motor atingiam rapidamente qualquer localidade isolada da costa de Ilhabela onde houvesse um morador ou algum produto para transportar e por essa razão não demoraram a se impor como meio de transporte da população e modificar o caráter da pesca na região.

Com a difusão da pesca de cerco, pequenas comunidades caiçaras que praticavam a pesca como atividade complementar e de subsistência "são postas na órbita daquele mercado (Santos)...muitos bairros distantes continuam a praticar suas formas tradicionais de pescaria, de modelos portugueses, sob o estímulo de barcos de Santos, que se limitam a recolher o peixe por elas capturados e a introduzir um único elemento novo na situação, a presença de um preço." (Mussolini, 1980: 243 e 244).

Mais do que introduzir um preço, os barcos a motor mudaram a situação da pesca em relação ao mercado. Os pescadores tinham o produto, porém, não havia compradores uma vez que o mercado de peixe fresco ficava em Santos, cidade muito distante do Litoral Norte, situada a mais de $100 \mathrm{~km}$ de Ilhabela, o que tornava inviável o seu transporte por canoas de voga. Assim o excedente da produção era escalado, salgado e conservado seco para ser consumido nos períodos de carência. Esporadicamente algum excedente de peixe fresco era comercializado em Ilhabela e São Sebastião, mas somente o da zona do canal. Uma pequena parte da produção de peixe seco, sempre relacionada com eventuais excedentes, era embarcada nas canoas de voga junto com os tonéis de aguardente para ser vendida em Santos. Dessa forma, a produção pesqueira basicamente era destinada para o consumo das famílias e compunha, junto com a banana e a farinha de mandioca, a base da alimentação caiçara. 
Os barcos a motor reduziram a distância entre os pescadores de Ilhabela e o mercado de Santos, pela diminuição do tempo gasto na viagem pelas canoas de voga, de cerca de cinco dias para apenas um. A grande novidade trazida pelos barcos a motor foi a possibilidade do pescador da Baía dos Castelhanos colocar o seu peixe fresco no mercado de Santos, onde todos os peixes tinham preço independentemente de sua procedência ou técnica de captura empregada, e nessa cidade compor o preço médio de toda a produção pesqueira comercializada na região sul-sudeste do Brasil.

Outro aspecto interessante dessa questão é o que representava para o pescador estabelecer um "preço" para o produto, anteriormente sem preço. Mussolini (1980: 249) comenta que pescadores que viviam nas praias do Bonete, Anchovas e Indaiauba, uma das regiões mais isoladas de Ilhabela, passaram a remeter para os barcos a motor no Saco do Sombrio, a tainha "sem preço", capturada de forma tradicional em suas redes de arrastão. Ao serem entregues às embarcações, os peixes ganhavam um preço e deixavam de ser um item de subsistência, um alimento, para se transformarem em mercadoria. A mercadoria peixe vendida no mercado de Santos transformavase em dinheiro que podia comprar outras mercadorias que os pescadores tradicionais de Ilhabela não produziam e que eram essenciais para as suas atividades, inclusive da pesca, como redes, fios de nylon, anzóis, roupas, ferramentas, etc. Esse mecanismo simples de conversão produto-dinheiroproduto revelava como um contingente populacional, que vivia segregado em praias e costeiras isoladas de Ilhabela, pôde se inscrever, por intermédio dos barcos a motor, no processo mais amplo de circulação de mercadorias no sulsudeste brasileiro.

Ser proprietário de cerco exigia uma mobilização considerável de capital, tendo em conta a pequena circulação de dinheiro em Ilhabela na época, e envolvia a participação de artesãos especializados na sua confecção. Em 1951, um cerco custava entre Cr\$25.000,00 e Cr\$30.000,00. (França, 1954: 133). De acordo com Mussolini (1980: 278), em 1946, um cerco saía por aproximadamente Cr\$18.000,00. Panagens de formas e tamanhos padronizados eram encomendadas de redeiros de diversos lugares de Ilhabela, que as entregavam confeccionadas para 0 entralhador. A 
modelagem correta de um cerco dependia da habilidade do mestre entralhador em cortar e perfilar as diferentes panagens de rede. Entralhar um cerco custava $\mathrm{Cr} \$ 6.000,00$, sendo $\mathrm{Cr} \$ 3.000,00$ pagos para o entralhador e CR\$ 3.000,00 para os redeiros. Para os serviços de reparo e conservação, eram pagos $\mathrm{Cr} \$ 100,00$ por dia ao trabalhador, mas na maioria das vezes era o dono quem cuidava desses serviços.

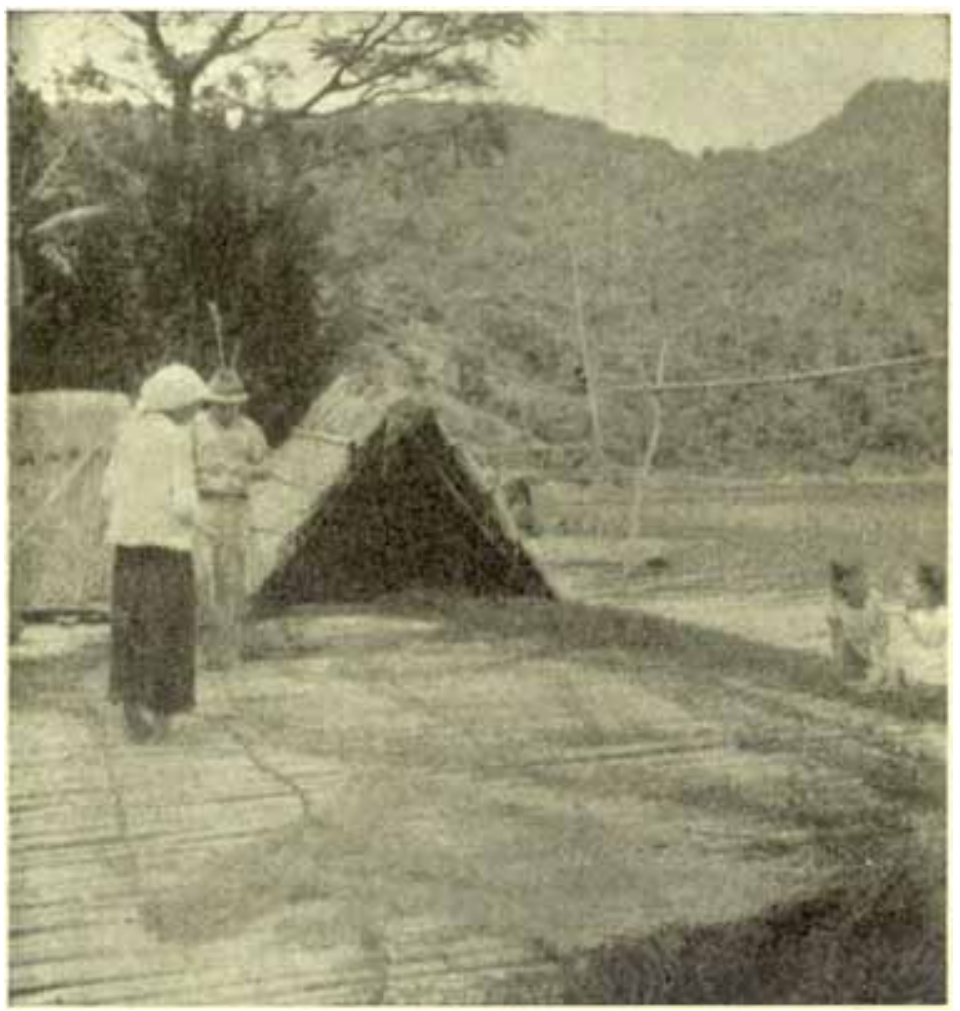

Foto 18, extraída de França, 1954:132).Varal construído com bambus sobre a costeira no Saco do Sombrio para a realização de serviços de reparo e manutenção das redes de cerco. A proprietária, uma Sra japonesa, acompanha atentamente o trabalho do artesão.

Os cercos eram instalados em costeiras e cada um contava com equipagem permanente de 4 a 5 camaradas que podiam receber salários fixos de $\operatorname{Cr} \$ 1.000,00$ a Cr\$ 1.200,00 por mês ou terem participação no pescado. Nesse caso, uma metade ficava com o proprietário do cerco e a outra era repartida entre os camaradas, inclusive com o proprietário, se ele participasse da operação de visita. Os barcos a motor tinham uma tripulação entre 3 a 6 marinheiros que recebiam salários na base de $\operatorname{Cr} \$ 1.200,00$ por mês. (França, 1954: 133 e levantamento de campo do autor). 
Segundo o Sr. Francelízio morador da Praia Mansa e proprietário de cerco, o aparelho permanecia na água pescando cerca de duas semanas e depois era retirado para receber reparos e banhos de proteção. O Sr. Pedro Madalena da Praia Vermelha, também proprietário de cerco, informou que na sua juventude ia ao Sombrio com o seu pai vender lenha para o Sr. Kamati, que era queimada como combustível para preparar a tinta empregada nos banhos de proteção das panagens das redes do cerco, revelando, ainda que em padrões mínimos, mais um aspecto de como essa atividade pesqueira sustentava uma economia monetarizada na Baía dos Castelhanos.

Até meados do século passado, Ilhabela ainda era uma das principais áreas de pesca do Brasil meridional e o Saco do Sombrio continuava a ser freqüentado por barcos de pesca de Santos e Rio de Janeiro, que vinham em busca dos peixes capturados nas redes de cerco. Indicador do sucesso dessa forma de pescaria, havia a fábrica de gelo na praia dos Barreiros, Ilhabela, cuja produção de $60.000 \mathrm{~kg}$ mensais era insuficiente para atender a demanda das embarcações (França, 1954:134-135). Entre os anos de 1925 e 1932 havia aproximadamente 50 barcos a motor freqüentando a costa de Ilhabela, representando $80 \%$ da frota dessas embarcações matriculadas no Porto de Santos. Nessas duas décadas (1920 a 1930), a Baía dos Castelhanos recebeu um afluxo de caiçaras vindos de outras partes de Ilhabela e do continente, atraídos pelo comércio existente em decorrência da proliferação das redes de cerco. Muitos se estabeleceram com suas famílias nas imediações do Saco do Sombrio, formando núcleos habitacionais onde antes não havia moradores. $O$ Sombrio, que até a chegada dos japoneses sequer era um povoado, teve nesses anos seu apogeu, quando chegou a contar com uma população calculada entre 450 e 500 pessoas e abrigava em suas águas calmas cerca de 20 a 25 barcos por noite. "As casas, os varais para a secagem de redes e mesmo os ranchos para canoas passaram a dependurar-se nas rochas vizinhas ao mar, as primeiras, de preferência, subindo até níveis da ordem de $150 \mathrm{~m}$ de altura. Quatro vendas, abastecidas pelos barcos de pesca que ali estacionavam e 113 habitações, em geral toscas, de caráter provisório, foram o reflexo da incomparável posição do local. (França, 1954: 155). 
Tanto França (1954) como Mussolini (1980), argumentam que a agricultura da Baía dos Castelhanos foi bastante prejudicada pelo sucesso da pesca de cerco, principalmente pela presença marcante dos barcos a motor, que retiravam braços da roça para o trabalho na pesca. Efetivamente, muitos moradores locais, principalmente jovens, preferiam trabalhar como camaradas de cerco ou embarcados, porque encontravam na pesca uma atividade mais dinâmica, articulada comercialmente com o mercado santista e que remunerava melhor as suas jornadas de trabalho. Muitos deles, inclusive, migraram para Santos, atraídos por outras possibilidades de trabalho que o setor pesqueiro propiciava. Por outro lado, esse contingente significativo de trabalhadores e de tripulantes das embarcações que se dedicava exclusivamente à pesca, criava novas demandas, principalmente por alimentos e serviços, como os citados para a manutenção do cerco e confecção de redes, e também por outros, relacionados a pequenos reparos nas embarcações e a construção de canoas, por exemplo. Assim, foram atraídos para a área muitos artesãos que se dedicavam a essas atividades complementares à pesca de cerco, e também famílias de agricultores que produziam excedentes de alimentos em suas roças e que se destinavam ao consumo dos trabalhadores empregados na pesca. Moradores antigos da Baía dos Castelhanos relatam que o trecho entre a Praia da Figueira e o Saco do Sombrio foi , no passado, muito ocupado por famílias que se dedicavam a produção de alimentos. As capoeiras e touceiras de bambu existentes atualmente nos morros, testemunham a veracidade da informação. 


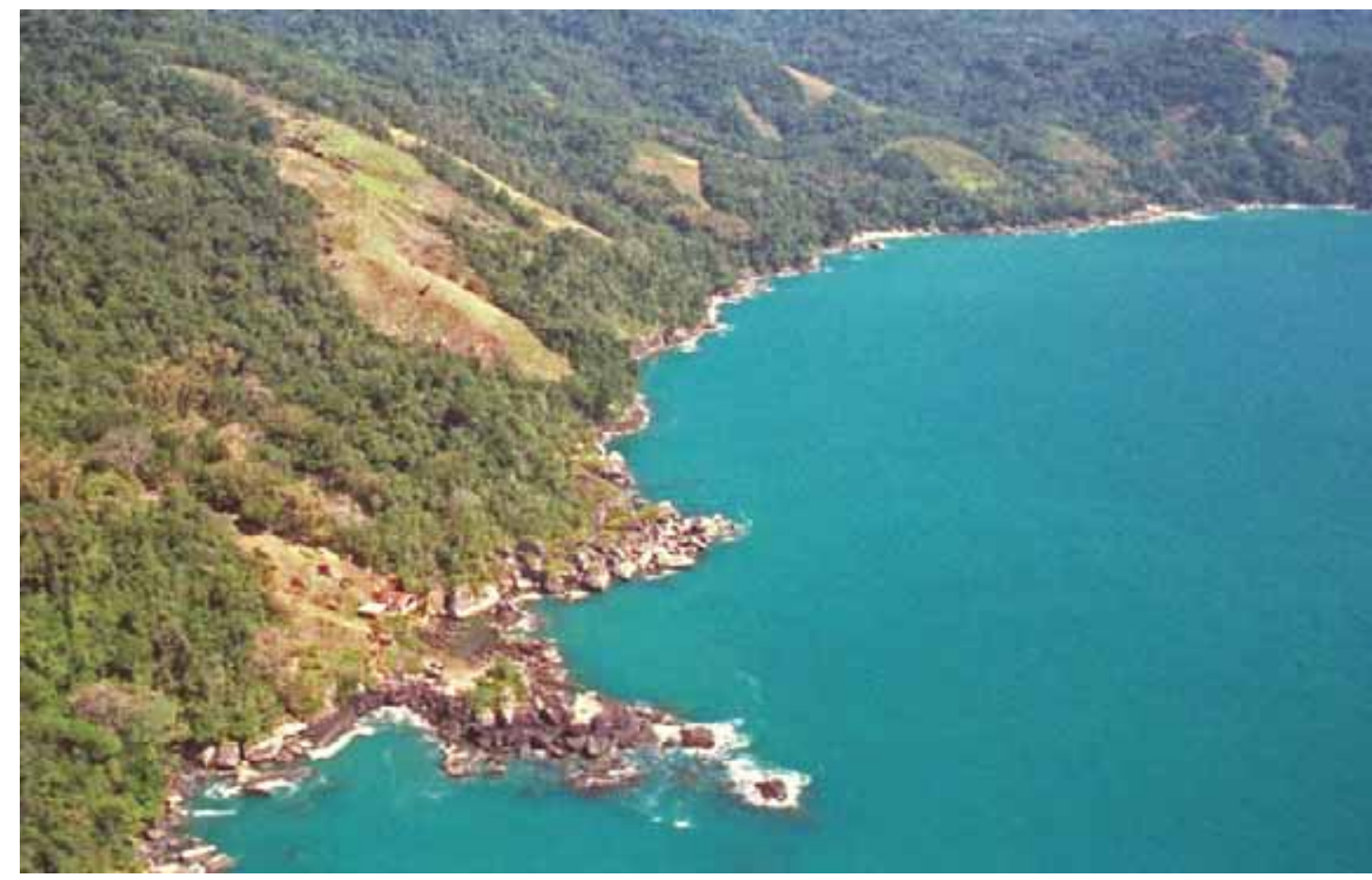

Foto 19, P. Noffs, 1988. Codó (ou Codói como dizem os caiçaras) localizado entre o Saco do Sombrio e a Praia da Figueira. Os campos e as capoeiras em estágio inicial e médio de regeneração indicam ter existido intensa atividade agrícola no local algumas décadas atrás.

França (1954) considera que a decadência da pesca de cerco tem início com uma seqüência de anos de pescaria ruim na década de 1930, agravada por outros fatores, como a eclosão da Segunda Guerra Mundial, que afastou os japoneses do mar. Ainda assim, em 1946 existiam 21 cercos instalados em Ilhabela e 10 na Baía dos Castelhanos (Mussolini, 1980: 280). No ano de 1951, foram cadastrados 30 cercos em Ilhabela, sendo 3 no Saco do Sombrio de um total de 8 na Baía dos Castelhanos (França, 1954:131). Em 1960, Mussolini (1980) registrou 112 moradores no Saco do Sombrio. Nessa década, seja pelo avanço de outros métodos e equipamentos de pesca mais modernos e eficientes na costa sul e sudeste brasileira, ou pela diminuição dos cardumes no litoral de Ilhabela, ou ainda pela concorrência com outros meios de transporte, a pesca de cerco tinha perdido muito de sua importância e os barcos a motor deixaram de freqüentar a região para essa finalidade. Em 1992 foram registrados apenas 37 moradores, em 2002, 25 e em 2007, a população tinha diminuído ainda mais, restando apenas 14 moradores no Saco do Sombrio. 
Figura 1 - Saco do Sombrio em 1951

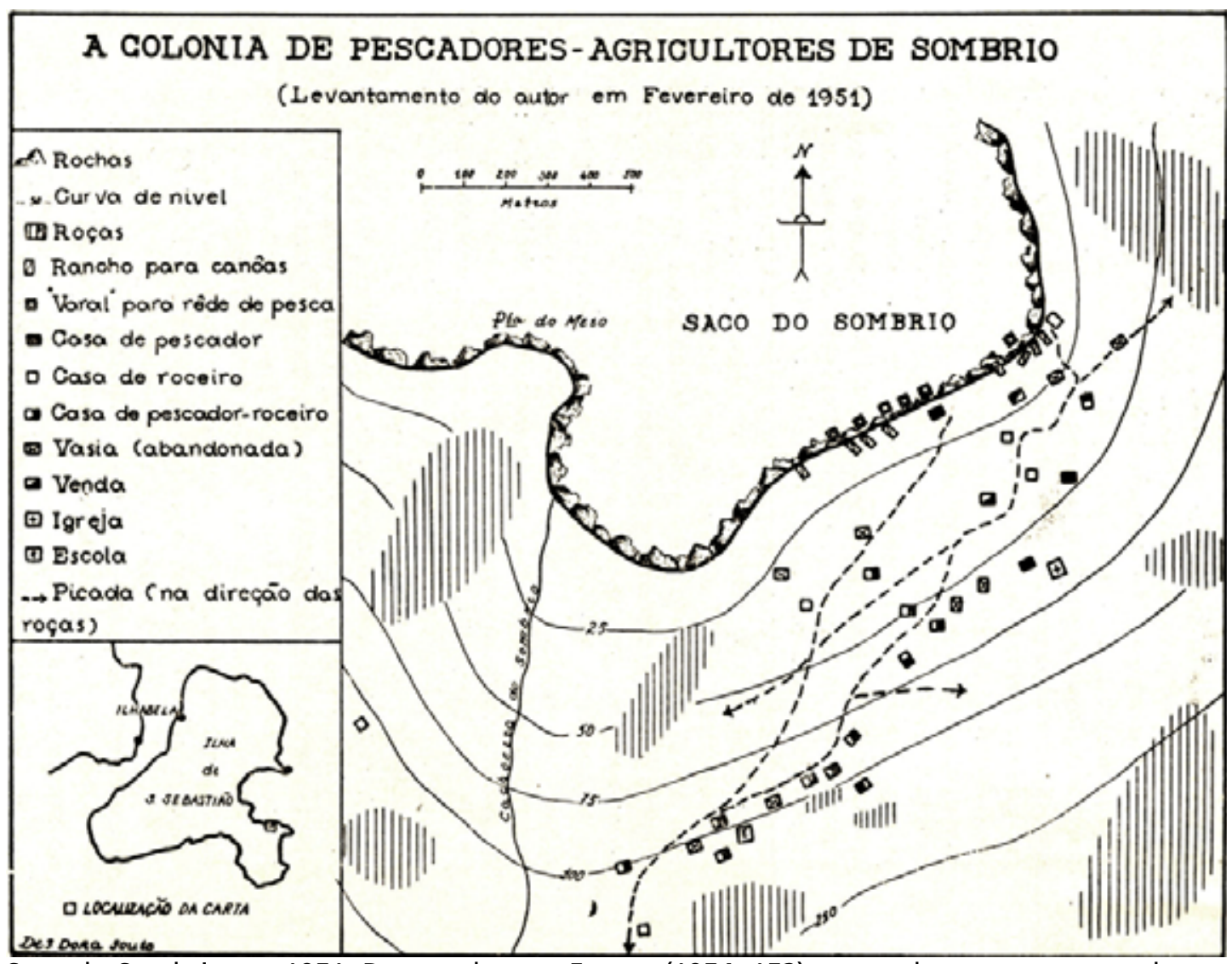

Saco do Sombrio em 1951. De acordo com França (1954: 152), autor do mapa, o povoado era decadente, com 8 moradias vazias, 1 escola fechada, 2 vendas, sendo uma fechada, e a presença de apenas 3 chefes de família que se dedicavam exclusivamente à pesca.

\section{b) O Engenho de Pinga e os Bananais}

"Trabalhava um pouco com Barbosa um pouco com Leonardo, um pouco com Barbosa um pouco com Leonardo, e assim foi. Quando trabalhava com Barbosa era no bananal - ' tinha bananal ali em cima na pancada d'água, carregava de lá nas costas até aqui na cachoeira, dali então carregava no carro de boi até a praia, embarcava na canoa para daqui então fazer a baldeação de navio, e o barco levava a banana, ia até Santos...' Eram esses mesmos barcos que traziam mantimentos para o Sr. Barbosa e para o Sr. Leonardo. Pirati, Ubatuba eram os nomes dos barcos. Quando era tempo de colheita mandava o recado para o barco, então juntava o pessoal do Barbosa e do Leonardo e faziam a colheita de banana... Quando trabalhava para o 
Leonardo era para carregar bagaço de cana: colocava no sol, depois que tava seco então tirava do sol, botava no paiol para depois então ir para o forno, para torrar e fazer a rapadura o açúcar. Na roça de cana, cortava cana, amarrava cana, carregava cana." (Trecho do depoimento do Sr. Pedro Euzébio, morador do Canto do Ribeirão - Pirró, 2003: 63).

Assim era a vida para muitos dos moradores na Baía dos Castelhanos em meados do século $X X$.

O Sr. Sebastião, pai do Sr. Pedro Euzébio, veio da Praia da Caveira, costa leste de Ilhabela, para trabalhar no Engenho do Leonardo Reale na década de 1920. Chegou a trabalhar por algum tempo no Engenho Velho, que ainda funcionava no Canto do Ribeirão e que fechou logo depois. Poucos são os moradores atuais da Baía dos Castelhanos que viram os antigos engenhos de aguardente funcionando, já que remontam ao tempo da escravidão, mas sua existência ficou registrada no imaginário da população; algumas ruínas ainda podem ser vistas próximas à estrada, antes do início da subida da serra.

Assim como o Sr. Sebastião, antigos moradores, já falecidos, vieram de outras localidades de Ilhabela para trabalhar na lavoura da cana-de-açúcar para a produção de pinga na Baía dos Castelhanos. Sr. Pedro Madalena, da Praia Vermelha, conta que seu avô veio de Itapicirica, um lugar na costa sul de Ilhabela, para trabalhar no corte e transporte da cana na fazenda do Engenho Velho.'

Durante quatro décadas, as duas últimas do século $\mathrm{XIX}$ e as duas primeiras do século $\mathrm{XX}$, a produção de aguardente para o mercado de Santos sustentou a economia de Ilhabela. Desde a segunda metade do século XIX, com a decadência do cultivo e comércio do café na região, o município vinha perdendo população e conseguiu estancar com os engenhos de pinga nesse período, o fluxo migratório para outras cidades da região, principalmente para Santos, conforme pode ser verificado no quadro a seguir.

\footnotetext{
1 “...atingiram (os engenhos) um total de 36 na segunda década deste século (XX), tendo chegado a existir um na mais isolada praia do perigoso costão sul (praia do Bonete) e surgindo vários na de acesso difícil do leste da Ilha (inclusive dois na praia dos Castelhanos)" (França, 1954: 105).
} 
Quadro 1 - Evolução da população em Ilhabela entre 1854 e 1950

\begin{tabular}{cc} 
ANO & POPULAÇÃO \\
\hline 1854 & 10.769 \\
\hline 1890 & 7.361 \\
\hline 1920 & 8.052 \\
\hline 1934 & 6.215 \\
\hline 1940 & 5.568 \\
\hline 1950 & 4.800
\end{tabular}

Fonte: França, 1954: 145, 146 e 150

Parte considerável do contingente populacional que deixou llhabela era constituída de ex-escravos que migraram para Santos em busca de postos de trabalho que não existiam no Litoral Norte.

Eram tempos difíceis. Os barcos a motor estavam substituindo as canoas de voga no transporte de mercadorias e punham um fim ao breve período de relativa prosperidade que a retomada da produção de pinga nos pequenos engenhos movidos a roda d'água havia propiciado.

Ilhabela ingressava em um novo período de êxodo populacional. Era relativamente comum famílias inteiras se deslocarem pelo seu território a procura de trabalho antes de migrarem para outros municípios. Onde ainda houvesse um pequeno engenho produzindo, para lá se dirigiam essas famílias em busca dos serviços perdidos nos engenhos fechados em outras praias.

$\mathrm{Na}$ Praia dos Castelhanos havia ainda dois engenhos em funcionamento. O Engenho Velho, mais antigo, operava desde o século anterior com mão-de-obra escrava. "ao percorrermos várias vezes o contorno da Ilha, não encontramos senão nas pequenas praias isoladas da costa leste e na de Castelhanos áreas que foram com segurança, devastadas em larga escala e pela primeira vez, naqueles longos e calmos anos" (França, 1954: 149). Assim pode-se dizer que lavoura da cana para a produção de pinga foi a primeira atividade agrícola expressiva desenvolvida na Baía dos Castelhanos. O Engenho Velho desapareceu junto com as canoas de voga. O engenho do Sr. Leonardo Reale continuou em atividade pelo menos até o início da década de 1960. 


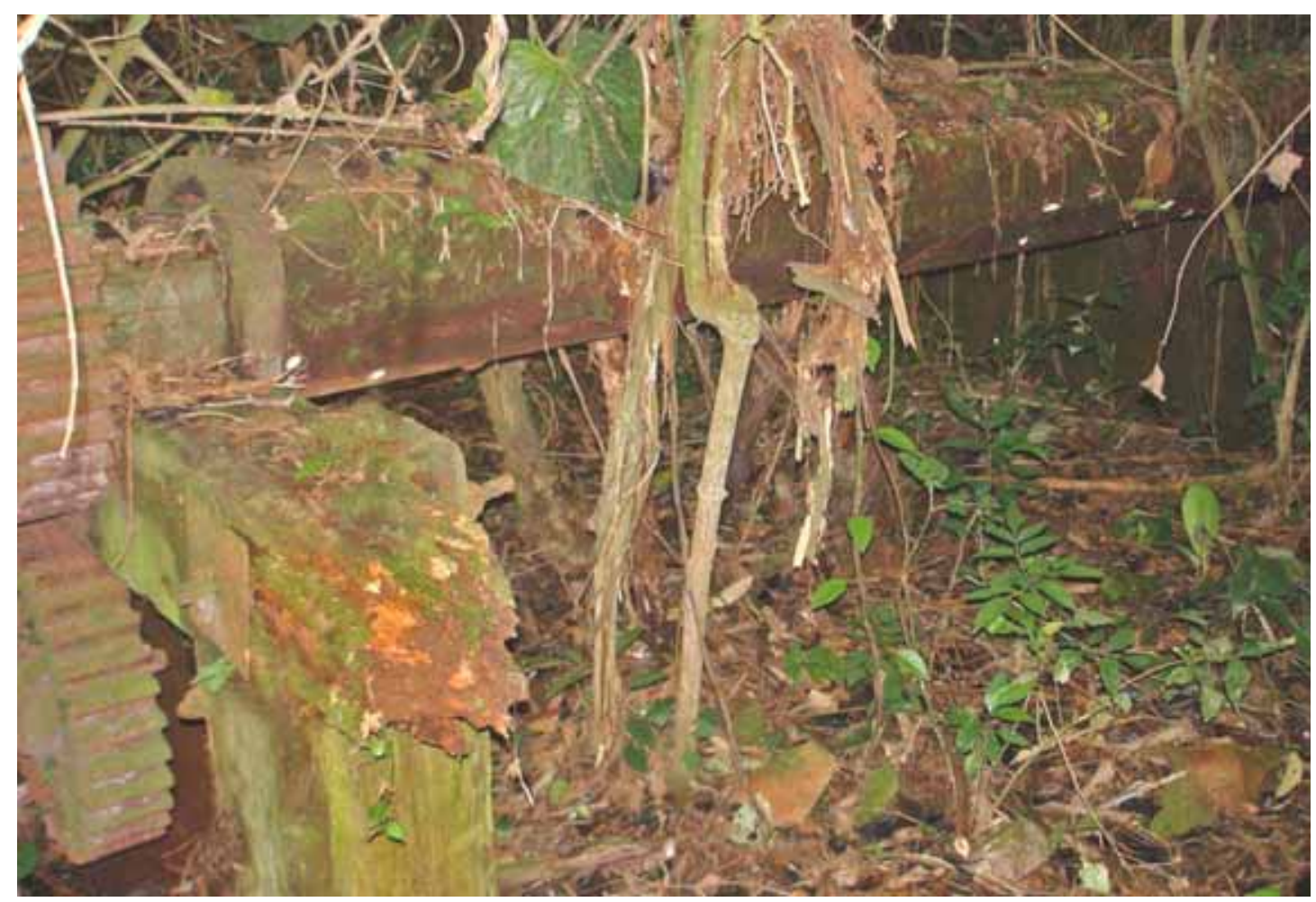

Foto 20, P. Noffs, 2007. Ruínas do engenho do Sr. Leonardo Reale

A chegada dos antepassados de Sr. Pedro Madalena e do Sr. Pedro Euzébio à Baía dos Castelhanos coincide com o fim daqueles longos e calmos anos e o início de novas atividades econômicas em Ilhabela, propiciadas pela introdução da pesca de cerco e dos barcos a motor. O pai de Sr. Pedro Madalena, devido ao fechamento do Engenho Velho, mudou-se para a Praia Vermelha, onde passou a se dedicar a outras atividades. A família do Sr. Pedro Euzébio permaneceu no Canto do Ribeirão, trabalhando na fazenda do engenho do Reale e mais tarde, na fazenda do Barbosa. A sua família e a família de seus filhos ainda moram no Canto do Ribeirão.

Os moradores mais velhos das praias Vermelha, Mansa e dos Castelhanos relatam que trabalharam no engenho do Reale. O serviço basicamente se restringia ao corte e transporte da cana. Recebiam por dia trabalhado e o pagamento era feito aproximadamente de 15 em 15 dias. É difícil precisar o quanto se ganhava exatamente, uma vez que, além de terem trabalhado no engenho em períodos diferentes, os moradores não se recordam muito bem. Apenas se sabe que se ganhava muito pouco. O Sr. 
Joaquim, do Canto da Lagoa, por exemplo, fala em 500 réis por dia para os serviços de colheita e transporte da cana e de 1.500 réis para os que trabalhavam no machado (limpeza e preparo da terra para o plantio). Recorda-se que $1 \mathrm{~kg}$ de carne seca custava 1.500 réis na venda do Barbosa. (Cadastro das famílias caiçaras, das casas de turistas e das atividades comerciais na Baía dos Castelhanos - anexo)

Cabe destacar que as terras do engenho eram cultivadas também com a banana prata, que complementavam a produção da aguardente, garantindo a sustentação comercial da propriedade do Sr. Leonardo Reale.

"Além da lavoura de subsistência e pesca, o Litoral Norte conheceu o desenvolvimento do cultivo da banana, introduzida a partir da Baixada Santista, desde o século XIX, e intensificada a cultura no segundo quartel do século XIX. No entanto, ela só se tornaria relativamente importante em fase posterior, já no século XX." (Silva, 1975: 81).

Os bananais constituíam a atividade agrícola mais importante da Baía dos Castelhanos até o início da década de 1960. Cultivada essencialmente para o comércio, a produção de banana prata era escoada, por intermédio dos barcos a motor, diretamente para o mercado de Santos. "Em culturas comerciais a banana depende de transportes regulares. Por isso, as lavouras localizam-se nas imediações das praias do Canal de São Sebastião, particularmente nas da entrada sul e no nordeste e leste da llha (baía de Castelhanos), até onde costumam aportar semanalmente um ou dois barcos de transporte, que servem ao escoamento feito para o mercado santista." (França, 1954: 124). A banana era produzida em toda a Baía dos Castelhanos, mas os principais bananais encontravam-se nas praias Mansa e dos Castelhanos. Merecem destaques os bananais do Sr. Pedro Rafael de Souza, na Praia Mansa, do Sr. Manoel Rafael, no Canto da Lagoa e o do Sr. Barbosa, no Canto do Ribeirão.

A produtividade dos maiores bananais era estimada em 80 dúzias de cachos por mês. Enquanto os canaviais ocupavam as terras próximas ao engenho, preferencialmente as baixadas e as porções convexas e ensolaradas dos morros, os bananais adaptavam-se melhor às partes côncavas, sombreadas e mais úmidas. Exigiam constantes serviços de manutenção, que se definiam 
basicamente pela limpeza do terreno e pelo corte das árvores e arbustos que cresciam rapidamente entre as bananeiras. Para essa finalidade e também para o corte e transporte da fruta, eram recrutados trabalhadores no local e praias vizinhas que recebiam em dinheiro pelas tarefas realizadas.

O mapa e a foto a seguir mostram que os bananais ocuparam porções consideráveis do terreno e se estenderam por muitos grotões nos morros que circundam a Baía dos Castelhanos.

Mapa 4 - A Floresta e a Exploração do Solo na Baía dos Castelhanos

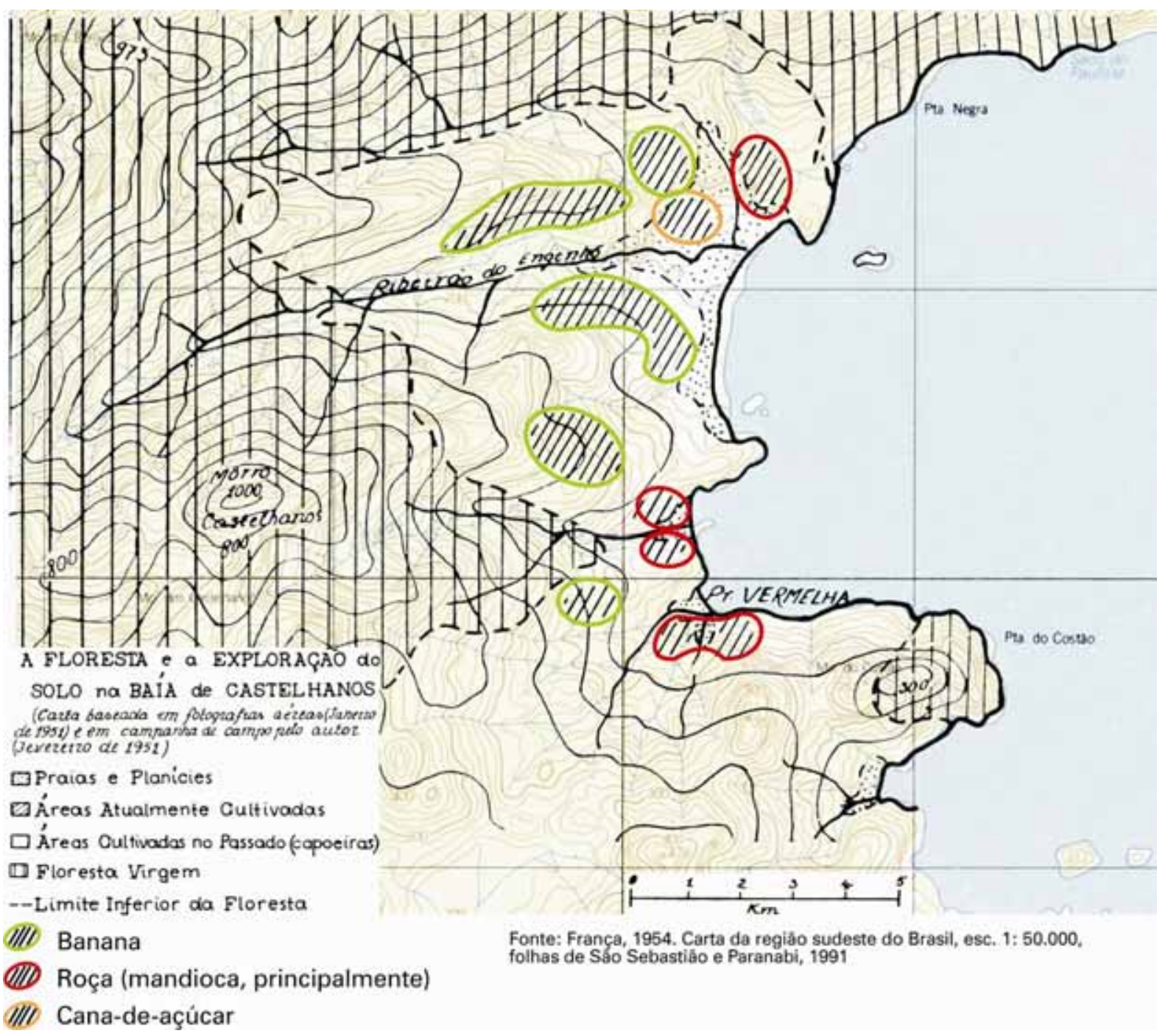

Mapa esquemático adaptado de França, 1954, apresentando as áreas cultivadas na Baía dos Castelhanos em 1951 e em anos anteriores. As informações para localizar as roças e os cultivos de banana e cana-de-açúcar foram obtidas junto aos moradores locais e da interpretação de fotografias aéreas de 1962. 


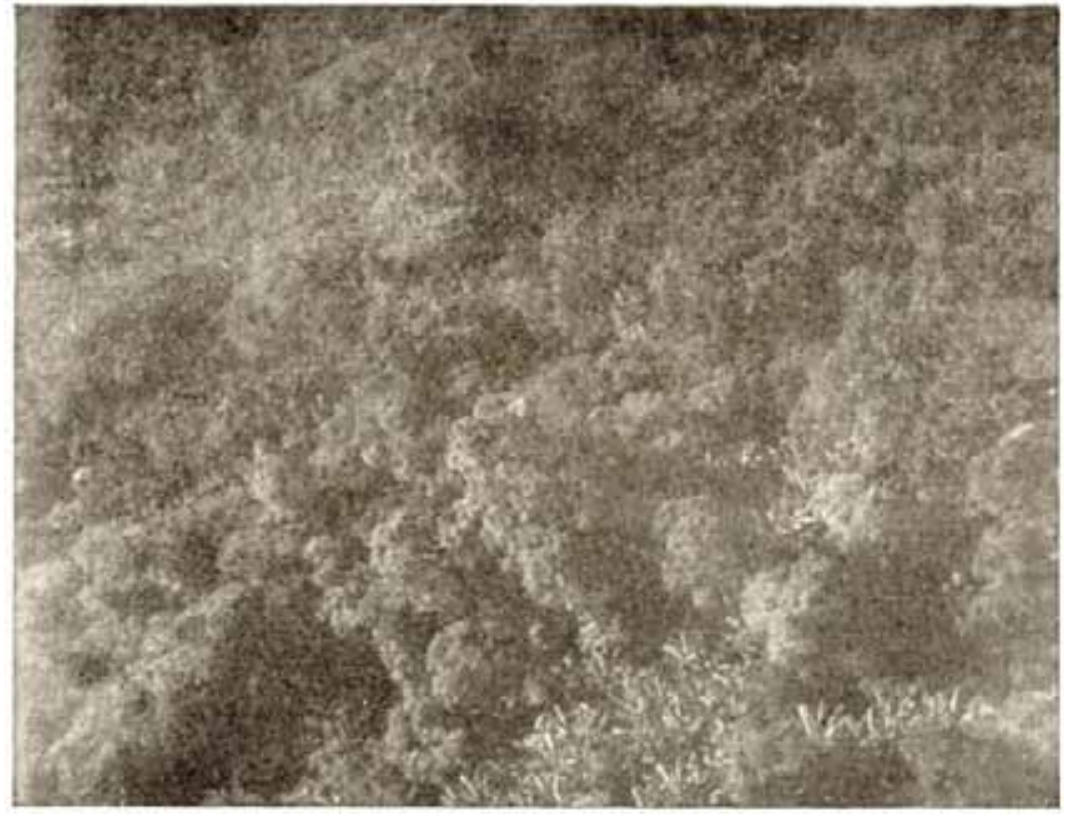

Foto 21, extraída de França, 1954: 123 Trecho do bananal do Sr. Manoel Rafael no Canto da Lagoa já atingindo a serra na região do Morro dos Castelhanos

A banana era transportada do morro até a baixada nas costas dos trabalhadores. Cada homem podia carregar entre 6 e 12 cachos de banana por viagem, dependendo da sua força e do tamanho dos cachos. Do pé da serra a banana era levada por carro de boi até as canoas na praia, para depois serem acondicionadas nos barcos a motor que a transportavam para Santos. No Canto da Lagoa e nas Praias Mansa e Vermelha, a fruta era transportada nas costas dos trabalhadores diretamente para a praia, sem a utilização do carro de boi.

Os barcos a motor transportavam a banana para Santos, onde era vendida no mercado atacadista. Na viagem de retorno à Baía dos Castelhanos o dono do bananal recebia os valores correspondentes à venda efetuada.

O regime de trabalho e os valores recebidos pelos trabalhadores eram semelhantes aos praticados na lavoura da cana.

c) O Cotidiano na Baía dos Castelhanos até o Final dos Anos $\mathbf{5 0}$

Até a abertura da estrada de terra de São Sebastião para Bertioga e Santos em 1962, e do serviço de balsas para a realizar a travessia do canal de São Sebastião em 1964, todo o município de llhabela e a costa norte de 
Ubatuba, dependiam dos barcos a motor para realizarem o comércio com o mercado santista, e em menor escala, com o do Rio de Janeiro.

Assim, durante aproximadamente 50 anos, a Baía dos Castelhanos teve na pesca de cerco e na lavoura da banana, as suas principais atividades comerciais. Nesse período, inicialmente a pesca de cerco desempenhou um papel mais preponderante. Com a saída gradativa dos japoneses do litoral paulista a partir da segunda guerra mundial, os cercos passaram a ser manejados também pela população caiçara e dividiam com as fazendas ${ }^{2}$ a produção dos principais artigos de exportação para o mercado santista.

Cabe destacar que o predomínio de uma atividade não excluía a outra. O Sr. Otávio, filho do Sr. Barbosa que era proprietário de um dos maiores bananais da Praia dos Castelhanos, relata que sua família possuía dois cercos, um que pescava na Laje Preta, próxima à Praia da Caveira e outro em sociedade, no costão da Praia da Figueira. O mesmo ocorria com as famílias que tinham na pesca sua principal atividade e que recorriam à agricultura para complementar seus meios de subsistência. De um modo geral, pode-se dizer que todas as famílias praticavam simultaneamente a pesca e a agricultura, mas somente algumas eram proprietárias de cerco ou de bananal.

"...roças pequenas, abertas nas clareiras da mata, produtoras de alimentos básicos para a família, e com alguns excedentes para o mercado local, combinadas por algumas poucas fazendas voltadas primordialmente para produtos de exportação, e secundariamente para o cultivo de alimentos destinados a seus grupos domésticos. Sítios de alimentos e fazendas justapõem-se na paisagem agrícola, de maneira desorganizada e bastante dispersa" (Marcílio, 2006:40) retratam um modelo de organização da produção que ocorria em outros locais do Litoral Norte, inclusive na Baía dos Castelhanos.

A situação da família do S. Barbosa, que era proprietária de bananal, de dois cercos e da única venda, e a do S. Pedro Euzébio, que trabalhava para o S. Barbosa e tinha sua roça em terras cedidas por ele, servia de exemplo da convivência no espaço de fazendas e roças.

\footnotetext{
${ }^{2}$ Assim eram denominadas as propriedades rurais no Litoral Norte que produziam para o comércio. A banana era a principal mercadoria, mas eram cultivadas outras frutas, como mexerica, limão, laranja, abóbora etc.
} 
$\mathrm{Na}$ base de toda a produção das famílias caiçaras estava a pequena lavoura de subsistência, ou simplesmente, a roça. A roça, nos dizeres de Dona Celeste, viúva de Seu Barbosa e moradora do Canto do Ribeirão, "produzia de tudo: batata-doce, milho, abóbora, abacaxi, laranja, mandioca para fazer farinha e para comer. Tinha também a criação: galinha, pato, porco...fazia muita banha, mas tudo era para o consumo das famílias. Para vender, era mais a pimenta, os passarinhos (tucano, sabiá, papagaio, macuco) que eram caçados e ficavam presos nas gaiolas esperando o barco." (Cadastro das famílias residentes na Baía dos Castelhanos - anexo: x). Dona Sebastiana, do Saco do Sombrio, lembra que os barcos levavam para Santos também as gaiolas para passarinhos que os caiçaras construíam artesanalmente especialmente para o comércio. ${ }^{3}$

Praticamente todas as famílias caiçaras tinham suas roças, inclusive as que eram proprietárias de bananal ou de rede de cerco. Em uma economia que produzia poucas mercadorias e a circulação de dinheiro era restrita, provinha da roça o alimento do dia-a-dia. Entretanto, como já foi dito, existiam famílias que tiravam seu sustento apenas da produção da roça e da comercialização de alguns eventuais excedentes, que podiam também se originar da pesca. Da. Erotildes, moradora do Canto da Lagoa e que foi criada em Galhetas, localidade próxima ao Saco do Sombrio, conta que sua família vivia da produção da roça, da criação de animais e de um pouco de banana que entregavam para o barco.

O Sr. Joaquim Lucio do Canto da Lagoa acrescenta outras informações que ajudam a compreender melhor esse período. A sua família, como a maioria das existentes na Baía dos Castelhanos, tinha na roça a base da sua subsistência. Para complementar a renda familiar, trabalhava no engenho do Reale, cortando e transportando cana para a moagem, e como camarada nos

\footnotetext{
${ }^{3}$ Em depoimento prestado a Pirró (2002: 65), o Sr. Otávio, morador do Canto do Ribeirão, conta: "O barco vinha e buscava tudo tudo, pimenta, passarinho. O quanto de passarinho nós vendemos! Naquele tempo não tinha nada de florestal, nós pegávamos periquito, tucano, macuco, sabiá; às vezes o barco levava, 40, 50 casais de tucano. Pegava com alçapão, todo mundo pegava; naquele tempo era bom, tudo nós vendíamos. Nós guardávamos em casa, o barco vinha na sexta feira, então era só levar na praia que eles levavam. Antigamente não era multado, não tinha nada disso. Tinha muito mais passarinho, eles vinham na porta, hoje em dia não se vê mais." Não há dúvida do caráter predatório da atividade, praticada exclusivamente com finalidade comercial e, portanto, opondo-se a idéia de que os caiçaras, dependendo dos ciclos da natureza e produzindo basicamente para o consumo, causavam poucos danos a natureza.
} 
cercos dos japoneses. Por volta de 1950, adquiriu seu próprio cerco que foi instalado na ponta da Lagoa. Assim como ele, muitos homens prestavam serviços remunerados nas lavouras de cana e banana e nas redes de cerco.

Em relação à alimentação, a farinha de mandioca era consumida principalmente acompanhando o peixe e o feijão, que nas casas mais pobres, eram apenas cozidos na água sem nenhum outro tempero além do sal. Também se consumia a farinha pela manhã, acompanhando o café de cana (café preparado com a garapa da cana, que substituía a água e o açúcar). Praticamente todas as famílias plantavam mandioca e fabricavam a farinha em fornos simples e domésticos, mas a maior parte delas não possuía a "casa de farinha" e utilizava gratuitamente a de algum parente ou vizinho.

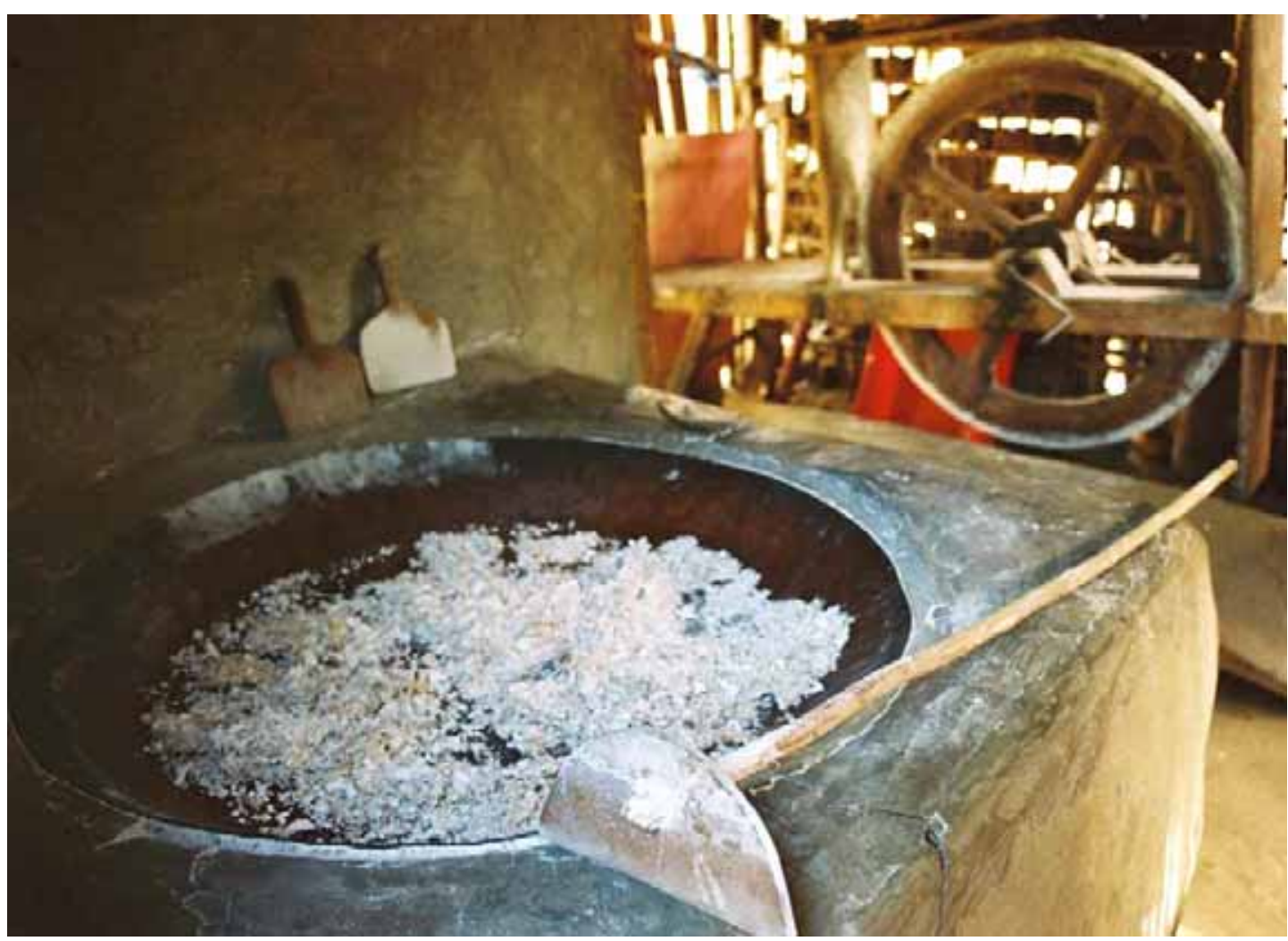

Foto 22. P. Noffs, 2005. Casa de farinha da família do Sr. Anízio e Da. Leopoldina na Praia Vermelha 


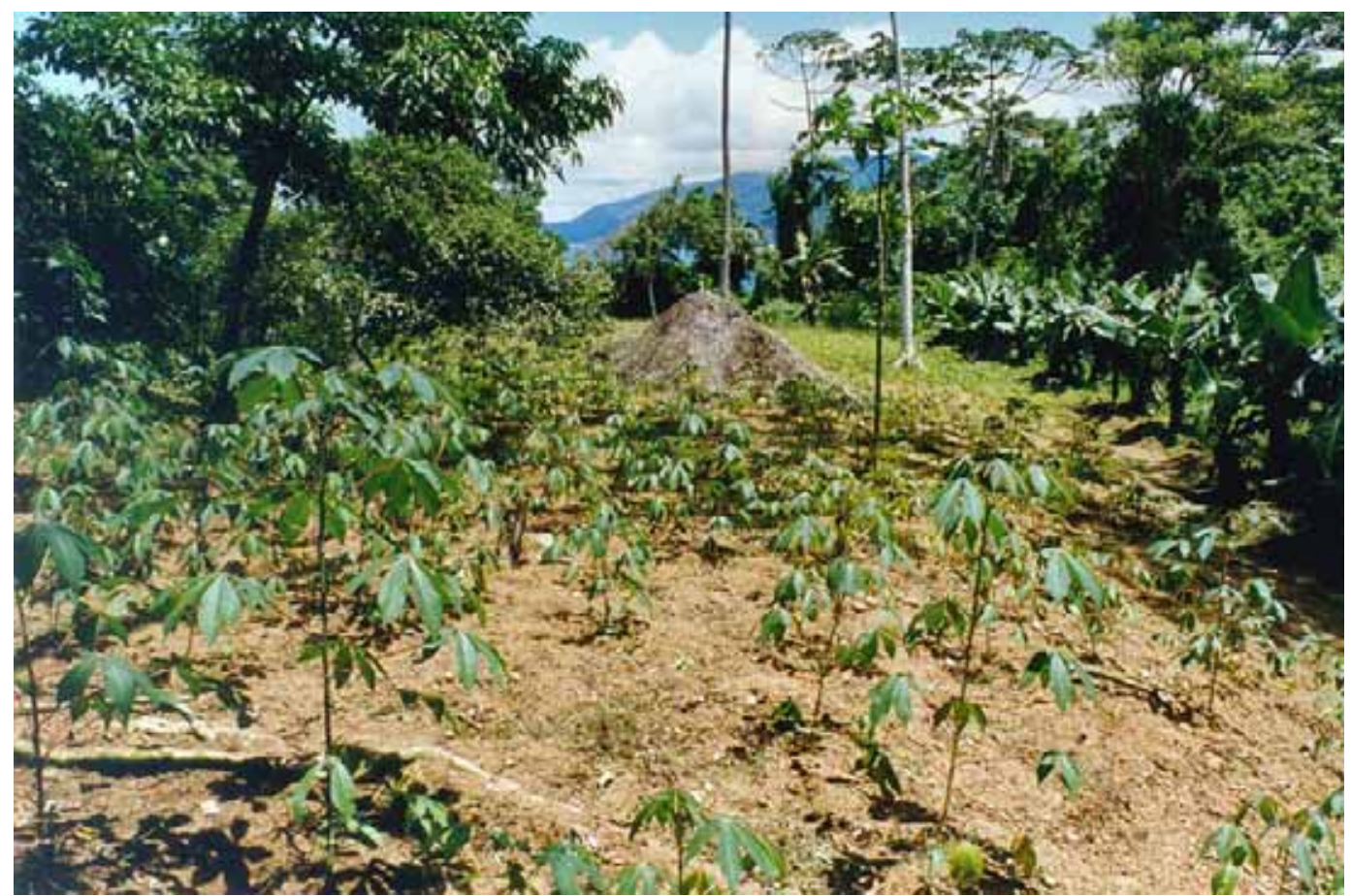

Foto 23. P.Noffs, 1997. Roça de mandioca da Da. Celeste no Canto do Ribeirão

De modo geral, a farinha era produzida para o consumo da própria família e assim relata a maior parte da população mais antiga da Baía dos Castelhanos. No entanto, alguns moradores contam que a farinha era produzida para vender. Esse é o caso da família do Sr. Anízio, da Praia Vermelha, que produzia por gleba plantada de mandioca, cerca de 10 sacos de 22 kg cada e que se destinava ao mercado de Santos. Mussolini (1980: 250) afirma que, passada a fase áurea da pesca de cerco no Saco do Sombrio, "o isolamento indispensável se tornou impossível...de maneira que a farinha de mandioca que 'hoje é o forte do lugar', deixou de ser o símbolo de uma produção de subsistência para se converter num produto de exportação para toda a área."

Em síntese, a construção do espaço no período entre 1920 e meados da década de 1960 foi obra da produção mercantil simples articulada ao mercado de Santos pelos barcos a motor. Em qualquer lugar da Baía dos Castelhanos, havia uma família caiçara produzindo mandioca, feijão, batata-doce, milho etc. Ao redor das casas, invariavelmente feitas de pau-a-pique, encontravamse as fruteiras e os animais eram criados soltos no terreiro. Trabalhava-se 
algum dia no bananal, no engenho ou ainda como camarada no cerco para ganhar algum dinheiro, que se somava àquele recebido na venda de algum excedente da roça.

Entretanto, havia famílias que além da roça para a produção de alimentos, também eram proprietárias de lavouras comerciais de banana ou de aparelhos de cerco, nos quais pessoas das outras famílias, que só tinham a roça, trabalhavam para produzir mercadorias que eram destinadas ao comércio com a cidade de Santos.

Completando o quadro da produção mercantil simples, havia a presença dos pequenos armazéns (ou vendas, como eram conhecidos esse tipo de estabelecimento comercial na época), que se encarregavam de abastecer de produtos diversos a população local. Como já mencionado, no Saco do Sombrio, no auge da pesca de cerco, chegaram a existir quatro deles e em 1951 foram registrados a presença de dois, sendo que apenas um deles estava funcionando. A venda do Sr. Barbosa era um desses estabelecimentos que serviam à população da Baía dos Castelhanos em meados do século passado. $A$ sua importância dava-se pelo fato de ser o único que atendia aos moradores desde a Praia Vermelha até o Canto do Ribeirão, onde se localizava. "A venda do meu marido ficava ali, no canto da praia, bem onde o Pedro Euzébio fez a sua primeira casa. O Barbosa aproveitava o barco e ia junto com a produção para Santos e de lá trazia as mercadorias. Trazia carne seca, feijão, café, sal grosso, lataria, biscoito, fumo, cigarro, querosene, sabão em pedra, sabonete... bebida só a pinga. Pegava um pouco no engenho para vender em garrafa ou em dose durante o tempo que ele ficava fechado $A$ venda era muito sortida, tinha de tudo, vinha gente de todos os cantos da Baía dos Castelhanos, até do Sombrio vinha gente para comprar na venda." (entrevista com Da. Celeste realizada pelo autor em 04/2007).

A existência das pequenas vendas na Baía dos Castelhanos além de suprir os moradores locais de gêneros de primeira necessidade, cumpria um outro papel, que era de promover a sociabilidade. "O Barbosa era muito festeiro. Ali (na casa dele) era salão de baile antigamente. Ele gostava e emprestava a casa dele pra quem gostava. Fazia casamento...quando alguém casava, fazia a festa de casamento na casa dele. Mesmo um bailezinho 
simples, um forrozinho da roça, ele emprestava a casa dele. Ele tava velhinho mas ele também gostava de sacudir um pouquinho...ele emprestava a casa dele pro pessoal fazer festa. Mas tinha de ser na regra. Se qualquer um pisava na bola, ele tocava pra fora e não entrava mais...ele emprestava a casa dele pra fazer um bailinho da roça, um batizado..." (trecho do depoimento de Da. Leopoldina e de Sr. Anízio prestado para o autor em agosto de 2007). A venda funcionava também como "estabelecimento de crédito" ao vender fiado para uma população que detinha pouco dinheiro.

Assim, o capitalismo se realizava na Baía dos Castelhanos sem promover relações de produção tipicamente capitalistas. Dois aspectos importantes podem ser destacados no modo como a produção mercantil simples foi incorporada ao processo geral de circulação de mercadorias nesse período:

1- Dependência dos barcos a motor. A produção local de mercadorias, fosse resultado das fazendas, da pesca de cerco ou do excedente das roças e de outras formas de pescaria, articulava-se diretamente com o mercado de Santos por intermédio dos barcos a motor. De igual modo, as mercadorias consumidas na Baia dos Castelhanos, tanto os gêneros de consumo (alimentos, roupas etc.), como as ferramentas, materiais e equipamentos necessários à pesca e à lavoura e ao artesanato eram trazidas por essas embarcações diretamente daquela cidade. A circulação de mercadorias e de dinheiro entre os povoados era mínima, quase inexistente. A troca, quando ocorria, era de produto por produto e ainda assim, quase circunscrita a membros de uma mesma família. Dessa forma, os barcos a motor representavam a possibilidade de contato com o mundo exterior, com as cidades. Transportavam pessoas entre as cargas, aceitavam encomendas, mandavam e traziam recados de parentes que moravam fora. Cobravam seu preço para isso. Não há caiçara remanescente desse período que não reclame dos preços cobrados, do dinheiro recebido a menos pelas bananas embarcadas, etc. Assim, pode-se afirmar, sem exagero, que a produção local estava subordinada aos interesses dos armadores de Santos, proprietários dos barcos a motor que respondiam pela circulação de mercadorias e pessoas na Baía dos Castelhanos e em outras áreas expressivas do Litoral Norte paulista. 
2- A função administrativa da cidade de Ilhabela. Nas últimas décadas do século XIX e primeira metade do XX, a economia brasileira passou por profundas transformações, impulsionadas pelo desenvolvimento da cafeicultura no estado de São Paulo, interessando a esse trabalho destacar:

- a consolidação de Santos como o principal porto exportador do Brasil e a relevância regional que essa cidade passa a ter na organização da produção e circulação de mercadorias no litoral paulista;

- a industrialização e a formação da metrópole paulistana, principalmente após a década de 1930;

- a modernização e diversificação agrícola e a formação de pólos agroindustriais no interior de São Paulo, introduzindo no campo relações tipicamente capitalistas de produção e subordinando a sua dinâmica e aos interesses de mercado, outras relações de trabalho, como a familiar, presente na produção mercantil simples.

Setores do Vale do Paraíba e o Litoral Norte, áreas pioneiras na penetração da cafeicultura em território paulista, ficaram à margem desse processo e só perifericamente interessaram ao capitalismo urbano-industrial que se consolidava no sudeste brasileiro no início da década de 1960, quando a infra-estrutura viária de São Paulo já era bastante complexa, contando com rodovias de pista dupla que ligavam as principais regiões produtoras do interior a capital e aos portos de Santos e Rio de Janeiro. A industria automobilística nacional que começara a ser implantada na década anterior, crescia rapidamente e o transporte rodoviário de pessoas e mercadorias passou a ser mais importante que o ferroviário.

Desde 1914, o Litoral Sul e o Vale do Ribeira paulista contavam com a ferrovia Santos a Juquiá para transportar para o porto santista a sua importante produção de banana, destinada ao mercado externo brasileiro. Até o final da década de 1950, havia no Litoral Norte uma rodovia de terra com tráfego precário interligando as cidades de Ubatuba, Caraguatatuba e São Sebastião. De Caraguatatuba, também por estrada de terra, podia-se chegar a São José dos Campos e ao Vale do Paraíba. As populações de regiões 
consideráveis dos territórios de Ilhabela, São Sebastião e Ubatuba, por não contarem com nenhuma infra-estrutura viária, viviam isoladas e precisavam percorrer a pé grandes distâncias para chegarem às sedes de seus municípios.

Reflexo dessa situação e da perda de importância do Litoral Norte no universo agrário brasileiro, a população de llhabela, que era de 8.052 pessoas em 1920, decresce continuadamente até chegar a 4.800 habitantes em 1950 (França, 1954: 145, 146 e 150). A área plantada no município, segundo estimativas realizadas em 1951, era de apenas 2.612 ha, ocupadas majoritariamente com roças, quando, um século antes havia 12.600 ha de terras cultivadas, principalmente com café, produto de maior valor comercial. (França, 1954: 113 a 115). Completa esse quadro de esvaziamento econômico, a decadência da pesca de cerco, que tinha conhecido seu apogeu por volta de 1930. A economia do município de Ilhabela em 1950, praticamente era constituída de atividades rurais, conforme demonstram os dados apresentados no quadro a seguir.

Quadro 2 - Ocupação da população por setores de atividades rurais e composição das populações urbana e rural em 1950

\begin{tabular}{|c|c|c|}
\hline ATIVIDADES & POPULAÇÃO & $\%$ \\
\hline \multicolumn{3}{|l|}{ População dependente de atividades rurais } \\
\hline Exclusivamente agrícola & 1224 & 29,6 \\
\hline Principalmente agrícola e secundariamente pesca & 1482 & 35,8 \\
\hline Principalmente pesca e secundariamente agrícola & 892 & 21,5 \\
\hline Exclusivamente pesca & 315 & 7,6 \\
\hline Outras atividades rurais & 231 & 5,5 \\
\hline População Rural & 4144 & 86,3 \\
\hline População Urbana & 656 & 13,7 \\
\hline População Total & 4800 & 100 \\
\hline
\end{tabular}

Das 656 pessoas que dependiam de atividades consideradas urbanas, apenas 279 residiam na cidade de Ilhabela. Outras 312 viviam em áreas suburbanas localizadas ao longo do canal de São Sebastião e 105 em áreas consideradas rurais. É bastante interessante a constatação de que, de 407 
pessoas que moravam na cidade de Ilhabela, foram identificadas 168 que dependiam de atividades diretamente ligadas à pesca e a agricultura. Nesse mesmo ano, no Litoral Norte, para uma população de 23.500 moradores, a população urbana era de apenas 3780 pessoas, 16,1\% do total (França, 1954: 45 e 46), mostrando que Ilhabela não era exceção na realidade regional.

Assim, a cidade de Ilhabela não desempenhava nenhum papel de importância na organização da produção. As áreas produtoras, principalmente aquelas localizadas nas costas norte, leste e sul, por intermédio dos barcos a motor, estabeleciam comércio diretamente com o mercado de Santos, restando à sede do município apenas algumas funções administrativas. O espaço da produção mercantil simples na Baía dos Castelhanos não apenas era rural, como prescindia dos núcleos urbanos de Ilhabela e São Sebastião para se constituir.

\section{d) $O$ Isolamento}

"Foi quando acabou o serviço com o Leonardo que o Sr. Pedro começou a pescar. Leonardo foi para a vila ser prefeito e os filhos ficaram, mas não cuidaram direito, não deram conta do serviço do pai, não cuidavam, não roçavam, então o mato cresceu. Porém, o serviço não parou, continuavam trabalhando para o Sr. Barbosa. O Sr. Pedro conta que o Barbosa ficou até o fim, mas depois faleceu, ficou somente seu filho Otávio, que não deu conta de tudo sozinho, ainda mais que machucou a perna..." (Trecho do depoimento do Sr. Pedro Euzébio, morador do Canto do Ribeirão - Pirró, 2003: 63 )

Acabou o serviço com o Leonardo, com o Barbosa, depois com o Sr. Pedro Rafael e também com muitos outros que produziam para o mercado de Santos. O que o Sr. Pedro Euzébio não podia saber é que estava vivendo o fim de um período bastante peculiar na história do Litoral Norte: o do mercado de Santos articulando a produção mercantil simples por intermédio dos barcos a motor.

A abertura da estrada de terra de São Sebastião para Bertioga e Santos em 1962 (atual Dr. Manoel Hyppólito do Rego - SP-55), e do serviço de balsas para realizar a travessia do canal de São Sebastião em 1964, trouxeram 
profundas implicações para a Baía dos Castelhanos. A principal e mais imediata delas foi a do transporte de mercadorias e de pessoas passar a ser realizado por ônibus e caminhões. Em conseqüência, a costa sul de São Sebastião e llhabela deixaram de ser freqüentadas pela frota santista de barcos a motor.

A produção do espaço no Litoral Norte ganhou novos contornos com a complementação da infra-estrutura viária, interligando Santos com todas as cidades do Litoral Norte. Assim, "esses centros constituem hoje um prolongamento da urbanização do sudeste brasileiro no caso impulsionado principalmente pela Grande São Paulo, Baixada Santista, Vale do Paraíba Paulista e Rio de Janeiro." (Silva, 1975: 202).

O turismo, que já estava presente no litoral entre as cidades de São Sebastião e Ubatuba, favorecido pela expansão e melhoria do sistema viário, cresce continuadamente, redefine os perfis de antigos bairros caiçaras, iniciando a urbanização do espaço rural da produção mercantil simples. (Silva, 1975: 201, 202)

Enquanto isso, a Baía dos Castelhanos, sem transporte rodoviário, entra em seu período de isolamento mais profundo, que vai durar até 1977 quando as obras da estrada de terra chegaram à praia.

A produção mercantil simples, sustentada pela pesca e pelas lavouras de banana prata, cana de açúcar para a produção de aguardente e roças, ao perder sua ligação com o mercado de Santos, entra em colapso. O Engenho do Sr. Leonardo Reale produziu pela última vez em meados da década de 1960 e em seguida foi fechado. As lavouras de cana e os bananais foram abandonados em toda a Baías dos Castelhanos por falta de condições objetivas para escoar a produção. A floresta avançou sobre as plantações, de tal sorte que atualmente restam poucos testemunhos no espaço desse passado recente.

Sem os barcos a motor e as lavouras comerciais, a economia da Baía dos Castelhanos foi reduzida basicamente à produção de alimentos, garantida pelo trabalho familiar nas roças e na pesca. A troca em dinheiro passa a depender da produção de excedentes dessas atividades, principalmente da pesca e da farinha de mandioca, e passa a se realizar nos mercados de llhabela 
e São Sebastião. Os peixes eram consumidos in natura e quando se conseguia uma boa pescaria, o excedente era escalado e armazenado seco. Parte da produção de peixe seco e de farinha de mandioca tinha que ser reservada à venda nas cidades para fazer algum dinheiro para poder comprar sal grosso e algumas ferramentas e apetrechos de pesca, que constituíam os itens fundamentais de consumo das famílias caiçaras.

Da. Leopoldina, moradora da Praia Vermelha, revela, de forma muito interessante, outros aspectos de como se realizava o comércio entre a Baía dos Castelhanos e a cidade. "A roupa, não. Não era o barco que trazia. la lá em São Sebastião comprar numa loja de uma pessoa conhecida, que conhecia o povo todo daqui...Também vinha aqui. Ele vinha a pé com a mala de fazenda, como chamavam antigamente a mala de tecidos. Ele conhecia a comunidade toda, todo mundo gostava...Dava uma entrada, pagava no outro mês o restante. Vendia roupa também...sapato..." (trecho do depoimento de Sr. Anízio e Da. Leopoldina para o autor em 08/2007, referindo-se ao Sr. João Elias, dono do Bazar Fátima em São Sebastião). Mais adiante, nesse mesmo depoimento, ela conta que "a roupa era feita aqui. Eles traziam o tecido, a gente comprava e fazia a roupa. Aqui tinha muita costureira. Tinha a Celeste, tinha a minha tia (Da. Joana) na Praia Mansa, tinha no Castelhanos a mãe da Iza...máquina Singer, todo mundo tinha uma maquinazinha de mão. Quem tinha mais condição, tinha uma máquina de pé, a Singer que pedala. Até calça de homem a gente fazia e vendia."

$\mathrm{Na}$ ausência de meios de transporte, os moradores da Baía dos Castelhanos precisavam realizar a pé as viagens à vila (como os caiçaras denominavam genericamente o destino das viagens às áreas urbanas ao longo do canal de São Sebastião). "Antigamente (antes da abertura da estrada para a Praia dos Castelhanos) o peixe era escalado e seco. Quando juntava uma boa quantidade, a gente arrumava tudo direitinho em fardos de $20 \mathrm{~kg}$ e juntava 3 ou 4 amigos e levava tudo nas costas até a cidade. la a pé pela trilha. Saia às 6 horas da manhã e chegava na vila lá pelas 10 horas. Depois de vender tudo e comprar as coisas que precisava, visitava os parentes e organizava as coisas que tinha de trazer, também em fardos de $20 \mathrm{~kg}$, mais ou menos, e voltava na parte da tarde. Chegava de volta na Praia Mansa depois das 6 horas da tarde." (entrevista realizada com Laércio da Praia Mansa em 04 de 2007). 
Mas nem sempre iam a pé. Quando a quantidade era muita, o peixe seco era transportado para São Sebastião ou llhabela por canoa a remo. O Sr. Anízio, da Praia Vermelha, conta que os viajantes saíam por volta das 4 horas da manhã e, se desse tempo, retornavam no fim da tarde. Se não, pousavam na cidade e voltavam pela manhã do outro dia.

O empobrecimento foi geral na Baía dos Castelhanos com o fim dos barcos a motor, mas o pessoal que morava no trecho entre a Praia da Figueira e o Saco do Sombrio foi mais prejudicado, por terem de transpor o Morro do Costão que separa esse setor da Baía dos Castelhanos, da Praia Vermelha, tornando a viagem para a cidade mais difícil e demorada.

As canoas a remo, que sempre estiveram presentes no cotidiano caiçara de qualquer parte do litoral sul-sudeste brasileiro, passam a ser utilizadas mais amiúde como o único meio de transporte no interior da Baía dos Castelhanos e vizinhanças, além do uso habitual que se fazia delas como meio de trabalho para as atividades pesqueiras.

Sem produção significativa de mercadorias, a circulação de dinheiro se restringiu ainda mais. Conseqüentemente, a venda do Sr. Barbosa, a única que ainda funcionava em toda a Baía dos Castelhanos, fechou logo após sua morte em meados da década de 1960. Sem a venda do Barbosa, o cotidiano também se empobreceu e a vida se tornou mais difícil.

\section{DA SITUAÇÃO DE ISOLAMENTO PARA A DE RARIDADE - AS TRANSFORMAÇÕES DA SOCIEDADE BRASILEIRA E A URBANIZAÇÃO DO LITORAL NORTE}

Quando finalmente as obras da estrada de terra, iniciadas alguns anos antes no bairro do Perequê, chegaram a Praia dos Castelhanos em 1977, os primeiros viajantes encontraram uma paisagem muito diferente daquelas existentes por todo o Litoral Norte de São Paulo, inclusive na própria Ilhabela.

Dependendo da procedência de quem a avistava, a paisagem podia assumir determinadas características, que se moldavam às intenções e interesses do viajante. 
Fosse o observador estudante, pesquisador acadêmico ou simpatizante da "causa ambientalista", a Praia dos Castelhanos era vista (e é ainda) como um lugar habitado esparsamente por famílias de pescadores, que tinham suas roças onde plantavam alimentos para a subsistência e às vezes sobrava alguma coisa que era vendido na cidade. Viviam já há algumas gerações em harmonia com a natureza, explorando os recursos naturais de modo sustentável. A natureza era o território caiçara, de toda a comunidade, apropriado coletivamente. Era onde se coletavam as matérias primas para o artesanato e se estabeleciam as roças itinerantes.

Do ponto de vista do caiçara, a estrada significava, num primeiro momento, a possibilidade de escoar seus produtos. Afinal de contas, havia pelo menos 15 anos que viviam isolados do mercado e finalmente iriam poder estabelecer relações com a cidade e com tudo o que ela representava.

Já o especulador, muito antes de começarem as obras da estrada, já tinha observado a paisagem, por terra, pelo mar e até pelo ar, e enxergara muitas terras baratas, que trataram de comprar a preços ínfimos.

Claro, para os caiçara, a terra era lugar de trabalho e os frutos que extraia da terra com seu trabalho é que podiam ser vendidos. Por isso, e pela condição de isolamento do mercado em que se encontrava, não tinha noção de "valor e renda" e de quais outras finalidades a terra poderia ter além de ser objeto, meio de trabalho e lugar da moradia. Mas o especulador, de modo muito diferente do pesquisador ou do simpatizante da "causa ambientalista", desenhava no espaço quase vazio, futuros empreendimentos imobiliários e antevia lucros fantásticos.

E o mesmo Estado que tinha construído a estrada, ainda no ano de 1977, enxergou a necessidade de se conservar a natureza e criou o Parque Estadual de Ilhabela - PElb, ato que veio a interferir significativamente no futuro da Baía dos Castelhanos, modificando as intenções originais dos moradores, especuladores, visitantes em geral e inclusive do próprio poder público, nas suas esferas municipal, estadual e federal. De imediato, para não esquecer de mencionar, serve de exemplo um projeto abortado pela criação do Parque, o loteamento Vila Reale. O Sr. Reale, dono daquele engenho de pinga que havia sido fechado alguns anos antes e que foi para a vila ser 
prefeito, fracionou as terras de sua propriedade (e, dizem, também aquelas que não eram suas) e pôs os lotes imediatamente a venda, sem implantar nenhuma infra-estrutura. Vários foram vendidos e demorou muito tempo, mais de 20 anos, para que as primeiras casas fossem construídas sobre lotes evidentemente irregulares (ausência de arruamento, sistema de coleta e tratamento do esgoto, lotes sobre ou próximos a cursos d'água etc.), contrariando toda a legislação ambiental em vigor no País e as normas que regulamentam a construção civil nas áreas de entorno do Parque.

De lá para cá, todas essas perspectivas e interesses vêm atuando na produção do espaço, quase sempre de forma conflitante.

Assim, à primeira vista, a estrada para os Castelhanos, parecia estar ligando dois mundos diferentes, dois tempos distintos: de um lado, o rural, o espaço da produção e reprodução do campesinato, em muito determinado pelo tempo e ritmo da natureza; do outro, o espaço urbano, do movimento frenético das atividades e negócios de turismo, regido pelos feriados prolongados e temporadas de verão.

Efetivamente, em meados dos anos 70, o espaço urbano estava consolidado no Litoral Norte. Cerca de 20 anos antes, na década de 1950, em decorrência da melhora do sistema viário de acesso à região e de circulação entre as cidades de São Sebastião, Caraguatatuba e Ubatuba desencadeou-se o movimento turístico que seria responsável pela transformação do espaço rural da produção mercantil simples existente nas inúmeras praias desses municípios, em espaço urbano dos balneários e das áreas de turismo. "Embora acentuada na década de 60, a urbanização foi conseqüência da alta rentabilidade do capital aplicado em imóveis na década anterior, tendo como forte estímulo o ritmo inflacionário do período. Parte desse capital originouse no próprio local, ocorrendo o investimento de capitais comerciais ou poupança de autônomos na organização de loteamentos. Outra parte foi conseqüência da vinda de capitais acumulados no Planalto, aplicados no litoral para fins de renda ou como investimento para o lazer" (Silva, 1975: 166). Segundo o autor, nessa época, o Litoral Norte já constituía um prolongamento da urbanização do sudeste brasileiro e integrava o grande mercado nacional e internacional. 
Convém destacar que o processo de urbanização assinalado esteve, até meados da década de 1970, circunscrito ao litoral situado entre as cidades de São Sebastião e Ubatuba e, em Ilhabela, apenas à região do canal. Nas áreas ao norte de Ubatuba, sul do litoral fluminense, norte e costa oceânica de Ilhabela, sem acesso rodoviário, o turismo praticamente inexistia. Na costa sul de São Sebastião, devido à estrada de terra permitir apenas trânsito precário na maior parte do ano, existia um movimento turístico, mas a urbanização a ele associado desenvolvia-se lentamente. O período que vai de 1962 a meados da década de 1970 podia ser caracterizado como o da etapa liberal da construção de um novo espaço na costa sul de São Sebastião, pois a aquisição das terras dos caiçaras era resultado das iniciativas de compradores isolados, permitindo que o urbano se desenvolvesse gradualmente. No espaço, no lugar das roças, das fruteiras, dos ranchos de pesca, começavam aparecer as residências de turistas. As transformações, ocorrendo lentamente, não promoviam uma ruptura brusca com a estrutura anterior da produção mercantil simples. Os novos proprietários e usuários em geral acreditavam estar "compartilhando" a praia com os caiçaras. (Noffs, 1988: 45)

A década de 1970 foi particularmente marcada por obras e planos grandiosos dos governos militares, das quais podem ser destacadas no setor rodoviário, a Transamazônica e a Rio - Santos (BR 101). A Rio - Santos foi concebida com dois objetivos principais: integrar as regiões portuárias e industriais da Baixada Santista, Angra dos Reis e Rio de Janeiro; e de promover o aproveitamento turístico de $500 \mathrm{~km}$ de litoral com cerca de 250 praias entre as duas maiores cidades brasileiras. O governo militar considerava esse litoral estratégico para a integração plena das Regiões Metropolitanas de São Paulo e Rio de Janeiro, Baixada Santista e Vale do Paraíba. A região, além de concentrar praticamente todo o parque industrial, os pólos petroquímicos e a infra-estrutura portuária do país, abrigava ainda as obras da usina atômica de geração de energia elétrica de Angra dos Reis. Do projeto original, apenas o trecho entre Ubatuba e Rio de Janeiro foi totalmente construído. O restante do empreendimento, desde seu início, no entroncamento com a rodovia Guarujá - Piaçaguera no município de Santos, até Caraguatatuba, passando por Bertioga e São Sebastião, não foi concluído, sendo abandonado quando 
as obras encontravam-se já bastante adiantadas. A ligação rodoviária da Baixada Santista com o Rio de Janeiro pelo litoral continuava dependendo da utilização da antiga estrada Bertioga - São Sebastião com cerca de 100 km de terra e de duas travessias de balsa - de Santos para Guarujá e de Guarujá para Bertioga.

Além da Rio - Santos, fazia parte do planejamento do governo militar a abertura de novas rodovias de acesso ao litoral e a reforma e modernização das existentes, com o objetivo de permitir que as "vocações" industriais, portuárias e turísticas da região fossem plenamente realizadas. A rodovia dos Tamoios - SP-99, principal acesso ao Litoral Norte, foi totalmente remodelada em meados da década, mesmo período em que a rodovia Oswaldo Cruz - SP125, que liga Taubaté a Ubatuba passou por reforma, recebendo melhorias e modificando o traçado em alguns trechos. Ainda na década de 1970 foram iniciadas as obras para a implantação da rodovia Moji das Cruzes - Bertioga, SP-98, que foi concluída em 1982.

Ainda relacionado à obra da rodovia Rio - Santos, cabe mencionar o Projeto Turis, iniciativa do Governo Federal, que por intermédio da Embratur, desenvolveu um amplo e ambicioso estudo, que pretendia diagnosticar as potencialidades e propor ações para desenvolver o turismo ao longo do litoral entre as duas cidades, de forma ordenada e compatível com as demais "vocações" mencionadas. Assim como a própria rodovia, o projeto ficou inconcluso, mas trouxe, à sua época, o foco para a discussão sobre o modelo de turismo que se desejava para esse litoral e despertou o interesse de investidores e especuladores para a realização de negócios na região. (Santos, 1972, apêndice em Silva, 1975: 255 e Projeto Turis, 1973)

Foi nesse contexto de grandes obras e ações voltadas à integração e desenvolvimento do território nacional que o governo de São Paulo planejou a implantação em llhabela de duas obras viárias para explorar integralmente seu potencial turístico: uma contornando toda a extensão da ilha de São Sebastião; e a outra atravessando o espigão, ligando a região do canal diretamente à Praia dos Castelhanos. Ambas de terra. A primeira foi parcialmente implantada, chegando até a Praia de Jabaquara, ao norte, e ao sul, até a Praia do Bonete (ocorreram problemas com a estabilidade de 
encostas próximo ao Bonete e o acesso a essa praia foi interrompido definitivamente, de modo que a estrada atualmente segue apenas até a Ponta da Sepituba). A estrada para os Castelhanos permanece aberta ao tráfego, mas atualmente, como já foi dito antes, sofre problemas sérios de manutenção e tendo o tráfego bastante prejudicado.

Assim, a década de 1970 se destacou pelos grandes projetos de infraestrutura que não chegaram a ser totalmente implantados, tanto em Ilhabela como no Litoral Norte, mas serviram aos interesses de especuladores, grileiros e oportunistas do mercado imobiliário. Data dessa época a maior parte da compra da posse da terra dos caiçaras, nem sempre de modo legal ou legítimo, e do lançamento de loteamentos (muitos deles que existiam apenas em planta) ao longo de toda a costa oceânica de Ilhabela e do Litoral Norte que receberia as obras da Rio - Santos (Santos, 1972 op citada).

De todas as obras viárias, a que provocou maior impacto no litoral de São Sebastião, e também de llhabela, foi a complementação e o asfaltamento da rodovia SP-55 (Bertioga-São Sebastião), na primeira metade da década de 1980, permitindo finalmente a integração das cidades do Litoral Norte com a Baixada Santista, Regiões Metropolitana de São Paulo, Vale do Paraíba e Rio de Janeiro. $O$ acesso às praias da costa sul de São Sebastião para quem partia de São Paulo, que antes se realizava preferencialmente pelas rodovias Presidente Dutra e dos Tamoios, passando pelas cidades de São José dos Campos e Caraguatatuba, agora podia ser feito tanto pela rodovia MojiBertioga (SP-98) como pelo sistema Anchieta-Imigrantes, passando por Cubatão e não mais por Guarujá, evitando assim a travessia das duas balsas e reduzindo o percurso em cerca de 100 quilômetros (dependendo do bairro de origem e da praia de destino).

Em conseqüência da facilidade de acesso, em poucos anos o turismo explodiu nessa área do Litoral Norte, configurando um espaço fortemente urbanizado. O comércio, os bares e restaurantes, as danceterias, a infraestrutura de serviços, os condomínios residenciais, os hotéis e pousadas, atividade urbanas que apareciam timidamente até então na costa sul de São Sebastião, proliferaram-se por suas praias nas décadas de 1980 e 1990, a exemplo do que já ocorria na maior parte do Litoral Norte. Os problemas 
recorrentes das grandes cidades brasileiras (moradia precária e carência de serviços básicos de saúde, educação e saneamento básico) fizeram-se presentes. Nesse novo espaço, nada mais acontecia lentamente. A rapidez e a violência do processo de urbanização varreram do mapa as atividades rurais tradicionais do litoral e aquela "convivência harmoniosa" entre turistas e caiçaras. Foram substituídas por edificações e loteamentos, regulares e clandestinos, voltadas tanto aos turistas, quanto a uma população crescente de emigrantes, atraídos à região para trabalharem na construção civil e no setor de comércio e serviços. Também esse é o quadro que vem ocorrendo em Ilhabela na região do canal nos últimos anos. A população do município que era de 5.857 pessoas em 1970, passou para 26.167 em 2006. No mesmo período, a população do Litoral Norte passou de 48.000 para 278.480 pessoas, chegando a 1,3 milhão durante os meses de verão. A taxa de expansão demográfica na região é de $3,3 \%$, enquanto a média paulista é de apenas 1,5\%. (Seade, 2007 e Arnt e Wainer, 2006, citado por Mendonça, 2007).

No final do século $X X$, o espaço não só estava urbanizado no Litoral Norte, como mostrava seu lado mais perverso. Para além dos condomínios, hotéis, pousadas e danceterias, aparecia nos morros acima da rodovia e nos sertões mais afastados da orla praiana, a outra face do urbano: o território da pobreza e da favela, ocupado por uma população de trabalhadores mal remunerados e de desempregados, da qual os caiçaras não se distinguiam mais. 
Figura 2 - Favelas em Maresias

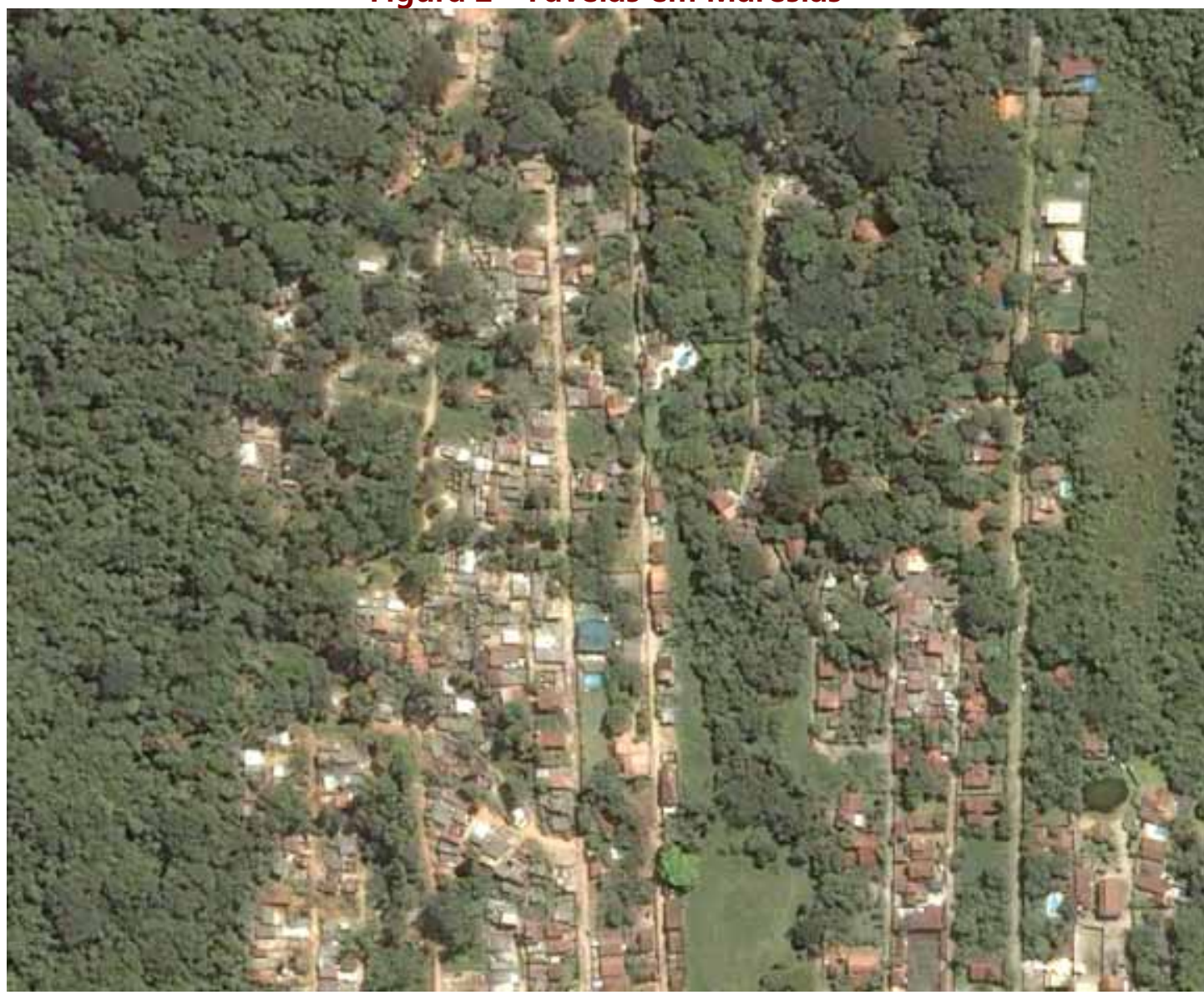

Favelas avançando sobre a Mata Atlântica em Maresias, São Sebastião. O espaço urbanizado do Litoral Norte mostra seu lado mais perverso. (Imagem Google Earth, 2005)

Na Baía dos Castelhanos, durante as décadas de 1980 e 1990, devido às condições de tráfego precárias da nova estrada de terra, chegaram apenas reflexos dessa urbanização. Os caiçaras observavam aumentar lentamente o fluxo de embarcações turísticas e de pessoas que procuravam suas praias e enseadas para passar o dia ou, para uma estadia mais prolongada, armar barracas em campings selvagens. Também algumas poucas casas de turistas foram construídas nesse período, mas não se seguiu a implementação de uma estrutura física comercial condizente para explorar o movimento sazonal de visitantes. Acompanhando o ritmo lento de crescimento do turismo, os caiçaras foram abandonando suas roças e passaram a se concentrar na atividade pesqueira.

Como não foi possível se estabelecer um transporte rodoviário regular pela nova estrada, os moradores locais servem-se muito pouco dela, a não ser 
para continuarem realizando a pé viagens para a cidade. Gradativamente, com o crescimento do turismo nas cidades de Ilhabela e São Sebastião, a demanda por peixe fresco aumentou muito. Assim, as canoas a motor foram se impondo como o meio de locomoção mais eficiente para o transporte de mercadorias e de pessoas entre as localidades da Baía dos Castelhanos e a zona urbanizada ao longo do Canal de São Sebastião.

Enquanto em todo o Litoral Norte a urbanização predatória se encarregava de suprimir do espaço o universo da produção mercantil simples, a Baía dos Castelhanos continuava se apresentando como um lugar de características especiais. A arquitetura de suas casas e ranchos de pesca, a disposição espacial dos povoados nas praias e costeiras, as canoas, os cercos flutuantes e os equipamentos de pesca, os utensílios domésticos etc. ainda estavam fortemente presentes no espaço e constituíam manifestações da cultura e da obra artesanal caiçara que se combinavam com as belezas naturais na configuração da paisagem.

Um fenômeno interessante começava a ganhar corpo no Brasil na década de 1970, mas que certamente já vinha ocorrendo há mais tempo. Tratava-se da procura de novas formas de lazer no mundo rural como meio de se contrapor ao cotidiano desgastante da vida nas cidades industrializadas, principalmente de São Paulo e Rio de Janeiro. "A sociedade fundada na aceleração do ritmo da industrialização passa a ser questionada pela degradação das condições de vida dos grandes centros. O contato com a natureza é, então, realçado por um sistema de valores alternativos, neoruralista e antiprodutivista. O ar puro, a simplicidade da vida e a natureza são vistos como elementos "purificadores" do corpo e do espírito poluídos pela sociedade industrial. O campo passa a ser reconhecido como espaço de lazer ou mesmo como opção de residência." (Carneiro, 1997: 3).

Até o começo da década de 1970, as muitas praias das costas sul de São Sebastião e norte de Ubatuba não contavam com distribuição de energia elétrica e nem com outros tipos de serviços tão comuns em todo o estado de São Paulo. Ao norte de Ubatuba, nem estrada havia. Vivia-se nesses lugares, da pesca, das roças e das plantações de banana. O espaço era basicamente rural e o urbano limitava-se às habitações das famílias caiçaras, a igreja, a 
presença da venda e de alguma casa de turista. Era uma vida simples, vivida de acordo com os ritmos da agricultura e da pesca artesanal. Todas as praias eram assim. Todas eram muito bonitas. Por isso, não era de se estranhar que uma parte considerável do contingente populacional que estava fugindo dos problemas e da poluição das grandes cidades, encontrasse nas costas sul de São Sebastião ou norte de Ubatuba a harmonia com a natureza e a vida simples que estavam procurando.

Entretanto, o crescimento do número de turistas no litoral fazia aumentar a demanda por mais serviços e infra-estrutura. A melhoria nos serviços e na infra-estrutura atraía mais turistas, que demandavam novas obras e exigiam a presença cada vez maior de novos trabalhadores. E assim, ao longo das décadas de 1970, 1980 e 1990, as características iniciais que atraíram turistas para essas praias foram gradativamente sendo destruídas, principalmente depois da construção de rodovias asfaltadas.

E se esse movimento em busca do natural ocorreu primeiro nas praias ao sul de São Sebastião e norte de Ubatuba, preservando a costa oceânica de Ilhabela, foi porque aqueles lugares estavam mais acessíveis. Havia turismo e interesses imobiliários na Baía dos Castelhanos, mas nessas décadas, estavam mais restritos a compra de terras e ao movimento de turistas que se dirigiam a suas praias organizados em grupos para passar o dia em feriados, finais de semana e nos meses de temporada. Atualmente, são poucas as praias nos litoral norte de São Paulo e sul do Rio de Janeiro com características semelhantes as da Baía dos Castelhanos, e a pressão para incorporá-las ao circuito do turismo é cada vez maior. Por isso, a Baía dos Castelhanos (também - Saco do Mamanguá em Parati e outros) deixou de ser um lugar isolado para transformar-se em espaço raro, dotado de características excepcionais que não se encontram mais no litoral paulista.

A cultura caiçara constituiu lugares especiais no espaço. Esses lugares tornam-se alvo das populações das grandes cidades e de interesse de empreendimentos turísticos que, ao se implementarem, introduzem novas relações de produção que destroem as condições que permitiram a existência desses lugares especiais. Pode-se concluir que não há razões especiais para que essa dinâmica deixe de ocorrer na Baía dos Castelhanos. 


\section{CAPÍTULO 4 \\ CAIÇARAS, TURISTAS E O ESTADO NA BAÍA DOS CASTELHANOS}

\section{A TRANSFORMAÇÃO DA TERRA EM MERCADORIA}

Em 1992, o Instituto Florestal da Secretaria de Meio Ambiente de São Paulo apresentou o trabalho "Ilhabela - Diagnóstico Sócio-econômico e Ambiental". Passados cerca de 40 anos da publicação de "A llha de São Sebastião" de Ary França, e dos últimos artigos de Gioconda Mussolini sobre a pesca e pescadores em Ilhabela, surgia um estudo específico sobre as populações caiçaras residentes na costa oceânica do município.

Aquela Baía dos Castelhanos descrita por França no início da década de 1950 como área de produção da banana e de pinga e de sua exportação para o mercado de Santos por intermédio dos barcos a motor, já não existia mais. Em 1992, a pesca artesanal aparecia como a principal atividade comercial praticada pela população local, cuja produção era basicamente encaminhada de canoa a motor pelos próprios caiçaras para os mercados de Ilhabela e São Sebastião.

Não são muitos os registros do que se passou durante esses 40 anos, mas sabe-se que em 1962, de acordo com o levantamento aerofotogramétrico realizado pela Aerofoto Natividade Ltda para o Instituto Agronômico do estado de São Paulo, a agricultura na Baía dos Castelhanos ainda era bastante desenvolvida e podia ser constatada uma quantidade razoável de edificações, indicando um número de moradores significativamente maior do que em anos posteriores. Em 1978, a área que antes estava cultivada com banana e cana-de-açúcar, aparece agora recoberta pelas formações secundárias da Floresta Ombrófila Densa Submontana e Ombrófila Densa das Terras Baixas. As fotos a seguir ilustram bem as duas situações. 


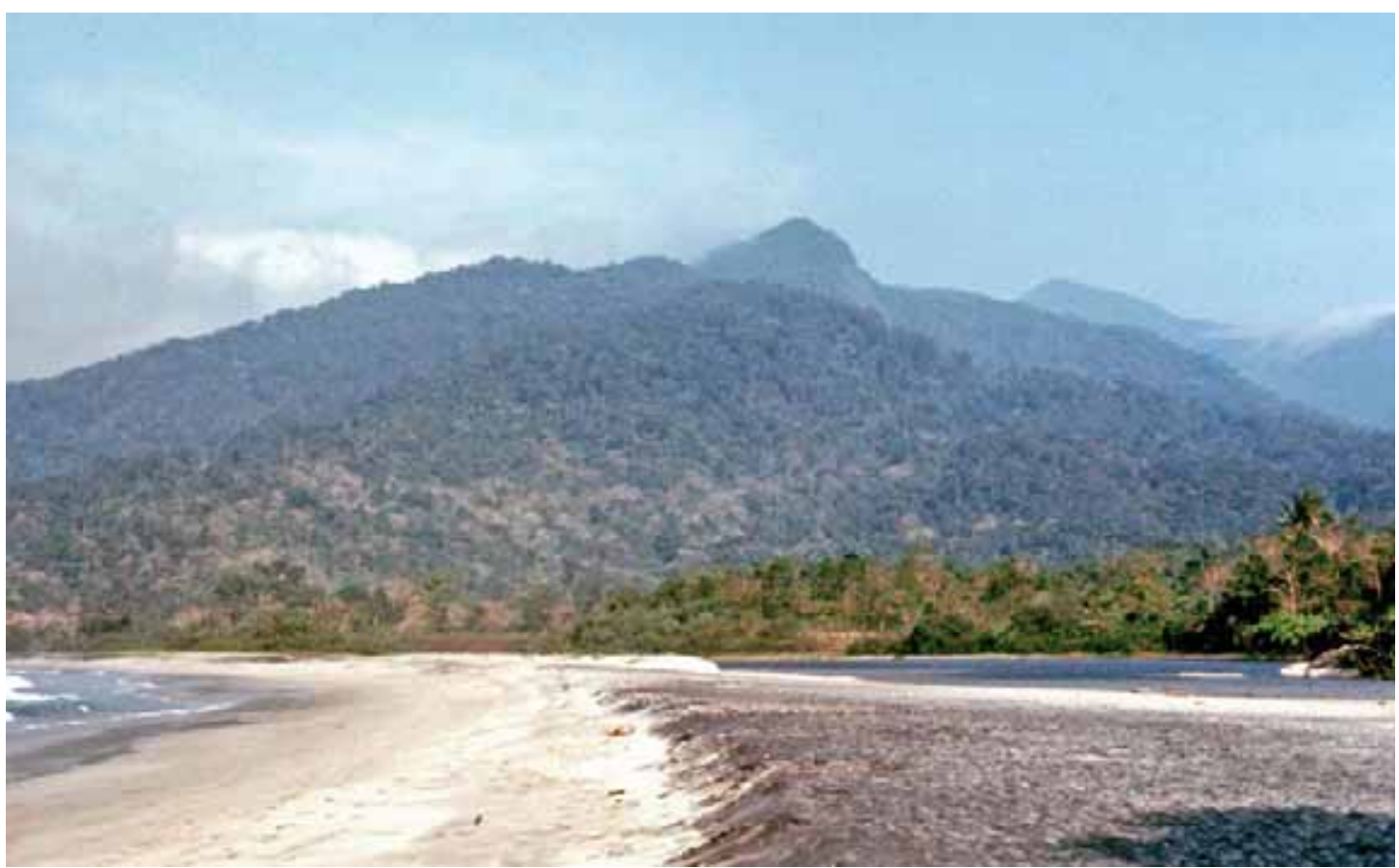

Foto 24. P. Noffs, 1976

Acima, a planície e o morro dos Castelhanos vistos a partir do Canto do Ribeirão em 1976. Abaixo, aerofoto de 1962 mostrando aproximadamente a mesma área. As glebas em plena exploração agrícola abaixo, aparecem acima recobertas pela mata em estágio médio e avançado de regeneração.

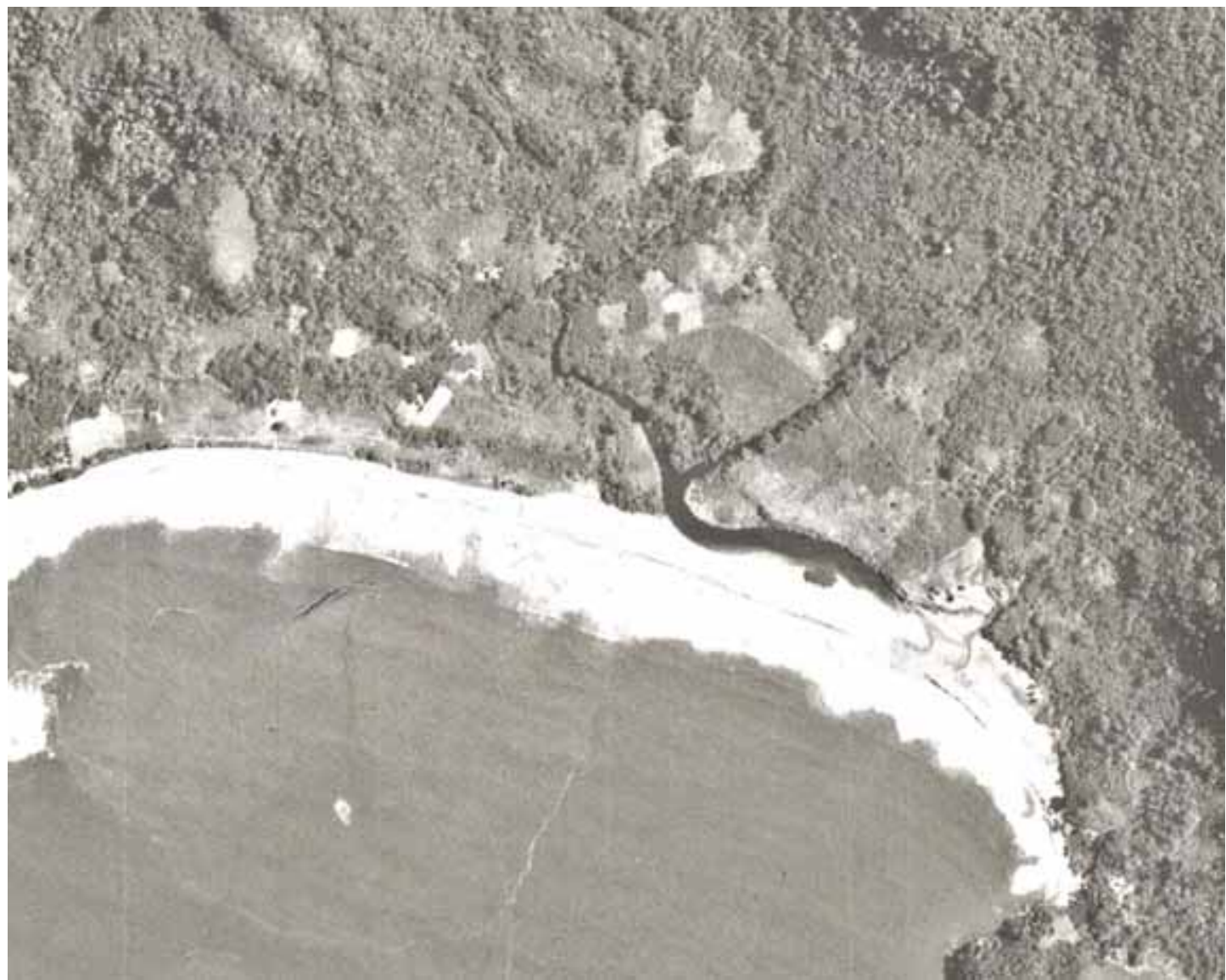

Figura 3 - Canto do Ribeirão em 1962. Aerofoto Natividade, esc. 1: 25.000, 1962. 
Refletindo o fechamento da economia, a Baía dos Castelhanos via sua população encolher, passando de 550 pessoas em 1951 para apenas $153 \mathrm{em}$ 1992. Fica evidente que a estrada aberta em 1977 não foi suficiente para articular consistentemente a produção agrícola local com os mercados de Ilhabela e São Sebastião. Tampouco a estrada foi construída com essa finalidade.

Em 1992, praticamente todas as terras, propriedades de famílias caiçaras, tinham sido vendidas. Mas, segundo esse mesmo trabalho do Instituto Florestal, existiam apenas 5 casas de turistas construídas em toda a Baía dos Castelhanos, sendo que uma delas tratava-se da moradia do "Sr. Canindé", um migrante de origem nordestina que há muitos anos se estabelecera na Praia dos Castelhanos e tinha um pequeno restaurante que explorava o movimento turístico que começava a ganhar corpo com a nova estrada. As quatro restantes eram segundas residências de turistas, duas delas localizadas no Canto da Lagoa, uma na Praia Vermelha e a outra no Saco do Sombrio. O IF não menciona, mas existia, pelo menos desde 1988, uma outra casa de turista construída na ponta da Garoupa, num lugar chamado Codó (ou Codói como é conhecido pelos caiçaras), localizado entre a Praia da Figueira e o Saco do Sombrio, totalizando 6 casas de turistas na Baía dos Castelhanos.

Com base nessas informações, pode-se dizer que o turismo ainda era insipiente e não estava materializado no espaço em 1992.

Mas não era o número reduzido de edificações relacionadas ao turismo e o desaparecimento da agricultura mercantil, que tinha cedido lugar à pesca artesanal na organização do comércio, que dava importância ao relatório do I.F. O que ele trouxe de novo foram informações sobre a transferência da posse da terra das famílias caiçaras para especuladores e turistas de llhabela e São Paulo, principalmente. Começavam a ficar visíveis as relações complexas da produção do novo espaço na Baía dos Castelhanos, relações estas que cada vez mais o subordinava ao capital urbano dos negócios do turismo e que o distanciava do campesinato litorâneo.

Apesar da presença de apenas 5 casas e de um único estabelecimento comercial voltados ao turismo, o I.F. constatava que praticamente todas as terras de propriedade de famílias caiçaras já tinham sido vendidas em 1992. 
Na Praia dos Castelhanos, os títulos de domínio das posses foram passados, segundo declarações dos moradores locais aos técnicos do Instituto, há aproximadamente 20 anos para as seguintes pessoas: Claudio Vanzolini, Alberto Storacci, Cecília de Abreu Teles e Hélio Reale (este último, filho do Leonardo Reale, aquele que foi ser prefeito em Ilhabela e deixou o engenho para trás).

A Praia Mansa foi vendida pelo Sr. Pedro Manoel de Souza e seu irmão para o Sr. Cláudio Vanzolini há cerca de 30 anos. Já a Praia Vermelha, segundo informaram o Sr. Pedro Madalena e seu irmão Anízio em 1992, o comprador foi o Sr. Mário Volcoff, que tinha adquirido as terras há 15 anos antes.

O mesmo Mário Volcoff comprou a Praia da Figueira do pai de Da. Conceição há 40 anos, segundo essa senhora, moradora mais antiga do lugar, informou ao I.F. em 1992. Os filhos do Sr Odorico, marido de Da. Conceição, contaram aos pesquisadores do IF que há alguns anos antes o Sr Mário Volcoff havia voltado à Praia da Figueira para obter documentação mais consistente das terras e conseguiu a assinatura de Sr Odorico, aproveitando-se de seu estado de embriaguês.

No Saco do Sombrio, dois moradores locais tinham transferido a posse de suas terras para os senhores Osmar Soalheiro e Flávio de Moraes dos Santos.

Como podem ser observadas, as datas sobre as transações são conflitantes e díspares. Mas, associando essas informações com outras obtidas diretamente de alguns desses moradores ou de seus descendentes, pode-se concluir que a maior parte delas ocorreu ao longo das décadas de 1960 e 1970, coincidindo com a época de expectativa de grandes projetos viários para o Litoral Norte. Trecho do artigo do jornalista Rubens Rodrigues dos Santos comentando a obra da rodovia Rio-Santos, esclarece muito bem o "espírito do setor imobiliário" da época: "Logo depois de iniciados os trabalhos de abertura da Rio-Santos intensificaram-se toda sorte de especulações imobiliárias e tentativas de obtenção ilegítima de documentos de posse e domínio na área servida por essa estrada. Houve até mesmo um caso de incêndio criminoso de um cartório de registro de títulos Muitos caiçaras 
ignorantes foram espoliados de seus legítimos direitos sobre terras onde viviam há mais de vinte e cinco anos. Simularam-se permanências em glebas, alteraram-se demarcações, forjaram-se títulos de domínio. Enfim, a região passou a ser o campo de ação de numerosos grileiros e espertalhões, sendo mais do que certa a existência de documentos falsificados de posse e domínio..." (jornal O Estado de São Paulo de 23 de Julho de 1972, reproduzido por Silva, 1975: 260).

Tão comum quanto em Ilhabela, o fenômeno da transferência maciça de terras dos caiçaras para os especuladores podia ser observado em qualquer lugar do Litoral Norte, principalmente na costa norte ainda virgem de Ubatuba, e na costa sul de São Sebastião, esta contando com a estrada de terra recém aberta, mas com tráfego precário. Ao atravessar Maresias, podiam ser vistas placas sobre as cercas de arame farpado, indicando que todas aquelas terras que se entendiam de um lado a outro da praia, pertenciam ao Sr. Celso Amaral. Transpondo a serra em direção a Boiçucanga, as cercas eram as mesmas, mas as placas agora indicavam a propriedade privada do Sr. Walkir Vergani, que chegou a pagar (segundo os caiçaras) com latas de goiabada a compra da posse de muitos moradores locais. Anos depois, ainda em vida, viria a ser homenageado pelo poder público do município de São Sebastião, ao dar o seu nome para a escola pública e à principal avenida do lugar. Em Toque Toque Pequeno foi a empresa Albuquerque e Takaoka que se encarregou da compra das terras. Em qualquer praia que se chegasse em finais dos anos 60 e início dos 70, antes do nome do lugar, apareciam as placas indicando a propriedade privada de alguém.

O turismo estava consolidado no Litoral Norte no começo da década de 1970 e se constatava a tendência de expansão em direção às áreas ainda não exploradas de Ilhabela, Ubatuba e São Sebastião. As praias, os rios, as cachoeiras, a cultura caiçara, as paisagens litorâneas, enfim, todo esse conjunto de elementos que constituíam o espaço, do ponto de vista do mercado, estava disponível, mas não podia ser consumido, por não operar objetivamente como mercadoria. (basicamente por falta de infra-estrutura de permanência e de acesso ao local). Assim, uma importante massa de consumidores estava separada da mercadoria natureza: as praias estavam de 
um lado e os turistas de outro (literalmente verdadeiro em se tratando da costa oceânica de Ilhabela). Isso ocorria porque o que estava disponível era o espaço rural da Pequena Produção Mercantil, onde a terra, para ser fracionada e dividida em pequenas parcelas acessíveis a esses consumidores urbanos, precisava se desvincular da sua condição de objeto e meio de trabalho.

Vários agentes concorreram - e ainda concorrem - para o processo de parcelamento da terra rural do campesinato litorâneo e para sua transformação em solo urbano do turismo, dos quais merecem ser destacadas as figuras do especulador e do empreendedor capitalista.

O especulador se aproveitava da separação entre o bem turístico e o turista para obter vantagem mais tarde quando essas duas figuras se aproximassem. Para o empreendedor capitalista imobiliário, não havia vantagem alguma nessa separação; o sucesso de seu negócio - um projeto de loteamento ou qualquer outra obra do setor imobiliário - depende de amplas condições de acesso dos turistas consumidores ao local do bem turístico. Em se tratando de um empreendimento do setor imobiliário, para a produção da mercadoria lote urbano (edificado ou não) é preciso percorrer diversas etapas, desde a obtenção do título de propriedade em substituição ao da posse da terra, seguido da elaboração do projeto (composto por projetos específicos de arruamento, paisagismo, drenagem, coleta e distribuição de água, coleta, tratamento e disposição do esgoto etc), que deve ser submetido à aprovação dos órgãos públicos, e terminando pela contratação das empreiteiras e implantação das obras correspondentes. Nesse processo são envolvidos agentes financeiros, escritórios de arquitetura, projetistas, empreiteiras, escritórios comerciais, abarcando desde trabalhadores braçais a técnicos especializados. O lucro, como em qualquer ramo da produção capitalista, é resultado da apropriação pelos agentes empreendedores (financiadores, projetistas, empreiteiros) da mais valia gerada pelo sobretrabalho dos operários e técnicos comprometidos em todas as etapas da produção da mercadoria lote urbano.

O objetivo principal do especulador era vender caro a terra que tinha comprado (ou obtido) barato. Antevia na terra rural, carente de infra- 
estrutura, a implantação futura de projetos governamentais relacionados principalmente à abertura ou reforma de estradas e ao fornecimento de energia elétrica. Ao agir assim, imobilizando capital na compra da terra, estava apenas convertendo seu dinheiro em renda capitalizada, "em direito de extrair uma renda da terra e ao mesmo tempo direito de recobrar inteiramente e até mesmo com acréscimo o seu capital mediante a simples conversão contrária da renda capitalizada em capital" (Martins, 1981: 167). Certamente, o objetivo de um especulador em comprar terras dos caiçaras não era o de cobrar renda pela exploração da propriedade agrícola. Até poderia fazer isso, mas enquanto o espaço estivesse circunscrito ao universo rural da Pequena Produção Mercantil, a expectativa de se extrair renda da terra era muito baixa, uma vez que a atividade agrícola desenvolvida no Litoral Norte ocupava os piores solos no âmbito da agricultura do sudeste brasileiro, tinha baixo nível tecnológico e seus produtos principais, a banana e a farinha de mandioca, enfrentavam muitos problemas de transporte até chegarem ao mercado, caracterizando uma situação de desvantagem frente a outras áreas produtoras. Por isso, os especuladores aguardavam que a implantação de obras públicas, das quais quase sempre tinham conhecimento prévio, incorporassem valor ao espaço. $E$, se essas obras favorecessem 0 desenvolvimento do turismo e da urbanização do litoral, ampliariam ainda mais o processo de valorização do espaço e as possibilidades de se extrair renda da propriedade privada do solo. Outros aspectos podem ser mencionados em relação à transformação do espaço rural em urbano, como, por exemplo, o novo uso do solo, urbano, se voltar mais para a moradia, comércio e serviços, permitindo assim que aquelas propriedades rurais compradas dos caiçaras pudessem ser fracionadas e vendidas em lotes menores, de tal forma que no processo final de reconversão da renda capitalizada em capital, o montante obtido fosse muito superior ao preço pago originalmente.

Algumas vezes a especulação era velada, vinha disfarçada de empreendimento imobiliário. Com o objetivo de obter preços maiores, a terra era fracionada e loteada. Apesar de muitos loteamentos terem obtido aprovação dos órgãos públicos responsáveis, talvez através de meios escusos, 
os projetos não passavam de fachada e nenhuma das obras previstas era implementada, pelo menos pelo especulador. Depois dos lotes vendidos e edificados, os moradores (donos de lotes ou de segundas residências de uso turístico) pressionavam o poder público para a implantação de obras básicas de infra-estrutura viária e de fornecimento de água e energia elétrica que eram de responsabilidade do especulador, repetindo-se a mesma estratégia dos loteamentos clandestinos das regiões metropolitanas brasileiras.

A enorme quantidade de empreendimentos imobiliários que se sucederam no Litoral Norte ao longo dos últimos 30 anos revela que os especuladores estiveram mais presentes durante a etapa de transformação da terra rural em urbana. Os empreendimentos capitalistas ergueram-se depois, quando as terras estavam livres da sua condição de objeto e meio de trabalho. Muitas vezes, essas figuras se confundiam. Tanto o especulador de terras poderia encabeçar um projeto imobiliário em bases empresariais, quanto o empreendedor capitalista especular com o preço da terra antes de desenvolver o seu projeto. Ambos só tinham em mente obter o maior retorno possível aos seus capitais, não importando se os meios empregados para esse fim fossem lícitos ou ilícitos.

Em meados da década de 1960, provavelmente em 1966, foi assinado um convênio entre a prefeitura de Ilhabela e o D.E.R. - Departamento de Estradas de Rodagem do Estado de São Paulo para a construção das estradas de rodagem Perequê - Castelhanos e a Perimetral, contornando toda a Ilha de São Sebastião, na gestão do Sr. Leonardo Reale. Assim, antes que essas obras se iniciassem, foram lançados vários loteamentos em toda a costa leste de Ilhabela, quase todos em área de costeira, distantes de qualquer praia. 0 mapa $\mathrm{n}^{\circ} 5$ ilustra muito bem a estratégia dos especuladores de Ilhabela, registrando a presença de 10 loteamentos, sendo que os discriminados com os números de 1 a 9 foram extraídos da planta de 1995, na escala 1:25.000 da prefeitura de Ilhabela, denominados "Parque Estadual de ilhabela e Loteamentos sem Acesso". O décimo loteamento, denominado Bonete, foi retirado de uma cópia de material de divulgação de uma imobiliária da cidade de Ilhabela, e é apresentado em destaque na figura $n^{\circ} 1$. Destaca-se que os 
loteamentos de número 6, 7, 8 e 9, além de estarem situados sobre áreas de costeiras, não seriam atendidos pela estrada projetada.

Mapa 5 - Loteamentos sem Acessos na Costa Oceânica de Ilhabela

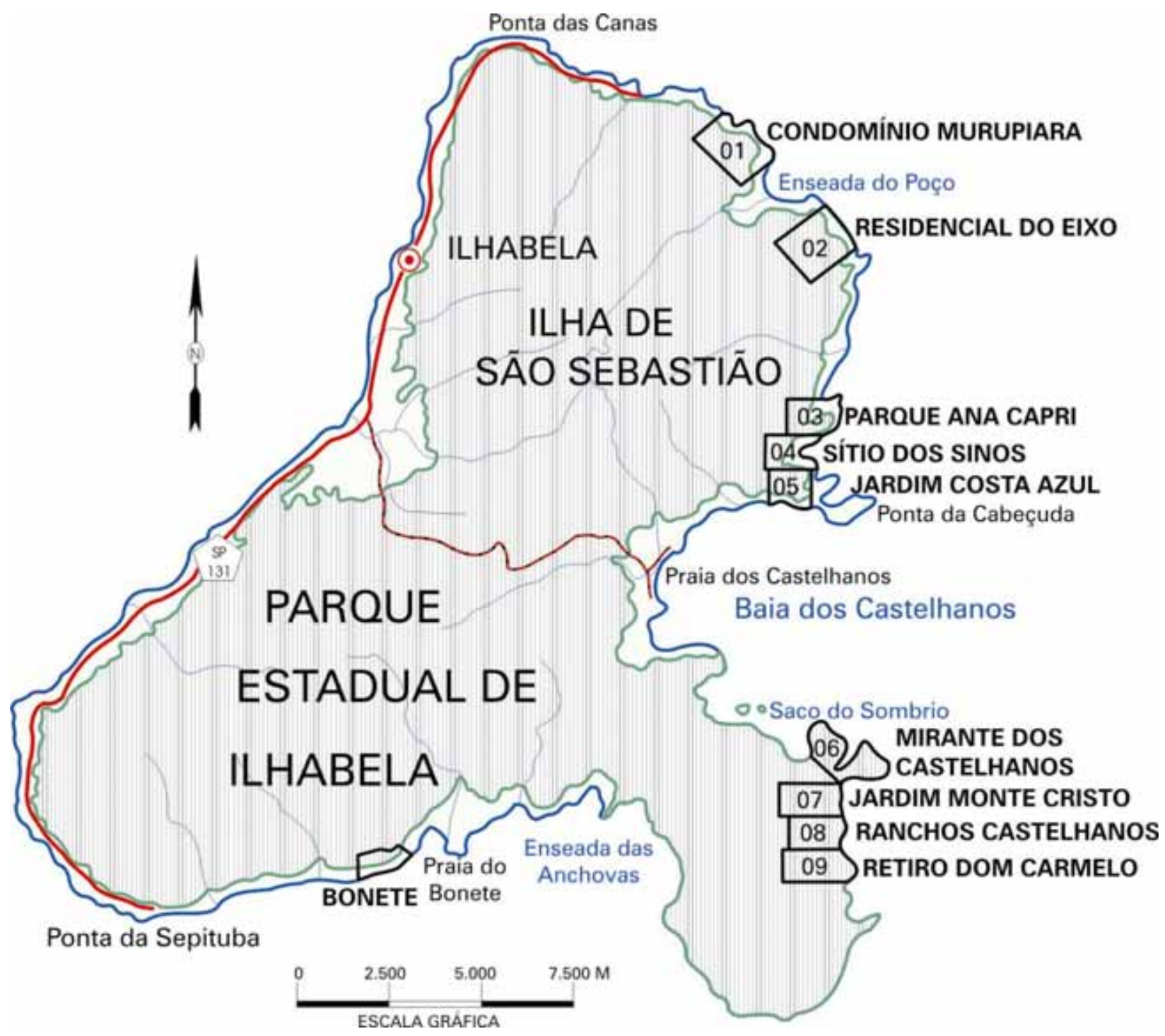

Fonte: Parque Estadual de Ilhabela e Loteamentos sem Acesso -Prefeitura Municipal de Ilhabela, 1995. 
Figura 4 - Loteamento Bonete

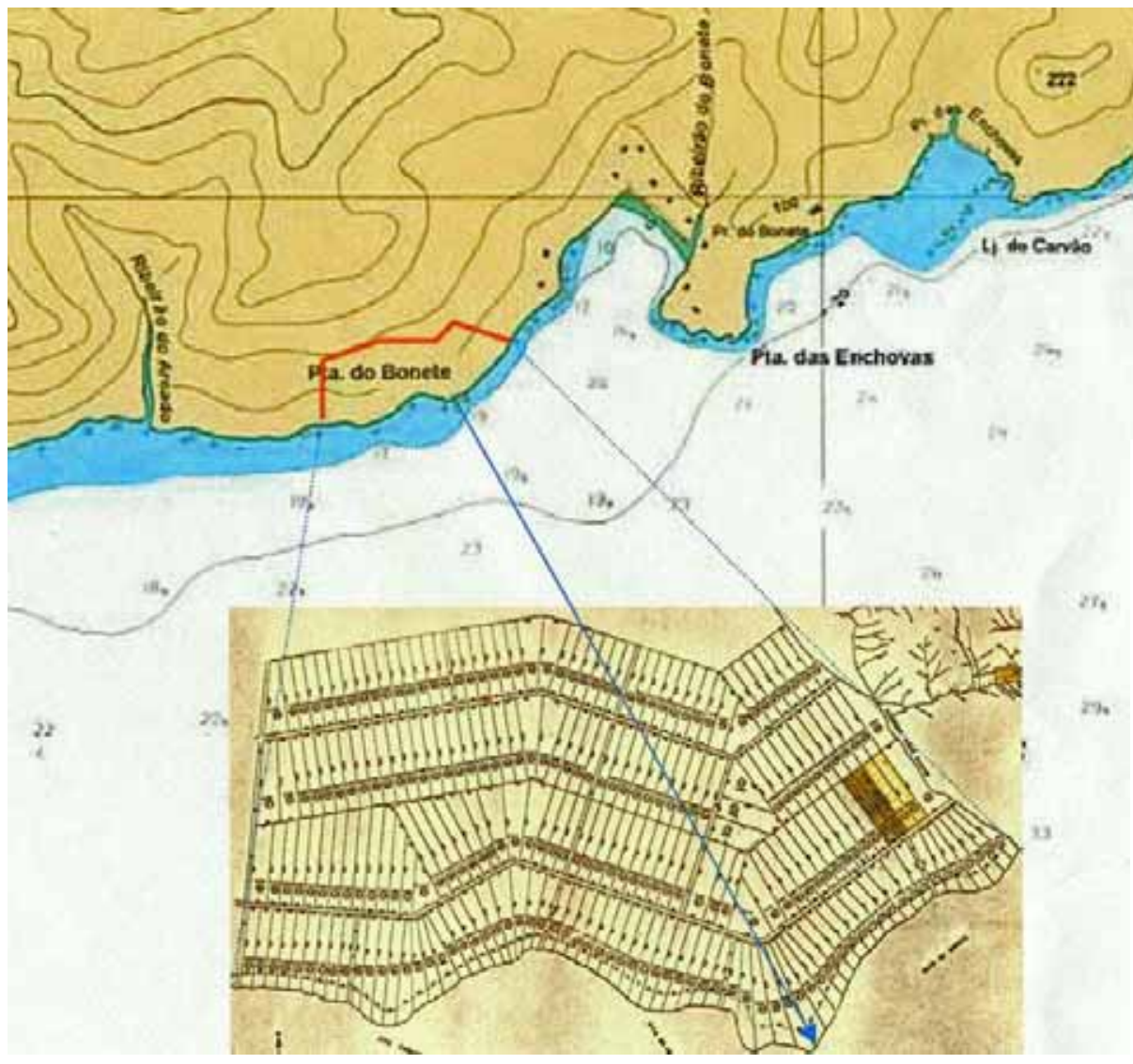

Duzentos e vinte e dois lotes projetados para a praia do Bonete. Muitos foram vendidos, nenhuma obra do projeto foi implementada e até recentemente, a prefeitura cobrava o IPTU dos incautos compradores.

Novamente o artigo do jornalista Rubens Rodrigues dos Santos é bastante revelador: "As Prefeituras dos Municípios cortados pela RioSantos, como conseqüência da visão estreita da maioria dos prefeitos e vereadores, encontram sempre mil e uma razões para aprovar todos os projetos de loteamento, justificando esse ato com a argumentação de que "eles trarão mais progresso para a cidade". Na estreiteza de visão desses senhores, ou talvez no sentir os bolsos um pouco mais cheios, concede-se registro a loteamentos que a rigor só existem no papel, sem ruas e avenidas abertas, guias, sarjetas, galerias de águas pluviais, e todos os demais melhoramentos que devem estar concluídos antes de iniciada a venda dos lotes. Depois de realizadas as transações o feliz e enriquecido proprietário dos loteamentos simplesmente transfere para a pobre Prefeitura a responsabilidade por tais melhoramentos. $E$ os incautos compradores dos lotes que se virem para conseguir sua realização. Isso já está ocorrendo em 
larga escala ao longo da Rio-Santos." (jornal O Estado de São Paulo de 23 de Julho de 1972, reproduzido por Silva, 1975: 260)

Muitos lotes foram vendidos e praticamente nenhuma casa foi construída, principalmente devido ao fato das obras da estrada perimetral terem sido interrompidas antes de alcançarem a costa oceânica de llhabela. Além disso, a estrada Perequê - Castelhanos, desde a sua abertura, jamais ofereceu condições de tráfego adequadas para veículos de passeio.

A aprovação em 1966 pela prefeitura de Ilhabela dos loteamentos Vila Reale e Balneário Castelhanos na Praia dos Castelhanos revela outra faceta da proximidade entre o especulador e o poder público. Em verdade, não se tratava sequer de uma proximidade, uma vez que o dono dos loteamentos era o próprio prefeito, Sr. Leonardo Reale, já citado, que deixou o engenho e mudou-se para a cidade.

Lançados juridicamente como loteamentos distintos, na prática eram apenas um único empreendimento que, de real, tinha apenas o nome e os carnês de lançamento das prestações para pagamento dos lotes. Todo o resto era fictício: arruamento, coleta e destinação do esgoto, rede de distribuição de água encanada etc. Em relação à legalidade das terras sobre as quais foram projetados os loteamentos, até os dias atuais, caiçaras e turistas contestam a legitimidade da propriedade em nome da família Reale. Alegam que o Sr. Leonardo Reale, aproveitando-se de seu poder político, apresentou como sua, a posse de terras que eram de outras famílias.

Mas que interesse poderia haver em lançar um loteamento numa praia distante que sequer contava com acesso rodoviário? Aliás, em 1966, nem ao menos havia serviço de balsa para realizar a travessia do continente para Ilhabela. A seqüência de leis e decretos apresentada a seguir talvez esclareça esta indagação.

Em 1968, prefeitura de llhabela, na gestão do Leonardo Reale promulgou a lei $n^{\circ} 28 / 68$, da qual destacam-se os artigos $3^{\circ}$ e $4^{\circ}$ :

Artigo $3^{\circ}$ - É aprovado o Plano de Urbanização da orla marítima das praias de CASTELHANOS e LAGOA, compreendendo o BAIRRO DE CASTELHANOS e respectivos Bairros vizinhos, denominados RIBEIRÃO DOS CASTELHANOS E LAGOA DOS CASTELHANOS. 
Artigo $4^{\circ}$ - Dito plano consiste no traçado da AVENIDA DE PROLONGAMENTO a RODOVIA TRANSVERSAL do D.E.R. e seu prosseguimento acompanhando a praia, sob a denominação de AVENIDA BEIRA-MAR, com largura mínima de 20 metros - na conformidade da PLANTA anexa, que fica fazendo parte integrante da presente.

No ano seguinte, "CONSIDERANDO o convênio proposto à PREFEITURA pelo Departamento de Estradas de Rodagem do Estado de S.Paulo-D.E.R., objetivando, a efetivação do $2^{\circ}$ trecho da Estrada de Rodagem PerequeCastelhanos; CONSIDERANDO, ainda, a necessidade da previsão de área adequada para a distribuição viária entre o ponto final da estrada em referencia, e a Avenida Beira-Mar objeto da Lei $n^{\circ}$ 28/68.", a prefeitura decretou como de utilidade pública a área necessária para a implantação da rodovia, conforme disposto nos artigos $1^{\circ}$ e $2^{\circ}$ do decreto $n^{\circ} 09 / 69$. $O$ artigo que segue é bastante interessante e remete ao próximo artigo, que tratará do terreno que virará estacionamento: 4\%: "Fica ainda declarado de utilidade pública, um terreno retangular, de propriedade de quem de direito, medindo 50 (cinqüenta) metros por 100 (cem) metros, situado ao longo do trecho final da Estrada Perequê-Castelhanos, junto à estaca '608' da planta anexa".

Em 1970, o artigo $n^{\circ} 2$ da lei n 01/70 que "Autoriza a Prefeitura a adquirir, e doar ao D.E.R., os imóveis necessários ao $2^{\circ}$ trecho da Estrada Perequê-Castelhanos" é muito esclarecedor: "Na autorização objeto desta lei acha-se compreendida a faixa correspondente ao leito da Estrada, e respectivas áreas remanescentes, bem como a área prevista para adaptação como mirante turístico e páteo-de-estacionamento, no lugar denominado CUME, e o terreno destinado à distribuição viária no terminal da Estrada, devidamente identificados no DECRETO $n^{\circ}$ 09/69 de 22 de dezembro de 1969".

Passaram-se vários anos, ocorreram problemas técnicos, as obras atrasaram e a estrada só ficou pronta em 1977. Sem perder tempo, a lei $n^{\circ}$ 43/78 "Aprova plano viário no bairro Lagoa dos Castelhanos, em complemento à Lei de Urbanização $n^{\circ}$ 28/68" que em seus três artigos, dispõem o seguinte:

"Artigo $1^{\circ}$ - No trecho ao longo da Praia denominada Lagoa dos Castelhanos, fica definida em 330 metros a extensão da AVENIDA BEIRA-MAR 
prevista na Lei $n^{\circ}$ 28/68 de 21 de novembro de 1968, contados a partir da divisa norte da 'Vila Reale', ou seja, a partir da área para estacionamento de veículos prevista na Lei $n^{\circ} 3 / 70$ de 19 de junho de 1970, e com término no cruzamento com o traçado da RUA ' 1 ' da planta do 'Balneário Castelhanos', aprovada pela Municipalidade em 16 de novembro de 1966.

Artigo $2^{\circ}$ - Fica definida a diretriz inicial do acesso viário ao bairro da Praia Mansa, através da Rua ' 1 ' mencionada no Artigo anterior, cujo leito previsto fica alargado para 14 metros ao longo de toda sua extensão, mantido o rumo leste-oeste do traçado consignado no respectivo projeto.

Artigo $3^{\circ}$ - Em complemento ao disposto no Artigo $2^{\circ}$, fica igualmente definido o prolongamento do acesso viário para o bairro da Praia Mansa, através da abertura de um ramal que, partindo da Rua '1', num ponto situado a 310 metros da faixa de marinha, segue em direção a aquele bairro com o rumo norte-sul até a cota 60 e por um trecho de 256 metros em linha reta, com largura uniforme de 14 metros."

Em matéria de favorecer os interesses privados, a prefeitura de Ilhabela inovou. Esse conjunto de medidas aprovadas por leis e decretos simplesmente transfere para o poder público a responsabilidade material e financeira pela implantação da infra-estrutura básica de acesso aos lotes, além de garantir o paisagismo do entorno do empreendimento. $O$ mapa $n^{\circ} 6$ permite visualizar espacialmente as principais medidas previstas e não deixa dúvida de que o plano de urbanização e de estímulo ao turismo na Baía dos Castelhanos não vai um palmo além dos limites do Vila Reale e Balneário Castelhanos foi concebido para favorecer os dois loteamentos.

Muitos lotes foram vendidos nos loteamentos da costa oceânica de Illhabela, mas poucas casas foram construídas, principalmente porque:

- as obras da estrada Perequê - Castelhanos e Perimetral sofreram atrasos e só foram concluídas em 1977;

- a construção da estrada Perimetral foi interrompida antes de alcançar as praias da costa oceânica do município;

Porém, o principal motivo para que esses lotes não fossem edificados foi a criação do Parque Estadual de Ilhabela - PEIB. 


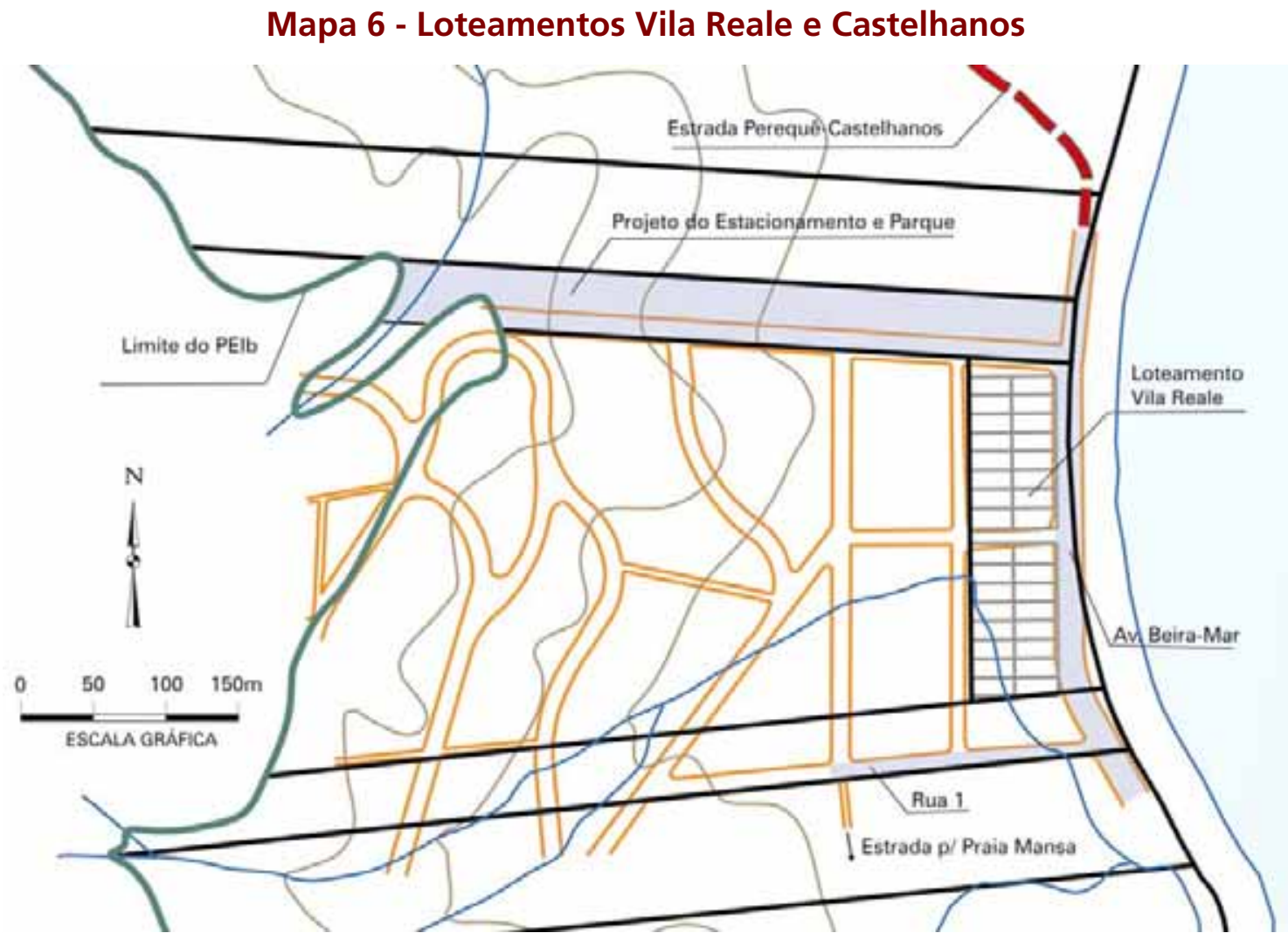

Fonte: Leis municipais de Ilhabela $n^{\circ}$ 28/68, 01/70 e 43/78.

\section{O ESTADO E O PODER PÚBLICO LOCAL}

a) O Parque Estadual de Ilhabela - PElb e a Legislação Ambiental

Criado pelo decreto $\mathrm{n}^{\circ} 9.414$ de vinte de janeiro de 1977, O Parque Estadual da Ilhabela - PElb, ocupa uma área de 27.025 ha e $83 \%$ do território do município de Ilhabela. Seus limites foram definidos por cotas altimétricas que variam conforme a localização: na face voltada para o canal de São Sebastião, o Parque situa-se acima da cota 200m, e na face oceânica, o limite varia entre a cota $100 \mathrm{~m}$ e a divisa com terrenos de marinha (cota zero). Todas as ilhas, ilhotas e lajes que compõem o arquipélago de Ilhabela foram contidas pela delimitação do PElb, além das comunidades caiçaras das ilhas Vitória e de Búzios, dos sacos do Sombrio e das Tocas e da praia da Figueira. 
As áreas que contornam o Parque são consideradas como zona de amortecimento, uma vez que interagem com os ambientes de floresta protegida, e foram instituídas com o propósito de minimizar os impactos negativos sobre a unidade. Posteriormente, essas áreas foram tombadas pelo Patrimônio Histórico do Estado de São Paulo (Tombamento da Serra do Mar Resolução CONDEPHAAT № 40 de 05/06/1985); que estabeleceu diretrizes, normas e recomendações preliminares visando garantir a ocupação controlada nessas áreas consideradas como de alta sensibilidade ambiental.

Portanto, nas áreas abrangidas pelo Parque, a agricultura, a caça e o artesanato, tradicionalmente desenvolvidas pelos caiçaras, passaram a encontrar severas restrições legais para serem praticados. O corte de madeira para a confecção de canoas e de casas de pau-a-pique hoje é proibido, dificultando o caiçara de desenvolver duas de suas atividades mais importantes. Essas proibições estendem-se também à construção civil e a qualquer outro tipo de projeto imobiliário voltado ao uso privado. Entretanto na Baía dos Castelhanos, apenas na praia da Figueira e no Saco do Sombrio os limites do Parque atingem a cota zero (chegam até a linha da costa). Nas praias do Gato, dos Castelhanos, Mansa e Vermelha, o limite do Parque vai até a cota 100 metros acima do nível do mar. Assim, nessas localidades, as restrições ao uso do solo são menos severas e estão definidas nas normas e recomendações do CONDEPHAAT que acompanham 0 decreto de tombamento.

Além do governo estadual, responsável pela criação e administração do Parque, outras instituições de pesquisa, públicas e privadas, aplicam recursos financeiros em projetos científicos e em trabalhos de apoio às comunidades caiçaras existentes no interior do Parque ou nas áreas de amortecimento. Destaca-se um acordo de cooperação internacional entre o governo do Estado de São Paulo e o Kredinstalt für Wiederaufbaum - KfW, um banco de desenvolvimento ligado ao governo alemão para a realização do Plano de Manejo da Mata Atlântica, que resultou na aplicação de recursos a fundo perdido no Parque, destinados tanto para a compra de equipamentos para sua administração e fiscalização, quanto à realização de pesquisas científicas. 
A presença de uma sede administrativa do Parque na cidade de Ilhabela facilita a atuação dos órgãos públicos de fiscalização, de movimentos ambientalistas e de ONGs - Organizações Não Governamentais.

O PElb é administrado pelo Instituto Florestal - I.F., da Secretaria de Meio Ambiente de São Paulo. Outro órgão dessa secretaria que tem atuação preponderante em Ilhabela é o DEPRN - Departamento Estadual de Proteção dos Recursos Naturais, encarregado de fiscalizar o cumprimento da legislação ambiental incidente sobre o Estado de São Paulo e de licenciar qualquer atividade ou obra que implique na supressão de vegetação nativa, corte de árvores nativas, intervenção em áreas de preservação permanente e manejo da fauna silvestre.

Dessa legislação, interessa diretamente à Baía dos Castelhanos, por impor severas restrições ao uso do espaço e dos recursos naturais locais, a Resolução CONAMA n 303 de 20/03/2002 que regulamenta o Novo Código Florestal brasileiro de 15/09/1965 e dispõe sobre parâmetros, definições e limites de Área de Preservação Permanente - APP.

Assim, em decorrência da presença do PElb ou da legislação ambiental em vigor, o uso do solo na Baía dos Castelhanos para qualquer atividade que não seja a conservação do meio ambiente, encontra-se severamente restringido ou proibido pela legislação ambiental e depende de autorização prévia do DEPRN para ser implementada.

O Plano Diretor de Desenvolvimento Socioambiental do Município de Ilhabela aprovado em outubro de 2006, regulamentou e estabeleceu novas diretrizes para o uso do solo, resultando em uma legislação ainda mais restritiva à edificação e implementação de projetos turísticos na Baía dos Castelhanos. 
b) O Poder Público Municipal e o PDDSA - Plano Diretor de Desenvolvimento Socioambiental do Município de Ilhabela

O poder público municipal é responsável pelas leis de uso e ocupação do solo, fiscalização das edificações e estabelecimentos comerciais, e aprovação de obras de construção civil e de projetos imobiliários. (resguardadas as restrições legais da legislação ambiental em vigor)

No Plano Diretor de Desenvolvimento Socioambiental do Município de Ilhabela - PDDSA, aprovado em 05/10/2006, foram estabelecidas as seguintes diretrizes para o uso e ocupação do solo na Baía dos Castelhanos:

Art. 10 - Zona de Alta Restrição 1 (ZR1) - Compreende as áreas que possuem como características relevos de inclinação predominante acima de $47 \%$, recobertos por floresta ou não, constituindo -se zonas de alta restrição de uso por razões geotécnicas e ecológicas.

$\S 1^{\circ}$ - São definidas como ZR1 as áreas compreendidas entre o nível do mar e a cota de $100 \mathrm{~m}$ de altitude que se estendem da Praia do Jabaquara pela vertente do Oceano Atlântico até o córrego da Sepituba no extremo sul do município.

$\S 2^{\circ}$ - Exclui-se da zona definida no caput a Zona de Restrição Total ZRT e Zona de Interesse Especial ZIE.

$\S 3^{\circ}$ - Será permitido uso/ocupação em módulos de tamanho mínimo de $10.000 \mathrm{~m}^{2}$ com taxa de ocupação residencial de 10\%, coeficiente de aproveitamento de 0,10 e taxa de ocupação comercial de $10 \%$ e coeficiente de aproveitamento de 0,20, respeitadas as diretrizes de ocupação definidas em lei.

$\S 4^{\circ}$ - É vedada abertura de vias de acesso e impermeabilização para circulação terrestre de veículos automotores.

$\S 5^{\circ}$ - É de responsabilidade do empreendedor que atuar nessas áreas o abastecimento de água e disposição e tratamento de resíduos líquidos e sólidos provenientes do empreendimento.

$\S 6^{\circ}$ - Resguarda-se o direito de uso aos parcelamentos anteriores a este Plano, legalmente aprovados, obedecidas as diretrizes para ocupação constante na presente lei. 
É interessante notar como todas essas restrições e exigências legais não impediram a ocupação irregular e ilegal do solo na Baía dos Castelhanos. As transgressões são de todos os tipos e vêm sendo cometidas principalmente por turistas, mas também por caiçaras, algumas já há algum tempo. Vejamos alguns exemplos, iniciando por obras ilegais no interior do PElb:

O trecho da Baía dos Castelhanos que se estende desde a praia da Figueira até o Saco do Sombrio é de rara beleza e um dos lugares mais bonito do Litoral Norte. Por se encontrar inteiramente no interior do Parque Estadual de Ilhabela, é proibida a construção de qualquer tipo de obra ou de infraestrutura, destinadas ao lazer ou ao comércio particular. No Saco do Sombrio, em área antigamente ocupada pela marinha, o Yacht Clube de Ilhabela construiu um atracadouro, um restaurante e outras edificações para uso exclusivo de seus associados e empregados. No Codó, ponta da Garoupa, existe há muitos anos duas casas, uma de turista e outra de caseiro, erguidas no interior do Parque. Na praia da Figueira também há construções ilegais, somando quatro edificações. A obra do Yacht Clube se sobressai, dominando a paisagem do Saco do Sombrio. Constitui uma grave agressão à beleza cênica do lugar e à arquitetura caiçara remanescente no lugar.

As fotos a seguir ilustram edificações irregulares no interior do PEIB e outros exemplos de transgressão na Baía dos Castelhanos.

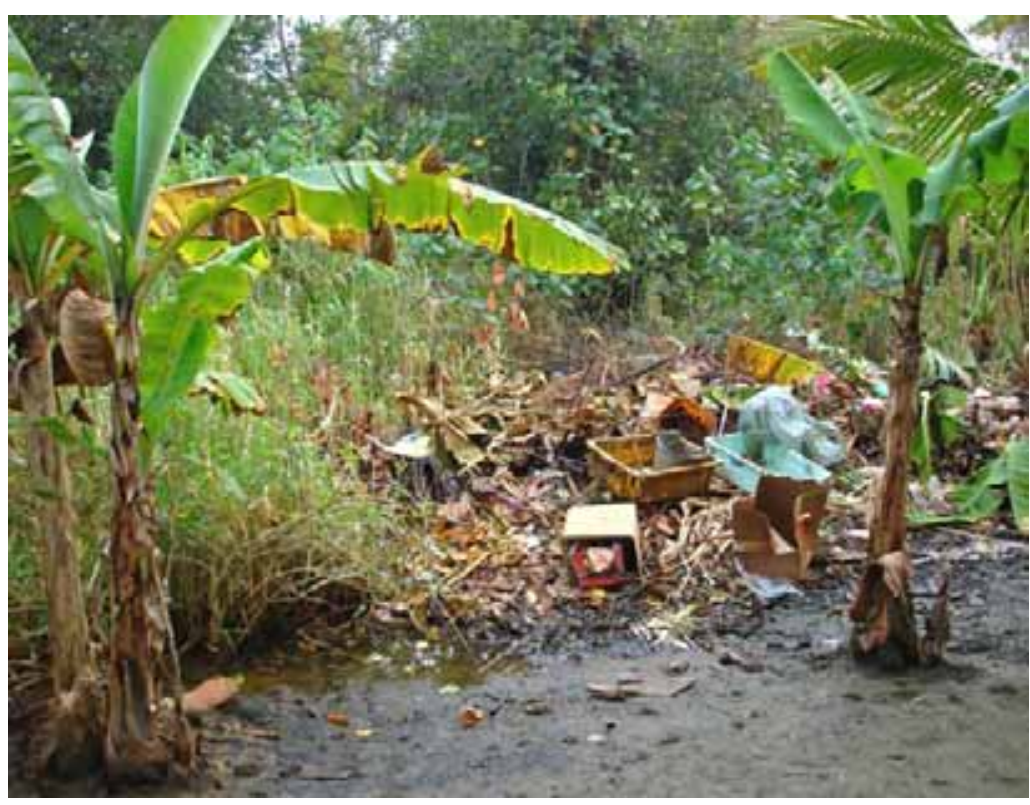

Foto 25. P. Noffs, 2007. Lixo de uma família caiçara se acumulando sobre o mangue na barra do córrego da Lagoa, revelando que novos hábitos de consumo podem trazer problemas para a conservação do meio ambiente e à saúde pública 


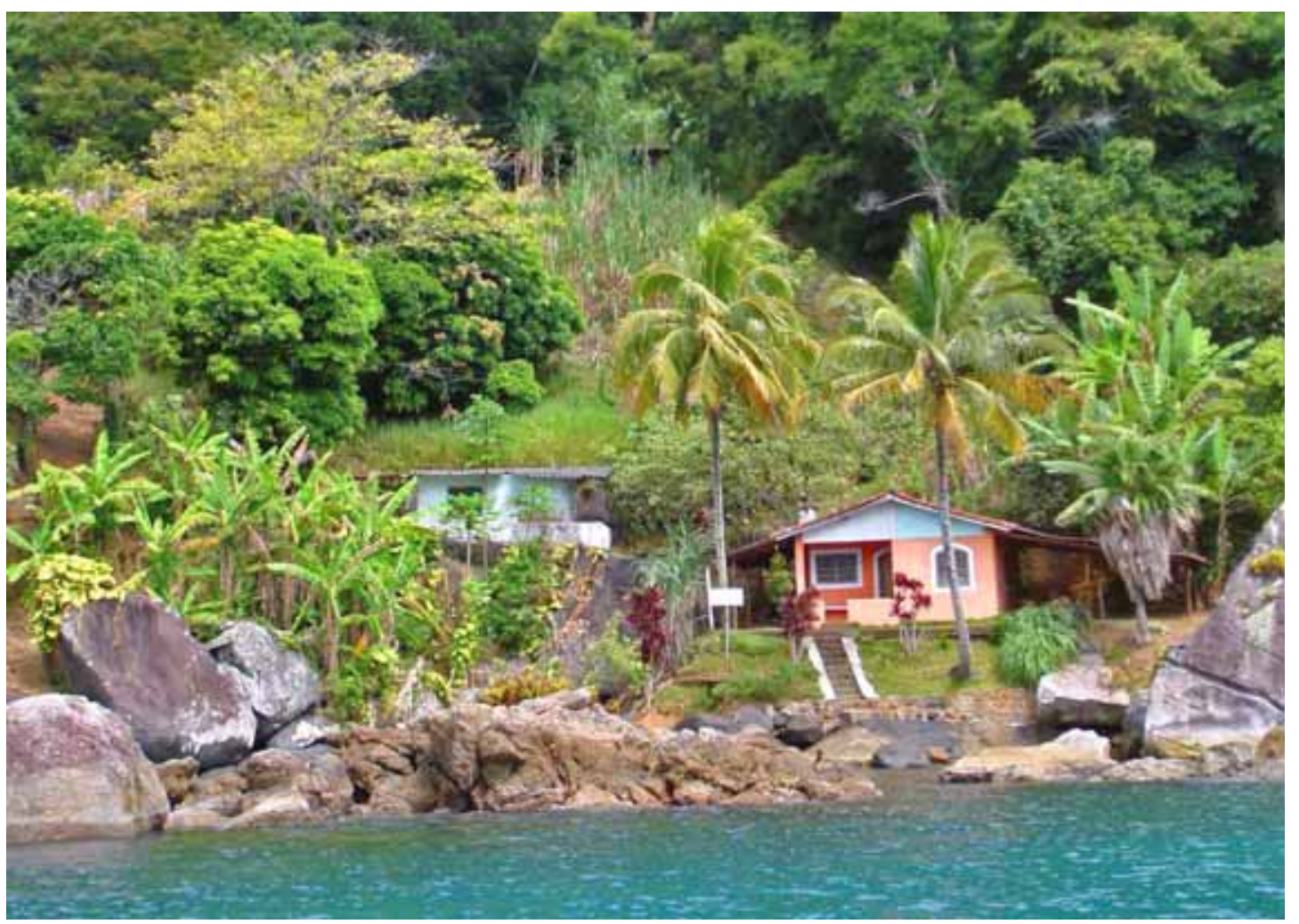

Foto 26 e 27. P. Noffs, 2007. Edificações de uso privado construídas no interior do PElb. Acima, casas de turista no Codó. Abaixo, estrutura do Yacht Club de Ilhabela, com atracadouro, restaurante e casa dos empregados, que atende apenas a seus associados e comprometeu o patrimônio arquitetônico e paisagístico do Saco do Sombrio

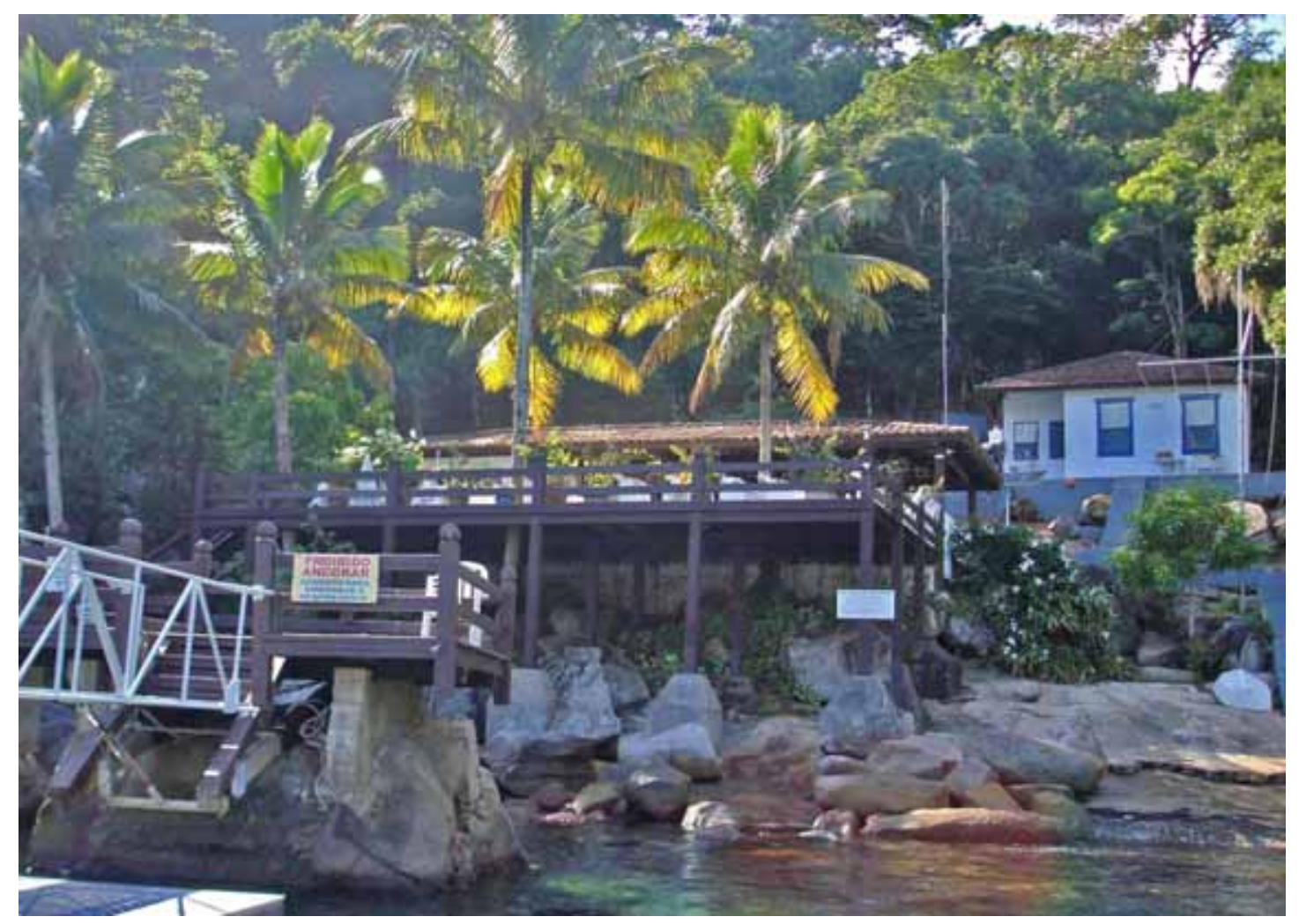




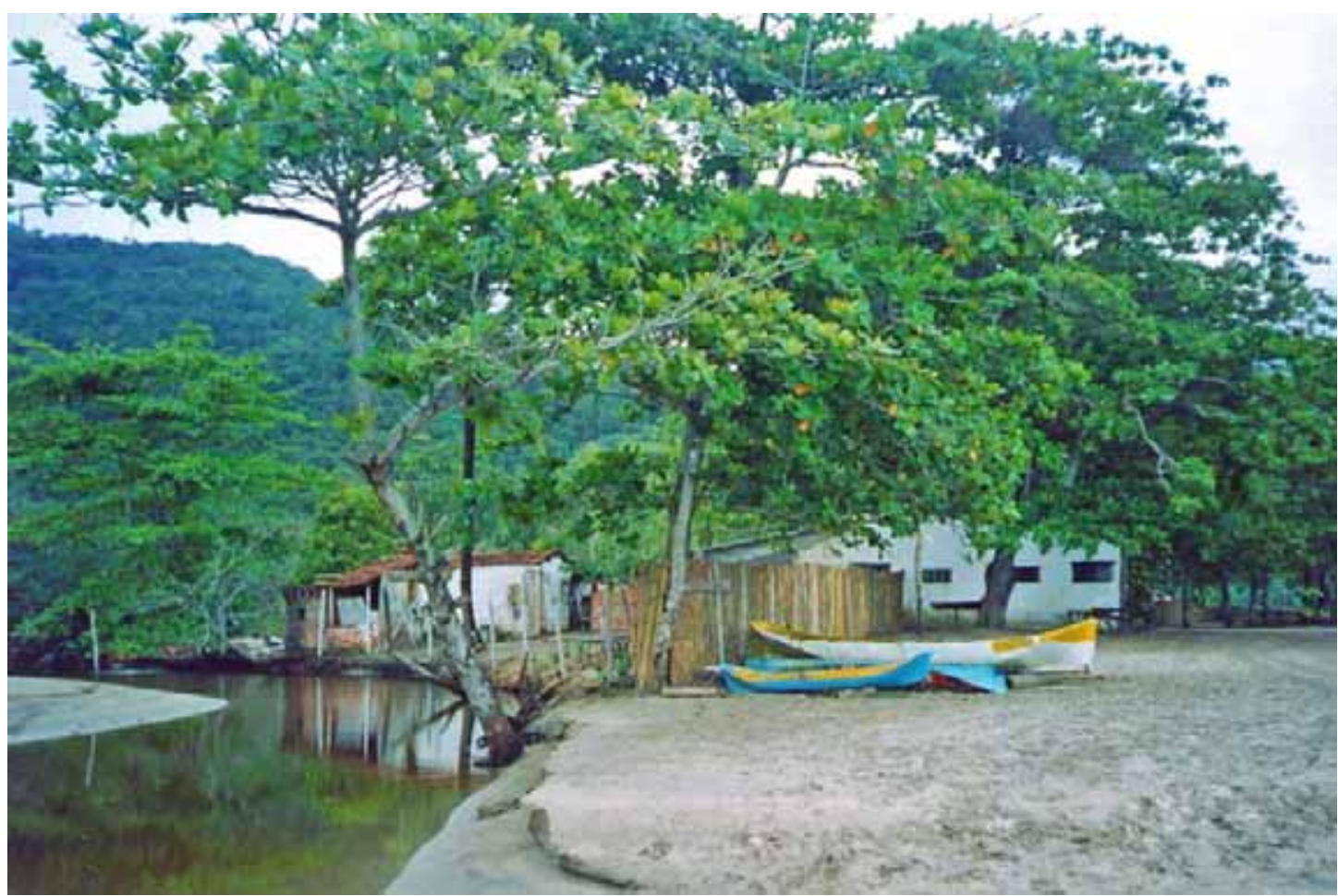

Foto 28. M. Pirró, 2003. Bar e camping do Fábio, mais conhecido como Canindé, seu proprietário original, com parte de suas edificações construídas sobre o mangue existente na barra do córrego da Lagoa. O esgoto dos banheiros e dormitórios localizados na parte de trás é lançado diretamente nas águas desse córrego.
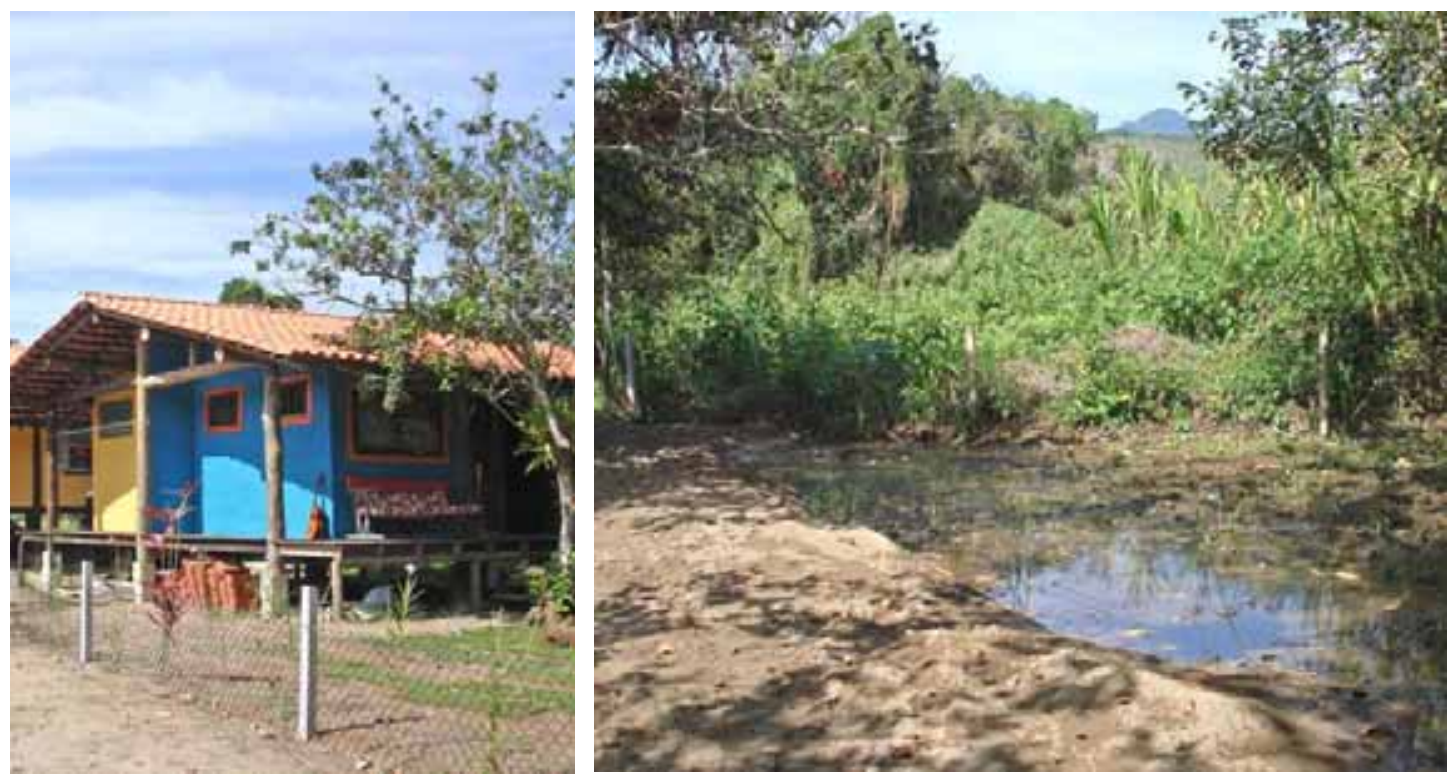

Foto 29 e 30. P. Noffs, 2007. Duas casas de turistas construídas em lotes de $13 \mathrm{~m} \times 30 \mathrm{~m}$ remanescente do loteamento Vila Reale. A azul ocupa o lote de fundo e é geminada com a edícula da casa amarela que ocupa o lote da frente. O fundo do lote da casa azul situa-se sobre um charco que periodicamente é inundado pelo córrego da Lagoa. Como o lote tem 30 metros de profundidade, encontra-se inteiramente dentro de área de preservação permanente. Portanto, o proprietário não poderia ter obtido autorização do DEPRN para edificar no local. Aliás, todos os 32 lotes do Vila Reale, de acordo com o Plano Diretor do Município e com o Código Florestal são ilegais. 
A prefeitura é responsável pela manutenção da estrada de terra que dá acesso à praia dos Castelhanos, entretanto, no trecho que atravessa o Parque (praticamente toda a estrada), é necessária a aprovação prévia da direção do PElb para a realização de obras, a qual nem sempre é concedida. Ultimamente, os serviços de manutenções têm sido pouco freqüentes, impossibilitando o tráfego de automóveis de passeio. As poucas obras de reforma e manutenção usualmente são implementadas sem sistema de drenagem e os cuidados ambientais necessários. Em conseqüência, a cada novo período de chuvas, ocorrem problemas sérios de erosão e desbarrancamentos e a estrada se torna intransitável, exigindo novas intervenções, demandando mais obras e provocando novos impactos ambientais.

O acesso às demais localidades da Baía dos Castelhanos é feito a pé ou por barcos e canoas particulares. A prefeitura mantém apenas o serviço de transporte escolar por barco (pertencente a um morador do Saco do Sombrio) para as crianças das Praias da Figueira e do Saco do Sombrio que freqüentam a escola da Praia Mansa.

Um aspecto muito interessante do esforço do Estado de regulamentar o uso do território em Ilhabela e especificamente nas áreas do PElb e de seu entorno compreendidas pelo tombamento da Serra do Mar, é a forma como as populações caiçaras são retratadas e conceituadas.

O mesmo Estado que legislou para favorecer os empreendimentos da família Reale no período de 1966 a 1978, anos mais tarde institui um Plano Diretor que destina porções consideráveis do território do município para uso exclusivo das famílias caiçaras. Como fundamentando desta ação está o conceito de População Tradicional, que o Plano Diretor de Ilhabela definiu como "Grupos humanos culturalmente diferenciados, fixados em uma determinada região, historicamente reproduzindo seu modo de vida em estreita dependência do meio natural para sua sobrevivência." Para estas populações e os territórios por elas ocupados, foram previstas as seguintes diretrizes especiais definidas pela Zona de Interesse Especial ZIE, referida no $2^{\circ}$ parágrafo do artigo 10 citado acima: 
Art. 14 - Zona de Interesse Específico (ZIE) Compreende as áreas ocupadas pelas comunidades tradicionais, as áreas de Patrimônio Histórico e Cultural, bem como Sítios Arqueológicos.

$\S 1^{\circ}$ - São Zonas de Interesse Específico as áreas com a seguinte delimitação na Ilha de São Sebastião: limites laterais pelo divisor de águas de cada sub-bacia hidrográfica contígua à praia ou costeira onde se encontram as moradias de cada uma das comunidades até atingir a cota que define o limite do Parque Estadual de Ilhabela segue pela quota $100 \mathrm{~m}$ até encontrar outro divisor de águas que se estende até o mar.

$\S 2^{\circ}$ - As diretrizes de uso e ocupação desta zona seguem as diretrizes da legislação estadual e federal por tratar-se de área de entorno de Unidade de Conservação.

$\S 3^{\circ}$ - São atividades permitidas na Zona de Interesse Específico das comunidades tradicionais:

a) Atividades representativas das práticas culturais caiçaras como pesca artesanal, agricultura de roça, artesanato, festas entre outras e acesso aos recursos ambientais;

b) Atividade de promoção ambiental com restauração e conservação das Áreas de Preservação Permanente, de modo a garantir qualidade de vida ao ambiente e às futuras gerações;

c) Atividades de promoção socioeconômica de baixo efeito impactante.

Enquanto especialistas do Departamento de Geografia da USP e da prefeitura trabalhavam na elaboração do Plano Diretor de Ilhabela, detalhando diretrizes para proteção das comunidades caiçaras e de sua cultura, e, a despeito da resolução CONDEPHAAT que confere às áreas do entorno do PEIB um status especial, o único conjunto de habitações tipicamente caiçara existente em toda a Baía dos Castelhanos, portanto de relevante importância arquitetônica, foi totalmente destruído. Em seu lugar, foram erguidas 4 grandes casas de turistas, cujo proprietário não deve ter encontrado dificuldades em obter da prefeitura e do DEPRN a autorização necessária para a derrubada das casas e a nova construção. 


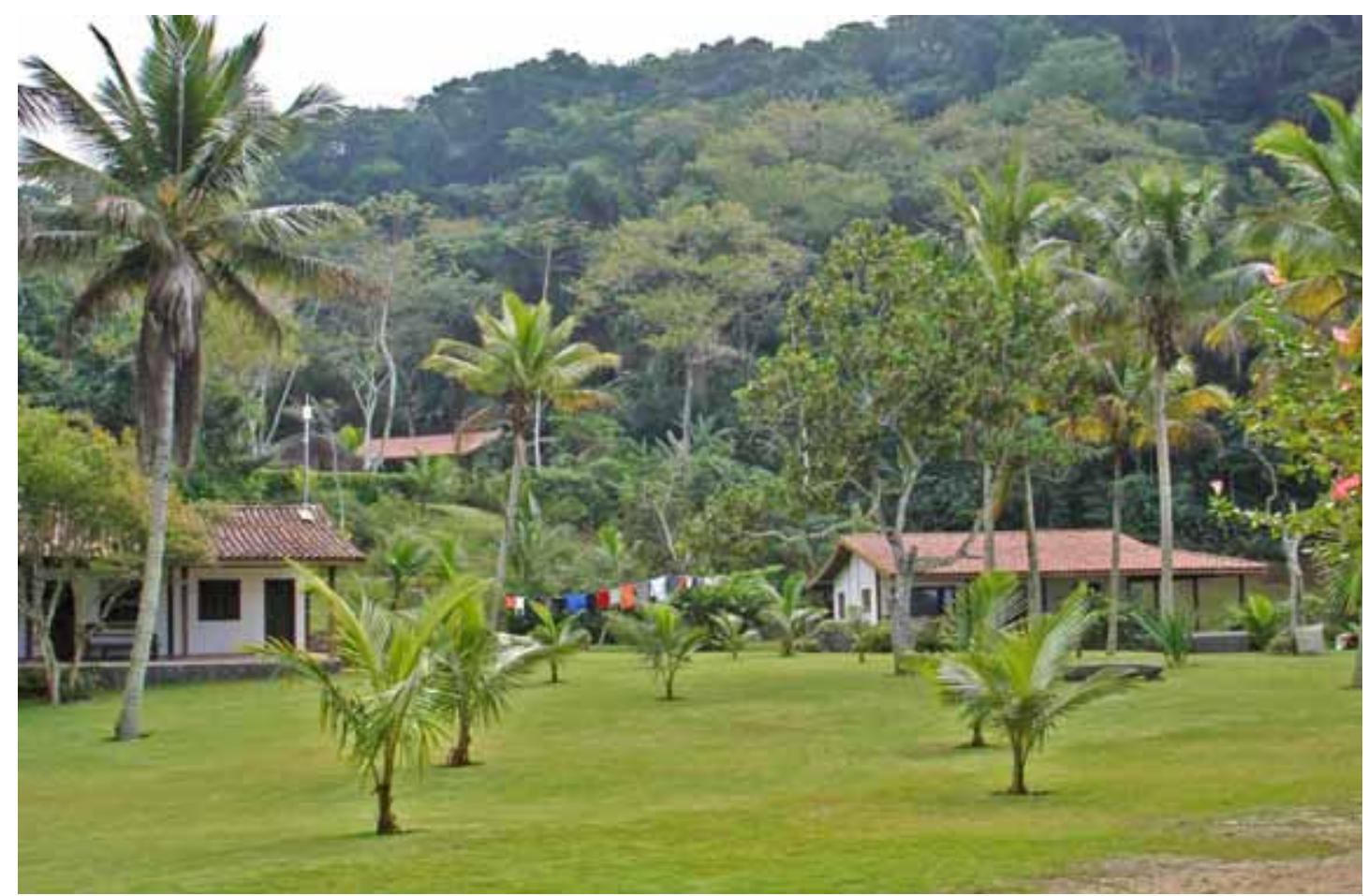

Foto 31. P. Noffs, 2007.

Casas novas de turista construídas na Praia Vermelha no lugar das antigas com arquitetura típica caiçara

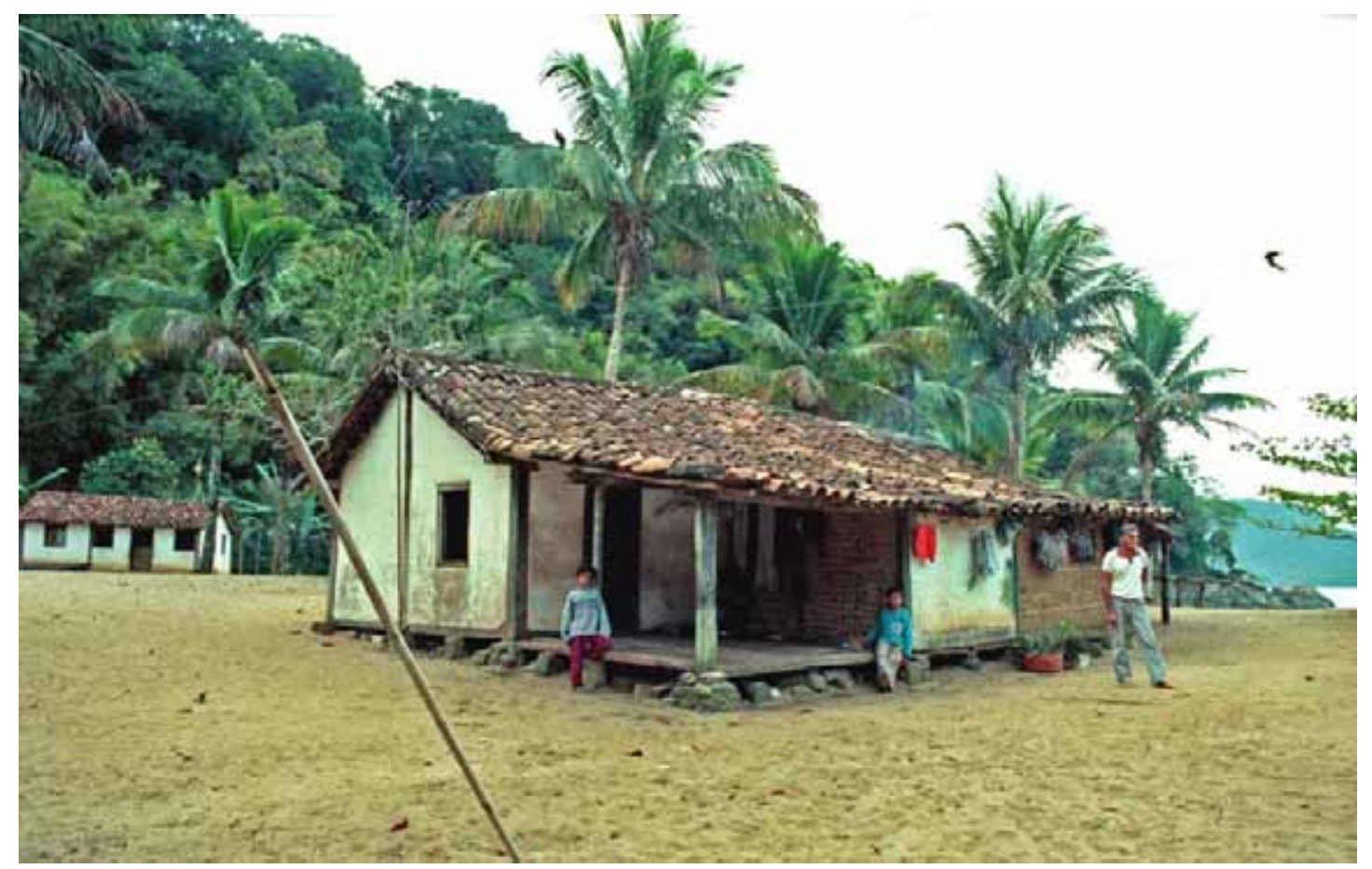

Foto 32. P. Noffs, 1996. 
Os órgãos locais de fiscalização e planejamento da Secretaria do Meio Ambiente de São Paulo também conferem às populações caiçaras uma condição especial. O relatório "Subsídios para o Plano de Manejo do Parque Estadual de Ilhabela / PEIB: Inserção das Comunidades Caiçaras" propõe algumas medidas que explicitam a visão governamental (ou pelo menos de alguns setores do governo) para essas populações.

"1. As áreas ocupadas pelas comunidades tradicionais caiçaras inseridas nos limites do PEIB, como a Ilha da Vitória, Porto do Meio e Guanxuma - Ilha de Búzios, Saco do Sombrio e Praia da Figueira, sejam geridas no Plano de Manejo como Zona Histórico-cultural Caiçara, sendo assegurada a sua permanência e o modo de vida caiçara, através do estabelecimento de Termos de Compromisso entre o órgão executor e os representantes das familias;

2. As áreas ocupadas pelas comunidades tradicionais caiçaras do entorno do PEIB, onde se encontram as vilas caiçaras e as áreas de uso sustentável das comunidades da Praia Vermelha, Praia da Serraria, Saco do Eustáquio, Praia de Indaiatuba, Praia do Bonete, Praia das Enchovas, Praia Mansa, Canto da Lagoa, Canto do Ribeirão e Guanxuma, sejam geridas como Zona de Uso Tradicional, sub-zona da zona de amortecimento, conforme previsto no Plano de Gestão Ambiental.

Em ambos os casos devem-se assegurar que:

Os critérios de ocupação e crescimento espacial das moradias e de uso dos recursos naturais renováveis sejam regulados, comunidade por comunidade, através de um processo intenso de negociação com as comunidades e com a participação do conselho consultivo do PEIB, tendo em vista as áreas de vila caiçara e de uso tradicional predefinidas neste documento" (Instituto Florestal, 2005: 22 - relatório interno, consultado na sede do PElb em Ilhabela).

Este mesmo relatório apresenta uma série extensa de características (extraídas de Diegues, 1996) para enquadrar as populações da costa oceânica de Ilhabela como tradicionais, da qual selecionamos algumas:

- "Caracterizam-se por uma grande dependência do uso dos recursos naturais renováveis, sobretudo os pesqueiros, a partir do qual constroem um modo de vida particular ligado ao mar; 
- Pertencem a ele e apropriam-se de um território onde os grupos sociais se reproduzem econômica, social e simbolicamente, as praias e morros onde habitam e estabelecem suas comunidades;

- Permanecem e ocupam esse território por várias gerações, ainda que membros individuais possam ter-se deslocado para centros urbanos de onde podem voltar para a terra de seus antepassados, segundo suas necessidades e os ciclos econômicos regionais;

- Pela importância das atividades de subsistência, ainda que a produção de mercadoria, mais ou menos desenvolvida, indique a vinculação com o mercado local e regional, como é o caso da produção pesqueira" (op citada, página 33)

Ainda em 1992, em um de seus primeiros trabalhos técnicos realizados sobre o PElb, afirmava-se "que, certamente, as tradicionais famílias moradoras da região são os reais indicadores do verdadeiro potencial dos recursos naturais existentes e de sua autêntica forma de manejo, e que sua territorialidade deve ser observada em qualquer tentativa de zoneamento" (Ilhabela - Diagnóstico sócio-econômico, 1992: 11), ficando claro em todo o seu conteúdo que o relatório de 2005 apenas detalhou o que se apresentava como intenção em 1992.

Assim, as políticas públicas voltadas à administração do território em Ilhabela, definiram, ainda que de forma oficiosa, que famílias caiçaras podem morar no interior do PElb, sendo-lhes permitido construir novas habitações para abrigar desdobramentos da família nuclear. É o que já vêm acontecendo na Baía dos Castelhanos, na Praia da Figueira, nas Galhetas, Codó e Saco do Sombrio. São situações, descritas a seguir, que explicitam as contradições do estado frente à gestão das terras públicas.

- Na Praia da Figueira existem quatro casas com moradores caiçaras, porém, ao contrário do que descrevem o Plano Diretor e os relatórios do I.F. (1992 e 2005), não se trata de um bairro, nem de um aldeamento e tampouco de uma vila caiçara, já que habitam o lugar por consentimento dos atuais proprietários da praia, para os quais prestam serviços (ver páginas 54 a 58 do 
Anexo - Cadastro das Famílias Caiçaras, das Casas de Turistas e das Atividades Comerciais na Baía dos Castelhanos).

São duas propriedades dividindo a praia: A da esquerda pertence ao Sr. Artur Ribeiro e foi comprada do Sr. Mário Volcoff, que por sua vez adquiriu os direitos possessórios da família do Sr. Odorico e Da. Conceição, caiçaras antigos da região. O Sr. Artur tem 4 edificações no local. (duas são casas), todas construídas ou reformadas por ele ou por seu antecessor. Uma é sua segunda moradia e a outra abriga a família do Sr. Maurício, filho de Sr. Odorico, que juntamente com sua mulher, foi contratado para prestação de serviços de manutenção e guarda da propriedade. Todas as edificações estão dentro do Parque, foram construídas ou reformadas após o decreto de sua criação em 1997 e são destinadas ao uso turístico privado.

A outra metade pertence ao Sr. José Antonio Vidal Xavier Mendonça, descendente do dono da fazenda de café que originalmente existia na Praia da Figueira em fins do século XIX e início do XX. S. Lauro, igualmente filho de Sr. Odorico, também é empregado e mora em uma casa de alvenaria construída com materiais cedidos pelo dono do local. Recentemente, com autorização do proprietário, foram construídas duas casas de pau-a-pique para abrigar desdobramentos da família de Sr. Lauro (uma filha, que se casou com um jovem da Praia Vermelha, e um filho, que no momento da realização da pesquisa, estava morando no Saco do Sombrio). Entretanto, segundo informações dos moradores locais, , não autorizam o Sr. José Antonio não consegue obter autorização da prefeitura e do DEPRN para construir casa para uso próprio de lazer.

Há uma quinta casa na Figueira, também tolerada pelo DEPRN e que foi construída em pau-a-pique, sobre a costeira norte da Praia, em posse formada pelo Sr. Maurício, que morava nela antes de ir trabalhar para o Sr. Artur. Atualmente uma parenta sua mora na casa.

- Na Praia das Galhetas também há uma casa, posse de uma família caiçara, construída no interior do PElb. Galhetas, tradicionalmente, sempre foi habitada por famílias caiçaras e lugar de produção de banana e de farinha de mandioca. No Codó são duas casas no interior do PIEb, ambas de um mesmo proprietário turista que as construiu há pelo menos 20 anos. 
- No Saco do Sombrio são 5 casas de turistas existentes no interior do PElb, todas identificadas no relatório "Subsídios para o Plano de Manejo do Parque Estadual de Ilhabela / PEIB: Inserção das Comunidades Caiçaras" elaborado para o I.F. em 2005. Em 1992, o mesmo I.F., órgão responsável pela administração do Parque, já informava a existência de duas casas de caiçaras cujas posses haviam sido transferidas para turistas. Diferentemente da Praia da Figueira e de outros locais no interior do PElb, no Sombrio, as casas dos turistas se "parecem" com as dos caiçaras, em uma estratégia evidente de confundir a fiscalização, conforme os moradores locais relatam. Em março de 2007 eram 3 as casas embargadas pelo ministério público estadual, o que, no entanto, não impede que continuem sendo utilizadas por turistas, comprovando a ineficiência da estratégia de preservação do território e cultura caiçara no PElb.

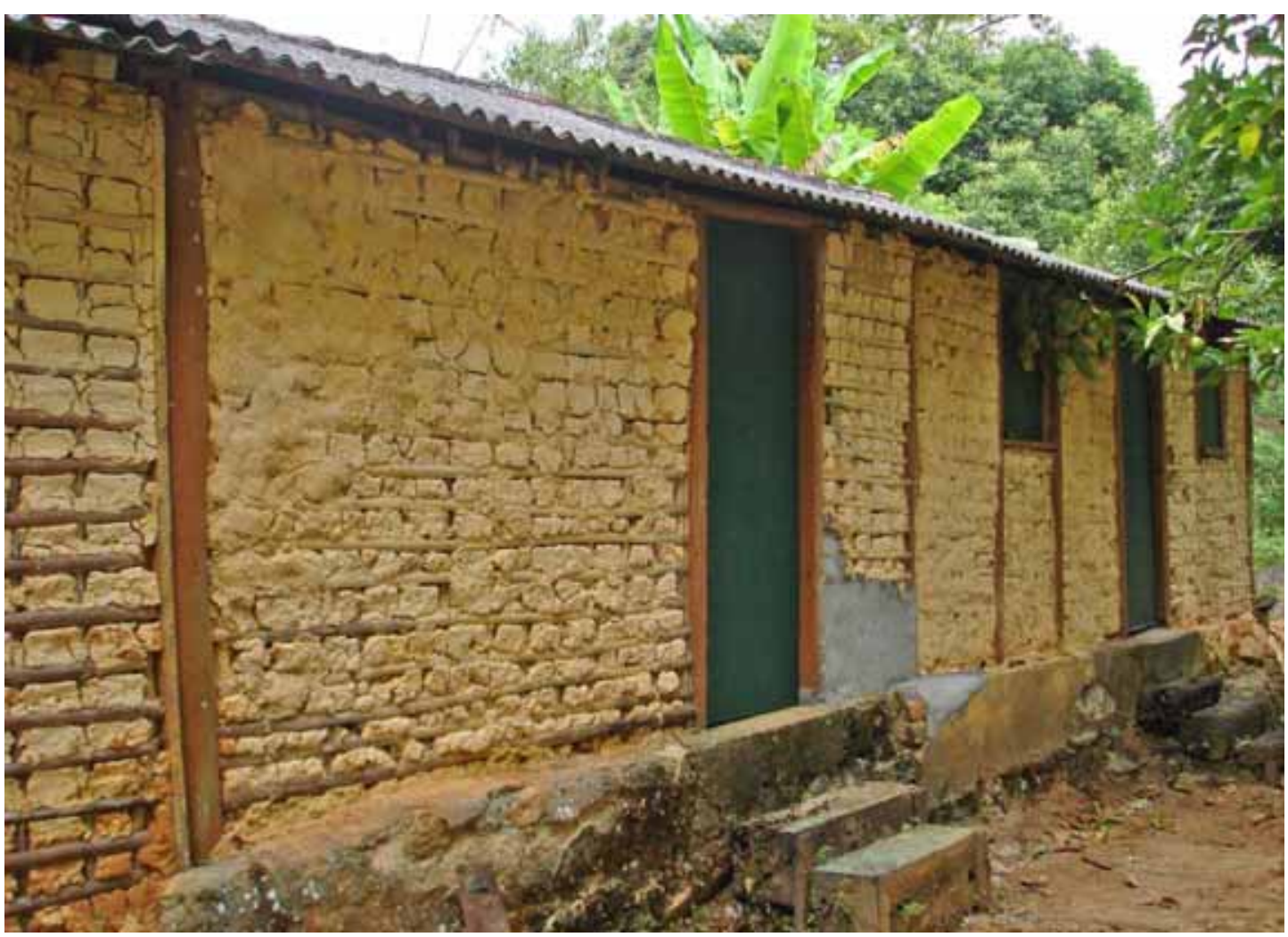

Foto 33. P. Noffs, 2007. Casa de turista no Saco do Sombrio comprada de caiçara e reformada mantendo suas características originais. Moradores locais informaram que ela está embargada, mas continua sendo utilizada. Há um caiçara do lugar contratado para realizar os serviços de manutenção e guarda da propriedade. 


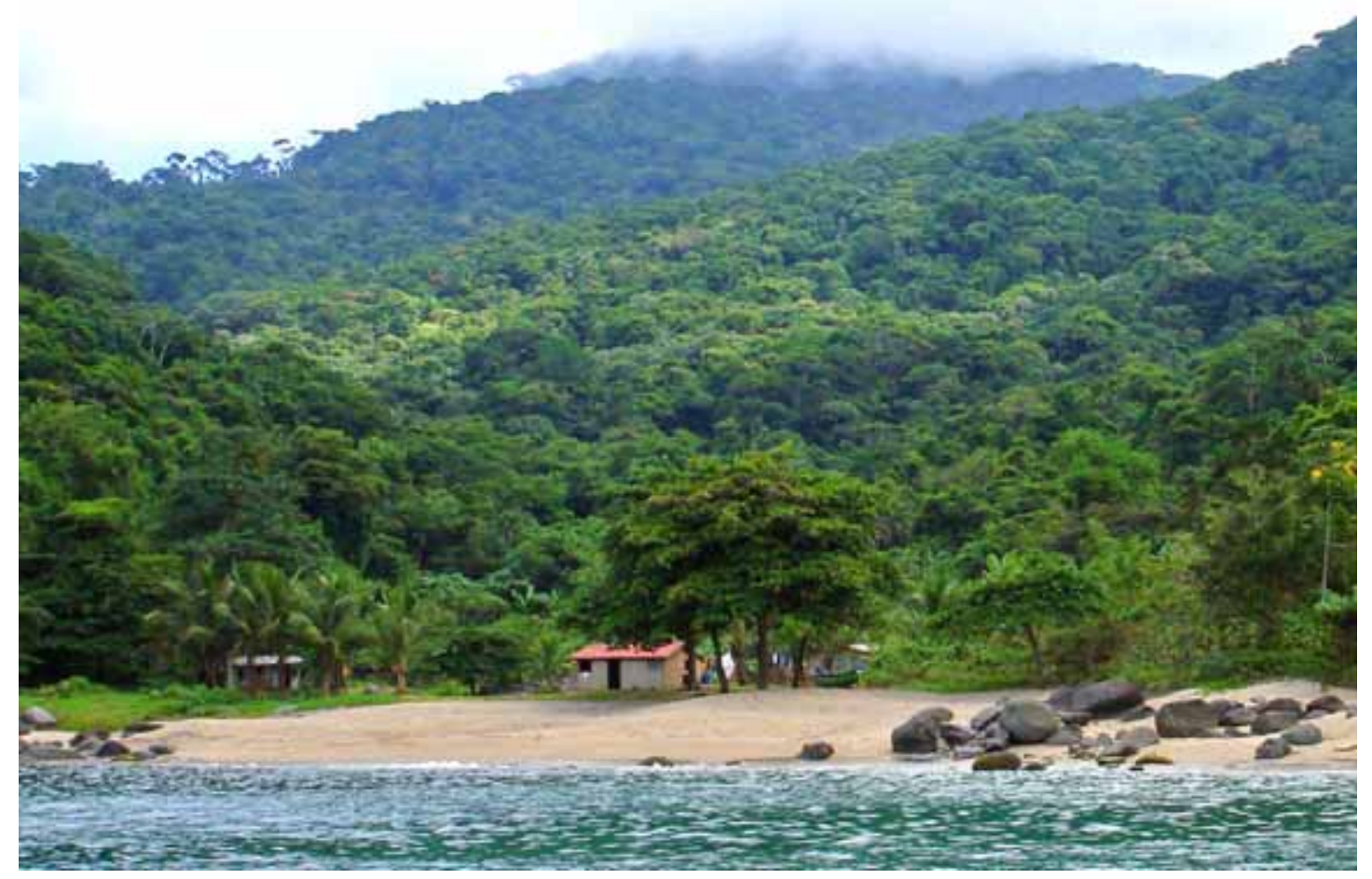

Foto 34. P. Noffs, 2007. Casa de S. Lauro, no canto direito da Praia da Figueira, propriedade de Sr. José Antonio Vidal Xavier Mendonça. À esquerda da foto, atrás dos coqueiros, casa de sua filha Katia e à direita, atrás da canoa, a de seu fliho Messias. Todas construídas no interior do PElb com o "consentimento" do DEPRN.

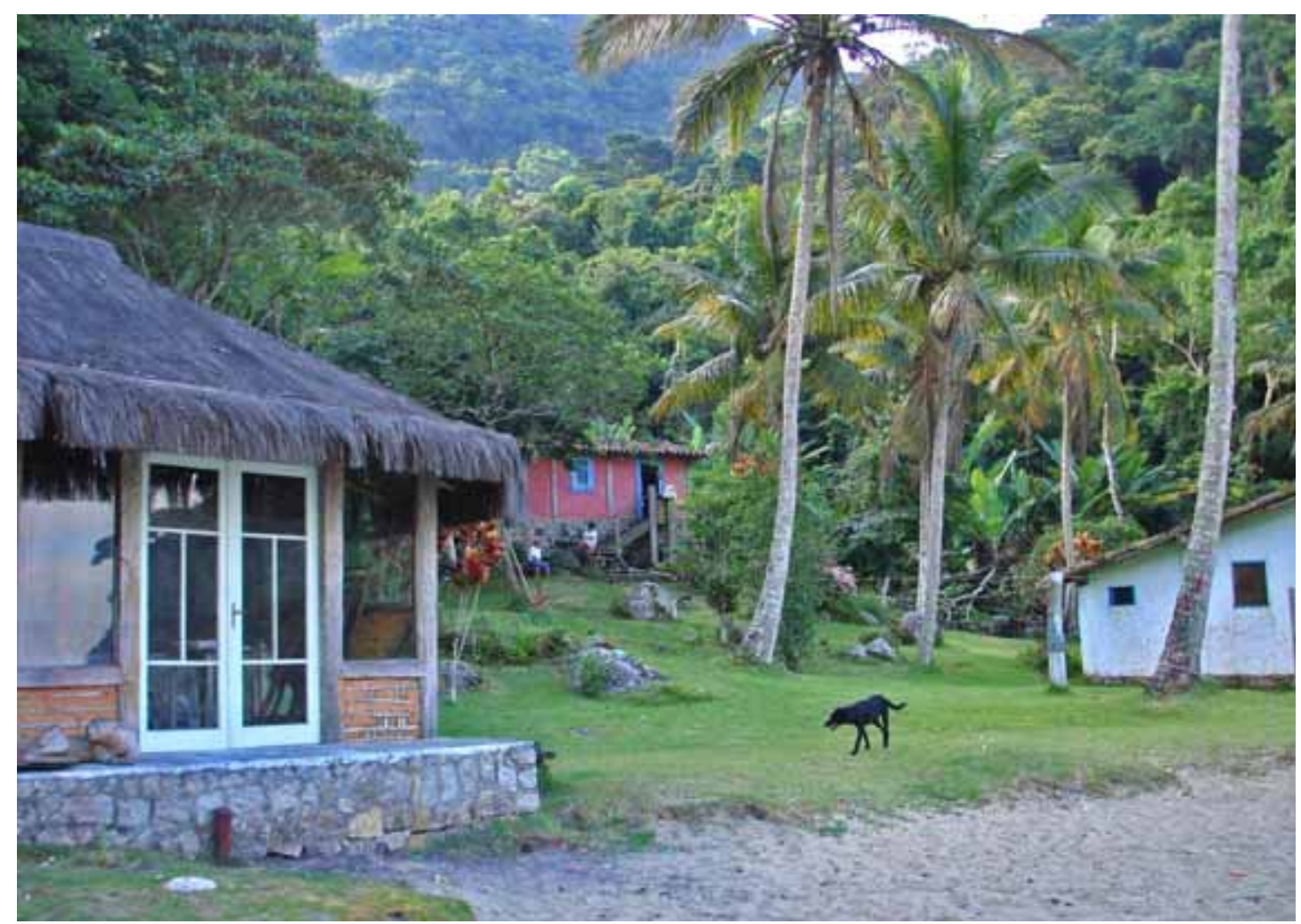

Foto 35. P. Noffs, 2007. Conjunto de casas de turista na propriedade do Sr. Artur Ribeiro, construídas no interior do PElb. No fundo, a moradia ocupada pela família do caseiro Maurício. 
O problema da legislação conservacionista e dos estudos e pesquisas voltados à proteção da cultura e do território caiçara, este entendido como necessário à prática da roça de subsistência, é a visão simplista de que a terra representa um modo de produção e o capital outro. Supõe-se a condição divina, de algo que sempre existiu e que sempre existirá, fruto da ilusão positivista de que a agricultura familiar e a pesca artesanal prescindem da história e de relações sociais de produção. Basta que alguns pesquisadores encontrem uma roça de mandioca e uma casa de farinha para determinar a existência de pelo menos três gerações de famílias convivendo em harmonia com a natureza e produzindo tudo aquilo que necessitam para viver. A roça de subsistência e a pesca artesanal caiçara, na perspectiva do estado (municipal e estadual), que regulamentou a ocupação do território, são consideradas fins em si mesmas, atividades que não fazem parte da economia de mercado e nem precisam dela para existir. Ao contrário, é o mercado que conspurca um "modo de produção" quase divino, puro, ao introduzir tentações (dinheiro) e que, conduzido por pessoas gananciosas, enganam os caiçaras ingênuos em transações mercantis, principalmente as relacionadas à propriedade da terra.

Os estudos e pesquisas que fundamentaram conceitualmente a elaboração do Plano Diretor do município e que norteiam a atuação dos órgãos estaduais locais, ignoraram que os engenhos de pinga e os canaviais espalhados por toda as costas norte, leste e sul de llhabela (para ficar na área abrangida pelas políticas públicas de proteção às "comunidades tradicionais", foram responsáveis pelo desmatamento de porções expressivas da Mata Atlântica (ver mapa $n^{\circ} 3$ na página 9); que a produção de alimentos sempre esteve presente no Litoral Norte integrada à economia regional do sudeste brasileiro; e que em momentos de empobrecimento econômico, como o que se sucedeu com a decadência do café, os produtores que permaneciam no local se voltavam à produção de alimentos como estratégia de sobrevivência. Se desconhece que a pequena produção mercantil em Ilhabela e na Baía dos Castelhanos que chegou até os dias atuais foi engendrada nas fazendas e engenhos; e que o Sr. Leonardo Reale, dono do engenho, o S. Barbosa, dono de fazenda de banana, de aparelhos de cerco e do armazém local, e o Sr. 
Pedro Euzébio que trabalhou para ambos, eram expressões da mesma relação social de produção.

É importante que se diga ainda que os bananais e as roças de produção de alimentos e de frutas conquistaram novas terras no interior da Mata Atlântica, estendendo os limites estabelecidos inicialmente pelos canaviais e cultivos de café. E essa devastação da floresta só não foi maior devido à incapacidade da pequena produção mercantil de sustentar o crescimento vegetativo da população, fazendo com que muitas pessoas migrassem para as cidades da região em busca de melhores condições de trabalho. E para não se prolongar demais nesse tema, pode-se dizer, por último, que as roças de produção de alimentos e a pesca artesanal com uso de canoas a remo encontradas no início da década de 1990 representavam a última etapa da decadência da agricultura comercial na Baía dos Castelhanos.

Enquanto o Estado, ao longo da década de 1990 e início da atual, voltase à elaboração de projetos, programas e leis para conservar e proteger a cultura, as atividades e o território caiçara, esse território já fora negociado e vendido há muito tempo para turistas e especuladores. Os caiçaras que hoje vivem na Baía dos Castelhanos constituíram novas posses ou simplesmente permaneceram nas terras vendidas por seus antepassados, readquirindo (ou lutam por readquirir) o direito possessório sobre elas. No entanto, atualmente, a pequena produção mercantil apresenta características muito diferentes, estando mais próxima do pequeno empresariado capitalista urbano que da produção familiar da banana ou da roça de subsistência.

O mapa $\mathrm{n}^{\circ} 7$ a seguir mostra a distribuição da propriedade fundiária na Praia dos Castelhanos, com base em informações fornecidas por uma imobiliária de Ilhabela. 


\section{Mapa 7 - Distribuição das Propriedades na Praia dos Castelhanos}

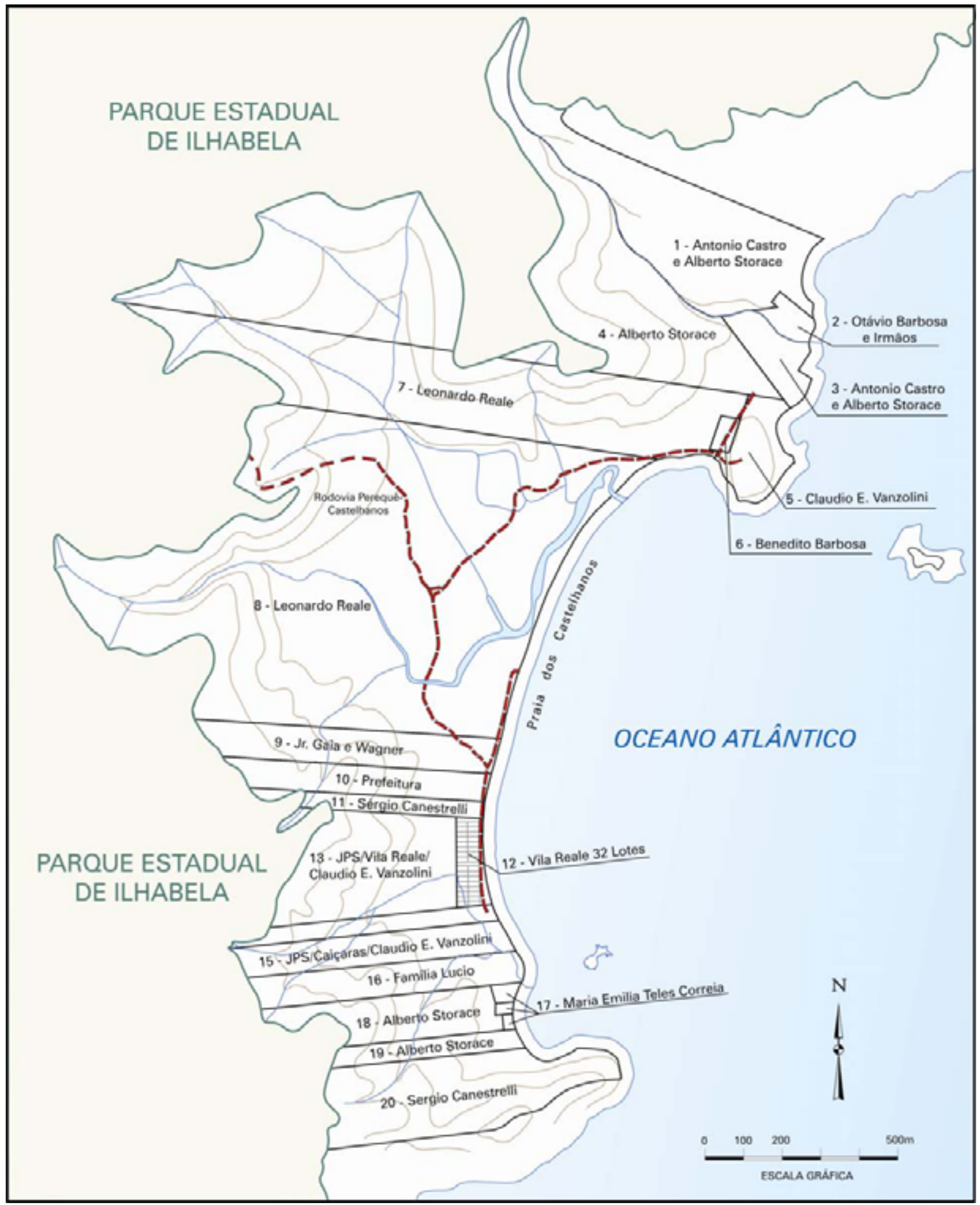

Fonte: Mapa das propriedades da Praia dos Castelhanos, escala 1: 5.000 de Alain B. Mantchev, 2007 (inédito) com base em croquis elaborados pela imobiliária Roberto Neves, no cadastro de imóveis da prefeitura de Ilhabela e no Cartório do Registro de Imóveis da Comarca de São Sebastião. 


\section{3 - CAIÇARAS NA BAÍA DOS CASTELHANOS}

"Há alguns anos atrás estive na ponta da Sepituba, último lugarejo em Ilhabela até aonde se pode chegar de automóvel na direção sul. Era uma tarde de inverno e chovia muito. Do alto do morro podia-se ouvir o motor de uma canoa encoberta pela chuva forte e a neblina.

O dono da venda onde eu estava, percebendo minha surpresa, explicou que se tratava de gente da praia do Bonete regressando de São Sebastião, onde tinha ido vender peixe e comprar mantimentos e outras coisas.

Alguns meses depois fui à praia de Castelhanos. Surpreendi-me com o mesmo cenário que havia visto 20 anos antes: casas de pau-a-pique, caiçaras pescando, uma ou outra roça de mandioca."

Esse texto abria meu projeto de doutoramento. Ao final da apresentação, formulava a seguinte indagação:

- que mundo é esse, tão perto de São Paulo, onde nada muda e as casas são iluminadas à luz de vela? Que pessoas são essas que percorrem diariamente grandes distâncias de canoa a motor, enfrentando o mar aberto e tempestades inesperadas, para vender e comprar poucas mercadorias para sobreviverem?

Onde nada muda? Não. Havia me enganado. Muitas coisas estavam em transformação. Algumas visíveis, como a própria presença das canoas a motor, utilizadas agora em lugar das caminhadas a pé, quando os caiçaras percorriam a pé mais de $20 \mathrm{~km}$ para atravessar a serra e vender e comprar produtos diversos na cidade; outras que não eram percebidas a primeira vista, como a transferência da posse da terra, que exigia investigação para ser constatada e compreendida.

Um olhar mais atento teria percebido também que a produção familiar de alimentos, enquanto atividade preponderante do espaço, estava acabando. Não por falta de território ou de leis e projetos governamentais que garantissem às famílias caiçaras o acesso à terra para dar continuidade às suas atividades. Estava terminando a etapa da pequena produção mercantil articulada ao mercado de Santos pelos barcos a motor e depois pelos caminhões. A urbanização do espaço em Ilhabela e Litoral Norte promovida 
pelo turismo se encarregou de por fim a ilusão de que a pequena produção de alimentos prescindia do mercado para existir.

De acordo com o I.F., em 1992 a pesca era a atividade econômica mais importante praticada na costa oceânica de llhabela. Do total de seus moradores, $48 \%$ tinham exclusivamente na pesca sua principal fonte de renda. Associada a outras atividades, o número chegava a $66 \%$ do total de moradores. Esse relatório apresentava outros dados importantes, como a presença de pensionistas que somavam $14 \%$ da população do lugar e de $20 \%$ de pessoas que dependiam de salários provenientes da prestação de serviços, constituindo uma massa relativamente expressiva de assalariados. Os dados demonstravam já nesse ano o aumento da monetarização da economia local, conforme pode ser observado no quadro abaixo.

\section{Quadro 3 - Principal Fonte de Renda dos Moradores da Costa Oceânica de Ilhabela}

$\begin{array}{ccc}\text { Atividade } & \text { \% da População } & \text { População Total } \\ \text { Pesca } & 48 & 344 \\ \text { Pesca/ Artesanato } & 12 & 86 \\ \text { Aposentadoria } & 14 & 100 \\ \text { Serviços/Salaário } & 20 & 144 \\ \text { Pesca/Serviços } & 6 & 43 \\ \text { Total } & 100 \% & 717\end{array}$

Fonte: Diagnóstico Sócio-econômico e Ambiental, I.F., 1992.

Obs.: Costa Oceânica: Praias do Jabaquara, Fome, Serraria, Caveira, Guanxuma, Estácio, Castelhanos, Mansa, Vermelha, Figueira, Indaiatuba, Enchovas e Bonete; Sacos do Sombrio e da Toca; Ilhas de Búzios e Vitória.

O relatório apresenta, também, as atividades artesanais desenvolvidas pelos caiçaras, destacando a confecção de canoas e remos; menciona o artesanato turístico, mas não o individualiza para efeitos de composição da renda. Também não são mencionadas outras atividades artesanais usualmente remuneradas, como a confecção, reforma, entralhamento e corte de panagens de redes, principalmente aquelas voltadas aos aparelhos de cerco. 
Uma das razões para o sucesso da pesca na Baía dos Castelhanos e em toda a costa oceânica de Ilhabela se deve ao aumento expressivo do turismo e a conseqüente procura por pescado e frutos do mar à época da abertura da estrada e nos anos seguintes. Mas, se não houvesse um sistema de transporte adequado, esse demanda não teria sido acompanhada por um aumento no comércio e na oferta de peixes pelos pescadores locais.

Depois de verem-se isolados de Santos com o fim da cabotagem durante a década de 1960 e da nova estrada aberta em 1977 não ter contribuído com quase nada para o escoamento de suas mercadorias por via terrestre, os moradores da costa oceânica de Ilhabela encontraram na pesca e no transporte do pescado pelas canoas a motor uma forma de se inserirem novamente na economia de mercado. Um século depois da fase heróica vivida pelos produtores do Litoral Norte quando, por meio das canoas de voga, inscreveram seu principal produto, a pinga produzida nos engenhos movidos à roda d'água, na circulação geral de mercadorias, os caiçaras do lugar desenvolveram seu próprio sistema de transporte

Desde a primeira metade do século $X X$ as canoas a motor utilizadas no Litoral Norte eram conhecidas dos caiçaras de Ilhabela. Inicialmente, os motores eram a gasolina e pouco econômicos. Dependendo das distâncias a serem percorridas, poderia encarecer muito o custo da viagem. Mais recentemente, com motores a diesel, mais modernos e eficientes, o uso dessas embarcações foi bastante difundido, ampliando os horizontes da pesca na Baía dos Castelhanos. Os pescadores puderam explorar áreas mais distantes de suas moradias, em busca de águas mais piscosas para instalarem seus apetrechos de pesca, além de poderem praticar outras formas de pescaria. Outro aspecto importante refere-se à forma das canoas a motor utilizadas na costa oceânica de Ilhabela. Contrariando a preferência usual por canoas mais bojudas e estáveis, os artesãos locais dão a elas forma mais delgada e alongada para conseguir maior velocidade e economia de combustível. Sacrificam a estabilidade e a segurança, mas tornam-nas mais vantajosas para o transporte de mercadorias por distâncias maiores.

Atualmente, a pesca permanece como a única atividade mercantil desenvolvida pelos caiçaras na Baía dos Castelhanos. A roça de produção de 
alimentos e as demais atividades agrícolas, nos padrões em que eram praticadas há alguns anos, desapareceram, restando no espaço apenas poucas galinhas e patos criados soltos pelos quintais e algumas pequenas glebas plantadas com mandioca próximas às casas. Somente dois moradores, em 2007, informaram ainda produzirem farinha, mas em quantidade bem modesta.

A lavoura foi abandonada, mas não por falta de território ou por restrições legais impostas pela legislação ambiental, ainda que efetivamente essas limitações existam. A valorização do espaço promovida pelo turismo em Ilhabela permitiu que o produto peixe fresco ganhasse um preço que até a década de 1970 ele não tinha. Tal situação levou os caiçaras a se concentrarem e se especializarem nessa atividade, direcionando seus meios de captura para as espécies de melhor aceitação no mercado (lula, por exemplo), além de investirem seus capitais em mais e melhores equipamentos, de armazenamento e transporte do pescado para a cidade.

No passado, nos tempos da pesca no Saco do Sombrio, o pescador caiçara entregava seu peixe a um intermediário, um barco dotado de câmara fria com gelo picado de uma frota de algum empresário santista, que colocava esse peixe no mercado atacadista de Santos; depois esse peixe iria circular muito por estruturas intermediárias até chegar ao consumidor final, na baixada litorânea ou no planalto. Qualquer vantagem que os caiçaras obtivessem por pescar em águas mais piscosas era anulada pelos intermediários dessa extensa cadeia que se interpunha entre o produtor local e o consumidor final.

Atualmente, pescar em águas piscosas traz uma grande vantagem para - pescador artesanal caiçara que é dono dos meios de armazenamento e transporte. Por haver uma grande procura por peixe fresco e frutos do mar, para atender o movimento do turismo os caiçaras entregam regularmente a produção das espécies mais nobres diretamente para os bares e restaurantes da Praia dos Castelhanos, de Ilhabela e São Sebastião. 


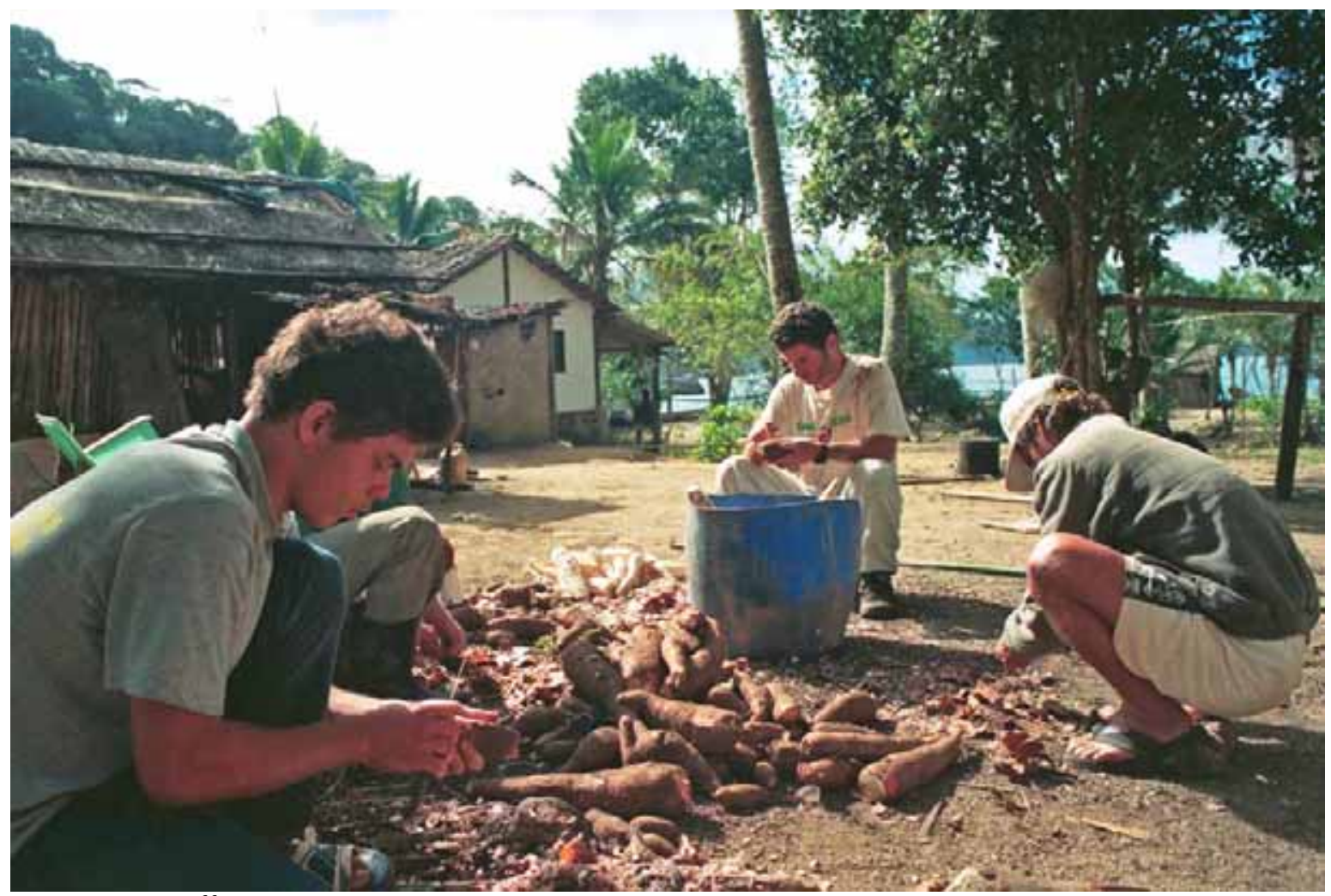

Foto 36. P. Noffs, 1997.

Os filhos de Da. Leopoldina descascam mandioca para o fabrico da farinha na Praia Vermelha em 1997. Seus parentes continuam fazendo a roça, mas a área cultivada sequer atende às necessidades domésticas, conforme se observa na foto de abril de 2007 abaixo e à esquerda. A capoeira em torno da gleba indica o abandono recente da lavoura. À direita, roça de mandioca no sertão da Praia Mansa, também em 1997, uma das últimas vezes que a área foi cultivada antes de ser abandonada.
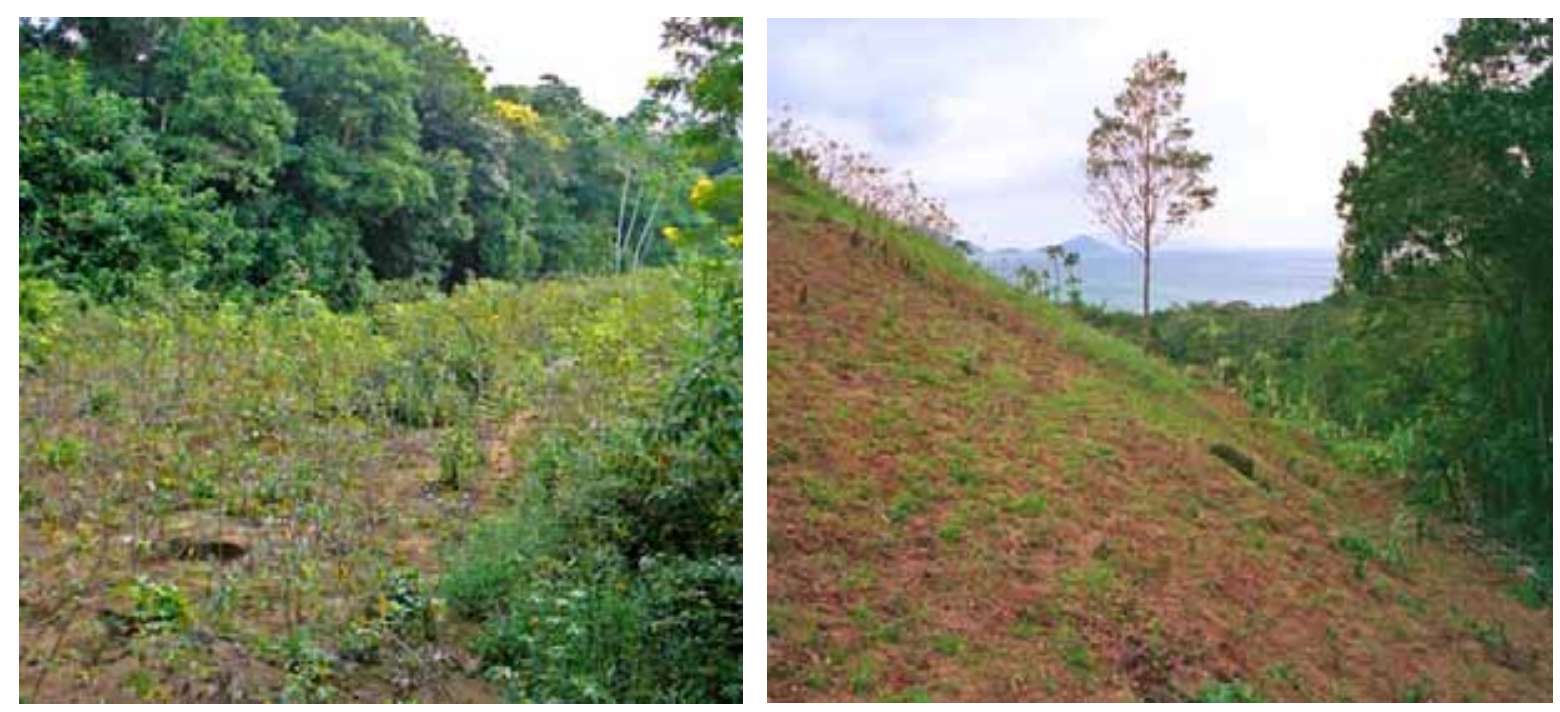

Foto 37 e 38. P. Noffs, 2007 e 1997. 
"Associado à atividade pesqueira, verifica-se, em algumas das comunidades um incipiente processo de acumulação de capital. O transporte do pescado desde há tempos encontra-se a cargo de pescadores proprietários de embarcações a motor. Antigamente, o transporte era realizado com base nas relações familiares e de vizinhança, não havendo qualquer cobrança pelo serviço; em seguida, passou-se a cobrar, em mercadoria (pescado), a realização do transporte. Atualmente, alguns pescadores adquirem o pescado daqueles que possuem canoas a remo, transformando-se nos primeiros intermediários na longa rede de intermediação existente entre os produtores e os consumidores. A viagem de entrega do pescado é aproveitada para a aquisição do gelo, elemento fundamental para a conservação da produção, posto que a maioria das praias não dispõe de energia elétrica. O controle sobre o gelo, além do acesso ao mercado representado pela canoa a motor, são fatores que contribuem para a estratificação social no interior da comunidade." (Maldonado, 2001: 98).

Tal dinâmica efetivamente ocorre e nos últimos anos tem se intensificado, porém não se trata de uma estratificação, mas de diferenciações sociais e econômicas que tendem a aumentar conforme a monetarização da economia local se amplia. Com o crescimento do turismo e a urbanização do Litoral Norte, especificamente em São Sebastião e Ilhabela, pode-se destacar que essas cidades abrigam durante $o$ ano todo um movimento firme de turistas, mesmo nos períodos de baixa temporada, criando assim uma demanda consistente por pescado fresco. As canoas a motor aproximaram desse mercado os caiçaras da costa oceânica de llhabela. O pescado entregue diretamente aos bares e restaurantes ou nas peixarias das cidades, torna-se competitivo em comparação ao de outras regiões do país e até do exterior, que apesar de capturado (ou produzido) em larga escala e com tecnologia mais moderna, tem de ser submetido a uma longa cadeia de intermediários até chegar a esses mesmos bares e restaurantes. Com isso, a pesca tem proporcionado um bom retorno aos capitais investidos, atraindo cada vez mais os moradores locais a sua prática.

A valorização do espaço da Baía dos Castelhanos é também resultado de sua condição de raridade. $O$ seu valor não tem relação com empreendimentos imobiliários ou com obras implementadas no passado. Até mesmo a ausência de infra-estrutura viária, de redes de distribuição de 
energia elétrica, de água e de esgoto não impediram esse espaço de se valorizar. A valorização decorre simplesmente do fato das suas singularidades - suas praias, enseadas, costeiras com piscinas naturais, rios com cachoeiras estarem bem preservadas, apresentarem beleza incomum e de se constituírem assim, em raridades no universo do Litoral Norte densamente urbanizado e dominado pelo turismo massificado. Simultaneamente, a valorização se completa com o desenvolvimento geral da sociedade e, em particular, das condições em que ocorreu a urbanização do Litoral Norte - rápido crescimento populacional, degradação da natureza, poluição, formação de favelas - que se encarrega de aproximar esse espaço raro, dotado de singularidades especiais, de um grupo cada vez maior de consumidores que não se importam em percorrer de jipe os $22 \mathrm{~km}$ de estrada de terra precária ou de contornar a ilha de São Sebastião em passeios de escuna programados pelos hotéis, agências de turismo e associações de jipeiros. A valorização do espaço na Baía dos Castelhanos pode favorecer os caiçaras de duas maneiras: os bares, restaurantes e campings que se instalaram na Praia dos Castelhanos para explorar o fluxo de turistas, compram peixe fresco e outros produtos diretamente no local; os caiçaras que são proprietários das terras onde moram também podem tirar proveito do valor do espaço, abrindo seu próprio negócio.

De todas as formas de pescaria praticadas na Baía dos Castelhanos, sem dúvida alguma a mais importante continua sendo a dos cercos flutuantes. Desde a entrada sul pela ponta da Pirassununga até a ponta da Cabeçuda ao norte, são 11 aparelhos de cerco instalados pelas costeiras da baía. Eles respondem pelo maior volume e variedade de espécies capturadas e, apesar de não haver estatísticas consistentes sobre o tema, as quantidades e valores comercializados seguramente constituem a base da economia da população caiçara do local. $O$ quadro $\mathrm{n}^{\circ} 4$ e o mapa $\mathrm{n}^{\circ} 8$ a seguir apresentam a relação dos cercos existentes, seus proprietários e a localização na Baía dos Castelhanos. 


\section{Quadro 4 - Relação dos Aparelhos de Cerco na Baía dos Castelhanos}

$\begin{array}{cc}\text { Ordem } & \text { Proprietário } \\ 1 & \text { Lauro } \\ 2 & \text { Cláudio / Daniel } \\ 3 & \text { Anízio } \\ 4 & \text { Pedro Madalena } \\ 5 & \text { Francelízio } \\ 6 & \text { Arlindo } \\ 7 & \text { Manoel } \\ 8 & \text { Elcio } \\ 9 & \text { Pedro } \\ 10 & \text { Gilmar } \\ 11 & \text { Rosário }\end{array}$

Local de Instalação

Laje Preta

Ponta da Lagoa

Laje do Crioulo

Próximo da Laje do Crioulo

Saco do Miranda

Costão da Figueira

Costão sul da Figueira

Ponta da Garoupa

Costeira norte do Sombrio

Saco do Sombrio

Ponta do Caraguatá
Local de Moradia do Dono

Canto da Lagoa

Canto da Lagoa

Praia Vermelha

Praia Vermelha

Saco do Miranda

Canto da Lagoa

Praia Vermelha

Saco do Sombrio

Saco do Sombrio

Saco do Sombrio

Fonte: Levantamento de campo, 2007.

Mapa 8 - Localização dos Aparelhos de Cerco na Baía dos Castelhanos

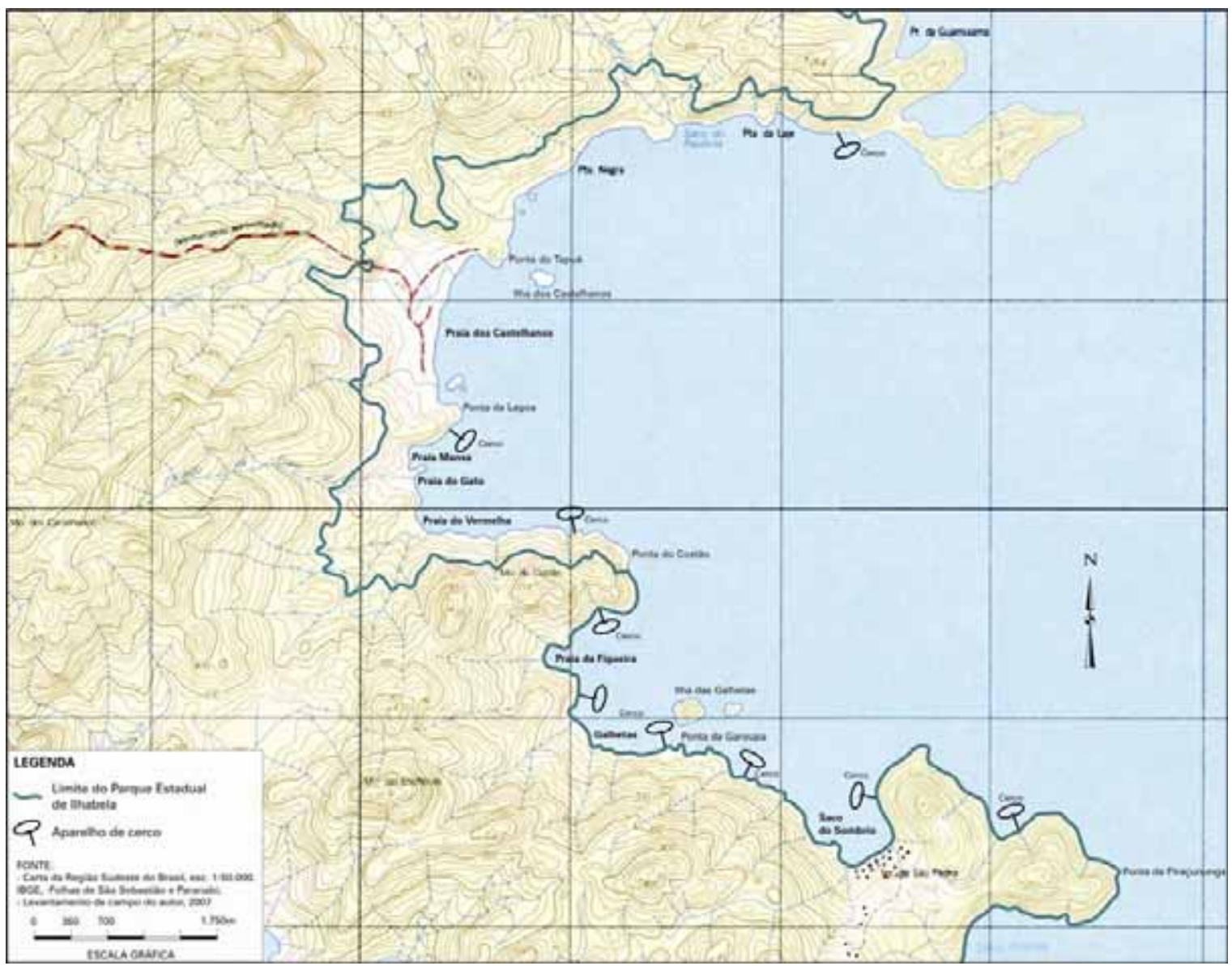


O pescador precisa de um capital relativamente grande para investir na pesca de cerco. Os cercos flutuantes são equipamentos artesanais de pesca complexos e um aparelho velho, completo, custa entre $R \$ 3.000,00$ e $R \$$ $5.000,00$. Para encomendar a um artesão a confecção de um aparelho novo completo, com todas as suas panagens, o pescador necessita dispor de cerca de $\mathrm{R} \$ 10.000,00$. Um cerco, novo ou velho, antes de ser instalado onde se vai pescar, precisa ser cortado (as suas panagens, inclusive as do caminho de cerco, precisam se adequar à profundidade do local e à distância da costeira) e o artesão irá cobrar cerca de $\mathrm{R} \$ 2.000,00$ a mais por esse serviço. Assim, se um pescador não dispuser de pelo menos $\mathrm{R} \$ 5.000,00$ de capital, quantia grande para os padrões locais, não poderá ser proprietário de cerco. (ver anexo, página xiv). Além disso, são necessárias duas canoas a remo para realizar duas ou três visitas diárias ao cerco para os serviços de despesca e, dependendo de onde o aparelho estiver instalado, o proprietário deverá ainda dispor de uma canoa a motor para rebocar as duas canoas a remo e transportar os quatro camaradas que trabalham na despesca.

Os proprietários de cerco realizam, em média, uma viagem de canoa a motor por semana à cidade, transportando entre 20 e $40 \mathrm{~kg}$ de pescado que é vendido para as peixarias de Ilhabela ou São Sebastião. Alguns entregam a produção para a cooperativa dos pescadores no Bairro São Francisco, município de São Sebastião, outras diretamente para bares e restaurantes. Obtém-se em média $R \$ 300,00$ por viagem, porém, chega-se a transportar 100 ou $200 \mathrm{~kg}$ de peixe em um só dia. Os preços variam de $R \$ 1,00$ / kg a $R \$ 10,00$ / kg. No verão, a lula atinge o preço de $R \$ 14,00 / \mathrm{kg}$, aumentando consideravelmente o movimento financeiro. Nos feriados, finais de semana e temporadas, os pescadores (todos eles, inclusive os que não são proprietários de cerco) entregam o pescado para os restaurantes e campings da praia. Peixe, camarão ou a lula são beneficiados antes pelos caiçaras, agregando valor à produção.

Praticamente todas as famílias caiçaras moradoras na Baía dos Castelhanos são proprietárias de embarcação a motor e algumas possuem também aparelhos de cerco. Todos os pescadores possuem pelo menos uma canoa a remo. 
Depois da pesca de cerco, o tresmalho (ou rede de emalhe ou simplesmente rede) é o tipo de pesca mais praticado no lugar. Os tresmalhos são redes mais simples e ficam armadas no fundo ou na superfície do mar, dependendo da espécie que se quer capturar, aprisionando-a em suas malhas. Constitui uma complementação à pesca de cerco e por ser uma rede simples, são confeccionadas pelos próprios pescadores, que aproveitam os dias de chuva para a tarefa. Ainda assim, existem pescadores que não possuem sequer um tresmalho. Nesse caso, resta a eles a pesca de linha com anzol, que também é praticada comercialmente na Baía dos Castelhanos. Procura-se capturar as espécies que vivem entre as pedras nas costeiras, lajes e parcéis, principalmente a garoupa, o badejo, o vermelho, o sargo e o pampo, que possuem boa aceitação no mercado.
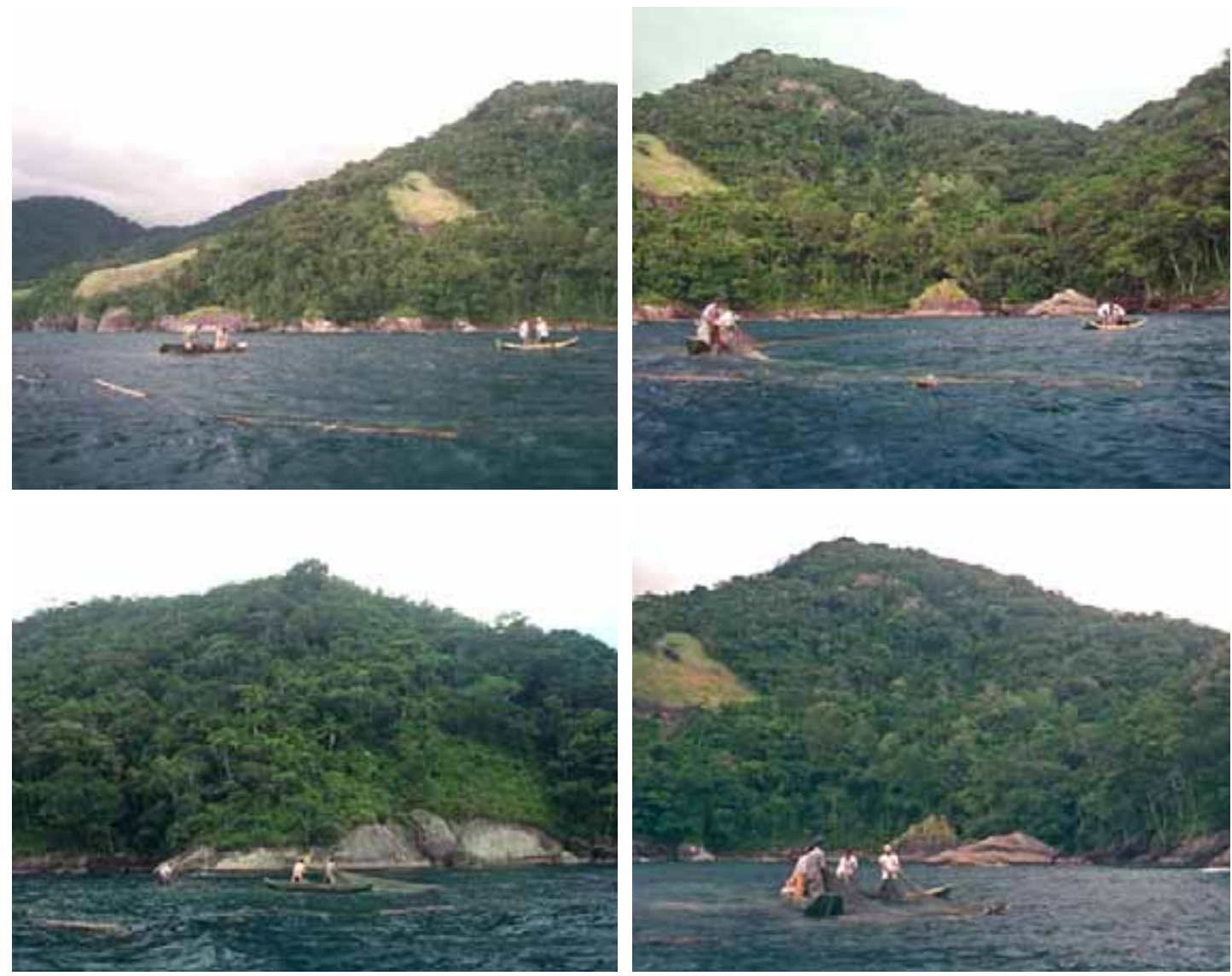

Fotos 39, 40, 41 e 42. P. Noffs, 1997. Pesca de cerco, a mais importante praticada na da Baía dos Castelhanos. As fotos ilustram a seqüência de uma visita ao aparelho do Arlindo, na costeira da Praia da Figueira, partindo da boca, por onde os peixes entram no cerco, até o copiador, onde é feita a despesca. 


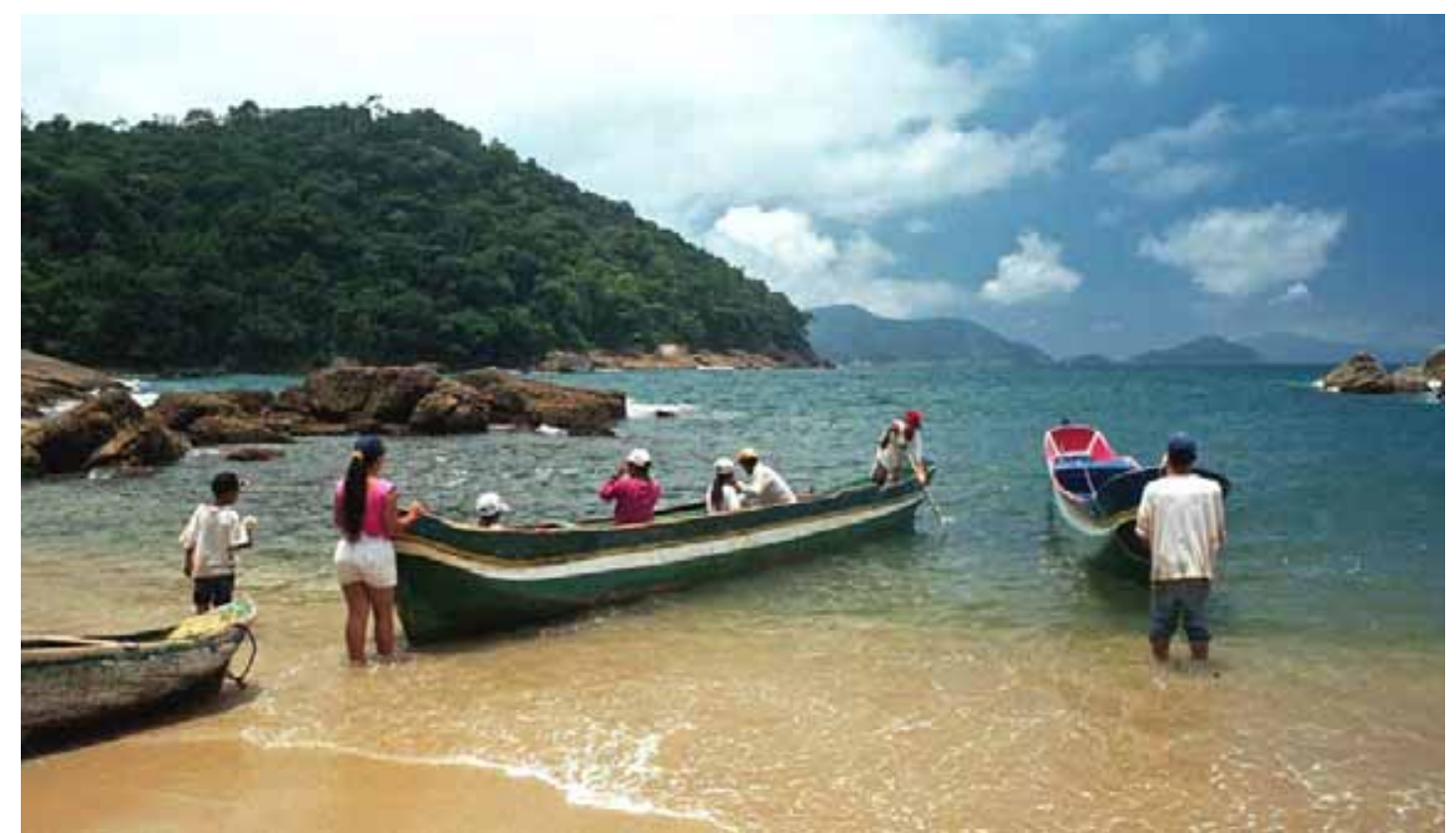

Foto 43. P. Noffs, 1997. Mulheres, crianças, todos vão pescar lula com auxílio de zangarelhos. De bom valor comercial, este molusco é um dos principais produtos da economia da Baía dos Castelhanos.

Merece ainda destaque a pesca da lula, também capturada com linha de mão, mas no lugar do anzol, emprega-se o zangarelho, conjunto de anzóis agrupados numa única peça.

\section{Quadro 5 - Frota de Embarcações na Baía dos Castelhanos}

$\begin{array}{cccccc} & \text { Rancho de Pesca } & \text { Canoa a motor } & \text { Canoa a remo } & \text { Barco ou batera } \\ \text { Canto do Ribeirão } & 0 & 0 & 6 & 0 \\ \text { Canto da Lagoa } & 3 & 5 & 20 & 0 \\ \text { Praia Mansa } & 1 & 6 & 12 & 1 \\ \text { Praia Vermelha } & 5 & 6 & 24 & 0 \\ \text { Praia da Figueira } & 0 & 2 & 3 & 1 \\ \text { Saco do Sombrio } & 1 & 2 & 10 & 3 \\ \text { Total } & 10 & 21 & 75 & 5\end{array}$

Fonte: Instituto Florestal, 2005, com atualização do autor em 2007.

Por falta de fornecimento público de energia elétrica na Baía dos Castelhanos, a questão do gelo torna-se problemática. Os pescadores que não possuem embarcação a motor são obrigados a entregar sua produção àqueles 
que dispõem dos meios de transportar e armazenar o gelo. O gelo é comprado picado na cidade por $\mathrm{R} \$ 3,00 / \mathrm{kg}$ e é transportado em sacos de 20 kg para a Baía dos Castelhanos, sendo que aproximadamente 1/3 do volume, nos dias mais quentes, é perdido durante a viagem. Os peixes são armazenados sob gelo picado em grandes caixas de isopor, aguardando o dia de transporte para a cidade.

As canoas a motor na Baía dos Castelhanos têm em média 8 metros de comprimento e uma capacidade de transporte de 1 tonelada. Uma canoa carregada consome em uma viagem de ida e volta da cidade cerca de 40 litros de óleo diesel, que custa para os caiçaras na cooperativa, $R \$ 2,20$ o litro.

Com a crise de fornecimento de energia elétrica provocada pela estiagem no ano de 2001, várias medidas governamentais foram tomadas na época para suprir a falta de energia, uma delas foi facilitar a importação de equipamentos de geração de eletricidade. Assim, pequenos geradores movidos a óleo diesel ficaram com preços acessíveis e se "popularizaram" na Baía dos Castelhanos. São empregados basicamente para iluminação e alimentação de televisores e aparelhos de som. Atualmente existem 5 geradores a diesel alimentando casas de caiçaras: 3 no Saco do Sombrio, alimentando 3 casas, 1 na Praia Vermelha alimentando 3 casas e 3 no Canto da Lagoa, alimentando cada um uma casa.

Na Praia Mansa existe uma câmara para refrigeração do pescado construída pelos moradores e pela prefeitura de Ilhabela. É alimentada por energia gerada hidraulicamente, da água captada do córrego local. O sistema também fornece energia hidrelétrica para iluminação de todas as casas da Praia Mansa, mas apenas algumas delas estão ligadas à Câmara Fria. A Câmara Fria é de uso comunitário e serve a todos os moradores da Baía dos Castelhanos, mas na prática, é utilizada apenas pelos moradores da Praia Mansa. Com a mesma finalidade de alimentar aparelhos de televisão e de som, muitos moradores usam baterias automotivas que carregam na cidade ou na Câmara Fria.

A escola e algumas casas de turistas da Praia Mansa são alimentadas por energia solar. Dos bares e campings da Praia dos Castelhanos, dois deles 
utilizam gerador a diesel, também para ligar lâmpadas e aparelhos de televisão e som.

O fortalecimento da pesca e do transporte pelas canoas a motor favoreceu o desenvolvimento de atividades correlatas. Algumas já foram mencionadas, como a confecção, reforma e adequação de panagens de rede de cerco. São serviços especializados, requerem experiência e são poucos os caiçaras habilitados para tais práticas. Os serviços mais simples de manutenção e consertos eventuais são executados pelos próprios donos dos cercos.

Outra tarefa do artesanato local é a construção das canoas, que envolve muitas etapas, desde a derrubada da árvore (atualmente, com as proibições impostas pela legislação ambiental, o DEPRN concede autorização apenas para utilização de árvores caídas naturalmente) no interior da mata, a execução dos primeiros desbastes e a escavação inicial, o transporte da canoa semipronta para a praia onde são realizados o desbaste até o acabamento final (sobre esse assunto, consultar Maldonado, 2001, que descreveu em profundidade todas as etapas na construção das canoas e seus significados para os caiçaras). As canoas que serão motorizadas requerem serviços de outros profissionais para assentar o motor, instalar o eixo transmissor e a hélice para a propulsão.

A presença significativa de canoas a motor e de outras embarcações que também trabalham com motor a óleo diesel, inclusive de geradores de energia, fez surgir a função do mecânico especializado em instalação, manutenção e conserto desses equipamentos, como é o caso do Reginaldo e do Ronaldo, moradores da Praia Mansa.

Aproveitando o movimento crescente de turistas em toda a Baía dos Castelhanos, muitos artesãos adaptaram suas habilidades à confecção de artesanatos de interesse turístico, destacando-se a produção miniaturas de embarcações típicas do lugar, algumas muitas bem elaboradas. Os principais artesãos se encontram nas praias Vermelha e Mansa, mas não existe estrutura alguma para divulgar e comercializar a produção dos artistas.

Outras atividades são desenvolvidas na Baía dos Castelhanos relacionadas direta ou indiretamente com 0 turismo e contribuem decisivamente para a monetarização da economia local, com destaque para os 
serviços públicos assalariados e as pensões do INSS, apresentadas na tabela a seguir.

\section{Quadro 6 - Empregados da Prefeitura e Pensionistas do INSS}

$\begin{array}{ccc} & \text { Pensionistas } & \text { Empregados da Prefeitura } \\ \text { Canto do Ribeirão } & 4 & 1 \\ \text { Canto da Lagoa } & 7 & 3 \\ \text { Praia Mansa } & 1 & 1 \\ \text { Praia Vermelha } & 3 & 0 \\ \text { Praia da Figueira } & 0 & 1 \\ \text { Saco do Sombrio } & 1 & 1 \\ \text { Total } & \mathbf{1 6} & \mathbf{7}\end{array}$

Fonte: Levantamento de campo, 2007.

Os empregados da prefeitura de Ilhabela são contratados basicamente para realizarem serviços de limpeza (varredura) das praias, exceto no Saco do Sombrio, onde o funcionário transporta (em sua própria embarcação com óleo fornecido pela prefeitura) as crianças do local e da Praia da Figueira para a escola da Praia Mansa, e no Canto da Lagoa que tem um funcionário contratado para fornecer a merenda que é servida às crianças das escolas da Praia Mansa e do Canto do Ribeirão. O lixo reciclável é recolhido nas praias e transportado para a cidade pelos próprios varredores em suas canoas, igualmente abastecidas com o óleo diesel fornecido pela prefeitura.

Completando o quadro dos trabalhos remunerados, alguns moradores prestam serviços em casas de turistas e nos bares e campings, inclusive naqueles de propriedade de caiçaras.

Na Praia dos Castelhanos (Canto do Ribeirão, Canto da Lagoa e Praia do Gato) existem 12 residências de turistas que esporadicamente recorrem aos moradores locais para a realização de serviços de capina de terreno, limpeza das casas etc. São contratados por dia ou por empreitada. Os nove estabelecimentos comerciais (bares/restaurantes e campings), igualmente recorrem aos caiçaras para auxiliar nos trabalhos de cozinha (basicamente para lavar louça e outros tarefas de limpeza) nos finais de semana prolongados e temporada. No Canto da Lagoa, três moradores caiçaras são 
empregados fixos e recebem por mês, dois para trabalharem como caseiros e um para realização de serviços gerais de capina e limpeza de terreno.

No Saco do Sombrio um único morador é contratado fixo como caseiro de três residências de turistas. Na Praia da Figueira são mais três pessoas que prestam serviços remunerados mensais fixos, totalizando assim, 7 pessoas em toda a Baía dos Castelhanos que são assalariados mensais.

$\mathrm{Na}$ Praia Vermelha ocorre uma situação especial. Os três chefes de família principais são empregados remunerados do Sr. Sérgio, proprietário de toda a praia, mas não são contratados para prestarem serviço ao empregador. Quando o Sr. Pedro Manoel de Souza vendeu a propriedade para o Sr. Mário Volkoff ficou estabelecido que o primeiro e todos os seus familiares poderiam continuar vivendo em suas casas. O comprador, um especulador de llhabela, a fim de garantir a posse futura da terra, contratou com carteira assinada, após a morte de Sr. Pedro, os seus três filhos para prestarem serviços em sua propriedade. O Sr. Mário Volcoff vendeu as terras para o Sr. Sérgio, que manteve o contrato de trabalho, também com a finalidade de garantir a posse da terra. Assim, existem três caiçaras assalariados na Praia Vermelha, mas que não prestam serviço algum para seu empregador. Considerando esses três, são dez os moradores que recebem salários mensais na Baía dos Castelhanos.

Também é importante destacar que há dez anos existia uma única casa de caiçara de alvenaria na Baía dos Castelhanos. Atualmente são cerca de 15 casas totalmente ou parcialmente construídas com esse material; grande parte dos moradores expressa a vontade de substituir suas residências de pau-apique por outras de bloco. 


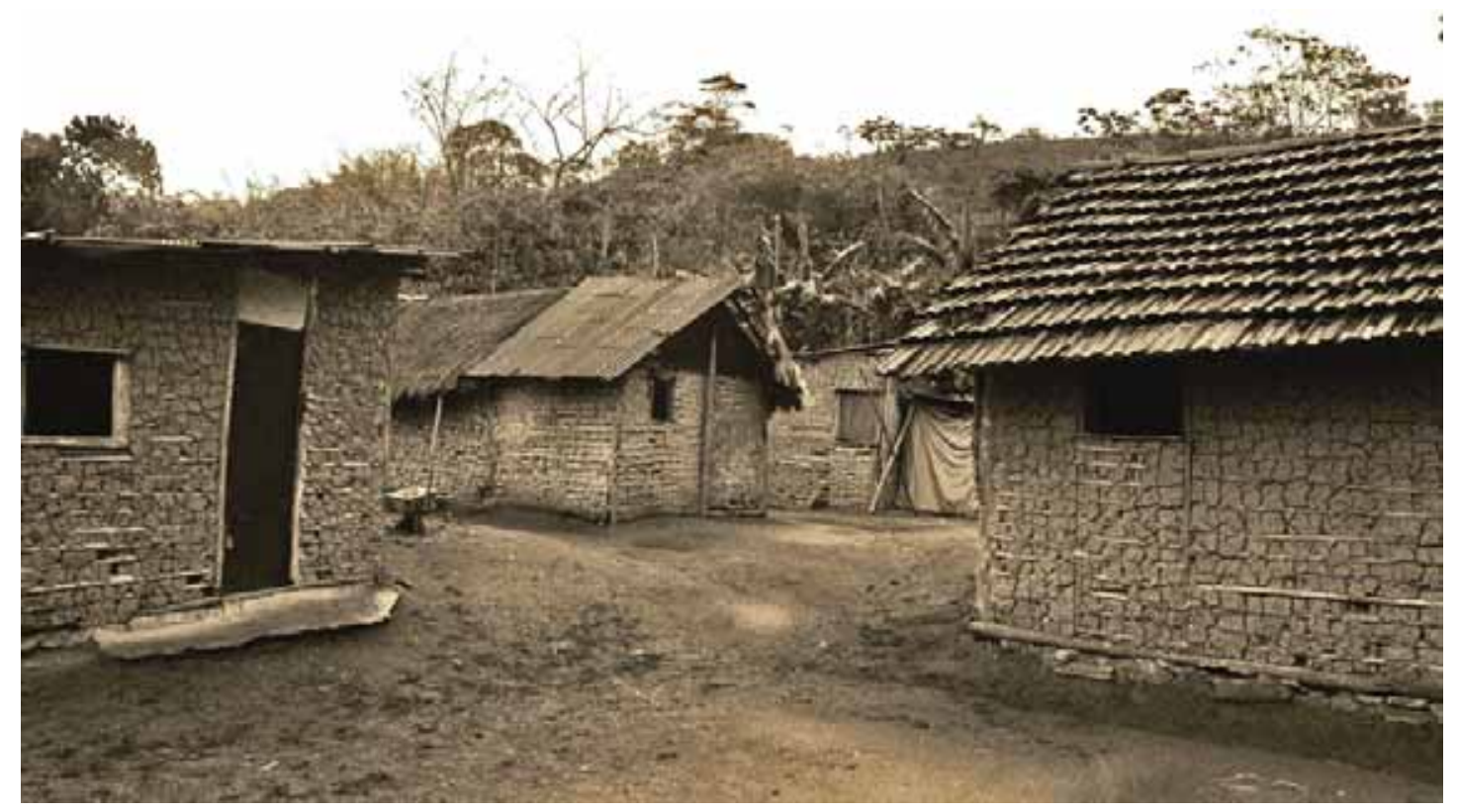

Foto 44 e 45. P. Noffs, 1996 e 2007. Há dez anos as casas eram de pau-a-pique, como essas no Canto da Lagoa. Atualmente o emprego da alvenaria é cada vez mais freqüente, tanto para novas casas, como para reformar as existentes.

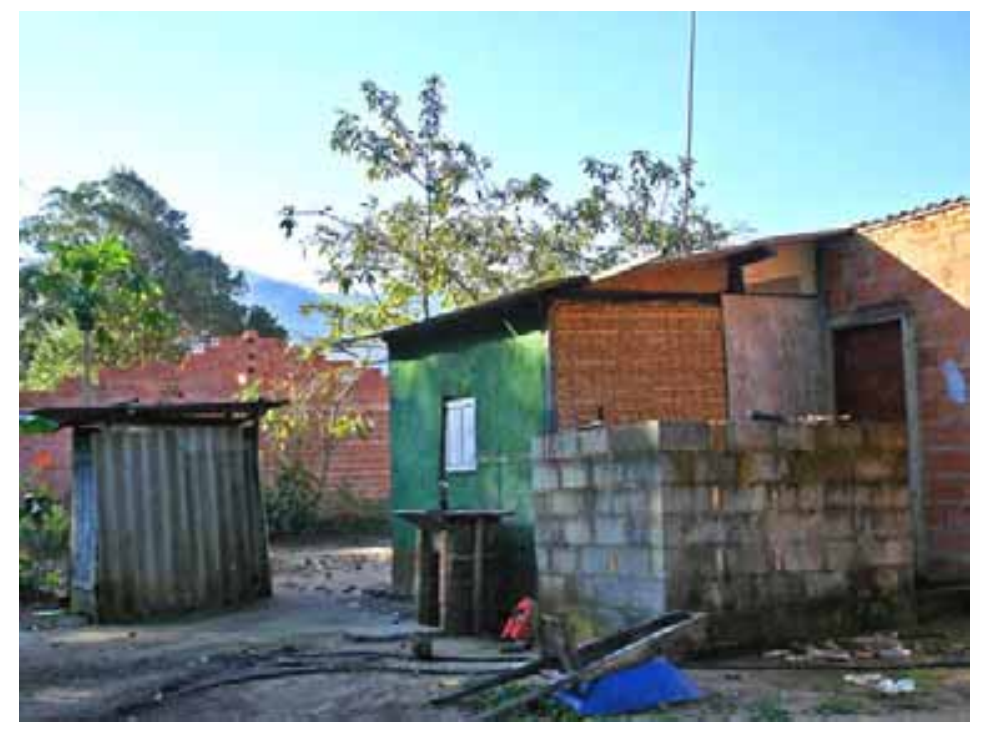

As casas de turistas, com algumas exceções, são todas de alvenaria e foram construídas com mão-de-obra contratada na cidade e que permaneceram no local apenas durante o período das obras. Ainda assim, alguns moradores, apenas três, declararam exercer a função de pedreiro e encanador e que prestam esses serviços para outros moradores caiçaras. $O$ quadro $\mathrm{n}^{\circ} 7$ a seguir, resume a situação das edificações existentes na Baía dos Castelhanos em 2007. 


\section{Quadro 7 - Edificações Existentes na Baía dos Castelhanos por Tipo de Uso}

\begin{tabular}{|c|c|c|c|c|c|c|c|}
\hline & $\begin{array}{l}\text { Canto da } \\
\text { Lagoa }\end{array}$ & $\begin{array}{l}\text { Canto do } \\
\text { Ribeirão }\end{array}$ & $\begin{array}{l}\text { Praia } \\
\text { Mansa }\end{array}$ & $\begin{array}{c}\text { Praia } \\
\text { Vermelha }\end{array}$ & $\begin{array}{l}\text { Praia da } \\
\text { Figueira }\end{array}$ & $\begin{array}{l}\text { Saco do } \\
\text { Sombrio }\end{array}$ & Total \\
\hline \multicolumn{8}{|l|}{ Edificação Residencial } \\
\hline Casa de caiçara & 16 & 9 & 8 & 0 & 1 & $7 *^{1}$ & 41 \\
\hline Casa de caiçara turista & 3 & 0 & 0 & 0 & 0 & 1 & 4 \\
\hline Casa de turista & $6^{*^{2}}$ & $6^{*^{3}}$ & 0 & 3 & 2 & $6^{*^{4}}$ & 23 \\
\hline Casa de turista c/ morador caiçara & 2 & 0 & 0 & 7 & 4 & 0 & 13 \\
\hline Casa de turista c/ caseiro & 0 & 0 & 0 & 1 & 0 & 1 & 2 \\
\hline Casa de turista comerciante & 4 & 1 & 0 & 0 & 0 & 0 & 5 \\
\hline \multicolumn{8}{|l|}{ Edificação Comercial } \\
\hline Estabelecimento caiçara & 3 & 0 & 0 & 0 & 0 & 0 & 3 \\
\hline Predominantemente Restaurante & 3 & 1 & 0 & 0 & 0 & 0 & 4 \\
\hline Predominantemente Camping & 2 & 0 & 0 & 0 & 0 & 0 & 2 \\
\hline late Clube & 0 & 0 & 0 & 0 & 0 & 1 & 1 \\
\hline \multicolumn{8}{|l|}{ Edificação Institucional } \\
\hline Escola & 0 & 1 & 1 & 0 & 0 & 0 & 2 \\
\hline Templo evangélico & 1 & 1 & 1 & 0 & 0 & 0 & 3 \\
\hline Ranchos de pesca & 3 & 0 & 1 & 5 & 0 & 1 & 10 \\
\hline \multicolumn{8}{|c|}{$\begin{array}{l}\text { Fonte: Levantamento de campo, } 2007 . \\
\text { Observções: } \\
\star^{1}-\text { - Uma casa de família caiçara localizada na Praia das Galhetas situada entre o Saco do Sombrio e a Praia } \\
\text { da Figueira. } \\
\star^{2} \text { - Casa inacabada onde fica o camping do Leo. } \\
\star^{3} \text { - Duas casas de turistas localizadas na Praia do Gato. } \\
\star^{4} \text { - Uma casa de turista localizada no Codó (ou Codói), próximo ao Saco do Sombrio. }\end{array}$} \\
\hline
\end{tabular}

\section{TURISTAS NA BAÍA DOS CASTELHANOS}

O movimento de turismo na Baía dos Castelhanos até o final da década de 1990 era reduzido. Ocorria apenas nos feriados e finais de semana dos meses de verão, quando a praia era procurada para passar o dia ou praticar camping selvagem. Nesse período, havia algumas poucas casas de turistas construídas, e apenas um único estabelecimento comercial para receber e explorar esse movimento sazonal de visitantes.

Entretanto, nos últimos 10 anos, as atividades de turismo se fortaleceram e começam a modificar o espaço. Três grandes fluxos principais de turistas podem ser percebidos: 
O primeiro, mais intenso, é formado pelos veículos com tração nas quatro rodas (jipes e utilitários) que utilizam a estrada de terra que atravessa o espigão para chegar a Praia dos Castelhanos. Esses veículos respondem pela massa de turistas que freqüenta as praias e enseadas da baía. A maior parte dos visitantes passa o dia na praia e retorna à cidade ao entardecer. Outros permanecem por mais tempo, abrigados em barracas instaladas nos campings existentes na Praia dos Castelhanos. O camping selvagem é proibido em toda a Baía dos Castelhanos por lei municipal, o que não impede muitos turistas de se instalarem em barracas próximos à barra do ribeirão dos Castelhanos.

Dos visitantes que chegam à Baía dos Castelhanos por via terrestre, parte utiliza seus próprios veículos, mas a maioria recorre à Associação dos Jipeiros de llhabela - grupo de proprietários de jipes e de outros veículos que se organizaram para explorar diversos roteiros turísticos em Ilhabela. Os grupos de visitantes podem ser organizados diretamente na associação ou por intermédio dos hotéis e agências de turismo em Ilhabela e São Sebastião. Os jipes transportam em média 6 pessoas por viagem, sendo quatro o número mínimo de passageiros. O preço cobrado é de $\mathrm{R} \$ 60,00$ em média por pessoa. Se os passageiros forem indicados pelos hotéis e agências de turismo, os primeiros ficam com $10 \%$ desse valor e os segundos com $20 \%$.

Os jipeiros atendem também aos moradores e comerciantes estabelecidos no local. Cobram cerca de $\mathrm{R} \$ 300,00$ para realizar uma viagem de ida e volta entre a Praia dos Castelhanos e o bairro do Perequê. Alguns caiçaras optam por esse serviço, apesar de poderem realizar a viagem de canoa a motor, que sairia muito mais barato, no entanto, mais demorada e menos confortável. Para os comerciantes, o frete dos jipes custa entre R\$ 200,00 e $\mathrm{R} \$ 250,00$, dependendo dos volumes a serem transportados, mais barato do que custa para os caiçaras, certamente por conta das refeições gratuitas que fazem nesses estabelecimentos.

Nos finais de semana normais, os jipes fazem em média 20 viagens. Nos feriados prolongados e finais de semana da alta temporada chegam a realizar 50 viagens por dia. Depois das canoas a motor, os jipes são o meio de transporte de passageiros e mercadorias mais importante entre a Baía dos Castelhanos e a cidade de llhabela. 
Outro fluxo de turistas importante é constituído por pessoas que chegam na Baía dos Castelhanos por embarcações, tanto em passeios organizados pelos hotéis e agências de turismo, como em lanchas ou veleiros próprios. Esses turistas exploram preferencialmente outros destinos dentro da Baía dos Castelhanos e na costa oceânica de Ilhabela.

Passeios de lancha organizados por uma agência de turismo para a Praia dos Castelhanos são oferecidos nas seguintes condições:

\section{"Praia de Castelhanos}

Localizada a leste de Ilhabela, com acesso de lancha, tem uma extensão de aproximadamente $1.500 \mathrm{~m}$, onde se localiza uma lagoa de águas cristalinas, existe também um acesso para a Cachoeira do Gato com uma caminhada de $40 \mathrm{~min}$. Onde se desvendará no meio da mata uma queda d'água de $80 \mathrm{~m}$ de altura. Cerca de 15 famílias de pescadores habitam o local. Navegam com uma lancha se dirigindo a mesma praia, passando por varias praias semidesertas e ilhas.

Embarque: 09:00hs

Retorno: 18:00hs

Preço: $R \$ 120,00$ /pessoa" (Extraído de www.maremar.tur.br/portugues)

Outra agência oferece uma variação desse passeio, incluindo um trecho por terra:

\section{"Praia de Castelhanos:}

Localizada a leste de Ilhabela, com acesso somente feito de $4 \times 4$ (off-road) ou barco, tem uma extensão de aproximadamente 1.500 mts, onde se localiza uma lagoa de águas cristalinas. Cerca de 15 famílias de pescadores habitam o local. Existe também um acesso para a Cachoeira do Gato com uma caminhada de 40 minutos, até onde se desvenda no meio da mata uma queda d'água de $50 \mathrm{mts}$ de altura.

Para grupos de 12 pessoas. Seis partem em Land Rover, atravessando a Mata Atlântica em uma estrada regada por cachoeiras e flora tropical, enquanto as outras seis pessoas navegam com uma lancha se dirigindo a mesma praia, parando em praias semi desertas com lagos refrescantes e cachoeiras. Chegando ao destino são trocados os passageiros da lancha com os do Land Rover para a viagem de retorno.

SAÍDA: 9:00 hrs

RETORNO: 18:00 hrs

PREÇO: R\$ 140,00/pessoa." (Extraído de www.itapemar.com.br/toursemilhabela.htm) 


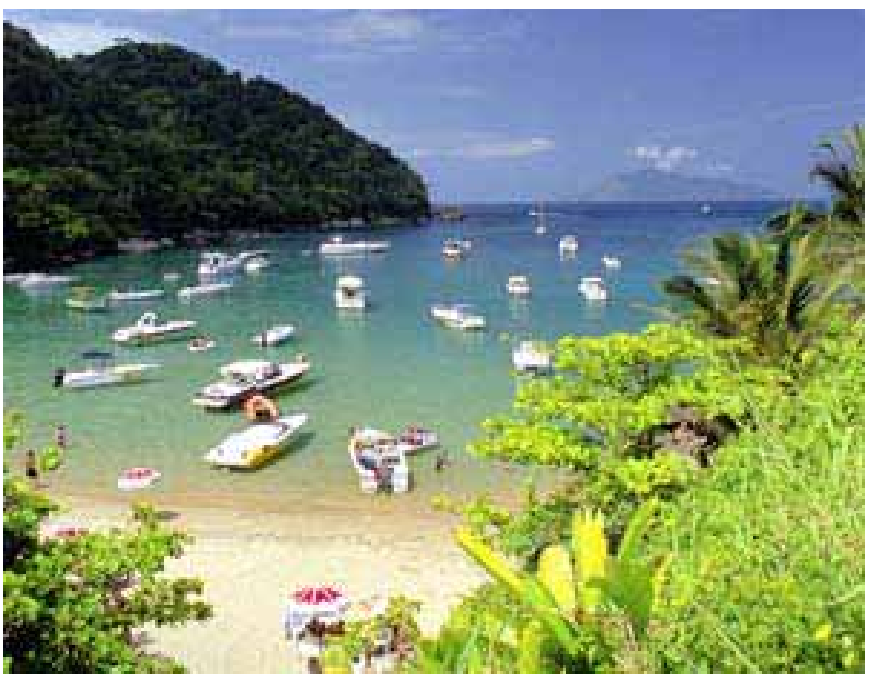

Foto 46. www. ilhabela.net/praias) Saco do Eustáquio na ponta da Cabeçuda, entrada norte da Baía dos Castelhanos, um dos destinos preferidos das embarcações turísticas.

Para receber todo esse movimento turístico, existem apenas nove estabelecimentos comerciais na Praia dos Castelhanos (Há também o late Clube de Ilhabela no Saco do Sombrio, que atende apenas a seus associados, apesar de estar localizado no interior do PElb). Apenas três deles são estabelecimentos de caiçaras, os demais, portanto, de turistas. Dos seis estabelecimentos de turistas, quatro são predominantemente restaurante/bar e dois predominantemente camping. O camping do Leo é administrado pelo Sr. Leosino, caiçara nascido no Canto do Ribeirão, mas é empregado do proprietário do terreno. Dos estabelecimentos caiçaras, dois são predominantemente restaurante / bar, sendo que o restaurante Castelhanos, o de maior movimento, atende a população local funcionando como bar e pequeno armazém. O restaurante da Laureana é efetivamente o único camping de quintal existente na Baía dos Castelhanos a que se refere o Plano Diretor do Município. Como o Restaurante Castelhanos, procura também servir aos moradores locais. 

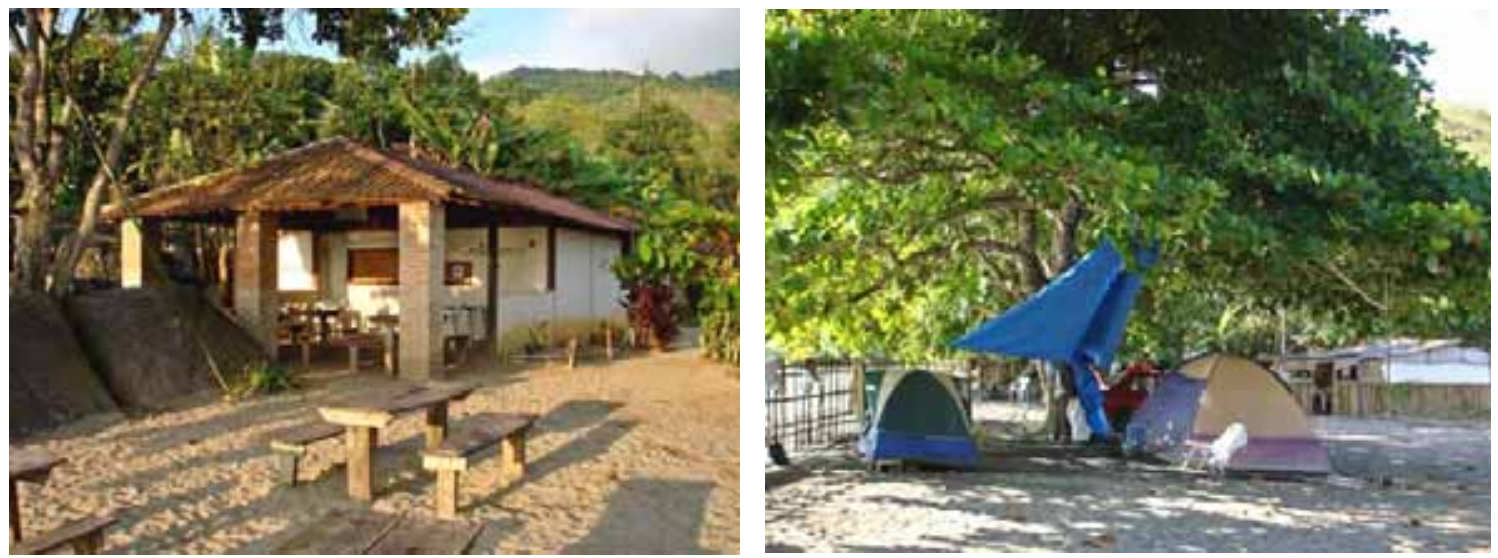

Foto 47 e 48. P. Noffs, 2007. Restaurante Castelhanos, da Vivian e Arlindo, atende a turistas e à população local. À direita, restaurante da Laureana, o único estabelecimento caiçara que efetivamente funciona como camping de praia.

Os movimentos de dinheiro mais expressivos são realizados pelos Marebar, Quiosque do Alemão e Bar Castelhanos, no Canto da Lagoa, e pelo Restaurante do Fernando, no Canto do Ribeirão. O Camping do Léo é o que recebe maior número de campistas, abrigando na alta temporada entre 20 e 30 barracas nos finais de semana. Em feriados prolongados recebe mais de 50 barracas.

Os campings e restaurantes / bares se abastecem de mercadorias nos supermercados de São Sebastião e Ilhabela e utilizam os serviços dos jipeiros, com exceção do Restaurante Castelhanos que transporta suas mercadorias por canoa a motor própria. Todo pescado servido nos estabelecimentos comerciais é adquirido dos pescadores locais. O peixe, o camarão e a lula são entregues limpos e prontos para irem à cozinha. Os restaurantes pagam aos pescadores preços bem mais vantajosos do que as peixarias da cidade. O quilo do peixe espada limpo e cortado em filés é vendido por $R \$ 8,00$ enquanto na cidade é entregue bruto por $\mathrm{R} \$ 1,00$. Cada restaurante compra na baixa temporada entre $R \$ 400,00$ e $R \$ 600,00$ de pescado dos caiçaras por mês. Na alta temporada, esses valores ascendem para $\mathrm{R} \$ 2.000,00$ a $\mathrm{R} \$ 3.000,00$ por mês.

O fluxo de turistas em um fim de semana comum de sol varia entre 100 e 200 pessoas. Nos feriados prolongados e finais de semana da alta temporada, somente a Praia dos Castelhanos chega a receber mais de 1.500 pessoas em um único dia. 

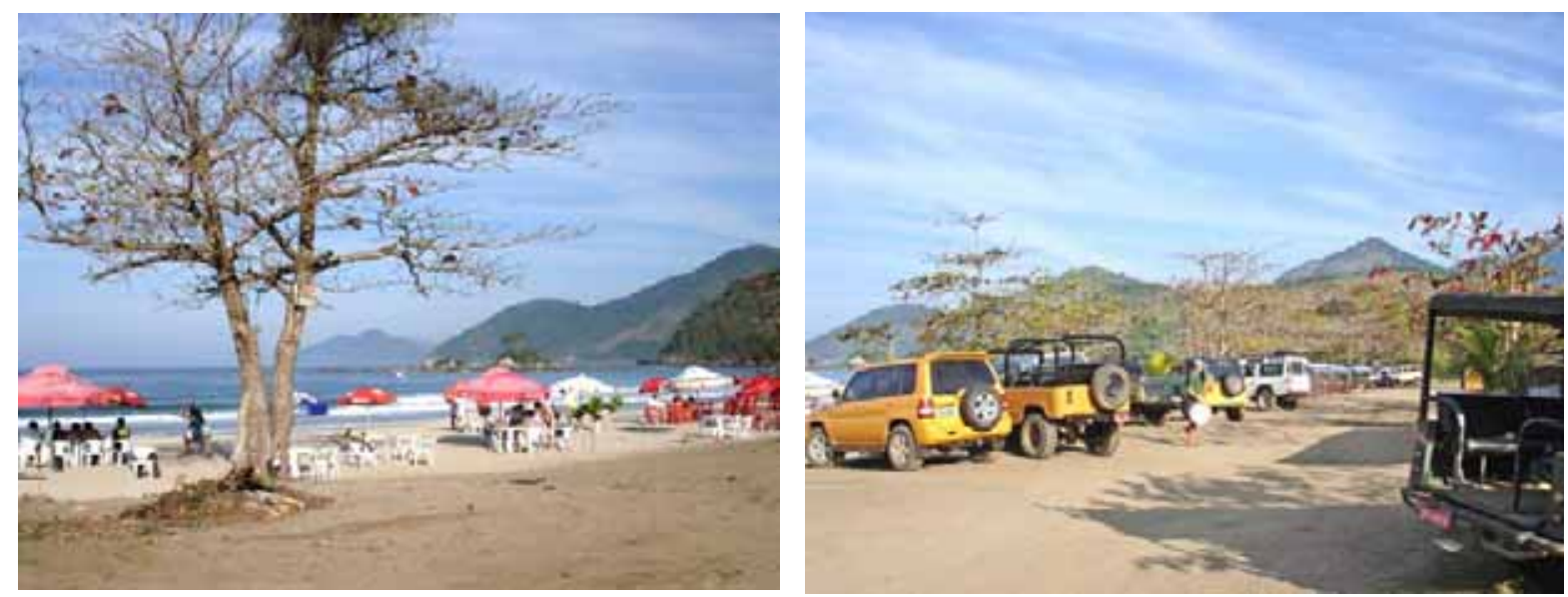

Foto 49 e 50. P. Noffs, 2007. Turistas e os veículos 4 X 4 no Canto da Lagoa, Praia dos Castelhanos, em um final de semana da baixa temporada.

Um terceiro fluxo de turistas que se dirige à Baía dos Castelhanos é constituído pelos proprietários de imóveis. Preferencialmente, essas pessoas se deslocam por terra, considerando que a maior parte das casas de turistas está localizada na Praia dos Castelhanos. Os que se dirigem às Praias Vermelha e da Figueira e ao Saco do Sombrio utilizam-se de embarcações próprias. A Praia Vermelha tem um único proprietário e quatro edificações construídas, além da residência do caseiro (ver anexo - Cadastro das Famílias Caiçaras, das Casas de Turistas e das Atividades Comerciais na Baía dos Castelhanos, informações sobre a Praia da Figueira, Codó e Saco do Sombrio). No Canto da Lagoa, as casas de turistas estão construídas em lotes de 13 metros de frente por 30 metros de fundo do loteamento Vila Reale, que, estranhamente, tanto a prefeitura quanto o DEPRN autorizam as edificações, contrariando a legislação ambiental e o plano diretor municipal. No Canto do Ribeirão as casas de turistas foram todas construídas em terrenos comprados dos caiçaras e algumas delas aproveitaram as edificações originais. Existem ainda duas casas de turistas construídas no caminho para a Praia do Gato, cujos proprietários procuram dificultar seu acesso aos visitantes. Esse é o procedimento também de todos os grandes proprietários de imóveis em toda a Baía dos Castelhanos, que procuram por todos os meios exercer o monopólio de acesso às praias onde têm suas propriedades. O Quadro 7 Edificações Existentes na Baía dos Castelhanos por Tipo de Uso, na página 127 e os mapas 9, 10, 11, 12 e 13 apresentam as edificações existentes na Baía dos 
Castelhanos e suas localizações. No Anexo - Cadastro das Famílias Caiçaras, das Casas de Turistas e das Atividades Comerciais na Baía dos Castelhanos encontram-se informações mais detalhadas sobre o mesmo tema.

Como já foi comentado, os estabelecimentos comerciais e os turistas proprietários de segundas residências, empregam muito pouco a mão-de-obra local e assim mesmo para a realização de serviços simples e braçais.

O dinheiro que circula pela Baía dos Castelhano, fruto do fluxo expressivo semanal de turistas, é apropriado quase que integralmente pelas agências de turismo e hotéis de llhabela e São Sebastião, pelos jipeiros e pelos bares, restaurantes e campings instalados na Praia dos Castelhanos. Uma diminuta fração desse dinheiro fica com os fornecedores de peixe e com os pequenos comerciantes caiçaras. Uma fração ainda menor, quase invisível, paga a mão-de-obra "desqualificada" que presta serviços para os consumidores e vendedores da mercadoria natureza. Talvez sobre algum dinheiro para o artesão que vendeu uma gamela ou uma miniatura de barco a motor.

A população atual da Baía dos Castelhanos é constituída de 209 pessoas, sendo que 187 são caiçaras e as demais, trabalhadores e comerciantes ligados às atividades de turismo. Em 2005, eram 187 os moradores do lugar e em 1992, somavam apenas 153 pessoas. Entretanto, em 1951, primeiro ano que se tem informação sobre a população total da Baía dos Castelhanos, moravam 550 pessoas no lugar. Sabe-se que em 1932, apenas no Saco do Sombrio os moradores eram em número de 500. Esses dados revelam que a produção mercantil simples enquanto esteve articulada ao mercado de Santos pelos barcos a motor, sustentou um contingente populacional mais expressivo. Com o fim do transporte marítimo entre Santos e o Litoral Norte, uma parcela significativa da população abandonou a Baía dos Castelhanos em busca de melhores condições de trabalho nas cidades de Ilhabela, São Sebastião, Santos e outras. A população local somente voltou a crescer com o restabelecimento dos meios de transporte com o mercado urbano de llhabela e São Sebastião, pelas canoas a motor e jipes, e com a consolidação das atividades de turismo, conforme pode ser observado no quadro a seguir. 
Quadro 8 - Evolução da População na Baía dos Castelhanos

$\begin{array}{lcccccc}\text { ANO } & \begin{array}{c}\text { Praia dos } \\ \text { Castelhanos }\end{array} & \begin{array}{c}\text { Praia } \\ \text { Mansa }\end{array} & \begin{array}{c}\text { Praia } \\ \text { Vermelha }\end{array} & \begin{array}{c}\text { Praia da } \\ \text { Figueira }\end{array} & \begin{array}{c}\text { Saco do } \\ \text { Sombrio }\end{array} & \text { Total } \\ 1932 & * & * & * & * & 500 & * \\ 1951 & 165 & * & * & * & 132 & 550 \\ 1960 & * & * & * & * & 112 & * \\ 1992 & 55 & 13 & 30 & 18 & 37 & 153 \\ 2002 & 84 & 13 & 24 & 18 & 25 & 164 \\ 2007 & 115 & 26 & 27 & 20 & 21 & 209\end{array}$

* Sem informação

Fonte: Anos de 1932 e 1951: França, 1954. Ano de 1960: Mussolini, 1980. Ano de 1992: Ilhabela, Diagnóstico Sócio-econômico e Ambiental - Instituto Florestal, 1992. Ano de 2002: Atualização de Ilhabela, Diagnóstico Sócioeconômico e Ambiental, Pirró, 2002. Ano de 2005: Subsídios para o Plano de Manejo do PElb, I.F., 2005. Ano de 2007: levantamento de campo do autor.

A Praia dos Castelhanos por receber o maior fluxo de turistas e concentrar a atividade pesqueira, mostra um crescimento populacional vigoroso e consistente a partir de 1992, inclusive abrigando um contingente já considerável de comerciantes e empregados no comércio. São 15 novas pessoas que vieram de outros lugares para trabalhar no local e representam $13 \%$ do total de moradores da praia e $7 \%$ da baía (quadro $n^{\circ} 9$ ).

\section{Quadro 9 - População da Baía dos Castelhanos por Segmento em 2007}

$\begin{array}{cccccccc}\text { População Residente } & \begin{array}{c}\text { Canto da } \\ \text { Lagoa }\end{array} & \begin{array}{c}\text { Canto do } \\ \text { Ribeirão }\end{array} & \begin{array}{c}\text { Praia } \\ \text { Mansa }\end{array} & \begin{array}{c}\text { Praia } \\ \text { Vermelha }\end{array} & \begin{array}{c}\text { Praia da } \\ \text { Figueira }\end{array} & \begin{array}{c}\text { Saco do } \\ \text { Sombrio }\end{array} & \begin{array}{c}\text { Total } \\ \text { Caiçara }\end{array} \\ \text { Institucional } & 61 & 38 & 25 & 25 & 20 & 18 & \mathbf{1 8 7} \\ \text { Turista proprietário comercial } & 0 & 1 & 1 & 0 & 0 & 0 & \mathbf{2} \\ \text { Empregado de Turista } & 5 & 3 & 0 & 0 & 0 & 0 & \mathbf{1 0} \\ \text { Total } & 5 & 0 & 0 & 2 & 0 & 3 & \mathbf{8} \\ & \mathbf{7 3} & \mathbf{4 2} & \mathbf{2 6} & \mathbf{2 7} & \mathbf{2 0} & \mathbf{2 1} & \mathbf{2 0 9}\end{array}$

Fonte: Levantamento de campo de 2007

A Praia Mansa dobrou sua população nos últimos 3 anos em conseqüência do número elevado de nascimentos no período e do retorno de uma família ao local. As praias Vermelha e da Figueira apresentam crescimento vegetativo nos últimos anos e também refletem um pouco da mobilidade interna dos moradores da baía, que em função dos casamentos, ora faz com que uma praia perca população, ora ganhe. De um modo geral, nos casamentos recentes, se um dos parceiros for morador da Praia dos 
Castelhanos, há a tendência do casal optar por morar nessa praia devido a maior oferta de trabalho e do seu maior dinamismo.

O Saco do Sombrio evidentemente foi o lugar que mais perdeu com o fim do comércio marítimo entre o Litoral Norte e a cidade de Santos. Viu sua população minguar ano após ano, até chegar nos atuais 21 moradores, sendo 18 caiçaras. Seus estabelecimentos comerciais foram fechando conforme sua importância pesqueira diminuía. A igreja de São Pedro, único templo católico existente na Baía dos Castelhanos, foi abandonada e ruiu, mesmo destino que teve o prédio da escola. A marinha deixou de operar no local e cedeu suas instalações para o late Clube de Ilhabela, que as utiliza de forma privativa. Os prédios grandes e feios, pintados de cinza escuro, impõem-se sobre a paisagem, deixando claro que o novo espaço da Baía dos Castelhanos não tem mais nada a ver com a produção mercantil simples de alimentos.

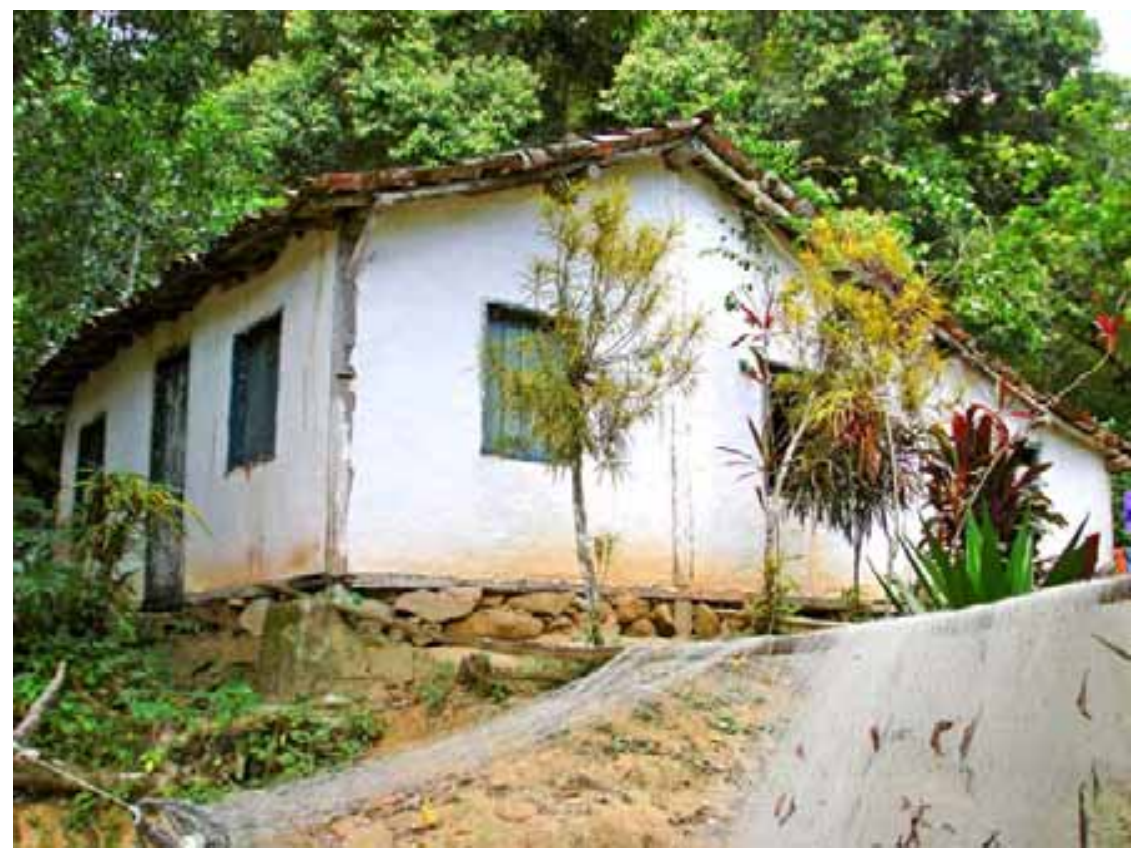

Foto 47. P. Noffs, 2007. Restou pouca coisa dos tempos antigos no Saco do Sombrio 


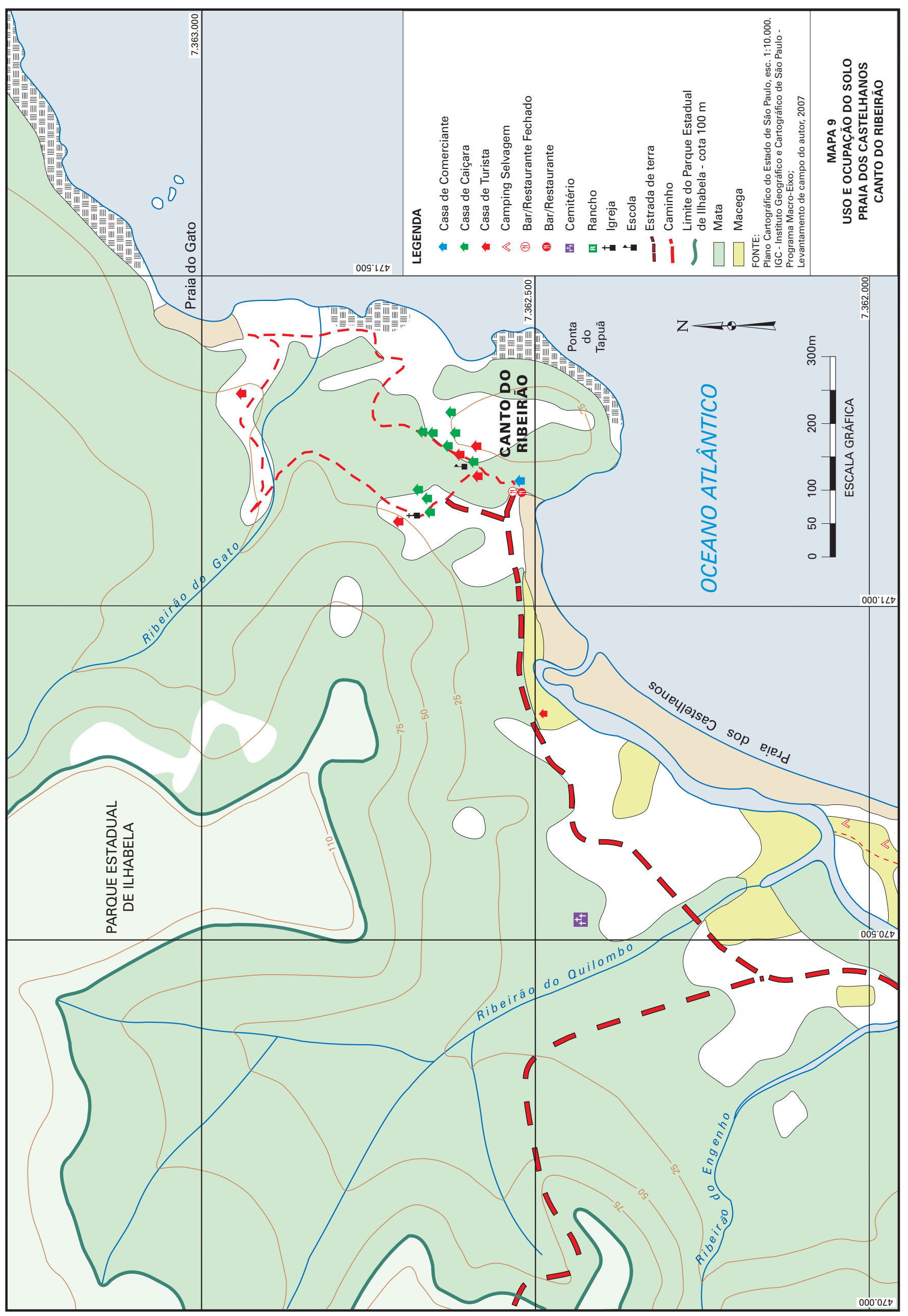




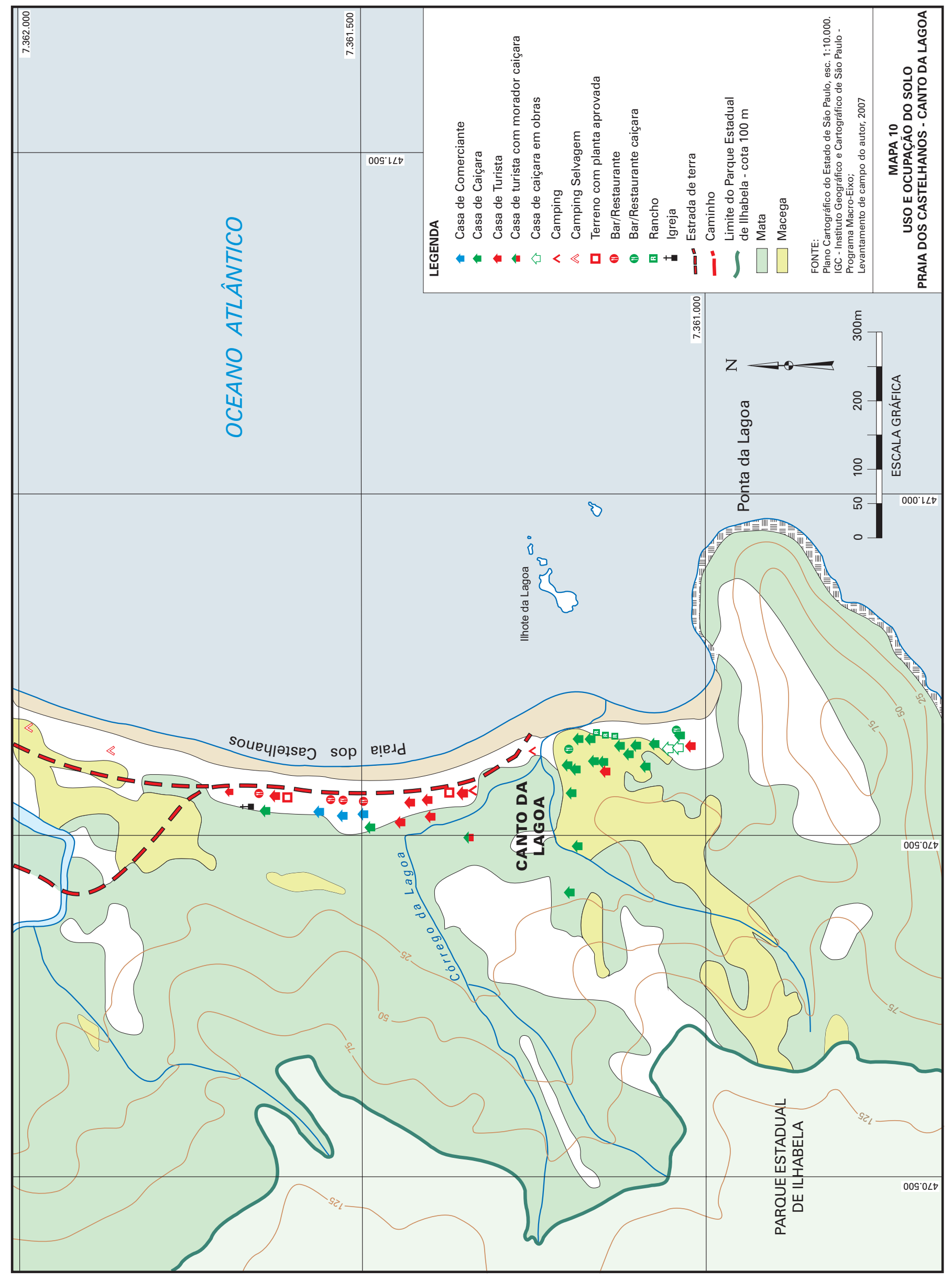




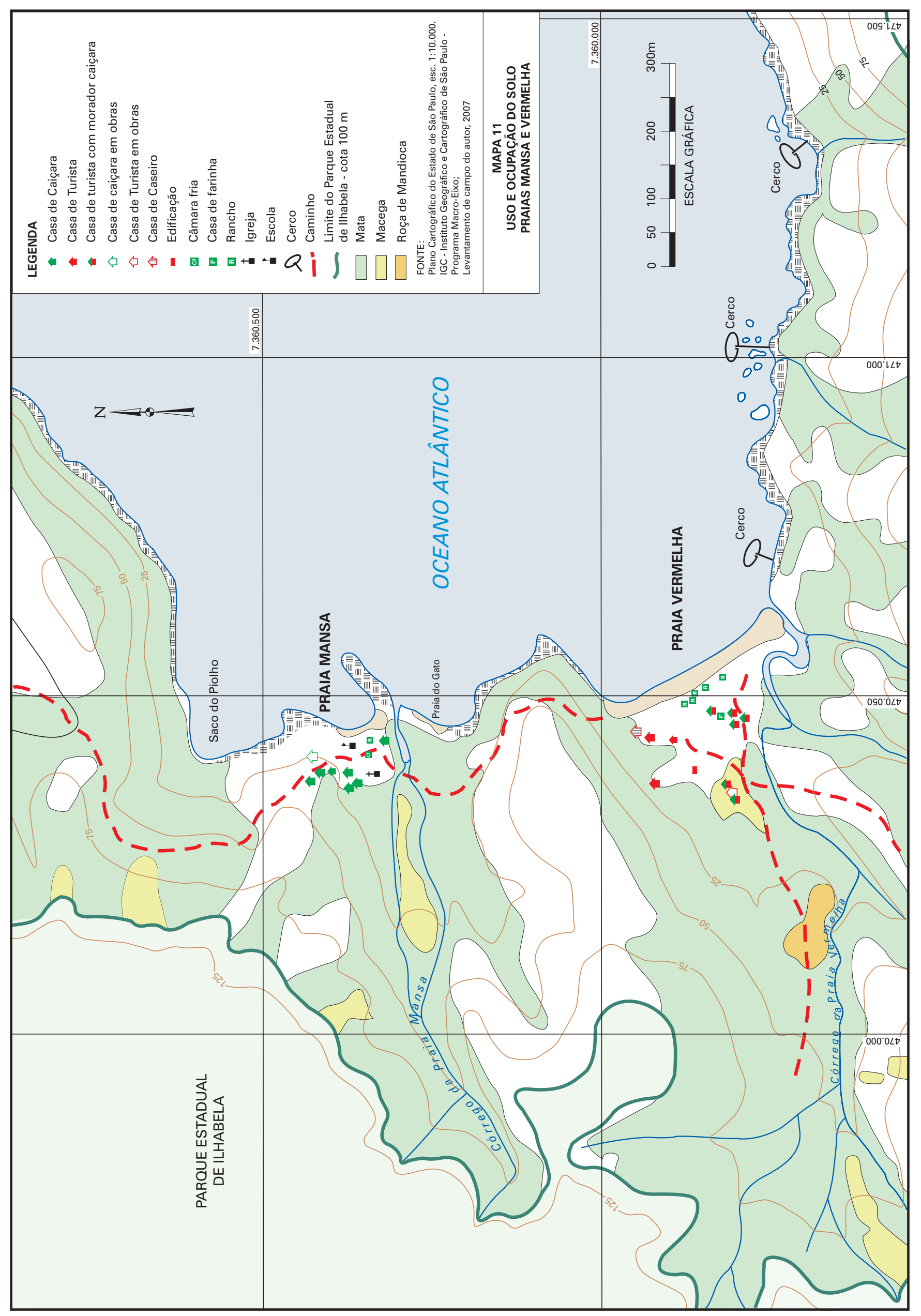




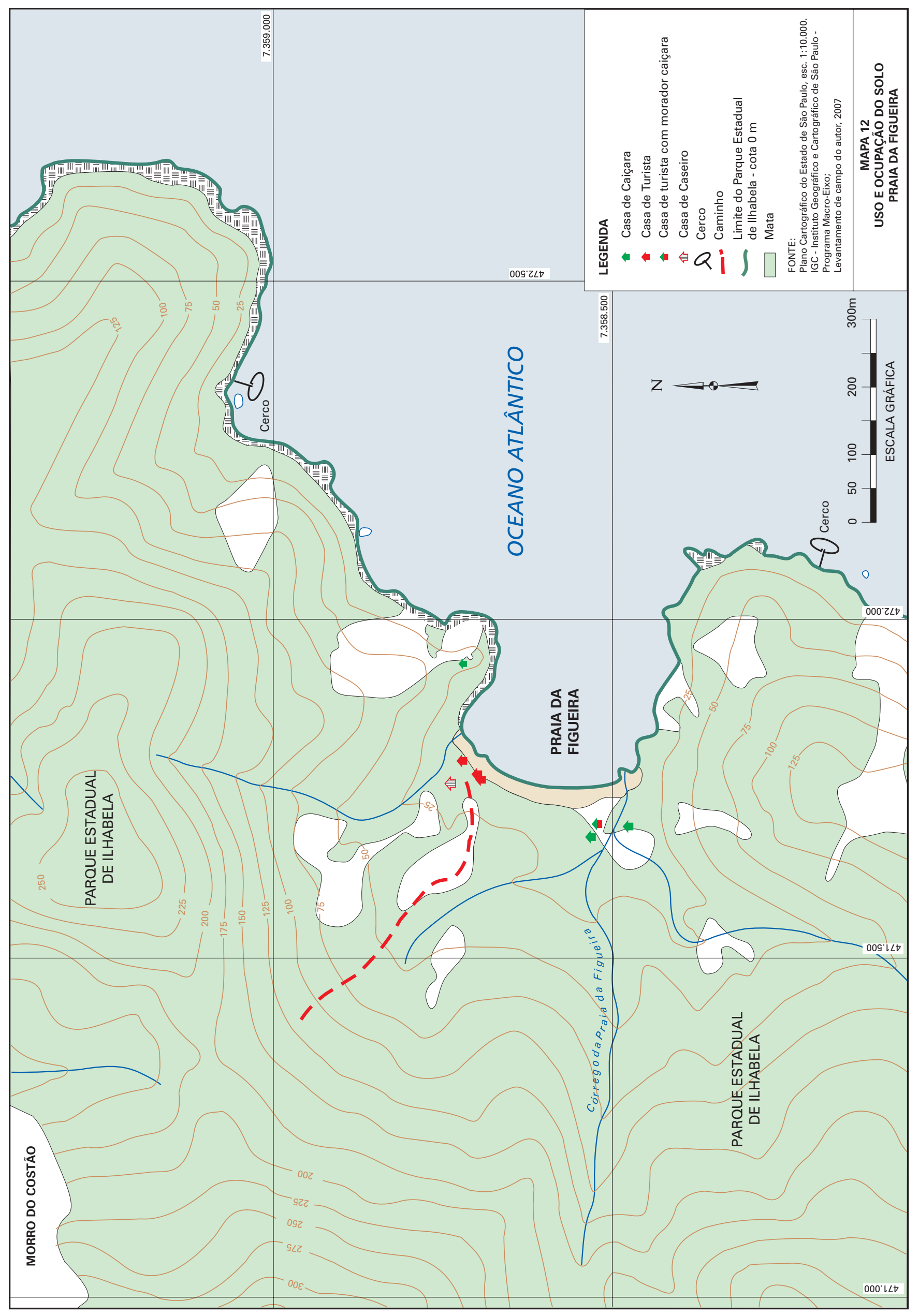




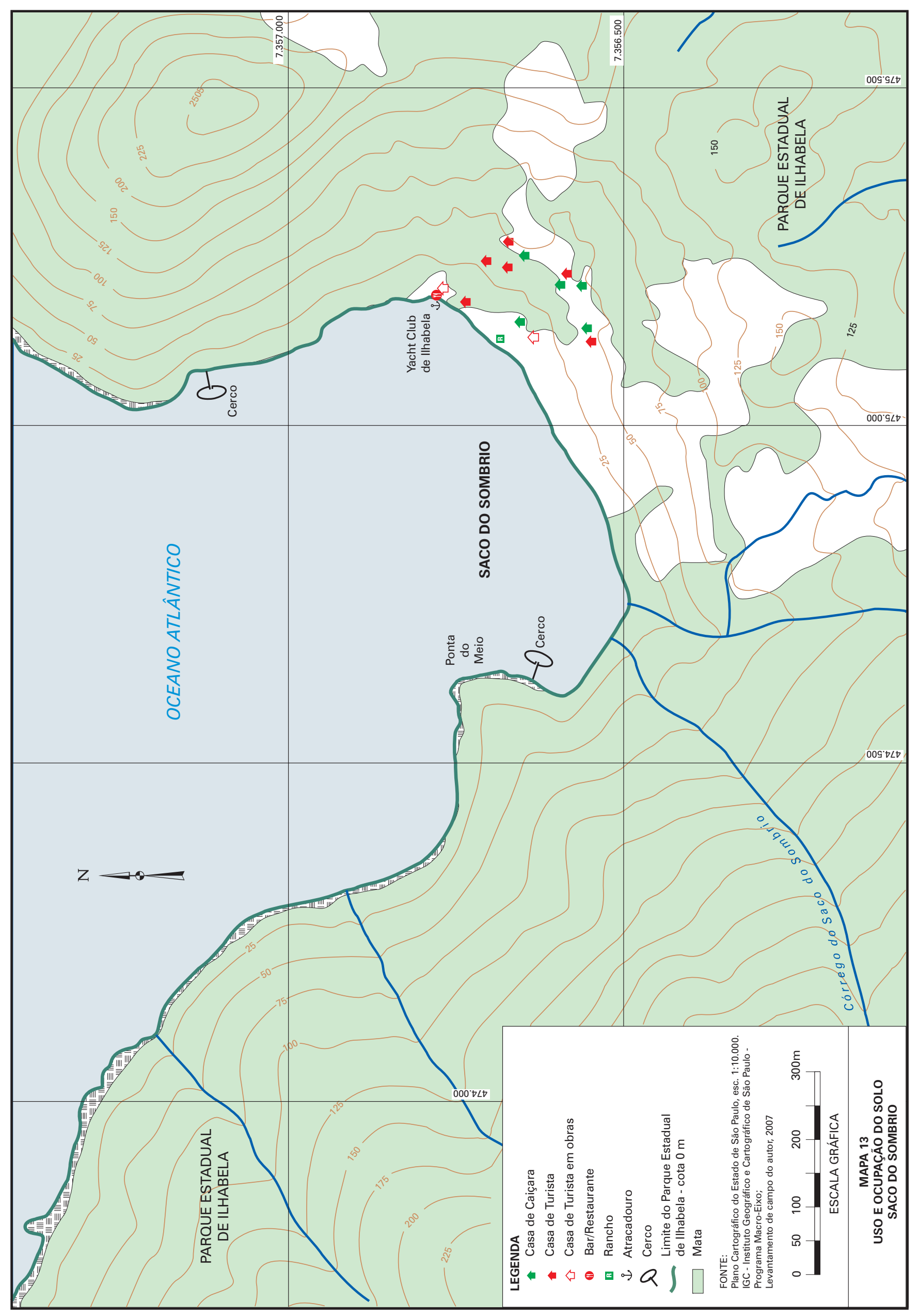




\section{CAPÍTULO 5 - A DISPUTA PELA HEGEMONIA DO ESPAÇO}

Afinal de contas, que características pode ter o espaço na Baía dos Castelhanos para atrair o interesse do estado, de turistas, especuladores, empreendedores capitalistas, grandes e pequenos, pesquisadores etc.?

Talvez antes da ciência, as agências de turismo e de publicidade tenham percebido a qualidade essencial que os turistas querem consumir: a natureza selvagem, a Mata Atlântica preservada, as piscinas naturais, as belas praias quase desertas. "Quase desertas" pois, além da "natureza exuberante", o turista consumidor poderá encontrar pessoas simples, pescadores, gente desprovida de vícios e de maldades, qualidades que tanta falta fazem aos moradores das grandes cidades.

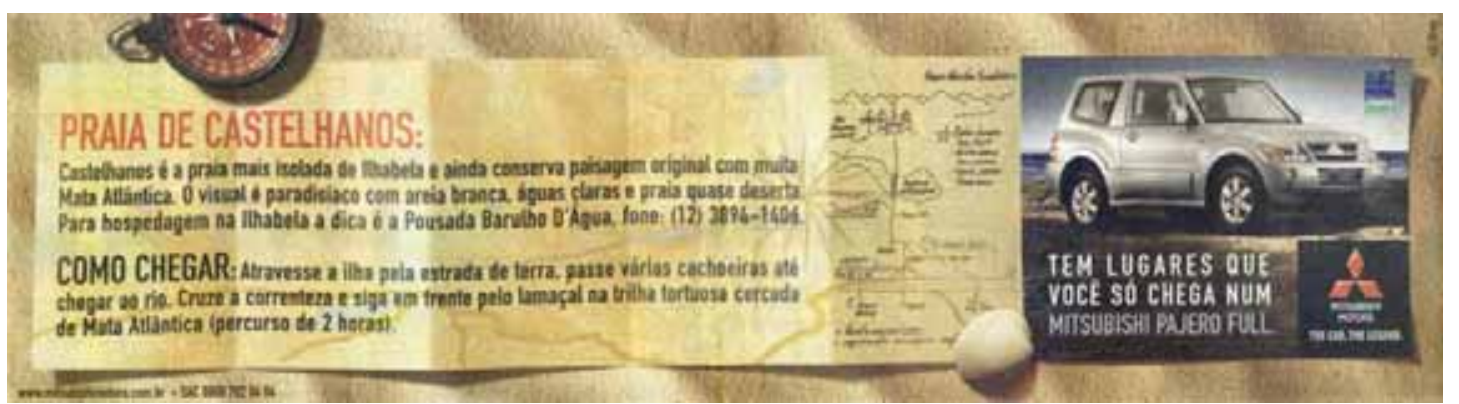

A propaganda cria símbolos que reforçam a idéia de uma natureza selvagem pronta para ser consumida com todo o conforto pelos turistas.

Não importa se a realidade dos caiçaras e da natureza não seja essa descrita pela propaganda. Interessa que pareça ser assim, que cumpra o objetivo de nos convencer que o contato com o natural, com o simples, com o selvagem, nos devolve um pouco da pureza que a vida atribulada na cidade grande nos retirou.

Um pouco forjada, um pouco verdade, os agentes de turismo oferecem uma natureza razoavelmente conservada, uma paisagem rara, dotada de qualidades que deixaram de existir em outras partes do Litoral Norte.

Alguns aspectos levam o espaço da Baía dos Castelhanos à condição de raridade. Em primeiro lugar, a busca pelo natural, a necessidade da natureza 
ser consumida como uma mercadoria igual às outras é conseqüência do fenômeno urbano, especificamente da cidade industrial. Um aspecto bastante comentado sobre a industrialização e a metropolização de São Paulo, principalmente na segunda metade do século XX, é o fato de ter acumulado e liberado capitais que puderam ser investidos em outras áreas, inclusive na de lazer.

Mas o fenômeno urbano é mais complexo e abrange outros aspectos. "La industrialización y la urbanización, asociadas y concurrentes, destrozan la naturaleza. El agua, la tierra, el aire, la luz, los elementos, en suma, están amenazados de destrucción." (Lefebvre, 1976: 33). E esses bens que estão ameaçados de serem destruídos, anteriormente eram fartos, ao contrário dos alimentos e de outros bens essenciais à reprodução das condições de vida, que eram escassos. Ainda que Lefebvre ao fazer esse comentário se referisse à obra de Marx e às cidades européias, tal fenômeno é facilmente reconhecível no Brasil, principalmente em São Paulo.

Até meados do século passado pode-se dizer que a cidade de São Paulo ainda não era totalmente "desnaturalizada". A natureza, o campo, o mundo rural estavam embricados no tecido urbano da cidade. Da mesma forma, o espaço que hoje compreende a região metropolitana, era o "sertão" da capital, lugar da produção agrícola, dos sitiantes, das olarias e da coleta de matérias primas (areia, argila, lenha) e, principalmente na região sul, lugar da floresta, da natureza, dos territórios de caça. O litoral estava muito distante e se algum significado turístico tinha, restringia-se às cidades de Santos e São Vicente.

O Litoral Norte ficava muito mais longe de São Paulo e seu espaço era agrícola. Como tal, configurava-se perifericamente ao espaço agrário das regiões centro-sul e oeste do estado onde se realizavam os cultivos do café, principal produto da economia brasileira na época. Assim, o Litoral Norte não se fazia "necessário" nem ao urbano, uma vez que a cidade tinha ao seu redor seus próprios sítios de lazer e de produção de alimentos (muito semelhantes às roças de produção de alimentos do litoral), e nem ao rural, considerando que o espaço agrário nacional e paulista estava voltando para a monocultura de exportação. 
Mas, é na segunda metade do século $X X$, mais precisamente, a partir da década de 1970, que o fenômeno urbano se consolida resultando, em concentração urbana, êxodo rural, extensão do tecido urbano, subordinação completa do espaço agrário. Para completar a destruição do natural na cidade, ocorrem a explosão demográfica e a formação da periferia sobre os antigos sítios de produção de alimentos e sobre as áreas de proteção ambiental. Nos anos que se seguiram, a poluição do ar, do solo e da água agrava esse quadro, tornando a natureza e o natural um bem significativamente escasso.

Simultaneamente, a cidade industrial produzia e acumulava riquezas, formando uma massa cada vez mais complexa e heterogênea de assalariados, empresários, profissionais liberais, e liberava capitais que eram investidos em infra-estrutura de acesso aos locais onde a natureza se encontrava preservada. Quanto mais o fenômeno urbano se aprofundava - metropolização e formação de novas metrópoles, tecnificação, ampliação do setor financeiro e de serviços, urbanização do campo, concentração da população e ampliação da periferia - mais a cidade perdia contato com a natural e se transformava em seu oposto. A natureza, disponível de forma abundante para toda a sociedade como valor de uso, estava se rarificando e passava a ser cobiçada. Impunha-se a necessidade do natural, de procurar incessantemente pelo natural, mas o que se buscava era um simulacro, uma representação da natureza, algo que já tivesse sido manipulado pelo capital e atendesse aos seus interesses. "Esos valores de utilización (elementos naturais) han entrado a formar parte de los valores de intercambio; su utilización y su valor de utilización, junto con los placeres naturales se van difuminando; al propio tiempo que se compran y se venden, se van haciendo cada vez más escasos. La naturaleza igual que el espacio, junto con el espacio, se ve a veces destrozada, fragmentada, vendida bajo forma de fragmentos "(Lefebvre, 1976: 39).

Assim, o natural destruído pela metrópole moderna é oferecido de volta pelo capital sob a forma de mercadoria. Os espaços naturais existentes anteriormente como valores de uso ao redor da cidade, incluindo o litoral, subordinam-se às "necessidades" do urbano e são incorporados pelo capital aos circuitos das trocas mercantis. O movimento de expansão da cidade 
industrial, de buscar o natural nos espaços adjacentes e de moldá-los para que pudessem ser consumidos como lazer de camadas da população urbana, alcançou o Litoral Norte expressivamente na década de 1970. Como já apresentado no capítulo três, as singularidades que motivaram sua procura, igualmente foram destruídas.

Atualmente o Litoral Norte encontra-se completamente urbanizado e integrado aos mercados nacionais e globais. As suas cidades e o seu território, por sua vez, também foram desnaturalizados, por mais paradoxal que pareça a afirmação. As praias, cachoeiras, os passeios pela mata, enfim, qualquer contato que se faça com o natural, é mediatizado pelo capital. Tudo é comprado e vendido. Além disso, o próprio tecido urbano com todos os seus problemas, vai se estendendo pelas praias e pelos sertões, desfigurando o natural. A natureza como valor de uso, como símbolo da harmonia, desapareceu, substituída pela representação do natural. "La problemática parcial relativa a la naturaleza queda así determinada: teóricamente, la naturaleza se nos aleja, mientras que los signos de la naturaleza y de lo natural se multiplican, sustituyan y suplantan a la verdadera naturaleza. (...) Dichos símbolos se producen masivamente y se venden." (Lefebvre, 1972: 33).

A Baía dos Castelhanos, nesse cenário de representações do natural no Litoral Norte, é um paradoxo. Como é possível existir nos dias de hoje um conjunto de praias e enseadas quase despovoadas e desprovidas de energia elétrica bem no centro do Litoral Norte?

A Baía dos Castelhanos, enquanto espaço onde o natural está fortemente presente, sobreviveu aos especuladores que compraram ou se apossaram das terras dos caiçaras pensando em tirar proveito das obras das estradas perimetral e transversal que estavam prestes a se iniciar. Entretanto, a transversal ficou parcialmente pronta e a perimetral praticamente se restringiu à zona do canal. Com isso, possíveis projetos imobiliários pensados para serem implantados na Baía dos Castelhanos foram abortados. Sobreviveu também ao projeto do Sr. Leonardo Reale, dono do engenho de pinga e depois prefeito de Ilhabela, que sem nenhuma sutileza e sem intenção alguma de aguardar pelo valor futuro da terra, tentou parcelar uma parte da 
Praia dos Castelhanos e rapidamente vender os "lotes de papel", mas não obteve sucesso integral em sua empreitada.

É justamente nesse momento ao longo da década de 1970 que se pode identificar o início da disputa pela hegemonia do espaço na Baía dos Castelhanos.

De início, é importante dizer que, se dependesse dos especuladores, dos interesses do capital imobiliário local e do Estado no início da década de 1970, não existiria paradoxo algum e nem se estaria falando em raridade. À época da ditadura militar, dos projetos grandiosos de integração e desenvolvimento nacional, da rodovia Rio-Santos, pretendia-se para Ilhabela o mesmo que estava sendo implementado no restante do Litoral Norte: infra-estrutura viária e energética e loteamentos de padrões variados que resultaram na urbanização das praias e destruição da produção mercantil simples e dos ambientes naturais.

Em 1974 tem início o governo Geisel. Paulo Egydio é nomeado em 1975 para governar o estado de São Paulo e desenvolve uma administração mais liberal comparada ao período anterior, fortalecendo as áreas de planejamento e de conservação da natureza, na tentativa de diminuir a acelerada degradação do meio ambiente que se verificava no litoral e na Região Metropolitana da Grande São Paulo - RMGSP. Foram estabelecidos, entre outras medidas para coibir e disciplinar o uso do solo nas áreas de interesse à proteção ambiental, os parques da Serra do Mar e de llhabela e a lei de conservação dos mananciais da RMGSP. E assim, somando-se às dificuldades naturais propiciadas pela presença da montanha e pelas condições sempre precárias da estrada Perequê-Castelhanos, a criação do PElb contribuiu eficazmente para a condição de raridade que a Baía dos Castelhanos veio assumir.

As políticas territoriais do governo Paulo Egydio e a presença material do PElb revelaram rupturas e contradições nos interesses pela exploração imobiliária do Litoral Norte e fortaleceram outros setores da burguesia que pensavam o turismo em bases menos predatórias. A partir do governo Montoro no estado de São Paulo, refletindo tendências mundiais, as questões ambientais passaram a ser consideradas nas políticas públicas territoriais, 
confrontando em llhabela os interesses dos políticos locais, muitos deles ligados tradicionalmente ao setor imobiliário, como ex-prefeito Reale e o atual Manoel Marcos. Como se sabe, essas políticas pouco contribuíram para o ordenamento e conservação ambiental do território do Litoral Norte e da própria Ilhabela, mas de alguma forma ajudam a entender o paradoxo da Baía dos Castelhanos.

Antes de se estender pelo significado das políticas territoriais e até para dar um pouco mais de significado a elas, é importante retomar a questão da raridade e da propriedade privada dos espaços naturais litorâneos, tão necessárias à reprodução das relações sociais da cidade industrial. Ao contrário do que afirmam muitos pesquisadores que trabalham com o conceito de populações ou comunidades tradicionais (Maldonado, 2001, Nogara, 2005 e outros), o espaço da Baía dos Castelhanos desde há muitos anos encontra-se fracionado e dividido em parcelas, que constituem as propriedades individuais e privadas. Parte dessas propriedades foram incorporadas no PElb (Praia da Figueira até o Saco do Sombrio) e passaram a fazer parte do patrimônio do Estado, ainda que os proprietários originais não tenham sido desapropriados. Um dos atributos da propriedade privada do solo no regime capitalista é a sua condição de auferir renda ao seu dono. "Toda renda se baseia no poder monopolista dos proprietários privados de determinadas porções do planeta. A renda monopolista surge porque os atores sociais podem aumentar seu fluxo de renda por muito tempo, em virtude do controle exclusivo sobre algum item, direta ou indiretamente, comercializável, que é em alguns aspectos, crucial, único e irreplicável." (Harvey, 2005: 222). As ciências espaciais fundamentadas na obra de Marx já destacaram a importância das rendas diferenciais e de monopólio para a construção do conceito de valor do espaço (Harvey, 1980, Costa e Moraes, 1984, Lefebvre, 1976 e outros). As rendas diferenciais são particularmente importantes para entender, por exemplo, porque lotes de igual tamanho num mesmo empreendimento imobiliário têm preços diferentes. Ou porque empreendimentos em tudo semelhantes, também apresentam preços desiguais dependendo da praia em que se localizam. Sem as rendas diferenciais seria impossível explicar como o espaço que não contém trabalho 
morto pode ser valorizado. Na Baía dos Castelhanos, é importante destacar seu aspecto "crucial, único e irreplicável" que propicia aos seus proprietários privados explorar a renda de monopólio. Voltemos ao questionamento inicial do capítulo: que características têm o espaço da Baía dos Castelhanos que o torna singular, irreplicável, a ponto de valer a pena pagar um preço adicional para ter acesso a ele? Sem dúvida alguma, seu capital simbólico, representado pelo conjunto harmônico de suas belas praias e enseadas que ainda existem preservadas - seus marcos especiais de distinção que fazem dela um lugar único - exerce um poder de atração importante em relação aos fluxos de capital de modo geral. (Harvey, 2005: 233).

A renda se manifesta de muitas formas na Baía dos Castelhanos. Em relação à renda diferencial, pode-se dizer que a Baía dos Castelhanos encontra-se mais "próxima" da cidade do que no passado. Nem a distância e nem o tempo foram encurtados, trata-se de uma proximidade relativa. Antes, a Baía dos Castelhanos era um lugar muito distante, já que existiam outras praias semelhantes as suas que tinham acesso mais fácil e ficavam mais próximas da "cidade". Com o esgotamento desses lugares, a Baía dos Castelhanos comparativamente a outros lugares semelhantes que ainda existam, principalmente em outros estados, tem uma localização mais vantajosa.

Internamente a baía, a Praia dos Castelhanos é a única que se pode chegar por estrada (estrada?), o que lhe confere uma localização privilegiada em relação às demais. Por isso, recebe muito mais visitantes que as outras e por esta razão, concentra as atividades comerciais voltadas ao turismo. Comparativamente às outras praias, seu espaço é mais valorizado (apesar de ter acumulado aproximadamente iguais trabalhos mortos da produção mercantil simples) e oferece vantagens que podem ser exploradas pelos proprietários particulares, como por exemplo, os campings de quintais. Internamente à Praia dos Castelhanos, as propriedades próximas ao mar (ou de frente para o mar), são muito melhor localizadas do que aquelas mais distantes, constituindo outra vantagem adicional.

Qualquer proprietário de uma fração do solo pode explorar a renda, igualando teoricamente turistas e caiçaras na condição de cobrarem pelo uso 
da propriedade, porém, a renda dissociada do negócio capitalista dificilmente será explorada com sucesso, nem mesmo com campings de quintais, que exigem pouco investimento para prosperarem. Vale lembrar que o camping selvagem foi proibido em toda a Baía dos Castelhanos, transformando por decreto o consumo da natureza como valor de uso em valor de troca. 0 usuário da praia apenas poderá ter uma estada mais prolongada no local se pagar uma taxa a algum proprietário. E se a questão é pagar pelo uso da praia, o camping que oferecer melhores condições (banheiro, chuveiro, cozinha, refeição e menor preço) tem vantagem sobre os demais, o que acaba favorecendo o investidor de fora que possui mais capital. Os campings e restaurantes de propriedade de caiçaras se aproveitam do excedente de movimento dos outros estabelecimentos.

A renda também se estabelece nas atividades da pesca. Estudos recentes revelam que a produção pesqueira de Ilhabela e São Sebastião tem diminuído e em 2003 representava cerca de $9 \%$ do total do Litoral Norte e apenas 1,4\% da produção do estado de São Paulo (Mendonça, 2007: 34). Inversamente, com o crescimento do turismo, verifica-se um aumento substancial no consumo de pescado e de outros frutos do mar, apesar de não haver estatísticas a respeito. Nesse sentido, os pescadores da Baía dos Castelhanos (e de toda a costa oceânica de Ilhabela) são duplamente favorecidos. Primeiro, por pescarem em águas piscosas e manterem sua produção nos mesmos patamares, encontram um mercado firme e em expansão para o seu pescado. Segundo, por verem diminuída a concorrência, devido ao abandono da pesca por muitos pescadores de outras regiões desses dois municípios. Por outro lado, precisam consumir cerca de 40 litros de óleo diesel para transportar sua produção para as cidades de Ilhabela e São Sebastião, perdendo no custo do transporte, a vantagem que têm por pescar em águas piscosas. O mercado local dos poucos bares e restaurantes da Praia dos Castelhanos, paga bem mais pelo pescado, mas tem movimento firme apenas em alguns períodos do ano.

A raridade é conseqüência da escassez e a propriedade privada do bem raro proporciona a renda. Nessas condições, a escassez pode ser manipulada quando "retira" do mercado o bem imóvel procurado pelo consumidor, 
forçando o maior preço no futuro. Já foi dito anteriormente que esta estratégia não deu resultado no passado, entretanto, indiretamente, a atuação do Estado tem contribuído para a valorização do espaço da Baía dos Castelhanos, retirando porções significativas de seu território do uso geral da sociedade. A criação do PElb subtraiu diretamente do mercado de terras (do mercado formal, pelo menos) cerca de metade de sua superfície. Na outra metade, onde se incluem as praias dos Castelhanos, Mansa e Vermelha e o limite do Parque está na cota $100 \mathrm{~m}$, as restrições legais estabelecidas para as áreas de entorno (todas as áreas entre a cotas 100 e o nível do mar), pelo Tombamento da Serra do Mar e pelo Plano Diretor do município de Ilhabela, as limitações para edificar são tantas que o empreendimento capitalista formal se torna inviável.

Todavia, nem a presença do PElb e nem as restrições legais impedem a realização do valor. Se todas as áreas protegidas legalmente fossem efetivamente destinadas à conservação do meio ambiente e ninguém e nenhuma atividade humana acontecesse em seu interior, poderia-se dizer, teoricamente, que essas terras perderiam, não seu valor em si, o valor de uso, e sim, seu valor de troca, sua condição de mercadoria. No outro extremo, ainda raciocinando hipoteticamente, se todas as áreas de posse do Estado fossem livres e tivessem estruturas viárias eficientes que permitissem também o livre acesso a elas, igualmente deixariam de se comportar como mercadorias para assumirem a condição de um bem natural, como a água e $\mathrm{o}$ ar, disponível como valores de uso para toda a sociedade.

Mas a realidade não é exatamente essa, a começar pelo acesso à Baía dos Castelhanos, que na prática é privatizado. Somente uma parcela muito reduzida da população composta de proprietários de veículos especiais ou com poder aquisitivo suficiente para pagar as despesas com hotel, jipeiro, escuna ou outro tipo de embarcação, tem condição de acesso ao local. As praias são públicas, todos podem usufruí-las livremente, mas o acesso a elas é privado. E isso ocorre não apenas pela ausência de meios de transporte adequados. Chegando à praia, o camping selvagem é proibido, forçando o usuário a pagar uma taxa a algum proprietário de camping "legal" para uma permanência maior. Os passageiros de lanchas e escunas, pagando somente 
para as agências de turismo, podem desfrutar das praias e enseadas no interior do PElb. E se a embarcação for particular e seu dono sócio do late Clube de Ilhabela, poderá utilizar suas instalações no Saco do Sombrio, construídas no interior do PElb, sem ter que pagar nada ao Estado. Já os moradores locais e mesmo qualquer navegante que queira atracar nesse cais, cedido pela marinha sem custo para o late Clube e com permissão do Instituto Florestal, que é o órgão do governo que administra o PElb, não terão permissão para isso.

Assim, a ação do Estado acentua a condição de raridade da Baía dos Castelhanos, mas a apropriação da renda que é fruto dessa raridade é realizada de forma privada.

Em relação à população caiçara que vive no interior do PElb e nas áreas de entorno, principalmente a da Praia dos Castelhanos, já foi visto no capítulo quatro que tanto os poderes públicos, municipal e estadual, toleram e incentivam a sua presença, mas sob determinadas condições, todas relacionadas à manutenção da sua cultura e hábitos tradicionais. Uma leitura acurada do artigo 38, item II e do artigo 39, item I do Plano Diretor do município vai identificar a boa vontade do legislador que objetiva preservar as "comunidades tradicionais", procurando garantir a elas sustentabilidade econômica por meio de ações que incentivem, dentre outras práticas, a pesca artesanal, a produção de farinha de mandioca e a capacitação para trabalhos na área de ecoturismo. Entretanto, outras pessoas, de Ilhabela ou de outro lugar, que não sejam integrantes das "comunidades tradicionais", podem empreender um negócio na Baía dos Castelhanos. Se forem competentes, vão obter lucro e na condição de proprietários da terra, vão se assenhorar também de uma fatia da renda da terra, que podem, o lucro e a renda, serem reinvestidos no próprio empreendimento, levando ao possível enriquecimento, caso obtenham sucesso em seus empreendimentos. Já os caiçaras, são reféns do território, onde, de acordo com o Plano Diretor, nem cerca e nem muro eles podem construir, quanto mais um grande empreendimento. Para permanecerem em suas praias, devem deixar o território livre para a perambulação de todos, enquanto os turistas que 
edificaram ou vierem a edificar no lugar, podem construir livremente seus muros e cercas para que ninguém perambule pelos seus territórios.

As contradições do espaço capitalista na Baía dos Castelhanos, ao invés de se atenuarem pela ação do Estado, são acentuadas ainda mais. Alguns setores que exploram os negócios de turismo se apropriam da renda gerada a partir da sua condição de raridade, que em grande parte é conseqüência da ação do Estado.

Os turistas donos de terra e de casas na Baía dos Castelhanos querem exercer o monopólio sobre a fração da superfície da terra que lhes pertence, não importando o tamanho de suas propriedades. Aproveitam-se da vizinhança do PElb, que lhes garante um espaço razoavelmente preservado e exclusivo. Não apreciam as atividades comerciais dos bares, restaurantes e campings, que atraem um fluxo muito grande de turistas, e se contrapõem aos seus desejos de uso exclusivo das praias.

Os comerciantes locais, jipeiros, agentes de turismo, donos de hotel e pousadas, tiram proveito da condição precária da estrada para terem o quase monopólio do transporte e da exploração dos fluxos de turistas para a Baía dos Castelhanos. A ação do Estado, restringindo o uso do solo, faz aumentar a participação deles na renda.

O setor imobiliário pressiona para que o Estado seja menos restritivo e possibilite o parcelamento do solo, criando um mercado imobiliário hoje inexistente na Baía dos Castelhanos.

Os caiçaras que permaneceram na Baía dos Castelhanos e que não venderam suas terras (ou que readquiriram ou lutam para readquirir o direito sobre elas), igualmente se beneficiam da valorização do espaço e da possibilidade de obter renda a partir de suas propriedades. Para isso, precisam de capital e técnica para empreender negócios competitivos e que lhes proporcione a inserção em condições de igualdade na economia capitalista global. O Estado pouco ou nada Ihes oferece. Sem escola, energia e transporte, não há como se inserir no mercado global competitivamente. $O$ município de Ilhabela enxergou uma sociedade rural que não existe mais e que, aliás, nunca existiu nos moldes como é apresentada em seu Plano Diretor. Enquanto se discute o desenvolvimento do capitalismo pleno em todo 
- Litoral Norte e a sujeição da natureza e de todas as relações sociais não tipicamente capitalistas à lógica moderna e global da produção de mercadorias, o Plano Diretor de Desenvolvimento Socioambiental do Município de Ilhabela se volta ao passado e decreta a proteção da roça de mandioca e das casas de farinha. Isso representa o aprisionamento do caiçara no território e sua condenação pobreza.

Para o Estado, a propriedade privada do turista pode gerar renda. A do caiçara, farinha de mandioca. 


\section{BIBLIOGRAFIA}

ALMEIDA, Antonio Paulino. Memória Histórica sobre São Sebastião. Revista de História, São Paulo, n. XIX, p 232. 1959.

CARNEIRO, Maria José. Ruralidade: Novas Identidades em Construção. http://www.eco.unicamp.br/nea/rurbano/textos/downlo/rurbzeze.html, 1997 Acesso em: 15 de set. de 2007.

CARVALHO, Maria da C. Vicente. Santos e a Geografia no Litoral Paulista. São Paulo: Tese de Doutorado, Faculdade de Filosofia Ciências e Letras da Universidade de São Paulo, 1944.

COSTA, W. Messias. Geografia Política e Geopolítica - Discursos sobre Território e Poder. São Paulo: Hucitec, 1992.

COSTA, W. Messias. O Estado e as Políticas Territoriais no Brasil. $7^{a}$ ed. São Paulo: Contexto, 1997.

COSTA, W. Messias; MORAES, A.C. Robert. Valorização do Espaço. São Paulo: Hucitec, 1984.

COSTA, W. Messias da. Subsídios para uma Política Nacional de Ordenamento Territorial. São Paulo: Depto de Geografia - Universidade de São Paulo (inédito), 2003.

DEAN, Warren. A Ferro e Fogo. São Paulo: Companhia das Letras, 1996.

DIEGUES, Antonio Carlos. Pescadores, Camponeses e Trabalhadores do Mar. São Paulo: Ática, 1983.

DIEGUES, Antonio Carlos. A mudança como modelo cultural: O caso da cultura caiçara e a urbanização. In: Enciclopédia caiçara, vol. 1, HUCITEC NUPAUB - CEC, São Paulo, 2004.

DIEGUES, Antonio Carlos; Nogara, Paulo José. O Nosso Lugar Virou Parque. NUPAUB - USP, São Paulo, 1999.

ESTERCI, Neide. Populações Tradicionais. In: Almanaque Socioambiental. Instituto Socioambiental, São Paulo,.2005

FRANÇA, Ary. A Ilha de São Sebastião. Boletim, 78, $n^{\circ} 10$, São Paulo, 1954. 
FURLAN, Sueli Angelo. Lugar e cidadania: implicações socioambientais das políticas de conservação ambiental. In: Enciclopédia caiçara, vol. 1, HUCITEC - NUPAUB - CEC, São Paulo, 2004.

GAUDEMAR, Jean Paul de. Mobilidade do Trabalho e Acumulação de Capital. Lisboa: Editorial Estampa, 1977. cap.5 O Conceito Marxista de Mobilidade do Trabalho. p.185-211.

GROSTEIN, Marta Dora. METRÓPOLE E EXPANSÃO URBANA a persistência de processos "insustentáveis". São Paulo Perspec. vol.15 no.1 São Paulo Jan./Mar. 2001

HEIDEMANN, Dieter. Migrantes e a Crise da Sociedade do Trabalho: humilhação secundária, resistência e emancipação. Jan. 2003.

HARVEY, David. A Justiça Social e a Cidade. São Paulo: Hucitec, 1980.

HARVEY, David. A Produção Capitalista do Espaço. São Paulo: Annablume, 2005.

KURZ, Robert. O Colapso da Modernização: da derrocada do socialismo de caserna à crise da economia mundial. 5. ed. rev.. São Paulo: Paz e Terra, 1999.

LEFEBVRE, Henri. De lo Rural a lo Urbano. 3. ed. Barcelona: Ediciones Península, 1965.

LEFEBVRE, Henri. El Derecho a La Ciudad. Barcelona: Península, 1965.

LEFEBVRE, Henri. Espacio y Política. Barcelona: Península, 1976.

LEFEBVRE, Henri. La Revolución Urbana. (Barcelona: Península, 1976.)

MALDONADO, Wanda. Da Mata para o Mar - A Construção da Canoa Caiçara em Ilhabela, SP. Dissertação de Mestrado. São Paulo: Programa de Pós Graduação da USP, 2001.

MARTINS, José de Souza. O Cativeiro da Terra. São Paulo: Livraria Editora Ciências Humanas, 1979.

MARTINS, José de Souza. Expropriação e Violência - A Questão Política no Campo. São Paulo: Hucitec, 1980.

MARX, Karl. O Capital. livro I, vol 1. Rio de Janeiro: Civilização Brasileira, 1974.

MARX, Karl. O Capital. livro 3, vol. 6. Rio de Janeiro: Civilização Brasileira, 1974. 
MENDONÇA, Juliano Borghi de. A Pesca Artesanal em Boiçucanga (São Sebastião - Sp). Propostas para a Revitalização e a Valorização da Atividade.

MORAES, Antonio Carlos Robert de. Ideologias Geográficas. São Paulo: Hucitec, 1996.

MORAES, Antonio Carlos Robert de. Geografia - Meio Ambiente e Ciências Humanas. 3. ed. São Paulo: Hucitec, 1981.

MUSSOLINI, Gioconda. Ensaios de Antropologia Indígena e Caiçara. Rio de Janeiro: Paz e Terra, 1980.

NOFFS, Paulo da Silva. Os Caiçaras do Toque Toque Pequeno - Um Estudo de Mudança Espacial. Dissertação de Mestrado. São Paulo: Faculdade de Filosofia Letras e Ciências Humanas da USP, 1983.

NOFFS, Paulo da Silva. Caminhos na Ilhabela. Inédito. São Paulo: CESPSMA de São Paulo, 1999.

NOGARA, Paulo J N; PIRRÓ, Mariana S A; MANTCHEV, Alain. Subsídios para o Plano de Manejo do Parque Estadual de Ilhabela: Inserção das Comunidades Caiçaras. Secretaria do Meio Ambiente do Estado de São Paulo Instituto Florestal. 2005

OURIQUES, Helton Ricardo. Turismo em Florianópolis. Florianópolis: Editora da UFSC, 1998.

PAPY, Louis. A Margem do Império do Café - A Fachada Atlântica de São Paulo. Boletim Geográfico, Rio de Janeiro, n 137, Ano XV CN6/IBGE, 1957.

PIRRÓ, Mariana. Atualização de Ilhabela, Diagnóstico sócio-econômico e ambiental. Inédito. São Paulo: Departamento de Geografia, USP, 2002.

PIRRÓ, Mariana. A Baía dos Castelhanos e seus Lugares: um olhar para o Lugar. Trabalho de Graduação Indicidual. São Paulo: Departamento de Geografia da USP, 2004

PORTER, Michel. A Vantagem Competitiva das Nações. Rio de Janeiro: Campus, 1993.

PRADO JR, Caio. Formação do Brasil Contemporâneo - Colônia. 7. ed. São Paulo: Brasiliense, 1963.

PRADO JR, Caio. Distribuição da Propriedade Fundiária Rural no Estado de São Paulo. Geografia , São Paulo, Ano 1, n’ 1, AGB, 1935. 
PRIORE, Mary del, VENÂNCIO, Renato. Uma História da Vida Rural no Brasil. Rio de Janeiro, Ediouro, 2006.

SANTANA, Paola Verri de. A Mercadoria Verde: a Natureza. In: DAMIANI, Amelia Luísa; CARLOS, Ana Fani Alessandri; SEABRA, Odette Carvalho de Lima (org.). O Espaço no Fim do Século: a Nova Raridade. São Paulo: Contexto, 1999.

SANTOS, Eliana Cristina M (Coord). Ilhabela - Diagnóstico Sócioeconômico e Ambiental. São Paulo: Governo do Estado de São Paulo, SMA I.F., 1992.

SANTOS, Milton. A Natureza do Espaço. $2^{a}$ ed. São Paulo: Hucitec EDUSP, 1997.

SANTOS, Rubens Rodrigues. É preciso planejar na área da Rio-Santos, 1972. In: Silva, Armando Corrêa da (org). O Litoral Norte do Estado de São Paulo. São Paulo: Instituto de Geografia - USP, 1975.

SANTOS, Milton; SILVEIRA, Maria Laura. O Brasil: Território e Sociedade no Início do Séc. XXI. Rio de Janeiro - São Paulo: Record, 2001.

SEABRA, Odette Carvalho de Lima. Santos - A Muralha que Cerca o Mar. São Paulo: Dissertação de Mestrado, FFLCH da USP, 1980.

SMA - Secretaria do Meio Ambiente de São Paulo. Atlas das Unidades de Conservação Ambiental do Estado de São Paulo - Parte 1 - Litoral. São Paulo, 1996.

SMA - Secretaria do Meio Ambiente de São Paulo. Planos de Manejo das Unidades de Conservação - Parque Estadual de Ilhabela - Fase 1 - Plano de Gestão Ambienta. www.ilhabela.org/PLANOGESTAO1.RTF. São Paulo, 1998.

SMA - Secretaria do Meio Ambiente de São Paulo; Instituto Florestal. Inventário Florestal da Vegetação Natural do Estado de São Paulo. São Paulo, 2005.

SILVA, Armando Corrêa da. O Litoral Norte do Estado de São Paulo. São Paulo: Instituto de Geografia - USP, 1975.

SILVA, José Graziano da (Org). Estrutura Agrária e Produção de Subsistência na Agricultura Brasileira. São Paulo: Hucitec, 1980 


\section{ANEXO}

CADASTRO DAS FAMÍLIAS CAIÇARAS, DAS CASAS DE TURISTAS E DAS ATIVIDADES COMERCIAIS NA BAÍA DOS CASTELHANOS

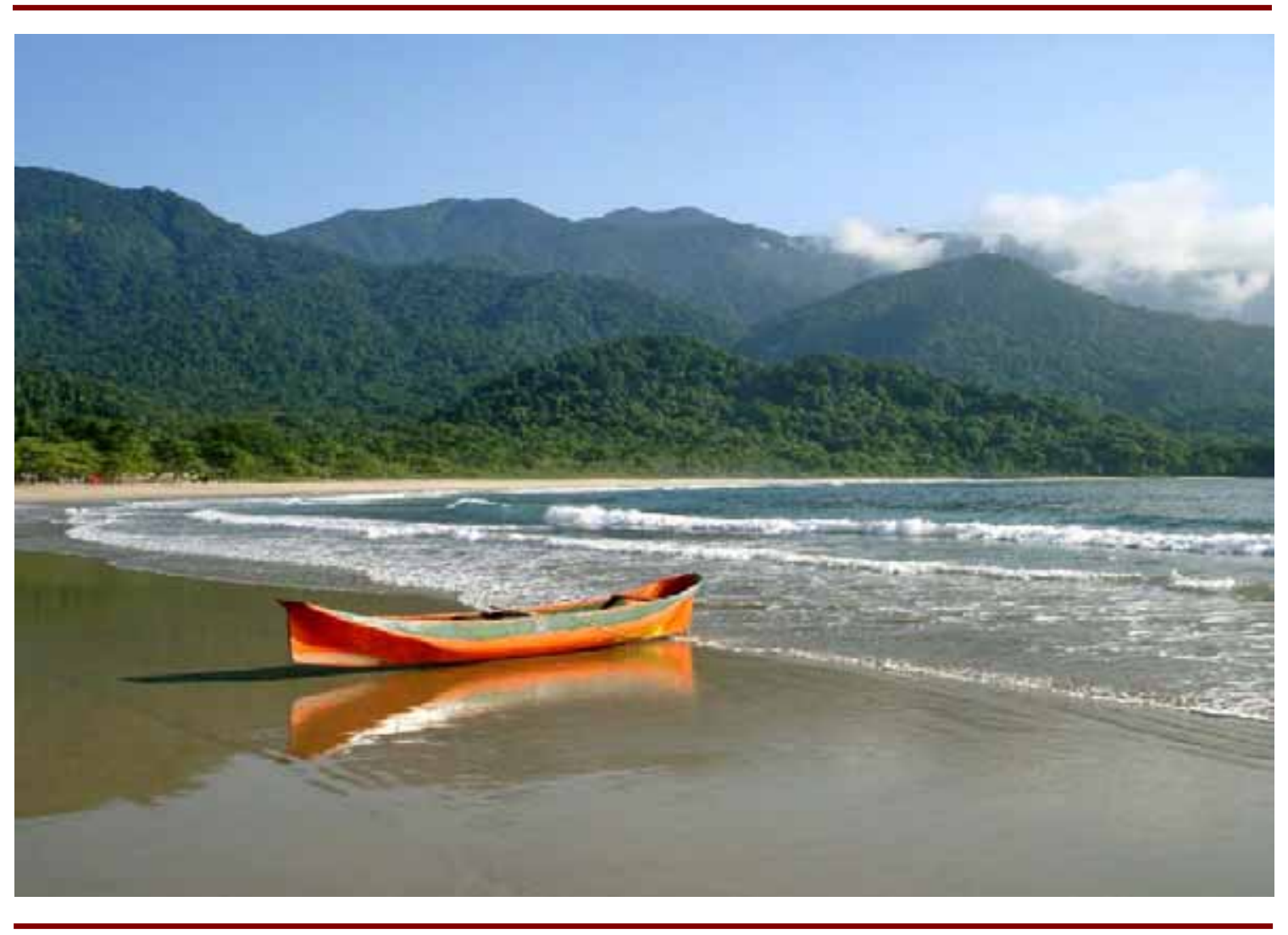

Trabalho de campo realizado no período de março a agosto de 2007 


\section{CADASTRO DAS FAMÍLIAS RESIDENTES NA BAÍA DOS CASTELHANOS \\ PRAIA DOS CASTELHANOS - CANTO DO RIBEIRÃO}

FAMÍLIA DE:

MAURO EUZÉBIO DE MORAIS

LOCALIZAÇÃO UTM:

$471.265 / 7.362 .655$

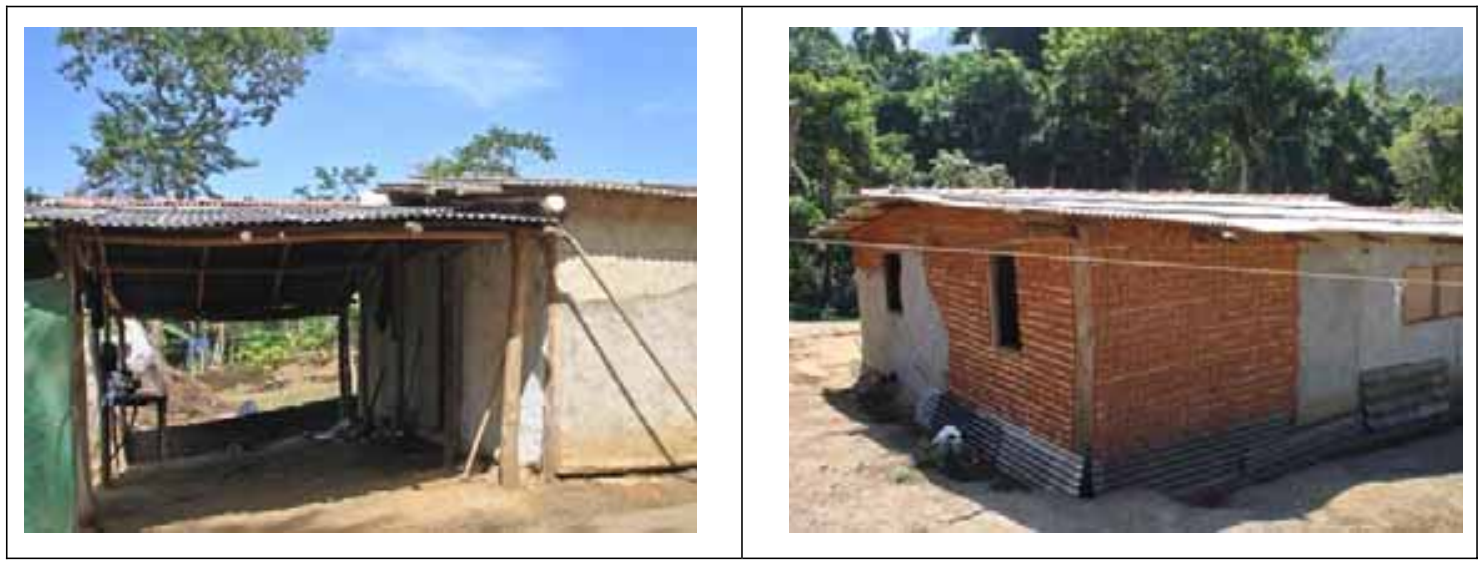

Data e local de nascimento: Canto do Ribeirão, 39 anos

Filiação: Pedro Euzébio de Morais, Canto do Ribeirão e Natalina de Souza Lucio de Morais, Canto da Lagoa

Estado Civil: Casado

Atividade profissional: Pescador, tem 2 canoas-a-remo e 6 redes.

Esposa: Janete Egino da Silva

Data e local de nascimento Mato Grosso, 34 anos

Filiação: Pais são do Mato Grosso, região de garimpo.

Atividade profissional: Trabalhos Domésticos

Filhos: Gesebéu, Gislaine, Moisés, Natália, Elizeu e Franciela Euzébio de Morais.

Observações: Informações fornecidas por seu irmão Manoel em 25/04/07

Total de moradores: 8 


\section{CADASTRO DAS FAMÍLIAS RESIDENTES NA BAÍA DOS CASTELHANOS PRAIA DOS CASTELHANOS - CANTO DO RIBEIRÃO}

FAMÍLIA DE:

LOCALIZAÇÃO UTM:
MANOEL EUZÉBIO DE MORAIS

$471.265 / 7.362 .655$

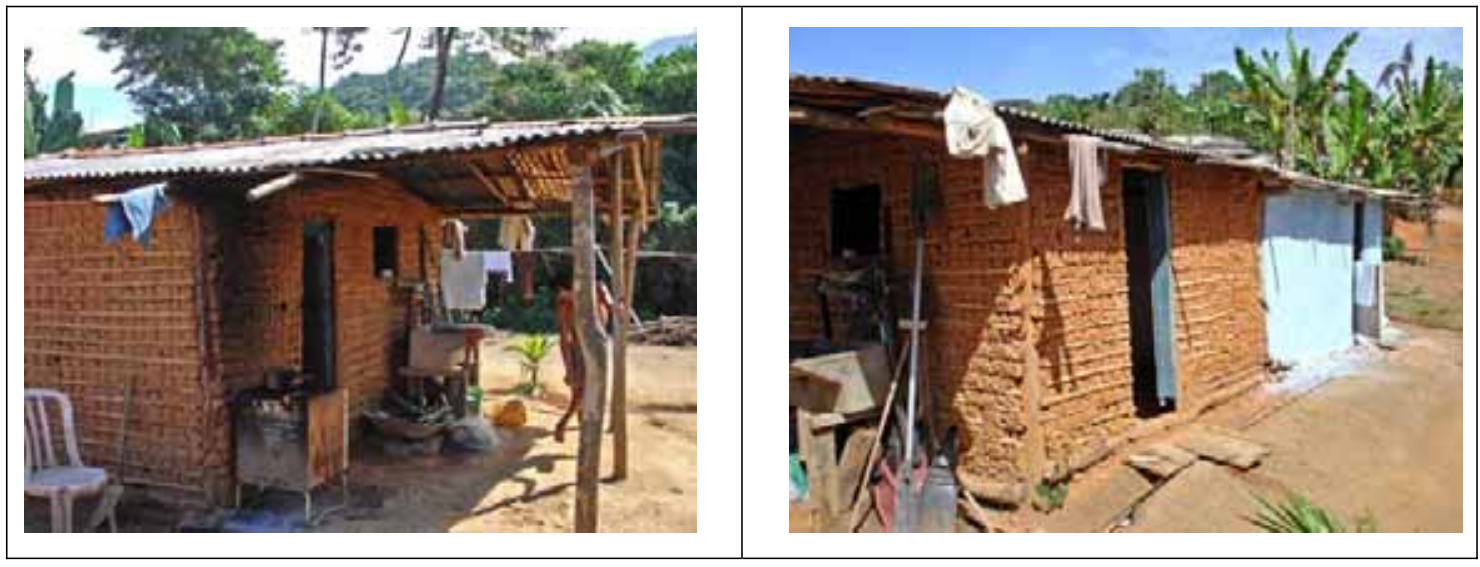

Data e local de nascimento: Canto do Ribeirão, 34 anos

Filiação: Pedro Euzébio de Morais, Canto do Ribeirão e Natalina de Souza Lucio de Morais, Canto da Lagoa

Estado Civil: Casado

Atividade profissional: Pescador, tem 1 canoa-a-remo e 6 redes com 600m de panagem ao todo.

Esposa: Denize Euzébio de Oliveira

Data e local de nascimento Porto Grande, São Sebastião, 28 anos

Filiação: Eraldo de Oliveira e Gertrudes Euzébio de Morais

Atividade profissional: Trabalhos domésticos

Filhos: Willian e Lilian Oliveira de Morais (Lilian mora com a Celeste e Otávio)

Observações: Entrevista realizada com Manoel e Denise em 25/04/07

Não possui gerador e nem estrutura para conservar o peixe. O pescado é levado fresco para o Arlindo, no Canto da Lagoa, que o transporta para a cidade. Cobra pelo gelo e óleo.

Total de moradores: 3 


\section{CADASTRO DAS FAMÍLIAS RESIDENTES NA BAÍA DOS CASTELHANOS \\ PRAIA DOS CASTELHANOS - CANTO DO RIBEIRÃO}

FAMÍLIA DE:

ADELINO EUZÉBIO DE MORAIS

LOCALIZAÇÃO UTM:

$471.259 / 7.362 .614$

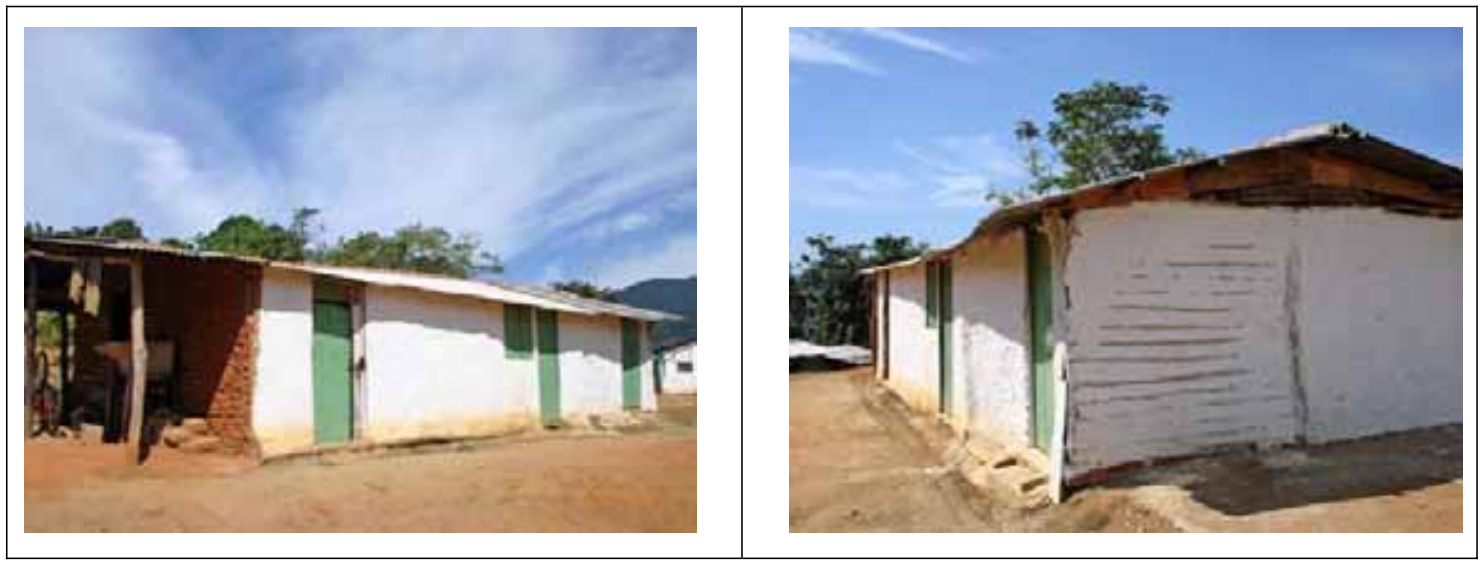

Data e local de nascimento: Canto do Ribeirão, 48 anos

Filiação: Pedro Euzébio de Morais, Canto do Ribeirão e Natalina de Souza Lucio de Morais, Canto da Lagoa

Estado Civil: Viúvo

Atividade profissional: Pescador

Filhos: Jefferson e Jennifer Euzébio de Morais.

Observações: Informações fornecidas por seu irmão Ondino em 25/04/07

Total de moradores: 4 


\section{CADASTRO DAS FAMÍLIAS RESIDENTES NA BAÍA DOS CASTELHANOS \\ PRAIA DOS CASTELHANOS - CANTO DO RIBEIRÃO}

FAMÍLIA DE:

IVO EUZÉBIO DE MORAIS

LOCALIZAÇÃO UTM:

$471.161 / 7.362 .654$
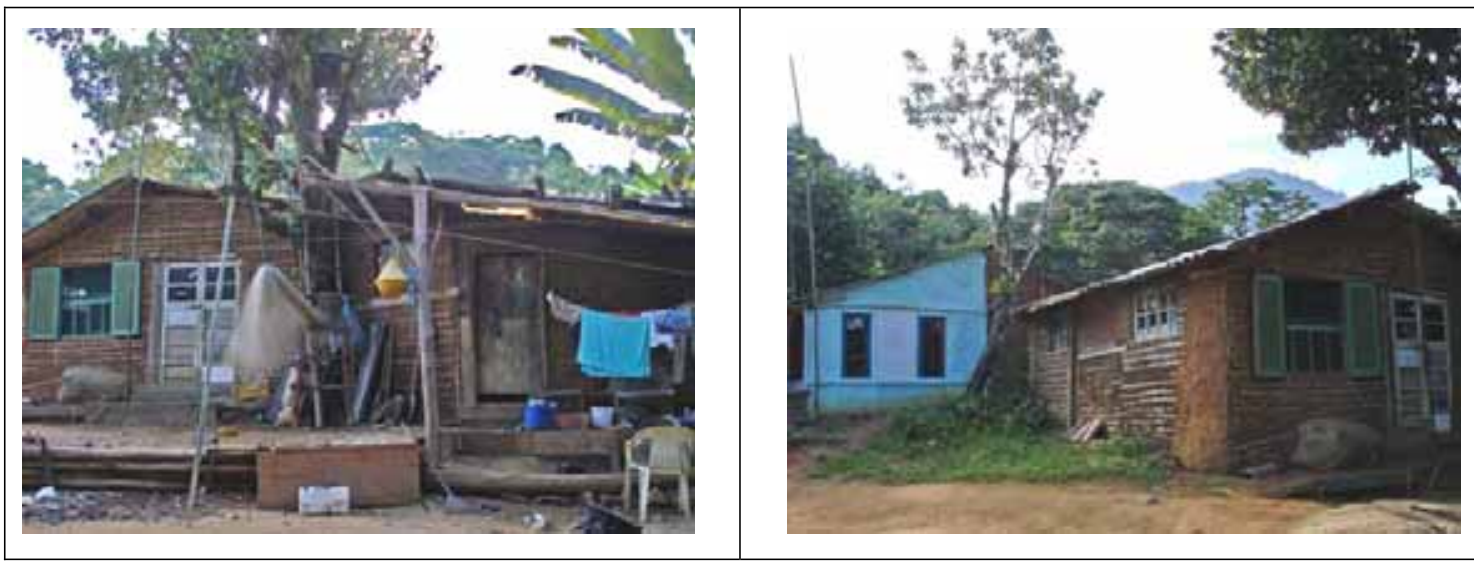

Data e local de nascimento: Canto do Ribeirão, 48 anos

Filiação: Benedito Euzébio dos Santos e Benedita Inácio dos Santos

Estado Civil: Casado

Atividade profissional: Pescador, tem 1 canoa-a-remo e rede

Esposa: Fátima de Souza Lucio

Data e local de nascimento Canto da Lagoa, 30 anos

Filiação: Joaquim e Conceição de Souza Lucio

Atividade profissional: Serviços domésticos

Filhos: Jackeline, Jane, Vinicios e Ivan Euzébio de Morais

Observações: Entrevista realizada com Ângela, irmã da Fátima, em 25/04/07

Total de moradores: 6 


\section{CADASTRO DAS FAMÍLIAS RESIDENTES NA BAÍA DOS CASTELHANOS \\ PRAIA DOS CASTELHANOS - CANTO DO RIBEIRÃO}

FAMÍLIA DE:

ADRIANO EUZÉBIO DE MORAIS

LOCALIZAÇÃO UTM:

$471.161 / 7.362 .654$

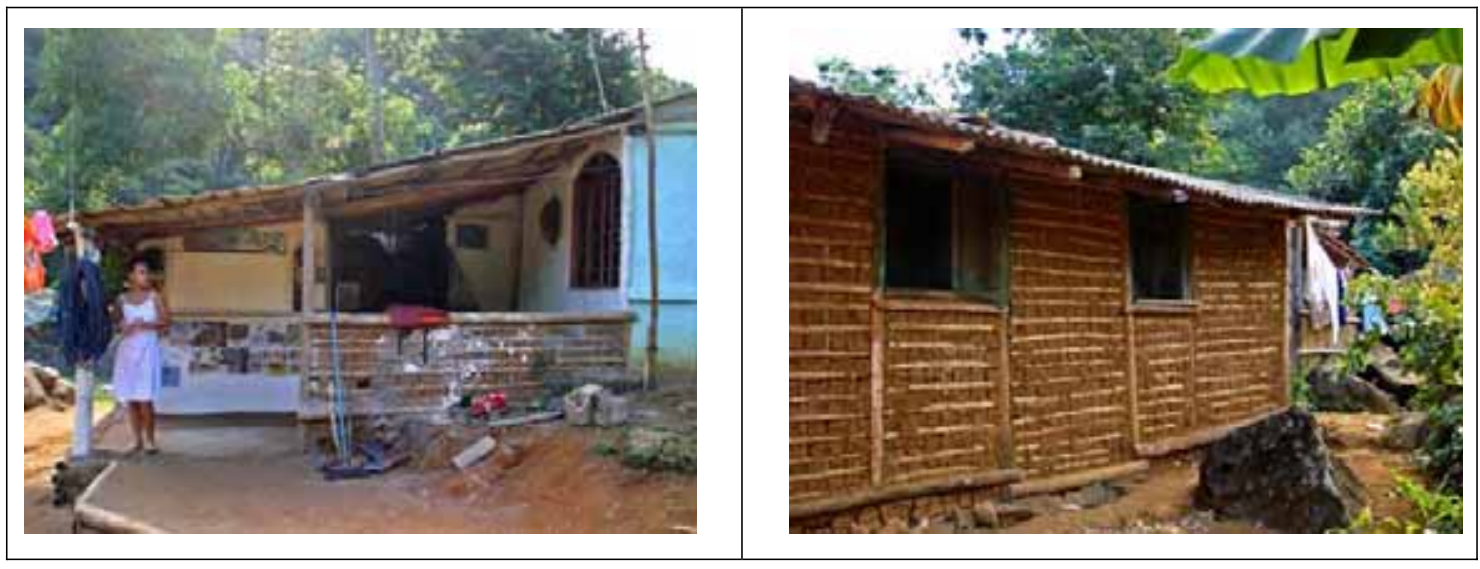

Data e local de nascimento: Canto do Ribeirão, 40 anos

Filiação: Benedito Euzébio dos Santos e Catarina Barbosa dos Santos

Estado Civil: Casado

Atividade profissional: Pescador pesca de linha; servente de pedreiro

Esposa: Ângela Maria de Souza Lucio

Data e local de nascimento Canto da Lagoa, 27 anos

Filiação: Joaquim e Conceição de Souza Lucio

Atividade profissional: Serviços domésticos

Filhos: Fabíola Cristina, Giovane, Jean e Fabrício Souza de Morais

Observações: Entrevista realizada com Ângela em 25/04/07

Total de moradores: 6 


\section{CADASTRO DAS FAMÍLIAS RESIDENTES NA BAÍA DOS CASTELHANOS \\ PRAIA DOS CASTELHANOS - CANTO DO RIBEIRÃO}

FAMÍLIA DE:

BENEDITO EUZÉBIO DE MORAIS

LOCALIZAÇÃO UTM:

$471.144 / 7.362 .660$

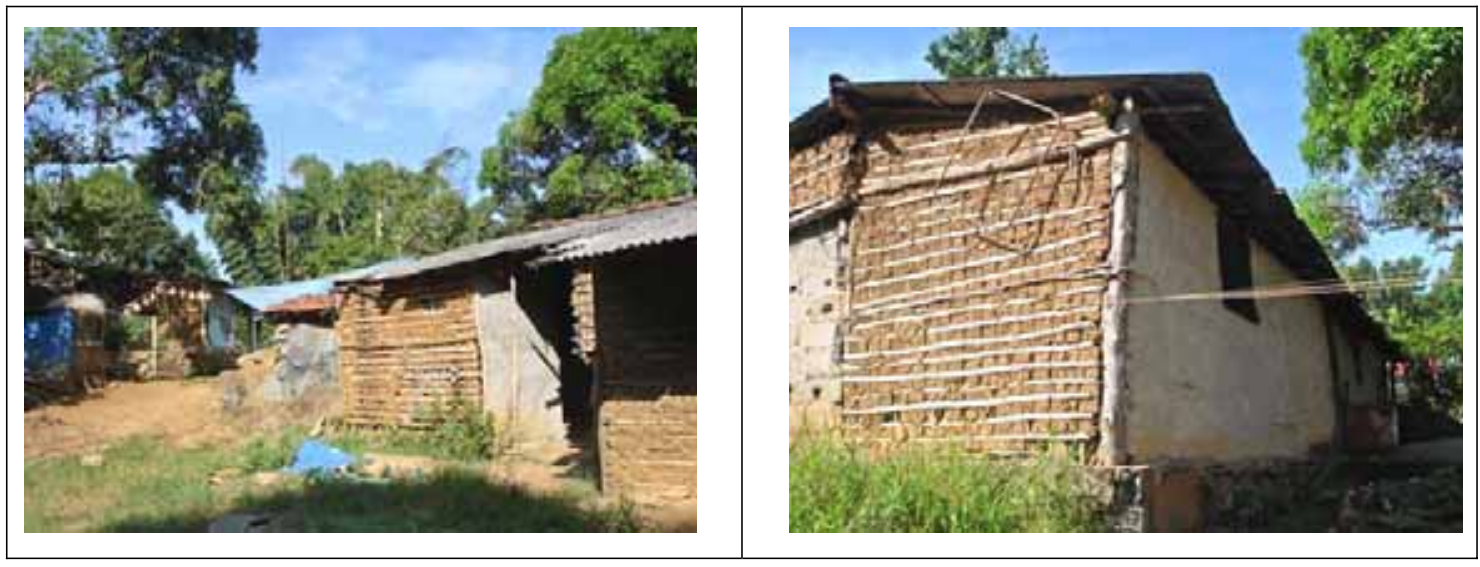

Data e local de nascimento: Canto do Ribeirão, 83 anos

Filiação: Sebastião Euzébio de Morais, praia da Caveira e Tereza Maria de Jesus, Búzios

Estado Civil: Casado

Atividade profissional: Pescador (não trabalha mais)

Esposa: Catarina Barbosa dos Santos

Data e local de nascimento: Canto do Ribeirão

Filiação: Benedito Barbosa, Canto do Ribeirão e Paula Maria de Jesus, Búzios

Atividade profissional: Trabalhos domésticos; pensionista do INSS

Filhos: Luiz Fernando Euzébio de Morais

Observações: Entrevista feita com o Benedito e Catarina em 25/04.

Começou trabalhando na roça e depois como embarcado. Com o tempo, comprou uma canoa e passou a viver como pescador. Bebia muito, perdeu os documentos e por conta disso, não conseguiu a pensão do INSS.

D. Catarina informou que seu pai, o famoso Barbosa, nasceu nos Castelhanos mas sua família era oriunda de Pernambuco.

Total de moradores: 3 


\section{CADASTRO DAS FAMÍLIAS RESIDENTES NA BAÍA DOS CASTELHANOS PRAIA DOS CASTELHANOS - CANTO DO RIBEIRÃO}

FAMÍLIA DE: ONDINO EUZÉBIO DE MORAIS

LOCALIZAÇÃO UTM:
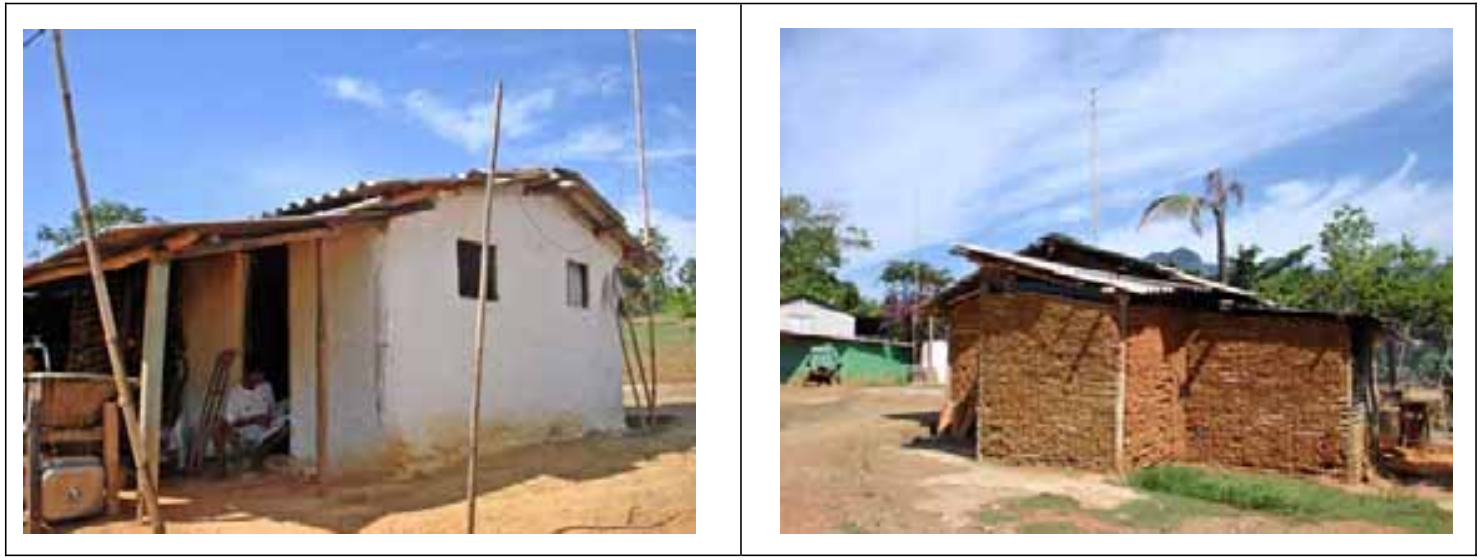

Data e local de nascimento: Canto do Ribeirão, 38 anos

Filiação: Pedro Euzébio de Morais, Canto do Ribeirão e Natalina de Souza Lucio de Morais, Canto da Lagoa

Estado Civil: Casado

Atividade profissional: Pescador; tem 3 canoas-a-remo e 3 redes

Esposa: Gertrude Euzébio de Morais

Data e local de nascimento: Canto do Ribeirão, 50 anos

Filiação: Benedito Euzébio de Morais, Canto do Ribeirão e Benedita Inácio dos Santos

Atividade profissional: Trabalhos domésticoas

Observações: Tem um rádio amador que não usa para trabalho.

Como todos seus irmãos, entrega o peixe fresco para o Arlindo transportar e vender na cidade. Paga para ele o gelo e o óleo.

Entrevista feita com o Ondino e Gertrude em 25/04.

Total de moradores: 2 


\section{CADASTRO DAS FAMÍLIAS RESIDENTES NA BAÍA DOS CASTELHANOS \\ PRAIA DOS CASTELHANOS - CANTO DO RIBEIRÃO}

FAMÍLIA DE:

PEDRO EUZÉBIO DE MORAIS

LOCALIZAÇÃO UTM:

$471.289 / 7.362 .621$

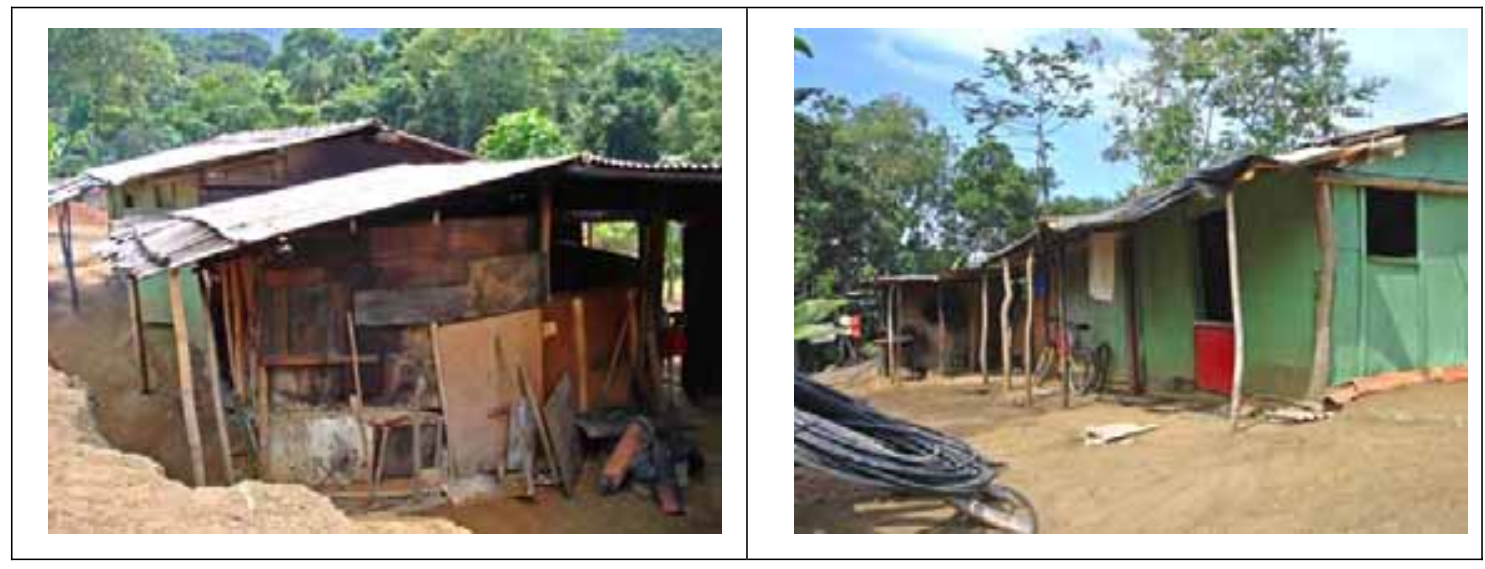

Data e local de nascimento: Canto do Ribeirão, 78 anos

Filiação: Sebastião Euzébio de Morais, praia da Caveira e Tereza Maria de Jesus, Búzios

Estado Civil: Casado

Atividade profissional: Pescador aposentado, pensionista do INSS

Esposa: Natalina de Souza Lucio Morais

Data e local de nascimento: Canto da Lagoa, 65 anos

Filiação: Benedito Lucio e Sebastiana Maria Quintina

Atividade profissional: Trabalhos domésticos

Filhos: Mauricio Euzébio de Morais (morou com o Messias no Toque Toque Pequeno)

Observações: Entrevista realizada com Pedro e Natalina em 25/04/07.

S. Pedro declarou ter 78 anos e que seu pai nasceu na África (veio como escravo em uma caixa de sapato). Entretanto, seu irmão Benedito declarou que o pai deles nasceu na Praia da Caveira.

Trabalhou alternadamente na roça e embarcado até se tornar pescador. Trabalhava para o Sr.. Leonardo Reale, dono do Engenho, moendo cana e recebia 1 cruzeiro por dia de trabalho. Na roça, trabalhava para o Barbosa para cortar e puxar banana para a praia, até a cachoeira (rio). Da cachoeira para a praia a banana era transportada por carro de boi. Ganhava 2 cruzeiros por dia nesse serviço.

Tinha sua própria roça, que era plantada em terra cedida pelo Barbosa. Plantava de tudo na roça, principalmente a mandioca para fazer farinha, que era feita na casa de farinha do Barbosa, que permitia que seu equipamento fosse utilizado gratuitamente.

Total de moradores: 3 


\section{CADASTRO DAS FAMÍLIAS RESIDENTES NA BAÍA DOS CASTELHANOS PRAIA DOS CASTELHANOS - CANTO DO RIBEIRÃO}

FAMÍLIA DE: CELESTE BARBOSA DE MORAIS

LOCALIZAÇÃO UTM:

$471.211 / 7.362 .386$

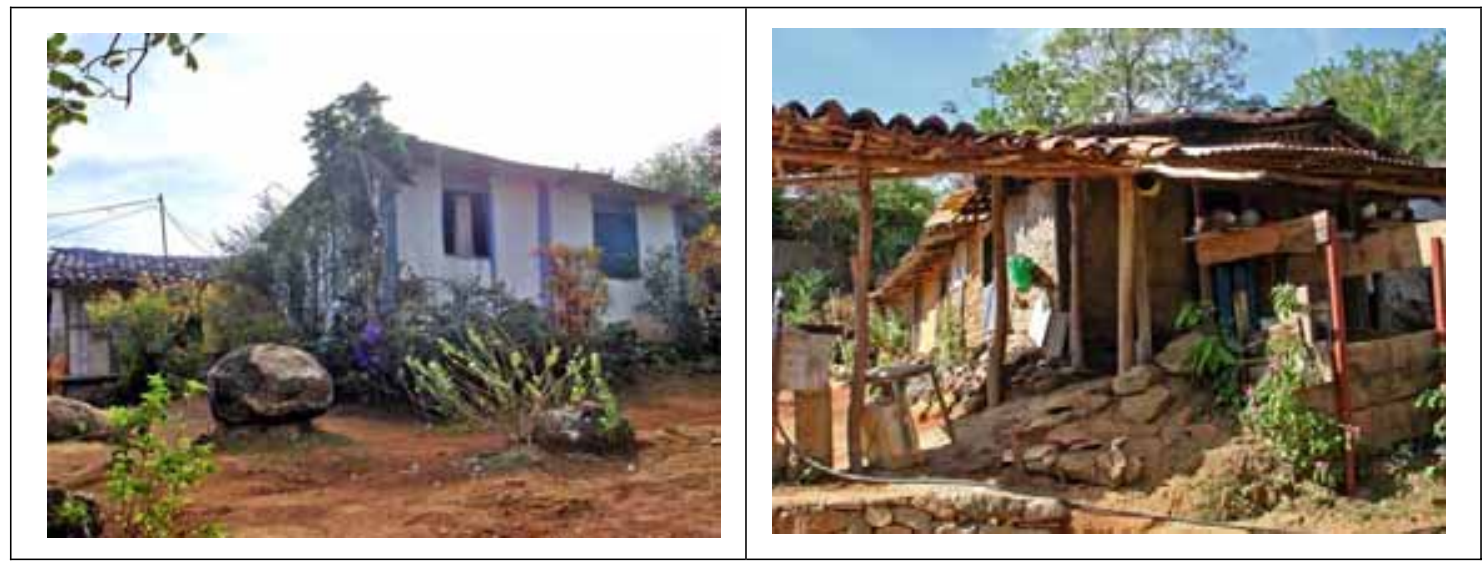

Data e local de nascimento: Guanxuma

Filiação: Sebastião Euzébio de Morais e Tereza Maria de Jesus (Guanxuma)

Estado Civil: Viúva

Atividade profissional: Trabalhos domésticos (aposentada, recebe pensão do INSS))

Enteado: Otávio Barbosa de Jesus

Data e local de nascimento: Canto do Ribeirão, 67 anos

Filiação: Benedito Barbosa de Jesus, Canto do Ribeirão e Paula Maria de Jesus, Búzios

Atividade profissional: aposentado (invalidez) recebe pensão do INSS

Filhos: Lilian, 11 anos, filha de Denise e Manoel, neta de S. Pedro Euzébio, mora com eles.

Observações: Entrevista realizada com Celeste e Otávio em 25/04/07.

S. Otávio declarou que a família de seu pai era de Pernambuco e que ele, seu pai, nasceu e foi criado no engenho velho, que ficava próximo da chegada da estrada, antes da cachoeira.

A fazenda de S. Barbosa produzia principalmente banana e as plantações iam até a serra. Colhia cerca de 60 a 80 dúzias de cachos. Da serra até a cachoeira, os cachos de banana vinham nas costas dos trabalhadores. O carro de boi trazia da cachoeira até a praia e da praia, a banana era levada de canoa até o barco que vinha de Santos buscar a banana. Tinham vários barcos que faziam o transporte de mercadorias da Ilhabela para Santos, foram mencionados o Irati e o Ubatuba.

Declarou também que, além da banana, os barcos transportavam para Santos pimenta e passarinhos, especialmente macucos e tucanos que eram caçados e ficavam aprisionados em gaiolas esperando para serem embarcados.

O S. Barbosa também tinha um pequeno armazém que ficava no canto da praia onde depois o S. Pedro Euzébio fez sua casa primeira casa (canto da praia).

D. Celeste contou que as vezes o Barbosa aproveitava o barco e ia junto com sua produção para Santos onde ia comprar mercadorias para abastecer sua venda. Trazia carne seca, latarias, querosene, fumo, 


\section{CADASTRO DAS FAMÍLIAS RESIDENTES NA BAÍA DOS CASTELHANOS PRAIA DOS CASTELHANOS - CANTO DO RIBEIRÃO}

cigarro, sal, bolacha, macarrão, bebidas, sabão, sabonete...A venda tinha de tudo e vinha gente de todos os cantos da Baia dos Castelhanos, até do Sombrio vinha gente para fazer compra na venda. Contou também que a roça produzia de tudo: batata doce, milho, abóbora, mixirica, mandioca para farinha e para comer. Tinha também as criações, galinha, pato, porco (faziam muita banha) mas tudo era para o consumo da família, para vender era mais a banana, a pimenta e os passarinhos. "Naquele tempo não era como hoje que é tudo proibido".

O Barbosa tinha ainda dois cercos, um na Laje Preta e outro em sociedade na Figueira.

Informaram que o Leonardo não morava nos Castelhanos. Tinha um encarregado que cuidava do engenho. "Favorita" era a marca da pinga produzida no engenho.

Antes da estrada, não tinha canoa-a-motor e os moradores faziam a pé a viagem para a cidade. lam fazer compras, que traziam nas costas (aproximadamente $20 \mathrm{~kg}$ ). Também visitavam parentes, iam ao médico e os homens gostavam de ir ao prostíbulo em São Sebastião, ali perto da igreja naquela rua que desce da praça para a praia. Quando tinham dinheiro, ficavam a noite toda festejando.

Atualmente precisam pagar cerca de $\mathrm{R} \$ 300,00$ para os jipeiros para fazer uma viagem de ida e volta da cidade.

Total de moradores: 3 


\section{CADASTRO DAS FAMÍLIAS RESIDENTES NA BAÍA DOS CASTELHANOS PRAIA DOS CASTELHANOS - CANTO DO RIBEIRÃO}

FAMÍLIA DE: $\quad$ FERNANDO HENRIQUE DA SILVA

LOCALIZAÇÃO UTM: $\quad 471.167 / 7.362 .526$

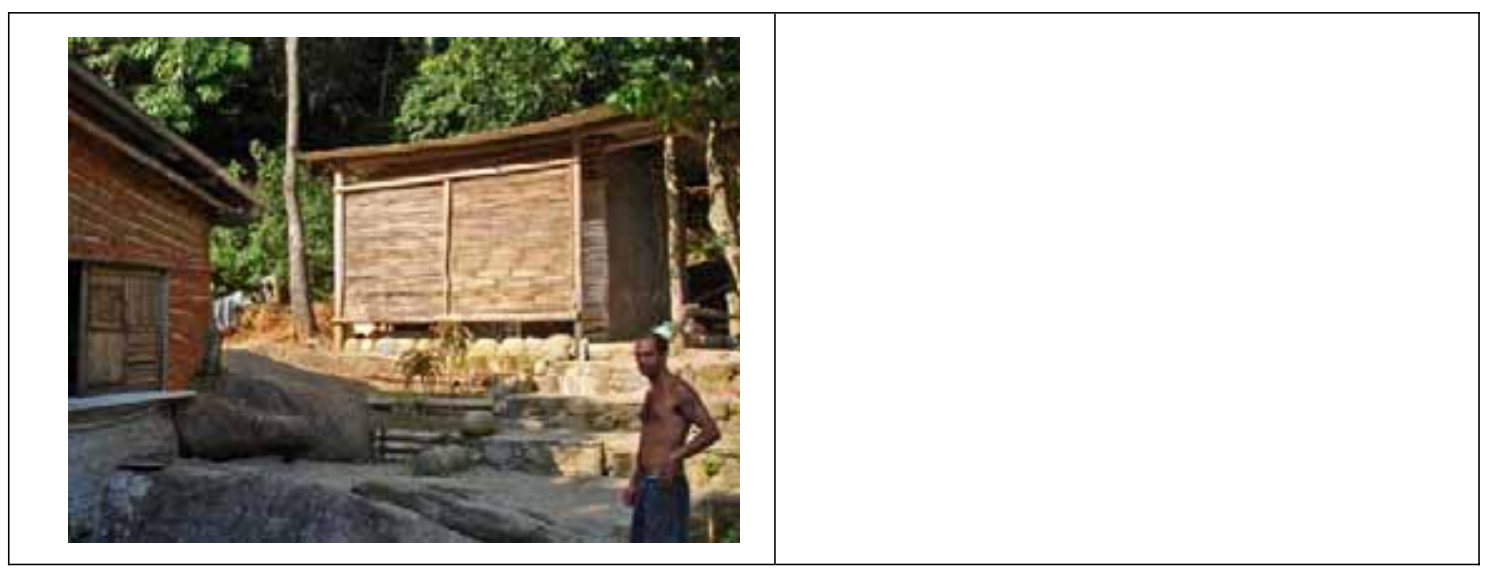

Data e local de nascimento: (?) (?)

Filiação: (?)

Estado Civil: Casado

Atividade profissional: dono de restaurante

Esposa: Tamires

Data e local de nascimento (?)

Filiação: (?)

Atividade profissional: (?).

Filhos: Allana da Silva

Observações: TURISTA

Total de moradores: 3

TOTAL DE MORADORES TURISTAS:

TOTAL DE MORADORES INSTITUCIONAIS: 


\title{
CADASTRO DAS FAMÍLIAS RESIDENTES NA BAÍA DOS CASTELHANOS \\ PRAIA DOS CASTELHANOS - CANTO DA LAGOA
}

\author{
FAMÍLIA DE: $\quad$ EROTILDES TEIXEIRA DA LUZ (68), ALHÃ \\ LOCALIZAÇÃO UTM : $\quad 470.601 / 7.361 .200$
}

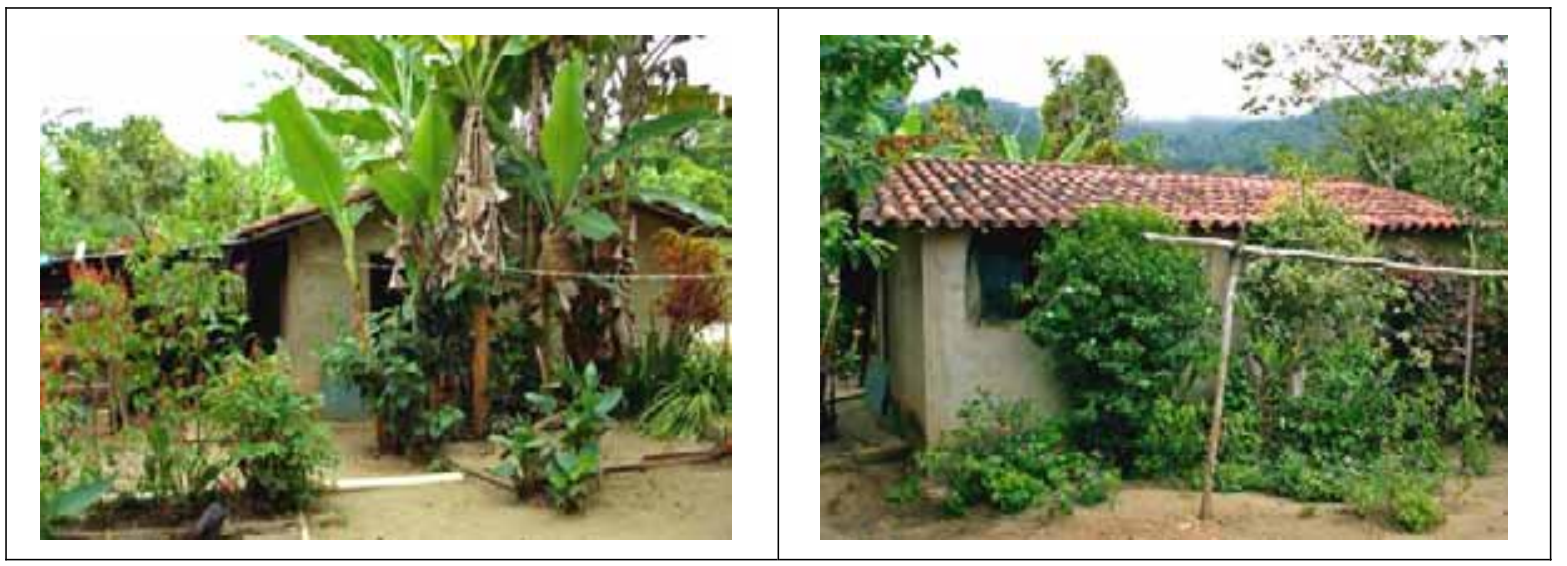

Data e local de nascimento: Saco do Sombrio em 24/09/1939 (68 anos)

Filiação: Julio Teixeira da Luz, Galhetas e Pedrina Teixeira da Luz, Indaiauba.

Estado Civil: Viúva de Pedro Francisco, Canto da Lagoa.

Atividade profissional: Aposentada

Filhos: Vive com ela seu neto Alan, filho de Cilene.

Observações: Entrevista realizada em 06/03/07

Informou que nasceu na Praia Mansa mas foi criada junto de seus 7 irmãos nas Galhetas. Nas Galhetas, a família vivia da lavoura. Produziam mandioca, feijão, milho, farinha, banana, mixirica... A banana era entregue para o barco e transportada para Santos.

Seu pai trabalhou, como assalariado, no cerco de Sr. Kamati.

Declarou que as terras do Canto do Ribeirão onde moram os familiares do S. Pedro Euzébio, são de propriedade dos herdeiros do Sr.. Leonardo Reale. No tempo do engenho, o Sr. Leonardo morava na cidade.

Contou que morava com a família de S. Pedro e Maria Alice e que a Maria Alice abandonou o S. Pedro e sua filha Marciana, recém nascida. Maria Alice tinha outras duas filhas de outros casamentos (Vivian e Cilene). Erotildes passou a cuidar das 3 meninas, principalmente de Marciana que era nenê ainda. E com isso passou a viver com ele como sua mulher.

Sua principal fonte de renda é a pensão do INSS (R\$380,00).

Total de moradores: 2 


\title{
CADASTRO DAS FAMÍLIAS RESIDENTES NA BAÍA DOS CASTELHANOS \\ PRAIA DOS CASTELHANOS - CANTO DA LAGOA
}

\author{
FAMÍLIA DE: \\ CILENE DE SOUZA E ÁUREO RAFAEL DE SOUZA \\ LOCALIZAÇÃO UTM: \\ $470.569 / 7.361 .192$
}

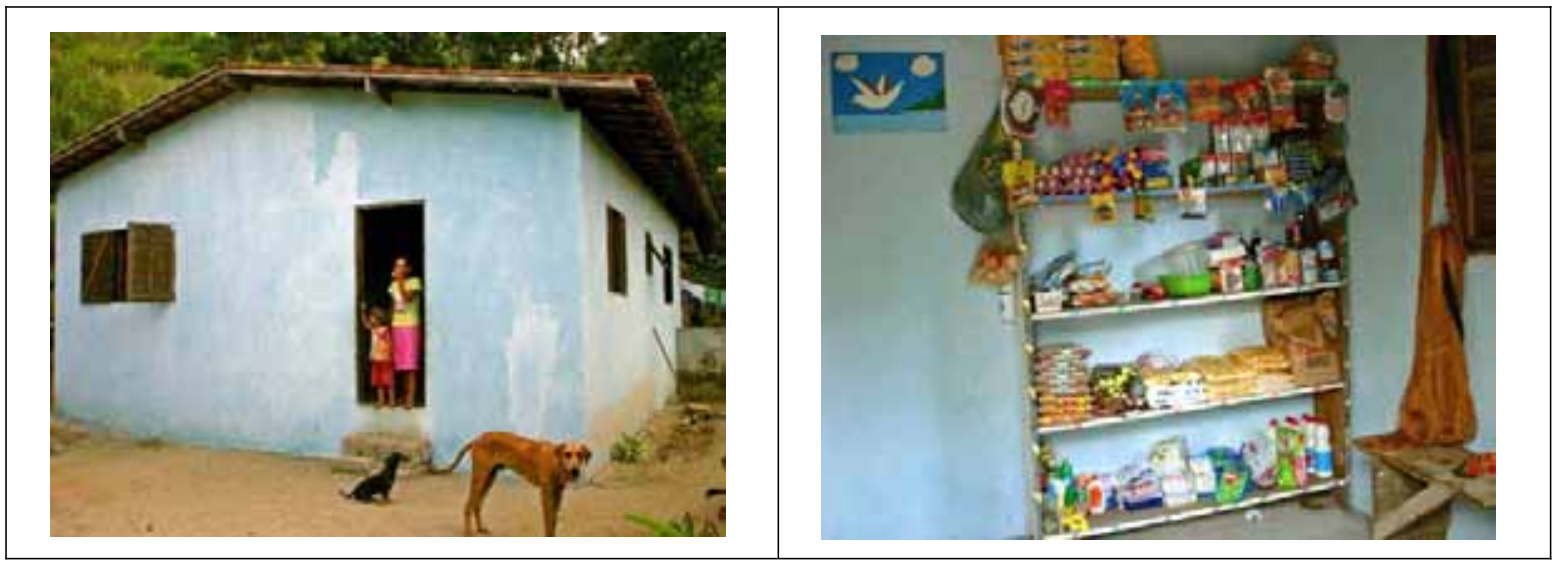

Data e local de nascimento: Praia Mansa

Filiação: Laércio de Souza, Praia Mansa e Maria Alice Gonçalves

Estado Civil: Casada

Atividade profissional: Pescadora, tem uma canoa; tem uma pequena venda em sua casa; faxineira em casa de turista.

Esposo: Áureo Rafael de Souza

Data e local de nascimento: P. Vermelha

Filiação: Pedro Rafael de Souza (Pedro Madalena), Praia Vermelha e Pedrina dos Santos Souza, P. Mansa.

Atividade profissional: Pescador, proprietário de cerco em sociedades com os irmãos e o pai na P. Vermelha. Tem canoa-a-motor.

Filhos: , Felipe e Samuel de Souza. Alan, filho de Cilene e Paulo de Souza, mora com a Avó Erotildes.

Observações: Entrevista realizada com Cilene em 07/03/07

Felipe também é filho do primeiro casamento.

A principal fonte de renda da família decorre da atividade profissional de Áureo.

Total de moradores: 4 


\section{CADASTRO DAS FAMÍLIAS RESIDENTES NA BAÍA DOS CASTELHANOS \\ PRAIA DOS CASTELHANOS - CANTO DA LAGOA}
FAMÍLIA DE:
VIVIAN GONÇALVES E ARLINDO DE SOUZA
LOCALIZAÇÃO UTM:
470.607 / 7.361 .179

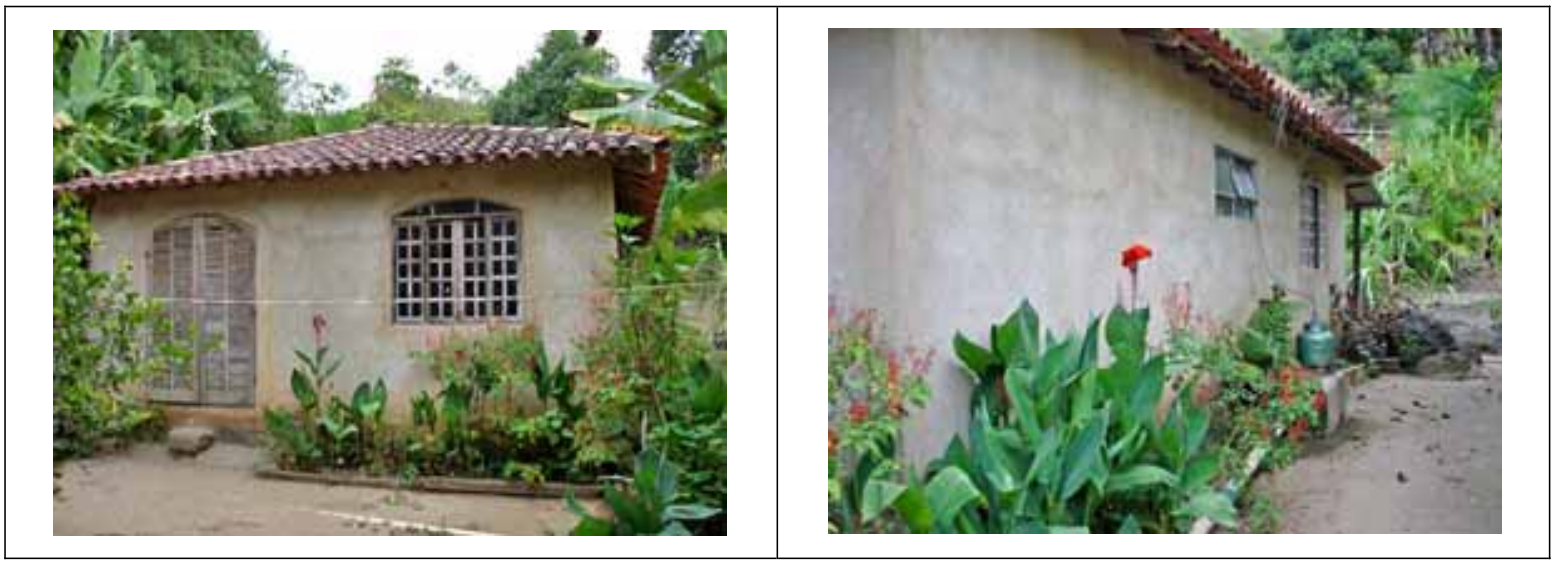

Data e local de nascimento: P. dos Castelhanos - Canto da Lagoa

Filiação: (?) e Maria Alice Gonçalves, P. dos Castelhanos - Canto da Lagoa.

Estado Civil: Casada

Atividade profissional: Proprietária do Restaurante dos Castelhanos.

Esposo: Arlindo de Souza (Sivoca)

Data e local de nascimento: P. Mansa, 1966

Filiação: Juvenal de Souza (P. Mansa) e Jessi dos Santos (Canto do Ribeirão)

Atividade profissional: Pescador, proprietário de cerco e de redes. Tem canoa-a-motor; presta serviço para a prefeitura - preparação da merenda escolar

Filhos: Pedro, Thiago e Aline Gonçalves de Souza

\section{Observações:}

- Possui gerador que alimenta um conjunto de lâmpadas, televisão e aparelho de som.

- Arlindo informou que um cerco velho completo custa entre $\mathrm{R} \$ 3.000,00$ e $\mathrm{R} \$ 5.000,00$. Já um cerco novo sai por aproximadamente $\mathrm{R} \$ 10.000,00$. Para cortar um cerco (cortar e dispor as panagens, inclusive as do caminho, de forma a adequar o cerco ao local aonde ele vai pescar - profundidade, distância da costeira etc) custa cerca de $\mathrm{R} \$$ $2.000,00$, podendo chegar a $\mathrm{R} \$ 3.000,00$.

- Entrega os peixes nas peixarias de Ilhabela e São Sebastião. As quantidades e qualidades do pescado variam muito, mas o movimento semanal médio é estimado em $R \$ 300,00$. Tem peixe que não pega nem $R \$ 1,00$ por $\mathrm{kg}$. Outros chegam a $R \$ 14,00 / \mathrm{kg}$. No verão, tempo de lula que tem ótimo preço no mercado, o movimento financeiro é bem maior. Também nos feriados, finais de semana e temporada, entrega o peixe para os restaurantes e campings da praia. Entrega o peixe limpo e filetado, o que agrega valor ao pescado.

- Em relação à pesca, basicamente compra gelo e óleo diesel na cidade. O gelo custa $\mathrm{R} \$ 3,00$ / por saco de $20 \mathrm{~kg}$ de gelo picado. O peixe é armazenado em gelo picado em caixas grandes de isopor, atrás do seu restaurante. O diesel custa $\mathrm{R} \$ 2,20$ na cooperativa e consome cerca de 40 litros de óleo por viagem, ida e volta. 


\section{CADASTRO DAS FAMÍLIAS RESIDENTES NA BAÍA DOS CASTELHANOS PRAIA DOS CASTELHANOS - CANTO DA LAGOA}

- O Arlindo também armazena e transporta para a cidade o peixe do pessoal do Canto do Ribeirão e de outros pescadores dos Castelhanos e de outras praias que não têm canoa a motor. Cobra apenas o gelo e o óleo correspondente ao volume transportado.

- O Arlindo tem projeto adiantado de construir uma peixaria em sua propriedade.

- Em relação à propriedade imobiliária,o Arlindo conta que há muitos anos atrás os avós da Vivian venderam todas as terras de herança da família, assim como os seus vizinhos, o pessoal da família Lucio, também venderam.

Venderam, mas continuaram morando no lugar, pois o comprador não "tomou posse" das terras compradas. Mais recentemente apareceram um advogado e dois "sujeitos mal encarados", a mando de um tal de Alberto Neves, pedindo que ele, Arlindo, saísse da terra, uma vez que esse Alberto era o novo dono. O Arlindo conta que o primeiro comprador, parece que o Alberto Estoráceo, aproveitou-se da ingenuidade, ignorância e do fato do avô da Vivian estar bêbado, para fazer negócio. Conta que, por estas razões, os descendentes não tinham para onde ir, permaneceram na propriedade (também o novo dono não veio reclamar a posse) e que depois de tanto tempo (uns 20 anos, mais ou menos) não iam entregar o lugar onde estavam morando para alguém que se dizia o novo dono da propriedade. Depois disso, o Arlindo disse que a prefeitura fez um acordo com os parentes da Viviam, herdeiros como ela dessa faixa de terra, demarcou o lote que cada um estava ocupando e legalizou a posse. Parece que o pessoal do Lucio, que viveu situação semelhante, não fez acordo. Outros parentes da Vivian, depois da venda inicial, ficaram por um tempo na terra e depois venderam a parte que ocupavam pela segunda vez. - O Arlindo declarou que paga $\mathrm{R} \$ 104,00$ por mês de imposto predial.

Total de moradores: 5 


\section{CADASTRO DAS FAMÍLIAS RESIDENTES NA BAÍA DOS CASTELHANOS \\ PRAIA DOS CASTELHANOS - CANTO DA LAGOA}

FAMÍLIA DE:

LUIZ CARLOS DE OLIVEIRA E NAIR RANGEL DE SOUZA

LOCALIZAÇÃO UTM:

$470.490 / 7.361 .189$

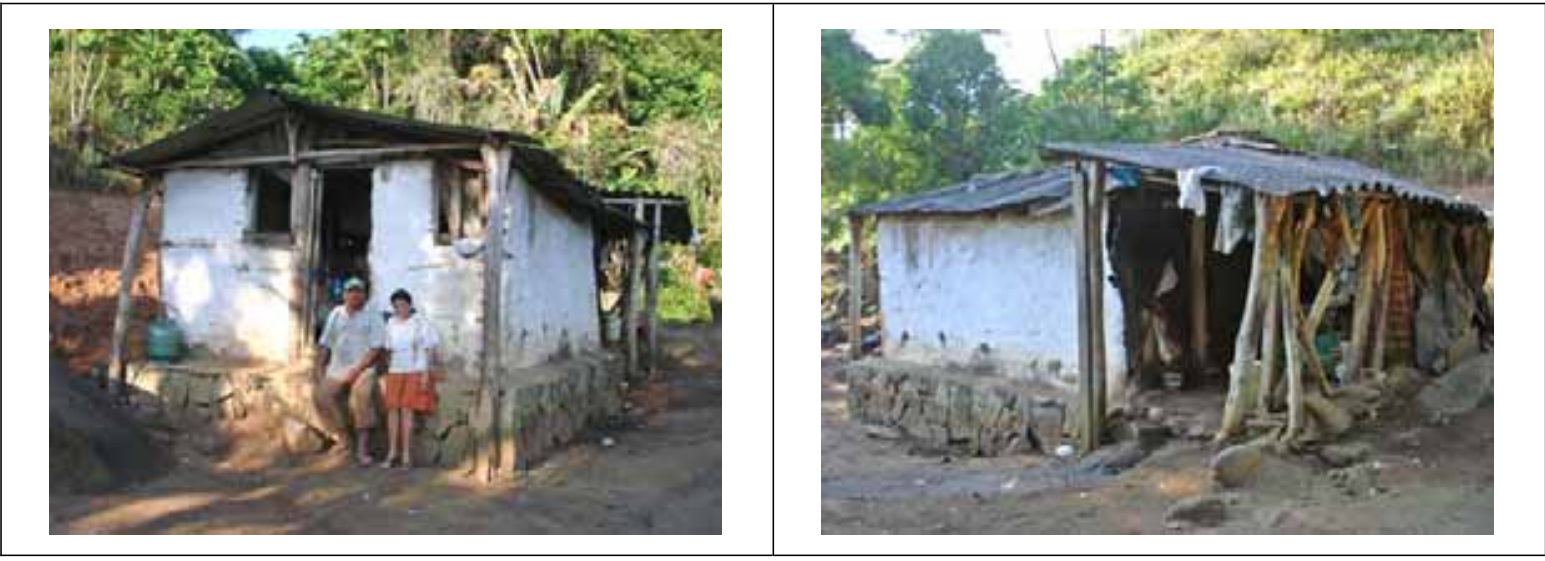

Data e local de nascimento: Praia dos Castelhanos, 54 anos

Filiação: Agostinho Henrique de Oliveira (Guanxuma) e Maria Gonçalves de Oliveira (Castelhanos)

Estado Civil: Casado

Atividade profissional: Pescador, possui uma canoa a remo. Pesca de linha.

Esposa: Nair de Souza Rangel

Data e local de nascimento Praia dos Sonhos, 54 anos

Filiação: Pais desconhecidos, foi criada na Praia dos Sonhos

\section{Observações:}

- Nair teve vários filhos com o primeiro marido - Henrique de Ubatuba e que morreu assassinado em Ilhabela - e 3 (Adriano Rangel de Souza, André Ricardo e Fernando) vieram junto com ela para os Castelhanos depois que se casou com o Luiz.

- Luiz informou que as terras de propriedade de seus avós, antes da existência da estrada, foram vendidas para o Sr. Alberto Estoráceo, que é dono da P. da Serraria, e este, mais recentemente, vendeu para o Sr. Alberto Neves. - A casa deles e a dos filhos foi construída na terra que originalmente pertencia a sua família.

- Luiz foi morar em São Sebastião depois que as terras foram vendidas. Foi o Arlindo que trouxe ele de volta para os Castelhanos.

Total de moradores: 2 


\section{CADASTRO DAS FAMÍLIAS RESIDENTES NA BAÍA DOS CASTELHANOS \\ PRAIA DOS CASTELHANOS - CANTO DA LAGOA}

FAMÍLIA DE:

LOCALIZAÇÃO UTM:
ADRIANO E ANDRÉ RANGEL DE SOUZA (IRMÃOS)

$470.427 / 7.361 .182$

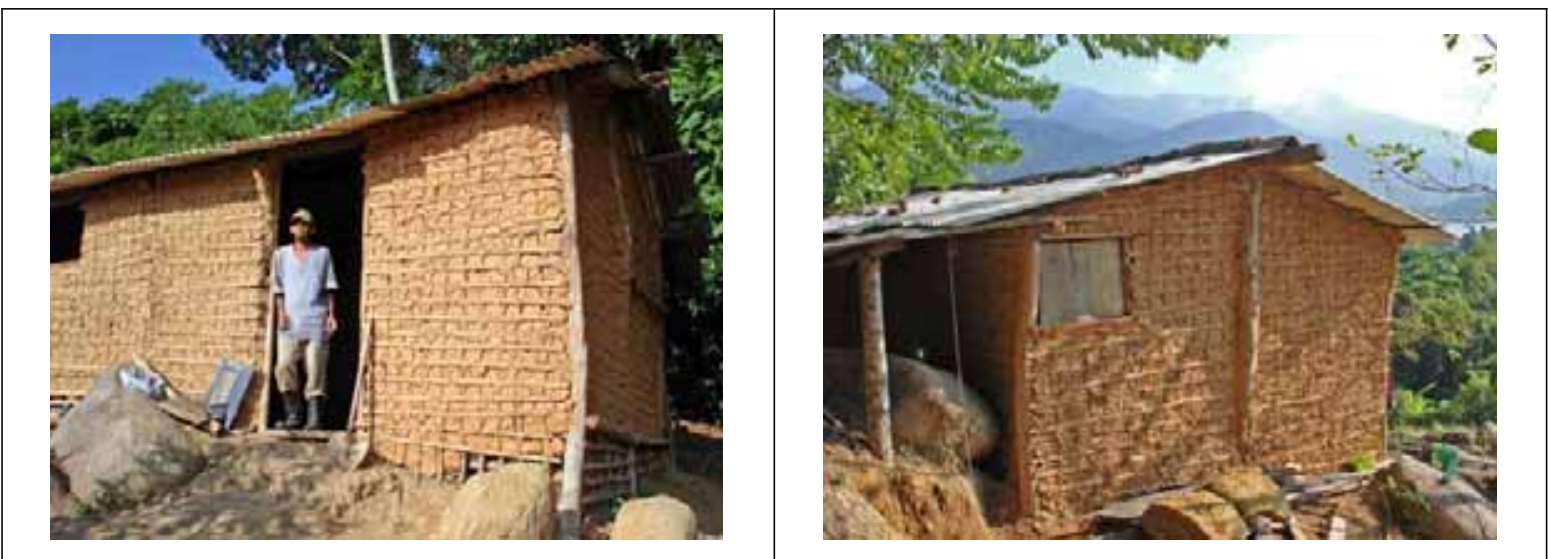

Adriano

Data e local de nascimento: Ilha de Búzios, 24 anos

Filiação: Nair Rangel de Souza (Praia dos Sonhos) e Henrique (Ubatuba)

Estado Civil: Solteiro

Atividade profissional: Pescador, pesca basicamente de linha, possui uma canoa a remo e uma rede. Presta serviços diários (limpeza de terreno, roçada, no bar do Fabio (antigo Canindé). Recebe R\$200,00 / mês

André

Data e local de nascimento: Ilha de Búzios, 15 anos

Filiação: Nair Rangel de Souza (Praia dos Sonhos) e Henrique (Ubatuba)

Estado Civil: Solteiro

Atividade profissional: Pescador, pesca basicamente de linha, possui uma canoa a remo

Total de moradores: 2 


\section{CADASTRO DAS FAMÍLIAS RESIDENTES NA BAÍA DOS CASTELHANOS \\ PRAIA DOS CASTELHANOS - CANTO DA LAGOA}

FAMÍLIA DE:

ONÉZIO GONÇALVES (BARROSO)

LOCALIZAÇÃO UTM:

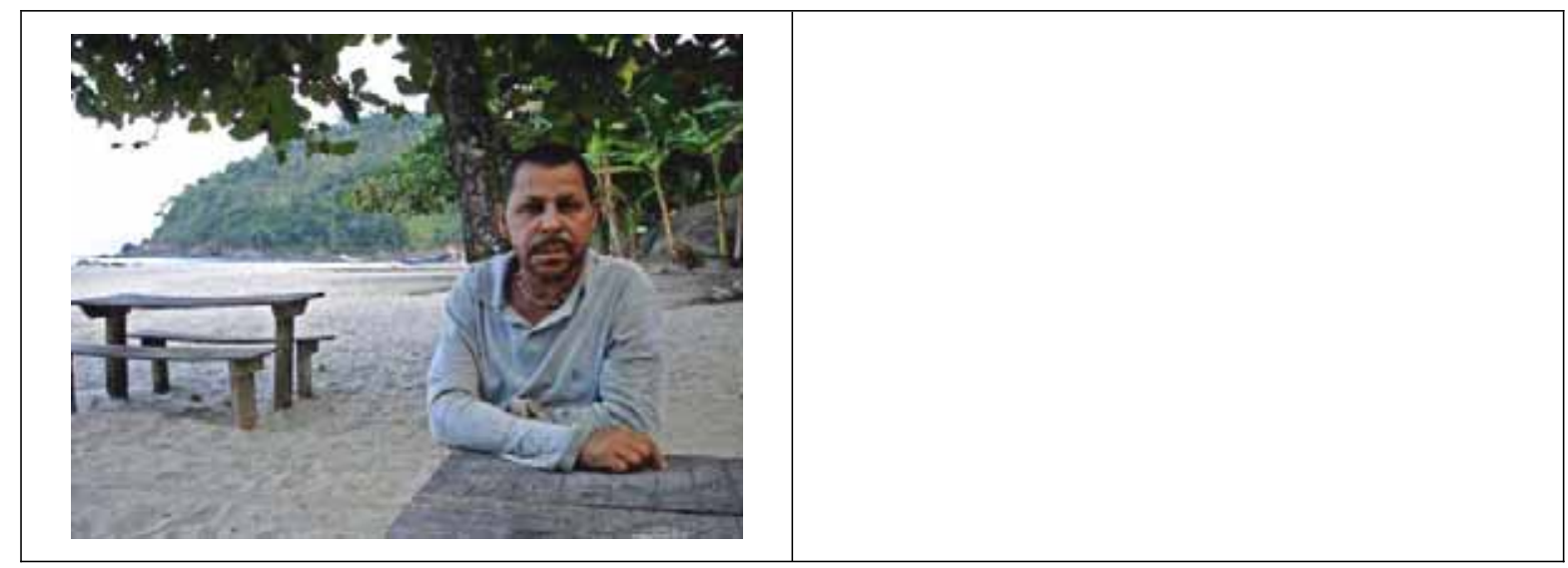

Data e local de nascimento: P. dos Castelhanos - Canto da Lagoa, 46 anos

Filiação: (Pedro Francisco Gonçalves e Alice de Oliveira ?)

Estado Civil: Solteiro

Atividade profissional: Presta serviços diários (limpeza de terreno, roçada etc.

Observações: Não tem moradia fixa, dorme nos ranchos ou onde permitem.

Total de moradores: 1 


\section{CADASTRO DAS FAMÍLIAS RESIDENTES NA BAÍA DOS CASTELHANOS \\ PRAIA DOS CASTELHANOS - CANTO DA LAGOA}

FAMÍLIA DE: $\quad$ Milton e Silvia de Souza Lucio

LOCALIZAÇÃO UTM: $\quad 0470.603 / 7.361 .085$

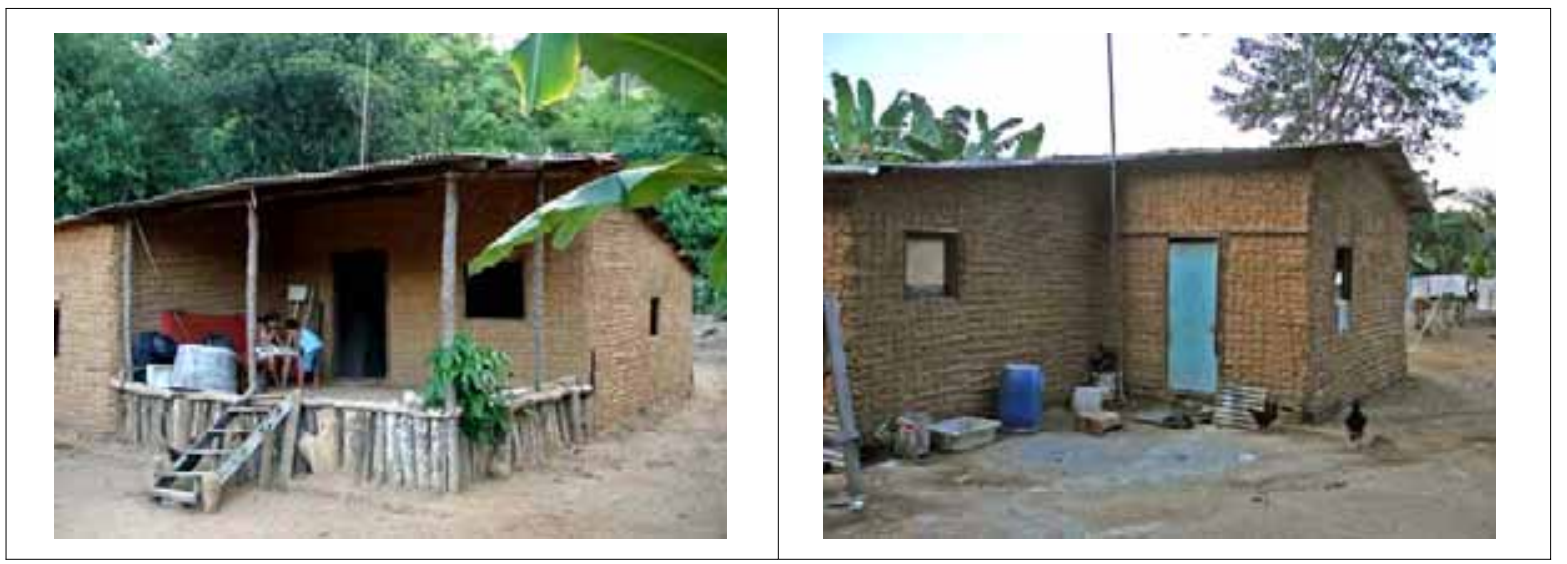

Data e local de nascimento: Praia dos Castelhanos (Lagoa), 42 anos

Filiação: Joaquim Lucio, Praia dos Castelhanos e Conceição de Souza Lucio, Praia Vermelha

Estado Civil: Casado

Atividade profissional: Pescador, possui 1 canoa-a-remo pequena, trabalha de camarada no cerco dos irmãos

Esposa: Silvia de Souza Lucio

Data e local de nascimento: Praia dos Castelhanos (Lagoa), 34 anos

Filiação: Alvira Madalena de Souza, Praia Mansa, e João Lucio de Jesus, Praia dos Castelhanos (Lagoa)

Atividade profissional: Presta serviço de faxina 1 dia/semana na casa de Dr. Rubens, perto do Maremar; Pescadora

Filhos: Lenita, Silvano, Lucas e Ezequiel de Souza Lucio

Obeservações: Entrevista realizada com Silvia. Informou que o peixe é vendido junto com o dos irmãos. Quando precisa trazer alguma compra da cidade, paga para o jipeiro $R \$ 150,00$. Viagem de ida e volta sai até por $R \$$ 350,00 .

Total de moradores: 6 
CADASTRO DAS FAMÍLIAS RESIDENTES NA BAÍA DOS CASTELHANOS

PRAIA DOS CASTELHANOS - CANTO DA LAGOA

FAMÍLIA DE:

JAIRO DE SOUZA LUCIO

LOCALIZAÇÃO UTM:

$470.646 / 7.361 .063$

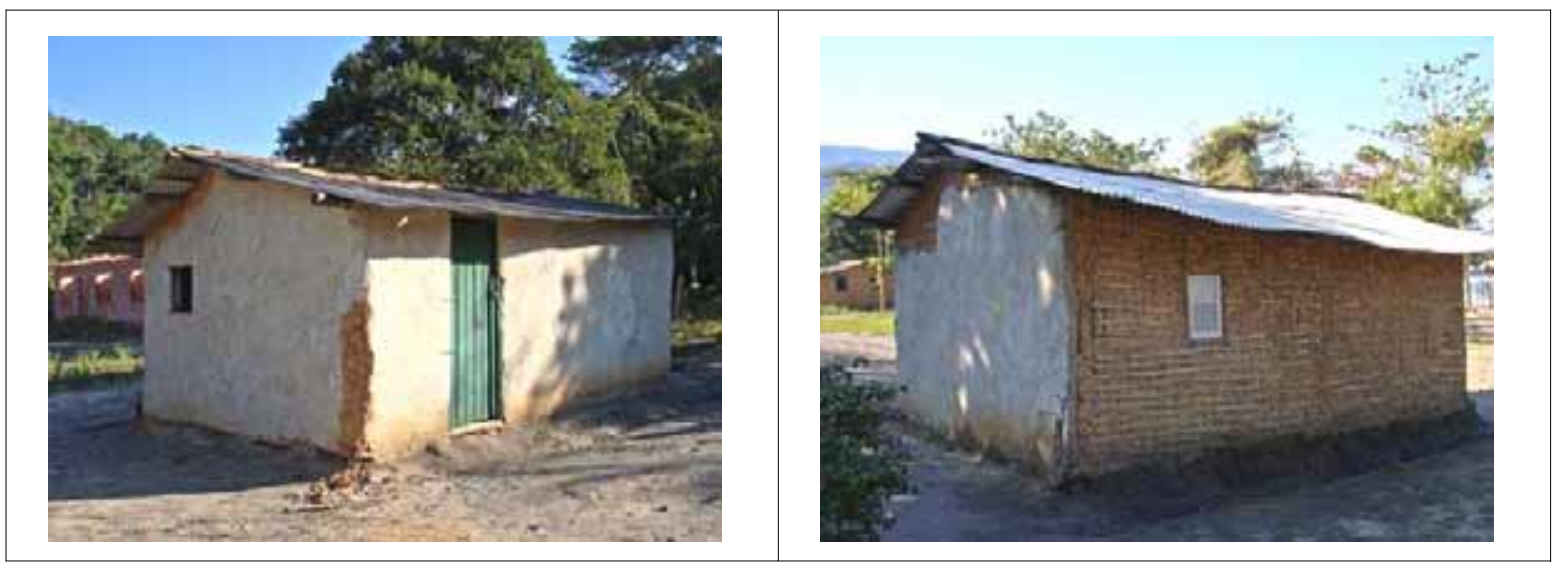

Data e local de nascimento: Canto da Lagoa, 25 anos

Filiação: Joaquim Lucio, Praia dos Castelhanos e Conceição de Souza Lucio, Praia Vermelha

Estado Civil: Solteiro

Atividade profissional: Pescador; tem uma canoa a remo.

Observações:

Trabalha de camarada no cerco do Irineu.

Total de moradores: 1 


\section{CADASTRO DAS FAMÍLIAS RESIDENTES NA BAÍA DOS CASTELHANOS \\ PRAIA DOS CASTELHANOS - CANTO DA LAGOA}
FAMÍLIA DE:
JOAQUIM DE SOUZA LUCIO
LOCALIZAÇÃO UTM:
$470.625 / 7.361 .109$

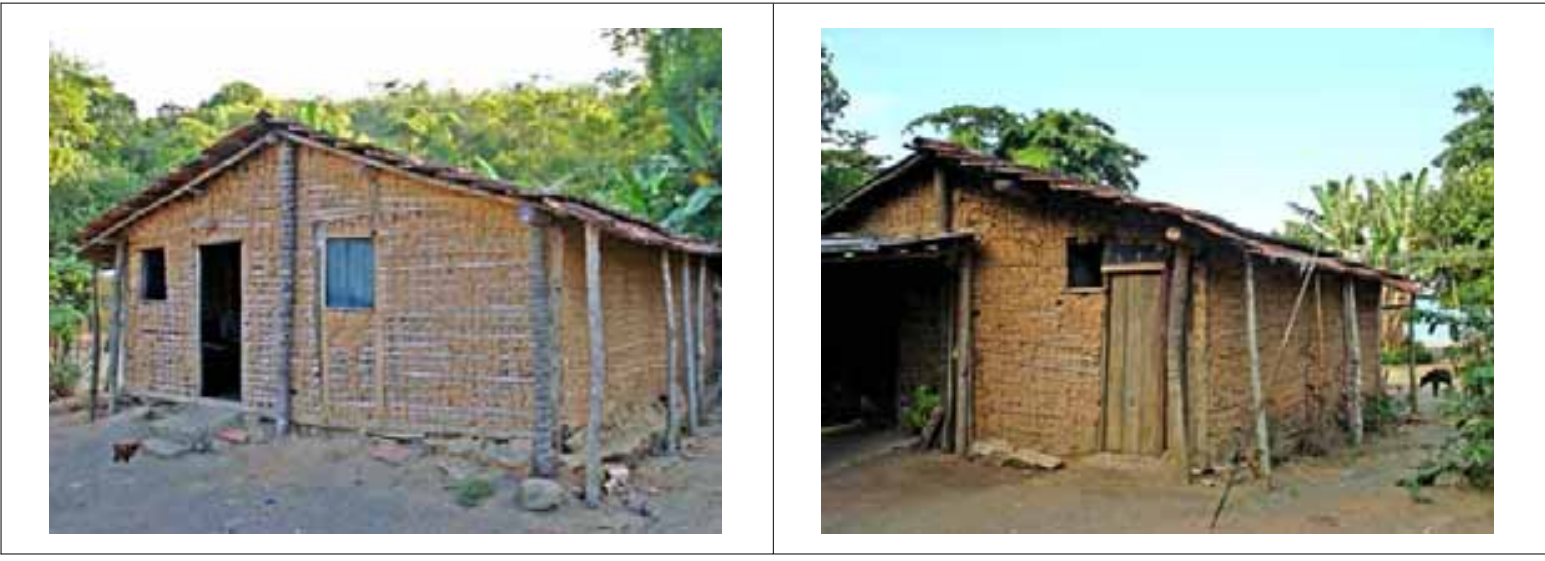

Data e local de nascimento: Praia dos Castelhanos, 1928

Filiação: Benedito Lucio, Praia Mansa e Sebastiana Luz, Praia Mansa

Estado Civil: Casado

Atividade profissional: Pescador; Roça; atualmente está aposentado e recebe pensão do INSS

Esposa: Conceição de Souza Lucio

Data e local de nascimento: Praia Vermelha, 64 anos

Filiação: Pedro Madalena Rafael de Souza (irmão de Manoel Madalena, que é pai de Pedro Madalena da P.

Vermelha) e Juventina, Praia dos Castelhanos.

Atividade profissional: Aposentada, Recebe pensão do INSS

Moradores: Benedito Firmino Lucio, irmão de Joaquim

Observações: Entrevista realizada com Joaquim e Conceição. Informaram que muita gente trabalhava no Engenho do Leonardo Reali e recebiam em dinheiro. Quem trabalhava no canavial, ganhava cerca de 500 réis por dia e que trabalhava no machado, recebia entre 1500 a 2000 réis por dia. $1 \mathrm{~K}$ de carne seca custava 1.500 réis na venda do Barbosa. Também tinha os bananais do Leonardo, Barbosa e Manoel Rafael. Eles pagavam + ou - a mesma coisa (500 réis). O mesmo barco levava a Banana e a pinga coma freqüência de 1 vez por mês. Tinha sua própria roça. Produzia-se de tudo. Muita criação, galinha, pato, porco (produzia banha), batata-doce, feijão, milho, abóbora, melancia, abacaxi, mexerica. Atualmente ninguém da família tem roça.

Lembra bem da presença dos japoneses pescando. Lembra-se de 3 cercos de japoneses, mas informa que brasileiros também tinham cerco. Assim como na roça, os camaradas do cerco ganhavam em dinheiro, 500 réis por dia e depois passou para 700 réis.

Por volta de 1950 fez seu próprio cerco que pescava na ponta da Lagoa. Atualmente está aposentado e são os filhos que continuam com o cerco, agora pescando no ilhote Grande (canto do Ribeirão). O pescado é transportado para Ilhabela na canoa dos sobrinhos que cobram o óleo diesel consumido e mais $\mathrm{R} \$ 1,00$ por quilo transportado.

Declarou que algumas vezes paga aos jipeiros para fazer viagens à cidade: $\mathrm{R} \$ 300,00$ ida e volta (está bem idoso e doente e não pode viajar de canoa). Recebe pensão do INSS: R\$ 380,00.

Total de moradores: 3 


\section{CADASTRO DAS FAMÍLIAS RESIDENTES NA BAÍA DOS CASTELHANOS \\ PRAIA DOS CASTELHANOS - CANTO DA LAGOA}

FAMÍLIA DE:

LOCALIZAÇÃO UTM:
HAROLDO DE SOUZA LUCIO

$470.635 / 7.361 .098$

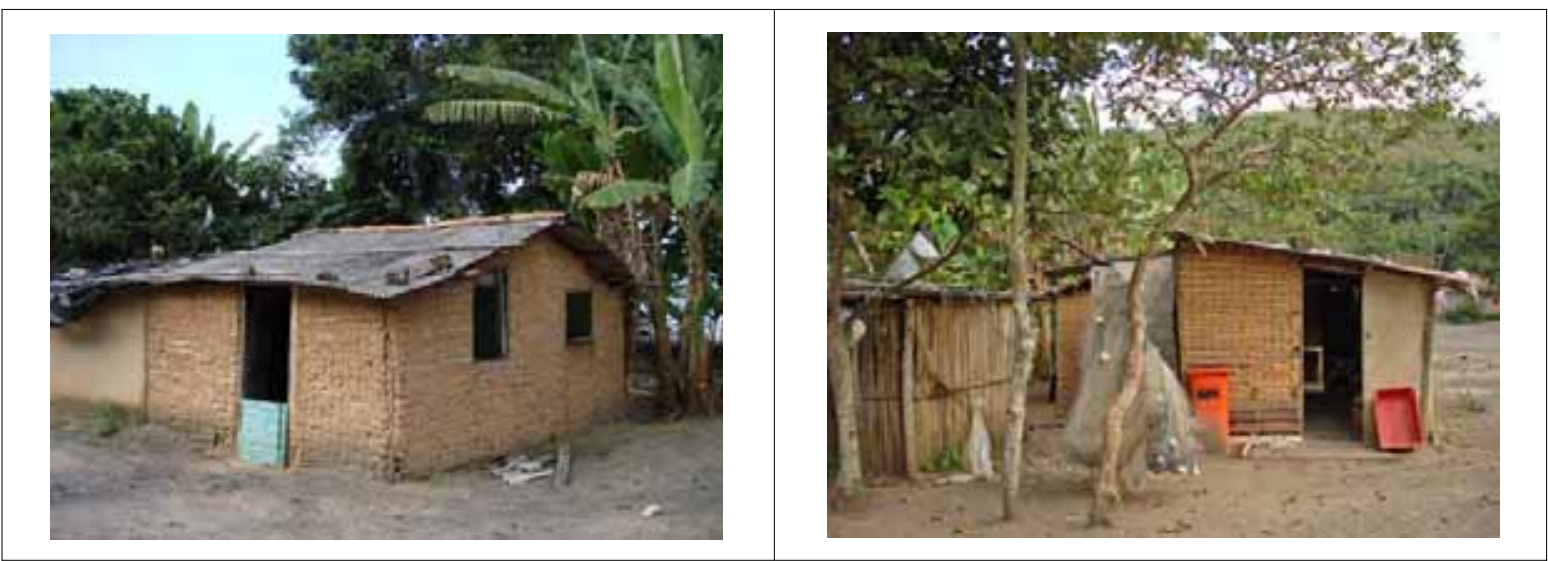

Data e local de nascimento: Canto da Lagoa, 36 anos.

Filiação: Joaquim Lucio, Praia dos Castelhanos e Conceição de Souza Lucio, Praia Vermelha

Estado Civil: Solteiro

Atividade profissional: Pescador; tem rede; tem canoa.

Total de moradores: 1 


\section{CADASTRO DAS FAMÍLIAS RESIDENTES NA BAÍA DOS CASTELHANOS}

PRAIA DOS CASTELHANOS - CANTO DA LAGOA

FAMÍLIA DE:

LOCALIZAÇÃO UTM:
ALTAMIR E ROSALVA DE SOUZA LUCIO

$470.634 / 7.361 .123$

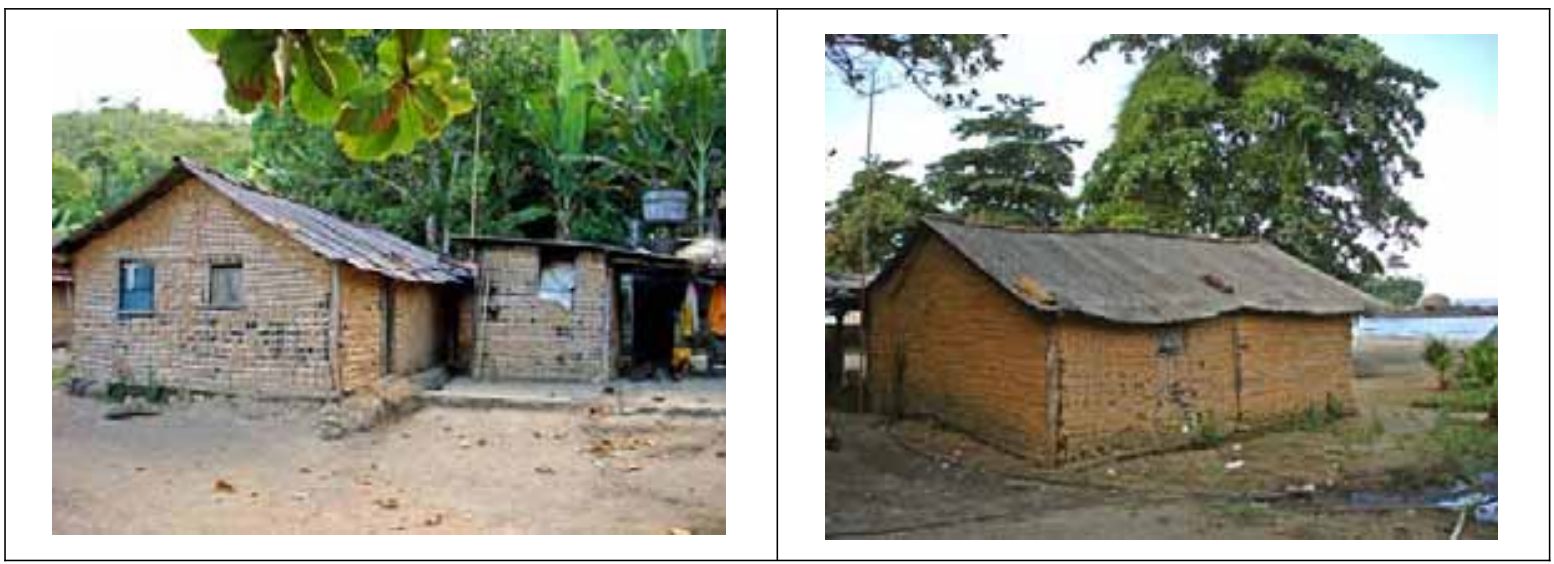

Data e local de nascimento: Canto da Lagoa, 41 anos

Filiação: Joaquim Lucio, Praia dos Castelhanos e Conceição de Souza Lucio, Praia Vermelha

Estado Civil: Casado

Atividade profissional: Pescador;

Esposa: Rosalva de Souza Lucio

Data e local de nascimento: P. dos Castelhanos, Canto da Lagoa, 33 anos

Filiação: João Lucio de Jesus e Elvira Madalena de Souza

Atividade profissional:

Filhos: Vanessa e Altamiro de Souza Lucio Jr

Total de moradores: 4 


\section{CADASTRO DAS FAMÍLIAS RESIDENTES NA BAÍA DOS CASTELHANOS}

PRAIA DOS CASTELHANOS - CANTO DA LAGOA

FAMÍLIA DE: LOCALIZAÇÃO UTM:
JOÃO LUCIO E ELVIRA MADALENA DE SOUZA

$470.613 / 7.361 .156$

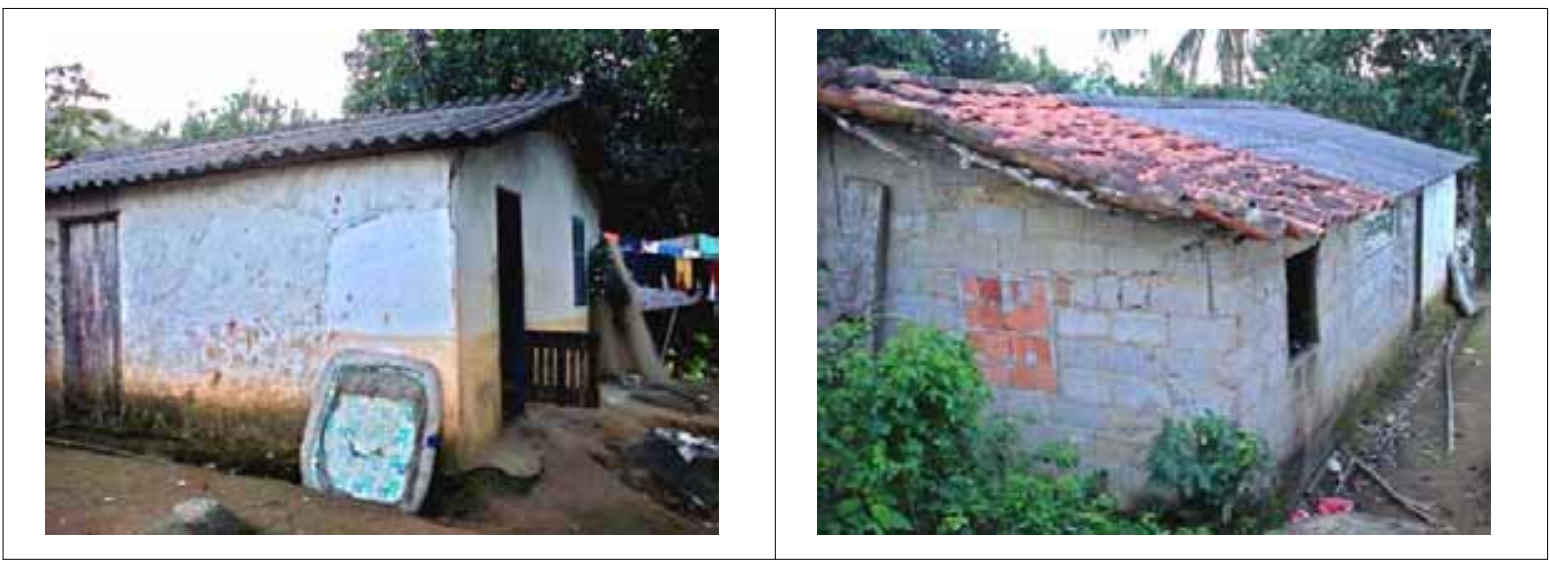

Data e local de nascimento: Praia dos Castelhanos, 75 anos

Filiação: Informou apenas que nasceram nos Castelhanos

Estado Civil: Viúvo

Atividade profissional: ; atualmente está aposentado, recebe pensão do INSS.

Esposa: Elvira Madalena de Souza (falecida)

Data e local de nascimento: Praia Mansa

Filiação: Pedro Rafael de Souza e Maria Madalena de Jesus

Observação:

- Sempre trabalhou na roça, tinha sua própria roça (banana, mandioca ...) mas trabalhou bastante cortando banana no bananal do Barbosa.

-A família de seu filho João de Souza Lucio $\mathrm{F}^{\circ}$ mora na mesma casa e é descrita a seguir:

Filhos: João de Souza Lucio $\mathrm{F}^{\circ}$ casado com Michele Patrícia da Silva

Data e local de nascimento: Praia dos Castelhanos, 26 anos

Filiação: João de Souza Lucio e Elvira Madalena de Souza (falecida)

Estado Civil: Casado

Atividade profissional: Pescador; tem 1 canoa a remo e 1 a motor; tem redes; trabalha de camarada no cerco do Irineu; presta serviços para a prefeitura - limpeza da praia

Esposa: Michele Patrícia da Silva

Data e local de nascimento: Mato Grosso, 19 anos

Filhos: João Marcos Silva de Jesus e Marcela Silva de Jesus

Total de moradores: 5 
CADASTRO DAS FAMÍLIAS RESIDENTES NA BAÍA DOS CASTELHANOS

PRAIA DOS CASTELHANOS - CANTO DA LAGOA

FAMÍLIA DE: $\quad$ CLAUDIO DE SOUZA LUCIO E SIMONE DOS SANTOS

LOCALIZAÇÃO UTM: $\quad 470.616 / 7.361 .152$

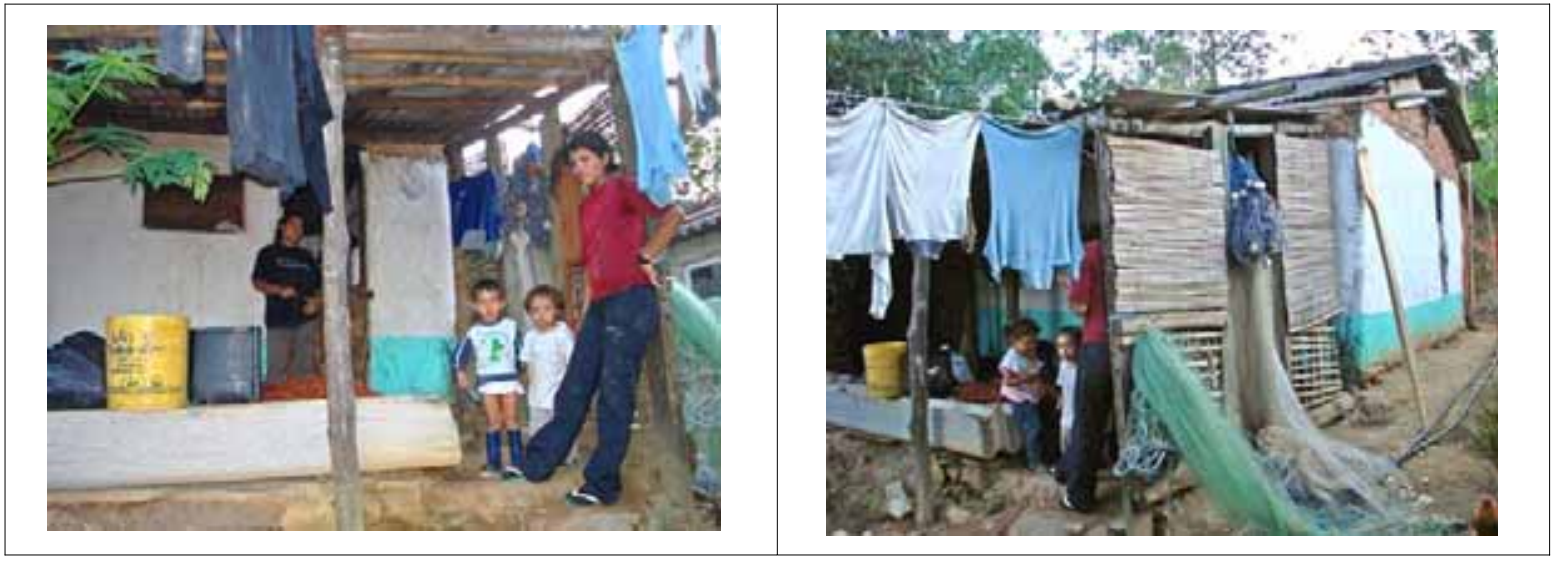

Data e local de nascimento: Canto da Lagoa, 39 anos

Filiação: João Lucio e Elvira Madalena de Souza (falecida)

Estado Civil: Casado

Atividade profissional: Pescador; tem 3 redes e 1 canoa a remo; pesca de camarada no cerco do Lauro

Esposa: Simone dos Santos

Data e local de nascimento: Praia da Figueira

Filiação: Lauro dos Santos, praia da Figueira, e Maria Euzébio de Morais dos Santos, praia da Serraria Atividade profissional:

Filhos: Natanael de Souza Lucio (2 anos)

Total de moradores: 3 


\section{CADASTRO DAS FAMÍLIAS RESIDENTES NA BAÍA DOS CASTELHANOS \\ PRAIA DOS CASTELHANOS - CANTO DA LAGOA}

FAMÍLIA DE:

LAUREANA DE SOUZA LUCIO E LUIZ MARCELO DOS SANTOS

LOCALIZAÇÃO UTM:

$470.651 / 7.361 .044$

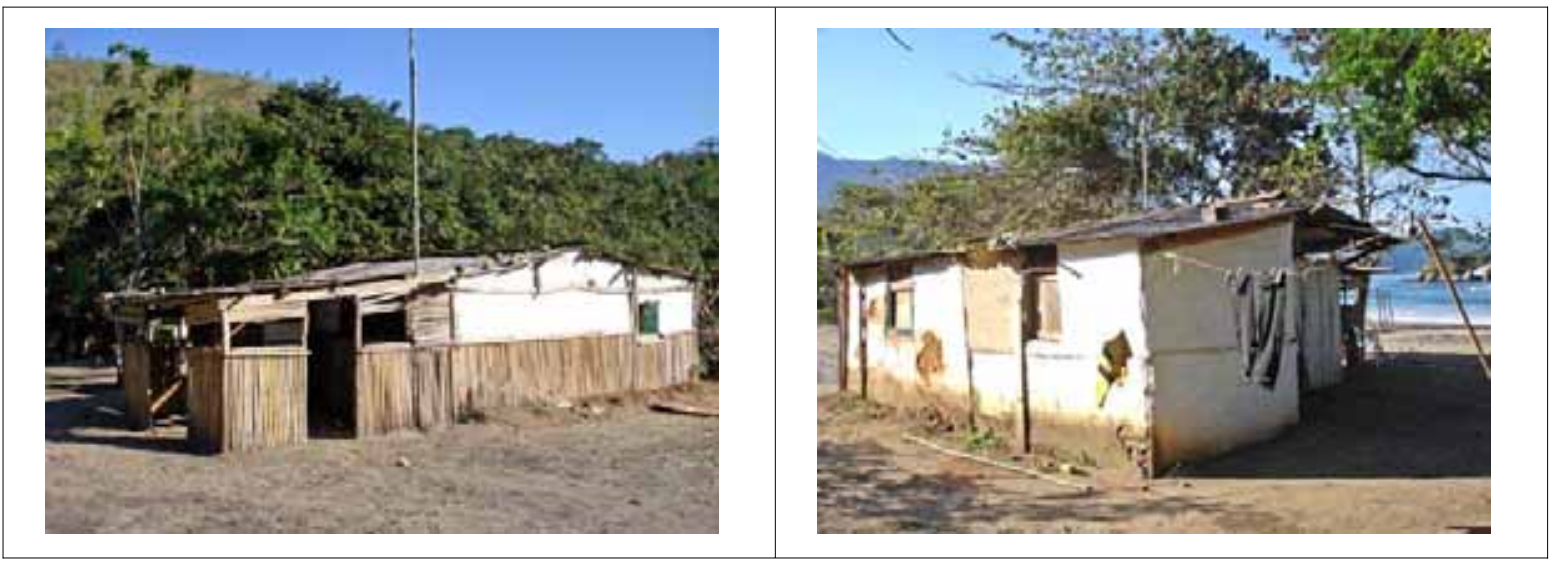

Data e local de nascimento: Canto da Lagoa, 23 anos

Filiação: João de Souza Lucio e Elvira Madalena de Souza (falecida)

Estado Civil: Casada

Atividade profissional: Tem um camping de quintal e um pequeno comércio.

Esposo: Luiz Marcelo dos Santos

Data e local de nascimento: Caraguatatuba, 32 anos.

Atividade profissional: Originalmente, era açougueiro, atualmente é pescador.

Filhos: Vitor Lucio dos Santos (7 anos)

Observações: Entrevista realizada com Laureana em 02/08/07.

Laureana informou que ela e o marido compraram o cerco de seu irmão Daniel e que possuem 2 canoas a remo. Declarou também que o Luiz visita o cerco junto com o Daniel e o Silvio, irmãos dela.

Em relação ao Camping, informou que na temporada pega até 20 barracas. Na temporada, serve refeições para turistas em geral.

Total de moradores: 3 


\section{CADASTRO DAS FAMÍLIAS RESIDENTES NA BAÍA DOS CASTELHANOS \\ PRAIA DOS CASTELHANOS - CANTO DA LAGOA}

FAMÍLIA DE: LOCALIZAÇÃO UTM:
IRINEU DE SOUZA LUCIO E DARCILA EUZÉBIO DE MORAIS

$470.642 / 7.361 .163$

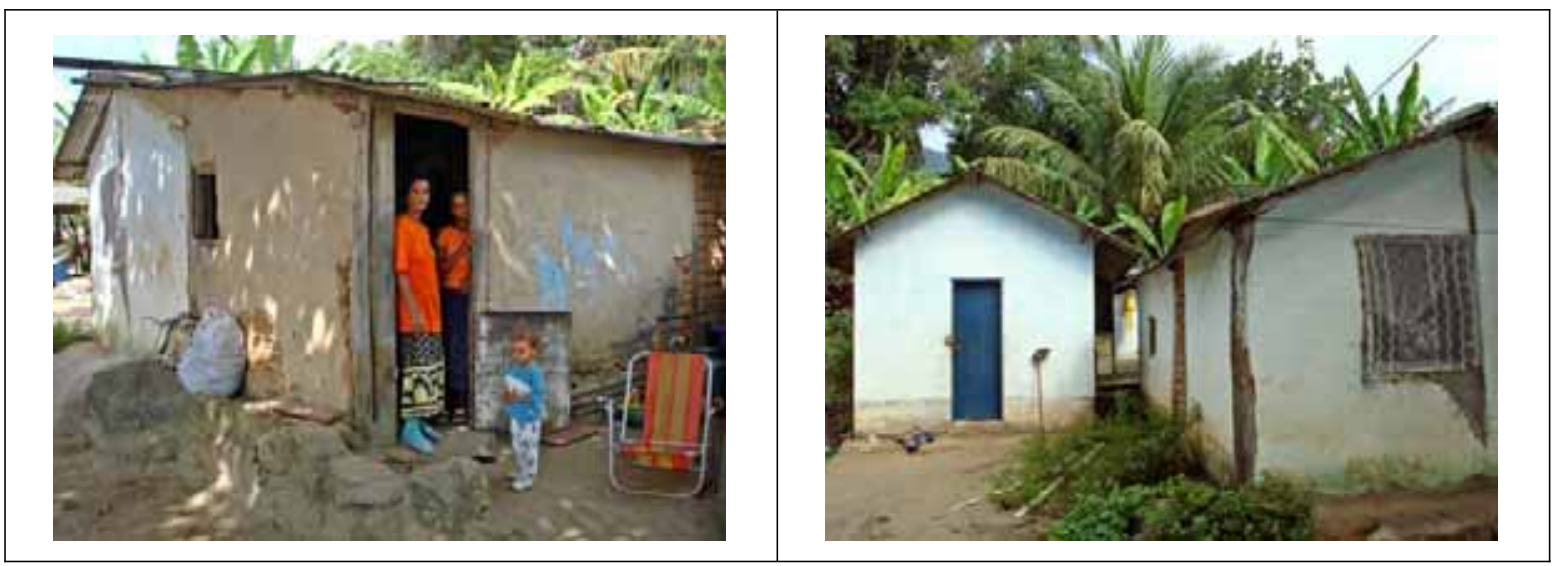

Data e local de nascimento: Praia dos Castelhanos, 36 anos

Filiação: João Lucio e Elvira Madalena de Souza (falecida)

Estado Civil: Casado

Atividade profissional: Pescador; tem cerco, uma canoa-a-motor e uma a remo; é funcionário da prefeitura.

Esposa: Darcila Euzébio de Morais

Data e local de nascimento: Praia dos Castelhanos, 1963

Filiação: Pedro e Natalina Euzébio de Morais, ambos da Praia dos Castelhanos

Filhos: Valdecir e Itamar de Souza Lucio, Andréia, Adriane, Cristiane e Alessandra Euzébio de Morais

Observações: Entrevista realizada com Darcila em 29/03/07.

Irineu possui um rancho

Foi informado que além do Irineu, a prefeitura emprega 2 coletores (estes em tempo parcial) para limpar e coletar o lixo da praia). Cerca de 70 a 75 sacos de lixo são transportados duas vezes por semana para a cidade na canoa do Irineu. Recebe uma cesta básica, 2 salários e óleo para o motor.

Dois coletores: um, João, é irmão do Irineu e cuida do canto da Lagoa e o outro, Leonino, cuida do canto do Ribeirão.

Na temporada, parte do pescado é vendido para os bares e restaurantes da praia dos Castelhanos. De resto, o pescado é transportado para a cidade.

Total de moradores: 8 
CADASTRO DAS FAMÍLIAS RESIDENTES NA BAÍA DOS CASTELHANOS

PRAIA DOS CASTELHANOS - CANTO DA LAGOA

FAMÍLIA DE: LAURO DE SOUZA LUCIO

LOCALIZAÇÃO UTM: $\quad 470.633 / 7.361 .147$

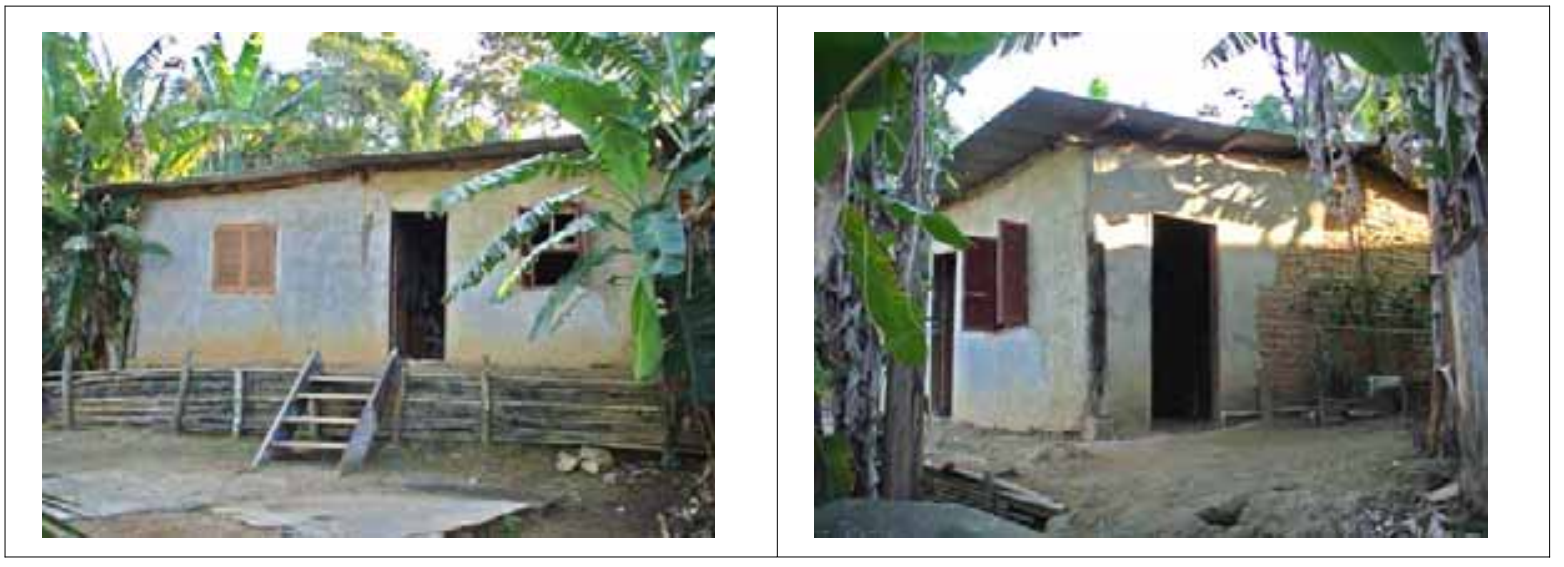

Data e local de nascimento: Canto da Lagoa, 45 anos

Filiação: João Lucio e Elvira Madalena de Souza (falecida)

Estado Civil: Casado

Atividade profissional: Pescador;

Esposa: Laurinda Mário de Morais

Data e local de nascimento (?)

Filiação: (?)

Atividade profissional: (?).

Filhos: Sem filhos

Observações: Entrevista realizada com Lauro em 02/08/07.

Lauro possui um rancho, 1 canoa a motor e 1 a remo. Tem cerco que está instalado na Laje Preta.

Informou que realiza, em média, uma viagem por semana à cidade para vender o pescado. Transporta de 20 a 40 kg de pescado que vende no Bairro São Francisco (cooperativa dos pescadores) ou em Ilhabela. Vende em média $\mathrm{R} \$ 300,00$ por viagem, mas tem vezes que consegue pescar 100 ou $200 \mathrm{~kg}$ de peixe em um só dia. Os preços variam muito e tem peixe que é vendido por $R \$ 1,00 / \mathrm{kg}$ e outros que alcançam mais de $R \$ 10,00 / \mathrm{kg}$. Gasta 40 litros de óleo diesel por viagem e o litro custa $\mathrm{R} \$ 2,20$.

Total de moradores: 2 


\section{CADASTRO DAS FAMÍLIAS RESIDENTES NA BAÍA DOS CASTELHANOS \\ PRAIA DOS CASTELHANOS - CANTO DA LAGOA}

FAMÍLIA DE: $\quad$ SILVIO DE SOUZA LUCIO

LOCALIZAÇÃO UTM: $\quad 470.633 / 7.361 .147$

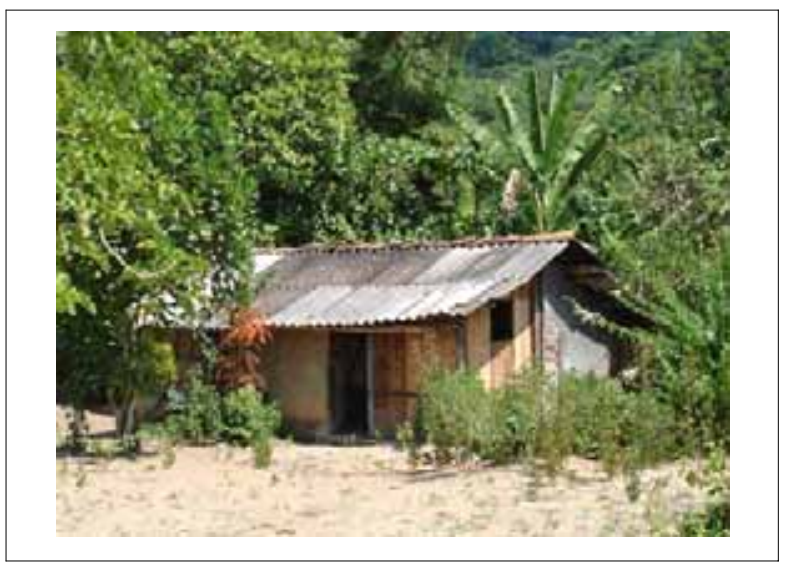

Data e local de nascimento: Canto da Lagoa, 45 anos

Filiação: João Lucio e Elvira Madalena de Souza (falecida)

Estado Civil: Casado

Atividade profissional: Caseiro; Pescador; trabalha nos restaurantes na temporada e feriados

Esposa: Maria Alice Gonçalves, P. dos Castelhanos, Canto da Lagoa, 53 anos

Data e local de nascimento P. dos Castelhanos, Canto da Lagoa

Filiação: Pedro Francisco Gonçalves e Alice de Oliveira, ambos da P. dos Castelhanos, Canto da Lagoa Atividade profissional: Aposentado, recebe pensão do INSS.

Filhos: Sem filhos

Observações: Casa cedida pelo dono do MAREBAR

Total de moradores: 2 


\section{CADASTRO DAS FAMÍLIAS RESIDENTES NA BAÍA DOS CASTELHANOS \\ PRAIA DOS CASTELHANOS - CANTO DA LAGOA}

FAMÍLIA DE:

ISADAE MARIA DE MORAIS E BENEDITO EUZÉBIO DE MORAIS

LOCALIZAÇÃO UTM:

Ao lado da igreja evangélica

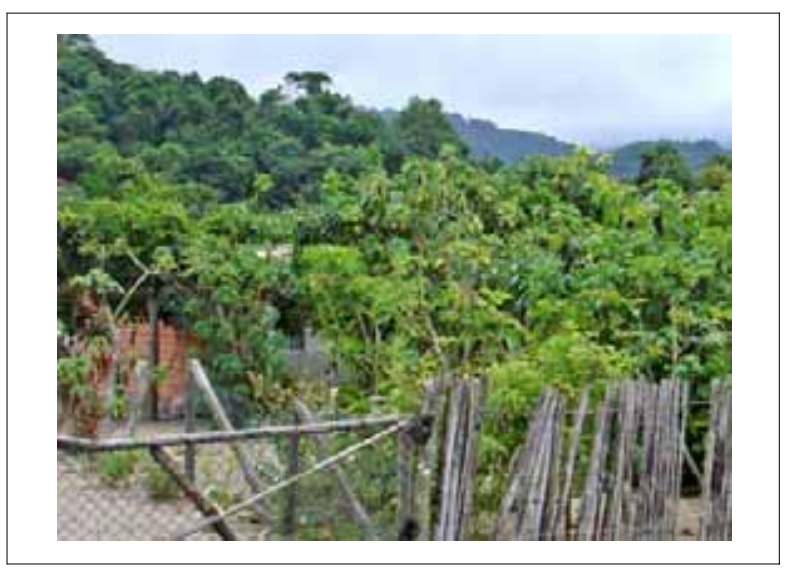

Data e local de nascimento:

Filiação: Manoel Florípedes dos Santos e Margarida Maria de Jesus

Estado Civil: Casada

Atividade profissional:

Esposo: Benedito Euzébio de Morais

Data e local de nascimento: P. dos Castelhanos, Canto do Ribeirão, 44 anos

Filiação: Pedro Euzébio de Morais, Canto do Ribeirão e Natalina Lucio de Morais, Canto da Lagoa.

Atividade profissional: Ambos são aposentados, recebem pensão do INSS.

Filho: Ailton Euzébio de Morais (filho do $1^{\circ}$ casamento de Isadae)

Observações: Segundo os moradores, a família da Isa vendeu as terras de sua propriedade e se mudaram dos Castelhanos. A Isa andou por vários lugares, inclusive morou no Paraguai e acabou retornando à Praia dos Castelhanos, onde está recuperando parte das terras que eram de posse da família

Total de moradores: 3 


\section{CADASTRO DAS FAMÍLIAS RESIDENTES NA BAÍA DOS CASTELHANOS \\ PRAIA DOS CASTELHANOS - CANTO DA LAGOA}

FAMÍLIA DE: $\quad$ LEOLINO BARBOSA DE JESUS E JUVENTINA DE SOUZA LUCIO

LOCALIZAÇÃO UTM: $\quad 470.505 / 7.361 .343$

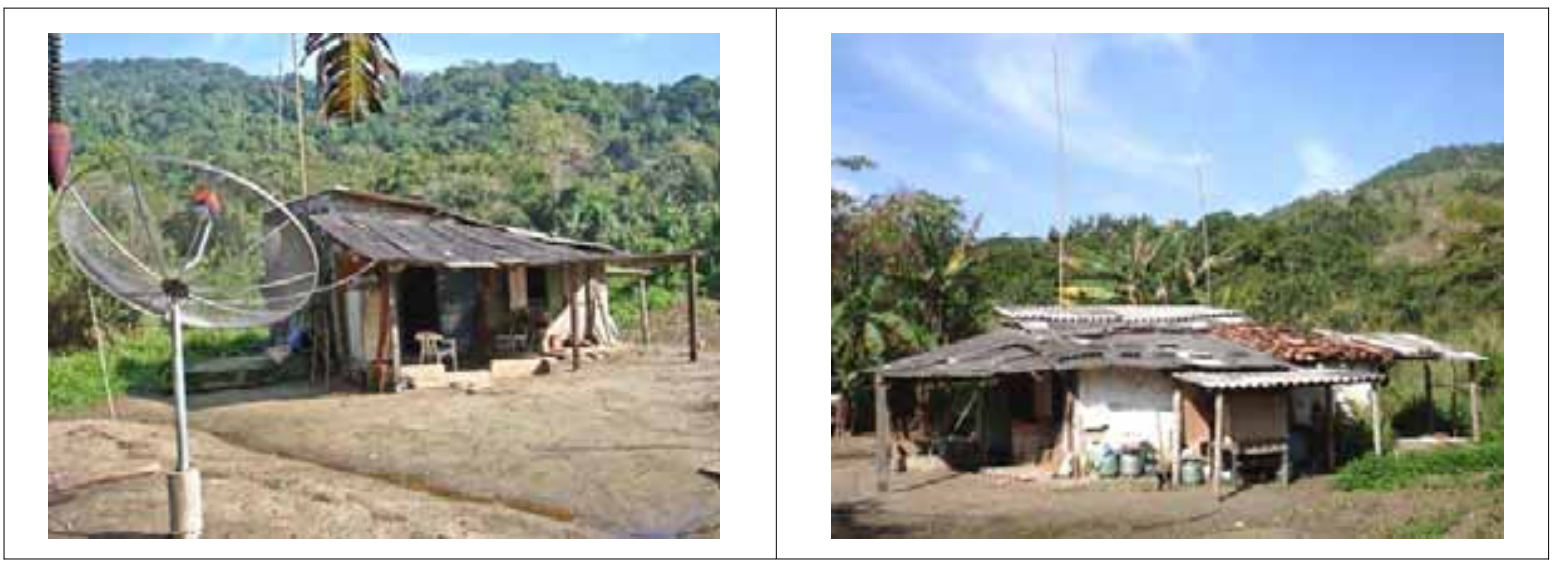

Data e local de nascimento: Canto do Ribeirão, 58 anos

Filiação: Benedito Barbosa de Jesus (falecido) e Celeste Maria de Jesus

Estado Civil: Casado

Atividade profissional: Empregado da prefeitura; Encarregado do Camping do Leo.

Esposa: Juventina de Souza Lucio

Data e local de nascimento Canto da Lagoa

Filiação: (?)

Atividade profissional: (?).

Filho: Patrícia de Souza Lucio ( $1^{\circ}$ casamento de Juventina)

Observações:

Entrevista realizada com Leolino em 04/08/07.

- Casa cedida pelo dono do Camping e do terreno.

- Leolino declarou que é empregado efetivo da prefeitura e que recebeR $\$ 780,00 /$ mês de salário, mais cesta básica e vale transporte. Declarou também que sua mulher e seu filho, Patrício Barbosa de Jesus (que não mora com ele) também são contratados da prefeitura, mas por tempo determinado.

- Informou que devia ter por volta de 14 anos quando seu pai, o Barbosa, morreu. Disse se lembrar que a venda do Barbosa vendia tamanco, café (que sua mãe mandava comprar café em coco na fazenda da Laje, no Perequê e que depois vendia torrado), refrigerantes (sua mãe e S. Anízio da P. Vermelha disse que não vendia).

Total de moradores: 3 
CADASTRO DAS FAMÍLIAS RESIDENTES NA BAÍA DOS CASTELHANOS

PRAIA DOS CASTELHANOS - CANTO DA LAGOA

FAMÍLIA DE:

FABIO

LOCALIZAÇÃO UTM:

$470.634 / 7.361 .255$

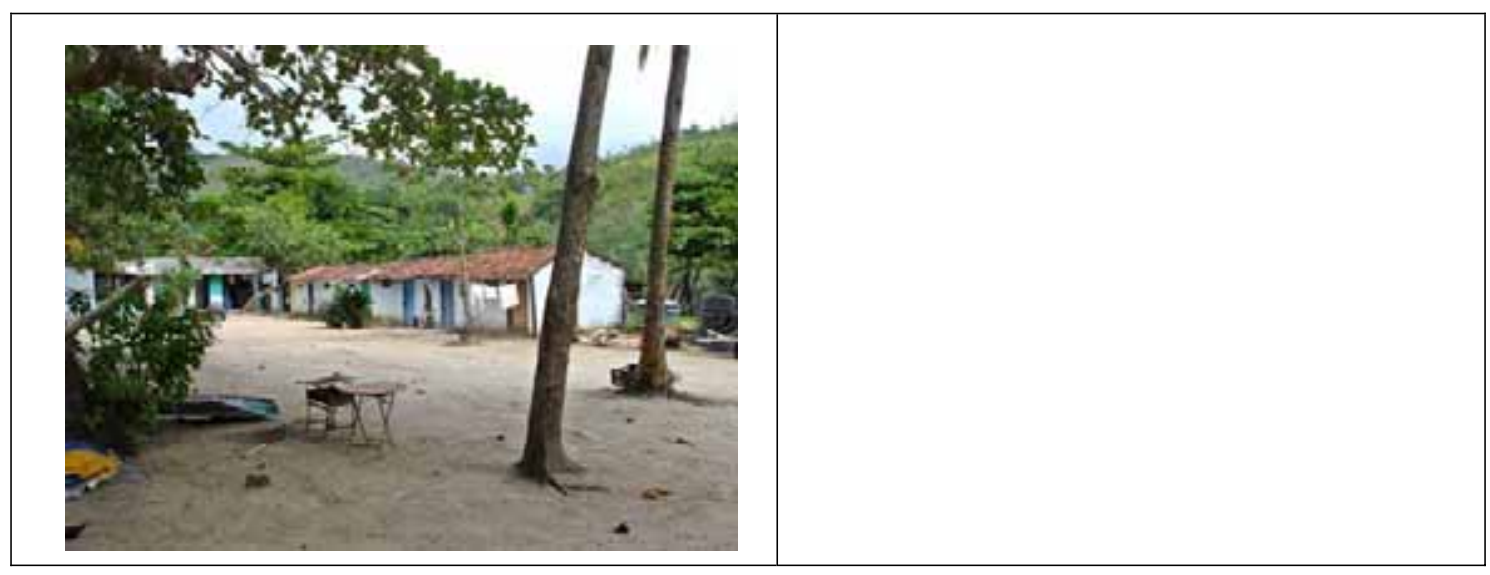

Data e local de nascimento: (?) (?)

Filiação: (?)

Estado Civil: Solteiro

Atividade profissional: Encarregado do restaurante/camping

Observações: TURISTA

- O Fernando, filho da Nair, trabalha e mora com ele.

Total de moradores: 2 , turista 1 
CADASTRO DAS FAMÍLIAS RESIDENTES NA BAÍA DOS CASTELHANOS

PRAIA DOS CASTELHANOS - CANTO DA LAGOA

FAMÍLIA DE:

RENATO, REINALDO E GILDA DO CARMO CAMARGO (IRMÃOS)

LOCALIZAÇÃO UTM:

$470.561 / 7.361 .498$

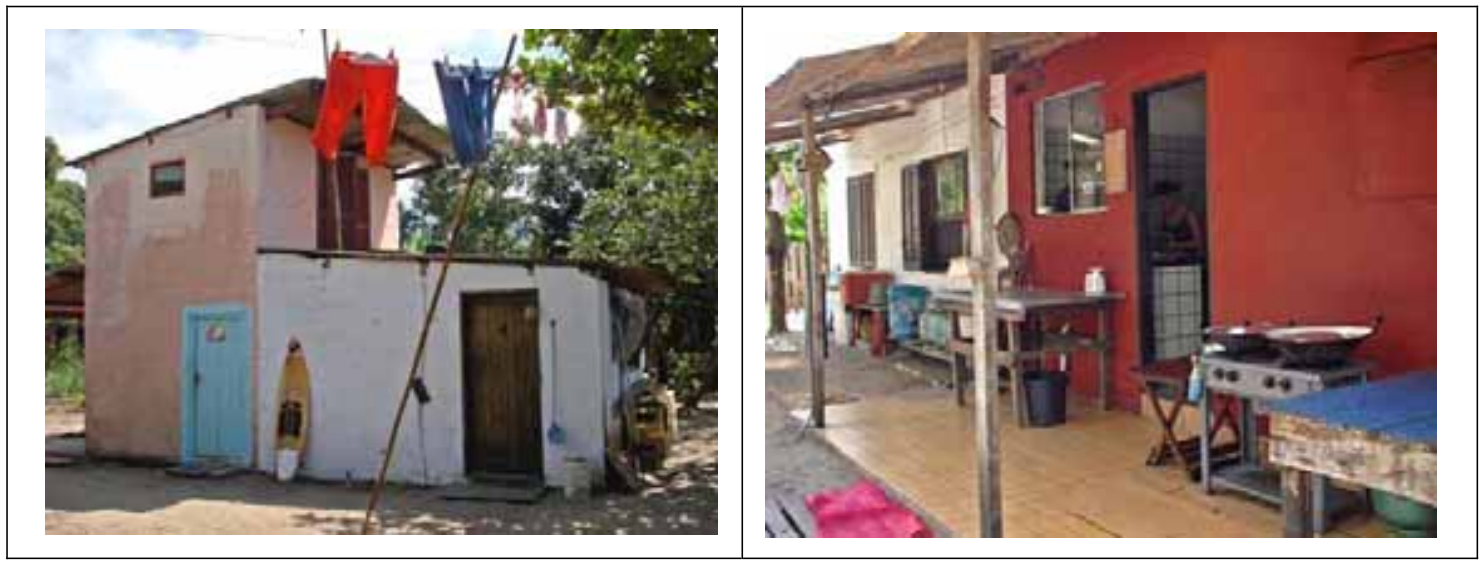

Atividade profissional: Proprietários de estabelecimento comercial

Observações: TURISTAS

- Eduardo Gonçalves Seabra é empregado deles e mora no local.

Total de moradores: 4 


\section{CADASTRO DAS FAMÍLIAS RESIDENTES NA BAÍA DOS CASTELHANOS}

PRAIA DOS CASTELHANOS - CANTO DA LAGOA

FAMÍLIA DE:

WANDERLEY DOS SANTOS VALÉRIO (ALEMÃO)

LOCALIZAÇÃO UTM:

$470.560 / 7.361 .529$

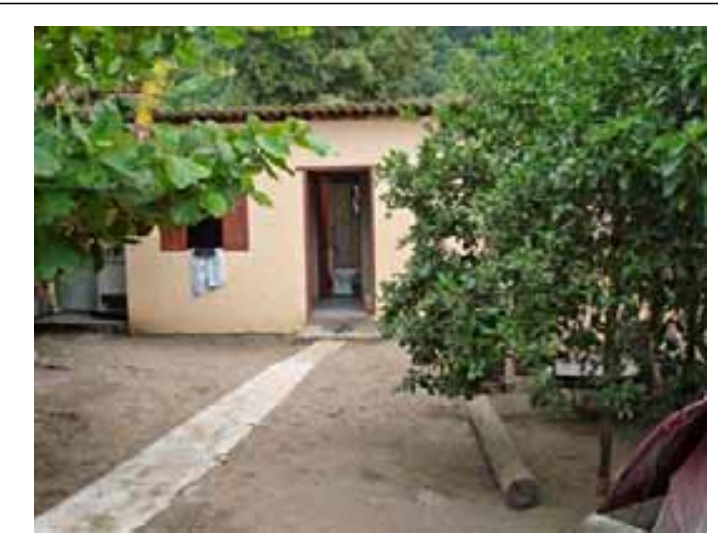

Atividade profissional: Proprietário de estabelecimento comercial

Observações: TURISTA

- Marcelo e Rodrigo são empregados e moram no local.

- Tem uma noiva que estuda em Minas Gerais e está se formando. Quando concluir o curso irá morar no local.

Total de moradores: 3 
CADASTRO DAS FAMÍLIAS RESIDENTES NA BAÍA DOS CASTELHANOS

PRAIA DOS CASTELHANOS - CANTO DA LAGOA

FAMÍLIA DE: $\quad$ EDUARDO E NAIR DOS SANTOS VALÉRIO (IRMÃOS)

LOCALIZAÇÃO UTM: $\quad 470.560 / 7.361 .529$

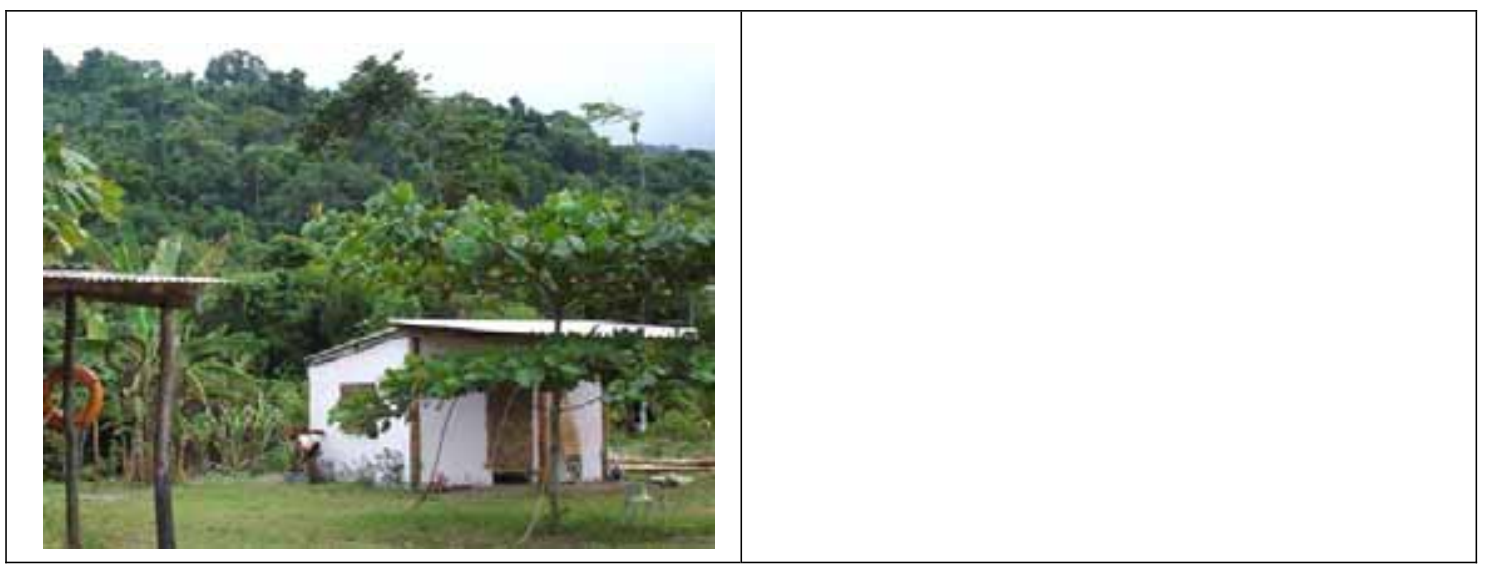

Atividade profissional: Proprietários de estabelecimento comercial

Observações: TURISTAS

- Moram dois empregados no local.

Total de moradores: 4

TOTAL DE MORADORES TURISTAS NO CANTO DA LAGOA:

TOTAL DE MORADORES CAIÇARAS NO CANTO DA LAGOA:

TOTAL DE GERAL DE MORADORES NO CANTO DA LAGOA:

TOTAL DE MORADORES TURISTAS NA PRAIA DOS CASTELHANOS:

TOTAL DE MORADORES INSTITUCIONAIS NA PRAIA DOS CASTELHANOS:

TOTAL DE MORADORES CAIÇARAS NA PRAIA DOS CASTELHANOS:

99

TOTAL DE GERAL DE MORADORES NA PRAIA DOS CASTELHANOS: 


\section{CADASTRO DAS FAMÍLIAS RESIDENTES NA BAÍA DOS CASTELHANOS}

\section{PRAIA MANSA}

FAMÍLIA DE: LAÉRCIO RAFAEL DE SOUZA

LOCALIZAÇÃO UTM: $470.439 / 7.360 .320$

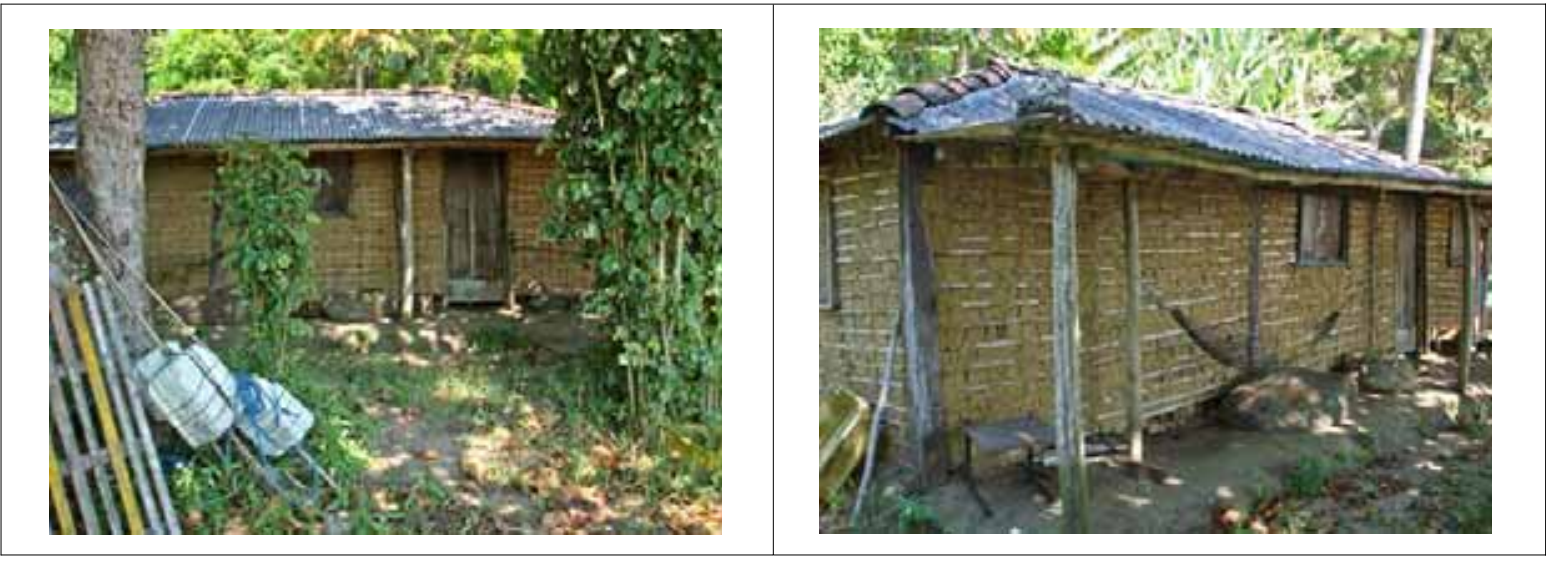

Data e local de nascimento:

Filiação: Pedro Rafael de Souza (P. Mansa) e Maria Madalena de Jesus (P. Mansa)

Estado Civil: Separado de Maria com quem teve 2 filhas criadas por Erotildes (Marciana e Cilene)

Atividade profissional: Pescador, artesão de redes de pesca, remos etc.

Observações: Informações obtidas com Angélica em 07/03/07 e diretamente com Laércio em 25/04/07. Laércio declarou que antes da abertura da estrada para os Castelhanos, o peixe era escalado e seco. Informou que quando juntava uma boa quantidade de peixes, eram organizados fardos de cerca de $20 \mathrm{~kg}$ cada um, que eram transportados nas costas das pessoas para serem vendidos na cidade. lam em grupos de 3 ou 4 amigos a pé pela antiga trilha. Saiam por volta das $6 \mathrm{~h}$ da manhã da Praia Mansa e chegavam às 10:00 h na Vila. Depois de comprarem outras mercadorias de suas necessidades, organizavam também fardos de $20 \mathrm{~kg}+$ ou e voltavam na parte da tarde, chegando na Praia Mansa por volta das $18 \mathrm{~h}$.

Total de moradores: 1 


\section{CADASTRO DAS FAMÍLIAS RESIDENTES NA BAÍA DOS CASTELHANOS}

\section{PRAIA MANSA}

FAMÍLIA DE:

REGINALDO RAFAEL DE SOUZA

LOCALIZAÇÃO UTM:

$470.372 / 7.360 .352$

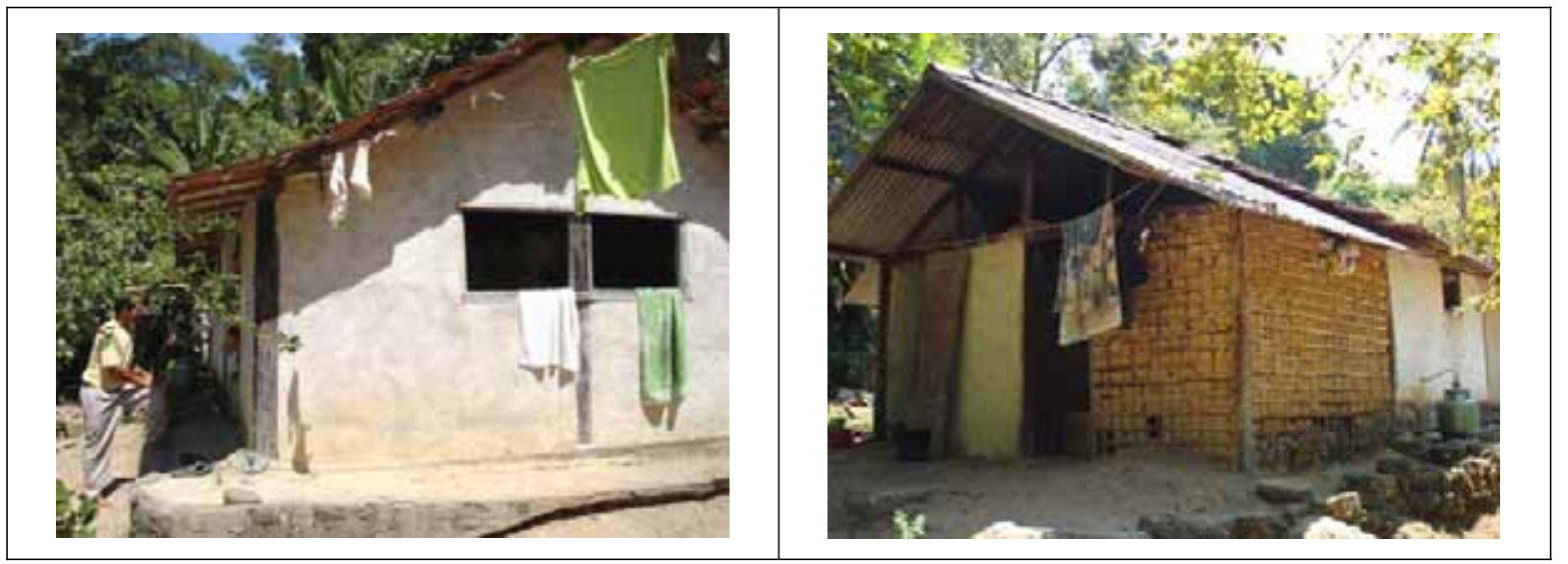

Data e local de nascimento: P. Mansa

Filiação: Francelízio Rafael de Souza (P. Mansa) e Elizabete Santana Fernandes (Ilhabela)

Estado Civil: Casado

Atividade profissional: Pescador; Carpinteiro, Pedreiro; Artesão de canoa e de remos; mecânico de motores a óleo diesel.

Esposa: Lucimara de Souza Romão

Data e local de nascimento: P. Vermelha

Filiação: Benedito de Souza Romão e Dalva Maria dos Santos Romão (ambos da P. Vermelha)

Filhos: Matheus, de 1 ano e 3 meses

Observações:

A família de seus pais foi morar na Barra Velha, cidade, e lá Lucimara conheceu o Reginaldo.

Total de moradores: 3 


\section{CADASTRO DAS FAMÍLIAS RESIDENTES NA BAÍA DOS CASTELHANOS \\ PRAIA MANSA}

FAMÍLIA DE:

FRANCELÍZIO RAFAEL DE SOUZA

LOCALIZAÇÃO UTM:

470.364 / 7.360.367
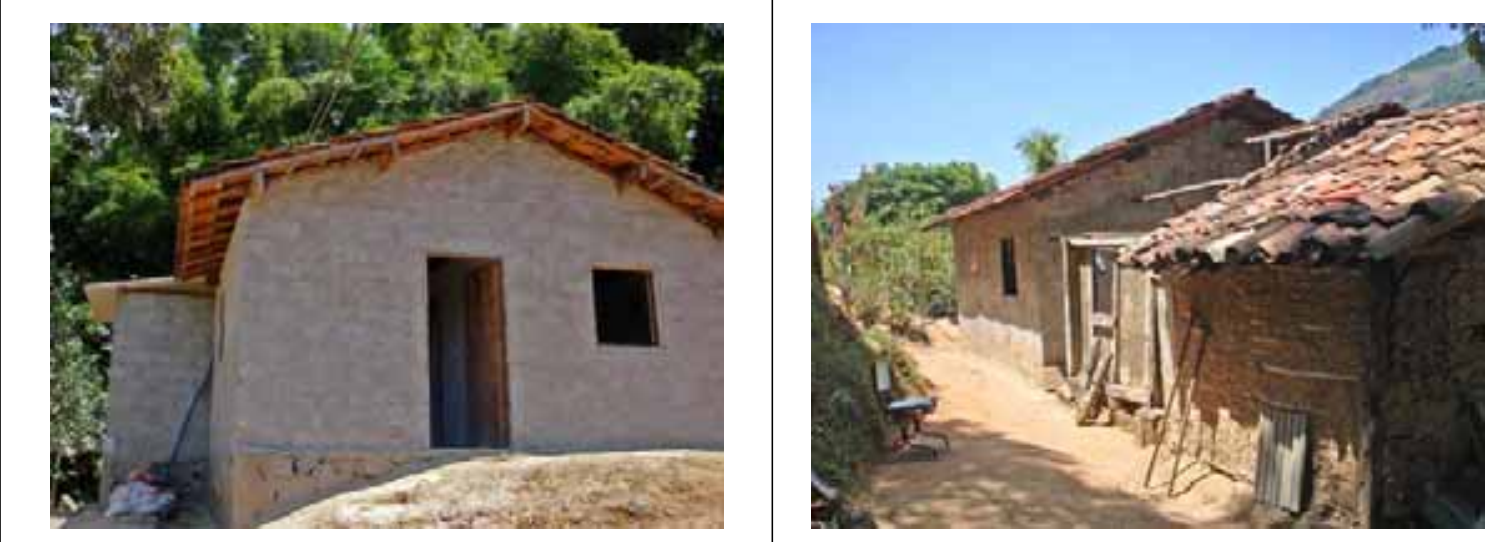

Data e local de nascimento: P. Mansa, 1935

Filiação: Pedro Rafael de Souza (P. Mansa) e Maria Madalena de Jesus (P. Mansa)

Estado Civil: Separado de Elizabete Santana Fernandes Santos, que conheceu nos Castelhanos.

Atividade profissional: Pescador, proprietário de Cerco; Artesão de canoa, de rede de cerco e de tresmalho. Aposentado, recebe pensão do INSS.

Filhos: Flávio Fernandes de Souza

\section{Observações:}

Informou que na sua juventude havia muita pesca de cerco no Sombrio, P. Mansa e P. Vermelha. Os cercos eram de japoneses. O barco vinha de Santos, esperava encher e transportava o pescado para Santos. Os peixes eram conservados em gelo.

Divisão do pescado: uma metade era do cerco e a outra dos camaradas (4 camaradas). O cerco ficava pescando aproximadamente 2 semanas e depois era retirado para manutenção. Nesse momento faziam-se as contas e os camaradas eram pagos.

Sobre os bananais, informou que na P. Mansa chegava-se a colher 80 dúzias de cachos. Colhia-se aproximadamente 1 vez por mês.

Tanto a banana quanto o pescado eram transportados de barco para Santos até meados da década de 1960 (coincide com a abertura da estrada São Sebastião- Bertioga). A partir dessa data, a banana deixou de ser produzida comercialmente na B. dos Castelhanos.

Sobre a produção de Pinga, informou que havia apenas um engenho na Baía, cujo proprietário era o Sr.. Leonardo Reale (que foi prefeito de Ilhabela) e que ficava no Canto do Ribeirão. A cana para a produção de pinga era plantada apenas no C. do Ribeirão e na sua propriedade. Os trabalhadores eram pagos em dinheiro, de 15 em 15 dias. Pagava-se muito pouco (+ ou -2 mil réis).

Tinha o barco da banana, o barco do peixe e o barco da pinga.

Em toda a Baía dos Castelhanos havia muita roça de Mandioca. Tinha também roça de feijão, cana, milho e batata doce. $O$ excedente da farinha era vendido.

Total de moradores: 2 


\title{
CADASTRO DAS FAMÍLIAS RESIDENTES NA BAÍA DOS CASTELHANOS
}

\section{PRAIA MANSA}

FAMÍLIA DE:

\author{
ÁLVARO DE SOUZA
}

LOCALIZAÇÃO UTM:

$470.384 / 7.360 .372$

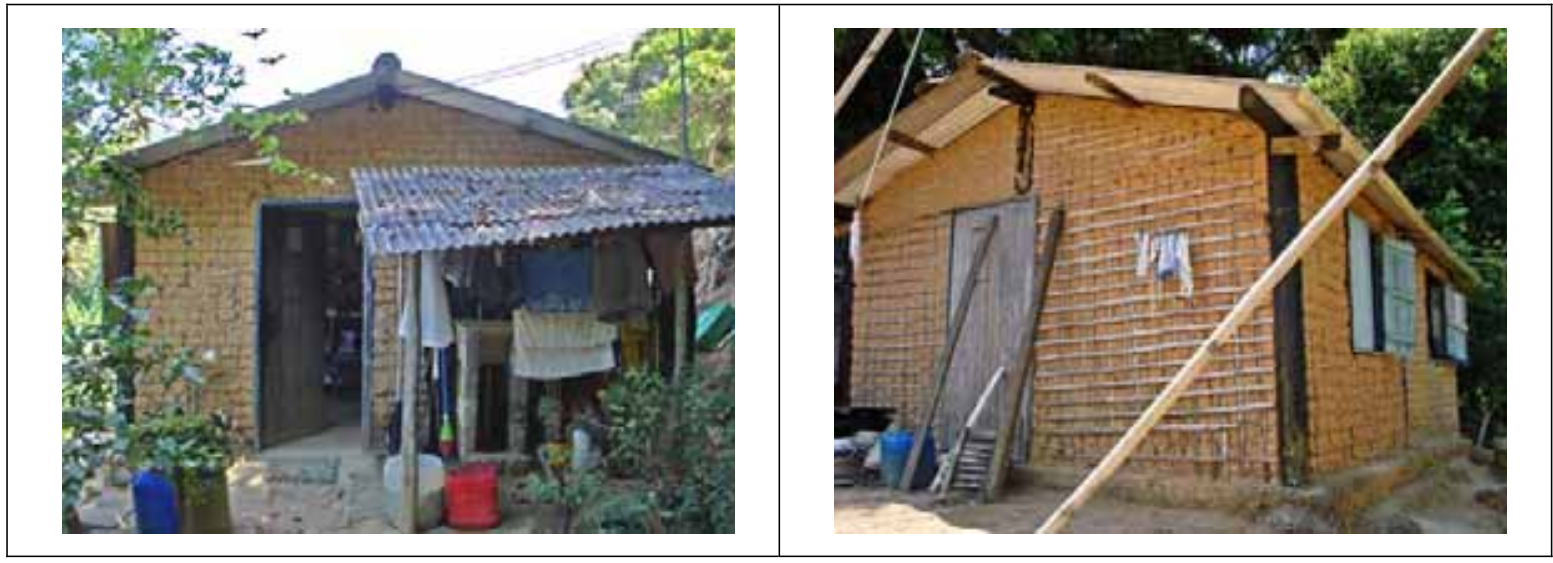

Data e local de nascimento: P. Mansa, 1962

Filiação: Juvenal de Souza (P. Mansa) e Jessi dos Santos (Canto do Ribeirão)

Estado Civil: Casado

Atividade profissional: Pescador; Artesanato turístico (barcos, remos); presta serviços para a prefeitura (limpeza da praia e manutenção do caminho).

Esposa: Rosilda Rafael de Souza

Data e local de nascimento: P. Vermelha, 1966

Filiação: Pedro Rafael de Souza (Pedro Madalena - P. Vermelha) e Pedrina Maria de Souza (Galhetas, depois Sombrio e depois de casada foi para P. Vermelha)

Filhos: Ana Laura (1989) e Ana Cláudia (1988)

\section{Observações:}

Informou que atualmente existem 7 cercos na B. dos Castelhanos:

\section{P. Mansa:}

- Marcelino, da P. Mansa, pesca na costeira da Figueira;

- Francelízio, que pesca na ponta do costão da Vermelha;

\section{Praia dos Castelhanos:}

- Irineu, pesca na ponta da Lagoa;

- Daniel/Luiz, também pesca na ponta da Lagoa;

- Silvio, pesca no canto do Ribeirão.

Praia Vermelha:

Almir, pesca no Criolo, costão da P. Vermmelha.

Total de moradores: 4 


\section{CADASTRO DAS FAMÍLIAS RESIDENTES NA BAÍA DOS CASTELHANOS}

\section{PRAIA MANSA}

FAMÍLIA DE: RONALDO DE SOUZA / ROSANA DE OLIVEIRA COSTA SOUZA

LOCALIZAÇÃO UTM: $470.388 / 7.360 .413$

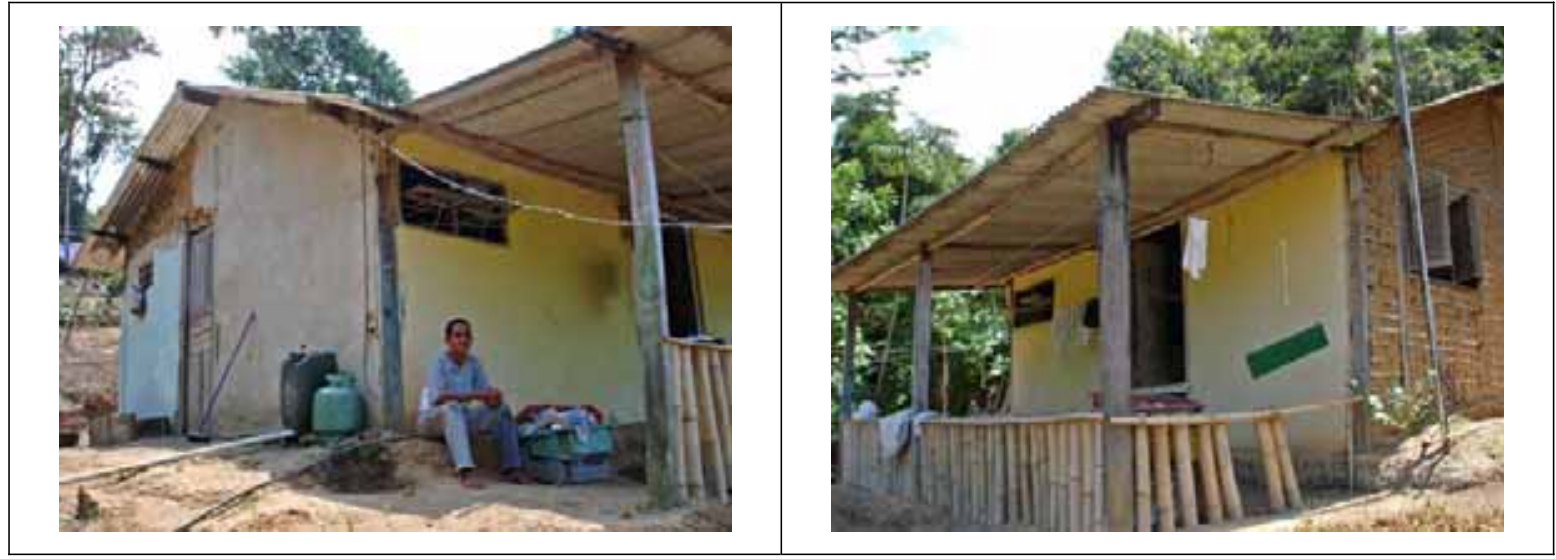

Data e local de nascimento: P. Mansa, (?)

Filiação: Juvenal de Souza (P. Mansa) e Jessi dos Santos (Canto do Ribeirão)

Estado Civil: Casado

Atividade profissional: Mecânico de barco; Pescador; Pedreiro, Encanador; Artesanato turístico (barcos, remos);Possui uma bateira, pesca nas proximidades da Ilha Vitória.

Esposa: Rosana de Oliveira Costa Souza

Data e local de nascimento: Ilha da Vitória, (?) mas se conheceram na cidade.

Filiação: Pedro Rafael de Souza (Pedro Madalena - P. Vermelha) e Pedrina Maria de Souza (Galhetas, depois Sombrio e depois de casada foi para P. Vermelha)

Filhos: Miriam - 7 anos, Taís - 2 anos e Estefani - 1 mês.

Total de moradores: 5 


\section{CADASTRO DAS FAMÍLIAS RESIDENTES NA BAÍA DOS CASTELHANOS}

\section{PRAIA MANSA}

FAMÍLIA DE: SIMONE DE SOUZA / LAUREANO DOS SANTOS

LOCALIZAÇÃO UTM: $470.369 / 7.360 .425$

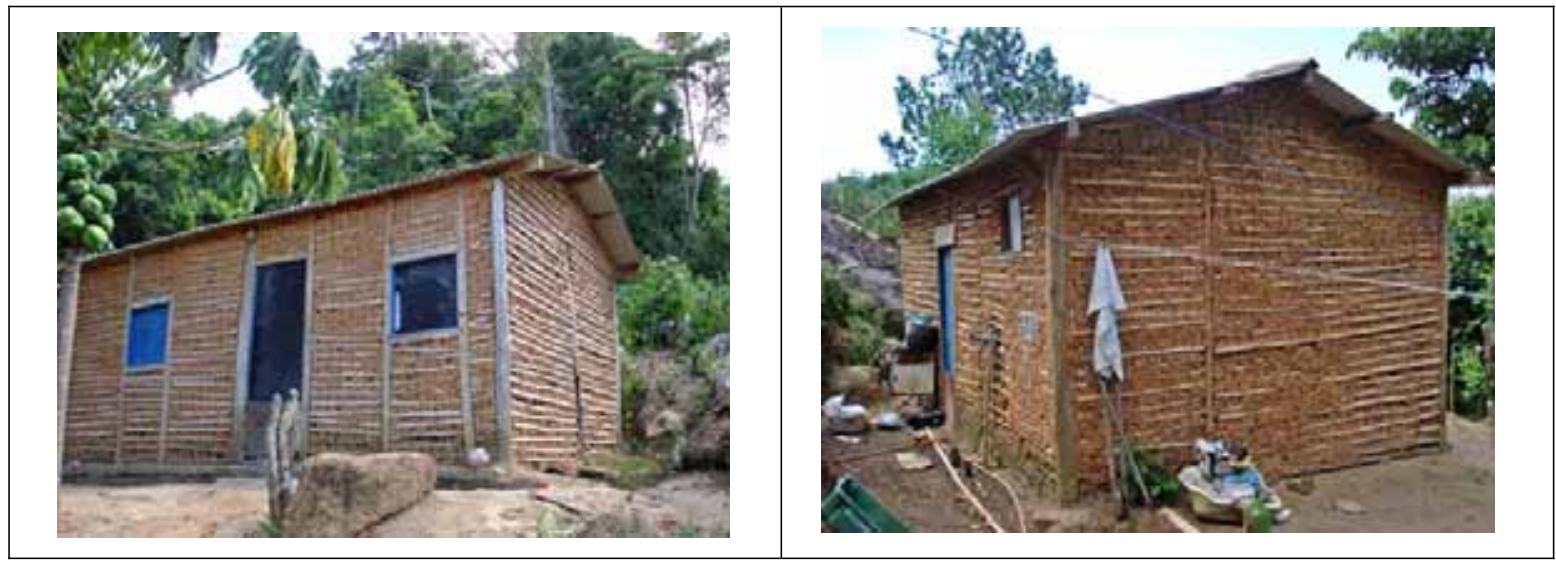

Data e local de nascimento: P. Mansa, (?)

Filiação: Juvenal de Souza (P. Mansa) e Jessi dos Santos (Canto do Ribeirão)

Estado Civil: Casada

Esposo: Laureano dos Santos

Data e local de nascimento: P. da Figueira, (?)

Atividade profissional: Pescador.

Filiação: Lauro dos Santos (P. Figueira?) e Maria Euzébio de Morais (Castelhanos?)

Filhos: Thiffany Valozinny de Souza (3 anos) e Leonardo dos Santos (1 ano)

Total de moradores: 4 


\section{CADASTRO DAS FAMÍLIAS RESIDENTES NA BAÍA DOS CASTELHANOS}

\section{PRAIA MANSA}

FAMÍLIA DE: MARCELINO / ANGÉLICA / LEANDRO / ELISÂNGELA DE SOUZA (IRMÂOS)

LOCALIZAÇÃO UTM: $470.388 / 7.360 .401$

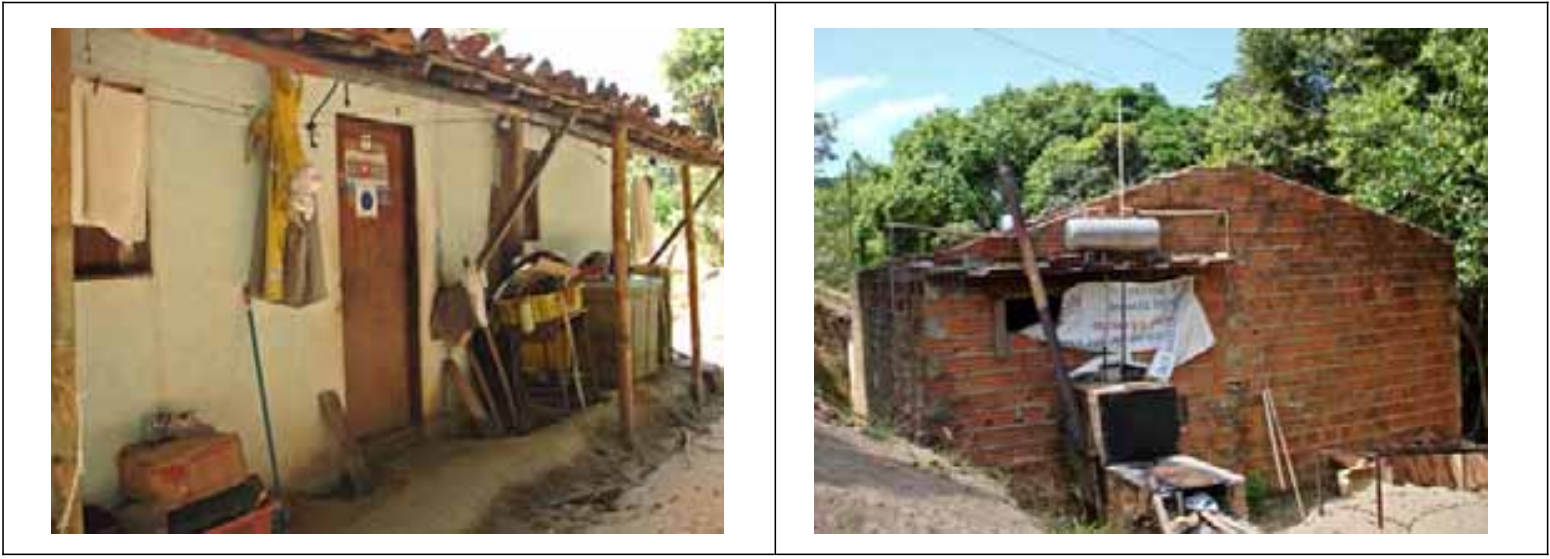

Marcelino de Souza

Data e local de nascimento: P. Mansa (42 anos)

Filiação: Juvenal de Souza (P. Mansa) e Jessi dos Santos (Canto do Ribeirão)

Estado Civil: Solteiro

Atividade profissional: Pescador; artesão de canoa, remos; artesanato turístico (passarinho, barco).

Angélica de Souza (32 anos)

Estado Civil: Solteira

Atividade profissional: Artesanato turístico.

Leandro de Souza (28 anos)

Estado Civil: Solteiro

Atividade profissional: Pescador; artesanato turístico.

Elisângela de Souza (? anos)

Estado Civil: Separada?

Atividade profissional: ?

1 filha - Jennifer de Souza Penha -6 anos

Total de moradores: 5 


\section{CADASTRO DAS FAMÍLIAS RESIDENTES NA BAÍA DOS CASTELHANOS}

\section{PRAIA MANSA}

FAMÍLIA DE:

PAULO SERGIO DE SOUZA

LOCALIZAÇÃO UTM:

$470.376 / 7.360 .428$

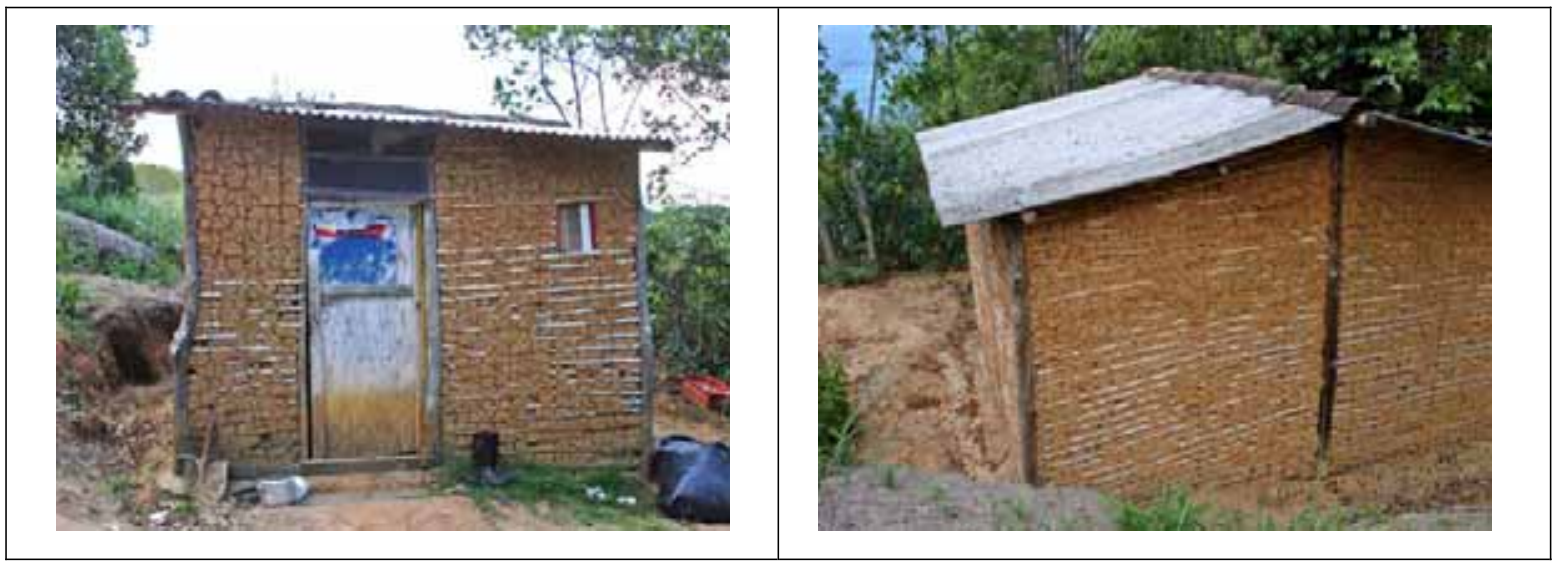

Data e local de nascimento: P. Mansa, (?)

Filiação: Juvenal de Souza (P. Mansa) e Jessi dos Santos (Canto do Ribeirão)

Estado Civil: Separado (Cilene de Souza)

Atividade profissional: Pescador; Artesanato turístico (barcos, remos).

Total de moradores: 1

TOTAL DE MORADORES INSTITUCIONAIS:

TOTAL DE MORADORES CAIÇARAS NA PRAIA MANSA: 


\section{CADASTRO DAS FAMÍLIAS RESIDENTES NA BAÍA DOS CASTELHANOS PRAIA VERMELHA}
FAMÍLIA DE:
ANÍZIO RAFAEL DE SOUZA
LOCALIZAÇÃO UTM:
$470.478 / 7.359 .835$

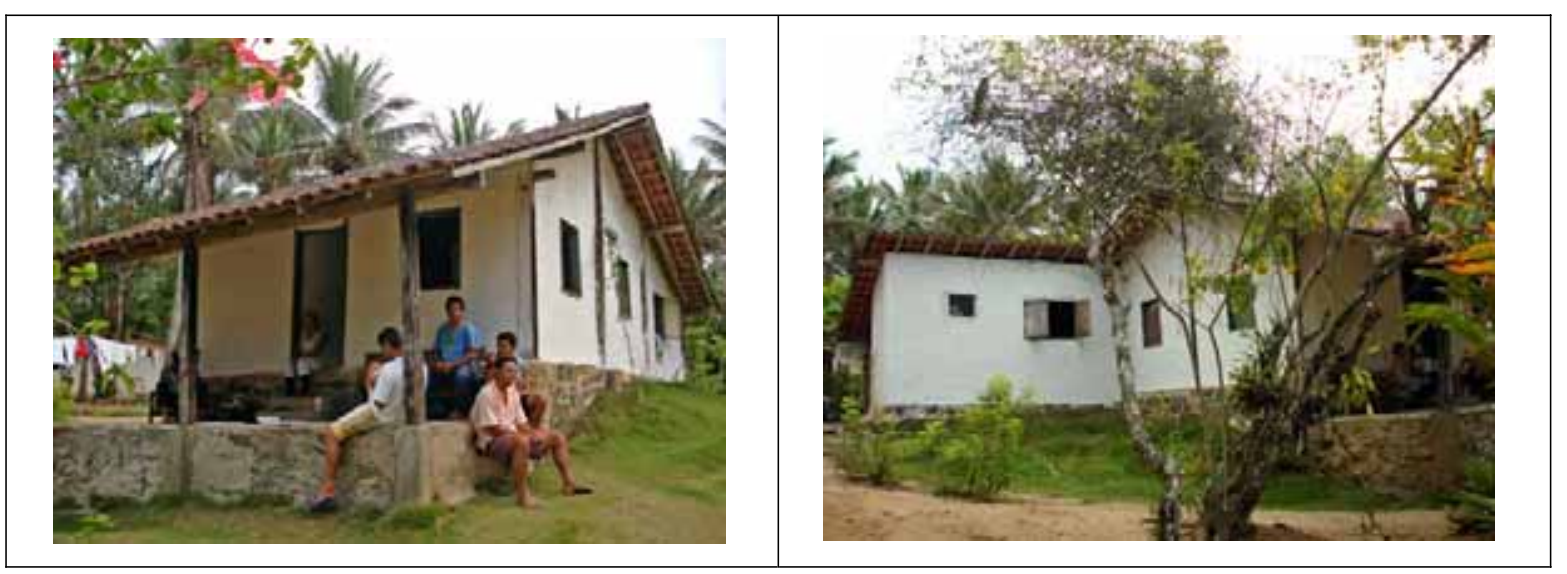

Data e local de nascimento: Praia Vermelha, 1940.

Filiação: Pedro Manoel de Souza, P. Castelhanos e Jorgina Inácio dos Santos, Ilha de Búzios

Estado Civil: Casado

Atividade profissional: Aposentado, pensionista do INSS; proprietário de cerco; tem canoa a motor, tem canoas a remo; é empregado do Sergio de Almeida, proprietário da praia; os filhos pescam e produzem artesanato turístico.

Esposa: Leopoldina Rafael de Souza

Data e local de nascimento: Praia Mansa, 1952

Filiação: José Rafael de Souza, Praia Mansa, e Idalina dos Santos Souza, Praia da Guanxuma

Filhos: Almir, André e Douglas

Observações: Entrevista realizada com S. Anízio e D. Leopoldina em 06/03 e 03/08/07.

Tem um gerador que alimenta todas as casas da família.

- S. Anízio informou que seu pai nasceu nos Castelhanos, foi para a P. Mansa e depois para a P. Vermelha. Foi para a P. Vermelha para trabalhar, para formar roça. Encontrou uma casa de pau-a-pique abandonada (onde hoje é do Sergio Andrade de Almeida), ocupou e lá constituiu sua família.

- D. Leopoldina conta que seu avô era festeiro de São João na Guanxuma e foi numa das festas que seus pais se conheceram e depois se casaram.

- Nos tempos de criança, S. Anízio trabalhava até março no cerco. De março a outubro, trabalhavam na roça. Produziam 10 sacos de farinha (22 kg cada) de mandioca. Esse era o único produto da roça que era vendido.

- O S. Anízio informou que seu pai vendeu as terras da família para o Sr. Mário Volcoff, que depois vendeu para o Sr. Sérgio, que construiu as 4 casas de turistas existentes atualmente. A sua casa (S. Anízio) e todas as outras de seus parentes igualmente foram construídas pelo Sergio e pertencem a ele. Originalmente, a casa onde mora pertencia a família Alexandre, moradores antigos da P. Vermelha.

- S. Anízio tem casa de farinha mas atualmente não plantou roça de mandioca.

- Tem gerador que alimenta um conjunto de lâmpadas, um aparelho de som, televisão. Consome 2 litros de óleo diesel por hora que resulta num gasto de aproximadamente $\mathrm{R} \$ 300,00$ por mês com combustível. 


\section{CADASTRO DAS FAMÍLIAS RESIDENTES NA BAÍA DOS CASTELHANOS PRAIA VERMELHA}

- o S. Anízio, a D. Leopoldina e seus filhos, principalmente o Almir, forneceram muitas informações sobre os moradores da Baía dos Castelhanos, antigos e atuais, e também sobre a pesca e seus equipamentos.

\section{TRECHOS DO DEPOIMENTO PRESTADOS POR S. ANÍZIO E D. LEOPOLDINA}

"A roupa, não. Não era o barco que trazia. la lá em São Sebastião comprar numa loja de uma pessoa conhecida, que conhecia o povo todo daqui...Também vinha aqui. Ele vinha a pé com a mala de fazenda, como chamavam antigamente a mala de tecidos. Ele conhecia a comunidade toda, todo mundo gostava...Dava uma entrada, pagava no outro mês o restante. Vendia roupa também...sapato..." (trecho referindo-se ao Sr.. João Elias, dono do Bazar Fátima em São Sebastião).

"A roupa era feita aqui. Eles traziam o tecido, a gente comprava e fazia a roupa. Aqui tinha muita costureira. Tinha a Celeste, tinha a minha tia (D. Joana) na Praia Mansa, tinha no Castelhanos a mãe da Iza...máquina Singer, todo mundo tinha uma maquinazinha de mão. Quem tinha mais condição, tinha uma máquina de pé, a Singer que pedala. Até calça de homem a gente fazia e vendia."

"O Barbosa era muito festeiro. Ali (na casa dele) era salão de baile antigamente. Ele gostava e emprestava a casa dele pra quem gostava. Fazia casamento...quando alguém casava, fazia a festa de casamento na casa dele. Mesmo um bailezinho simples, um forrozinho da roça, ele emprestava a casa dele. Ele tava velhinho mas ele também gostava de sacudir um pouquinho...ele emprestava a casa dele pro pessoal fazer festa. Mas tinha de ser na regra. Se qualquer um pisava na bola, ele tocava pra fora e não entrava mais...ele emprestava a casa dele pra fazer um bailinho da roça, um batizado..."

Total de moradores: 5
CASA DE FARINHA DE:
ANÍZIO RAFAEL DE SOUZA
LOCALIZAÇÃO UTM:
$470.473 / 7.359 .818$

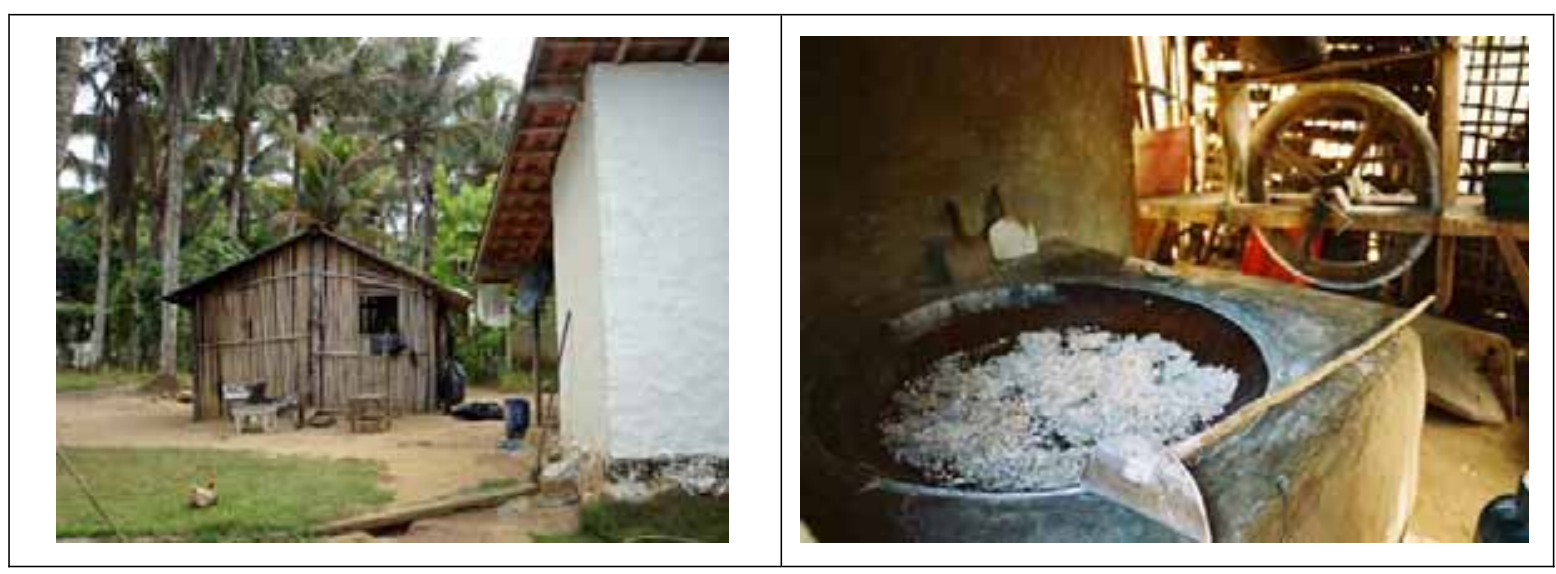




\section{CADASTRO DAS FAMÍLIAS RESIDENTES NA BAÍA DOS CASTELHANOS}

\section{PRAIA VERMELHA}

FAMÍLIA DE:

WALMIR RAFAEL DE SOUZA

LOCALIZAÇÃO UTM: $470.463 / 7.359 .804$

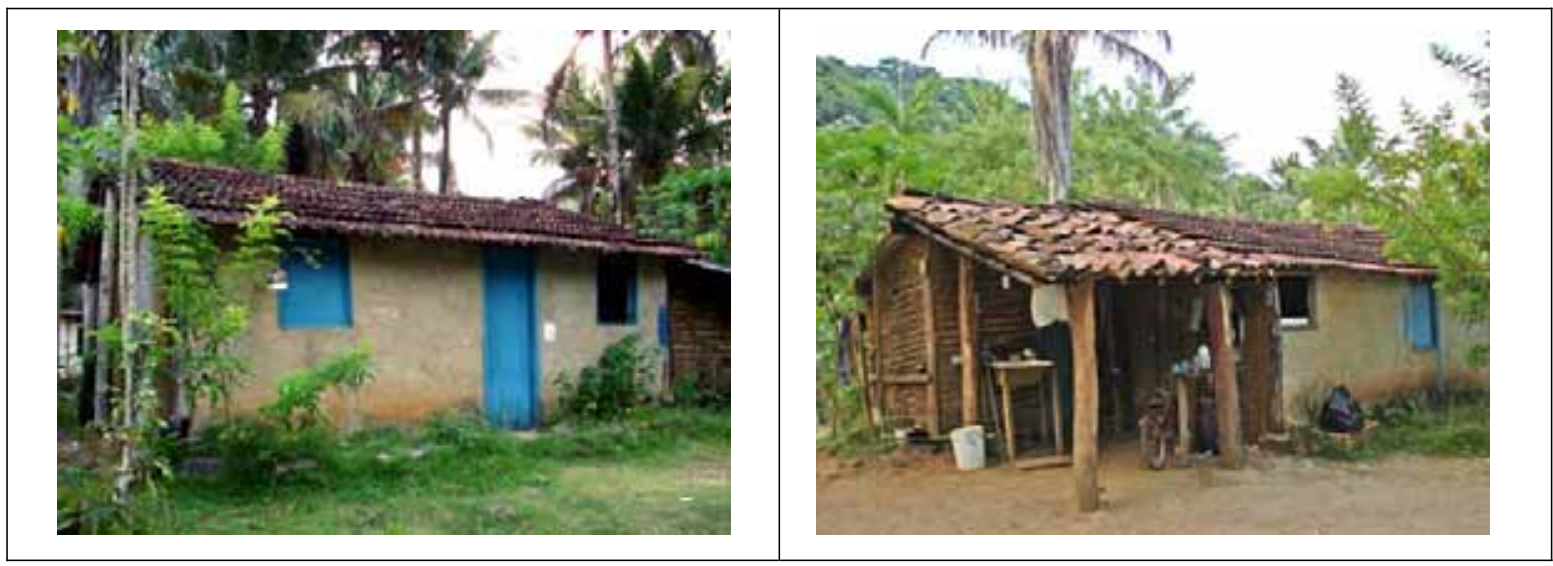

Data e local de nascimento: P. Vermelha, 29 anos.

Filiação: Anízio Rafael de Souza (P. Vermelha) e Leopoldina Rafael de Souza

Estado Civil: Separado

Atividade profissional: Pescador;

Filhos: Tem uma filha de 8 anos que fica com ele semana sim semana não

Total de moradores: 1 


\section{CADASTRO DAS FAMÍLIAS RESIDENTES NA BAÍA DOS CASTELHANOS}

\section{PRAIA VERMELHA}

FAMÍLIA DE:

EVANDRO RAFAEL DE SOUZA

LOCALIZAÇÃO UTM: $470.466 / 7.359 .786$

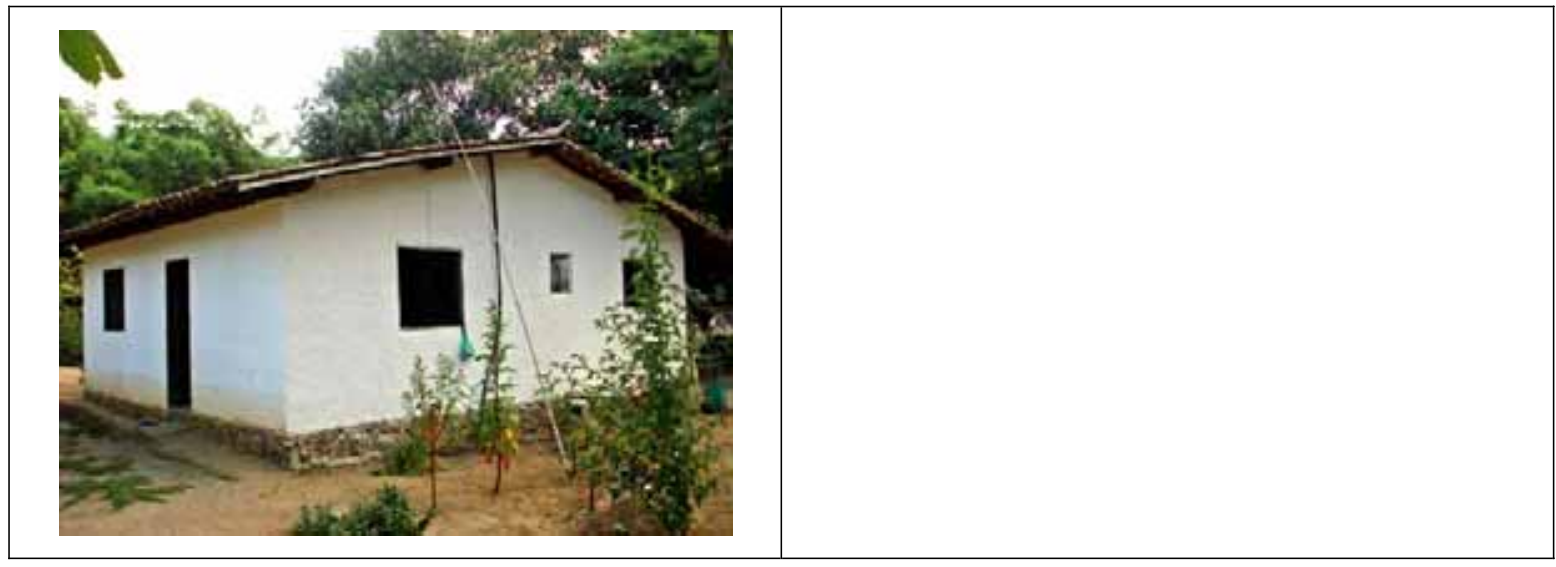

Data e local de nascimento: P. Vermelha, 27 anos.

Filiação: Anízio Rafael de Souza, P. Vermelha, e Leopoldina Rafael de Souza, P. Mansa

Estado Civil: Casado

Atividade profissional: Pescador; Roça de Mandioca, produz farinha.

Esposa: Marciana Gonçalves de Souza

Data e local de nascimento: P. dos Castelhanos - Canto da Lagoa, 27 anos

Filiação: Laercio de Souza (P. Mansa) e Maria Alice Gonçalves (Canto da Lagoa) Filha de Criação de Erotildes.

Filhos: Velerson Gonçalves de Souza (10), Raquel (9) e Alex (7)

Total de moradores: 5 


\section{CADASTRO DAS FAMÍLIAS RESIDENTES NA BAÍA DOS CASTELHANOS}

\section{PRAIA VERMELHA}

FAMÍLIA DE:

MANOEL RAFAEL DE SOUZA

LOCALIZAÇÃO UTM:

$470.473 / 7.359 .805$

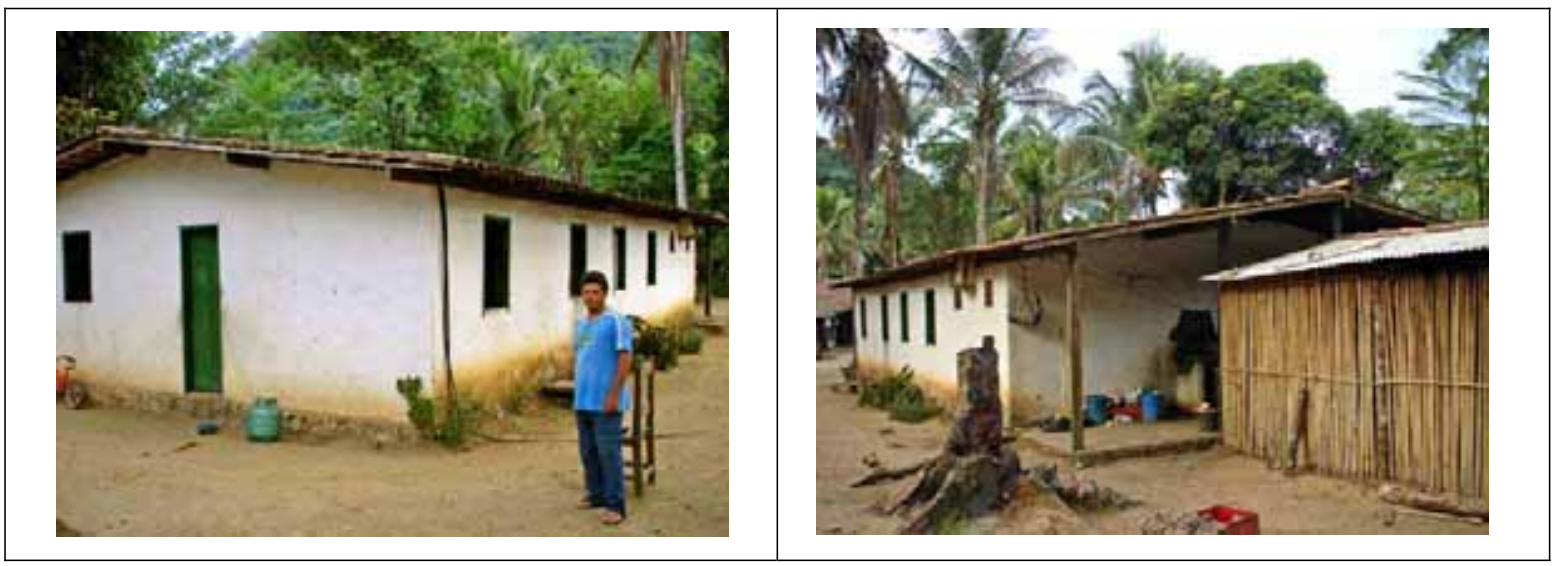

Data e local de nascimento: Praia Vermelha, ( ).

Filiação: Pedro Manoel de Souza, P. Castelhanos e Jorgina Inácio dos Santos, llha de Búzios

Estado Civil: Casado

Atividade profissional: Pescador

Esposa: Alaíde de Souza

Data e local de nascimento: Praia Vermelha.

Filiação: Pedro Rafael de Souza (Pedro Madalena) e (?)

Filhos: Maílson e Maísa Rafael de Souza

Total de moradores: 5 


\section{CADASTRO DAS FAMÍLIAS RESIDENTES NA BAÍA DOS CASTELHANOS}

\section{PRAIA VERMELHA}

FAMÍLIA DE:

ALEXANDRE DE SOUZA ROMÃO

LOCALIZAÇÃO UTM:

$470.478 / 7.359 .811$

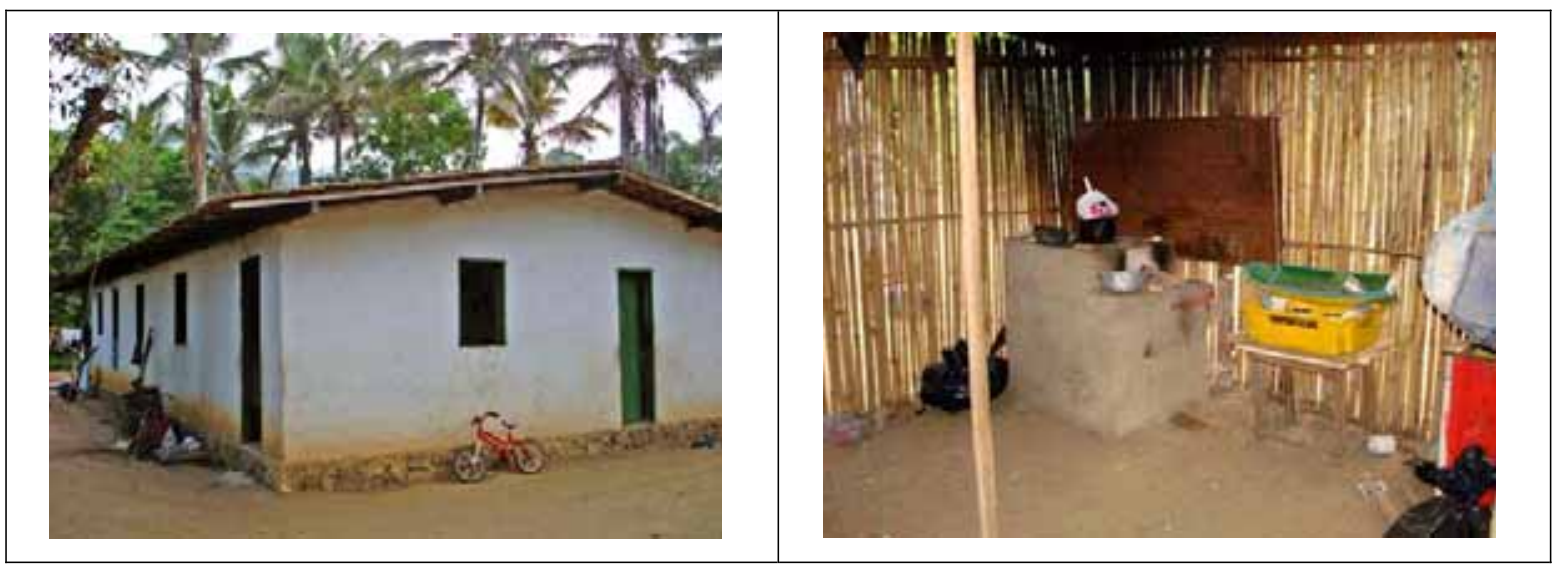

Data e local de nascimento: P. Vermelha, 26 anos

Filiação: Benedito de Souza Romão, P. Vermelha, e Dalva Maria dos Santos

Estado Civil: Casado

Atividade profissional: Pescador; Artesanato turístico

Esposa: Daice Rafael de Souza

Data e local de nascimento: Praia Vermelha, 22 anos.

Filiação: Manoel Rafael de Souza, P. Vermelha, e Alaíde de Souza, P. Vermelha.

Filhos: Wallace Romão de Souza

Total de moradores: 3 


\section{CADASTRO DAS FAMÍLIAS RESIDENTES NA BAÍA DOS CASTELHANOS}

\section{PRAIA VERMELHA}

FAMÍLIA DE: PEDRO RAFAEL DE SOUZA (PEDRO MADALENA)

LOCALIZAÇÃO UTM: $470.363 / 7.359 .821$
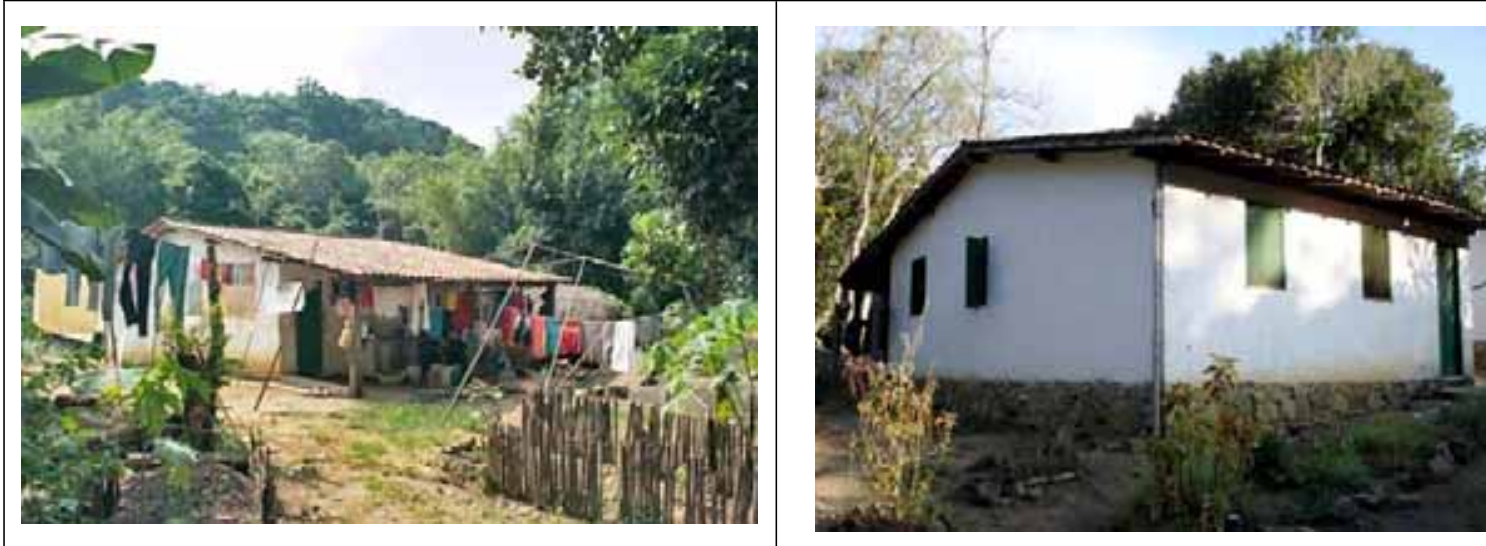

Data e local de nascimento: P. Vermelha, 72 anos.

Filiação: Pedro Manoel de Souza, P. Castelhanos e Jorgina Inácio dos Santos, Ilha de Búzios

Estado Civil: Casado

Atividade profissional: Pescador; proprietário de cerco; tem canoa-a-motor e canoas a remo; é aposentado e pensionista do INSS.

Esposa: Madalena Euzébio de Morais

Data e local de nascimento: Canto do Ribeirão, 50 anos

Filiação: Benedito Euzébio de Morais e Catarina Barbosa dos Santos, ambos do Canto do Ribeirão

Filhos: Maria Inêz de Souza, Arivaldo Rafael de Souza, José Roberto (neto)

Observações: Entrevista realizada com Pedro Madalena em 24/04/07.

- S. Pedro informou que a família de seu pai e seus avós era originária de Tapicirica, sul da Ilha, lá pros lados da Sepituba. Vieram trabalhar nos Castelhanos, fazenda Eng. Velho de produção de cachaça, mas S. Pedro não alcançou esse tempo. Seus parentes trabalhavam no corte e transporta da cana para o engenho.

- No seu tempo de criança S. Pedro conta que ia com seu pai levar lenha para o Kamati fazer tinta (antigamente a tinta era feita com o óleo da semente de palmeira espinhuda).

- Aproximadamente com 16 anos começou a trabalhar com a pesca e segue assim até os dias atuais. (seu avô se chamava Napoleão Rafael).

- S. Pedro também conta que o peixe, antes da estrada, era escalado, salgado e vendido seco na cidade. Quando tinha uma boa quantidade, era transportado por canoa a remo.

Total de moradores: 5 


\section{CADASTRO DAS FAMÍLIAS RESIDENTES NA BAÍA DOS CASTELHANOS}

\section{PRAIA VERMELHA}

FAMÍLIA DE:

WALDEMIR RAFAEL DE SOUZA

LOCALIZAÇÃO UTM:

$470.353 / 7.359 .806$

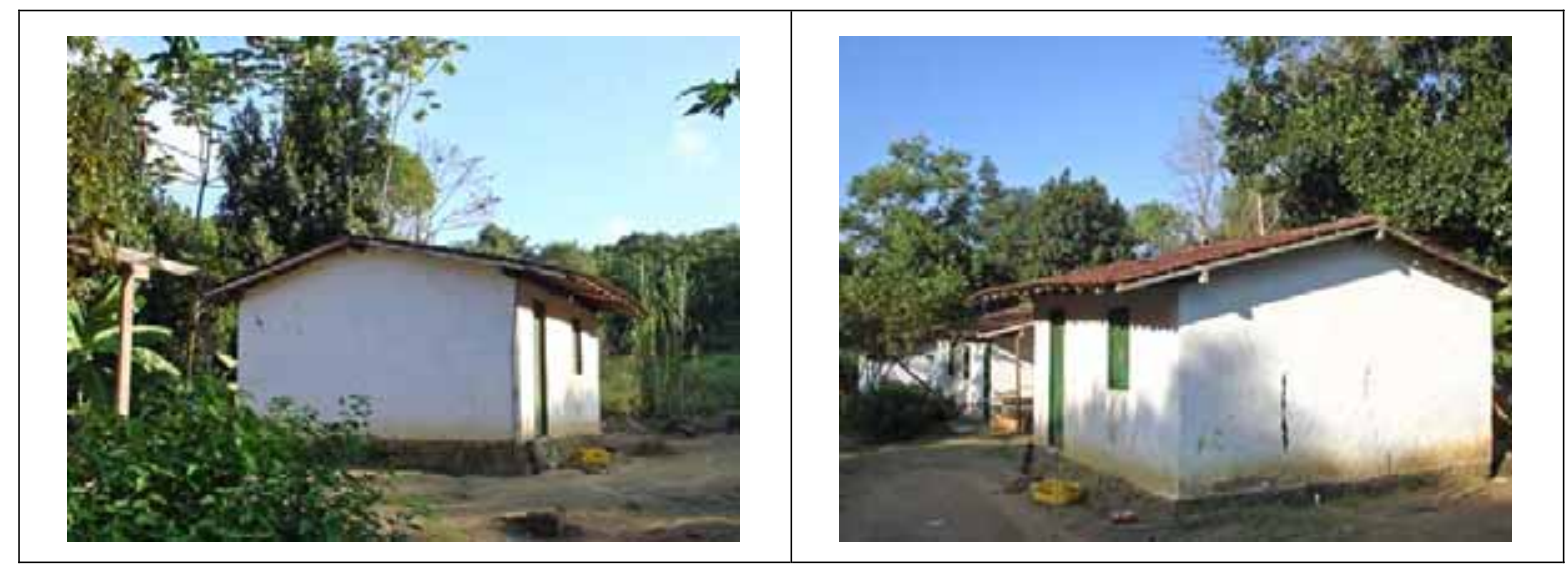

Data e local de nascimento: P. Vermelha, (?) anos.

Filiação: Pedro Manoel de Souza, P. Vermelha e Madalena Euzébio de Morais, Canto do Ribeirão Estado Civil: Solteiro

Atividade profissional: Pescador; proprietário de cerco junto com o pai; tem rede e canoa a remo; pensionista do INSS, aposentado por invalidez (problema de visão)

Total de moradores: 1 


\section{CADASTRO DAS FAMÍLIAS RESIDENTES NA BAÍA DOS CASTELHANOS}

\section{PRAIA VERMELHA}

FAMÍLIA DE:

CASEIRO DO SERGIO

LOCALIZAÇÃO UTM:

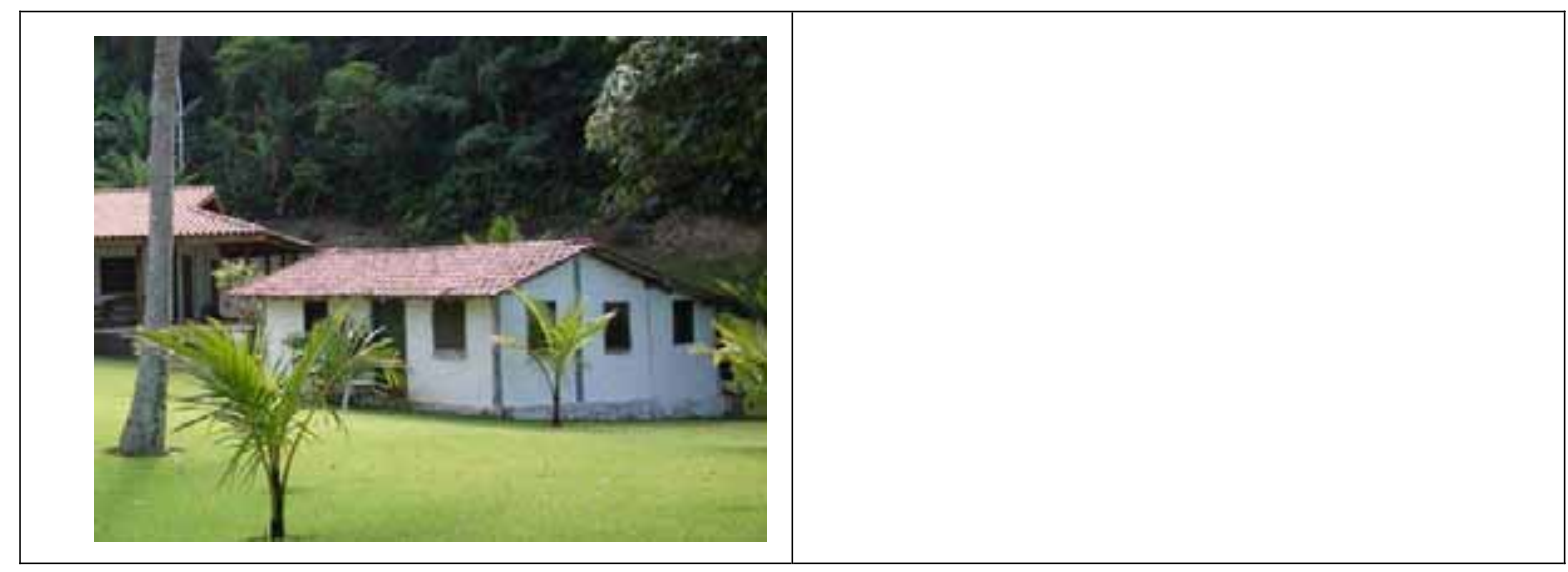

Data e local de nascimento: Paraná.

Filiação:

Estado Civil: Casado

Atividade profissional: Caseiro

Esposa: Nasceu no Paraguai, filha de brasileiros

Total de moradores: 2

Total de Moradores Turistas na Praia Vermelha:

2

Total de Moradores Caiçaras na Praia Vermelha:

25

Total Geral de Moradores na Praia Vermelha: 27 


\section{CADASTRO DAS FAMÍLIAS RESIDENTES NA BAÍA DOS CASTELHANOS PRAIA DA FIGUEIRA}

FAMÍLIA DE: LAURO DOS SANTOS E MARIA EUZÉBIO DE MORAIS DOS SANTOS

LOCALIZAÇÃO UTM: $471.698 / 7.358 .520$

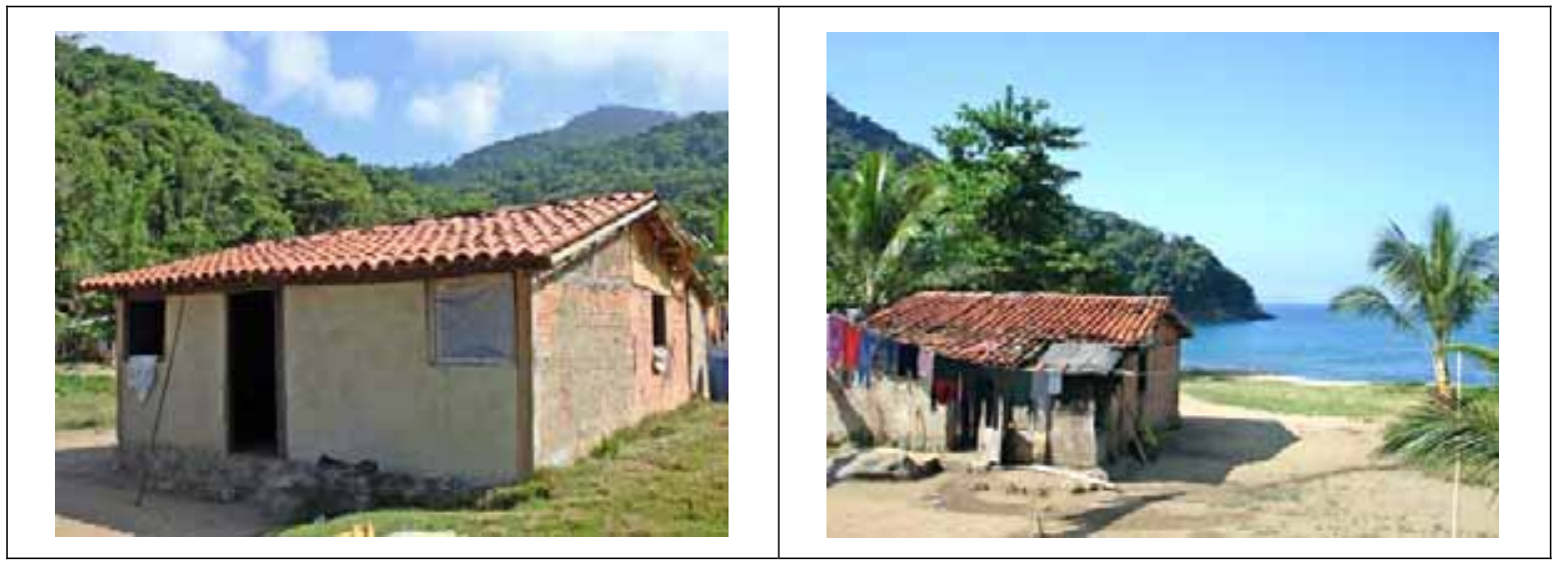

Data e local de nascimento: Praia da Figueira, 1946

Filiação: Odorico Inácio dos Santos e Conceição Inácio dos Santos, ambos das Galhetas Estado Civil: Casado

Atividade profissional: Pescador; artesão de canoa; caseiro; funcionário da prefeitura

Esposa: Maria Euzébio de Morais dos Santos

Data e local de nascimento: Praia da Serraria, 1955

Filiação: Benedito Euzébio de Morais, Praia da Serraria, e Benedita Euzébio de Morais, Guanxuma

Filhos moradores: Bruna dos Santos (10), Bruno dos Santos (13) e Caio dos Santos (8) e Roberto.

Observações: Entrevista realizada com o S. Lauro e D. Maria em 28/03/07.

- O S. Lauro informou que trabalhava embarcado na pesca junto com o tio de D. Maria e morava na casa dele na P. Deserta de São Sebastião. Maria também morava lá. Vieram festejar no Eustáquio e começaram a namorar na própria festa. Namoraram só um mês e se casaram.

- É pescador, não planta mais a roça, basicamente vive do trabalho de limpar a praia e recolher o lixo. Recebe 1 salário da prefeitura e outro por ser caseiro de José Antonio Vidal Xavier Mendonça, dono de meia praia - lado direito, da cachoeira.

- Não alcançou o tempo dos cercos dos japoneses. O pessoal mais antigo da Figueira, seus parentes, trabalhavam na roça e na pesca de cerco.

- O S. Lauro conta que a Praia da Figueira herdou o nome de Francisco Figueira, dono de uma fazenda de café que existiu até o começo do sec. XX. Os herdeiros do Sr.. João Margarida, sócio de Francisco, e que ficou com a fazenda, venderam a propriedade que teve vários donos até ser comprada pelo Sr.. José Antonio V. X. de Mendonça - uma metade. A outra metade foi comprada por último por Mário Wolkoff, atual dono do canto esquerdo.

- O Sr.. José Antonio não tem casa construída para seu uso na Figueira.

- A administração do Parque (PEIb) e o DPERN autorizam os funcionários e seus familiares a construírem casas para suas moradias, mas os proprietários da terra não podem construir.

Total de moradores: 6 


\section{CADASTRO DAS FAMÍLIAS RESIDENTES NA BAÍA DOS CASTELHANOS \\ PRAIA DA FIGUEIRA}

FAMÍLIA DE:

ANÍZIO RAFAEL DE SOUZA FILHO E KÁTIA DOS SANTOS

LOCALIZAÇÃO UTM: $471.694 / 7.358 .475$

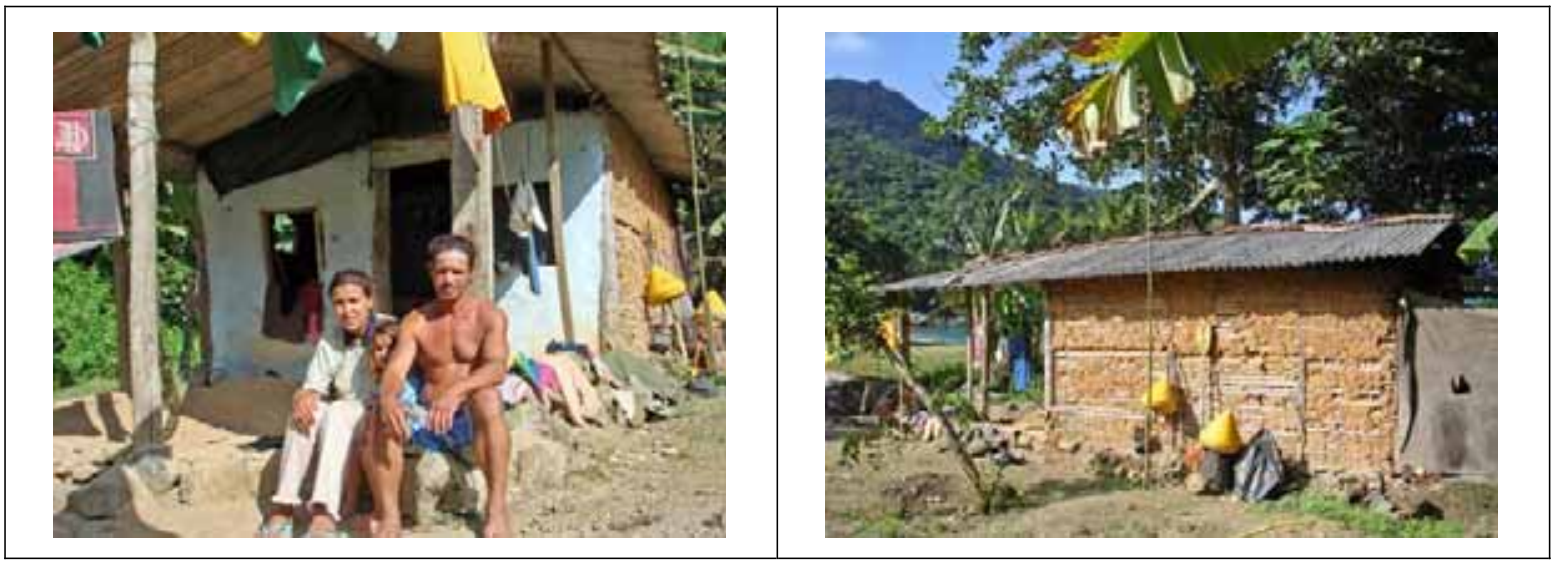

Data e local de nascimento: Praia Vermelha.

Filiação: Anízio Rafael de Souza e Leopoldina Rafael de Souza.

Estado Civil: Casado.

Atividade profissional: Pescador, tem uma canoa-a-remo, pesca de linha.

Esposa: Kátia dos Santos.

Data e local de nascimento: Praia da Figueira, 25 anos.

Filiação: Lauro dos Santos, praia da Figueira, e Maria Euzébio de Morais dos Santos, praia da Serraria

Filhos: Gabriel (6), Kássia (4) e Gabriela (2) de Souza Santos.

Total de moradores: 5 


\section{CADASTRO DAS FAMÍLIAS RESIDENTES NA BAÍA DOS CASTELHANOS \\ PRAIA DA FIGUEIRA}

FAMÍLIA DE: MANOEL MESSIAS DOS SANTOS

LOCALIZAÇÃO UTM: 471.682 / 7.358 .525

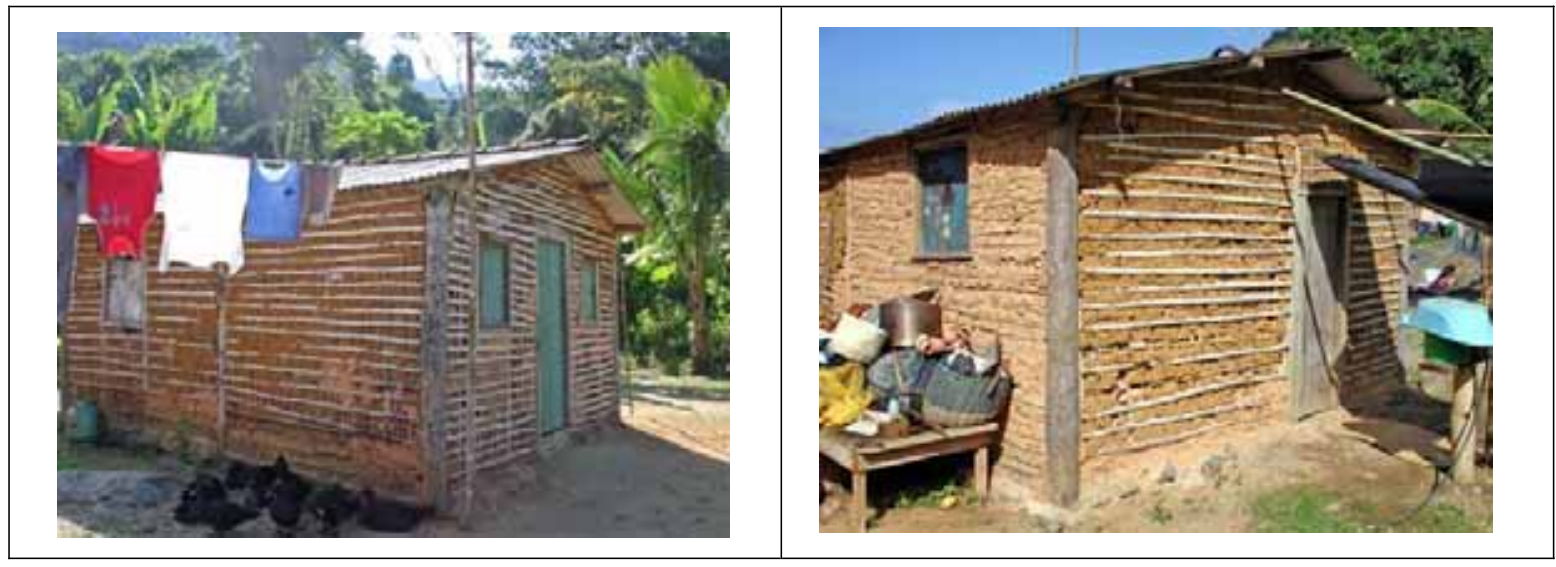

Data e local de nascimento: Praia Vermelha.

Filiação: Lauro dos Santos, praia da Figueira, e Maria Euzébio de Morais dos Santos, praia da Serraria Estado Civil: Solteiro.

Atividade profissional: Pescador.

- Informações dadas por seus pais. Atualmente está trabalhando no Sombrio e a casa está vazia. Tem uma televisão que funciona com bateria de automóvel e que carrega na praia Mansa ou na cidade.

Total de moradores: 1 


\section{CADASTRO DAS FAMÍLIAS RESIDENTES NA BAÍA DOS CASTELHANOS \\ PRAIA DA FIGUEIRA}

FAMÍLIA DE:

MAURÍCIO INÁCIO DOS SANTOS

LOCALIZAÇÃO UTM:

$471.759 / 7.358 .735$

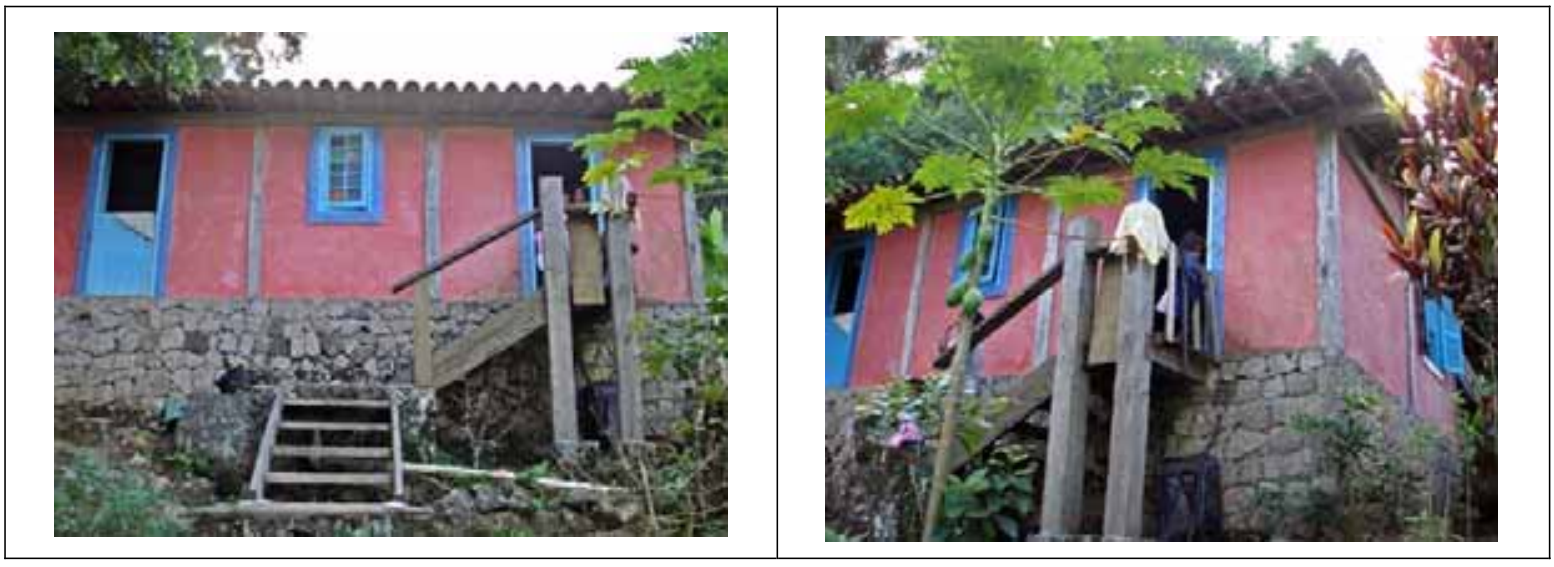

Filiação: Odorico Inácio dos Santos e Conceição Inácio dos Santos, ambos das Galhetas

Estado Civil: Casado

Atividade profissional: Pescador, tem uma batera e duas redes, uma de fundo e outra de superfície; caseiro.

Esposa: Elisabete Pereira da Silva Santos

Data e local de nascimento: (?) (?)

Filiação: (?) (?)

Filhos: Monize (12), Dener (10), Moriza (4) e Samira Inácio dos Santos(2) .

Observações: Entrevista realizada com a D. Elisabete em 28/03/07.

- D. Elisabete informou que ela e o marido trabalham como caseiros do Sr.. Arthur Ribeiro, proprietário do canto esquerdo da praia. Moram em casa cedida e construída pelo proprietário. Recebem, ela 1⁄2 salário e ele, 1 salário. - O Sr. Arthur tem mais 3 edificações na praia: uma casa antiga de pau-a-pique, reformada a adaptada para lazer casa que usa quando vai ao local; uma espécie de quiosque, com teto de palha e paredes de pau-a-pique e vidro; e uma pequena edificação de alvenaria, provavelmente usada para depósito.

- O S. Maurício tem uma batera, barco tipo trainera, pesca com suas duas redes, uma de fundo e outra de superfície. O pescado é transportado para Ilhabela.

- Tem uma roça de mandioca e produz farinha para seu consumo.

Total de moradores: 6 


\section{CADASTRO DAS FAMÍLIAS RESIDENTES NA BAÍA DOS CASTELHANOS \\ PRAIA DA FIGUEIRA}

FAMÍLIA DE:

FERNANDA

LOCALIZAÇÃO UTM:

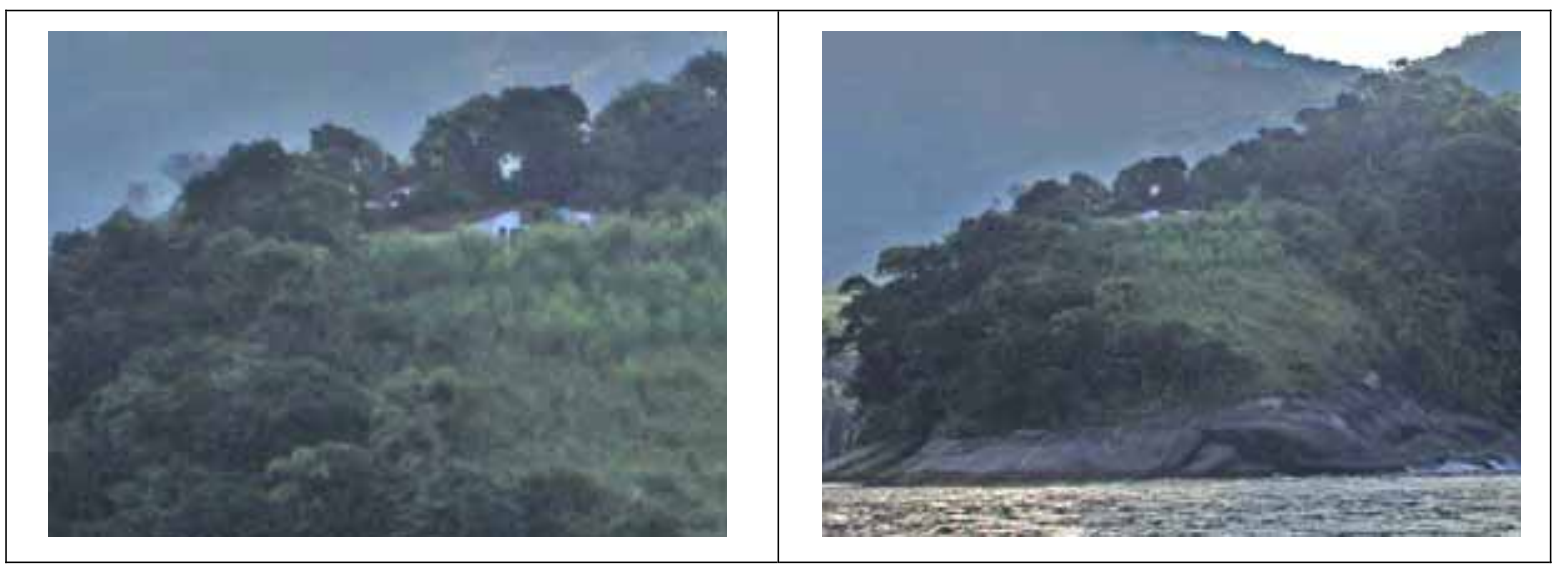

Data e local de nascimento: Praia Vermelha.

Filiação: ?

Estado Civil: Separada.

Atividade profissional: ?.

Observação: Informações dadas por Arlindo e Almir.

A casa onde mora encima do morro foi construída pelo S. Maurício, que morava lá antes de ir trabalhar como caseiro na casa de Arthur Ribeiro. Está cedida temporariamente para a Fernanda.

Filhos: Elaine

Total de moradores: 2

Total de moradores da Praia da Figueira: 


\section{CADASTRO DAS FAMÍLIAS RESIDENTES NA BAÍA DOS CASTELHANOS \\ SACO DO SOMBRIO}

FAMÍLIA DE:

BENEDITO PEDRO DOS SANTOS (BADICO) / ÂNGELA MARIA FONTES DE JESUS

LOCALIZAÇÃO UTM:

$475.149 / 7.356 .554$

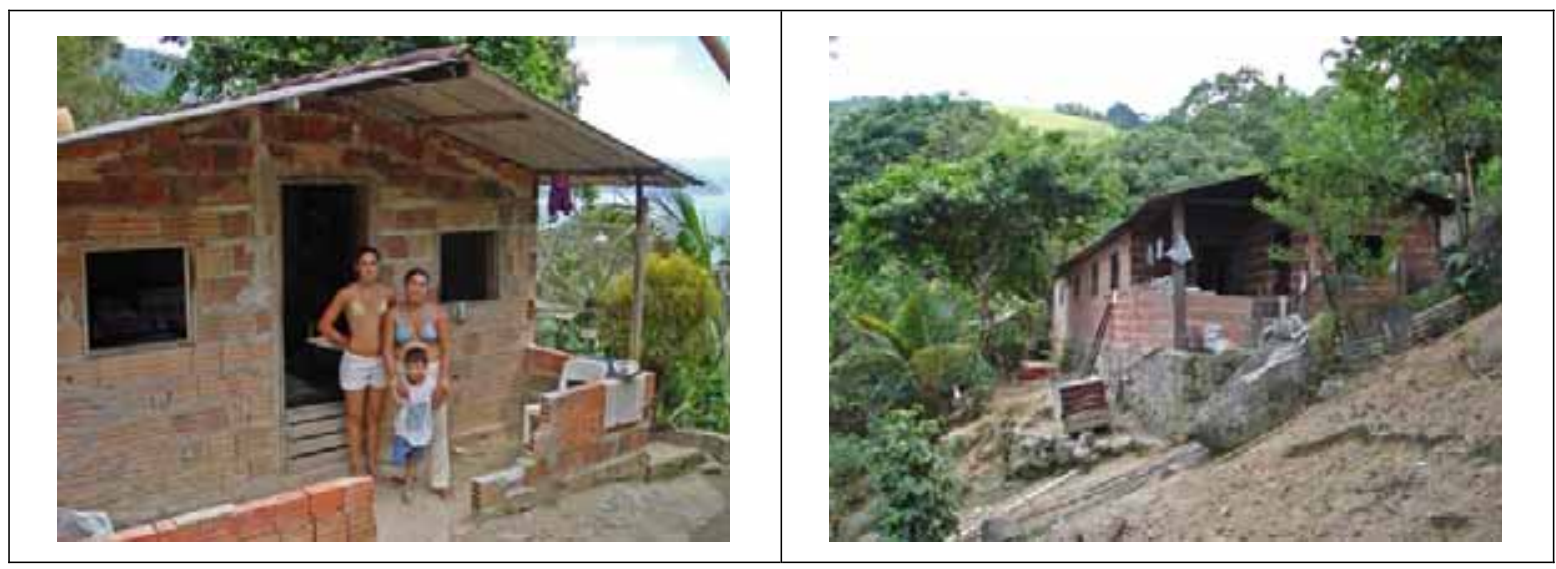

Data e local de nascimento: Saco do Eustáquio, 41 anos.

Filiação: Pedro Pacidônio dos Santos, Ilha de Búzios, e Venina Leonilda Costa, Saco do Eustáquio

Estado Civil: Casado

Atividade profissional: Pescador, tem uma batera e rede; pedreiro, faz alguns bicos.

Esposa: Ângela Maria Fontes de Jesus

Data e local de nascimento: Saco do Sombrio, 34 anos.

Filiação: Laércio de Jesus, Praia Vermelha, e Clarinda Fontes de Jesus, Saco do Sombrio

Filhos: Elisângela Jesus dos Santos (14) Inará J S. (11) e Willian J. S. (3).

Observações:

Entrevista realizada com D. Ângela em 28/03/07.

Informou que tem roça de mandioca, casa de farinha e que ainda produzem farinha.

Tem gerador que alimenta uma televisão, uma máquina tanquinho e lâmpadas. Consome aproximadamente $1,5 \mathrm{~L} /$ hora de diesel.

Total de moradores: 5 


\section{CADASTRO DAS FAMÍLIAS RESIDENTES NA BAÍA DOS CASTELHANOS}

\section{SACO DO SOMBRIO}

FAMÍLIA DE:

LOCALIZAÇÃO UTM:
PEDRO DOS SANTOS (PITICO)

475.152 / 7.356 .656

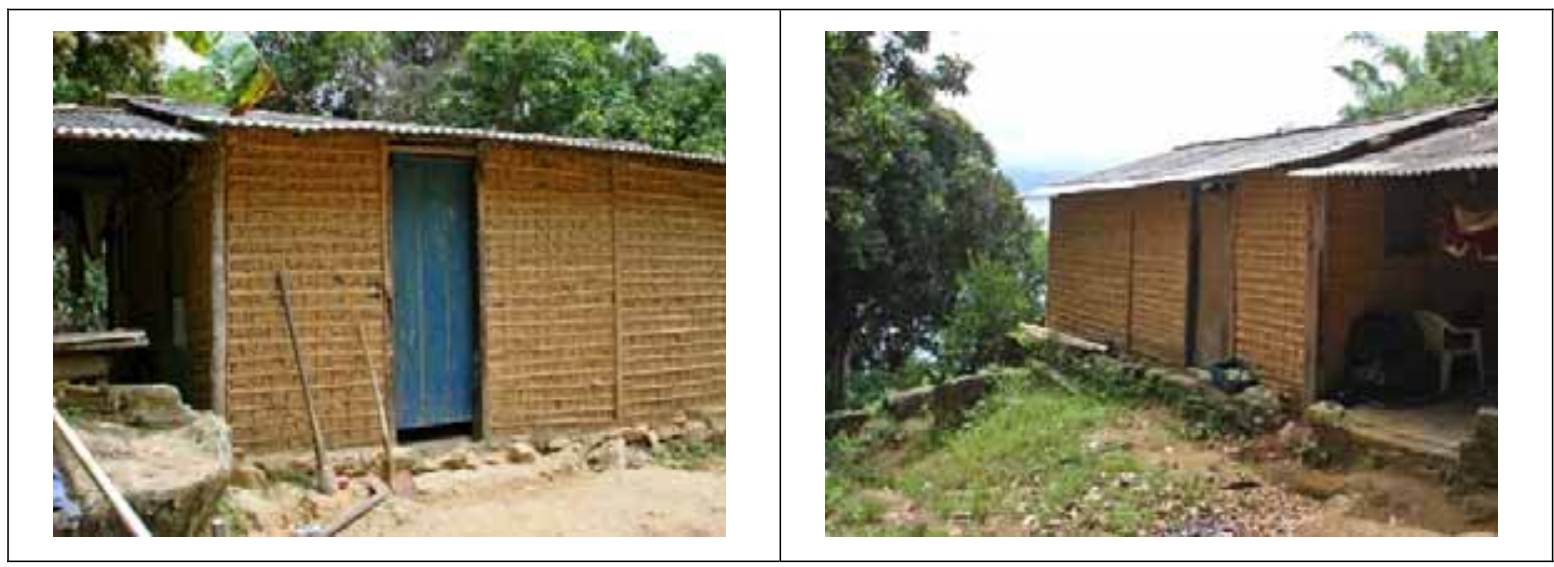

Data e local de nascimento: Saco do Eustáquio, 45 anos.

Filiação: Pedro Pacidônio dos Santos, Ilha de Búzios, e Venina Lenilda Costa, Saco do Eustáquio Estado Civil: Viúvo

Atividade profissional: Pescador, proprietário de cerco, tem uma batera; presta serviços para a prefeitura, transporte de crianças para a escola.

Total de moradores: 1 


\section{CADASTRO DAS FAMÍLIAS RESIDENTES NA BAÍA DOS CASTELHANOS \\ SACO DO SOMBRIO}

FAMÍLIA DE:

SEBASTIANA MARIA MADALENA DE JESUS

LOCALIZAÇÃO UTM:

$475.250 / 7.356 .672$

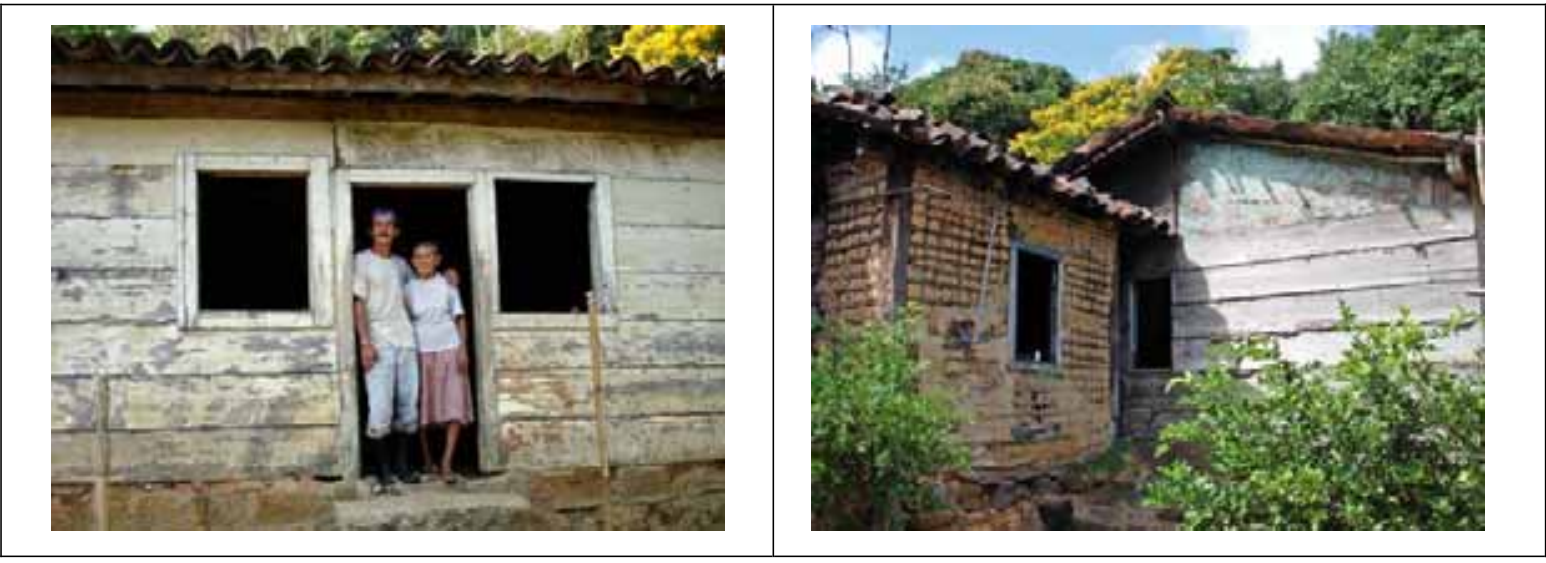

Data e local de nascimento: Praia Vermelha, 89 anos

Filiação: ?

Estado Civil: Viúva de Alcides de Oliveira

Atividade profissional: Aposentada, pensionista do INSS.

Filho: Alcides de Oliveira Filho (Zizinho)

Data e local de nascimento: Praia Vermelha, 52 anos.

Filiação: Alcides de Oliveira, Praia Vermelha, e Sebastiana Maria Madalena de Jesus, Praia Vermelha.

Estado Civil: Viúvo

Atividade profissional: Pescador, tem 1 canoa-a-remo e 6 redes grandes; caseiro, cuida de duas casas no Sombrio (Osmar Soalheiro e Ernesto - Zezo, ambos de São Sebastião); agricultor, tem roça de mandioca e produz farinha tem casa de farinha.

Observações: Entrevista realizada com Zizinho e Sebastiana em 28/03/2007.

D. Sebastiana informou que tinha um engenho em Galhetas, cujo dono era Joaquim Fontes. Produziu pinga + ou até 1940, não se recorda bem. Sua família tinha muita roça, plantava de tudo: abóbora, laranja...O barco pegava laranja, passarinho, gaiola, além de banana e peixe.

Total de moradores: 2 


\section{CADASTRO DAS FAMÍLIAS RESIDENTES NA BAÍA DOS CASTELHANOS}

\section{SACO DO SOMBRIO}

FAMÍLIA DE:

LOCALIZAÇÃO UTM:
ELCIO FONTES DE JESUS

$475.231 / 7.356 .580$

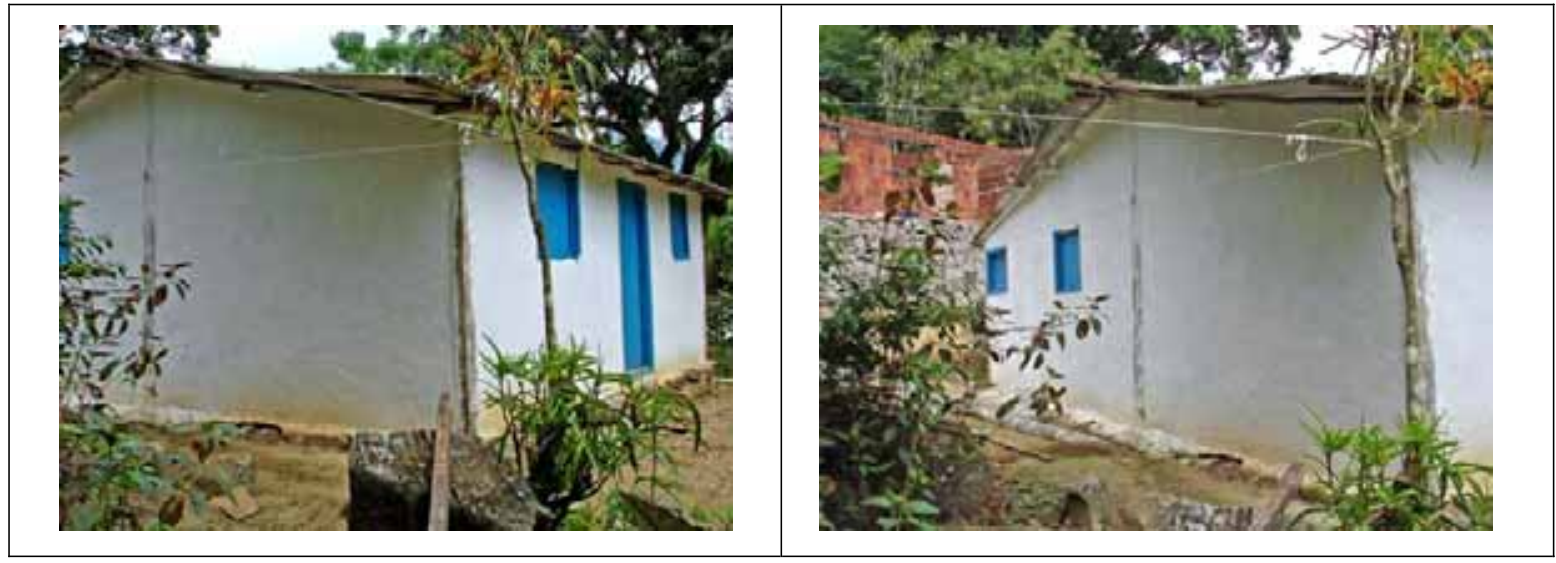

Data e local de nascimento: P. Vermelha, 58 anos

Filiação: Alcides Oliveira dos Santos e Sebastiana de Oliveira, ambos da P. Vermelha.

Estado Civil: Viúvo de Clarinda Fontes de Jesus

Atividade profissional: Pescador; proprietário de cerco.

Total de moradores: 1 


\section{CADASTRO DAS FAMÍLIAS RESIDENTES NA BAÍA DOS CASTELHANOS \\ SACO DO SOMBRIO}

FAMÍLIA DE:

LOCALIZAÇÃO UTM:
ROBERTO, JULIO E GIMILSON FONTES DE JESUS (IRMÃOS)

$475.201 / 7.356 .562$

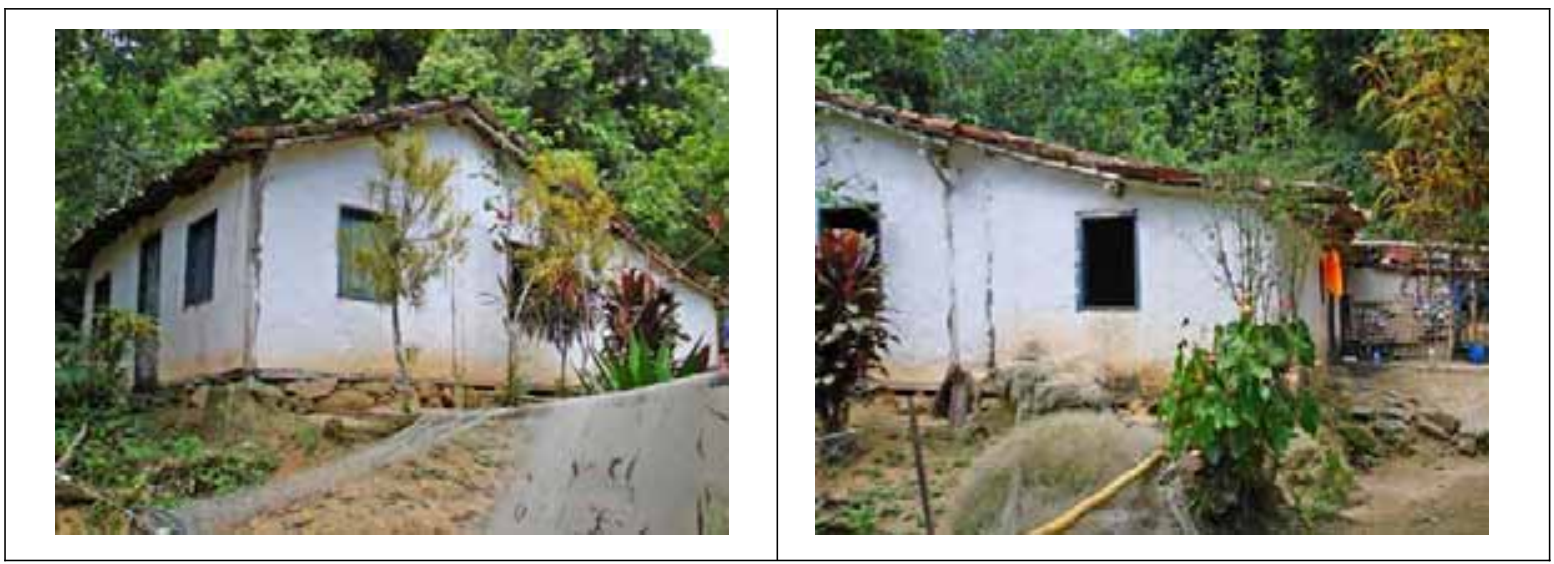

Data e local de nascimento: Saco do Sombrio, Roberto (26 anos ?), Julio, 23 anos e Gimilson, 15 anos Filiação: Elcio Fontes de Jesus, P. Vermelha, e Clarinda Fontes de Jesus

Estado Civil: Solteiro

Observações:

São pescadores, tem duas canoas-a-motor, redes e canoas-a-remo.

Tem gerador a óleo diesel.

Total de moradores: 3 


\section{CADASTRO DAS FAMÍLIAS RESIDENTES NA BAÍA DOS CASTELHANOS}

\section{SACO DO SOMBRIO}

FAMÍLIA DE:

LOCALIZAÇÃO UTM:
ILSON FONTES DE JESUS / CRISTINA TEIXEIRA DE JESUS

$475.213 / 7.356 .594$

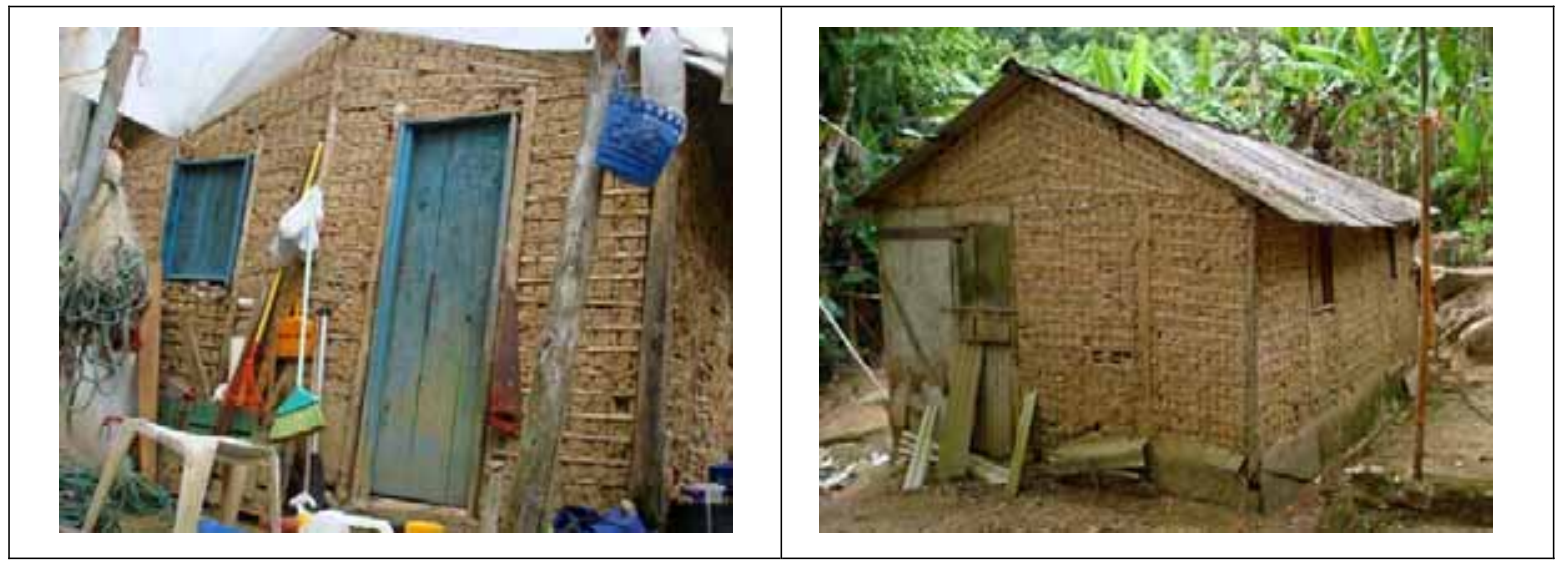

Data e local de nascimento: Saco do Sombrio, 34 anos

Filiação: Elcio Fontes de Jesus, P. Vermelha, e Clarinda Fontes de Jesus

Estado Civil: Casado

Atividade profissional: Pescador;

Esposa: Cristina Teixeira de Jesus

Data e local de nascimento: (?) (?)

Filiação: (?) (?)

Filhos: Ilson Aparecido Fontes de Jesus (7).

Total de moradores: 3 


\section{CADASTRO DAS FAMÍLIAS RESIDENTES NA BAÍA DOS CASTELHANOS}

\section{SACO DO SOMBRIO}

FAMÍLIA DE:

LOCALIZAÇÃO UTM:
LUIS FERNANDO DOS SANTOS

Praia das Galhetas

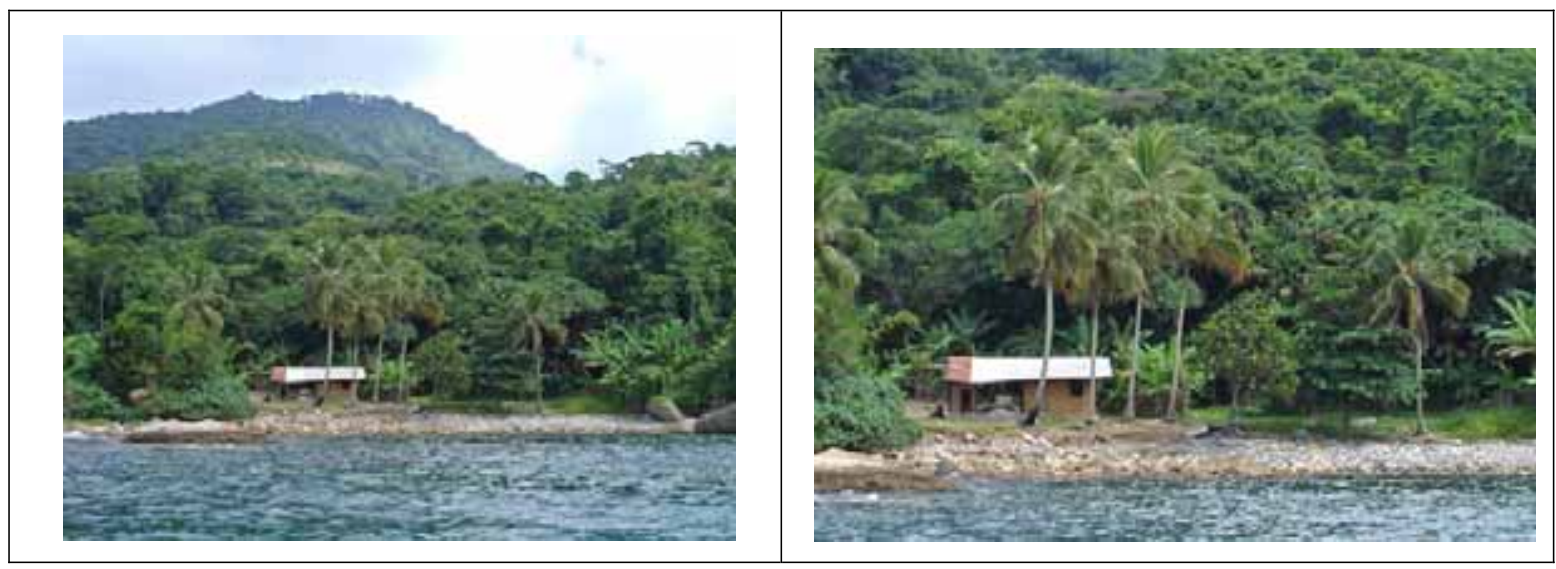

Data e local de nascimento: Saco do Sombrio, 28 anos

Filiação: Pedro Pacidônio dos Santos, Ilha de Búzios, e Venina Lenilda Costa, Saco do Eustáquio

Estado Civil: Casado

Atividade profissional: Pescador;

Esposa: Julia

Data e local de nascimento: (?) (?)

Filiação: (?) (?)

Filhos: Fernanda dos Santos

Observação: A família reside na Praia das Galhetas, situada a meio caminho entre o Sombrio e a Praia da Figueira. É a única família residente no local e a praia está totalmente dentro do Parque.

Total de moradores: 3 


\section{CADASTRO DAS FAMÍLIAS RESIDENTES NA BAÍA DOS CASTELHANOS \\ SACO DO SOMBRIO}

FAMÍLIA DE:

LEOSINO E ANEDITE FERREIRA MENDES

LOCALIZAÇÃO UTM:

$475.210 / 7.356 .771$

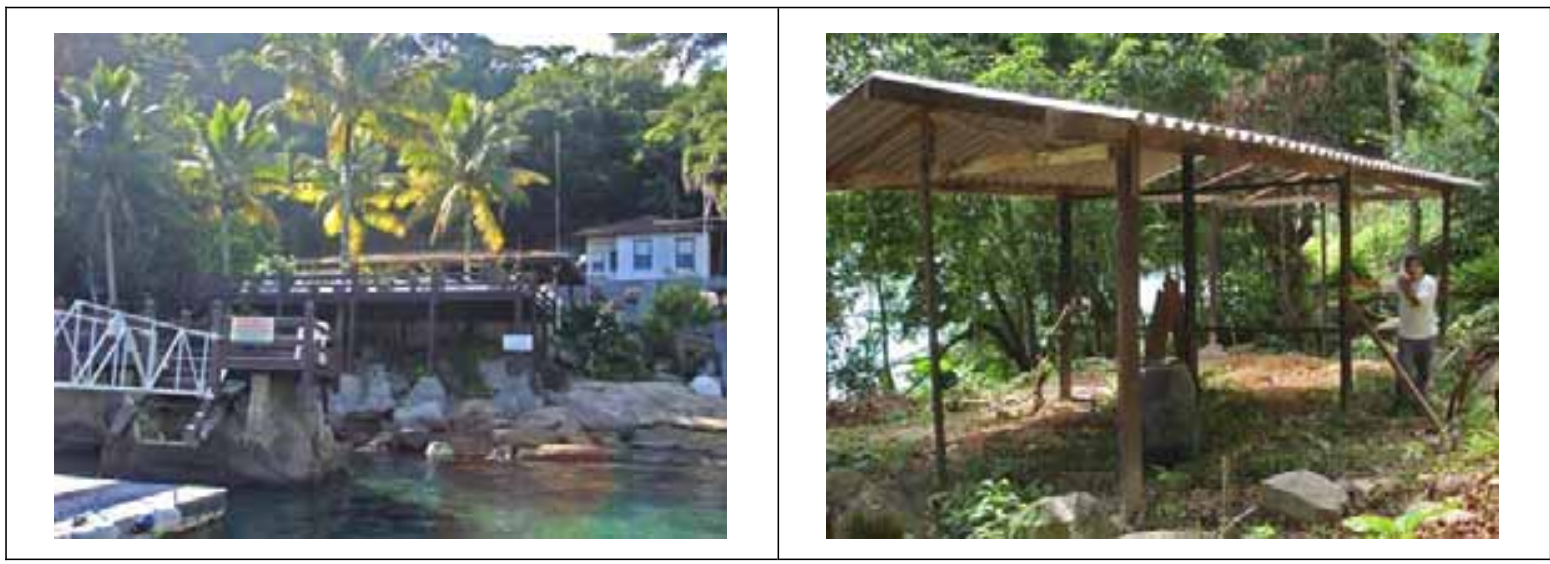

Data e local de nascimento: Minas Gerais

Filiação:

Estado Civil: Casado

Atividade profissional: Zelador do Yatch Club.

Esposa: Anedite Mendes de Souza

Data e local de nascimento: Minas Gerais

Atividade profissional: Cozinheira/Faxineira do Yatch Club.

Filiação:

Filhos: Leandro Mendes de Souza.

Observações:

Entrevista realizada com S. Leosino em 28/03/07. Leosino Informou que as suas famílias vieram de Minas para Ilhabela, na cidade e foi lá que se conheceram. Está há 10 anos morando no Sombrio e trabalhando (morando também) no late Clube. Atualmente está construindo uma casa no Sombrio, mais ou menos no mesmo padrão de como um turista vê a casa de caiçara local e declarou que pretende morar futuramente nesta casa. Não pensa em sair do Sombrio.

Total de Moradores Turistas do Saco do Saco do Sombrio: 03

Total de Moradores Caiçaras do Saco do Sombrio: 18

Total Geral de Moradores do Saco do Sombrio:

21

Total Geral de Moradores Caiçaras da Baía dos Castelhanos:

Total Geral de Moradores Turistas da Baía dos Castelhanos: 


\section{CADASTRO DE BARES, RESTAURANTES E CAMPINGS NA BAÍA DOS CASTELHANOS}

RESTAURANTE CASTELHANOS

LOCALIZAÇÃO UTM: $470.633 / 7.361 .194$

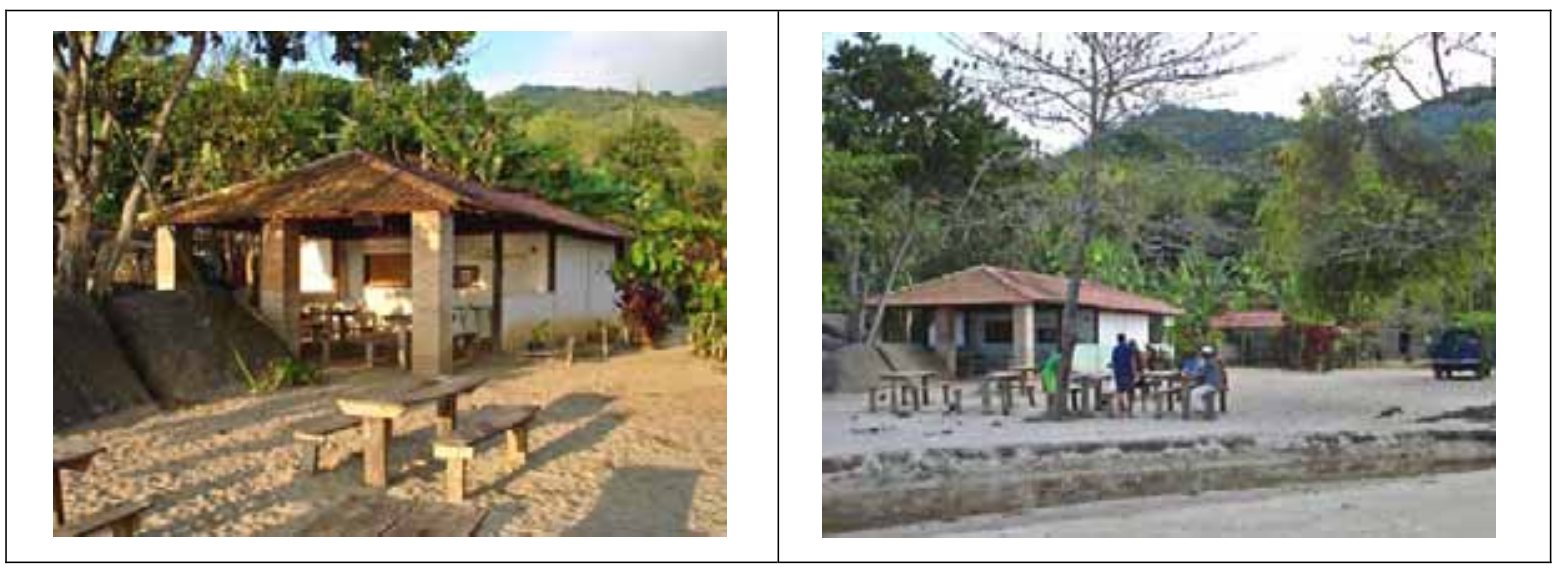

LOCALIZAÇÃO UTM: Canto da Lagoa

Proprietário: Vivian Gonçalves de Souza

Local de origem do proprietário: Caiçara, Canto da Lagoa

Características: Construção em alvenaria, padrão médio.

\section{Observações:}

- Atende basicamente a população caiçara, funcionando como bar e venda.

- Também é camping, cobra R\$ 6,00 por pessoa, mas não tem infra-estrutura de camping.

- Nos finais de semana, feriados e período de férias, movimenta também com turistas, servindo refeições + ou - no mesmo modelo dos outros bares.

- Compra as mercadorias em São Sebastião, geralmente no supermercado SEMAR.

- Tem gerador, mas basicamente trabalha com gelo comprado na cidade e iluminação a gás. 
CADASTRO DE BARES, RESTAURANTES E CAMPINGS NA BAÍA DOS

\section{CASTELHANOS}

RESTAURANTE LAUREANA

LOCALIZAÇÃO UTM:

$470.651 / 7.361 .044$

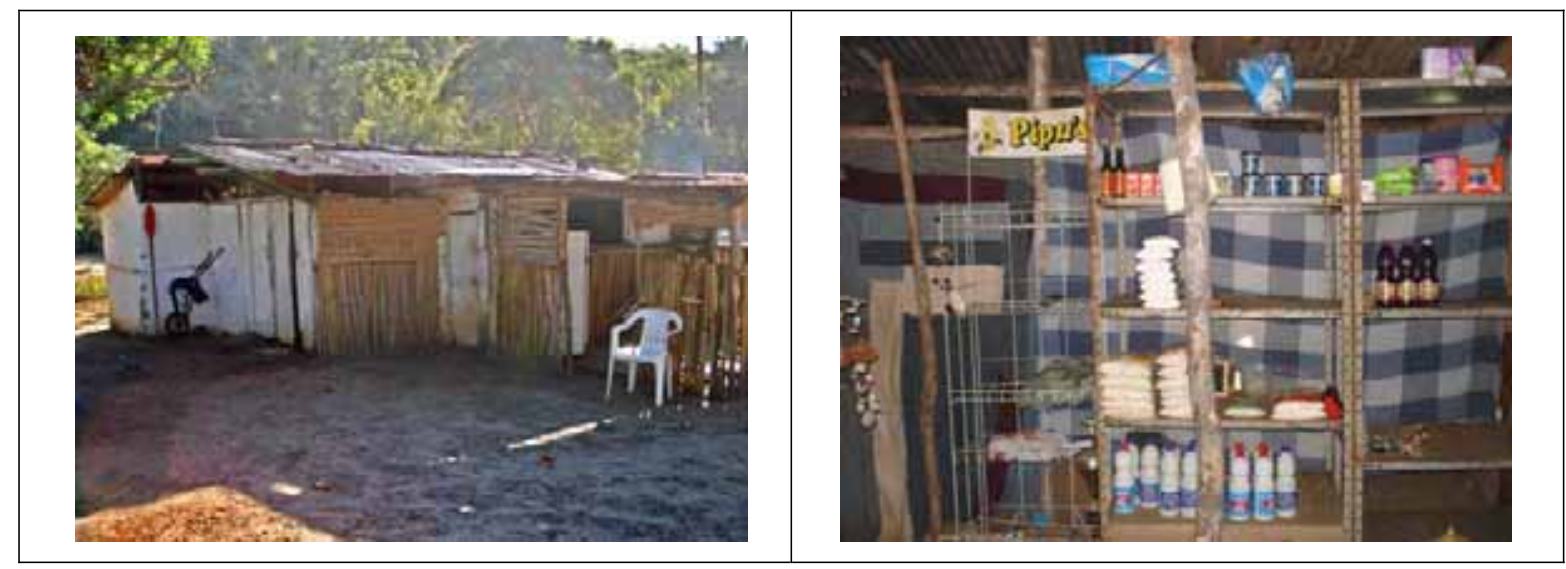

LOCALIZAÇÃo UTM: Canto da Lagoa

Proprietário: Laureana de Souza Lucio

Local de origem do proprietário: Caiçara, Canto da Lagoa

Características: Construção em pau-a-pique, modesta.

Observações:

- Camping de quintal, mas não tem infra-estrutura de camping.

- Serve refeições para turistas.

- Em feriados prolongados chega a pegar 20 barracas. 


\section{CADASTRO DE BARES, RESTAURANTES E CAMPINGS NA BAÍA DOS \\ CASTELHANOS}

RESTAURANTE E CAMPING DO FABIO

LOCALIZAÇÃO UTM:

$470.634 / 7.361 .255$

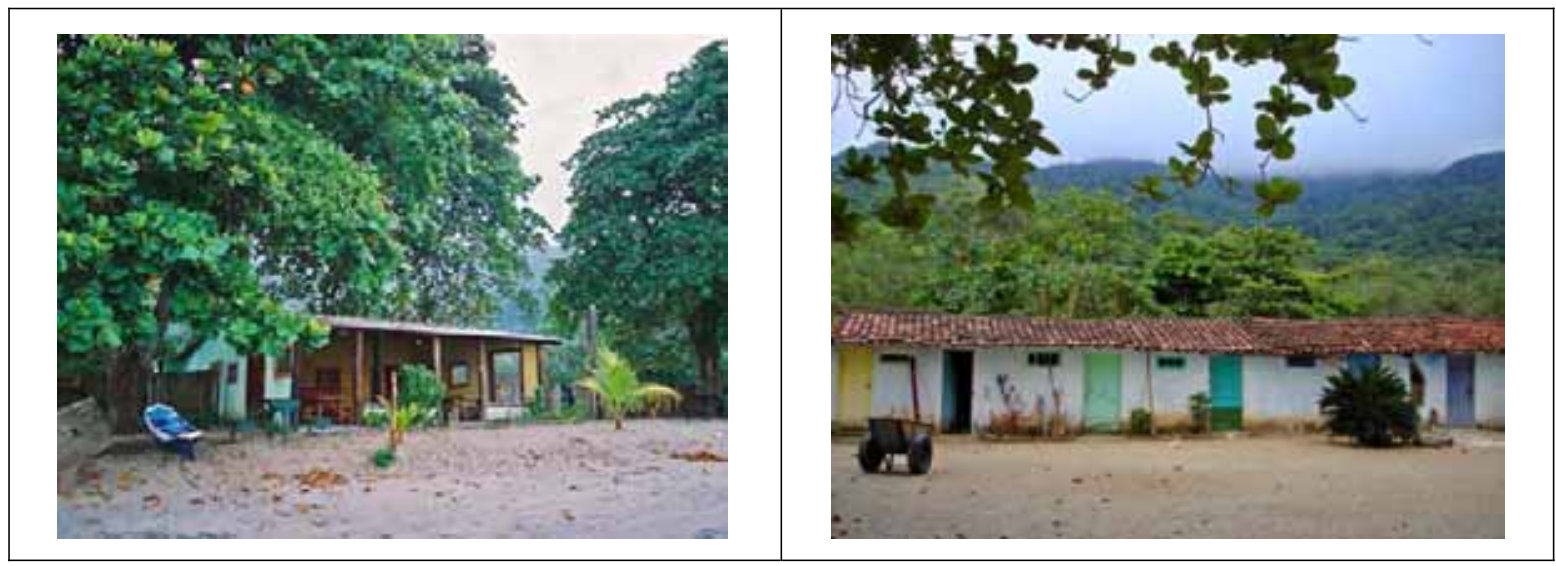

LOCALIZAÇÃO UTM: Canto da Lagoa

Proprietário: ? O Fábio é encarregado.

Local de origem do proprietário e moradia atual : ?

Características: Construção em alvenaria, padrão médio. Fundo, precário.

Observações: Primeiro proprietário foi Canindé, de origem (?) que vendeu em ? Aparenta decadência. 


\section{CADASTRO DE BARES, RESTAURANTES E CAMPINGS NA BAÍA DOS CASTELHANOS}

CAMPING DO LÉO

LOCALIZAÇÃO UTM: $470.567 / 7.361 .335$

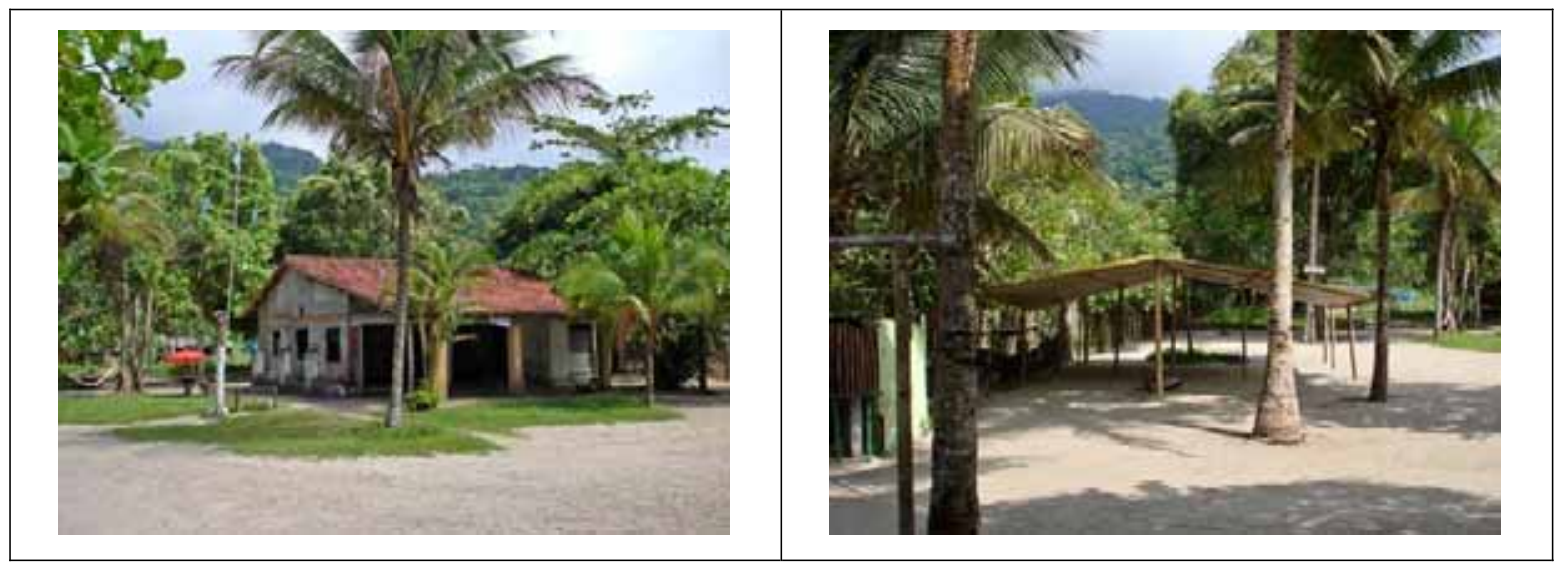

LOCALIZAÇÃO UTM: Canto da Lagoa

Proprietário: Leolino Barbosa de Jesus (encarregado)

Local de origem do encarregado: Caiçara, Canto do Ribeirão

Características: Construção em alvenaria, padrão médio, inacabada. (obra destinada à moradia do proprietário e serve precariamente de apoio ao camping)

Observações:

O Leo, encarregado, declarou que o camping tem planta aprovada na prefeitura, autorização do DEPRN e licença para funcionar como camping.

Segundo Leolino, o camping está instalado em terreno próprio, que é herança de família. Segundo os moradores locais e sua mãe, o terreno é propriedade de gente de fora e o Leo foi contratado para manutenção do terreno e teve autorização do proprietário para explorar o terreno como camping.

Em fim de semana na temporada pega de 20 a 30 barracas. Já pegou 78 barracas em um feriado prolongado.

Cobra R\$ 6,00 por pessoa por dia. Nos finais de semana, feriados e temporada, serve refeições preparadas por sua mulher. Quando tem movimento, contrata mão-de-obra local por dia para ajudar nos serviços de cozinha.

Tem gerador.

É filho de Celeste Maria de Jesus e Benedito Barbosa de Jesus. 


\section{CADASTRO DE BARES, RESTAURANTES E CAMPINGS NA BAÍA DOS CASTELHANOS}

RESTAURANTE MAREBAR

LOCALIZAÇÃO UTM:

$470.561 / 7.361 .498$

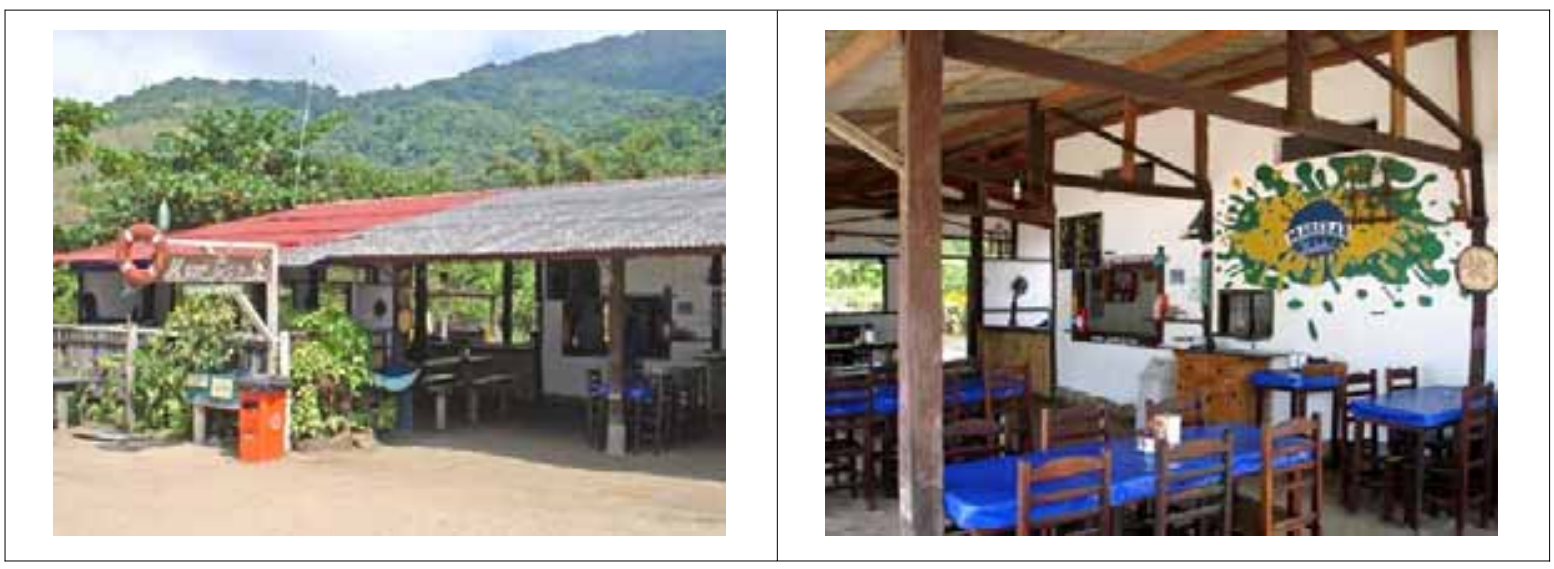

LOCALIZAÇÃO UTM: Canto da Lagoa

Proprietário: Irmãos Renato e Gilda Camargo

Local de origem do proprietário: Ilhabela

Características: Construção em alvenaria, padrão médio.

Observações:

- Renato é funcionário de Marcos Vitorazzo, proprietário do Maremar de Ilhabela, para tomar conta da propriedade nos Castelhanos. Renato e a irmã arrendaram a parte da frente do terreno, onde construíram e exploram o restaurante Marebar de Castelhanos.

- Funciona também como camping. Pode pegar até 10 barracas. Cobra R \$,00/ pessoa.

- A Gilda declarou que o movimento médio mensal na baixa temporada é cerca de $\mathrm{R} \$ 7.000,00$. Na alta temporada, movimenta em média por mês, $\mathrm{R} \$ 28.000,00$.

- Na baixa temporada compra cerca de $\mathrm{R} \$ 400,00$ / mês de peixe dos caiçaras. Na alta, os valores se aproximam de R\$ 2000,00/ mês.

- O peixe é comprado limpo e, dependendo da espécie, é também filetado. O peixe espada, por exemplo, é comprado limpo e cortado em filés por $R \$ 8,00 / \mathrm{kg}$. Na cidade, o mesmo peixe é vendido bruto por entre $\mathrm{R} \$ 1,00 \mathrm{e}$ $\mathrm{R} \$ 1,50$ por $\mathrm{kg}$.

- Gasta R\$1400,00 por semana em mercadorias para o restaurante.

- Tem gerador que alimenta lâmpadas e a televisão. Para o restaurante, utilizagelo em cubo. Um saco de 18 kg custa $\mathrm{R} \$ 12,00$

- Vende gás. O botijão é vendido por $R \$ 55,00$. Na cidade custa $R \$ 39$ ou $R \$ 40$.

- Paga frete de $R \$ 250,00$ para cada viagem a cidade para compra de mercadorias.

- Emprega mão-de-obra caiçara somente em dias de muito movimento e apenas para auxiliar na cozinha.

- Na parte dos fundos, moram o Sílvio Lucio e Maria Alice Gonçalves (mãe da Vivian e Cilene). O Sílvio é dono da casa de alvenaria construída sobre a pedra entre a casa de Irineu e o restaurante da Vivian, que está vazia. 


\section{CADASTRO DE BARES, RESTAURANTES E CAMPINGS NA BAÍA DOS CASTELHANOS}

QUIOSQUE DO ALEMÃO

LOCALIZAÇÃO UTM:

$470.560 / 7.361 .529$

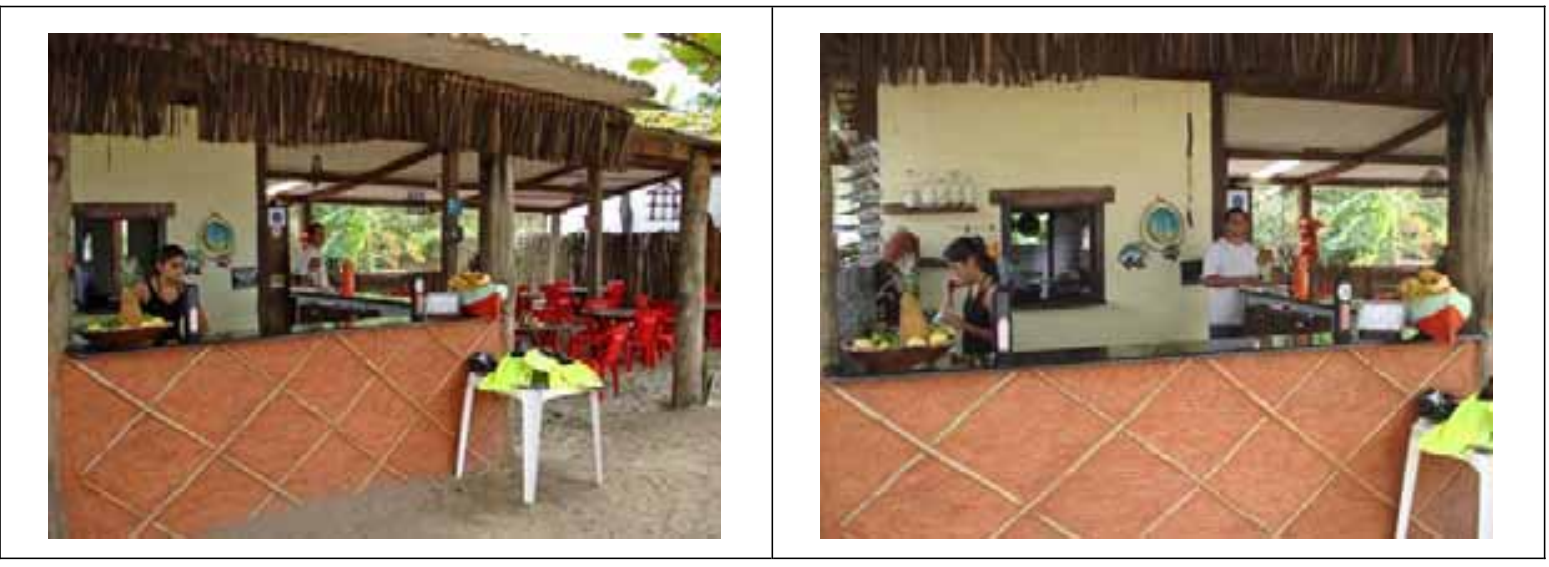

LOCALIZAÇÃO UTM: Canto da Lagoa

Proprietário: Wanderley dos Santos Valério

Local de origem do proprietário: Ilhabela, cidade.

Características: Construção em alvenaria, padrão médio. Instalações do bar/restaurante adequadas.

Observações: Tem autorização da prefeitura para funcionar como quiosque, mas está instalado como bar/restaurante.

Tem gerador.

Emprega mão-de-obra caiçara só com movimento. Compra peixe, lula, camarão dos caiçaras.

Informou que gostaria de oferecer produtos artesanais (há muita procura, segundo ele), mas não há produção local.

O restaurante está instalado em terreno próprio, que é herança de família. O Alemão (Wanderley) declarou ter nascido nos Castelhanos e que seu pai é originário do lugar. Foi criado e educado na cidade. Segundo ele, o Reale, na época da abertura da estrada, loteou toda a praia entre a Lagoa e o rib. do Engenho, se apossando de terras que não eram dele. O loteamento, Vila Reale, só existia na planta, vendia lotes com arruamento que não existiam e que nunca foram entregues. O restaurante está localizado em terras que eram da sua família e que o Leonardo se apossou sem direito. Ao longo de toda a llha, o Leonardo e sócios lançaram empreendimentos semelhantes e que a prefeitura cobrava impostos dos lotes fictícios que foram vendidos.

- O Alemão informou que na baixa temporada o restaurante compra de $R \$ 400,00$ a $R \$ 600,00$ de peixe, camarão, lula, tudo limpo, por mês, dos caiçaras. Na alta temporada compra por volta de $\mathrm{R} \$ 3.000,00$, um pouco de cada pescador.

- não tem gerador e utiliza gelo para os serviços do restaurante. $\mathrm{R} \$ 12,00$ custa o saco de $18 \mathrm{~kg}$ de gelo.

- 1 vez por semana vai a cidade fazer compras para abastecer o restaurante. Gasta aproximadamente $\mathrm{R} \$ 900,00$.

$\mathrm{Na}$ alta temporada vai duas vezes por semana a cidade para fazer compras. Compra tudo nos supermercados.

- Tem jipe, mas freta serviços dos jipeiros. Paga R\$200,00 por viagem a cidade.

- O movimento máximo diário pode chegar a $\mathrm{R} \$ 2.000,00$, mas só nos feriados grandes. 


\section{CADASTRO DE BARES, RESTAURANTES E CAMPINGS NA BAÍA DOS CASTELHANOS}

BAR CASTELHANOS

LOCALIZAÇÃO UTM:

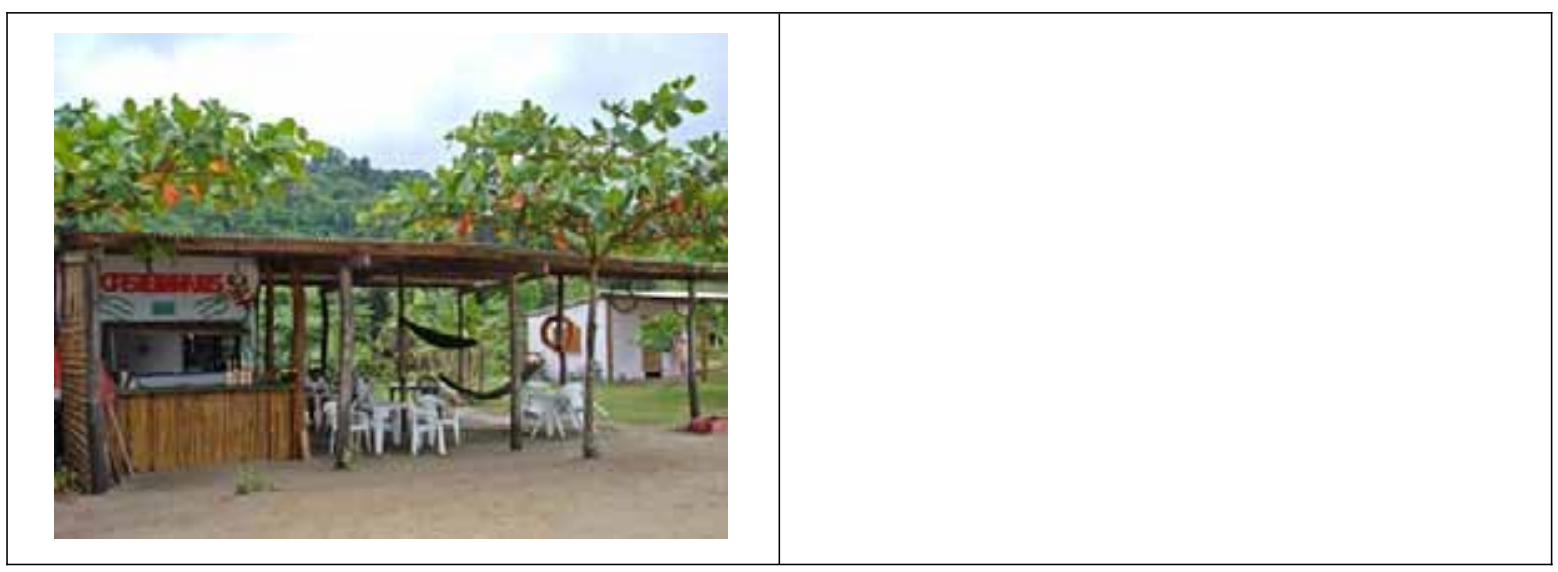

LOCALIZAÇÃo UTM: Canto da Lagoa

Proprietário: Eduardo dos Santos Valério

Local de origem do proprietário: Ilhabela, cidade.

Características: Construção em alvenaria, padrão médio, mais precárias do que a do irmão (Alemão).

\section{Observações:}

- Ainda não tem autorização da prefeitura para funcionar sequer como quiosque, mas, também como o irmão está instalado como bar / restaurante.

- De acordo com o Wanderley, dono do Quiosque do Alemão, o restaurante Castelhanos tem um giro semelhante ao seu e consome basicamente as mesmas mercadorias. Também paga frete aos jipeiros e compra frutos do mar dos caiçaras nas mesmas condições dos outros restaurantes. 


\section{CADASTRO DE BARES, RESTAURANTES E CAMPINGS NA BAÍA DOS CASTELHANOS}

COMIDA CASEIRA

LOCALIZAÇÃO UTM:

$470.570 / 7.361 .646$

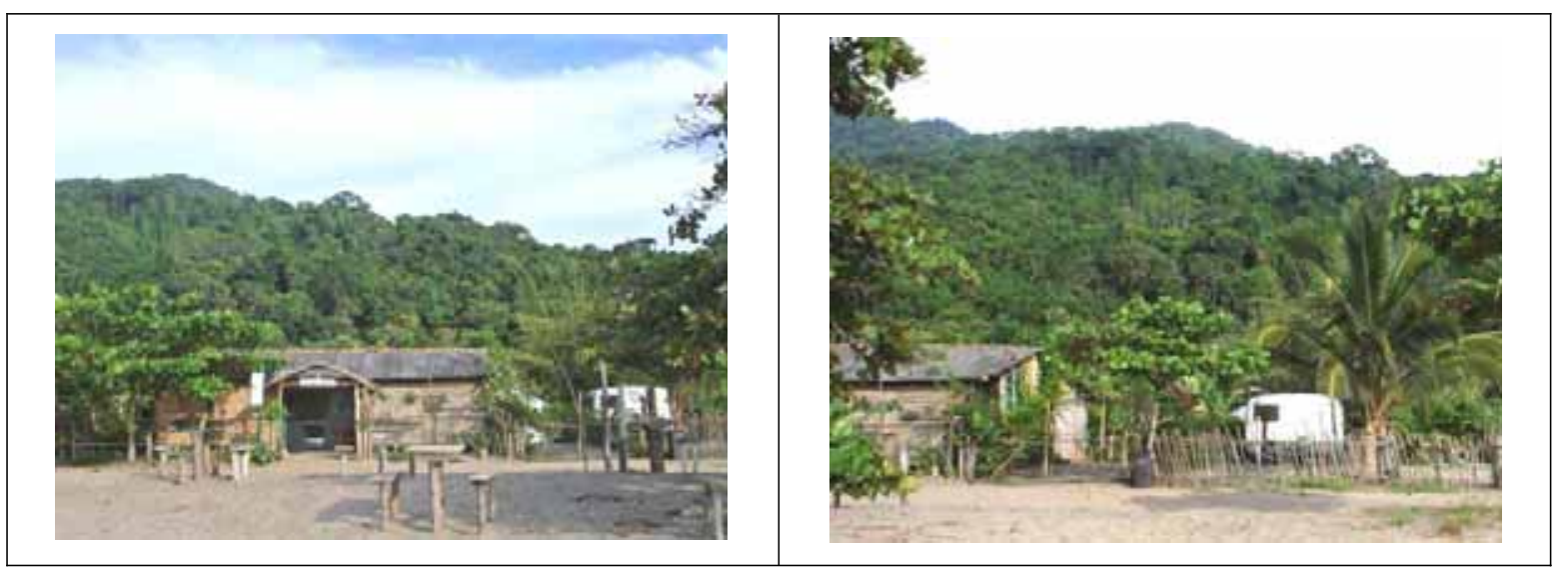

LOCALIZAÇÃo UTM: Canto da Lagoa

Proprietário:

Local de origem do proprietário:

Características: Construção em pau-a-pique e taquaras, instalações precárias

Tem gerador? 


\section{CADASTRO DE BARES, RESTAURANTES E CAMPINGS NA BAÍA DOS}

\section{CASTELHANOS}

BAR DO FERNANDO - CANTO DO RIBEIRÃO

LOCALIZAÇÃO UTM: $471.167 / 7.362 .526$

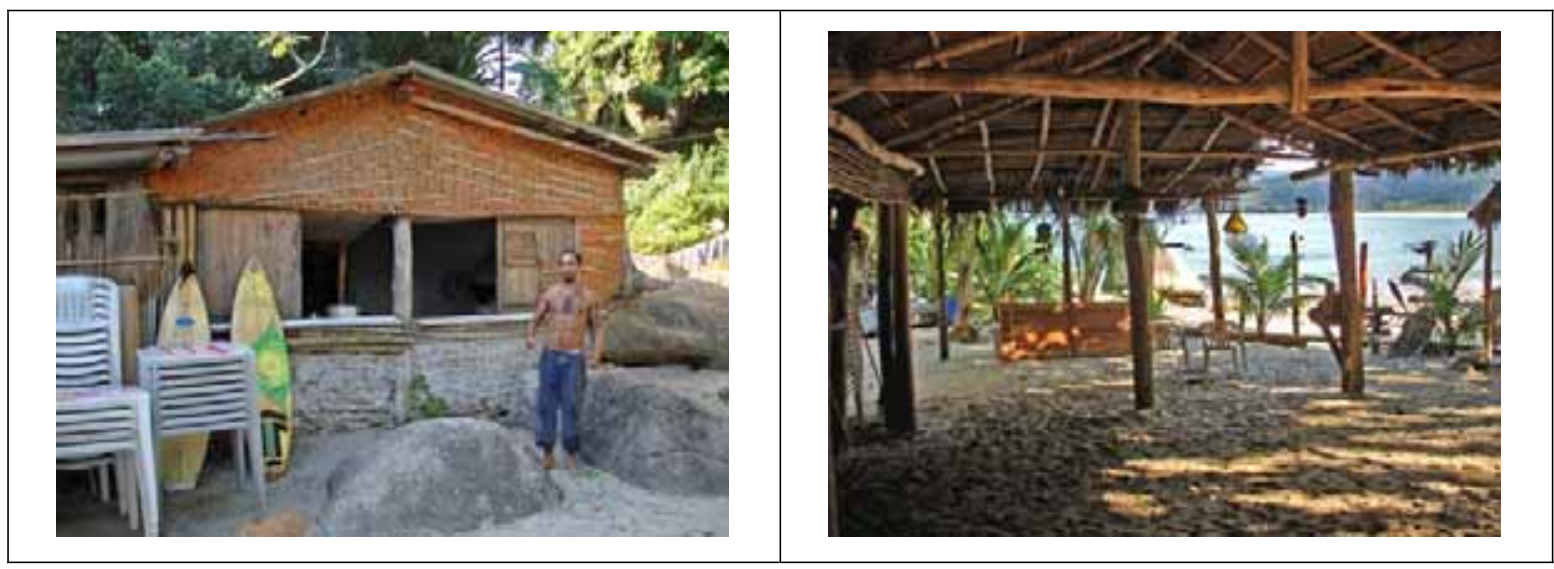

LOCALIZAÇÃo UTM: Canto da Lagoa

Proprietário:

Local de origem do proprietário:

Características: Construção em pau-a-pique e taquaras, instalações precárias

Tem gerador?. 


\section{CADASTRO DAS EDIFICAÇÕES INSTITUCIONAIS NA BAÍA DOS CASTELHANOS}

TEMPLO CONGREGAÇÃO CRISTÃ NO BRASIL
LOCALIZAÇÃO UTM:
$471.141 / 7.362 .671$

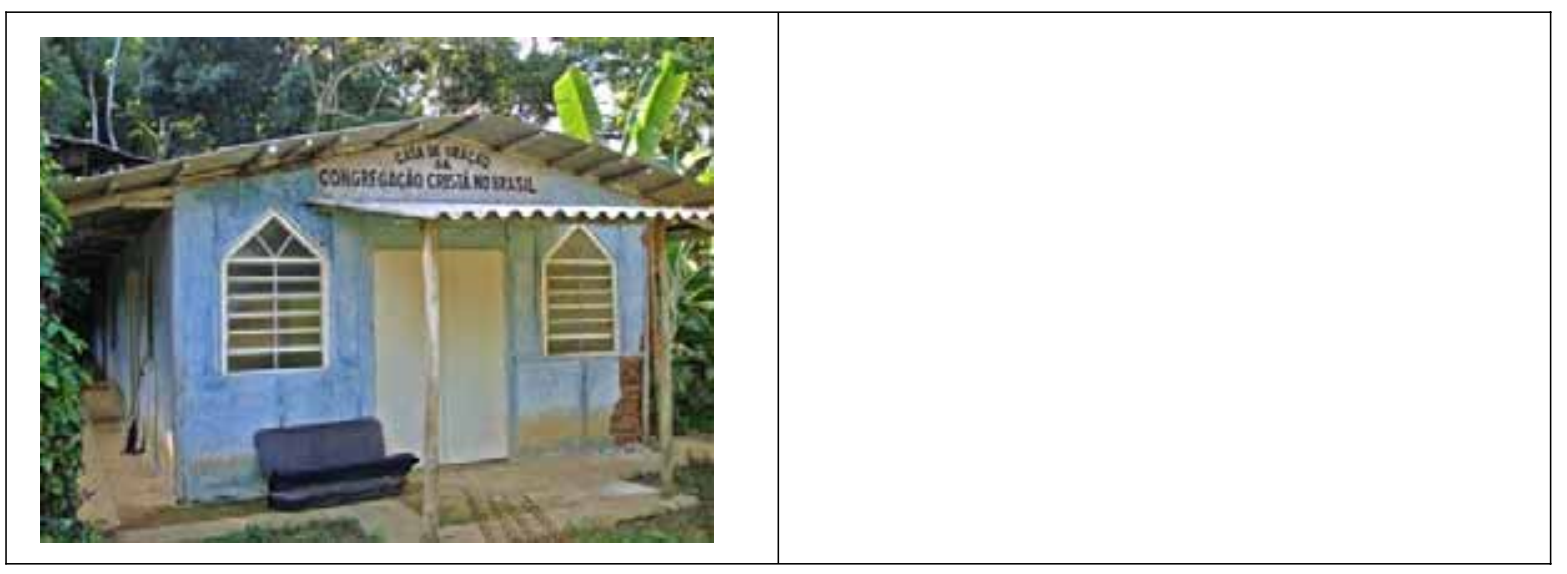

LOCALIZAÇÃo UTM: Canto Do Ribeirão

Características: Pau-a-pique, estava sendo reformada na data da visita.

Tem gerador: não

TEMPLO ASSEMBLÉIA DE DEUS

LOCALIZAÇÃO UTM: $\quad$ Fundo de Comida Caseira

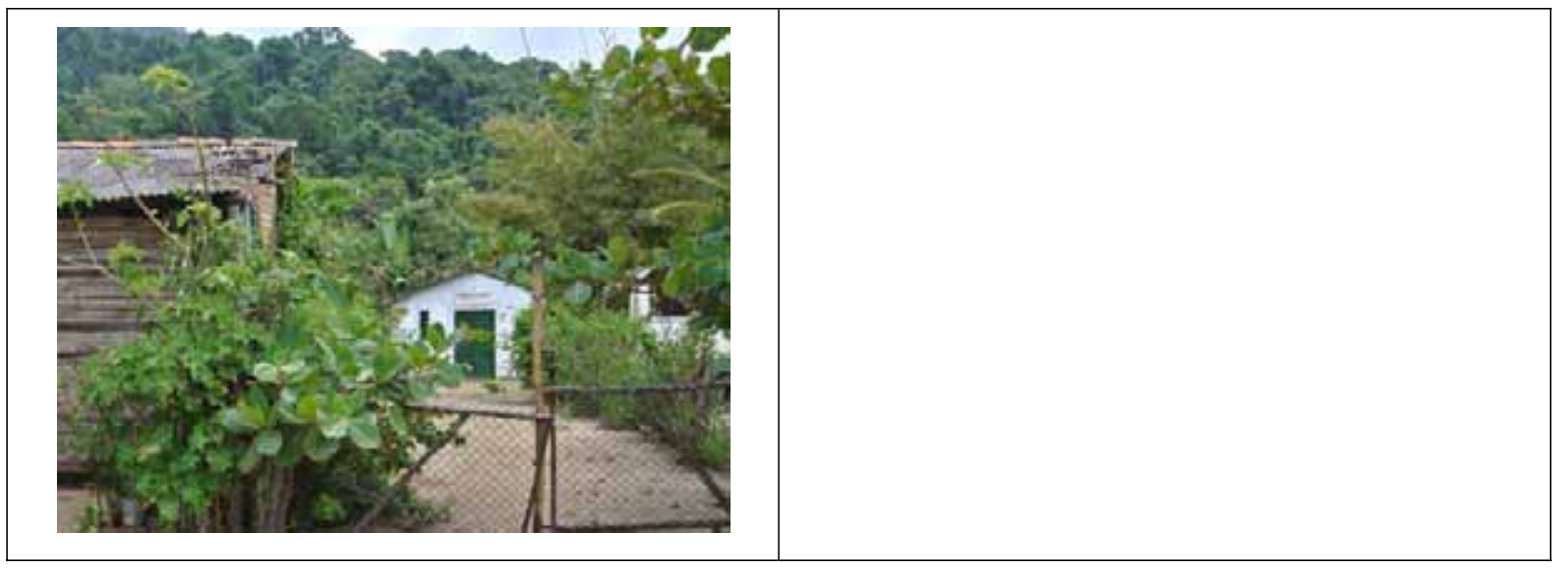

LOCALIZAÇÃo UTM: Canto da Lagoa, atrás do restaurante Comida Caseira

Características:

Tem gerador: não 


\section{CADASTRO DAS EDIFICAÇÕES INSTITUCIONAIS NA BAÍA DOS CASTELHANOS}

TEMPLO DEUS É AMOR

LOCALIZAÇÃO UTM:

$470.392 / 7.360 .425$

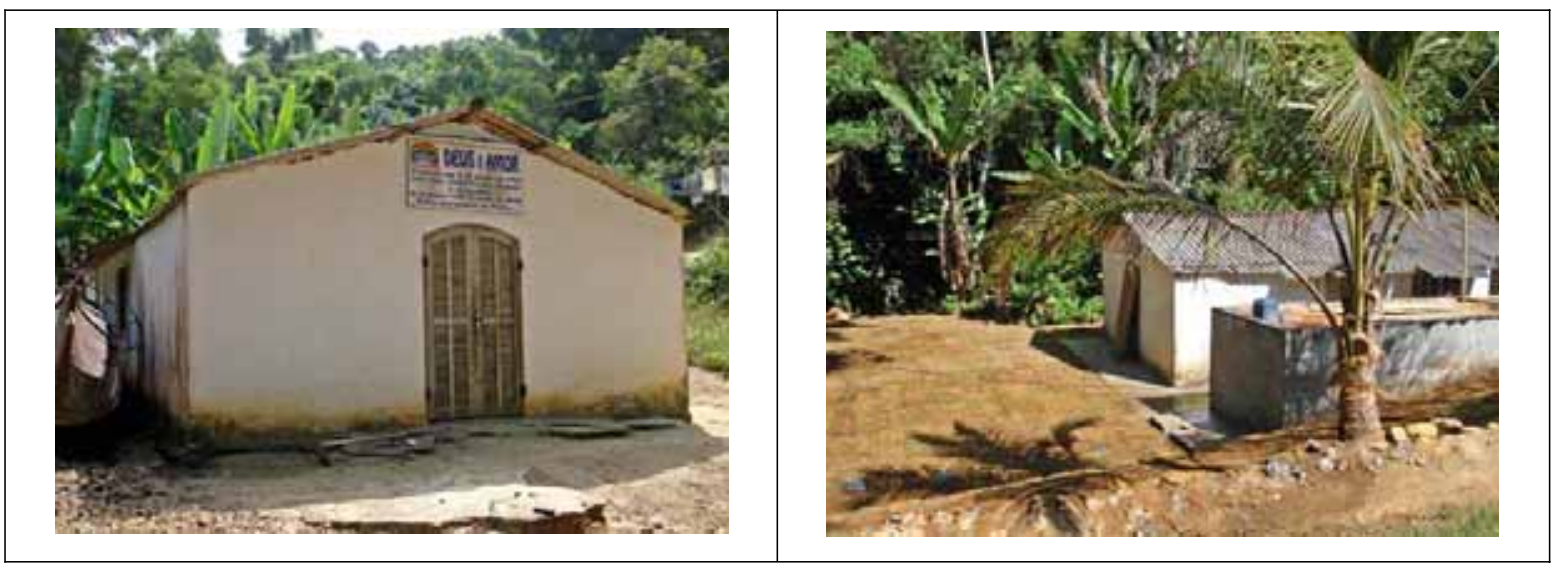

LOCALIZAÇÃO UTM: Praia Mansa

Características: Depois da implantação do Projeto Sagatiba bem em frente ao templo, a área entorno foi reformada.

Tem gerador: utiliza a energia gerada na câmara fria.

CÂMARA FRIA DA PRAIA MANSA

LOCALIZAÇÃO UTM:

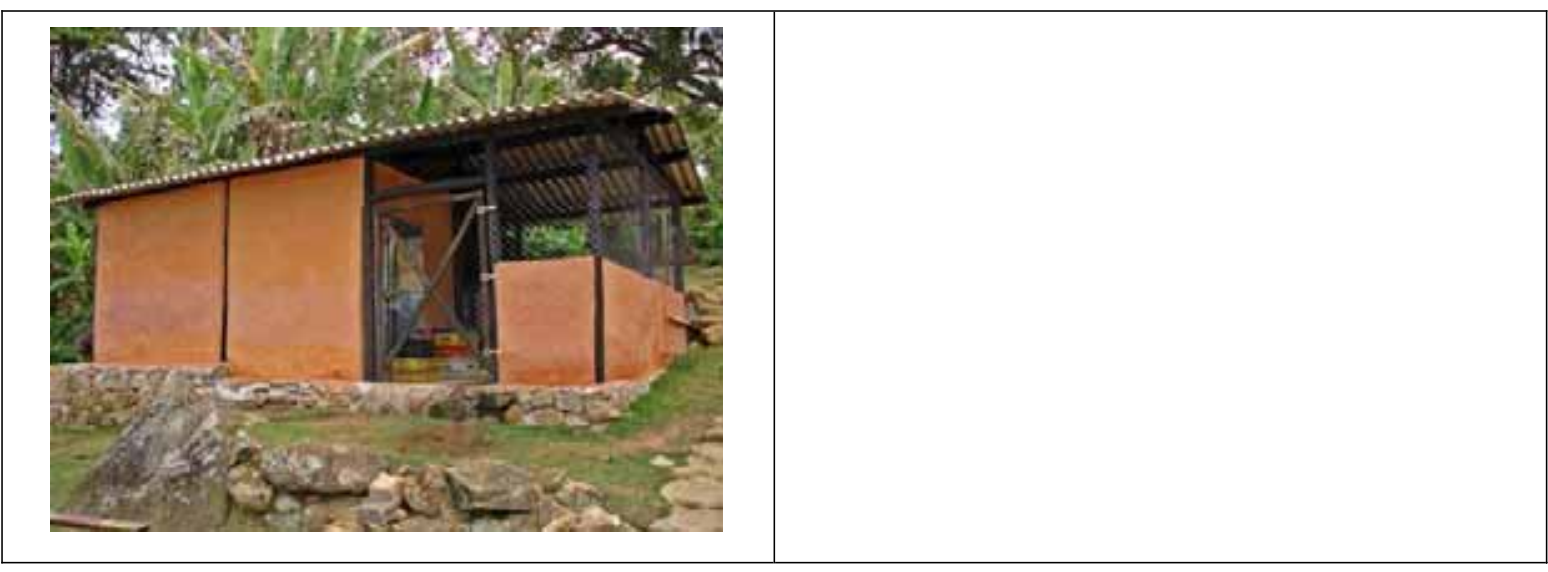

LOCALIZAÇÃO UTM: Praia Mansa.

Características: Câmara para refrigeração do pescado construída pelos moradores local e pela prefeitura de Ilhabela. É alimentada por energia gerada hidraulicamente a partir do córrego da Praia Mansa. O sistema também fornece energia hidrelétrica para iluminação de todas as casas da Praia Mansa, mas apenas algumas delas estão ligadas a Câmara Fria.

A Câmara Fria é de uso comunitário e serve a todos os moradores da Baía dos Castelhanos, mas na prática, é utilizada apenas pelos moradores da P. Mansa. 


\section{ESCOLA DE ENSINO FUNDAMENTAL 1 DA PRAIA DOS CASTELHANOS}

LOCALIZAÇÃO UTM:

$471.210 / 7.362 .601$

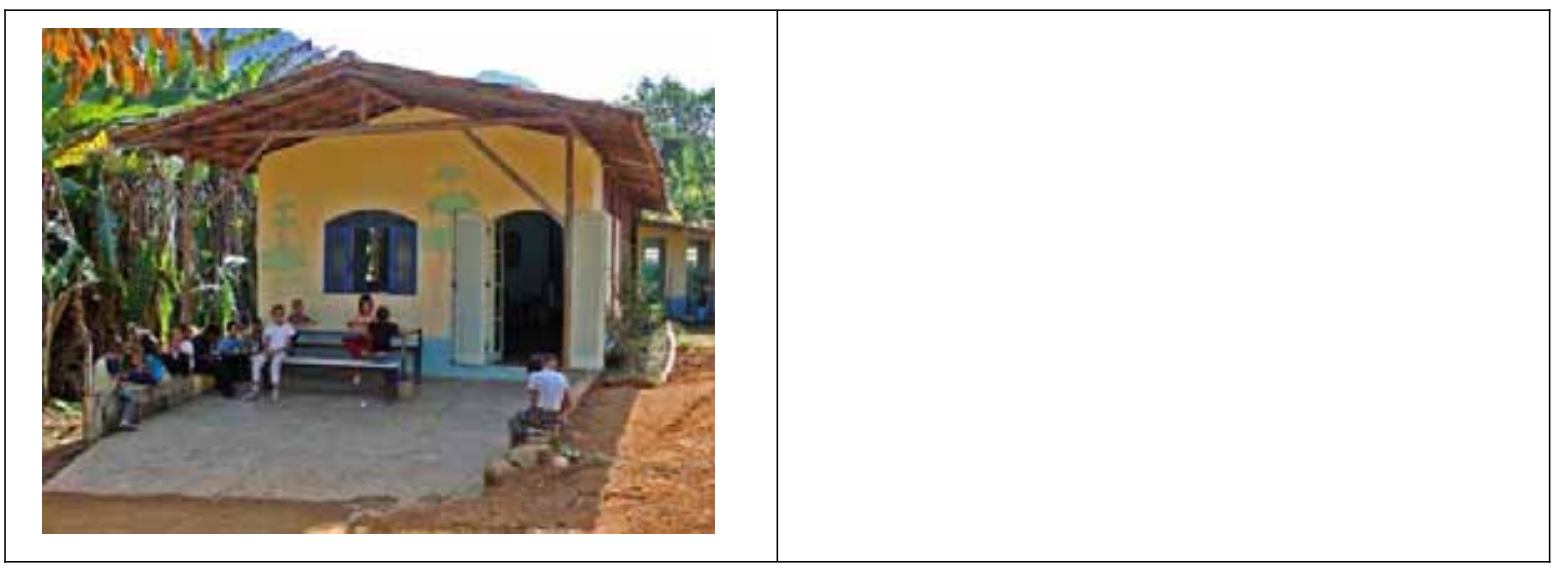

LOCALIZAÇÃO UTM: Canto do Ribeirão, Praia dos Castelhanos

Características: Casa alugada e adaptada para funcionar como escola. Atende às crianças da Praia dos Castelhanos, do Canto da Lagoa e do Canto do Ribeirão.

ESCOLA DE ENSINO FUNDAMENTAL 1 DA PRAIA MANSA

LOCALIZAÇÃO UTM:

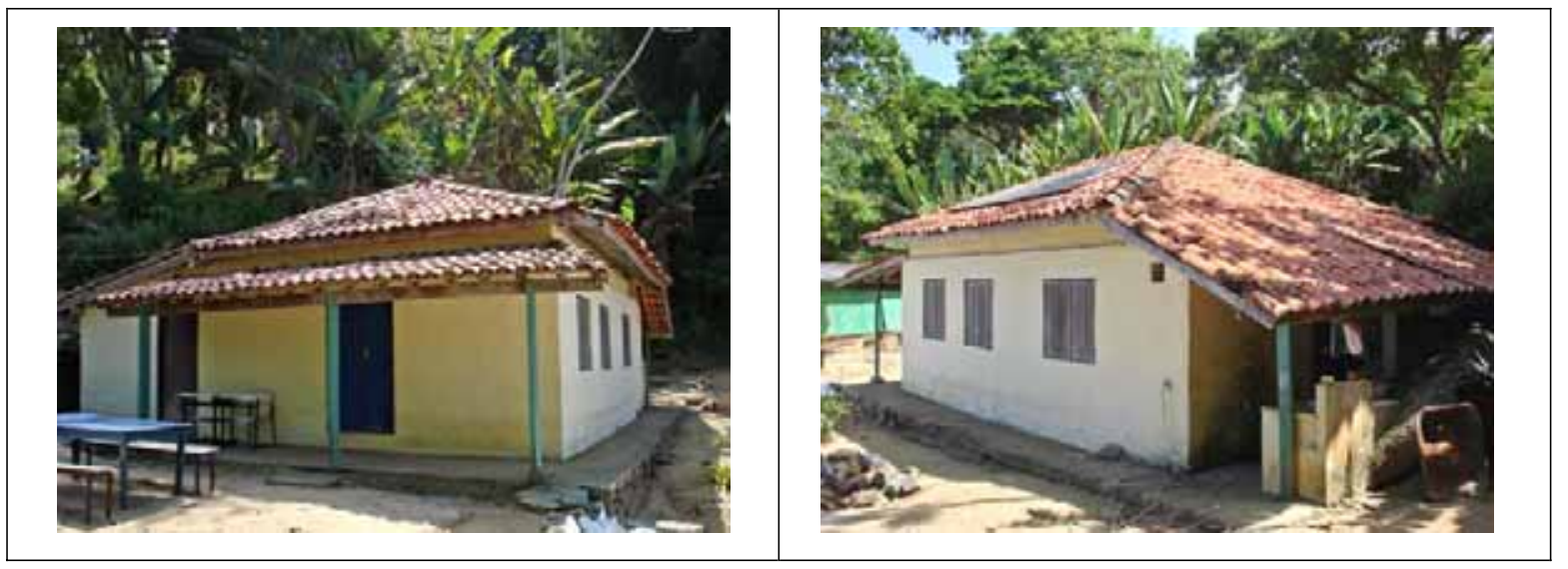

LOCALIZAÇÃO UTM: Praia Mansa

Características: Construção muito antiga, foi reformada no final da década de 1990. Atende às crianças das Praias Mansa, Vermelha da Figueira e do Saco do Sombrio. Desses dois últimos lugares, as crianças são transportadas de barco devido à distância e à falta de caminho para virem a pé. A prefeitura paga a um marinheiro do Saco do Sombrio realizar o transporte com o seu (dele) barco. Se chover ou o mar não permitir navegação, as crianças desses dois lugares ficam sem aula.

A escola funciona com energia solar. 


\section{CADASTRO DAS CASAS DE TURISTAS NA BAÍA DOS CASTELHANOS}

\section{PRAIA DOS CASTELHANOS}
CASA DE:
MARIA HELENA DE SOUZA LUCIO
LOCALIZAÇÃO UTM:
$470.640 / 7.361 .018$

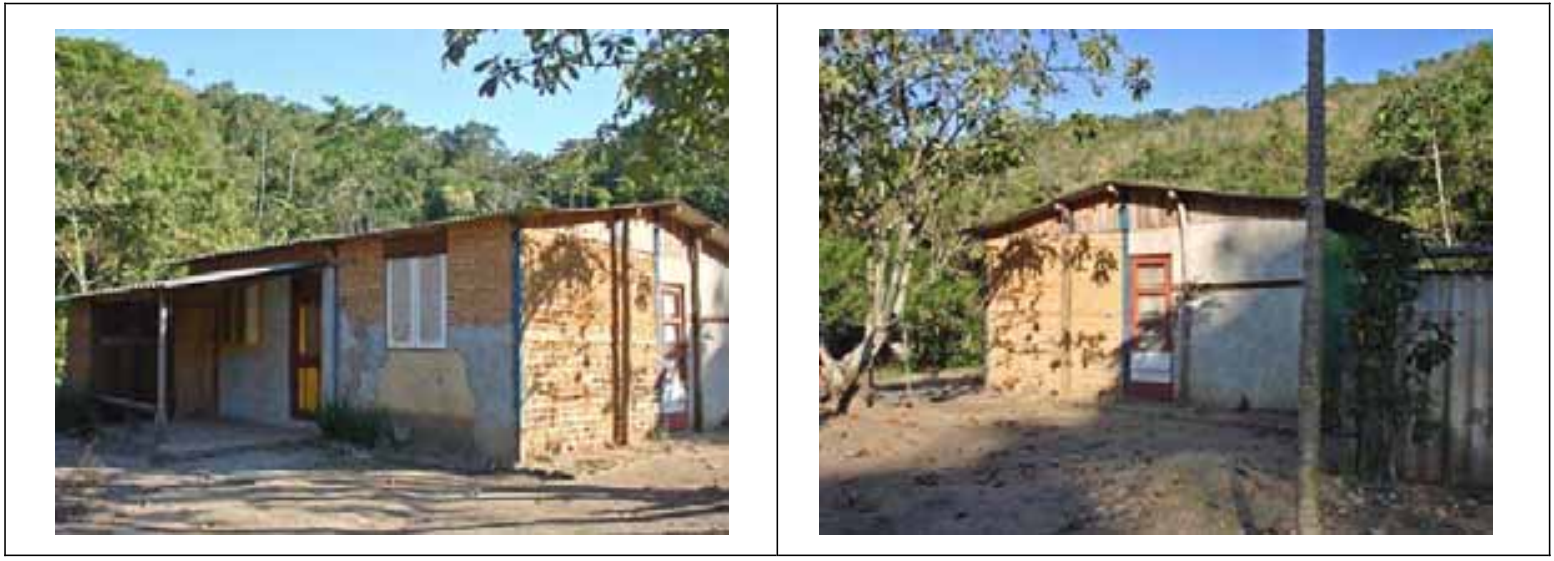

Moradia permanente: Caraguatatuba

Características da casa: Pau-a-pique, padrão razoável.

Caseiro: ?

Observações:

- Filha de Joaquim Lúcio

- Casou e foi morar em Caraguatatuba. Usa a casa para lazer.

CASA DE:

ISAURA DE SOUZA LUCIO

LOCALIZAÇÃO UTM:

$470.605 / 7.361 .143$

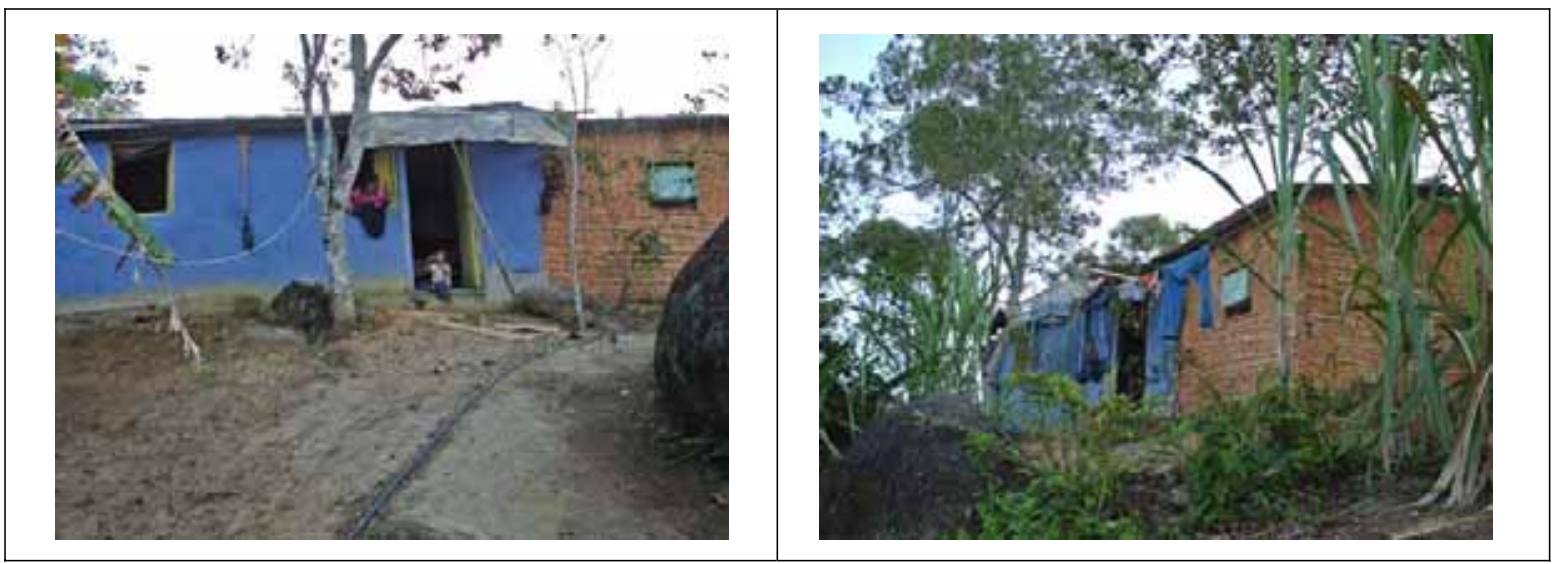

Moradia permanente: Bairro Enseada, São Sebastião

Características da casa: Pau-a-pique.

Caseiro: ?

Observações:

- Filha de João Lúcio

- Casou com Carlos e foi morar em São Sebastião. Usa a casa para lazer. 


\section{CADASTRO DAS CASAS DE TURISTAS NA BAÍA DOS CASTELHANOS \\ PRAIA DOS CASTELHANOS}

TERRENO DE:

TERRENO GRILADO

LOCALIZAÇÃO UTM:

Entre Camping do Leo e Terreno de Denise

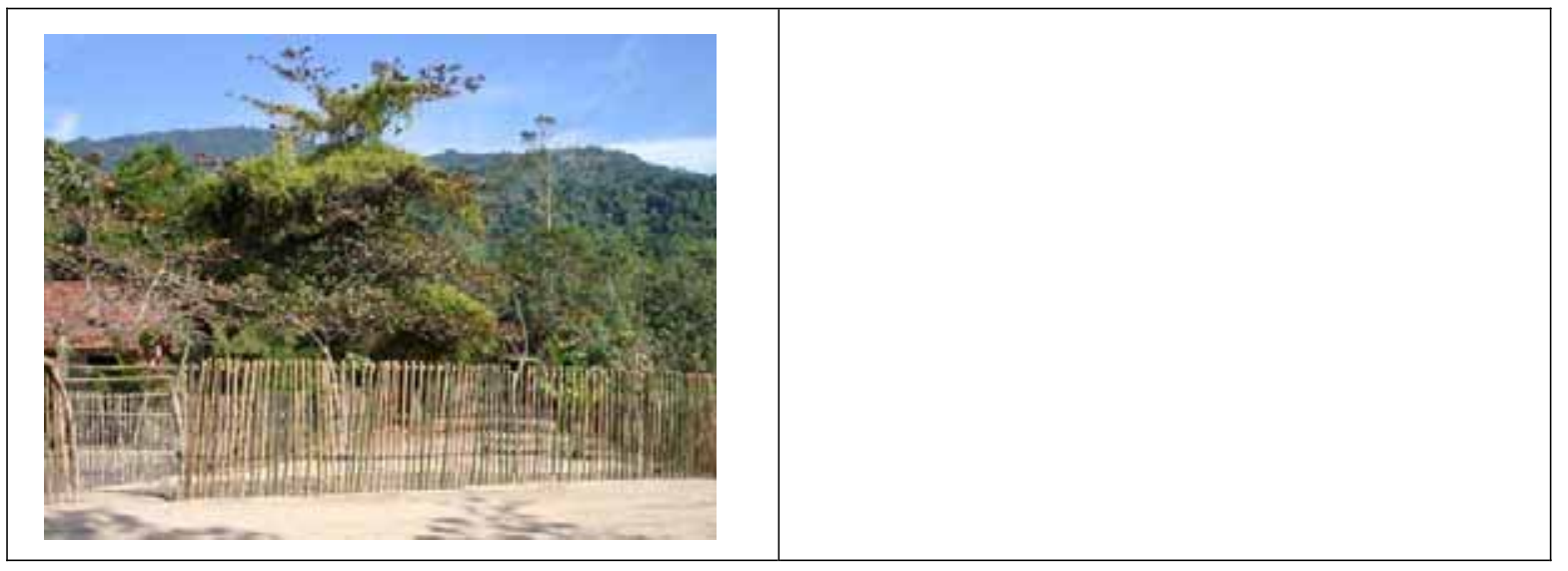

Moradia permanente:

Observações: Segundo informações dos vizinhos e de outro moradores, o terreno foi grilado, subtraído do Camping do Léo, com a conivência do próprio Leolino.

TERRENO DE:

DENISE NEVES (VERIFICAR)

LOCALIZAÇÃO UTM:

$470.573 / 7.361 .374$

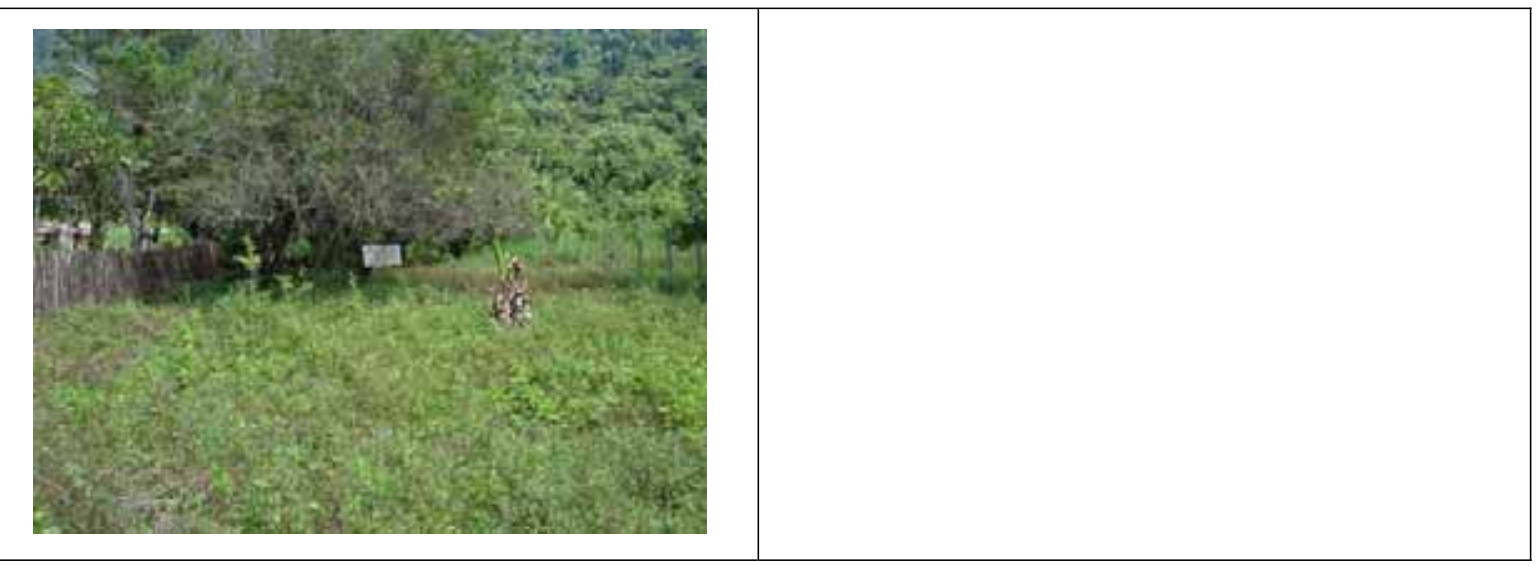

Moradia permanente:

Características da casa: Apenas planta aprovada. Pode ser projeto comercial.

Caseiro: ?

Observações: Terreno com planta aprovada, verificar se se trata de casa de veraneio ou comércio. Vizinha do Camping do Léo. 


\section{CADASTRO DAS CASAS DE TURISTAS NA BAÍA DOS CASTELHANOS \\ PRAIA DOS CASTELHANOS}

CASA DE:

VASCO PEREIRA BUENO NETO

LOCALIZAÇÃO UTM:

$470.560 / 7.361 .402$
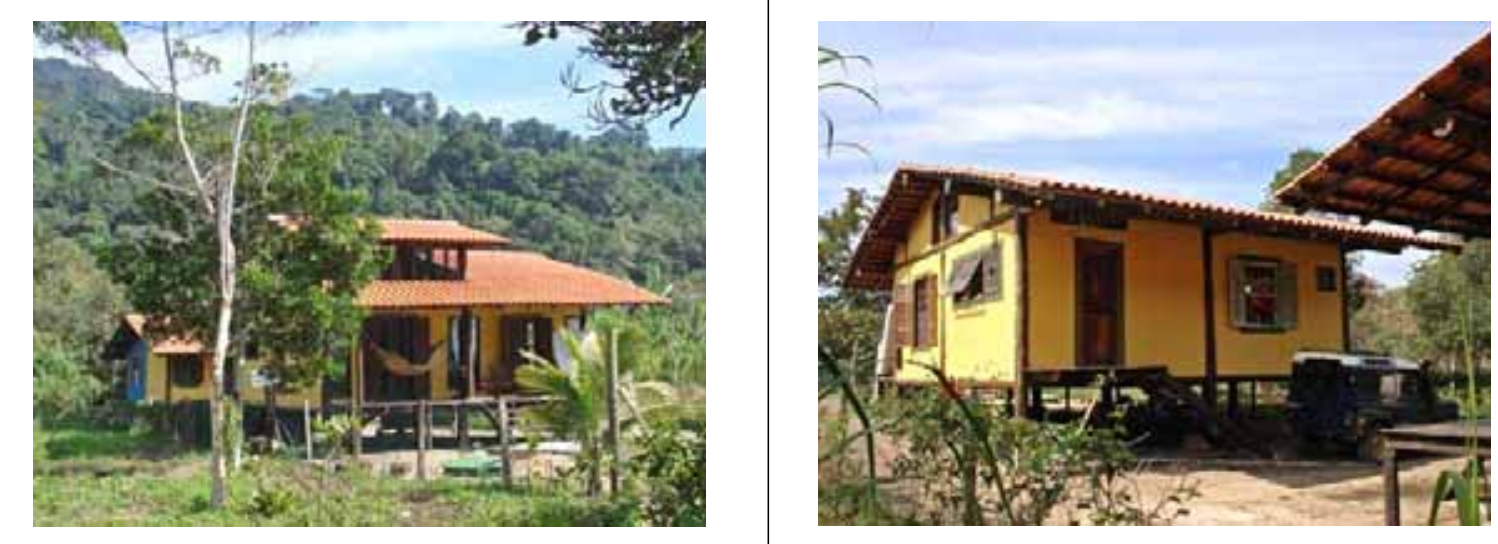

Moradia permanente: Ilhabela

Características da casa: Alto padrão.

Caseiro: ?

Observações:

- Tem gerador mas não tem rede elétrica instalada na casa

- Vasco informou que a sua casa e a da Beatriz (lote do fundo, casa azul geminada com sua edícula) foram construídas em lotes $13 \times 30$ do loteamento Vila Reale. Em sua opinião, se forem construídas casas em todos os lotes, evidentemente surgirão problemas ambientais e sanitários, por isso reinvidica que haja restrições para futuras obras.

- Informou ainda que não tem arruamento no loteamento e o acesso aos lotes de fundo se dá passando por dentro do lote de frente. Isso apenas para os lotes de frente para o mar. A ruas e os lotes da parte de trás do loteamento foram projetados sobre áreas de preservação permanente, inclusive parte deles fica sobre cursos d'água. 


\section{CADASTRO DAS CASAS DE TURISTAS NA BAÍA DOS CASTELHANOS \\ PRAIA DOS CASTELHANOS}

CASA DE:

BEATRIZ

LOCALIZAÇÃO UTM:

$470.530 / 7.361 .403$

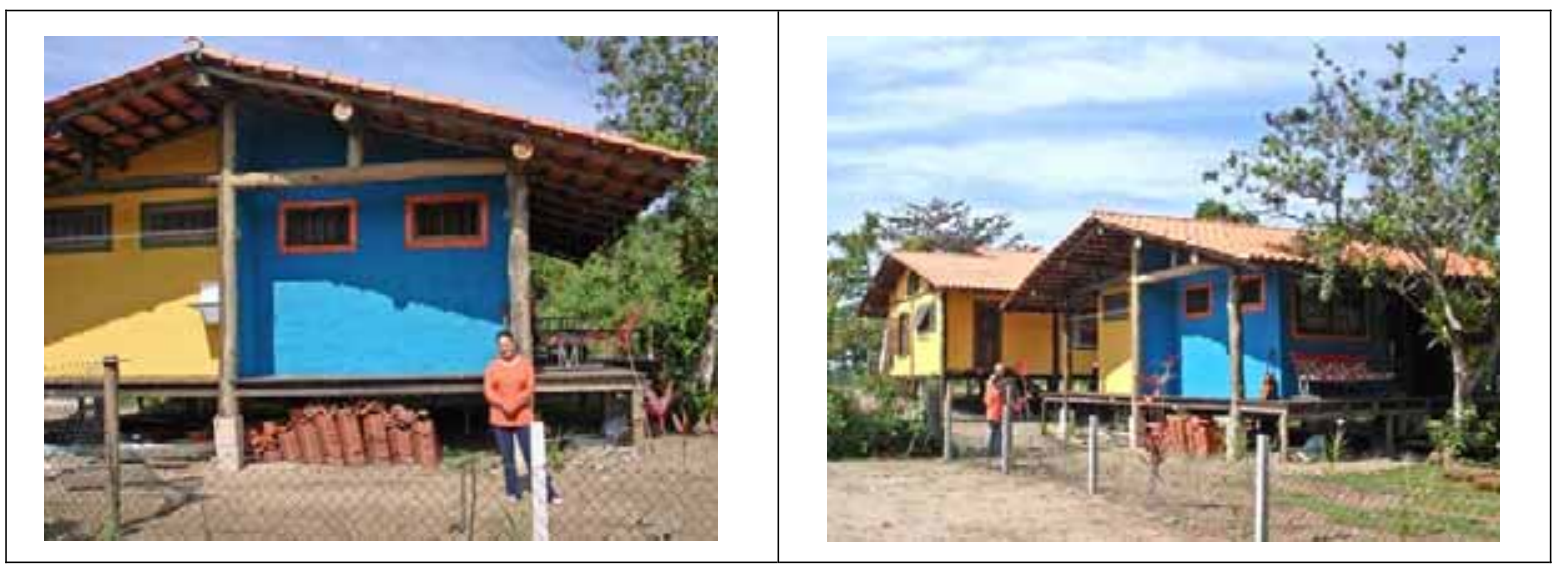

Moradia permanente: Ilhabela

Características da casa: Padrão médio.

Caseiro: ?

Observações:

- Ocupa o lote de fundo e sua casa é geminada com a edícula da casa do Vasco. O acesso ao seu lote se dá por dentro do lote do Vasco.

- O terreno deve estar dentro de área de preservação permanente (APP) pois o seu fundo sofre inundação do córrego da Lagoa. Como o lote mede 13 metros de frente por 30 de fundo, estaria assim inteiramente dentro da APP, mas a proprietária obteve autorização do DEPRN e da prefeitura para construir. 
CADASTRO DAS CASAS DE TURISTAS NA BAÍA DOS CASTELHANOS

\section{PRAIA DOS CASTELHANOS}

\section{CASA DE: \\ VERDE}

LOCALIZAÇÃO UTM:

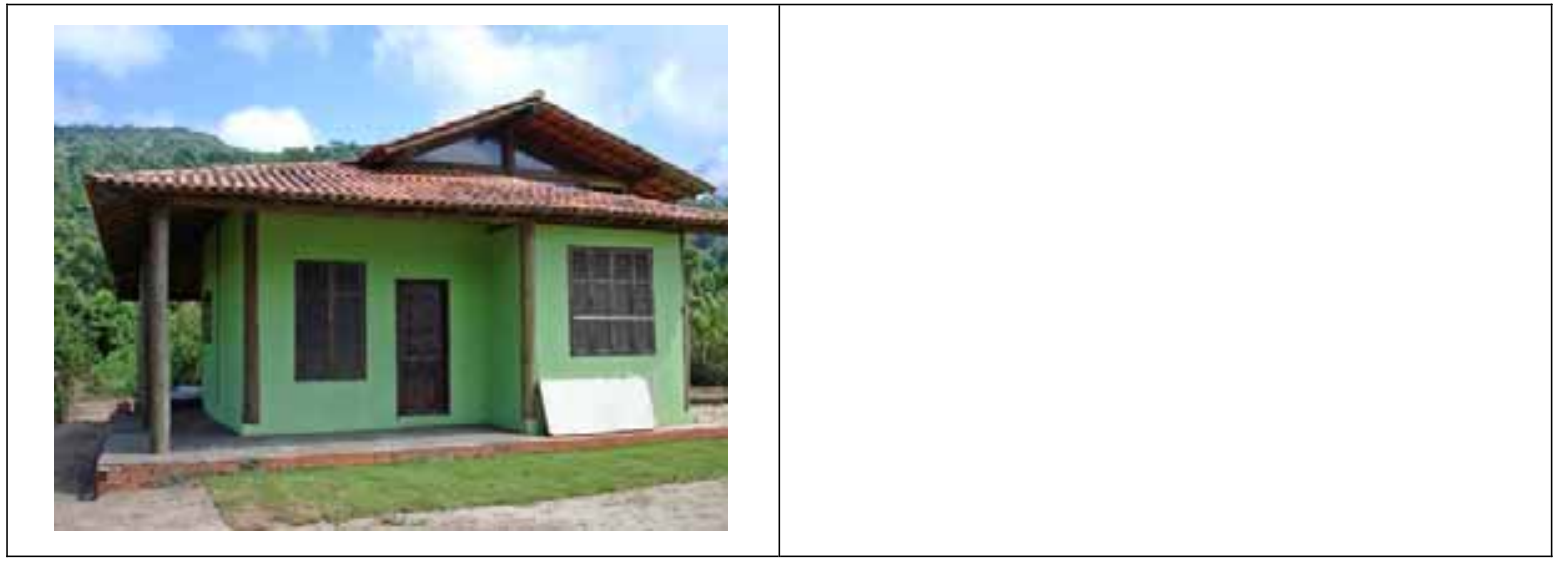

Moradia permanente:

Características da casa: alto padrão.

Caseiro:

Observações:

CASA DE:

VERDE (FUNDO)

LOCALIZAÇÃO UTM:

$470.521 / 7.361 .445$

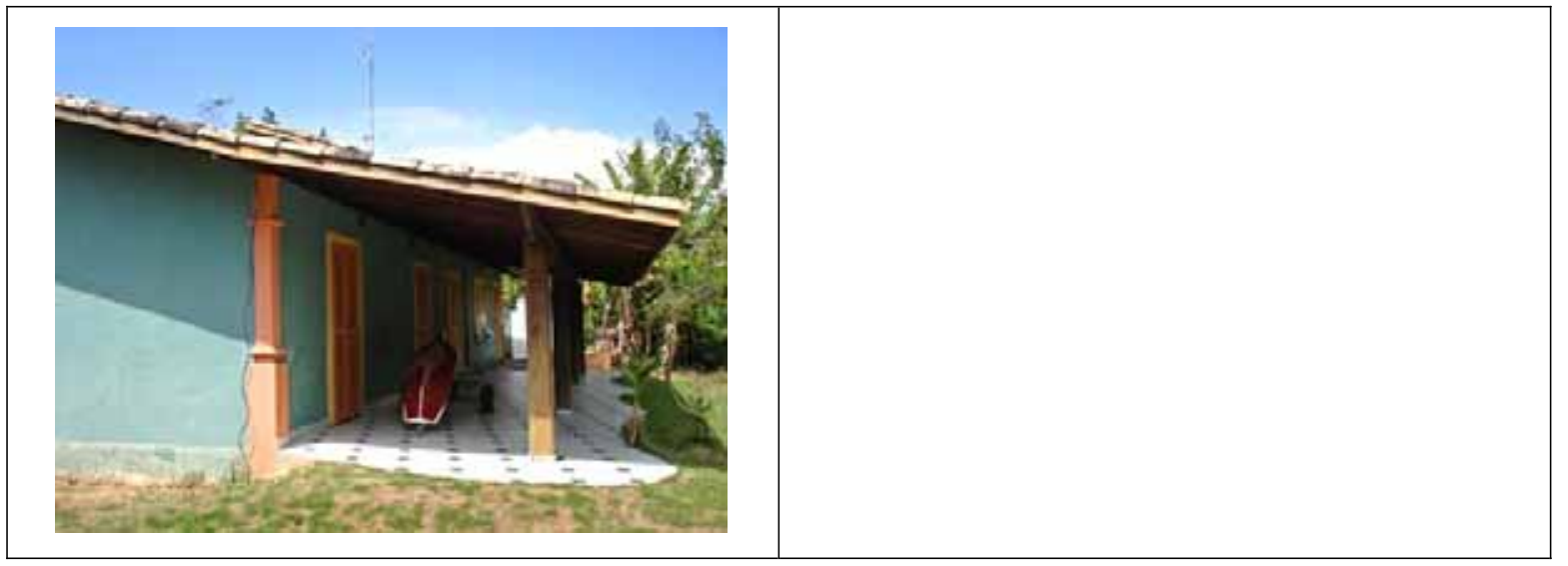

Moradia permanente:

Características da casa: médio padrão.

Caseiro: ?

Observações: 


\section{CADASTRO DAS CASAS DE TURISTAS NA BAÍA DOS CASTELHANOS \\ PRAIA DOS CASTELHANOS}

CASA DE:

TERRENO

LOCALIZAÇÃO UTM: AO LADO DA CASA DE PAU-A-PIQUE

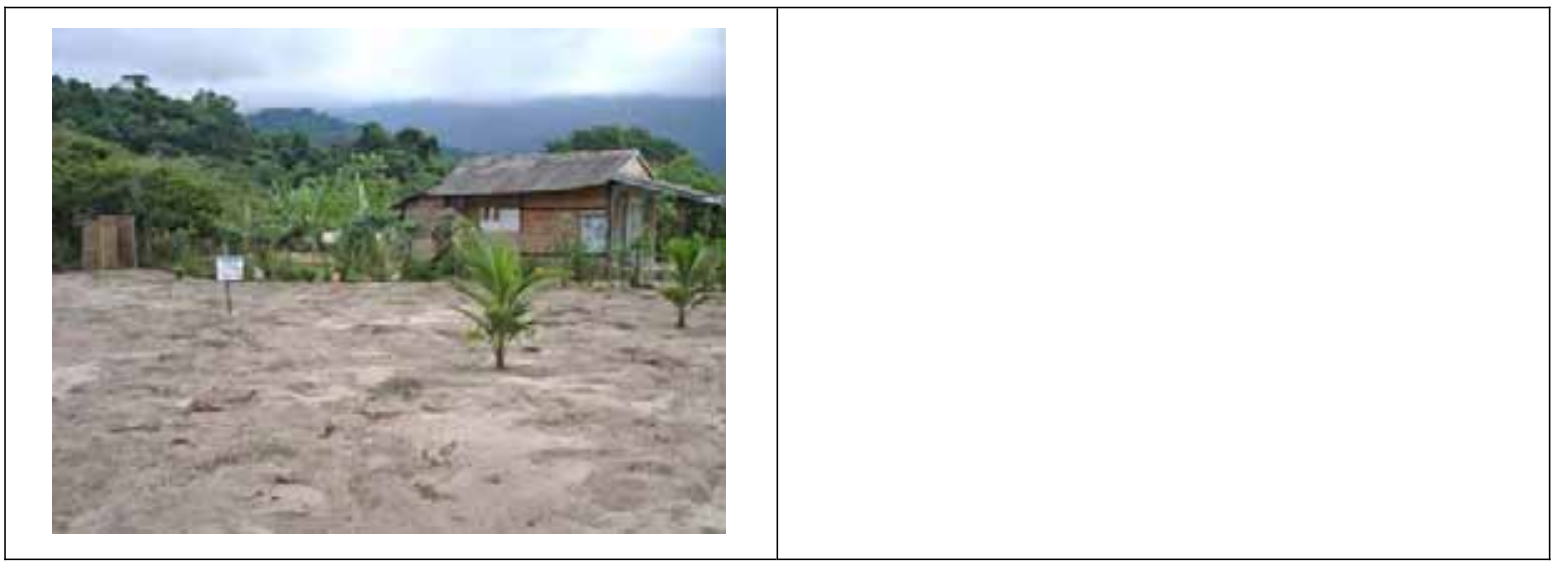

Moradia permanente:

\section{Características da casa:}

Caseiro: ?

Observações:

CASA DE:

PAU-A-PIQUE

LOCALIZAÇÃO UTM:

$470.565 / 7.361 .626$

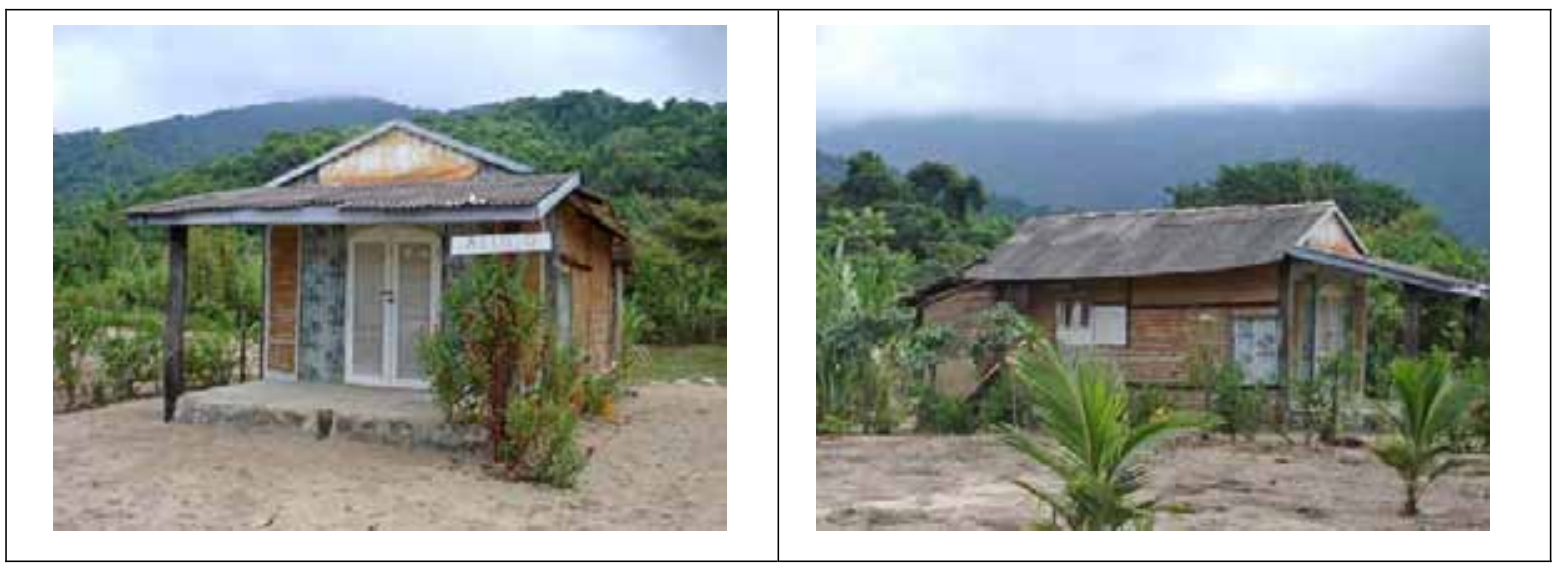

Moradia permanente: Praia dos Castelhanos

Características da casa: Casa de pau-a-pique

Caseiro:

Observações: A casa pertence a um filho da Isadae, caiçara moradora na Praia dos Castelhanos. Ele mora em São Sebastião e construiu a casa coma a finalidade de alugar para turistas, em área que, segundo Isadae, pertencia a sua família e que agora está retomando a posse. 


\section{CADASTRO DAS CASAS DE TURISTAS NA BAÍA DOS CASTELHANOS \\ PRAIA DOS CASTELHANOS}

CASA DE: SAPÉ

LOCALIZAÇÃO UTM: $\quad 470.574 / 7.361 .690$

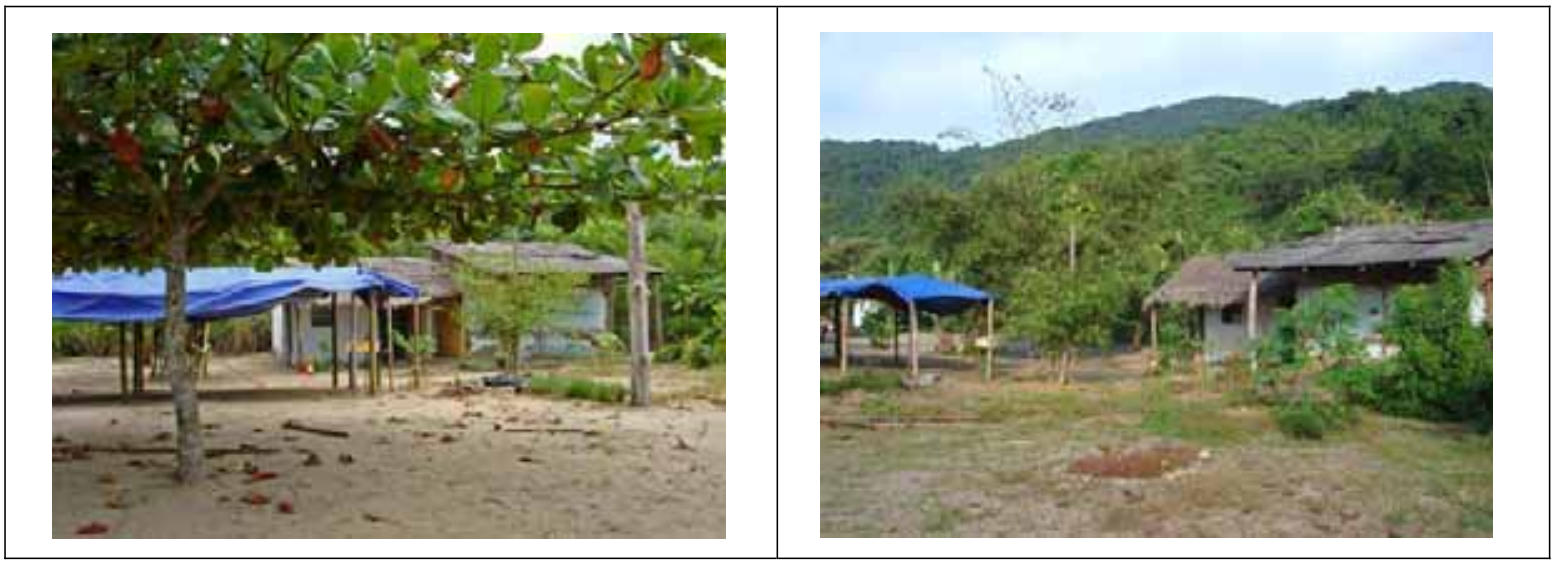

Moradia permanente:

Características da casa: Casa muito simples de pau-a-pique e telhado de sapé/brasilite

Caseiro: ?

Observações: 


\section{CADASTRO DAS CASAS DE TURISTAS NA BAÍA DOS CASTELHANOS PRAIA DOS CASTELHANOS}
CASA DE:
FRANCÊS
LOCALIZAÇÃO UTM:
471.194 / 7.362.584

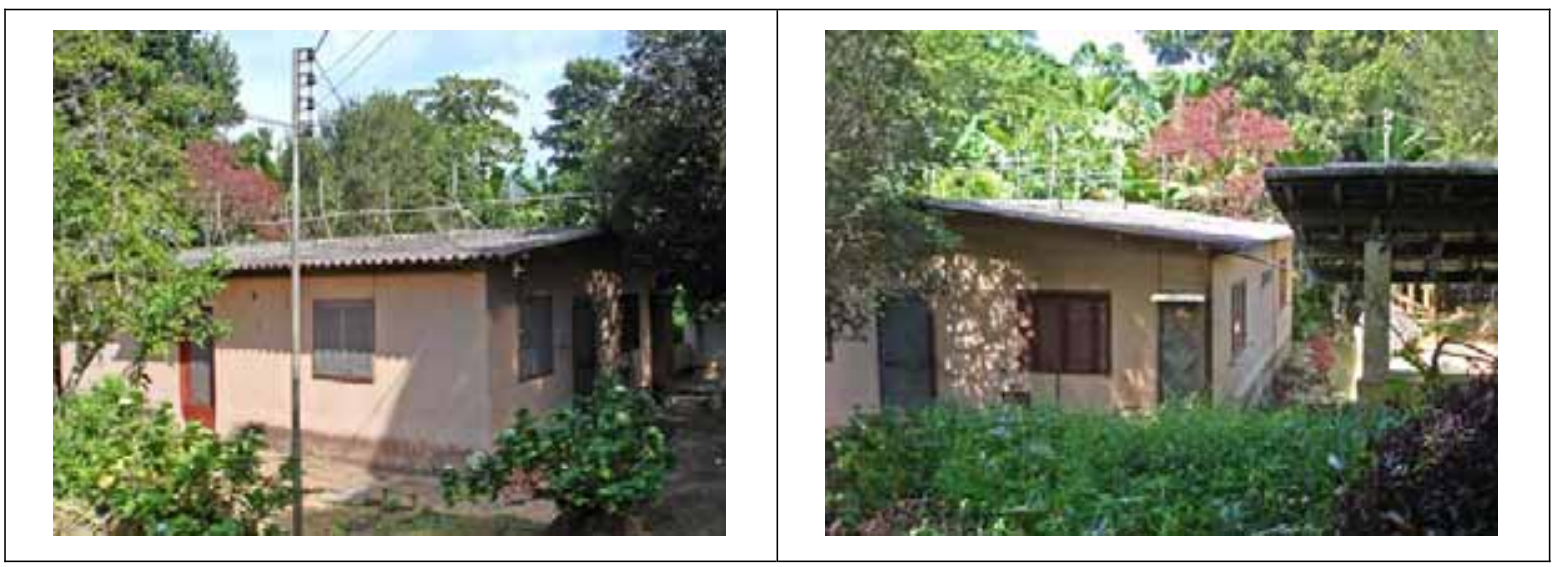

Moradia permanente:

Características da casa:

Caseiro: ?

Observações:

CASA DE: MÁRIO

LOCALIZAÇÃO UTM: $\quad 471.240 / 7.362 .614$

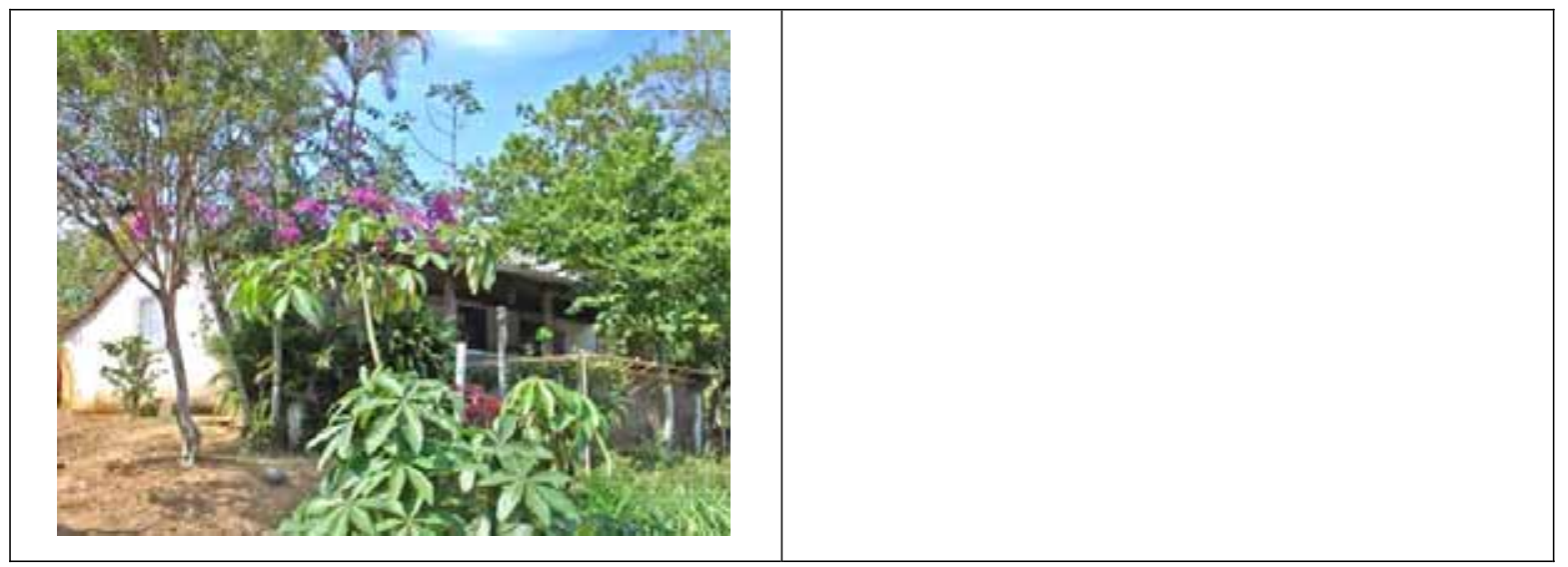

Moradia permanente:

Características da casa:

Caseiro: ?

Observações: 


\section{CADASTRO DAS CASAS DE TURISTAS NA BAÍA DOS CASTELHANOS \\ PRAIA DOS CASTELHANOS}

$\begin{array}{ll}\text { CASA DE: } & \text { WALDOMIRO } \\ \text { LOCALIZAÇÃO UTM: } & 471.233 / 7.362 .614\end{array}$

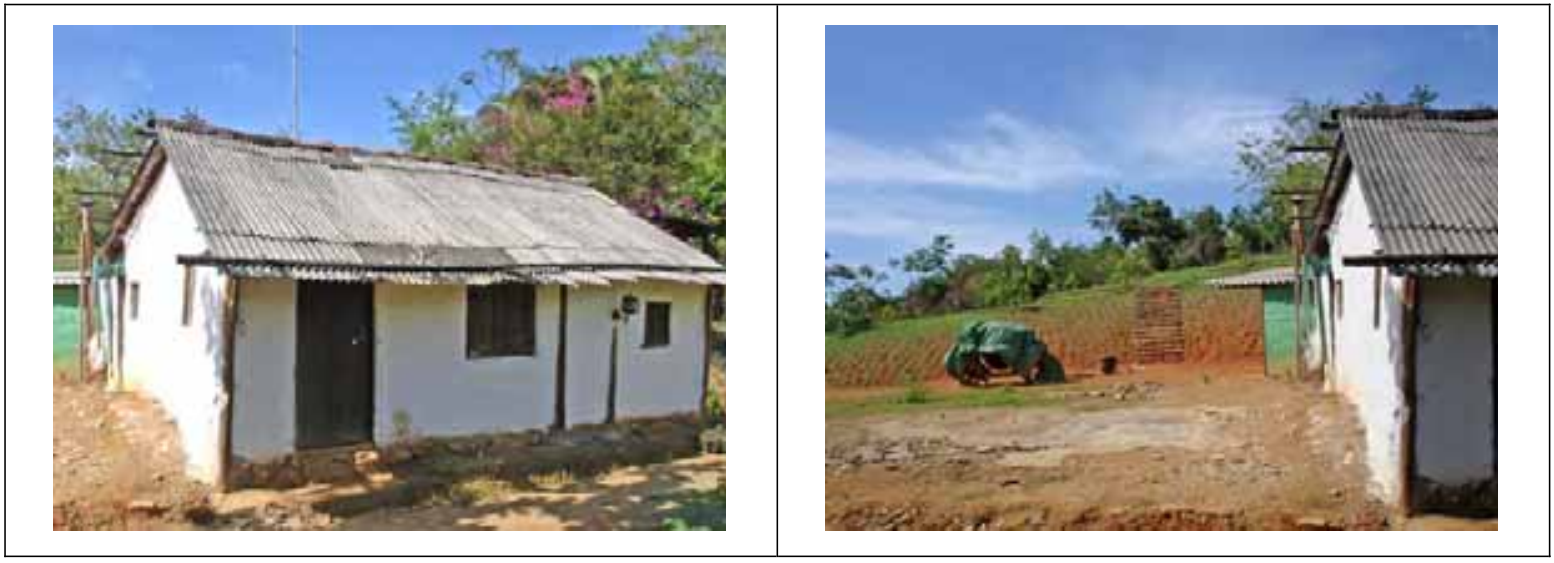

Moradia permanente:

Características da casa:

Caseiro: ?

Observações:

CASA DE:

TURISTA DO BONETE

LOCALIZAÇÃO UTM:

$471.133 / 7.362 .698$
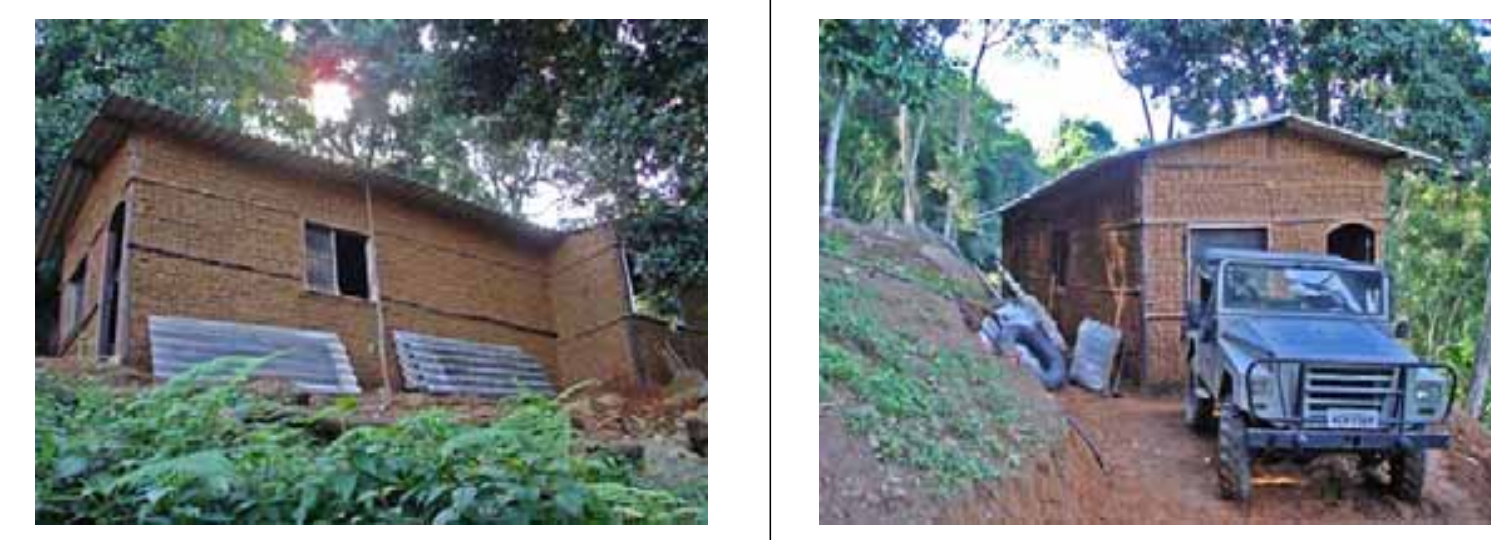

Moradia permanente:

\section{Características da casa:}

Caseiro: ?

Observações: A filha de S. Benedito Euzébio, a D. Adriana, que mora na P. da Serraria, disse que vendeu sua parte da herança da família para esse turista morador da P. do Bonete, Ilhabela. 


\section{CADASTRO DAS CASAS DE TURISTAS NA BAÍA DOS CASTELHANOS \\ PRAIA DOS CASTELHANOS}

CASA DE: $\quad$ GERHARD E HERMAN OU HÉLIO e JOSEVALDO

LOCALIZAÇÃO UTM: $\quad 471.320 / 7.362 .940$

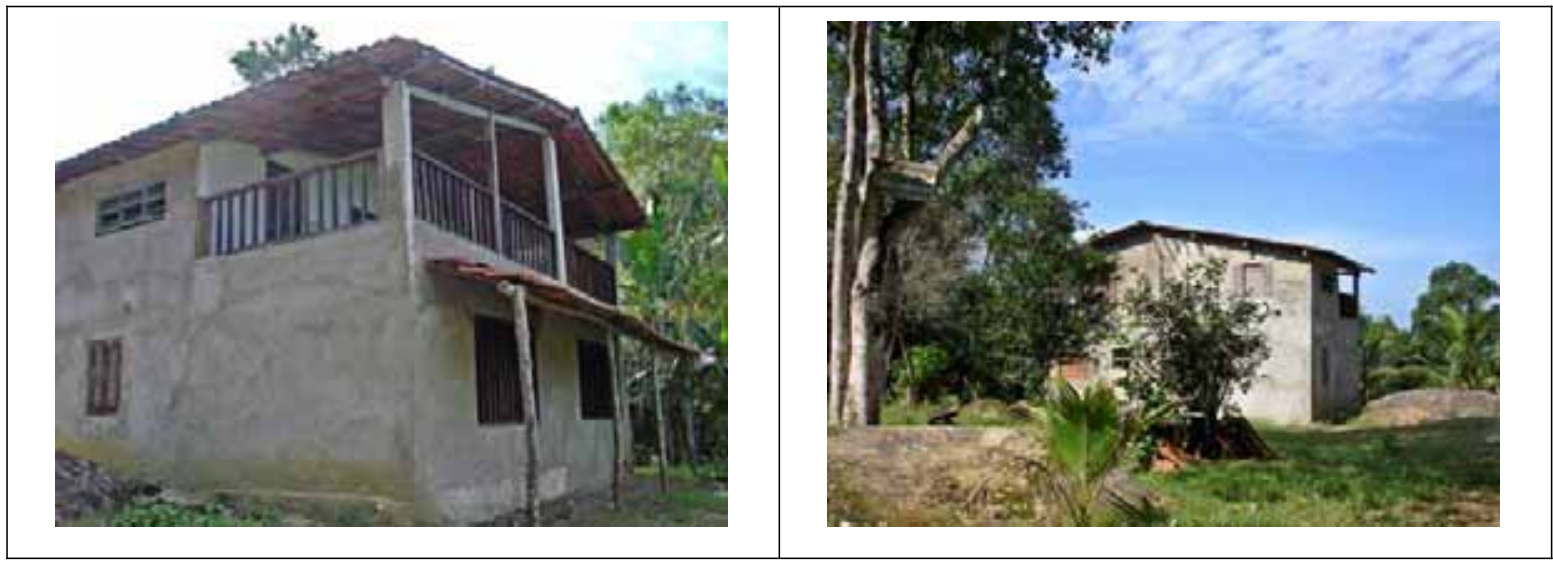

Moradia permanente:

Características da casa:

Caseiro: ?

Observações: Casa construída próxima à Praia do Gato 


\section{CADASTRO DAS CASAS DE TURISTAS NA BAÍA DOS CASTELHANOS}

\section{PRAIA VERMELHA}

CASA DE:

SERGIO DE ANDRADE DE ALMEIDA

LOCALIZAÇÃO UTM:

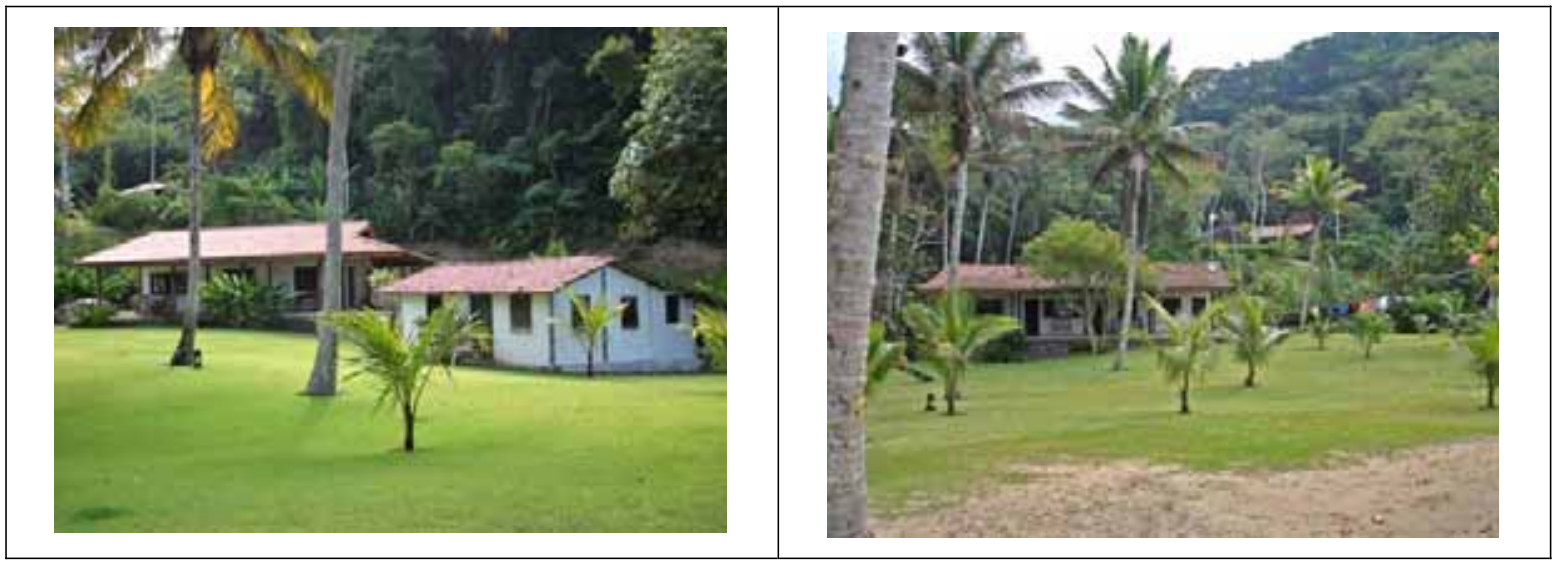

Moradia permanente: ?

Características da casa: Alvenaria, alto padrão +

Caseiro: Casal, sendo o marido oriundo do sul do Paraná, e a esposa, veio do Paraguai.

Observações: 


\section{CADASTRO DAS CASAS DE TURISTAS NA BAÍA DOS CASTELHANOS \\ PRAIA DA FIGUEIRA}

CASA DE:

ARTHUR RIBEIRO

LOCALIZAÇÃO UTM:

$471.781 / 7.358 .712$ E $471.769 / 7.358 .690$

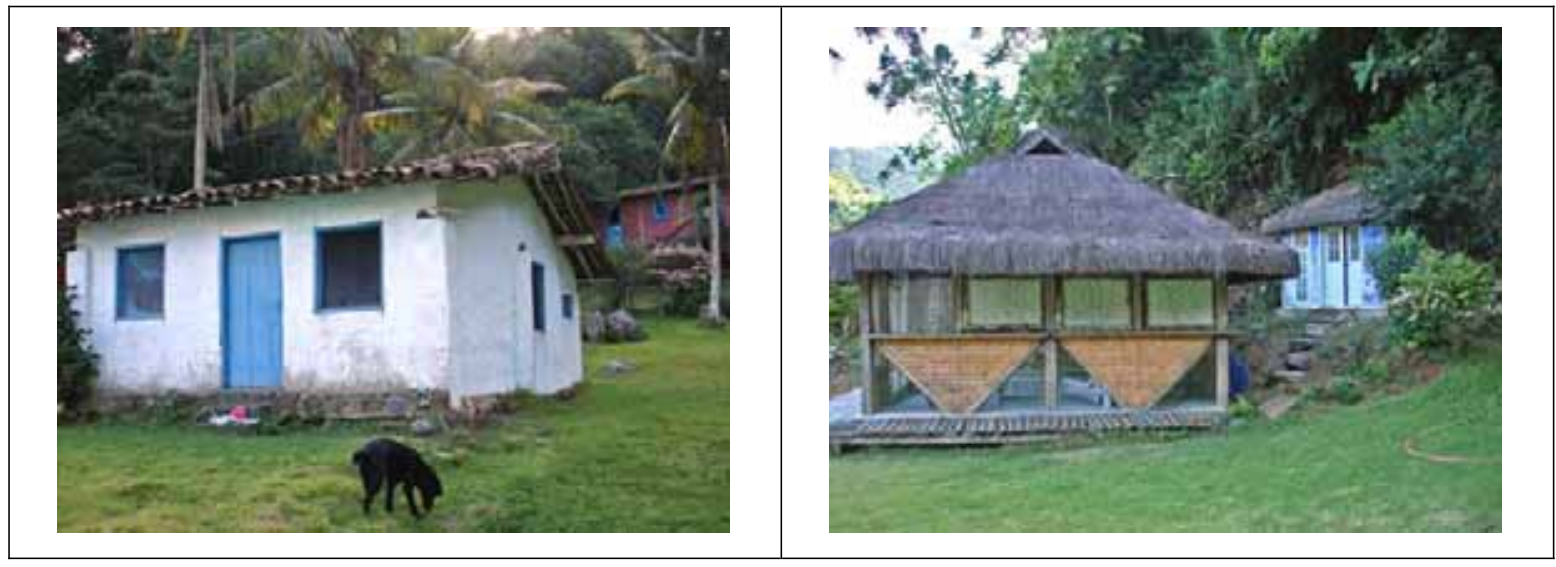

Moradia permanente: ?

Características da casa: Alvenaria, pau-a-pique, padrão médio rústico.

Caseiro:Maurício e Elizabete

Observações: Casas de padrão arquitetônico misto:

1- casa principal: pau-a-pique caiçara, rebocada e reformada, mas sem perder suas características originais, conserva inclusive o telhado com as telhas originais;

2- casa do caseiro, de alvenaria com utilização de muita pedra e madeira, simples, mas bem acabada arquitetonicamente. Tem padrão para ser a moradia principal;

3- Quiosque construído com madeira, vidro, tijolo e telhado de sapé, uma graça;

4- pequena casa que pode ser um depósito, de alvenaria e telhado de sapé, seguindo o mesmo padrão arquitetônico das demais construções.

Formam um belo conjunto, em harmonia com o ambiente. 


\section{CADASTRO DAS CASAS DE TURISTAS NA BAÍA DOS CASTELHANOS \\ SACO DO SOMBRIO}

CASA DE:

ERNESTO (Zezo)

LOCALIZAÇÃO UTM:

$475.270 / 7.356 .672$

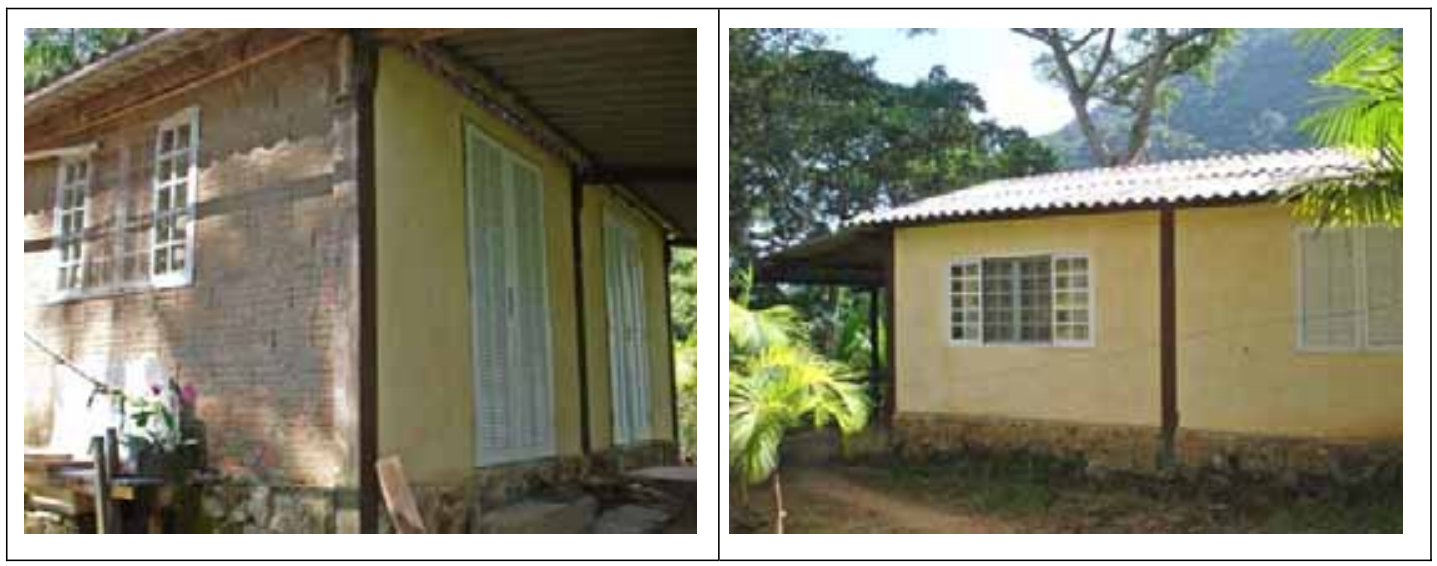

Moradia permanente: São Sebastião.

Características da casa: Alvenaria, padrão médio, ainda não terminada.

Caseiro: Zizinho

Observações: Casa possui gerador.

CASA DE:

(SEM INFORMAÇÕES DO PROPRIETÁRIO)

LOCALIZAÇÃO UTM:

$475.231 / 7.356 .580$
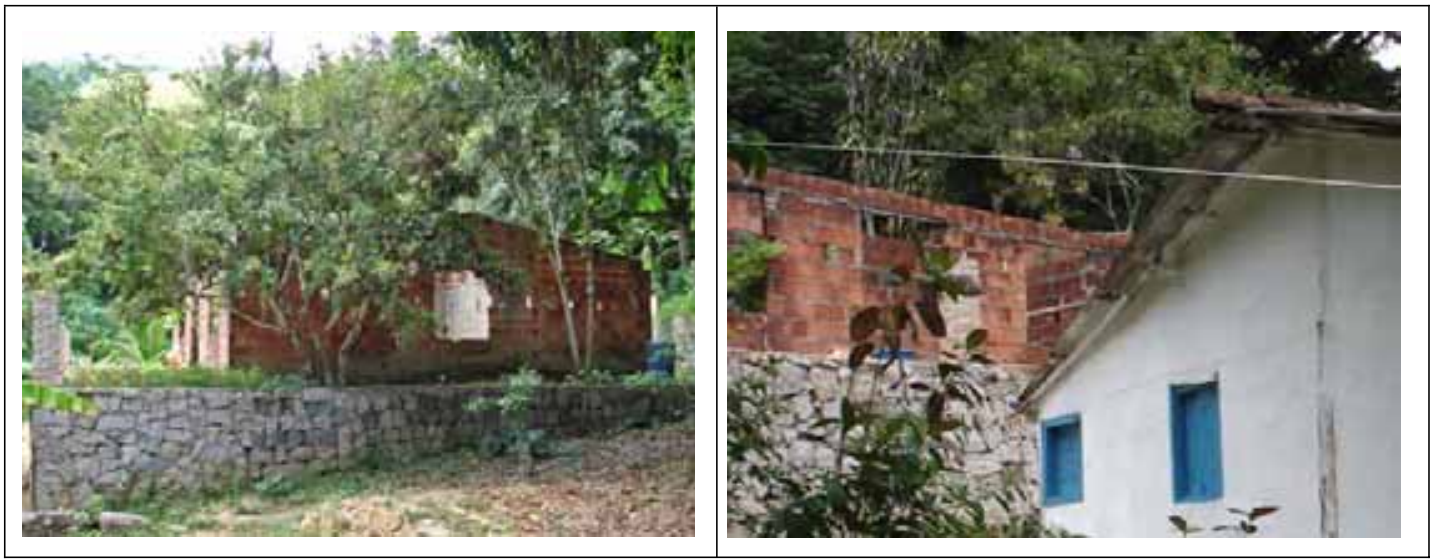

Moradia permanente: (?).

Características da casa: Alvenaria, não terminada.

Caseiro:

Observações: Embargada em fase de obra. 


\section{CADASTRO DAS CASAS DE TURISTAS NA BAÍA DOS CASTELHANOS SACO DO SOMBRIO}
CASA DE:
Dr JUAN (PREFEITO DE SÃO SEBASTIÃO)
LOCALIZAÇÃO UTM:
$475.235 / 7.356 .676$

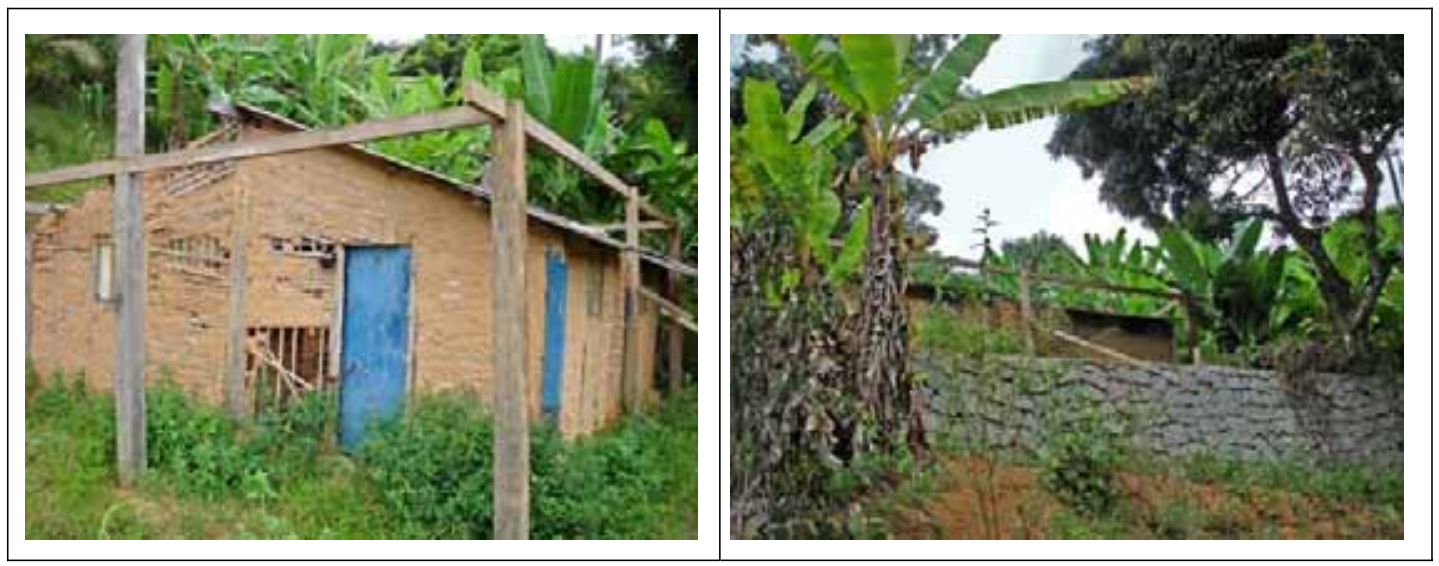

Moradia permanente: São Sebastião.

Características da casa: Pau-a-pique, em reforma.

Caseiro: Zizinho

Observações: Casa embargada no inicio da reforma e após obras de corte/aterro terminadas;

Informações fornecidas por moradores do local

CASA DE: $\quad$ OSMAR SOALHEIRO (DELEGADO DE POLÍCIA DE SÃO SEBASTIÃO)

LOCALIZAÇÃO UTM: $\quad 475.245 / 7.356 .705$

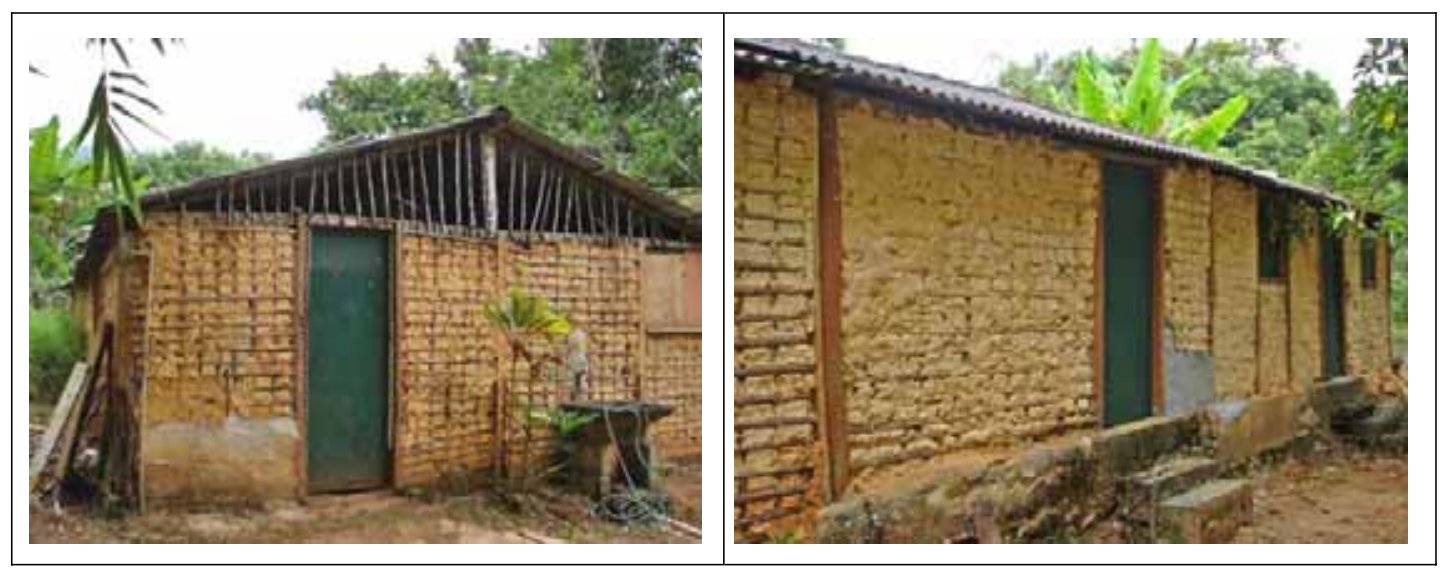

Moradia permanente: São Sebastião.

Características da casa: Pau-a-pique, em reforma.

Caseiro: Zizinho

Observações: Informações fornecidas por moradores do local 


\section{CADASTRO DAS CASAS DE TURISTAS NA BAÍA DOS CASTELHANOS SACO DO SOMBRIO}

CASA DE: MARIA DE JESUS SANTOS

LOCALIZAÇÃO UTM: $475.124 / 7.356 .672$

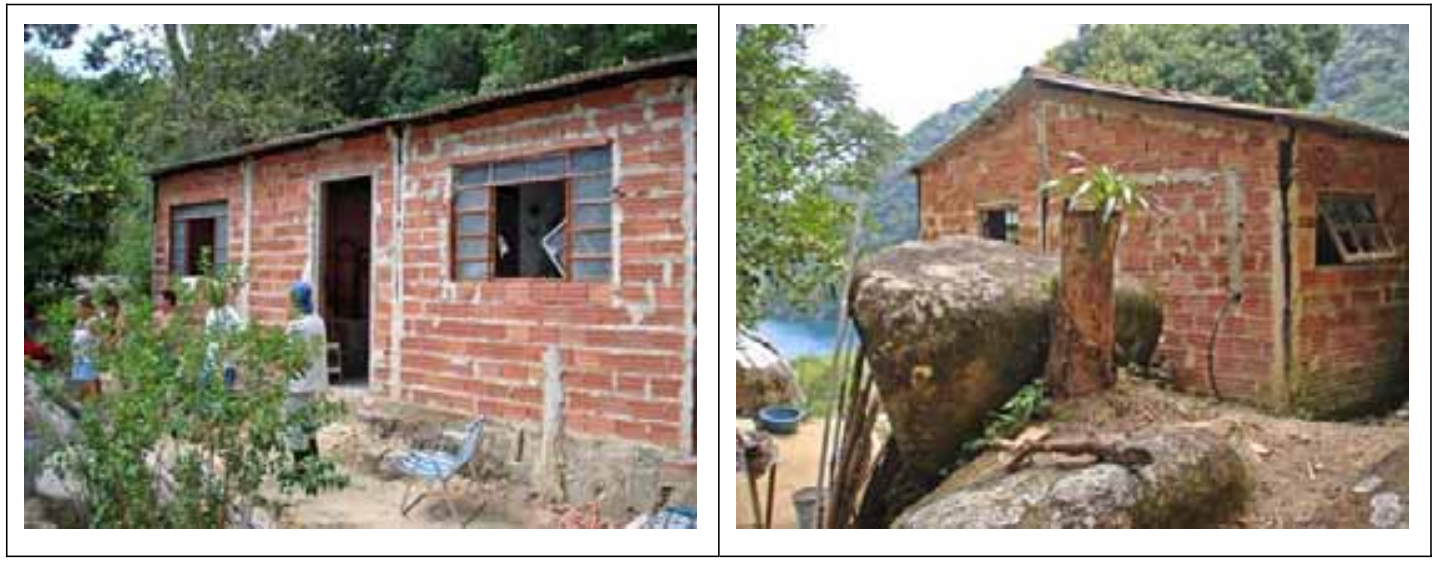

Moradia permanente: Ilhabela.

Características da casa: Alvenaria simples inacabada.

Caseiro: ?

Observações:

- Nasceu no Sombrio e a família também é originária do Sombrio. Mora em Ilhabela há muito tempo e vai ao Sombrio para lazer.

- Informou que se recorda bem do tempo do cerco do Sr.. Kamati. O pescado era salgado e seco e transportado em canoas de voga para Ilhabela. Haviam cercos instalados desde o Sombrio até a Praia Vermelha. Relatou que a D. Maria Kamati, filha doS. Kamati, causava muitos atritos com os demais moradores do local por querer se apossar de todas as terras.

- Em relação à agricultura, informou que no tempo do cerco dos japoneses, já se produzia-se comercialmente a banana. 


\section{CADASTRO DAS CASAS DE TURISTAS NA BAÍA DOS CASTELHANOS SACO DO SOMBRIO}

CASA DE: TURISTA CODÓI

LOCALIZAÇÃO UTM:

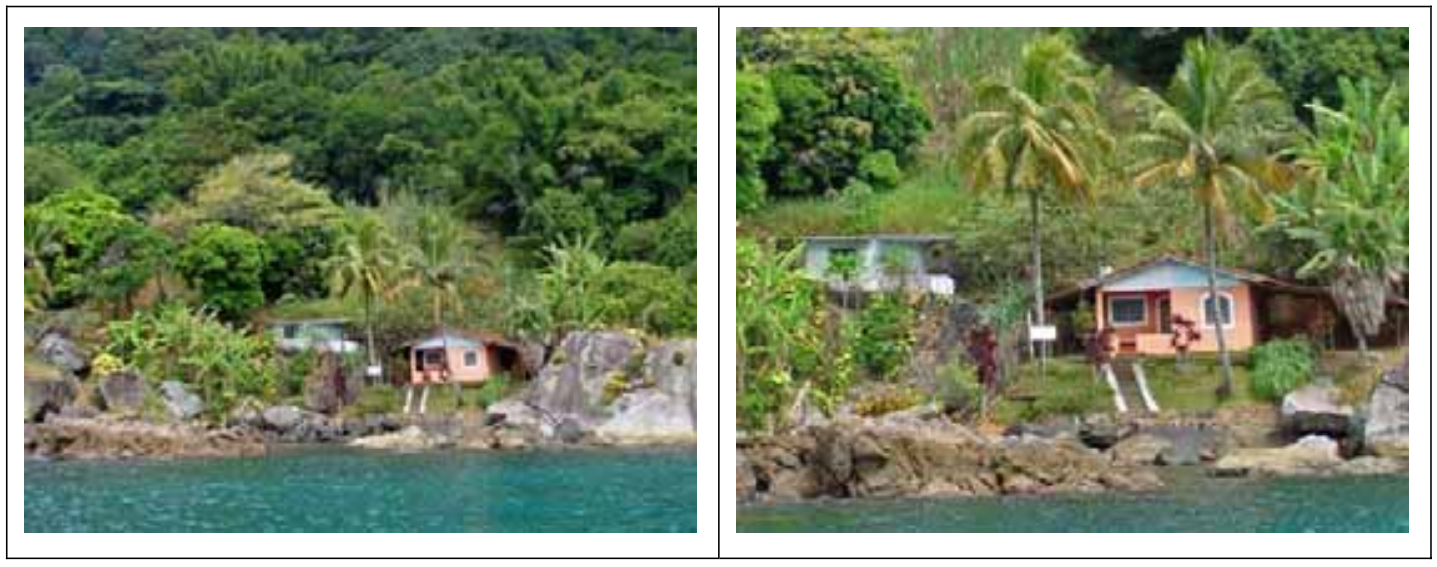

Moradia permanente:

Características da casa: Casa de alvenaria, padrão médio e casa de caseiro também em alvenaria Caseiro:

Observações: Codó ou Codói como é conhecido pelos caiçaras é uma piscina natural marinha localizada entre o Saco do Sombrio e a Praia da Figueira, bem em frente às ilhas das Galhetas. As casas estão construídas inteiramente dentro do Parque, que no local vai até a cota zero. 